\author{
UNIVERSIDADE DE SÃO PAULO \\ FACULDADE DE FILOSOFIA, LETRAS E CIÊNCIAS HUMANAS \\ DEPARTAMENTO DE SOCIOLOGIA \\ PROGRAMA DE PÓS-GRADUAÇÃO EM SOCIOLOGIA
}

\title{
A CUT no Governo Lula: \\ Da defesa da "liberdade e autonomia" à reforma sindical inconclusa
}

Mario Henrique Guedes Ladosky

Tese apresentada ao Programa de Pós-Graduação em Sociologia do Departamento de Sociologia da Faculdade de Filosofia, Letras e Ciências Humanas da Universidade de São Paulo, para a obtenção do título de Doutor em Sociologia

Prof. Dr. Iram Jácome Rodrigues

\section{São Paulo}


Aos meus dois grandes amores: Gabriel e Vinicius. Sem eles, minha vida não teria sentido nem graça alguma. Minha maior realização e orgulho é ser pai deles!! 


\section{Agradecimentos e homenagens}

A meus pais, Mario e Silvia, em primeiro lugar, por tudo que eles representam para mim. Graças a eles me tornei a pessoa que sou e estas palavras jamais poderão expressar o profundo amor e gratidão que sinto por ambos.

A meus irmãos, Ana Lucia e José Antônio, porque uma família não se faz apenas com pais e filhos. Com eles cresci em um ambiente saudável, pleno de carinho e respeito mútuo, e por isso estamos ligados por laços inquebrantáveis de amor fraternal.

A Ana Carolina, pelos filhos e pela força que sempre me deu quando fez parte da minha vida.

Sou o que sou pela família em que nasci, mas também pelas oportunidades que a própria vida foi colocando em meu caminho, cada uma delas proporcionando experiências e crescimento pessoal seja pela dor ou pela felicidade momentânea de uma realização.

Essa tese e minha própria vida, do jeito e com a intensidade que a vivo, não teria sido possível não fosse minha trajetória no movimento sindical cutista, combinado com o ambiente acadêmico por onde passei.

É humanamente impossível lembrar de todas as pessoas que conheci e que me engrandeceram.

No campo acadêmico, devo uma menção especial ao Prof. Iram Jácome Rodrigues, que aceitou ser meu orientador no Programa de Pós-graduação em Sociologia pela Faculdade de Filosofia, Letras e Ciências Humanas (FFLCH) da Universidade de São Paulo (USP). Ele nunca deixou de apostar que esse momento de conclusão do curso seria possível e esteve ao meu lado nos momentos mais difíceis da elaboração deste trabalho. Também não posso deixar de mencionar Cecília, sua esposa, sempre presente, incentivando e ajudando bastante com suas sugestões.

Mas, com todo respeito à USP, professores e colegas com quem tenho convivido, a minha "casa" é outra. Meus primeiros passos nessa longa jornada, onde fui me situando e conhecendo as coisas ao meu redor foram o curso de graduação em ciências sociais e o mestrado em sociologia pelo Instituto de Filosofia e Ciências Sociais (IFCS) da Universidade Federal do Rio de Janeiro (UFRJ). Lá foi o começo de tudo, onde comecei a dar os primeiros passos no Núcleo de Pesquisas Sindicais, o NUPES! Meus grandes amigos Marco Aurélio Santana, Ana Paula Melli, Jairo Garcia, Jaqueline Lavor, Paulo Henrique 
Tavares e o Prof. José Ricardo Ramalho, que além de amigo foi meu orientador no mestrado, foram fundamentais.

Já se passam mais de vinte anos de minha militância na CUT e dezoito desde que comecei a atuar no campo da formação sindical. Em todo esse período, os debates em sala com dirigentes e militantes sindicais proporcionaram saber tudo que sei sobre essa experiência fantástica da classe trabalhadora brasileira. Agradeço a todos(as) que compartilharam comigo esses momentos e o bom ambiente de debate.

Em especial aos amigos(as) e companheiros(as) da Escola Sindical São Paulo - CUT, onde trabalhei por oito anos. Junto com Ana Paula Melli (de novo!), Helena Bins, José Francisco Toledo, Pérsio Plensack, Rodrigo Gurgel e Luis Carlos Leite compartilhei um dos momentos mais ricos que tive na formação sindical, através do Programa Integrar de Formação de Dirigentes, da CNM. Inúmeros novos projetos se seguiram dentro da Escola São Paulo, e inúmeros novos(as) amigos(as) e companheiros(as) foram se acrescentando. Guardo todos os colegas da Escola com carinho no peito, mas merece uma menção especial Débora Felgueiras, minha parceira constante nos cursos de políticas públicas; e Elias Soares (Pintado) e Marilane Teixeira, com quem compartilho novos desafios no ramo químico da CUT. Lourdinha, Helanne e Jacira são hors concur...

$\mathrm{Na}$ impossibilidade de falar de todos os dirigentes e militantes que contribuíram em minha trajetória, agradeço e presto uma singela homenagem a todos(as) através da menção a três que foram e são especiais, cada um em um momento distinto de minha história.

O primeiro, Leônidas Cardoso Jr., militante da oposição sindical da construção civil do Rio de Janeiro. Sujeito gente finíssima e incomum de se encontrar (diria ser "exemplar único"). Trata-se de um verdadeiro diamante da classe trabalhadora. Embora tenha pouca escolaridade formal como se verifica entre tantos companheiros da categoria, tem raro conhecimento geral, leitor ávido de todo tipo de intelectual marxista, apreciador de ópera e outras finesses tão "exóticas" como ser nordestino com sotaque carregado e um rosto de alemão... Com tantos atributos positivos, Leônidas "deu azar" no meio sindical. Nunca conseguiu eleger-se dirigente de seu sindicato e, talvez por isso, nunca teve o reconhecimento que lhe é merecido. Como "menino" que ainda era no meio sindical, pude desfrutar da companhia sempre agradável desse companheiro, aprendendo com ele o be-abá da política. 
Outra pessoa inesquecível é Rita Lima. Dirigente do Sindicato dos Bancários do Espírito Santo (e depois da Direção Nacional da CUT), apostou em mim e aprovou minha contratação como assessor da secretaria de formação, da qual ela era a titular. Guerreira incansável, inteligente, exigente, perfeccionista, socialista coerente, extremamente humana e solidária. Graças a ela e a Maria Auxiliadora (nosso "anjo da guarda"), tive mais uma rica experiência logo de início em minha vida profissional. Pode-se dizer que foi quando "sai das fraldas" e comecei a me tornar "adulto" no movimento sindical. Com vinte e poucos anos, então, lá pude ter minhas primeiras grandes experiências como assessor sindical, organizando planos de formação para a categoria bancária desenvolvendo cursos para a base...

Na Escola Sindical São Paulo veio a fase de "amadurecimento", graças a Deus sempre inconcluso e incompleto para que possa continuar seguindo meu caminho em busca de estar sempre melhorando!...

Entre muitos dirigentes que participaram de cursos comigo, tive a sorte de conhecer Paula Francinete Costa Leite. Dirigente do Sindicato dos Municipais de São Paulo; ela aglutina um conjunto de qualidades que eu jamais encontrara em uma mesma pessoa no meio sindical até então: extrema inteligência, combinada com astúcia e capacidade de negociação; personalidade firme e decidida articulada com uma prática democrática; combativa "na dose certa", sem radicalismo inconsequente; guerreira "atuantemente ativa" como poucos (elétrica e incansável); líder nata por onde passa e com um senso ético e de honestidade a toda prova. Ah, se todo Sindicato tivesse uma Paula!!... Meia Paula, que fosse!!... Depois de anos de convívio compartilhando com ela uma caminhada recheada de companheirismo, amor e um profundo afeto mútuo, ainda me emociono ao testemunhar suas atitudes em defesa dos trabalhadores que representa com tamanha firmeza e me orgulho em poder acompanhar seu crescimento político constante no meio sindical!! Por fim, merece também uma menção a própria Universidade de São Paulo, que com todos os seus funcionários de apoio, de secretaria, de limpeza, de professores, proporciona o ambiente necessário ao estudo e à pesquisa de excelência socialmente reconhecida. Gente muitas vezes "invisibilizada" sem o que a própria USP não existiria.

A todos(as), muito obrigado!! 


\section{Resumo}

Esta tese trata da relação entre a CUT e a estrutura sindical corporativa no Brasil. O tema já foi amplamente estudado pela sociologia no meio acadêmico, e da mesma forma tem sido elemento de reflexão e debate entre dirigentes e militantes sindicais. Nesse sentido, a originalidade deste trabalho é revisitar o tema e analisa-lo à luz do contexto do governo Lula, eleito em 2002 para seu primeiro mandato como presidente da República com a plataforma de modernização da legislação sindical através de uma reforma sindical negociada por representantes do governo, empresariado e trabalhadores no Fórum Nacional do Trabalho (FNT).

Desse ponto de vista, essa tese se apropria de um debate já estabelecido sobre o conceito de corporativismo e faz um resgate histórico da CUT, dos anos 1980 aos dias atuais, enfatizando suas vicissitudes e contradições para a superação do modelo herdado da Consolidação das Leis do Trabalho (CLT), nas décadas de 1930 e 1940.

Dentro desse percurso, a instauração do governo Lula, apoiado pela CUT, acarretou possibilidades de avanços e conquistas sociais e em direção à liberdade e autonomia sindical, do mesmo modo que tensionou internamente as relações entre as correntes políticas da CUT ao colocar em pauta questões inéditas em sua trajetória como o ajuste entre a defesa de um governo identificado com bandeiras populares e a manutenção de uma postura autônoma e independente na defesa dos interesses dos trabalhadores.

A partir da trajetória da CUT, indicamos que essa central sindical conserva ainda elementos do corporativismo estatal, mas sua ação política em defesa da liberdade e autonomia sindical ao longo de sua história e também no FNT, ainda que não tenha sido conquistada, permitiu introduzir mudanças não previstas inicialmente na estrutura sindical oficial, logrando êxito parcial ao introduzir elementos do neocorporativismo e do pluralismo nas relações sindicais no Brasil.

Palavras-chave: sindicalismo; corporativismo; reforma sindical; CUT; governo Lula. 


\begin{abstract}
This thesis tells about the relation between CUT and the corporatist union structure in Brazil. This subject has already been studied widely by sociologist and, in the same way, it has been discussed among union leaders and militants.

So, the originality of this work is to review the subject and analyze it enlightened by the context of Lula's government, elected for president supporting the aim of up dating the unionist law through the negotiations gathering employers, employees and the government around a union reform in Labor National Forum (LNF).

From this point of view, this thesis takes into account the corporatist concept established, and replaces CUT's history, since the eighties until nowadays, emphasizing its difficulties to surpass the restrictions of the corporatist law in the 1930s and 1940s.

This way, Lula's government has brought many possibilities to achieve new social rights and to assure a new order to unionism, based on a union liberty concept. But, by contrast, it has brought also a conflict among CUT's leaders and militants that have faced an unusual challenge, as to defend the government against the conservatives and to keep on fighting for the workers interests.

So, we demonstrate with this work that CUT still keeps many elements of state corporatist, but, at same time, its practice defending union liberty along its history, and into LNF, has changed the union structure adding neo-corporatist and pluralist elements into union relationship in Brazil
\end{abstract}

Key words: unionism; corporatist; union reform; CUT; Lula's government. 


\section{Sumário}

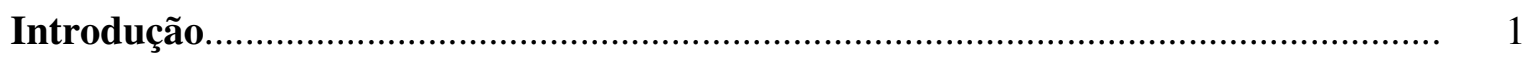

Capítulo 1 - A CUT e o Governo Lula................................................................................... 22

A nova realidade dos anos 1990........................................................................... 24

O interregno do governo de Itamar Franco............................................................ 26

A continuação do projeto neoliberal: o governo FHC e a "herança maldita"............ 28

Precarização do trabalho e criminalização dos movimentos sociais.......................... 31

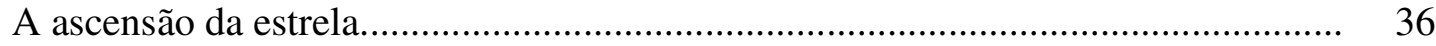

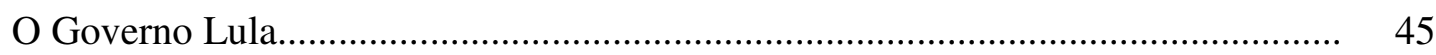

Impasses da CUT diante do governo Lula............................................................ $\quad 59$

Capítulo 2 - A trajetória da CUT frente ao corporativismo...................................... 75

Pluralismo, corporativismo estatal e neocorporativismo: arranjos para o modelo sindical brasileiro na atualidade............................................................................. $\quad 75$

Corporativismo estatal, populismo e desenvolvimento econômico brasileiro:

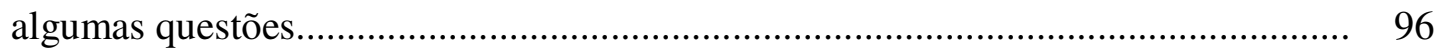

Mecanismos de incentivo e de constrangimento da estrutura sindical

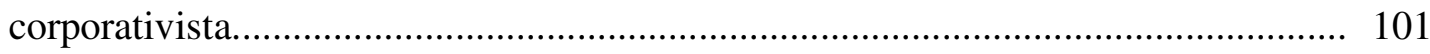

O “novo sindicalismo" e a fundação da CUT ................................................... 107

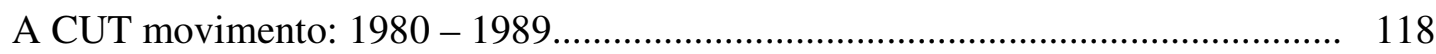




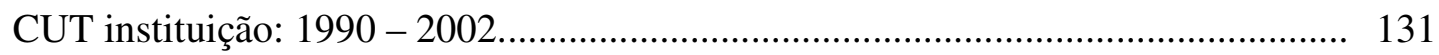

O enfrentamento com a estrutura corporativa.................................................... 162

Capítulo 3 - A reforma sindical inconclusa........................................................ 175

Uma terceira etapa na trajetória da CUT?........................................................ 175

Diagnóstico comum entre o MTE e a CUT acerca da atual estrutura sindical

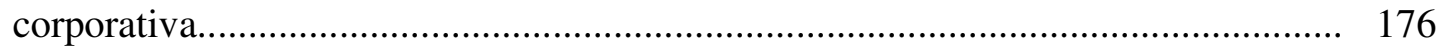

A instauração do FNT e o debate sobre a reforma sindical nas conferências estaduais

Opinião dos delegados ao $8^{\circ} \mathrm{CONCUT}$ sobre temas da reforma sindical................ 187

Projeto Estratégia e Organização da CUT: construindo o Futuro........................... 194

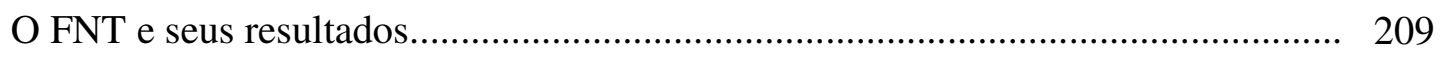

A PEC 369/05 e o Anteprojeto de Lei de Relações Sindicais (ALRS)............... 210

O Conselho Nacional de Relações de Trabalho (CNRT)................................ 212

Organização Sindical....................................................................... 215

Negociação Coletiva.................................................................................. 223

Composição de Conflitos de Trabalho................................................................. 226

A plataforma democrática da CUT e as posições político-ideológicas contrárias à PEC e ao ALRS...

Outras propostas de reforma da estrutura sindical corporativa............................. 247

Avaliação dos delegados ao $9^{\circ}$ CONCUT sobre a reforma sindical......................... 258

A reforma sindical fatiada e seus desdobramentos............................................. 271

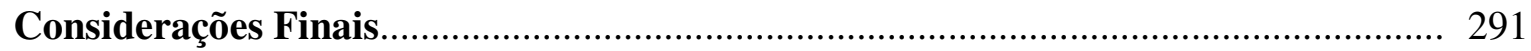

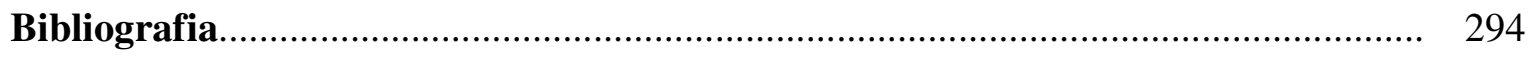




\section{Principais siglas citadas}

ALRS Anteprojeto de Lei de Relações Sindicais

ANAMPOS Articulação Nacional dos Movimentos Popular e Sindical

ASS Alternativa Sindical Socialista

CEBs $\quad$ Comunidades Eclesiais de Base

CECUT Congresso Estadual da CUT

CGT Central Geral dos Trabalhadores

CGT Confederação Geral dos Trabalhadores

CGTB Central Geral dos Trabalhadores do Brasil

CIOSL Confederação Internacional das Organizações Sindicais Livres

CNRT Conselho Nacional de Relações de Trabalho

CONCLAT Conferência Nacional da Classe Trabalhadora

CONCLAT Congresso Nacional da Classe Trabalhadora

CONCLAT Coordenação Nacional da Classe Trabalhadora

CONCUT Congresso Nacional da CUT

CONLUTAS Coordenação Nacional de Lutas

CSC Corrente Sindical Classista

CSD CUT Socialista e Democrática

CTB Central dos Trabalhadores e Trabalhadoras do Brasil

CUT Central Única dos Trabalhadores

DIAP Departamento Intersindical de Assessoria Parlamentar

DIEESE Departamento Intersindical de Estatística e Estudos Socioeconômicos

FNT Fórum Nacional do Trabalho 
Força Sindical

Medida Provisória

$\mathrm{MTb}$

Ministério do Trabalho (denominação até 1995)

MTE

Ministério do Trabalho e Emprego (denominação a partir de 1995)

NCST Nova Central Sindical de Trabalhadores

OIT Organização Internacional do Trabalho

PEC Proposta de Emenda Constitucional

PL Projeto de Lei

SDRT Sistema Democrático de Relações de Trabalho

SDS Social Democracia Sindical

UGT União Geral dos Trabalhadores

USI União Sindical Independente 


\section{Introdução}

Este estudo retoma a linha de pesquisa iniciada em 1987/88, e que resultou, em 1995, na dissertação de mestrado pelo Programa de Pós-graduação em Sociologia, no Instituto de Filosofia e Ciências Sociais da UFRJ, que se intitulava Movimento Sindical e Estratégia Corporativista: a trajetória e os impasses da CUT no Rio de Janeiro.

Na ocasião, já era claramente identificado por estudiosos e sindicalistas que um dos grandes dilemas/desafios do sindicalismo-CUT reside no paradoxo entre a bandeira da liberdade e autonomia sindical, uma das principais marcas de seu surgimento, e a acomodação à estrutura sindical corporativa à medida que conquistava inúmeros sindicatos e se consolidava como a maior central sindical brasileira.

A bibliografia sobre o tema polarizava muito fortemente em torno das categorias de superação e acomodação do sindicalismo-CUT em relação à estrutura sindical corporativista. Categorias que expressavam (ou refletiam) diferentes perspectivas e posições políticas/ideológicas nas publicações de caráter mais acadêmico, de militantes e dirigentes sindicais, bem como em resoluções de Plenárias e Congressos da própria CUT.

Naquele trabalho tentei fugir da polarização, propondo pensar a questão sob outro parâmetro:

“...Discutir se o movimento cutista conformou-se à estrutura sindical corporativista ou se a superou pressupõe, em ambas as hipóteses, que a estrutura sindical é algo "dado", onde os sujeitos são obrigados a atuar, reforçando-a ou não. Na perspectiva em que abordamos este problema, a estrutura sindical é um "espaço de relações" estruturado que "condiciona" a ação dos sujeitos da mesma forma que é mutável pela prática dos mesmos (...) Mais importante do que discutir a "adequação" ou "superação" do sindicalismo corporativista, é perceber quais relações são estabelecidas nas ações concretas de sindicalistas e militantes que alteram qualitativamente $o$ movimento sindical, em que concomitantemente se articulam "continuidade" e "transformação" da estrutura vigente" (LADOSKY, 1995: 28)

Essa perspectiva permanece válida, o que não minimiza ou torna secundária a importância do debate travado na literatura sociológica.

Nossa visão acerca deste tema é de que a estrutura sindical (como, aliás, qualquer estrutura social) compreende uma totalidade de relações que comporta contradições. E a partir delas 
se torna possíveis a intervenção e a ação dos sujeitos, interagindo com a estrutura, "adequando-se" e "superando-a"; não por inteiro, como bloco ou monolito, mas construindo sínteses possíveis condicionadas pelos contextos históricos concretos e correlação de forças políticas e conjunturais das classes, entre outras coisas, que compõem a complexidade humana e da vida em sociedade.

Dito de outro modo, a estrutura sindical corporativista "não é", por sua natureza intrínseca e taxativamente, camisa-de-força que amarra o movimento sindical. E, evidentemente, também não é, incondicionalmente, fator de propulsão das ações mais aguerridas do movimento sindical.

Preferimos refletir que a estrutura sindical corporativa "está sendo", em determinada conjuntura, camisa-de-força, mas que se torna, em outro contexto, fator favorável à ação sindical mais "combativa"/autônoma. A "variação" entre "estar sendo combativa" e "estar sendo camisa-de-força" se dá em função das forças políticas em disputa, que "usam" as condições oferecidas pelo sindicalismo oficial e corporativo (imposto sindical, unicidade sindical etc) em seus projetos políticos. O que explica, segundo essa ótica, por que a mesma legislação sindical corporativa manteve-se em períodos democráticos da história do país e também em períodos de exceção. E, em cada momento, viu as lutas sindicais avançarem e refluírem. É que a estrutura sindical oficial convive muito bem nos diversos contextos, permitindo à força política hegemônica desenvolver ações sindicais de acordo com o interesse e estratégia.

É importante ressaltar que, mesmo em contexto no qual predominam os aspectos de "camisa-de-força" da estrutura corporativa, há também elementos de combatividade presente. $\mathrm{O}$ mesmo ocorre no caso contrário: quando o contexto é mais favorável às ações de autonomia, verificam-se características da "camisa-de-força" travando o pleno desenvolvimento das lutas. ${ }^{1}$

\footnotetext{
${ }^{1}$ No primeiro caso, citam-se como exemplo histórico os antecedentes do novo sindicalismo, em meados dos anos 1970, quando se vivia no país o maior momento da repressão militar, ao mesmo tempo em que as primeiras lideranças começavam a despontar em seus sindicatos, desenvolvendo ação que procurava envolver os trabalhadores no "chão de fábrica" com a vida do sindicato. Do modo contrário, o início dos anos 1980 é dos momentos de atuação mais intensa do movimento sindical no Brasil, coexistindo com os mecanismos de controle da CLT.
} 
Uma leitura desse tipo, portanto, implica perceber que a estrutura sindical corporativa não essencialmente freia as lutas ou, por sua natureza, permite o avanço das lutas dos trabalhadores, mas que há em seu bojo ambas as possibilidades, contraditoriamente. Por isso ela não é, mas está sendo, de modo permanente, colocada em disputa entre distintas perspectivas políticas e ideológicas.

Daí a dificuldade em concluir projeto que proponha o fim do modelo sindical corporativo.

Mas a estrutura sindical corporativa no Brasil, pelo argumento anterior, jamais terá fim, por causa da sua adaptabilidade aos diferentes contextos históricos e ao projeto da força política então hegemônica?

Uma interpretação dessa natureza sobre a estrutura sindical corporativa não aceita a tese de imanência, pois seria contrário à linha adotada de análise. Explico: aceitar que a estrutura sindical corporativa nunca terá fim seria supor a falência da própria leitura dialética, pois as coisas estão em permanente mutação em virtude de contradições que carregam em si mesmas e na relação com os sujeitos históricos, que as transformam em outro ser.

A transformação é sempre processual, em um movimento permanente de tese-antítesesíntese que altera a qualidade da tese original.

É devido a possibilidade de superação da estrutura sindical a partir da ação dos sujeitos que se apresenta o desafio para parte do movimento sindical sobre como construir esse caminho, mesmo reconhecendo o "peso da estrutura" que empurra para a manutenção da ordem vigente. Por isso, adotamos a postura de compreender a estrutura sindical, não só pelo constrangimento à ação sindical, mas também pela possibilidade de sua superação pela intervenção dos sujeitos, que pressupõe permanentemente continuidades $e$ mudanças.

Esta tese, portanto, reconhece plenamente o efeito que a estrutura sindical corporativa ainda exerce na manutenção do status quo, mas quer evidenciar e ressaltar as mudanças processadas recentemente, apesar da persistência do modelo corporativo. Antíteses que emperram a engrenagem do modelo corporativo capazes, potencialmente, de abrir o tempo de um "novo sindicalismo", de fato, no futuro. 


\section{A Pesquisa}

O tema da pesquisa é a relação entre a Central Única dos Trabalhadores (CUT) e a estrutura sindical corporativa vigente no Brasil.

A CUT e a estrutura sindical corporativa já foram objeto de diversas pesquisas, existindo, portanto, bibliografia relativamente extensa sobre ambas.

No entanto, o atual momento histórico permite atualizar o debate à luz de novos acontecimentos.

O tema viu renovada a sua importância recentemente, quando, a partir de 2003, no governo Lula, foi aberto o processo de reforma sindical no então recém-criado Fórum Nacional do Trabalho $(\mathrm{FNT})^{2}$. O Fórum iniciou debate sobre a possibilidade de alteração da Constituição Federal e da CLT nos artigos que regulamentam a organização sindical, mobilizando diversos atores sociais: centrais sindicais, confederações oficiais, entidades patronais, operadores do judiciário trabalhista, o meio acadêmico, entre outros.

A CUT, desde sua origem, defende mudanças na estrutura sindical oficial em busca da liberdade e autonomia sindical. E teve, na ocasião, oportunidade ímpar para viabilização do projeto histórico de superação do corporativismo em direção à plena liberdade e autonomia sindical, e de ver realizada uma de suas principais bandeiras.

Portanto, a CUT decidiu, em seu $8^{\circ}$ Congresso Nacional ( $8^{\circ}$ CONCUT), realizado em 2003, desde o primeiro momento, apoiar firmemente a proposta de criação do FNT e participar ativamente de todo o processo de negociação estabelecido. Acreditava-se que a reforma sindical em curso permitiria "resolver", ou ao menos avançar, de modo significativo, sobre "questões históricas" debatidas pela CUT e pelos estudos acadêmicos sobre sindicalismo, como democratização dos sindicatos, organização nos locais de trabalho, maior representatividade das entidades sindicais e o fortalecimento de sua capacidade de negociação e contratação coletiva, alterando profundamente o padrão das relações de trabalho no Brasil.

\footnotetext{
${ }^{2}$ O FNT foi composto de forma tripartite por representantes das entidades sindicais de trabalhadores (centrais sindicais e confederações oficiais) e de empregadores, além de bancada governamental com membros do Ministério do Trabalho e Emprego (MTE).
} 
Passado pouco tempo verificou-se que a discussão entre os atores envolvidos em torno da reforma sindical mostrou ser bem mais complexa, com dificuldade de produzir consensos dentro da CUT, na bancada de trabalhadores e destes com os representantes patronais.

A despeito da posição histórica da CUT em favor das mudanças na estrutura sindical corporativa, a Central não teve atuação coesa nessa direção durante o FNT. Mesmo no conjunto do sindicalismo-CUT havia dúvidas e divergências.

A proposta de reforma sindical ampla e profunda à qual chegou o FNT expressa o frágil acordo entre as partes. Submetida à Comissão de Trabalho, de Administração e Serviço Público (CTASP), no Congresso Nacional, recebeu inúmeras outras propostas substitutivas e projetos de lei apensados. O que revela não só diversos interesses de grupos sociais não contemplados no projeto de lei do Executivo, mas principalmente resistência generalizada em promover qualquer alteração mais profunda na legislação sindical em vigor.

Se o projeto político-organizativo da CUT, elaborado ao longo de sua história, não pôde prosseguir com a profundidade almejada pela via da reforma sindical proposta no FNT, o atalho utilizado tem sido caminho tortuoso de alterações pontuais na legislação sindical, que tem promovido mudanças parciais na estrutura sindical corporativa. Refere-se aqui à Lei 11648, que reconhece legalmente as centrais sindicais como entidade sindical, e a portaria 186 do MTE, que favorece a pluralidade sindical. Há ainda discussão em andamento sobre a extinção do imposto sindical e o estabelecimento da contribuição de negociação coletiva como forma de financiamento das entidades sindicais.

Esta pesquisa não tem como indicar se o movimento em curso resultará na afirmação de novo modelo de organização sindical no Brasil, ou se sucumbirá ante a persistência do setuagenário corporativismo. Eventuais mudanças na legislação sindical não resolvem a questão da cultura política arraigada na prática de inúmeros dirigentes e militantes após décadas de vigência do modelo corporativo.

$\mathrm{Na}$ verdade, conforme indicado nesta introdução, a análise caminha na direção de que o resultado do movimento atual de reforma sindical será ainda um combinado entre parcelas 
do "velho" e do "novo", levando em conta não apenas a legislação, mas também a cultura política no meio sindical ${ }^{3}$. Daí a chamada do título - reforma sindical inconclusa.

Mas este trabalho não será um balanço dos debates do FNT, tampouco da proposta de reforma sindical ali gestada. O foco será o sindicalismo-CUT frente à estrutura sindical brasileira, haja vista a relevância da Central na história recente do sindicalismo brasileiro e sua posição diante do tema ${ }^{4}$.

Contudo, a pesquisa não tem a pretensão de ser algo conclusivo sobre a CUT e a estrutura sindical corporativa, mas simplesmente mostrar mais uma cena de um "filme" que continuará a se desenvolver. No entanto, as "cenas" atuais sobre as quais se debruçará a pesquisa são extremamente relevantes para compreender o enredo da trajetória da CUT, que talvez tenha repercussão no desenrolar de sua história e no desenho de novo modelo de organização sindical no Brasil.

Como objeto de tese na área da sociologia, interessa compreender como se constituiu a relação entre a CUT, genericamente falando, e a estrutura sindical corporativa, ao longo de sua trajetória, procurando identificar as transformações operadas na CUT e na estrutura sindical brasileira. ${ }^{5}$

O problema enfrentado na pesquisa diz respeito à ação do sindicalismo-CUT sobre a estrutura sindical corporativa no contexto do governo Lula. Concretamente, como o sindicalismo-CUT vem operando sua relação frente à estrutura sindical corporativa $e$ quais transformações têm se verificado em cada uma delas? Em que medida o projeto histórico presente na fundação da CUT, em defesa de um regime de liberdade e autonomia sindical, ainda permanece vigente?

\footnotetext{
${ }^{3}$ Precisamente neste ponto é pertinente o uso do conceito de habitus, de Pierre Bourdieu (1992), capacidade de determinada estrutura social ser incorporada pelos agentes de forma pré-reflexiva, por meio de disposições para sentir, pensar e agir, que cria um modus operandi.

${ }^{4}$ Motivo pelo qual não trataremos de outras centrais sindicais no trabalho, exceto quando necessário para compreender sobre a própria CUT e o sindicalismo-CUT, objeto da pesquisa.

${ }^{5}$ Cardoso (1999) talvez objetasse nossa análise, destacando que as mudanças em curso já vêm se processando há anos e independem da mudança da legislação. O argumento utilizado pelo autor, na mão inversa das análises mais comuns, lança mão de muitos dados do censo sindical do IBGE e outras fontes, para justificar a análise de que a miríade de sindicatos no Brasil representa a chegada da política e da "civilidade" da ação estatal nos rincões mais distantes do país; que o imposto sindical já não é mais a principal fonte para o custeio dos sindicatos; que o sindicalismo consegue penetrar nos locais de trabalho bem mais do que se costuma imaginar, por meio dos delegados sindicais... O autor assinala que a ação dos sindicatos extravasa, e muito, os estreitos limites do corporativismo.
} 
O pano de fundo para as mudanças na estrutura sindical corporativa e no sindicalismo-CUT é resumidamente: 1) a transformação no mundo do trabalho, em especial a precarização do trabalho e a desregulamentação do mercado de trabalho; 2) os diferentes projetos de sociedade em disputa; e, 3) junto com as diferentes perspectivas políticas em disputa, as mudanças no sistema de intermediação de interesses entre os atores, derivado do projeto hegemônico que ordenará a relação Estado - sociedade.

Evidentemente os elementos presente como pano de fundo não são estanque. Ao contrário, imbricam-se uns aos outros, resultado de luta política entre distintos atores na sociedade. Vem se alterando ao longo do tempo, provocando mudanças na estrutura sindical corporativa e no próprio sindicalismo-CUT.

Esta introdução indicará cada um dos elementos identificados, relacionando-os à questão central da pesquisa, a ação do sindicalismo-CUT e a transformação em curso na estrutura sindical corporativa.

\section{Os panos de fundo para a atuação do sindicalismo-CUT}

Uma das grandes questões sociológicas nos estudos mais recentes sobre sindicalismo é a pertinência dessa instituição na atualidade, a partir da crise provocada pelas intensas transformações no mundo do trabalho. (SANTANA e RAMALHO, 2003; RODRIGUES, 1999; HYMAN, 1994)

O alto grau de desemprego permanente - chamado desemprego estrutural -, o número cada vez maior de trabalhadores na informalidade e a precarização nas condições de trabalho (p. ex.: terceirização, flexibilização no uso da força de trabalho pela contratação temporária/parcial, flexibilização nas formas de remuneração etc.) têm provocado a reflexão se os sindicatos mantêm sua relevância nas relações de trabalho, tal como no período do pós-guerra, com o arranjo keynesiano do Estado de Bem-estar Social.

A posição mais pessimista afirma que os sindicatos são instituição em declínio terminal. O alto grau de dessindicalização no mundo seria a prova cabal do argumento de que os sindicatos não representam nem têm o que falar aos trabalhadores. (RODRIGUES, 1999) 
Os autores com viés otimista concordam que os sindicatos passam por grave crise no atual contexto, mas veem ainda possibilidades de ação coletiva, desde que renovem práticas e agendas, abrindo-se para novos temas. Como apoio a iniciativas de economia solidária (cooperativas), desenvolvimento sustentável, trabalhadores excluídos, e aprofundem a questão de gênero. Está em crise, segundo os otimistas, o tipo de sindicato forjado no período fordista, voltado exclusivamente para a negociação e contratação coletiva em nome dos assalariados, e com organização centralizada/“verticalizada" na relação direção-base. (HYMAN, 1994; MUNCK e WATERMAN, 1999; BEYNON, 2003)

Algumas sugestões e indicações desses autores sobre as novas práticas que os sindicatos deveriam adotar os aproximariam da experiência organizativa dos chamados novos movimentos sociais: mais "horizontalizados", com atuação em rede, mais plurais - para absorver a diversidade de sujeitos -, e democráticos.

Partindo da contribuição desses autores para refletir sobre o objeto de pesquisa, observa-se multiplicidade de "respostas" da ação sindical que não cabem em um campo polar entre "práticas antiquadas" e "práticas renovadas". O tema é mais complexo. Se se verificar a CUT em si mesma, há iniciativas em ambos os campos ${ }^{6}$.

A pesquisa deseja constatar a coexistência no sindicalismo-CUT das chamadas "práticas antiquadas" e "práticas renovadas" a que se refere Waterman. Torna-se mais complexa a

\footnotetext{
${ }^{6}$ Por um lado, tem havido preocupação crescente em ampliar sua agenda e o leque de intervenção e disputa de hegemonia na sociedade, o que é chamado genericamente de concepção sindical cidadã, ou simplesmente "CUT cidadã".

Temas como a questão da economia solidária, a busca da inclusão social em de projetos de Educação de Jovens e Adultos (EJA) e de alfabetização de adultos disputando concepção de educação com pedagogias mais tradicionais; a disputa de concepção político-pedagógica com o sistema "S" na formação profissional; as mulheres trabalhadoras; enfrentamento à discriminação racial e ao racismo; a juventude; a inclusão de pessoas com deficiência; meio ambiente; ações conjuntas com movimentos dentro da recém-criada Coordenação de Movimentos Sociais (CMS), articulação com o sindicalismo internacional e em redes de trabalhadores de empresas multinacionais, entre outros, estão na pauta da CUT e foram objetos de debate e resolução no último Congresso da CUT, o $8^{\circ}$ CONCUT.

No entanto, ao lado dessa agenda ampla voltada à disputa da hegemonia envolvendo temas e segmentos não tradicionalmente identificados com a questão sindical, na própria CUT se encontram também métodos de ação sindical e de tomada de decisão pautados na disputa de correntes e grupos políticos que se voltam para problemas absolutamente internos, constituindo um mundo com regras próprias, fora de sintonia com o contexto atual de transformações capitalistas.
} 
reflexão do autor em The New Social Unionism: A New Union Model for a New World Order, pois o chamado "novo modelo sindical" se imbrica com o "velho modelo sindical"7. A reforma sindical debatida durante o governo Lula procurou enfrentar os velhos dilemas do sindicalismo corporativo no Brasil. Os novos desafios identificados pela recente literatura sociológica passam ao largo da discussão no FNT, porque envolvem mudança cultural.

Os sindicatos não estão em situação terminal. Esta pesquisa situa-se, portanto, no mesmo campo interpretativo de que os sindicatos precisam se renovar em busca de diálogo mais amplo na sociedade, com os setores, e sobre temas não tradicionalmente abrangidos.

Contudo, a despeito de Waterman (1999), há que se considerar também que não se trata simplesmente de criar novos modelos de ação sindical, aproximando-se de padrão de ação mais afeito aos movimentos sociais. Sindicato é sindicato; movimento social é movimento social.

A ampliação do leque de intervenções dos sindicatos não deve fazer com que se perca a especificidade que caracteriza a instituição sindical. Por menor que seja, há um contingente de trabalhadores empregados que esperam de um sindicato a representação, negociação e contratação de assuntos estritamente trabalhistas, condições de trabalho e salários. Por isso um sindicato, por mais que se abra a temas da sociedade/comunidade, não pode perder de vista seu papel mais tradicional.

O sindicalismo-CUT tem procurado combinar novas e antigas demandas dos trabalhadores, para manter-se relevante para os nichos de trabalhadores que continuam empregados e tentar atingir a maioria que se encontra excluída do mundo do trabalho. Retomando o

\footnotetext{
${ }^{7}$ Se se considerar o que está sendo chamado de sindicalismo-CUT, ou seja, o conjunto mais amplo de instituições ligadas à CUT, como sindicatos, federações e confederações, a questão ganha novos contornos, pois muitas políticas geradas pela CUT não chegam àquelas entidades. Em outras palavras, a discussão e propostas da CUT sobre formação profissional, por exemplo, não são sequer do conhecimento de inúmeras Direções de sindicatos, federações e confederações... Diversos outros exemplos poderiam ser citados. Isso não significa dicotomizar a CUT de um lado, com "práticas renovadas", e as demais entidades, com "práticas antiquadas"; pois o inverso também ocorre. Há várias experiências de "práticas renovadas" em sindicatos, federações e confederações que não são do conhecimento ou não são incorporadas pela CUT.
} 
problema da pesquisa, o sindicalismo-CUT ${ }^{8}$ incorpora práticas voltadas aos novos desafios, sem, contudo, abandonar os velhos temas do corporativismo.

As iniciativas do sindicalismo-CUT pautadas pela ação que extrapola as questões estritamente relacionadas à classe trabalhadora começaram a tomar fôlego exatamente quando o Brasil se inseria no movimento de globalização de forma subordinada pela adoção de planos de ajustes econômicos que preconizavam a redução do papel social do Estado e sua capacidade de intervenção pró-ativa no mercado.

No primeiro capítulo serão abordados os graves efeitos sociais dessa política, sobretudo o desemprego e a precarização das relações de trabalho, implementada ao longo dos anos 1990, em especial a partir do governo de FHC.

Aqui se insere o segundo pano de fundo - os diferentes projetos de sociedade em disputa no país desde a década de 1990. A análise simplista identifica duas grandes visões: a primeira consubstanciada no ideário neoliberal; outra, pautada por um projeto democráticopopular. Evidentemente trata-se de simplificação grosseira. Espera-se que o leitor tenha, no capítulo 1, a percepção do quanto a realidade se mostra bem mais complexa do que o modo aqui apresentado. No entanto, no espaço dessa introdução, enfatiza-se que a disputa clarividente entre projetos de sociedade alterou o cenário pelo qual transitam os sindicatos, em especial o sindicalismo-CUT. Do mesmo modo afirma-se que os projetos distintos consubstanciam formas diferenciadas de encarar a reforma sindical, mesmo quando subsumida diante do "consenso" em torno da liberdade e autonomia sindical.

O que importa reter na introdução são as profundas mudanças no contexto econômico internacional e nacional - para o qual os projetos políticos em disputa concorreram na sociedade, fortalecendo uma ou outra perspectiva - que transformaram radicalmente o cenário de atuação do sindicalismo-CUT. Será mostrado que isso contribuiu, ao lado de outros fatores, para mudança na orientação da CUT e também no tipo de intermediação de interesses entre os grupos sociais face ao Estado.

\footnotetext{
${ }^{8}$ Não se pode, contudo, superestimar a introdução dos novos temas no interior da CUT, pois o grau de enraizamento dessa concepção é baixo, restrito a alguns setores - em especial o setor público da CUT - e a algumas lideranças. Como exemplo o depoimento de diversos dirigentes sindicais que participaram de atividades formativas no tema de políticas públicas, em especial sobre a ação nas Comissões Municipais de Trabalho e Emprego. O relato demonstra o quanto ainda falta de entendimento sobre a representação sindical nos conselhos de políticas públicas. (CUT, 1999)
} 
Antes do terceiro pano de fundo, deve-se ressaltar que, diante do contexto dos anos 1980 e 1990, de profundas mudanças na sociedade brasileira, persiste, de modo praticamente inalterado, a legislação sindical corporativa instituída nos anos 1930. Aparece então a questão se o corporativismo estatal não estaria em flagrante obsolescência e, consequentemente, estaria iminente a necessidade de alteração da legislação sindical. Em outras palavras, é possível à estrutura sindical corporativa persistir no novo contexto de desregulamentação e crise do trabalho?

O malogro da reforma sindical proposta no FNT em relação à superação da estrutura sindical corporativa fortaleceu as interpretações acerca de sua mera persistência ou mesmo de seu reforço simplesmente. Mas a visão dissimula as mudanças que vêm se processando de forma mais silenciosa, por meio de medidas administrativas tomadas pelo Ministério do Trabalho e Emprego (MTE), e a partir de práticas sindicais, ao arrepio da lei. Essa pesquisa compartilha a visão de que as mudanças em curso podem resultar futuramente na superação do atual sistema corporativo, o que não significa que o modelo vigente esteja inócuo e viva seu último momento. Não se alimenta aqui a perspectiva de que tais mudanças conduzirão a um regime de liberdade e autonomia sindical por si só, mas também não corresponderá mais ao projeto do modelo corporativo como em sua origem. As mudanças processadas indicam uma situação de coexistência, contraditória, entre o velho modelo corporativo e algo novo em processo, objeto de disputa política. Quanto mais persistirem os elementos da atual estrutura corporativa frente às transformações aludidas, adaptando-se ao novo contexto para deixar tudo como está, maior será a possibilidade de perda de legitimidade de representação sindical e efetivação, a frio, das medidas flexibilizadoras do mercado de trabalho, sem qualquer papel dos sindicatos na defesa dos interesses dos trabalhadores.

Passando ao terceiro pano de fundo - o sistema de intermediação de interesses entre os atores -, pensar na manutenção ou mudança da ordem corporativa pressupõe discussão que vai além da alteração na legislação sindical e da disputa de projetos na sociedade, refletindo também acerca das relações entre Estado e sociedade. Ou seja, o sentido de Nação que se quer erigir a partir de um projeto de sociedade, e o papel que caberá ao Estado na relação com os interesses dos atores na sociedade.

Schmitter (1979), apoiado em Manoïlesco, assinalou: 
"El corporativismo puro (léase social)... sólo podrá alcanzarse después del muy difundido desarrollo de la 'conciencia corporativa', y de un grado tal de interés en su integración nacional que las 'viejas' y 'artificiales' lealtades de clase y de partido hubiesen sido erradicadas o, al menos, gravemente socavadas. Esto, reconoce, está aún muy lejos y, mientras tanto, esos 'imperativos de la época' exigen acción, especialmente en la periferia. Allí, el corporativismo subordinado es la única respuesta: 'Es natural que las corporaciones se mantengan bajo una tutela. El tutor indicado ...es el partido único ...por un período transitorio" [1937:134], (SCHMITTER, 1979:55)

O corporativismo social, ou neocorporativismo, seria, para Manoïlesco, sequência do corporativismo estatal, fruto de desenvolvimento da sociedade.

A tese aqui desenvolvida trabalha a partir da hipótese de que, no Brasil, o corporativismo em seu tipo estatal ganha contorno diferenciado ao incorporar, nos anos 1980, elementos do corporativismo social e mesmo do pluralismo.

Compartilhamos a visão do autor de que os conceitos de corporativismo (estatal e social) e de pluralismo são um tipo ideal. (SCHMITTER, 1979: 25)

Segundo Cohn (1986), a acepção de tipo ideal em Max Weber significa:

“... recurso metodológico para ensejar a orientação do cientista no interior da inesgotável variedade de fenômenos observáveis na vida social. Consiste em enfatizar determinados traços da realidade (...) até concebê-los na sua expressão mais pura e consequente, que jamais se apresenta assim nas situações efetivamente observáveis. Por isso mesmo, esses tipos necessitam ser construídos no pensamento do pesquisador, existem no plano das idéias sobre os fenômenos e não nos próprios fenômenos”. (COHN, 1986:8)

Considerando tais panos de fundo e partindo desse ponto em comum que permeia a trajetória do sindicalismo-CUT e a estrutura sindical corporativa, esta pesquisa analisará o tema a partir de prisma metodológico que enfatiza duas grandes dimensões que se articulam e se complementam no que será chamado de dinâmica interna e dinâmica externa.

Tomado sob o ponto de vista da dimensão interna, o sindicalismo-CUT será compreendido como organização burocrática, com estatutos próprios, resoluções congressuais, identidades 
constituídas, disputa entre correntes e grupos políticos, ou seja, a dinâmica interna de existência.

A dimensão interna é influenciada diretamente pelo arcabouço jurídico da legislação sindical, que procura moldar certo padrão de intervenção pública das entidades sindicais.

No que se refere à sua dimensão externa, compreender-se-á o sindicalismo-CUT como órgão de "representação de classe". E que, por isso, tem a face pública de se constituir como ator social, lidando com questões externas à entidade, que se refletem nas lutas sociais e se relacionam com momentos mais intensos de mobilizações e refluxo da ação sindical.

A dinâmica externa das lutas sociais, por sua vez, relaciona-se a contextos mais gerais sociais, políticos e econômicos - do país. Em plano mais profundo, com transformações do próprio padrão capitalista de acumulação de capital.

Compreender o momento atual do sindicalismo-CUT frente à estrutura sindical corporativa implica reconhecer em sua trajetória as ambiguidades de seu projeto político-organizativo em relação à prática sindical vigente. Busca-se apreendê-la nas dimensões interna e externa, abrangendo campo de complementaridade e contradições entre ambas.

Analisar as vicissitudes da viabilização histórica da liberdade e autonomia sindical implica identificar em cada período da trajetória do sindicalismo-CUT como se estabeleceram as relações entre as dinâmicas internas (disputas internas do movimento sindical, resoluções congressuais etc.) e as dinâmicas externas (momentos de maior ou menor mobilização social, transformações no mundo do trabalho com precarização dos vínculos trabalhistas). E como a relação entre ambas "condicionou" cada contexto mais favoravelmente às mudanças ou à conservação da estrutura sindical oficial. Ainda que, frisamos, nenhuma delas (manutenção ou transformação) se imponha inteiramente sobre a outra.

Analisar a posição da CUT frente à estrutura sindical corporativista, considerando as dinâmicas internas e externas do sindicalismo-CUT, requer conhecer o contexto, que se alterou desde o surgimento da CUT, em 1983, até o momento de instalação do FNT, em 2003.

Em 20 anos, presenciou-se o fortalecimento da CUT e sua consolidação como a maior central sindical brasileira. A trajetória ascendente da CUT na sociedade brasileira deveu-se à sua força de mobilização com os trabalhadores, à conquista de diversas direções sindicais, 
e às lutas que ganharam as ruas e, muitas vezes, as galerias do Congresso Nacional e da institucionalidade política do país.

Os 20 anos que assistiram a "novos personagens entrando em cena", afirmando em alto e bom som a reivindicação de seus direitos de cidadania, também testemunharam no mesmo período profunda mudança na configuração econômica da sociedade brasileira. O modelo de substituição de importação, vigente desde a segunda metade do século XX e promotor de desenvolvimento vigoroso na economia do país, cedeu lugar à crise da dívida externa no início dos anos 1980, que se prolongou no que ficou conhecido como a "década perdida". A saída da crise, com a eleição do presidente Collor (1989) e do presidente Fernando Henrique Cardoso (1994 e 1998), foi a implementação de modelo neoliberal, no qual o mercado era o centro da solução dos problemas sociais, e o Estado se transforma no grande vilão, em especial os trabalhadores do serviço público.

O avanço político da (re)democratização em que se consolidou a institucionalização da participação da sociedade por meio de mecanismos de democracia direta em conselhos e vários fóruns bipartites e tripartites, coexistiu com período de ataque aos direitos sociais e trabalhistas. Conquistas históricas foram duramente atacadas como privilégios, e muitas retiradas.

A vitória de Lula na corrida presidencial de 2002 e de 2006 recolocou no cenário político a possibilidade de retomada do projeto sindical original da CUT em defesa da liberdade e autonomia sindical. Mas, tal como na filosofia de Heráclito (504-501 a.C.), "nada permanece parado, e, comparando o que existe à corrente de um rio, diz que não se poderia penetrar duas vezes no mesmo rio”. (Platão, Crátilo, 402 a.C.). O projeto político que deu origem ao sindicalismo-CUT foi sendo ressignificado. Não conseguiu ser recolocado no contexto do governo Lula, ao menos do modo como inicialmente se havia imaginado. Sua trajetória e conquistas adentraram outros caminhos da política.

A hipótese que guia este trabalho é de que, ao longo dos 25 anos de existência, a ação do sindicalismo-CUT veio provocando mudanças no modelo sindical corporativista. Diante de novo contexto e desafios do decorrer da trajetória da CUT, o projeto original em defesa da liberdade e autonomia sindical plena, consubstanciado na ratificação da Convenção 87 da Organização Internacional do Trabalho (OIT), agregou projeto de fortalecimento de participação nos espaços democráticos e de consolidação da cidadania, que inclui a 
redefinição da relação Estado/sociedade no Brasil. A bandeira de liberdade e autonomia sindical se ressignificou e continua vigente ao incorporar o intuito de fortalecer o papel de representação e negociação da Central nas instâncias bipartites e tripartites ${ }^{9}$.

Dito de outro modo, para enfrentar a pressão do ideário neoliberal hegemônico nos anos 1990, a CUT procurou se opor, ampliando o raio de ação e abraçou proposta alternativa que a aproxima de um modelo neocorporativo, fortalecendo-se como "jogador ativo" do sistema político.

Mas não foi só o enfrentamento ao neoliberalismo que conduziu a CUT a perfil neocorporativo, ou seja, por uma postura reativa e defensiva. As conquistas consubstanciadas na Constituição Federal de 1988, com a instauração de nova institucionalidade democrática no país - os diversos conselhos de políticas públicas e conferências -, com a participação de representantes dos trabalhadores, em que a CUT tem assento, foram também definidores de uma nova estratégia da CUT.

Desse ponto de vista, o caminho que conduziu a CUT a uma proposta neocorporativa não foi apenas reação ao neoliberalismo, mas fruto de conquistas de espaços democráticos na sociedade nos anos 1980. Conquistas fruto de intensa organização, mobilização e luta dos setores populares.

Para aprofundar o conceito de corporativismo, recorremos mais uma vez a Schmitter:

"El ejército de los corporativistas es tan dispar que nos hace pensar que la palabra corporación es en sí misma una etiqueta colocada a todo un grupo de botellas que luego se distribuyen entre diversos productores, cada uno de los cuales las llenará con su bebida predilecta. El consumidor deberá estar atento [Baudin, 1942:4-5]

La situación se confunde más aún por el hecho de que muchos teóricos, ideólogos y activistas contemporáneos están vendiendo la misma bebida con etiquetas diferentes. (...) En suma, considero simplesmente que hay demasiada variedad normativa e hipocrersía en el uso del corporativismo a nível ideológico para que sea un instrumento operativo útil en el análisis comparativo”. (SCHMITTER, 1979:18-19)

\footnotetext{
${ }^{9}$ Essa perspectiva que vem sendo construída na trajetória da CUT tem sido vigorosamente criticada por diversos autores no universo acadêmico, como Antunes (2006), Alves (2000), Boito Jr. (1994 e 1999), Galvão (2007). Mais adiante, entraremos nas considerações dos autores.
} 
Aqui, a complexidade do conceito de corporativismo. Há até mesmo polissemia no uso da expressão, e talvez devesse ser usada no plural: corporativismos. O corporativismo pode ser compreendido, por um lado, como projeto de sociedade e de Nação, que impele a determinada forma na relação entre Estado e sociedade. De outro, enquanto legislação que estabelece normas estipulando como devem ser tais relações. Também como cultura cultura política. $\mathrm{Ou}$, ainda, como padrão na relação Estado-sociedade imbuído de projeto de Nação. Por mais diversa seja a compreensão acerca do fenômeno, há conexões entre os vários sentidos que assume o conceito de corporativismo. Caberia perguntar, portanto: que tipo de corporativismo a CUT está procurando superar? O corporativismo enquanto norma/lei? O corporativismo como cultura? Ou como projeto de sociedade? Atuar na alteração legal da estrutura corporativa por si só conduz à superação do corporativismo como sistema político? Dúvidas pertinentes que precisariam ser enfrentadas para dar maior clareza ao projeto da CUT. Embora essas dimensões se relacionem e de certa forma se retroalimentem, a ênfase da CUT quando se refere à superação do corporativismo recai mais à alteração legal. Muitas vezes sem se dar conta que a cultura política corporativa enraizada no habitus de dirigentes e militantes sindicais interfere e inviabiliza o projeto.

Estudos sobre sindicalismo indicam a enorme complexidade que cercou a edificação da estrutura corporativa no Brasil, as vicissitudes do processo e as resistências no percurso. Grosso modo, de 1931 à promulgação da CLT, em 1943. A desmontagem dessa estrutura, tema desta pesquisa, também tem ocorrido de forma lenta e processual. Porém, talvez a diferença entre um processo e outro esteja no ator social protagonista - no primeiro, o Estado; no segundo, a CUT ${ }^{10}$ - e na governabilidade para levar adiante seu projeto. Considerando esses fatores - a menor governabilidade sobre seu projeto e a cultura consolidada no modus operandi de dirigentes e militantes sindicais - e talvez por causa deles, a CUT nunca conseguiu cumprir o propósito inicial de pôr fim à estrutura corporativa. Pelo menos não da maneira como supunha, em ato que marcaria o ápice de heroica luta. Ao contrário, cerne desta tese, as mudanças na estrutura corporativa estão se processando lentamente, em direção a um modelo com elementos do neocorporativo. E que

\footnotetext{
${ }^{10}$ Não queremos com isso afirmar que a CUT encarna com exclusividade o papel de promover a superação da estrutura corporativa, nem do ponto de vista histórico evidentemente, pois várias organizações tiveram esse desafio nos anos 1940, 1950 e 1960 (MUT, PUI e PUA, CGT, entre outros), nem mesmo na atualidade, em que ela concorre com o projeto de outras centrais sindicais para sua efetivação, embora a CUT tenha maior peso político/institucional e maior acúmulo na elaboração das alternativas ao corporativismo.
} 
permanece inconcluso justamente por causa do fato de que a implementação é parte de disputa ideológica em torno de projetos distintos de Nação. Estão em jogo a inclusão econômica, social e política da classe trabalhadora ou a prevalência dos interesses de mercado.

A CUT, portanto, permanece voltada para o fim da estrutura sindical corporativa, intenção que esbarra na cultura política enraizada em dirigentes e militantes sindicais. E se deve, entre outros fatores, às resistências abertas ou latentes em encampar na prática o fim do modelo corporativista herdado do regime de Vargas, obstaculizando as mudanças legais necessárias. Como projeto de Nação, a CUT aderiu ao padrão de relação Estado/sociedade baseado no corporativismo societal (neocorporativismo).

O processo de democratização dos anos 1980, do qual, entre outras coisas, resultou a criação e consolidação da CUT, e a promulgação da Constituição de 1988 conduziram ao arrefecimento dos constrangimentos vigentes na CLT e à efetivação de incentivos que minaram o ímpeto transformador do "novo sindicalismo". (Boito Jr., 1991a e 1991b).

Embora concorde com a análise de Boito Jr. acerca da perda de vigor do sindicalismo-CUT pelo fim da estrutura sindical corporativista, acentuo a divergência quanto à consequência da constatação. Para ele, o distanciamento da CUT da luta pelo fim da estrutura sindical corporativista significa capitulação e entrega a um sindicalismo de colaboração de classe:"o sindicato de Estado é, sempre, e ao contrário do que se passa com outros tipos de sindicalismo, uma instituição que amortece os conflitos de classe" (Boito Jr, 1991: 15 e 16 - grifo do autor).

Nossa visão é bem diversa. O sindicalismo-CUT tem operado mudanças paulatinas em sua estratégia não por ter em vista atuação meramente de colaboração de classes, mas para efetivar avanços nas lutas e conquistas sociais, alterando o caráter do corporativismo na sociedade brasileira. De corporativismo estatal para corporativismo societal, em que a central sindical teria papel preponderante de representação, negociação e conquistas.

A CUT traduziria, em sua estratégia, a combinação de corporativismo social, ou neocorporativismo (participação propositiva em espaços públicos, como as câmaras setoriais, ou mesmo em conselhos, como o Codefat, o Conselho Nacional de Desenvolvimento Social - CNDS - instituído no governo Lula, e diversos outros conselhos e comissões de políticas públicas) a aspectos do corporativismo estatal, baseados em 
políticas inclusivas e em incentivos, e não em constrangimentos. ${ }^{11}$ Do mesmo modo, a CUT conviveria também com algum grau de pluralismo diante da concorrência com as demais centrais sindicais, como Força Sindical, União Geral dos Trabalhadores (UGT), Nova Central Sindical dos Trabalhadores (NCST), Central Geral dos Trabalhadores do Brasil (CGTB), Coordenação Nacional de Lutas (Conlutas) e Intersindical.

A atuação da CUT na reforma sindical se baseou no princípio da liberdade e autonomia sindical, para fortalecer o poder de representação e de negociação sindical, em que o Estado, ao contrário de se retirar totalmente, teria papel de promover garantias legais para a liberdade sindical (a partir de legislação de sustento e do Conselho Nacional de Relações de Trabalho - CNRT) e de regular o mercado, introduzindo atores sociais como a CUT no desenho das políticas sociais e econômicas. Por exemplo, a partir das câmaras setoriais, ou mesmo na participação em conselhos como o Codefat, o CNDS do governo Lula etc.

O governo Lula tem sido parceiro estratégico da CUT, em que pese algumas divergências entre a central sindical e o governo. Seria possível erigir nesse governo uma ordem neocorporativa como sistema político, em um modelo de desenvolvimento com padrão popular de inclusão dos mais pobres (mas não mais no viés populista dos anos 1940/1950 e 1960), mesmo com concessões ao mercado.

O objeto desta pesquisa é o sindicalismo-CUT, conjunto de instituições que se complementam, e ao mesmo tempo guardam especificidades e certa autonomia políticoorganizativa: sindicatos filiados, federações e confederações filiadas ou orgânicas à CUT, CUTs estaduais e CUT Nacional.

Abordar a CUT sob esse prisma implica reconhecer a enorme diversidade, por vezes traduzida em conflito de interesses. Há a CUT com característica específicas no setor privado. E mesmo no setor privado, não se imprime o mesmo tom à CUT do setor metalúrgico e à da construção civil, por exemplo. E há CUT do setor público e entre os rurais. Do mesmo modo, a diversidade se completa nas regiões. A especificidade do sindicalismo-CUT na Região Norte é bem distinta do que se passa nas regiões Sul e Sudeste. Portanto, falar em CUT implica unidade em meio a enorme diversidade.

\footnotetext{
${ }^{11}$ Desse ponto de vista, mesmo a manutenção do imposto sindical é combatida no discurso, mas "tolerada" na prática; e não haveria mais a necessidade de constituir federações/confederações fora da legislação, mas que sejam reconhecidas pelo Ministério do Trabalho e Emprego (MTE).
} 
São foco da pesquisa as resoluções da CUT Nacional, tomadas nas reuniões da Direção, Plenárias ou Congresso, fórum máximo de deliberação da Central. Mas, se preciso, serão mencionadas as estratégias e práticas das demais entidades cutistas, como exemplo de ações do sindicalismo-CUT no enfrentamento da estrutura corporativista.

O trabalho está assim organizado:

$\mathrm{Na}$ introdução há um apanhado geral do que será exposto no corpo da tese, situando algumas questões.

O primeiro capítulo - A CUT e o governo Lula - procura elaborar breve digressão da história da CUT, a fim de ressaltar a construção da afinidade entre seus projetos. E também compreender o cenário que o presidente Lula teve que enfrentar ao tomar posse em 2003 e os conflitos que advieram, tensionando o sindicalismo-CUT e provocando as primeiras defecções de correntes políticas.

O interesse é revisitar esse contexto, para perceber as condições sob as quais Lula assumiu o governo em 2003 e o "passivo" que a CUT teve de administrar após o período adverso dos anos 1990, a fim de recuperar direitos atacados. É importante situar a distância social entre as condições reais do governo Lula e as demandas reprimidas da CUT. Não só para compreendermos o tensionamento interno diante da postura a ser adotada frente ao governo Lula (que gerou as primeiras cisões na história da CUT), mas também desdobramentos da reforma sindical, tema da pesquisa.

O segundo capítulo - A Trajetória da CUT frente ao Corporativismo - visa resgatar, mesmo sumariamente, a trajetória da CUT vis-à-vis à estrutura sindical corporativista. Em outras palavras, como a CUT solidificou seu caminho. Ou, ainda, como orientou concretamente propostas político-organizativas para superar a estrutura corporativa herdada de Vargas, propósito da Central no período de fundação, no início dos anos 1980. E as mudanças que ocorrem nessa trajetória.

O caminho tentará ser refeito, poupando detalhes que constam de farta bibliografia, e que, por isso, se tornaram praticamente de domínio público.

A intuição é que, ao se passar novamente pelo caminho, contando com o benefício do tempo - que permite compreensão a posteriori - talvez se identifiquem momentos de inflexão nessa trajetória que quem a viveu, dirigentes e militantes, no calor do debate e 
votações congressuais, não tinha possibilidade, exceto em exercício de "futurologia", de saber precisamente o "destino" então edificado para a Central.

Por outro lado, a vantagem de se olhar posteriormente aos acontecimentos carrega o risco da tautologia, ou seja, reconstituir o passado de modo a justificar o que se vive no presente. Como se todos os passos tivessem sido dados para chegar à situação da atualidade.

Cumpre o dever de "reviver" o ambiente em que as decisões foram tomadas, entendendo a lógica e os argumentos que as presidiram naquele momento, mas conhecendo os desdobramentos futuros.

O capítulo terceiro trata especificamente da Reforma Sindical, amplamente debatida no FNT. Tendo identificado nos capítulos anteriores a relação CUT/governo Lula, suas dificuldades e desafios diante da estrutura sindical corporativa, se abordarão como ocorreram os debates, êxitos alcançados e o impacto, na CUT, da discussão gerada no FNT. Seguem algumas reflexões nas considerações finais.

A sociologia sempre posicionou como tema metodológico central a relação sujeito-objeto. Diversos autores das ciências sociais, dos clássicos aos contemporâneos - Durkheim, Weber, Marx, Lévi-Strauss, Malinowski e Bourdieu, entre outros - adotaram diferentes perspectivas na busca de postura isenta do pesquisador diante do tema pesquisado.

Esta pesquisa tomou toda a precaução necessária para não impregnar no resultado final do trabalho a percepção do autor como militante que trabalha profissionalmente na área de formação sindical da CUT há mais de 20 anos (desde 1987).

$\mathrm{Na}$ trajetória pessoal acompanhei vários eventos e momentos que marcaram a trajetória da CUT.

O lugar de onde foram acompanhados os principais acontecimentos da história da CUT possibilitou facilidades no desenvolvimento da pesquisa, ao mesmo tempo que provoca o risco de o trabalho se perder na tênue linha demarcatória entre o cientista social e o profissional militante. Tarefa difícil. Não há como dicotomizar pesquisador/militante. Não se trata de ser ora pesquisador, ora militante. A identidade construída nessa trajetória carrega, intrinsecamente, a dupla dimensão. Evidentemente não cabe ao autor fazer juízo de valor, mas compreender "o estado da arte" e refletir quais caminhos se seguirão na longa e 
tortuosa estrada da CUT ante o corporativismo, as inovações surgidas e tributos do passado que se consolidam.

Espero conseguir, como pesquisador, contribuir para a reflexão da militância, que tem a tarefa prática de seguir aperfeiçoando a CUT, encarando os novos desafios da organização dos trabalhadores. Sempre em busca de uma sociedade socialista e democrática, pautada na cidadania ativa e justiça, e em maior igualdade entre as pessoas. 


\section{Capítulo 1 - A CUT e o governo Lula}

Discorrer sobre a relação da CUT com o governo Lula implica remontar uma antiga história, que vem do final dos anos 1970, quando a CUT e o PT não existiam formalmente, mas estavam sendo gestados a partir das lutas populares do período ${ }^{12}$.

A CUT, desde a sua fundação, em 1983, esteve fortemente associada ao PT. Em todas as campanhas do candidato Lula à presidência, desde 1989, exerceu papel importante de capilaridade entre os trabalhadores, no conjunto da sociedade.

A associação CUT-PT se explica pelo momento histórico em que ambas foram criadas, fruto do mesmo movimento vigoroso de ascensão dos movimentos sociais no final dos anos 1970 e início da década de 1980, que marcou a história do Brasil.

Conforme Sader (1988), "novos personagens entraram em cena”. Trabalhadores do campo e das cidades, nas fábricas, bancos, escolas, hospitais e escritórios, servidores públicos e da iniciativa privada foram aos poucos ganhando espaço no "teatro" em que se desenrolava a política brasileira. Reivindicavam todos os direitos a que nunca tinham tido acesso e se opunham àquilo que representava obstáculo.

Ganhou corpo um caráter popular à luta contra a ditadura militar, redemocratização da sociedade e luta por direitos em todas as esferas da sociedade: direito à saúde e educação pública, universal e gratuita; reforma agrária; recuperação das perdas salariais para a inflação, contra a carestia e aumentos reais de salário; defesa do emprego etc.

De acordo com Sader, a raiz daquele movimento fundamentava-se em três grandes pilares: primeiramente, a teologia da libertação, que imprimia caráter mais popular e emancipatório ao trabalho religioso das Comunidades Eclesiais de Base (CEBs) e Pastorais. Pelo método "ver-julgar-agir", inúmeros cristãos analisavam a difícil realidade social do povo, à luz dos ensinamentos do evangelho, e colocavam-se em ação para mudar a situação.

O segundo pilar foi a contribuição do marxismo como instrumento de explicação da sociedade capitalista, que provinha de inúmeros grupos organizados de esquerda, alguns

\footnotetext{
${ }^{12}$ Há um conjunto enorme de autores que percorreram esse caminho. Nesta tese parti de minha dissertação de mestrado (LADOSKY, 1995) e tomei emprestadas as contribuições de HARNECKER, 1994; SADER, 1988; SANTANA, 2001; RODRIGUES, 1997; RODRIGUES, 1990 e 1991; ZANETTI, 1993 e VÉRAS, 2002. Exatamente porque essa é uma história há bastante tempo analisada, furtei-me em fazer uma digressão longa e detalhada do período.
} 
deles experimentado a via armada de enfrentamento ao regime militar. Adensava-se a capacidade analítica sobre o sistema capitalista, desvendando forma específica de exploração sobre o trabalho e contradições da sociedade de classes.

E o terceiro pilar ficou conhecido como "novo sindicalismo", que aglutinava dirigentes egressos dos sindicatos oficiais, mas, a partir da sua prática, se tornou importante ponto de apoio para as lutas sociais, sobretudo nas campanhas salariais. ${ }^{13}$

Juntos, os três "afluentes" formaram um grande rio, do qual partiu a criação do Partido dos Trabalhadores (PT) em 1980; da Central Única dos Trabalhadores (CUT), em 1983; e do Movimento dos Trabalhadores Sem Terra (MST), em 1984. Atores centrais no cenário político brasileiro nos anos 1980, exerceram significativo papel de pressão popular sobre a Assembleia Nacional Constituinte em torno dos direitos sociais e trabalhistas.

Refletindo o contexto de democratização e grande vigor das organizações populares, a bancada de pouco mais de 20 deputados federais, ligados aos partidos de esquerda, enfrentou o "Centrão" (bloco de parlamentares conservadores) e conseguiu garantir, na Carta Magna, diversos direitos sociais, posteriormente regulamentados em legislação específica. Surgiram, por exemplo, o Sistema Único de Saúde (SUS) e o Estatuto da Criança e do Adolescente (ECA), entre outras reivindicações. O reconhecimento do avanço social ficou explícito nas palavras do então presidente do Congresso, o deputado Ulysses Guimarãres, quando, na promulgação da Constituição, em 1988, afirmou que era "Constituição cidadã".

No mesmo ano, 1988, o PT deu grande salto nas eleições municipais, conseguindo eleger, pela primeira vez, prefeitos de grandes capitais, como São Paulo, Porto Alegre e Vitória.

No ano seguinte, na primeira eleição direta à presidência da República após o regime militar, Lula, a principal liderança e expressão de todo o movimento popular e sindical, por pouco não vence o pleito.

Um dos fatores que explicam tamanha ascensão das lutas sociais encontra-se no movimento sindical ligado à CUT, que em poucos anos galga a direção de vários sindicatos e se legitima politicamente como a maior e mais representativa central sindical do país. Mas a capacidade de ação da CUT, segundo vários autores, foi "tonificada" pela manutenção da

\footnotetext{
${ }^{13}$ Voltaremos a esse ponto mais adiante, aprofundando, no capítulo 2, a análise do surgimento e da trajetória da CUT.
} 
estrutura sindical corporativa durante o período vigente da ditadura militar. Ao conquistar os sindicatos, o movimento cutista foi se apropriando de recursos financeiros, políticos e culturais e os disponibilizando para as lutas. (RODRIGUES, 1991; CARDOSO, 2003) Dados de Noronha (1991:95) indicam que houve crescimento de aproximadamente $1.800 \%$ no número de greves, de 1978 a 1988. Mobilizou-se no período um número anual de grevistas que se tornou 60 vezes maior: as jornadas não trabalhadas saltaram de 1,8 milhão para 132 milhões de horas. ${ }^{14}$

"A transição brasileira, apontada na literatura como pacto de elites, conservadora, ou, na expressão de O'Donnell e Schmitter, a 'transição transada', teve como contraparte a liberalização da expressão dos conflitos sociais. Mais que a liberalização, conforme assinalou Bolívar Lamounier, a cada passo da consolidação da democracia, a eclosão de novas demandas. Isto é, o lento processo de reconstituição da democracia formal no Brasil foi simultâneo à manutenção da exclusão de importantes segmentos sociais na definição das regras do jogo e à inexistência de avanços em direção à democracia social, sendo porém acompanhado de um processo crescente de pressões sociais. A greve foi uma das expressões mais evidentes dos temas e interesses não pactuados, não 'transados', mas altamente competitivos e conflituosos do processo de transição no Brasil." (NORONHA, 1991:97)

Paradoxalmente, ao longo dos anos 1980, a estrutura sindical oficial, corporativista, foi deslocada pela ação de força política vigorosa do sindicalismo-CUT: de uma posição histórica de freio das lutas, para a sustentação de condições materiais e políticas às ações no contexto específico dos anos 1980.

\section{A nova realidade dos anos 1990}

Os anos 1990, no entanto, marcariam profundas alterações no cenário político, que se desenrolaram desde o início dos anos 1980.

Segundo Mattoso (1999), a dinâmica do mercado de trabalho nos anos 1980 teve como uma de suas características acompanhar o nível de atividade econômica do país, de modo que a retração da atividade nos anos 1981-83 se expressou na elevação do desemprego. E o aquecimento no período 1984-86 trouxe melhora na oferta de emprego.

\footnotetext{
${ }^{14}$ Nota do autor: "Jornadas perdidas representam a somatória do resultado da multiplicação do número de grevistas pelo número de dias parados de cada greve de um determinado período ou ano." (NORONHA, 1991:95)
} 
No entanto, para o autor, viveu-se, nos anos 1990, um novo ciclo na atividade econômica no país.

"Na década de 1990 a situação alterou-se profundamente. Nesses últimos anos, o desempenho produtivo não foi apenas medíocre e resultante de efeitos de oscilações do ciclo econômico sobre o mercado de trabalho. A geração de emprego sofreu as consequências profundamente desestruturantes de um processo de retração das atividades produtivas, acompanhado do desmonte das estruturas preexistentes, sem que se tenha colocado no lugar outras capazes de substituí-las. Jogou-se fora o bebê com a água do banho. (...) Os anos 1990 indicam um desempenho negativo, sendo que no período 1995-98 a redução da geração de postos de trabalho formais ocorreu todos os anos, mesmo quando houve algum crescimento do PIB.” (MATTOSO, 1999: 11-17)

O início do "desmantelamento" da estrutura produtiva brasileira, de acordo com o mesmo autor, começou a ter seu primeiro contorno após a vitória de Fernando Collor de Mello nas eleições presidenciais de 1989, quando assume e promove radical abertura comercial do mercado brasileiro às importações. A justificativa para essa política era combater a inflação galopante que se estendera na década anterior, com a entrada de produtos com preço baixo no mercado nacional; e promover o desenvolvimento da indústria nacional, que se veria mais exposta à concorrência internacional e teria que se modernizar com maior celeridade. O resultado dessa política foi um mergulho do país na recessão, com o Produto Interno Bruto (PIB) tendo alcançado, em 1990, a marca de 3,4\% negativo, e uma taxa de desemprego aberto de $4,3 \%$ no mesmo ano. ${ }^{15}$

No mesmo período, grandes empresas começavam a aderir às inovações tecnológicas e organizacionais que nos chamados países centrais (Europa, EUA e Japão) eram padrão hegemônico em relação ao taylorismo-fordismo.

Os sindicalistas passam a se deparar com o instrumento de Programas de Qualidade Total para obter o compromisso dos trabalhadores com os interesses da empresa. Kanbam, Justin-time, modelo japonês, automação flexível, reengenharia, reestruturação produtiva,

\footnotetext{
${ }^{15}$ Dados do PIB têm como fonte IBGE, BC, Secex, FGV/IBRE/Conjuntura econômica, Indicadores IESP (MATTOSO, 1999:30). Na mesma tabela de evolução do PIB observamos que nos dois anos seguintes do governo Collor o crescimento econômico foi de 1,0\% e de - 0,5\%, respectivamente em 1991 e 1992. Em relação aos dados de desemprego, a fonte utilizada pelo autor foi a PED/SEADE-DIEESE e a PME/IBGE, e diz respeito ao total das regiões metropolitanas. Se considerarmos o desemprego total apenas na região metropolitana de São Paulo, a taxa em 1990 alcançou 10,3\%. Nos dois anos seguintes do governo Collor a taxa de desemprego no país chegaria a 5,8\% e a 15,2\% na região metropolitana de São Paulo (MATTOSO, 1999:12)
} 
terceirização etc. entram em pauta na agenda sindical e no vocabulário dos sindicalistas. (SANDRI, 1994)

Com as ações tomadas pelo governo Collor e grandes empresas transnacionais, o Brasil entrou subordinadamente no movimento de globalização de mercados.

O Estado, que pouco tempo antes havia se comprometido a promover a justiça social por meio dos direitos firmados na nova Constituição, passou a ser atacado diretamente pelo governante da ocasião. Os servidores públicos foram alvo direto de desmoralização pública, sob a pecha de "marajás", e os "privilégios" os principais causadores da crise fiscal do Estado. A “ordem” era reduzir o tamanho do gasto público a partir da redução dos serviços prestados pelo Estado, conforme figurino costurado pelas "regras" do Consenso de Washington: reduzir o papel do Estado, deixando as forças de mercado atuar livremente. Em uma só palavra: firmar o neoliberalismo no Brasil.

Na avaliação de Artur Henrique da Silva Santos, presidente da CUT no período 2006-2009, a CUT e seus sindicatos viveram naquele período um dos piores momentos de sua trajetória. Enfrentaram as inovações organizacionais das empresas, que disputavam corações e mentes dos trabalhadores nos locais de trabalho em meio à forte recessão, que desmobilizava a ação reivindicatória, diante de um governo legitimado pela consagração eleitoral do voto direto. (SOUZA, 2008)

No campo sindical, a CUT passou a ter corrente oponente de peso, com a criação da Força Sindical, fundada em março de 1991 sob a concepção de "sindicalismo de resultado". É, segundo algumas interpretações, visão afeita ao neoliberalismo para fazer a disputa com a CUT. (GIANNOTTI, 2002)

As denúncias de corrupção envolvendo a alta cúpula do governo deram outro tom à conjuntura. O movimento sindical, então na defensiva, alterou a correlação de forças quando se lançou, com outros setores da sociedade, à enorme campanha em defesa da ética na política, que resultou no processo de impeachment do presidente Collor e posse de Itamar Franco como presidente da República.

\section{O interregno do governo Itamar Franco}

O movimento iniciado no governo Collor de implementação de um projeto neoliberal teve pequeno interregno entre 1993 e 1994, quando se arrefeceu durante o governo do presidente Itamar Franco, então vice de Collor, que tomou posse definitiva em dezembro de 1992. 
As condições políticas da posse de Itamar Franco obedeceram a peculiaridades da conjuntura, impulsionado pela força das mobilizações de rua que haviam exigido a saída do presidente Collor.

O governo de Itamar foi formado por um conjunto de forças políticas heterogêneas, que procuraram dar sustentação ao novo presidente, diante da crise sem precedentes na história do país. Por esse motivo, o governo Itamar oscilou entre políticas contraditórias: de um lado, o ideário de tipo nacionalista; de outro, a pressão pela aceitação do projeto neoliberal em andamento.

O resultado foi a paralisação do movimento de privatização das empresas estatais e o estímulo à indústria nacional, simbolizado pela retomada da produção do Fusca, carro popular da Volkswagen que havia saído de linha. Além disso, o governo Itamar foi o principal fiador do Plano Real, precursor da futura política econômica do presidente Fernando Henrique Cardoso, até então comandando o Ministério da Fazenda.

Do ponto de vista do movimento sindical, o curto período da presidência de Itamar sinalizou a possibilidade de alternativa importante para participação mais ativa na negociação de novo desenho na política industrial do país em uma direção oposta à dada no governo Collor.

Ao contrário da desestruturação, seriam firmadas as câmaras setoriais, instrumento de negociação tripartite entre governo, empregadores e trabalhadores, em diversos setores econômicos tendo em vista agir dentro de cadeias produtivas para promover a elevação das vendas e da produção, com a manutenção do emprego. Foram organizadas câmaras no setor de bens de capital, eletroeletrônicos, indústria naval e outras. A de maior êxito foi a do setor automotivo. “As principais medidas tomadas para 'alavancar' os setores foram a renúncia fiscal, com a redução das alíquotas do Imposto de Circulação de Mercadorias e Serviços (ICMS) e do Imposto sobre Produtos Industrializados (IPI)”. (DIEESE, 2005) O presidente Itamar se comprometeu pessoalmente, avalizando acordo entre os sindicatos de petroleiros e a Petrobras, concedendo reposição das perdas salariais mais ganho real. As eleições presidenciais de 1994 teriam que pôr fim às contradições de um governo errático, entre um tipo de nacionalismo desenvolvimentista e o neoliberalismo. 


\section{A continuação do projeto neoliberal: o governo FHC e a "herança maldita"}

O ideário neoliberal volta fortemente, e se completa nos dois mandatos seguidos do presidente Fernando Henrique Cardoso - 1995 a 2002.

Ressalte-se o estudo de Adalberto Cardoso, segundo o qual "dados em Batista Jr. (1998:46-47) revelam que os países do G-7 aumentaram o gasto público (como proporção do Produto Interno Bruto, PIB) de 36,3\% na média do período 1978-82, para 39,4\% entre 91-95. Nos países da Organização para Cooperação e Desenvolvimento Econômico (OCDE), o salto foi de 37,3\% para $40,7 \%$. A dívida pública bruta deu um salto espetacular na OCDE de $42 \%$ para $66,61 \%$ do PIB, nas duas pontas. Ao contrário do que apregoa a cartilha neoliberal, pois os Estados nacionais no primeiro mundo estão aumentando sua presença na geração do produto. $\mathrm{Ou}$, como afirma Batista Jr., "o 'neoliberalismo' reina, mas não governa, e as homenagens prestadas a essa ideologia contrastam com a limitada influência prática no mundo desenvolvido" (id., p.49). Isso leva Mattoso (1996:35) a afirmar que a idéia de Estado mínimo que alimenta o discurso neoliberal tem componente que se destina "preferencialmente para o consumo de governos de países do sul"." (CARDOSO, 2003:83)

Entretanto, adverte o autor, "na periferia do capitalismo, o discurso neoliberal ganhou substância e fomos (brasileiros, argentinos, chilenos, mexicanos...) todos muito zelosos na aplicação da receita”. (CARDOSO, 2003:84)

Resumidamente, o autor mostra a lógica do receituário neoliberal que articula os seguintes fatores: abertura comercial - exposição das empresas nacionais à concorrência internacional - câmbio valorizado em relação ao dólar - acúmulo de déficits na balança comercial - necessidade de atração de capital externo para equilibrar as contas públicas e sustentar a política cambial ("paridade" com o dólar) - necessidade de elevar a taxa de juros para atrair esse capital externo (o chamado "capital especulativo") - acúmulo da dívida pública interna - necessidade de reequilibar as contas públicas por meio de ajustes fiscais - aumento na arrecadação a partir de impostos; contenção de gastos públicos - com a promoção da Reforma do Estado (privatizações e desregulamentação de direitos, entre eles os direitos trabalhistas). Tudo isso para o Estado ficar enxuto e permitir o livre funcionamento do mercado.

As medidas econômicas adotadas no início do primeiro mandato de FHC foram continuação do Plano Real do governo Itamar. Fernando Henrique assumiu o Ministério da 
Fazenda em maio de 1993, retirando iniciativas que dotassem o Estado de capacidade indutora da atividade econômica do país. Segundo Mattoso, "Collor e Fernando Henrique Cardoso apostaram todas as fichas na 'modernidade' supostamente virtuosa da desregulamentação da concorrência e da globalização financeira internacional (...) $[\mathrm{FHC}]$ acreditou que bastava integrar o país rapidamente à nova economia internacional, sem nenhum tipo de salvaguarda. Para tanto, consolidou a abertura comercial e financeira indiscriminada, iniciada por Collor e Itamar Franco, dispensou a constituição de um projeto de desenvolvimento ou de políticas setoriais de defesa da produção e do emprego nacionais como 'corporativas' ou 'inflacionistas'." (MATTOSO, 1999: 22-25)

Para debelar a inflação que insistia em voltar em alto patamar, a política econômica adotada pelo novo governo residiu em ancorar o valor da nova moeda (Real) ao valor do dólar americano $^{16}$. O grande êxito do controle inflacionário, que levou ao aumento do consumo e, no curto prazo, à elevação da produção e do emprego, ofuscou a percepção de outros efeitos que aquela política traria em longo prazo.

“....a conta de transações correntes do balanço de pagamentos, refletindo o processo de reversão ocorrido nos saldos da balança comercial - que de superavitária se tornou, ano a ano, deficitária - e de elevação dos déficits da balança de serviços, também passou a apresentar, ano a ano, déficits elevados e crescentes, que implicaram aumento dramático da vulnerabilidade externa do país. Comparando-se os períodos pré-Real (1990/1994) e pós-Real (1995/1998), consta-se que o saldo acumulado da balança comercial evoluiu de superávit de US\$ 60,3 bilhões para déficit de US\$22,4 bilhões. O saldo negativo acumulado pela balança de serviços passou de US\$ 70,5 bilhões para US\$ 92,7 bilhões. Como decorrência, o saldo negativo da conta de transações correntes passou de US\$ 1,6 bilhão para US\$105,8 bilhões." (FILGUEIRAS e PINTO, 2003)

A consequência da deterioração das contas externas, segundo os autores, foi a piora das finanças do setor público ${ }^{17}$ e manutenção de elevadas taxas de juros, levando à redução do PIB de 4,22\% em 1995, para 0,13\% em 1998.

Em suma, com exceção da estabilidade monetária - que, posteriormente, em 1999 e em 2002, também evidenciou, mais explicitamente, suas dificuldades -, o desempenho da

\footnotetext{
${ }^{16}$ Em março de 1994 o governo Itamar lança a Unidade Real de Valor (URV), transformada no Real em julho. A inflação, de $750 \%$ no primeiro semestre, cai para $18,6 \%$ no segundo. O dólar cai até R\$ 0,83 . No dia 3 de outubro, Fernando Henrique é eleito presidente da República no primeiro turno. (DANTAS, 2003)

17 A dívida líquida do setor público aumentou sistematicamente, tanto em termos absolutos, quanto como proporção do PIB. A dívida líquida do setor público evoluiu de R \$ 153,7 bilhões (30\% do PIB), em dezembro de 1994, para R\$385,9 bilhões (41,7\% do PIB) em dezembro de 1998.
} 
economia brasileira no primeiro governo FHC se mostrou muito ruim, tendo culminado, dramaticamente, com grande crise cambial, que atingiu o auge no início do segundo governo.

Assim, este se iniciou sob o signo de dois grandes problemas, durante muito tempo os mais graves da economia brasileira: a vulnerabilidade externa do país e a fragilidade financeira do setor público - que dificultavam o crescimento do PIB, a redução das taxas de desemprego e a gestão das políticas macroeconômicas e principalmente sociais.

A análise do segundo governo FHC evidencia que, a despeito da mudança do regime cambial, os problemas continuaram a existir. Apesar de a desvalorização do real, em janeiro de 1999, ter impedido - pelo lado da conta de transações correntes - o aprofundamento da deterioração do balanço de pagamentos do país.

Entretanto, a despeito dos problemas do modelo e gozando de grande prestígio popular pelo controle da inflação, o governo federal incrementou a redução do Estado por meio de programas de privatização das empresas estatais da União. Em 1994 se iniciou o processo de extinção dos monopólios estatais em telecomunicações, petróleo e energia elétrica, com as reformas constitucionais de ordem econômica. Em 1996 começou a fase de transferência de serviços públicos à iniciativa privada nas áreas de transporte, telecomunicações e eletricidade. Atingiu-se a cifra de R 91 bilhões com a venda das ações na Bolsa de Valores em dois mandatos de FHC. Em maio de 1997 foi vendida a Companhia Vale do Rio Doce por R \$ 3,34 bilhões. E em julho de 1998 privatizado o Sistema Telebrás, por R 22 bilhões (DANTAS, 2003).

Sob a alegação ideológica de que, pelo fato de serem estatais, eram menos eficientes, a Companhia Siderúrgica Nacional (CSN), Vale do Rio Doce, Embratel, o sistema Telebrás (Telesp, Telerj, etc.), por exemplo, se tornaram empresas da iniciativa privada de capital nacional ou estrangeiro.

O recurso obtido pela venda dessas companhias era drenado em boa medida para o equilíbrio das contas federais, pois deveria ser honrado o compromisso com os investidores que aportavam dólares em papéis do Tesouro Nacional. A crise financeira da Coreia e da Malásia, em 1997, levou à desvalorização da moeda daqueles países e afetou o Brasil que se viu obrigado a aumentar a taxa básica de juros, a Selic, de $19 \%$ para $45 \%$. No ano 
seguinte, em agosto de 1998, a crise da moratória russa fez o Brasil sofrer ataque especulativo elevando ainda mais a taxa básica de juros, que subiu para 49,75\%.

Esse foi um dos motivos que fizeram o país a recorrer a empréstimo de US\$ 41,5 bilhões do Fundo Monetário Internacional (FMI) em novembro de 1998, depois de garantida a reeleição de FHC.

No calendário de crises internacionais que balançaram com o Brasil, houve ainda a forte crise econômica da Argentina, acentuada ao final de 2001, que contou com forte mobilização popular diária em oposição ao governo do presidente Fernando de la Rua, que renunciou ao cargo em 20 de dezembro.

Por outro lado, os direitos sociais conquistados com a Constituição de 1988 eram sonegados pela contínua deterioração dos serviços públicos. Surgiu nova "modalidade" de política social, que Vera Telles (2001) chamou de "refilantropização". Ao invés de garantir direitos constitucionais, apelava-se para programas sociais em que os beneficiários eram agraciados pela ação de entidades do Terceiro Setor, sobretudo ONGs, em substituição ao Estado. O programa de maior envergadura e visibilidade do governo federal foi o Comunidade Solidária. O então titular do Ministério da Administração e Reforma do Estado (Mare), Luis Carlos Bresser Pereira, formulou como eixo de sua proposta de reforma do Estado a concepção social-liberal (BRESSER PEREIRA, 1996), meio termo entre o Estado de Bem-Estar Social e o Neoliberalismo. Para ele, o Estado não deveria abdicar totalmente da função social, mas exercê-la em parceria com entidades não estatais. Com base nessa concepção, aprovou-se no Congresso Nacional a lei 9.790/99, que criava as Organizações da Sociedade Civil de Interesse Público (Oscips).

Os anos de mandato de Fernando Henrique Cardoso trouxeram novas dificuldades para a CUT e sindicatos, que ficaram atordoados, em nova defensiva política e ideológica.

\section{Precarização do trabalho e criminalização dos movimentos sociais}

A primeira demonstração de força do presidente em relação ao movimento sindical cutista aconteceu na greve dos petroleiros ${ }^{18}$, de 3 de maio a 2 de junho de 1995.

\footnotetext{
${ }^{18}$ A greve dos petroleiros fez parte de um movimento mais amplo do funcionalismo público federal e de estatais, que cobravam do novo governo o cumprimento de acordos feitos com o ex-presidente Itamar Franco. Poucos dias depois da deflagração da greve unificada, eletricitários e trabalhadores do Correio voltaram ao trabalho, diante das evidências de endurecimento e da impossibilidade de abertura das negociações. (RIZEK, 1998)
} 
Segundo Rizek (1998), o governo recém-empossado de FHC procurou criminalizar a greve dos petroleiros, forjando na opinião pública a oposição entre a defesa de privilégios representada na bandeira dos trabalhadores pela reposição das perdas inflacionárias, e a defesa do interesse público mais geral, expresso na defesa do Plano Real. Para a autora, outras questões estavam em jogo, como a desindexação salarial frente à inflação e a quebra do monopólio da Petrobras, que ocorreu em agosto do mesmo ano, 1995.

$\mathrm{O}$ endurecimento do governo e o fechamento de qualquer possibilidade de negociação fizeram da greve uma verdadeira guerra. A imprensa alardeava à população, no quinto dia da greve, a redução dos estoques de gás. Corria-se às distribuidoras a fim de evitar problemas a partir da continuidade do movimento ${ }^{19}$. Da mesma forma, a empresa anunciava prejuízos da ordem de R 200 milhões, pela importação de nafta e diesel. Diante disso, o Tribunal Superior do Trabalho (TST) julgou a greve abusiva, decorridos sete dias do movimento. A partir daí passou a cobrar R\$ 100 mil dos sindicatos por dia parado $^{20}$. O Exército ocupou as refinarias de Presidente Getúlio Vargas, no Paraná; Paulínia, Capuava e Henrique Lage, no Estado de São Paulo: 85 trabalhadores foram demitidos por justa causa. Diante dos fatos, a Folha de S. Paulo divulgou o resultado de pesquisa de opinião, em que "60\% dos paulistanos eram contra a greve; 55\% consideravam-na injusta e 53\% viam-na como resultado de objetivos políticos contra o governo FHC. A greve dos petroleiros era vista como responsável pela falta de todos os derivados de petróleo e combustíveis, inclusive o álcool, que também escasseava nos postos de abastecimento. Tratava-se de uma campanha vitoriosa no sentido de mobilizar a opinião pública" (RIZEK, 1998:6)

Após acirramento das tensões e impasse, a greve chegou ao fim com derrota em todos os sentidos e punição "exemplar", demonstrando que o novo governo não toleraria ações mais contundentes dos sindicatos questionando a política econômica adotada. A derrota política imposta aos sindicatos de petroleiros teve efeito simbólico em todo o movimento sindical.

\footnotetext{
${ }^{19}$ Em 1998, segundo a autora, a imprensa noticiaria a manipulação dos estoques de gás durante a greve, admitida publicamente por quadros gerenciais da empresa: em conjunto com as empresas distribuidoras, os estoques haviam sido premeditadamente escondidos.

20 "Esse fato teria importantes consequências posteriores, já que os petroleiros acabaram por enfrentar a penhora de suas sedes e de todo o patrimônio de suas entidades representativas, além de um conjunto de dificuldades na sustentação dos trabalhadores demitidos na direção de suas entidades. Em vários momentos, de 1995 a 1997, a OIT interveio, apelando ao presidente da República pela anistia da dívida sindical, negada peremptoriamente pelo Executivo. Essa anistia acabou sendo concedida apenas em junho de 1998, na conjuntura das novas eleições presidenciais, logo após as denúncias de que a direção da Petrobrás, em conjunto com as distribuidoras, tinha ocultado os estoques de gás de cozinha." (RIZEK, 1998:5)
} 
Com a derrota dos petroleiros, FHC, com enorme popularidade, passou, no campo trabalhista, à ofensiva sobre os direitos dos trabalhadores, para flexibilizá-los e desonerar o custo das empresas com a força de trabalho.

Da mesma forma, o neoliberalismo, sob a égide de FHC, não aceitou o mecanismo das câmaras setoriais como instrumento de elaboração de política industrial pactuada na sociedade. Essas iniciativas também foram desmobilizados pelo novo governo.

Para Krein e Teixeira, "as características principais das medidas adotadas foram: 1. precarização do trabalho, tornando o contrato e as condições de trabalho mais frágeis, especialmente no tocante à redução de direitos trabalhistas e eventualmente previdenciários; 2. maior liberdade às empresas para contratar e dispensar empregados, reduzindo os custos do trabalho ou estimulando negociações coletivas descentralizadas; 3 . retirada do Estado das atribuições relacionadas à proteção de direitos trabalhistas e/ou previdenciários; 4. mudanças no papel do sindicato". (KREIN e TEIXEIRA 2003:39)

Os autores organizaram um quadro, que reproduzo abaixo:

Principais mudanças legais entre 1994 e 2000

\begin{tabular}{|c|c|c|}
\hline Tema & Iniciativas & Efetividade \\
\hline $\begin{array}{l}\text { Trabalho por tempo } \\
\text { determinado (lei } \\
\text { 9.601/98) }\end{array}$ & $\begin{array}{l}\text { - A essência está em desvincular o } \\
\text { contrato por prazo determinado da } \\
\text { natureza dos serviços prestados; } \\
\text { - Muda os critérios de rescisão e } \\
\text { reduz as contribuições sociais }\end{array}$ & $\begin{array}{l}\text { Entre } 1998 \text { e } 2001 \text {, somente } \\
42.620 \text { pessoas foram contratadas } \\
\text { por essa modalidade de contrato. } \\
\text { É um número ridículo, se } \\
\text { considerarmos que o Brasil, em } \\
\text { 2001, tinha } 11,5 \text { milhões de } \\
\text { desempregados. Os dados } \\
\text { mostram que não é reduzindo } \\
\text { direitos que se amplia o emprego }\end{array}$ \\
\hline $\begin{array}{l}\text { Denúncia da } \\
\text { Convenção 158 da OIT } \\
\text { (Decreto 2100/96) }\end{array}$ & $\begin{array}{l}\text { - É ratificada e, dez meses depois, } \\
\text { denunciada pelo governo brasileiro; } \\
\text { - Elimina mecanismos de inibição da } \\
\text { demissão imotivada; } \\
\text { - Reafirma a possibilidade de } \\
\text { demissão sem justa causa }\end{array}$ & $\begin{array}{l}\text { Continua prevalecendo a Lei do } \\
\text { FGTS, que permite demitir sem } \\
\text { justa causa. Fator que explica } \\
\text { nossa alta rotatividade no } \\
\text { emprego, ou seja, mais de } 30 \% \\
\text { dos trabalhadores trocam de } \\
\text { emprego por ano, pois as } \\
\text { empresas no Brasil têm grande } \\
\text { facilidade para despedir. }\end{array}$ \\
\hline $\begin{array}{l}\text { Cooperativas de } \\
\text { prestação de serviços } \\
\text { (Lei 8.949/94) }\end{array}$ & $\begin{array}{l}\text { - Possibilita que trabalhadores se } \\
\text { organizem em cooperativas de } \\
\text { prestação de serviços e executem o } \\
\text { trabalho dentro de uma empresa, sem } \\
\text { caracterização de vínculo empregatício }\end{array}$ & $\begin{array}{l}\text { As cooperativas de trabalho } \\
\text { explodiram depois da aprovação } \\
\text { dessa lei. É o setor de } \\
\text { cooperativas que mais cresce no } \\
\text { Brasil, pulando de } 699 \text {, em } 1996 \text {, } \\
\text { para } 2.807 \text { em } 2002 \text {. Estamos }\end{array}$ \\
\hline
\end{tabular}




\begin{tabular}{|c|c|c|}
\hline & $\begin{array}{l}\text { e, portanto, sem os direitos trabalhistas } \\
\text { assegurados na legislação e na } \\
\text { Convenção Coletiva. }\end{array}$ & $\begin{array}{l}\text { falando só das cooperativas } \\
\text { cadastradas na Organização das } \\
\text { Cooperativas do Brasil (OCB) }\end{array}$ \\
\hline $\begin{array}{l}\text { Trabalho em tempo } \\
\text { parcial (MP 1709/98) }\end{array}$ & $\begin{array}{l}\text { - O salário e os demais direitos } \\
\text { trabalhistas estarão em conformidade } \\
\text { com a duração da jornada trabalhada. } \\
\text { A principal novidade é a possibilidade } \\
\text { de o trabalhador ter um período de } \\
\text { férias menor que } 30 \text { dias; } \\
\text { - Não prevê a participação do } \\
\text { sindicato na negociação }\end{array}$ & $\begin{array}{l}\text { O contrato parcial já estava } \\
\text { previsto na lei brasileira. A } \\
\text { novidade é o empregador poder } \\
\text { dar férias por um período menor } \\
\text { do que } 30 \text { dias. Olhando os } \\
\text { instrumentos normativos } \\
\text { depositados no banco de dados da } \\
\text { CNI, vemos que a contratação por } \\
\text { prazo parcial aparece em } 3,4 \% \text {, } \\
\text { em 2000, enquanto até } 1999 \text { os } \\
\text { números eram inexpressivos. }\end{array}$ \\
\hline $\begin{array}{l}\text { Suspensão do contrato } \\
\text { de trabalho (MP } \\
\text { 1726/98) }\end{array}$ & $\begin{array}{l}\text { - Suspensão do contrato de trabalho, } \\
\text { por um período de } 2 \text { a } 5 \text { meses, } \\
\text { vinculado a um processo de } \\
\text { qualificação profissional, desde que } \\
\text { negociado entre as partes; } \\
\text { - O trabalhador, caso seja demitido } \\
\text { após o término da suspensão, tem o } \\
\text { direito de receber as verbas rescisórias } \\
\text { e uma multa equivalente a um salário. }\end{array}$ & $\begin{array}{l}\text { A suspensão do contrato, ou lay } \\
\text { off, é medida com pouquíssima } \\
\text { efetividade. No banco de dados } \\
\text { da CNI, apesar de constar uma } \\
\text { elevação em 2000, o } \\
\text { aparecimento ocorre apenas } 2 \% \\
\text { dos } 241 \text { documentos analisados. } \\
\text { Ela começa a aparecer um pouco } \\
\text { mais nas grandes empresas } \\
\text { metalúrgicas, especialmente em } \\
\text { São Paulo }\end{array}$ \\
\hline $\begin{array}{l}\text { Trabalho estágio (MP } \\
\text { 2164/99 e Lei } \\
6.494 / 77)\end{array}$ & $\begin{array}{l}\text { - Amplia as hipóteses de utilização } \\
\text { do estágio, desvinculado da formação } \\
\text { acadêmica e profissionalizante. }\end{array}$ & $\begin{array}{l}\text { O trabalho na forma de estágio } \\
\text { cresceu muitíssimo no período } \\
\text { recente, especialmente nos } \\
\text { bancos e repartições públicas. }\end{array}$ \\
\hline $\begin{array}{l}\text { Banco de horas (Lei } \\
9.061 / 98 \text { e MP } \\
1709 / 98)\end{array}$ & $\begin{array}{l}\text { - Possibilita que a jornada seja } \\
\text { organizada anualmente, conforme as } \\
\text { flutuações da produção ou do serviço } \\
\text { (anualização da jornada); } \\
\text { - Amplia para um ano o prazo de } \\
\text { compensação das jornadas semanais } \\
\text { extraordinárias de trabalho, através de } \\
\text { acordo ou convenção coletiva. }\end{array}$ & $\begin{array}{l}\text { Constam do registro do MTE } \\
1.651 \text { acordos específicos sobre } \\
\text { banco de horas, abrangendo mais } \\
\text { de } 700 \text { mil trabalhadores, em } \\
\text { quatro anos de sua vigência. Os } \\
\text { acordos estão fortemente } \\
\text { concentrados no setor industrial, } \\
\text { correspondendo a } 67 \% \text { do total } \\
\text { registrado. O banco de horas } \\
\text { aparece em } 50 \% \text { de convenções e } \\
\text { acordos do setor metalúrgico dos } \\
\text { Estados de PR, RS e SP no ano } \\
\text { de } 2000 \text {. Portanto, é medida de } \\
\text { grande impacto e aparece com } \\
\text { constância nas relações de } \\
\text { trabalho. }\end{array}$ \\
\hline
\end{tabular}


Principais mudanças legais entre 1994 e 2000

\begin{tabular}{|c|c|c|}
\hline Tema & Iniciativas & Efetividade \\
\hline $\begin{array}{l}\text { Liberação do trabalho } \\
\text { aos domingos (Lei } \\
\text { 10.101) }\end{array}$ & $\begin{array}{l}\text { - Autoriza, a partir de } 9 \text { de novembro } \\
\text { de } 1997, \text { o trabalho aos domingos no } \\
\text { comércio varejista em geral, sem a } \\
\text { previsão de passar por negociação } \\
\text { coletiva. }\end{array}$ & $\begin{array}{l}\text { Não tem estatística, mas é fácil } \\
\text { perceber a quantidade de } \\
\text { comerciários que estão nos } \\
\text { supermercados e nos shoppings. }\end{array}$ \\
\hline $\begin{array}{l}\text { PLR - Participação nos } \\
\text { Lucros e Resultados } \\
\text { (MP 1029/94; Lei } \\
10.101 \text { a partir de } \\
\text { 19/12/2000, que } \\
\text { reproduz a MP 1982- } \\
77 / 2000 \text { ) }\end{array}$ & $\begin{array}{l}\text { - Viabiliza o direito de os } \\
\text { trabalhadores participarem dos lucros e } \\
\text { resultados da empresa, a partir da } \\
\text { negociação; } \\
\text { - } \quad \text { Determina que o valor da } \\
\text { remuneração, em PLR, não incide } \\
\text { sobre os encargos trabalhistas e não é } \\
\text { incorporado ao salário; } \\
\text { - Introduz a possibilidade de } \\
\text { mediação e arbitragem pública ou } \\
\text { privada; } \\
\text { - Define uma periodicidade mínima } \\
\text { de seis meses na distribuição de } \\
\text { benefícios de PLR; } \\
\text { - Focaliza a negociação na empresa; } \\
\text { - Abre a possibilidade de } \\
\text { remuneração variável; } \\
\text { - Retira o foco da mobilização por } \\
\text { salário real/produtividade; } \\
\text { - Introduz os temas da agenda da } \\
\text { empresa na negociação; } \\
\text { - É uma alternativa ao fim da política } \\
\text { salarial, ao possibilitar algum ganho de } \\
\text { remuneração sem reajuste nos salários. }\end{array}$ & $\begin{array}{l}\text { A PLR é um tema de grande } \\
\text { centralidade nas negociações } \\
\text { coletivas, tanto para trabalhadores } \\
\text { como para empregadores. } \\
\text { Segundo pesquisa em oito } \\
\text { setores, a PLR foi destacada } \\
\text { como a principal novidade nas } \\
\text { negociações, tanto pelos } \\
\text { empregadores como pelos } \\
\text { dirigentes sindicais. É um tema } \\
\text { que, em muitas categorias, } \\
\text { mobiliza mais que o próprio } \\
\text { reajuste salarial. Ela está } \\
\text { substituindo a negociação por } \\
\text { aumento real (produtividade) e } \\
\text { compensando reajustes menores } \\
\text { que a inflação passada, em muitas } \\
\text { categorias. Está contribuindo para } \\
\text { rebaixar o valor dos salários em } \\
\text { termos reais. O resultado, junto } \\
\text { com o desemprego e a crise, é } \\
\text { que o trabalho está perdendo } \\
\text { participação na renda nacional, } \\
\text { caindo de } 32 \% \text {, em 1992, para } \\
26,5 \% \text { em } 2001 .\end{array}$ \\
\hline
\end{tabular}

A fragilidade dos sindicatos e da CUT nesse período levou à explosão dos processos individuais na Justiça Trabalhista. Dados compilados por Adalberto Cardoso (2003) demonstram a judicialização dos conflitos capital-trabalho, em virtude da obstaculização das ações de cunho mobilizatório e de força nas mesas de negociação coletiva. "Na década de 1990 ocorreu verdadeira explosão de demandas. Em 1998, ápice do processo de crescimento, as 1.109 varas do trabalho existentes no país acolheram cerca de 2 milhões de processos trabalhistas, 98\% dos quais relativos a conflitos individuais". (CARDOSO, 2003:124) E continua: "Entre 
1988 e 1997 ocorre efetiva explosão nas demandas, com cada ano recebendo 112.489 processos a mais do que o ano anterior. Isso significa multiplicar por três o ritmo de crescimento...". (CARDOSO, 2003:162)

\section{A ascensão da estrela}

Os anos do primeiro mandato de FHC (1995-1998) deixaram o sindicalismo-CUT atordoado. Mais uma vez na defensiva, como ocorrera nos anos Collor. Com a diferença de que, ao contrário de Collor, FHC manteve a popularidade em alta todo o período, o que lhe permitiu a reeleição, em 1998, no primeiro turno, mesmo enfrentando turbulência no plano internacional com a crise financeira da Rússia, em agosto de 1998, que ameaçava a estabilidade do Plano Real.

Reempossado presidente em janeiro de 1999, Fernando Henrique logo promoveu forte desvalorização cambial. O segundo mandato perdeu o "encanto" que o efeito estabilizador da política cambial do Plano Real havia permitido nos anos anteriores. No segundo mandato, a estabilidade conseguida com o câmbio teria que ser substituída pela contenção fiscal, motivo pelo qual FHC mandou ao Congresso a proposta da Lei de Responsabilidade Fiscal (LRF) ${ }^{21}$, aprovada em maio de 2000.

A crise do Plano Real e os efeitos deletérios do desemprego e da precarização das políticas sociais, que haviam permanecido "invisíveis" aos olhos da população por causa da estabilidade da moeda e contenção da inflação, começaram a se tornar mais evidentes. A estagnação econômica de um país que mantém seu PIB praticamente inalterado passou a ser o destaque das notícias sobre o governo.

No segundo mandato, a popularidade de FHC diminui gradativamente.

Em 1999, primeiro ano do segundo mandato, se noticiou:

"O governo do presidente Fernando Henrique Cardoso alcançou o pior índice de popularidade na pesquisa nacional realizada pelo Ibope e divulgada ontem pela Confederação Nacional da Indústria (CNI). O resultado da pesquisa mostra que $44 \%$ dos entrevistados consideram a administração de Fernando Henrique ruim ou péssima e apenas $18 \%$ têm avaliação positiva, entre bom e ótimo. A

\footnotetext{
${ }^{21}$ A Lei Complementar $n^{\circ}$ 101, de 4 de maio de 2000, intitulada Lei de Responsabilidade Fiscal - LRF, estabelece normas de finanças públicas voltadas para a responsabilidade na gestão fiscal, mediante ações em que se previnam riscos e corrijam desvios capazes de afetar o equilíbrio das contas públicas, destacando-se o planejamento, o controle, a transparência e a responsabilização como premissas básicas. (http://www.tesouro.fazenda.gov.br/hp/lei_responsabilidade_fiscal.asp)
} 
falta de confiança no presidente é ainda maior: $62 \%$ disseram não confiar, enquanto $35 \%$ confiam nele. Foram entrevistadas 2 mil pessoas com mais de 16 anos em todo o País, entre os dias 13 e 17 de maio. Ou seja, a pesquisa foi feita antes da divulgação dos diálogos obtidos por escuta telefônica clandestina no Banco Nacional de Desenvolvimento Econômico e Social (BNDES), que indicariam interferência de Fernando Henrique no leilão do Sistema Telebrás. Pela primeira vez na série de pesquisas realizadas pela parceria entre Ibope e CNI desde 1996, entre os mais pobres a avaliação negativa do governo de Fernando Henrique (39\%) superou a positiva (24\%). [...]o maior medo do brasileiro continua sendo o desemprego. Pela primeira vez desde que a CNI vem realizando a série de pesquisas, o medo do desemprego foi mencionado pela maioria dos entrevistados - 52\% declararam-se com muito medo de perder o emprego, enquanto $6 \%$ já tinham sido afetados pelo desemprego. Na maioria dos casos, era o chefe de família quem estava desempregado. Além disso, $71 \%$ dos entrevistados acham que nos próximos seis meses haverá um aumento do desemprego. Quase metade das pessoas ouvidas, $48 \%$, acredita que o governo deveria incentivar as pequenas empresas para melhorar os índices de emprego.” (CARNEIRO, 1999)

A face mais evidente do malogro do segundo mandato de FHC foi a crise energética, que levou ao racionamento de energia elétrica de $20 \%$ no consumo nas regiões Nordeste, Centro-Oeste e Sudeste, de abril de 2001 a fevereiro de 2002, quando foi suspenso. Em agosto de 2001 o governo recorre pela segunda vez a empréstimo do FMI, que prevê desembolso de R $\$ 15$ bilhões, e estende-se até o fim de 2002. (OESP, 2003)

Cresce a perspectiva de vitória de Lula à presidência da República.

O $12^{\circ}$ Encontro Nacional do PT, de 14 a 16 de dezembro de 2001, em Recife, aprova a resolução "Um outro Brasil é possível”, que avalia o governo FHC, apresenta alternativas e defende ampla política de alianças para derrotar o governo nas eleições de 2002.

"A política de alianças deve orientar-se pelo respeito a um programa de governo antineoliberal capaz de propor a abertura de um novo ciclo de desenvolvimento para o país, que defenda uma mudança do modelo econômico assentada em um amplo programa de inclusão social, com radicalização da democracia e inserção soberana do Brasil no mundo. Ela deve articular forças políticas nacionais e estaduais que não necessariamente estarão juntas no primeiro turno. [...] Nosso objetivo deve ser o de construir uma aliança ampla, com forças políticas de esquerda e de centro, que estejam em oposição ao governo FHC e às políticas neoliberais, e que concordem com um programa alternativo, capaz de superar os impasses políticos, econômicos e sociais com os quais o país se defronta. Esse programa deve ser objeto de amplo e mobilizador debate. Nossa candidatura deve expressar a trajetória do PT nesses anos, traduzindo a oposição parlamentar e social que 
fizemos em propostas alternativas que possam liderar um amplo movimento por uma nova política, agregando todos os que desejam resgatar o sentimento de soberania nacional e por uma economia solidária e eficiente. É preciso reforçar o diálogo com essas forças de oposição a FHC, buscando uma ampla aliança no primeiro turno das eleições presidenciais." (PT, 2001a: 18-19)

No mesmo Encontro, o PT divulga também o documento "Diretrizes do Programa de Governo do PT para Brasil - A ruptura necessária”. A proposta era construir um novo modelo de desenvolvimento brasileiro articulando três eixos estruturantes - social, democrático e nacional -, três dimensões intrinsecamente relacionadas no projeto.

A dimensão social implica retomada do papel indutor do Estado na economia, colocando o "social como eixo do desenvolvimento econômico". O que significava voltar as políticas ao fortalecimento do mercado interno, gerando a elevação da participação da classe trabalhadora no consumo. O que fortaleceria setores econômicos de atendimento dessas demandas, como construção civil e agricultura familiar (impulsionada pela reforma agrária), resultando no aquecimento de contratações e, consequentemente, aquecimento geral da economia nacional e em nova oferta de empregos.

Afirma o documento que "o novo modelo de desenvolvimento subordinará, pois, a dinâmica econômica aos objetivos e às prioridades macrossociais que, no atual estágio do país, são fundamentalmente três: a) a inclusão de 53 milhões de brasileiros, subcidadãos, que sobrevivem em condições de extrema precariedade, sem acesso aos bens e serviços essenciais a uma vida minimamente digna; b) a preservação do direito ao trabalho e à proteção social de milhões de assalariados, pequenos e médios produtores rurais e urbanos, inativos de baixa remuneração e jovens que buscam ingressar no mercado de trabalho (todos ameaçados pelas tendências excludentes do atual modelo econômico); e c) a universalização dos serviços e direitos sociais básicos, com a elevação progressiva da qualidade dos serviços prestados e o crescente envolvimento da população na sua gestão (...) Avançar em direção a esses objetivos implicará persistente esforço de crescimento econômico e de ampliação da capacidade de geração de emprego, de expansão e redirecionamento do gasto público e de democratização dos direitos de propriedade e utilização da terra e do capital, no campo e nas cidades, inclusive através do fomento da economia solidária. Implicará também elevar progressivamente o piso de remuneração da força de trabalho, para transformar o salário mínimo em um salário básico compatível com a satisfação das necessidades essenciais de cada família." (PT, 2001b)

$\mathrm{O}$ aspecto nacional no projeto de desenvolvimento apresentado tem seis dimensões para a redução da vulnerabilidade e da dependência externa: 1) recuperar o saldo comercial e 
reduzir o déficit na conta de serviços do balanço de pagamentos, com vistas à diminuição acentuada do déficit em transações correntes; 2) corrigir os desequilíbrios oriundos da abertura comercial por meio da revisão da estrutura tarifária e da criação de proteção não tarifária, amparada pelos mecanismos de salvaguarda da OMC, para atividades consideradas estratégicas; 3 ) adequar a política relativa ao capital estrangeiro às diretrizes e às prioridades do novo modelo econômico (ou seja, implantar mecanismos de regulação da entrada de capital especulativo e reorientar o investimento direto externo com critérios de seletividade que favoreçam o aumento das exportações, a substituição de importações, a expansão e a integração da indústria de bens de capital e o fortalecimento de nossa capacidade endógena de desenvolvimento tecnológico); 4) regulamentar o processo de abertura do setor financeiro; 5) denunciar do ponto de vista político e jurídico o acordo atual com o FMI, para liberar a política econômica das restrições impostas ao crescimento e à defesa comercial do país e bloquear as tentativas de reestatização da dívida externa, reduzindo a emissão de títulos da dívida interna indexados ao dólar; 6) consolidar a vocação de multilateralidade do comércio exterior brasileiro mediante políticas direcionadas à diversificação de mercados, ao fortalecimento e ampliação do Mercosul e à retomada do projeto de verdadeira integração latino-americana, ao estabelecimento de programas de cooperação econômica e tecnológica com potências emergentes, como Índia, China e África do Sul.

Afirma ainda o documento: "Tal como está proposta, a Alca é um projeto de anexação política e econômica da América Latina aos EUA, cujo alvo principal, pela potencialidade de seus recursos e do seu mercado interno, é o Brasil. (...) Em outras palavras, rechaçar essa proposta, tal como está sendo apresentada, é requisito essencial para viabilizar o objetivo de redução de nossa dependência e vulnerabilidade externas. (...) O essencial da proposta está na afirmação de que "mais do que um 'Projeto Nacional', trata-se de formular um projeto que incorpore a defesa da nação e se proponha a transformá-la e a lutar por outra ordem internacional (...) Um outro modelo de desenvolvimento demandará, necessariamente, um Estado democrático forte, com um novo padrão de ação na economia que, sendo distinto daquele do período nacional-desenvolvimentista, permita superar o quadro de desestruturação institucional e de subordinação da ação estatal às esferas de decisão financeira, herança da ideologia do Estado mínimo na década de 1990”. (PT, 2001b)

No que diz respeito ao eixo da democracia no novo modelo de desenvolvimento, o documento afirma repetidamente ser essencial um novo contrato social para alavancar o 
crescimento: "Um novo contrato social, em defesa das mudanças estruturais para o país, exige o apoio de amplas forças sociais que deem suporte ao Estado-Nação brasileiro. As mudanças estruturais estão todas dirigidas a promover a inclusão social - portanto, distribuir renda, riqueza, poder e cultura. Os grandes rentistas e especuladores serão atingidos diretamente pelas políticas distributivistas e, nessas condições, não se beneficiarão do novo contrato social e serão penalizados. Já os empresários produtivos de qualquer porte estarão contemplados com a ampliação do mercado de consumo de massas e com a desarticulação da lógica puramente financeira e especulativa que caracteriza o atual modelo econômico. Crescer a partir do mercado interno significa dar previsibilidade e estímulo ao capital produtivo". (PT, 2001b)

A Lei de Responsabilidade Fiscal, afirma o documento, deveria ser reformulada de tal modo que estivesse submetida à responsabilidade social e não aos interesses exclusivos do sistema financeiro.

Seria dado ao Estado novo papel: "Um novo modelo de gestão pública, no contexto de um Estado forte - em contraposição ao "Estado mínimo" e à correspondente fé cega nos mecanismos de mercado -, deve ser um Estado que, além de democrático e participativo, desempenhe as funções que lhe caberão de maneira adequada. Isto significa, por um lado, a recuperação do planejamento estratégico de governo, como instrumento para a remontagem da capacidade estratégica de ação do Estado (prever, planejar, agir, investindo ou coordenando iniciativas com o setor privado e a sociedade), tendo em conta a necessidade de integração de ações setoriais em muitas das iniciativas prioritárias e o interesse de monitorar resultados das ações. Por outro lado, significa a reorganização da forma de prestar serviços públicos, conferindo-lhes qualidade com economia de recursos. Outro grande desafio, que, presidido pela noção de avaliação de resultados, deve incorporar o uso de tecnologias modernas, a reformulação de rotinas e procedimentos, a melhoria dos ambientes de trabalho e, como é óbvio, a valorização dos servidores públicos e de suas condições salariais e de trabalho (sempre tendo em conta que, dadas as defasagens de salários ante as limitações de recursos, a melhor maneira de realizar negociações democráticas é tratá-las em espaços de debate público mais amplos, como o orçamento participativo)”. (PT, 2001b)

Por fim, o documento com as Diretrizes conclui:

"As diretrizes de programa de governo anteriormente estabelecidas não têm a pretensão nem de detalhar propostas de ação nem de abarcar todos os assuntos e aspectos que estarão sob a responsabilidade do governo democrático e popular. Elas pretendem apenas, por um lado, avançar linhas gerais de ação e de políticas que, com o devido detalhamento, pretenderão se concretizar como prática de governo; por outro lado, elas se propõem a tornar clara uma concepção de governo 
para o Brasil, um projeto que, articulando as dimensões social, nacional e democrática, seja capaz de contribuir para a construção de uma nação soberana, inclusive socialmente, e democrática. Porque, para nós, programa de governo é para valer”. (PT, 2001b)

A proposta apresentada com as linhas gerais do novo modelo de desenvolvimento a ser implementado pelo governo democrático-popular de Lula não era exatamente um programa socialista de governo, como criticaram internamente algumas correntes do PT. Tratava-se, assumidamente, de programa mais de tipo keynesiano, antineoliberal. Contemplaria não apenas aspectos econômicos na reorganização do Estado, mas também políticos, ao reforçar espaços de participação da sociedade civil em diversos fóruns tripartites e conferências públicas. ${ }^{22}$ Mas no contexto em que foi divulgado, causou enorme celeuma entre os agentes do mercado.

Em artigo publicado sobre a cobertura das eleições presidenciais de 2002 em quatro grandes jornais do país, Aldé afirma que "entre 15 e 28 de maio, Lula atinge 43\% das intenções de voto, à frente da soma dos concorrentes, enquanto os outros três disputam o segundo lugar. O PT aproveita a vantagem para flertar com os descontentes do PMDB. A dianteira de Lula nas pesquisas de intenção de voto transforma-se num pesadelo para o mercado financeiro nacional e estrangeiro, visto que os banqueiros preferem o candidato oficial. O pessimismo faz as bolsas caírem. A partir de maio, este é um dos assuntos predominantes nos jornais, ganhando vários destaques, manchetes e primeiras páginas, numa retomada do mal afamado risco-Brasil. Em junho, os jornais chegam a cunhar termos como "lulômetro" e falam em antipetismo. O dólar não para de subir, e qualquer coisa, como a declaração de George Soros de que o Brasil mergulharia no caos se não elegesse Serra (junho), serve para alimentar várias páginas de noticiário negativo, vinculando a tensão econômica às eleições. (...) Embora os jornais noticiem que as propostas econômicas apresentadas pelos candidatos em debates são semelhantes, também há muito espaço para o terrorismo econômico devido à especulação financeira. O OESP é o diário, entre os estudados, que mais endossa as teses terroristas, revelando uma cobertura mais extensa e negativa para Lula, que atinge $51 \%$ negativas, $31 \%$ neutras e $13 \%$ positivas na primeira quinzena de maio, e produz seu maior

\footnotetext{
${ }^{22}$ Os espaços de participação da sociedade civil nos anos recentes no Brasil são fruto da Constituição Federal, que no artigo $1^{\circ}$, parágrafo único, determina que "todo o poder emana do povo, que o exerce por meio de representantes eleitos ou diretamente, nos termos desta Constituição" (grifo meu). Em função disso foram criados, em leis de âmbito federal, estadual e municipal, os diversos conselhos de políticas públicas com representação da sociedade civil, em geral paritária com o número de representantes do Estado. O governo Lula apenas reforçaria esse caráter do Estado, introduzindo novos conselhos e fóruns tripartites, além dos já existentes.
} 
pique de notícias negativas para o candidato petista, apresentando, na segunda quinzena de maio, uma pauta $61 \%$ negativa, $20 \%$ neutra e $18 \%$ positiva". (ALDÉ, 2002)

No decorrer da campanha eleitoral de 2002 e com as pesquisas de intenção de voto indicando a iminente vitória eleitoral de Lula, as "forças de mercado" começam a se agitar. Temiam que o novo presidente, em se confirmando a vitória nas urnas, resgatasse no governo plataforma mais radical de mudanças para o país, inaceitável para os setores mais conservadores e para o "mercado". O sinal da inquietação era o aumento da inflação que já se verificava naqueles meses pelo "medo" que a mera perspectiva da vitória de Lula causava.

A cronologia da crise econômica em 2002 não deixa dúvida do cenário sombrio que aguardava o novo governo. Em fins de maio o dólar ultrapassa R \$ 2,50, o Banco Central (BC) anuncia a correção diária das cotas dos fundos de renda fixa pelo valor dos títulos no mercado secundário. Com isso, os fundos sofrem perdas, a classe média se assusta, o risco Brasil passa de 1000 pontos e o dólar segue em ritmo de alta. De maio a setembro a turbulência se agrava. A dívida pública, impulsionada pelos títulos corrigidos pelo câmbio, ultrapassa os $60 \%$ do PIB no fim de julho, o dólar atinge R \$ 3,47 e o risco Brasil bate recorde, com 2.390 pontos. No dia 6 de setembro, o FMI e o Brasil fecham novo acordo, que garante o aporte de $\mathrm{R} \$ 30$ bilhões até o fim de 2003, desde que o país continue a cumprir as metas fiscais. Nas semanas anteriores ao primeiro turno das eleições presidenciais e até o segundo turno, no dia 27 de outubro, o mercado financeiro vive momentos de grande nervosismo, o dólar chegando a $\mathrm{R} \$ 4,00$ e o risco Brasil atingindo 2.400 pontos. A inflação dispara, ultrapassando $12 \%$ ao ano. (OESP, 2003)

Com o objetivo de tranquilizar o mercado financeiro, a cúpula da campanha de Lula decide lançar um manifesto à Nação, que ficou conhecida como "Carta ao Povo Brasileiro". Antônio Palocci narra os bastidores da elaboração da "Carta ao Povo Brasileiro" e de sua passagem como ministro da Fazenda do primeiro mandato do presidente Lula.

Em relação à elaboração da "Carta ao Povo Brasileiro", Antônio Palocci afirma: "Todos sabiam que Lula era candidato com chances reais de vencer as eleições e, por isso, era minimamente razoável que deixasse mais claro possível suas posições sobre os temas mais delicados, que já tiravam a tranquilidade do mercado. (...) Para ajudar a evitar um cenário caótico no presente e assegurar mínimas condições de governabilidade para os meses que se seguiriam, 
seria necessário, concluíram os presentes ${ }^{23}$, afirmar com todas as letras que o PT saberia o que fazer quando estivesse no poder (...) Em vez de um programa inteiro, seria um Manifesto de Lula à Nação. Aprovada a ideia do documento, foram definidos ali mesmo os itens que deveriam compor o manifesto: cumprimento de contratos, compromisso fiscal, metas de inflação e câmbio flutuante". (PALOCCI, 2007: 28)

Concluída a redação do manifesto, Lula o divulgou em entrevista coletiva à imprensa, no dia 22 de junho de 2002, na Conferência Nacional: Programa de Governo.

A "Carta ao Povo Brasileiro" inicia tecendo críticas à política do governo FHC: "O Brasil quer mudar. Mudar para crescer, incluir, pacificar. Mudar para conquistar o desenvolvimento econômico que hoje não temos e a justiça social que tanto almejamos. Há em nosso país uma poderosa vontade popular de encerrar o atual ciclo econômico e político. Se em algum momento, ao longo dos anos 90, o atual modelo conseguiu despertar esperanças de progresso econômico e social, hoje a decepção com os seus resultados é enorme. Oito anos depois, o povo brasileiro faz o balanço e verifica que as promessas fundamentais foram descumpridas e as esperanças frustradas (...) $\mathrm{O}$ sentimento predominante em todas as classes e em todas as regiões é o de que o atual modelo esgotou-se. Por isso, o país não pode insistir nesse caminho, sob pena de ficar numa estagnação crônica ou até mesmo de sofrer, mais cedo ou mais tarde, um colapso econômico, social e moral." (PT, 2002)

$\mathrm{O}$ documento reitera, portanto, serem imprescindíveis as mudanças, mas adverte: "O PT e seus parceiros têm plena consciência de que a superação do atual modelo, reclamada enfaticamente pela sociedade, não se fará num passe de mágica, de um dia par ao outro. Não há milagres na vida de um povo e de um país. Será necessária uma lúcida e criteriosa transição entre o que temos hoje e aquilo que a sociedade reivindica. O que se desfez ou se deixou de fazer em oito anos não será compensado em oito dias. O novo modelo não poderá ser produto de decisões unilaterais do governo, tal como ocorre hoje, nem será implementado por decreto, de modo voluntarista. Será fruto de uma ampla negociação nacional, que deve conduzir a uma autêntica aliança pelo país, a um novo contrato social, capaz de assegurar o crescimento com estabilidade. Premissa dessa transição será naturalmente o respeito aos contratos e obrigações do país.” (PT, 2002)

E por fim, para acalmar os agentes do mercado, afirma: “...para nós, o equilíbrio fiscal não é um fim, mas um meio. Queremos equilíbrio fiscal para crescer e não apenas para prestar contas aos

\footnotetext{
${ }^{23}$ Segundo o autor, estavam presentes na reunião, ocorrida em um restaurante de Ribeirão Preto (SP), em maio de 2002, Lula, José Dirceu, Aloizio Mercadante, José Genoíno, Zeca do PT, e Guido Mantega, além dele próprio. (Palocci, 2007:26)
} 
nossos credores. Vamos preservar o superávit primário o quanto for necessário para impedir que a dívida interna aumente e destrua a confiança na capacidade do governo de honrar os seus compromissos. Mas é preciso insistir: só a volta do crescimento pode levar o país a contar com um equilíbrio fiscal consistente e duradouro.” (PT, 2002)

Nas palavras de Palocci, a repercussão da Carta aos Brasileiros "foi um sucesso total. (...) Os receios sobre a futura política econômica foram, aos poucos, se dissipando. Alguns setores do PT e da própria sociedade criticaram duramente a Carta, classificando-a como uma exagerada concessão aos mercados. Foi necessário um trabalho posterior para explicar, repetidas vezes e com muita paciência, que se tratava somente de um conjunto de compromissos recomendados pelo bom senso político e econômico (...) Afinal, manter o equilíbrio fiscal e o câmbio flutuante, cumprir os contratos e controlar a inflação constituem tão-somente compromissos normais de qualquer governo sério que não deseja buscar na aventura fácil do populismo as saídas para enfrentar suas dificuldades de natureza econômica. A Carta aos Brasileiros se tornaria, mais tarde, uma espécie de ponte para a política econômica a ser adotada com a posse do futuro governo." (PALOCCI, $2007: 36-37)^{24}$

A vitória de Lula, com $61 \%$ dos votos no segundo turno da eleição (52,4 milhões de votos), no dia 27 de outubro de 2002, representou um marco na história do Brasil. Pela primeira vez era eleito presidente da República um candidato oriundo do segmento popular da sociedade, que tem, na sua, a trajetória de tantos outros brasileiros pobres: fome, trabalho infantil, migração do Nordeste para a região industrial do $\mathrm{ABC}$ em um simples caminhão pau-de-arara; a vida dura no trabalho em empresa metalúrgica, que mutilou seu dedo em acidente de trabalho; e a dificuldade de acesso ao estudo.

Mais do que isso, um candidato eleito por um partido de esquerda como o PT, fundado sob o impulso das lutas e da organização popular e sindical, responsável pelas principais conquistas sociais na Constituição Federal e pela construção da democracia no Brasil apoiada na participação popular, de intelectuais, artistas, trabalhadores do campo e da cidade, de todas as categorias organizadas. A eleição de Lula representou a vitória de todos aqueles personagens que, aproximadamente 20 anos antes, haviam entrado em cena. E de

\footnotetext{
${ }^{24}$ Para Ricardo Antunes, "a Carta aos Brasileiros, assinada em plena campanha eleitoral, era uma clara demonstração de que o governo do PT seria fiador dos grandes interesses financeiros, sob imposição do FMI. Por isso ela se tornou conhecida pelos seus críticos como Carta aos Banqueiros..." (ANTUNES, 2006)
} 
os que, mesmo antes dos anos 1970, se organizavam e lutavam por uma sociedade mais justa.

Ele mesmo o reconheceu, em seu discurso na noite da vitória, na avenida Paulista, e em $1^{\circ}$ de janeiro de 2003, em seu discurso de posse no Palácio do Planalto. Rendeu homenagem a tantas pessoas que participaram da longa caminhada e não estavam presentes naquele momento: Betinho, Henfil, Paulo Freire, Chico Mendes, Margarida Alves, e muitos outros que se foram. Uma verdadeira catarse, a celebração dos movimentos sociais, de várias gerações e de todas as regiões do país.

O presidente Lula também reconheceu em seu discurso de posse as dificuldades que enfrentaria a partir daquele momento:

"Vamos mudar, sim. Mudar com coragem e com cuidado. Com humildade e ousadia. Mudar tendo a consciência de que a mudança é um processo gradativo e continuado, não um simples ato de vontade, não um arroubo voluntarista. Mudança por meio do diálogo e da negociação. Sem atropelos ou precipitações. Para que o resultado seja consistente e duradouro (...) Teremos que manter sob controle as nossas muitas e legítimas ansiedades sociais, para que elas possam ser atendidas no ritmo adequado e no momento justo. Teremos que pisar na estrada com os olhos abertos - e caminhar com os passos pensados, precisos e sólidos. Pelo simples motivo de que ninguém pode colher os frutos antes de plantar a árvore. Mas começaremos a mudar já, pois, como diz a sabedoria popular, uma longa caminhada começa pelos primeiros passos.” (Lula, 2003)

No do dia seguinte, 2 de janeiro de 2003, o país viveria o primeiro dia do mandato de um presidente operário. A festa se renderia à dura realidade de comandar o país.

\section{O governo Lula}

A trajetória de Lula à frente da presidência da República está ainda em construção. Dependendo do ponto de vista que se adota, naturalmente, há uma visão mais positiva ou mais crítica em relação ao seu desempenho no comando do país. Situação difícil em uma análise que se pretende sociológica e que tem, por esse motivo, a obrigação de fugir à tentação do juízo de valor.

Mesmo correndo tais riscos, procurarei fazer uma breve cronologia dos fatos e realizações do governo Lula, enfatizando os aspectos que geraram grande debate na esquerda em geral, e no sindicalismo-CUT em particular.

Ressaltamos nas seções anteriores deste trabalho que era dramático o quadro socioeconômico herdado por Lula. E diante dele, a opção feita foi a da prudência nas 
mudanças para um novo modelo de desenvolvimento, mantendo aspectos centrais da política econômica de FHC, sinalizado na "Carta ao Povo Brasileiro" com a alusão à manutenção do superávit primário nas contas públicas; ao cumprimento de metas de inflação; e ao cumprimento dos contratos com os credores internos e externos.

Em seu livro de memória sobre a experiência no governo, Antonio Palocci relembra o diálogo que teve com Lula, já eleito presidente, acerca do tom do relatório final da equipe de transição: “A situação é bem pior do que parecia. (...) A boa notícia - continuei - é que talvez só o seu primeiro ano de governo esteja perdido. Vamos gastá-lo todo só para pôr a casa em ordem. (...) A má notícia - acrescentei - é que talvez não possamos reverter a crise em apenas um ano. Se cometermos qualquer vacilo, a crise pode nos custar dois anos de governo. $\mathrm{O}$ quadro era sombrio. Era preciso decidir a melhor forma de transmitir as informações à opinião pública". Ao que Lula teria dito a Palocci: "Eu quero que você faça um relatório verdadeiro, mas sem agressões. Onde houver problemas reais, diga. Mas não carregue nas tintas. Nós temos é que tranquilizar o país e dizer que vamos botar ordem na casa. Não me interessa ficar acusando o Fernando Henrique e depois ter que pagar a conta. Não quero isso". (PALOCCI, 2007:44-45)

O relatório da equipe de transição ressalta o quadro grave da crise pela qual o país passava, mas também contemporiza: "A instabilidade atual questiona os próprios avanços que se obtiveram com a estabilidade da moeda, o controle relativo da inflação e um marco institucional e federativo fortalecido pela responsabilidade fiscal. Esses foram progressos a serem creditados em boa parte ao governo que ora se encerra, conquistados com os esforços de todos os brasileiros. Não fazemos tábula rasa dos últimos oito anos e não partilhamos da visão daqueles que acham que tudo deva ser reinventado. Por isso mesmo, temos insistido com todo o didatismo possível que em nosso governo não haverá medidas exóticas, quebra de contratos ou condescendência com a irresponsabilidade fiscal. Também temos dito que não pretendemos provocar bolhas de crescimento econômico a partir de uma permissividade perigosa com a inflação...” (PALOCCI, 2007: 45-46) O próprio ex-presidente Fernando Henrique Cardoso reconheceu em entrevista "o que estão dizendo sobre a herança que recebem não tem consistência. $\mathrm{O}$ documento final da transição não faz uma crítica efetiva à nossa política macroeconômica. Aliás, estão se propondo a seguir a do meu governo, pelo menos no combate à inflação e no respeito aos contratos" (HAMU, 2003.)

Tais posturas surpreenderam os opositores de Lula, sobretudo parlamentares do PSDB e do PFL (atual DEM), e a base histórica de sustentação social do PT. Como se de um instante 
para o outro os sinais tivessem se invertido: alguns tendo a "obrigação" de criticar medidas que eram adotadas e que antes apoiavam; e outros apoiando justamente o que mais criticavam anteriormente. Nessa situação de confusão de sinais foram se configurando blocos de apoio e de oposição ao governo Lula no Congresso Nacional, mesclando em cada um dos campos parlamentares de espectros político-ideológicos e de trajetórias totalmente distintas. Simplificando bastante o cenário, havia parlamentares de partidos "de direita" e "de esquerda" nos dois referidos blocos. Na verdade, perdeu sentido falar em "direita" e em "esquerda". A controvérsia não estava apenas no Congresso Nacional ou na sociedade: dentro do próprio governo, ministros e assessores se colocavam em posições diferenciadas, muitas vezes antagônicas, diante da política econômica adotada, conforme Frei Betto (2007).

De fato, Antonio Palocci assinala a dificuldade que foi o primeiro ano do governo Lula e a pressão vinda de todos os setores da sociedade, inclusive do próprio PT:

"Os meses pareciam se arrastar, e 2003 custava para chegar ao seu final. Mesmo com juros altos e o aumento do superávit, a inflação não cedia. Houve uma pequena melhora, quase pífia, e, com isso, as primeiras críticas não tardaram a surgir. Vieram, inicialmente, do setor produtivo, que almejava, de forma legítima, uma queda mais rápida dos juros. Em seguida, partiram do próprio Partido dos Trabalhadores, onde alguns setores mais à esquerda ainda estavam em estado de choque com os rumos da política econômica adotada. Afinal, muitos aspectos da política econômica nos primeiros meses de 2003 pareciam se confrontar com o que os principais economistas do PT defenderam durante anos." (PALOCCI, 2007:74-75)

Na opinião de Palocci, maio de 2003 parece ter sido o momento de maior pressão contra a política de juros altos e superávit primário elevado ${ }^{25}$.

Apreende-se de Frei Betto (2007) que, ao "gosto amargo" do remédio das medidas econômicas, somava-se certa inexperiência do novo governo no comando do país. Desde dificuldade de organização de agenda, falta de traquejo em lidar com a máquina burocrática do Estado, dificuldade de comunicação dentro do governo e deste com a sociedade; letargia nas ações; conflito de opinião quanto ao rumo de políticas sociais e tomada de decisões

\footnotetext{
${ }^{25}$ A meta de superávit primário em 2003 foi de 4,25\% do PIB, maior do que no mandato de FHC, que tinha meta de 3,75\%. A taxa de juros em maio foi mantida em 26,5\% ao ano, a mesma de fevereiro. Mesmo com tais medidas, a inflação permanecia em 17,2\% no acumulado de 12 meses, fechado em maio.
} 
desvinculadas de uma estratégia consciente pelo governo pesavam também para gerar uma percepção de inércia.

Em novembro, dia 26, o Congresso Nacional aprovou a reforma da Previdência enviada pelo Planalto. O conteúdo da nova lei, publicada em 19/12/2003, visava adequar os gastos da Previdência à política contenciosa do Ministério da Fazenda, interessada em reduzir o déficit da Previdência pública. A alteração nas regras de aposentadoria dos funcionários públicos teve o sentido de adiar a retirada do mercado de trabalho e reduzir benefícios.

Os servidores do Regime Próprio de Previdência Social (RPPS) passaram a ter como critério para requerer aposentadoria a elevação da idade mínima, aumento no tempo de efetivo exercício no cargo em que se der a aposentadoria, e aumento no tempo de contribuição. Além disso, definiu teto de R 2.400 para os vencimentos ${ }^{26}$.

No entanto, o resultado político mais visível para a sociedade foi a primeira crise do PT no comando do governo, em que parlamentares do partido votaram contra a orientação do Planalto e o desfecho foi a expulsão deles na Convenção Nacional do PT, em 14/12/2003, em Brasília ${ }^{27}$. Capitaneados pela senadora Heloísa Helena, esses parlamentares formaram tempos depois o Partido Socialismo e Liberdade (PSOL), agregando outros parlamentares das hostes do PT, que deixaram a sigla descontentes com os rumos do governo e com a condução do Partido.

Apesar das pressões internas e externas, o presidente Lula resistiu e persistiu na política econômica adotada, arriscando todo o capital político e prestígio junto aos trabalhadores, como reconheceu anos depois publicamente, em cerimônia para dirigentes e militantes do Sindicato dos Químicos do ABC, em outubro de 2008. Disse na ocasião ter consciência de que muitos militantes do movimento sindical e do PT poderiam ter se frustrado com as medidas adotadas em seu primeiro ano de mandato, mas tinha convicção de que, apesar de duras, eram necessárias.

Os resultados da política econômica começaram a surtir o efeito desejado pelo governo apenas no final de 2003: inflação anual em 9,3\%, com tendência de queda; risco Brasil

26 Ver a íntegra da Emenda Constitucional $\mathrm{n}^{\mathrm{o}} 41$ (EC 41), artigo $2^{\circ}$ e $\operatorname{artigo} 5^{\circ}$ (http://www.planalto.gov.br/Ccivil_03/Constituicao/Emendas/Emc/emc41.htm)

${ }^{27}$ Foram expulsos do PT a senadora Heloísa Helena (AL) e os deputados federais Luciana Genro (RS), João Fontes (SE) e João Batista Oliveira de Araújo, o Babá (PA). Com exceção de João Fontes, todos fundaram o Partido Socialismo e Liberdade (PSOL). O PSOL foi fundado no dia 6 de junho de 2004, mas só teve o registro definitivo pelo TSE em 15 de setembro de 2005. 
desceu para 463 pontos; o dólar no patamar de $\mathrm{R} \$ 2,88$. Os agentes de mercado não tinham mais por que se preocupar com o governo Lula. (PALOCCI, 2007: 203)

No entanto, os efeitos se fizeram acompanhar de elevado custo social. As atividades econômicas, voltadas para o mercado interno, tiveram desempenho ruim, o que levou o PIB e o PIB per capita a cair, em 2003, 0,2\% e 1,5\%, respectivamente. O consumo das famílias diminuiu $3,3 \%$ e o investimento caiu 7,2\%. A taxa média de desemprego havia alcançado 12,9\% nos últimos 12 meses, e na Região Metropolitana de São Paulo atingiu 19,9\% em 2003 - a maior desde o início da pesquisa em 1985, chegando a alcançar, em alguns meses, 20,6\% da População Economicamente Ativa (PEA). O rendimento médio dos assalariados também sofreu o impacto do baixo dinamismo da economia. Segundo o IBGE, os dados, para as seis regiões metropolitanas principais do país, indicam que esses rendimentos, que vinham caindo desde julho de 2002, continuaram a cair, sistematicamente, em 2003 (redução de 15,2\%, passando de $\mathrm{R} \$ 980$ para $\mathrm{R} \$ 831$ ). Portanto, mantendo a tendência de queda que já vinha ocorrendo. (FILGUEIRAS e PINTO, 2004; FREI BETTO, 2007)

"Em suma, como se pode constatar, a política econômica adotada pelo Governo Lula no primeiro ano de sua gestão não se desviou um milímetro sequer da orientação seguida pelo governo anterior. Muito pelo contrário, reafirmou no discurso e nas ações implementadas essa orientação, em especial aprofundando-a no que se refere à Reforma da Previdência e ao ajuste fiscal, que, segundo as autoridades econômicas, foi insuficientemente realizado pelos governos FHC, isto é, os superávits primários deveriam ter sido maiores!”. (FILGUEIRAS e PINTO, 2004)

A expectativa era de que, vencida a guerra contra a inflação, a partir de 2004, ganhariam maior relevo os avanços na área social. Para Filgueiras e Pinto:

“... com o passar do tempo, essa suposta estratégia política - que previa a manutenção da mesma política econômica do governo FHC durante um certo período não claramente definido, no qual a obtenção da confiança dos "mercados" se constituiria em peça central, com o objetivo de ganhar o tempo necessário para se criar as condições que permitiriam a transição para um outro modelo de desenvolvimento, com a implementação de novas políticas econômico-sociais - se mostrou ser apenas um discurso político apaziguador conjuntural, que serviu de justificativa, durante os meses iniciais do governo, para a manutenção do mesmo modelo econômico. Desse modo, por imposição factual, aos poucos esse discurso foi sendo abandonado; embora, vez por outra, ainda se continue a lembrar a "herança maldita". Já há algum tempo, ele vem sendo substituído pela afirmação 
recorrente de que não há nem haverá um "Plano B", isto é, não haverá qualquer mudança essencial no rumo da política econômica.

Portanto, o uso de políticas ortodoxas não é um expediente meramente provisório que, uma vez conseguindo-se a confiança dos "mercados" e a estabilidade da economia, será abandonado. Em suma, tendo em vista tudo o que foi implementado até agora, bem como a aliança política cada vez mais conservadora que dá sustentação política ao governo Lula, a possibilidade de haver uma transição para uma nova política econômica é praticamente nula" (FILGUEIRAS e PINTO, 2004)

Na opinião desses autores:

"O governo Lula, com pouquíssima resistência do principal partido de sua base de sustentação (o PT), e algumas vezes até com o seu apoio explícito, capitulou frente ao ideário e às políticas liberais ${ }^{28}$. Independentemente da manutenção, e até repetição à exaustão, do discurso de mudança. Com isso, apenas reproduz a experiência dos partidos socialistas e social-democratas europeus, que chegaram ao poder, nos anos 80, com Mitterrand na França, Craxi na Itália, Papandreu na Grécia e Felipe Gonzáles na Espanha. Por motivos óbvios, essa mudança de 180 graus jamais será assumida retoricamente - a não ser pontualmente - pelo governo Lula e seus integrantes. No entanto, como já se viu, documentos produzidos pelo Ministério da Fazenda ${ }^{29}$, bem como o discurso das autoridades econômicas, em particular do ministro da Fazenda e do presidente do Banco Central, defendem e justificam, explicitamente, toda a política econômica ortodoxa implementada até o presente momento, desqualificando qualquer possibilidade de sua mudança." (FILGUEIRAS e PINTO, 2004)

Para Ricardo Antunes, "se em 2002 a vitória eleitoral de Lula sinalizava o início da desmontagem da fase neoliberal, quase ao final do seu governo pode-se constatar que ele mais preservou do que demoveu o neoliberalismo. Tornou-se parte atuante da engrenagem neoliberal. Sua maior engenharia política foi implementar a "feliz confluência" entre os interesses do mundo financeiro (que nunca acumularam tanto) com a cúpula do chamado "sindicalismo de negócios", que se apoderou dos fundos públicos. Tudo ao contrário do que sempre defendeu”. (ANTUNES, 2006).

\footnotetext{
28 Nota dos autores: "Até mesmo com seus integrantes mais à esquerda reconhecendo que assumiram posições equivocadas no passado, como justificativa para a adoção de políticas que antes repudiavam".

${ }^{29}$ Nota dos autores: "O documento intitulado "Política Econômica e Reformas Estruturais", apresentado ao FMI no início de abril, reafirmava o compromisso de se continuar obtendo superávits fiscais primários de 4,25\% do PIB ao ano, até o final do governo Lula; além de apresentar simulações para a evolução da dívida pública, com base na hipótese de obtenção desse percentual de superávit, até o ano 2011.
} 
A continuidade da política econômica de FHC no governo Lula é consensual em todas as análises, qualquer seja o prisma utilizado. Entretanto, mesmo sem negar, Palocci pontua questões que acentuam a diferença entre os dois governos:

"A diferença ficou por conta do conjunto da obra - desta vez, o governo conseguiu avançar, ao mesmo tempo, em questões como crédito, equilíbrio nas contas externas e reformas microeconômicas, o que não aconteceu no período anterior (...) Caso típico foi a ampliação do acesso ao sistema bancário, permitindo a abertura de contas simplificadas e sem custos, beneficiando milhões de pessoas que estavam de fora desse circuito. A adoção do crédito consignado abriu caminho para as diversas inovações (...) Mas o que caracterizou de forma mais nítida a diferença entre a política econômica de Lula e a de seus antecessores foi a forte ação do governo na área social, ao mesmo tempo que era implementado o ajuste fiscal. (...) Enquanto, de um lado, se faziam esforços no sentido de recuperar a estabilidade econômica, de outro o governo atuava para aprofundar os avanços sociais. O resultado foi a estabilização econômica acompanhada da melhoria dos indicadores de desigualdade, a ascensão de 7 milhões de pessoas à classe média e a elevação dos ganhos de renda dos mais pobres, em níveis sustentáveis." (PALOCCI, 2007:99100)

Malgrado a manutenção da política de ajuste restritiva, o governo Lula conseguiria, ao final de 2004, uma elevação no PIB de 5\%. O desenvolvimento das políticas sociais prosseguia em passos lentos, dada a necessidade do superávit primário e dos juros ainda em patamar elevado.

O Programa Bolsa-Família foi criado em outubro de 2003, instituído pela Lei 10.836 . Viabilizou-se a transferência de renda para 3,6 milhões de famílias ainda no mesmo ano, ampliando para 6,5 milhões de famílias em 2004, até alcançar as 11,4 milhões de família que vivem abaixo da linha de indigência no Brasil. ${ }^{30}$

Quando parecia que o governo teria maior tranquilidade para desenvolver seus programas, a 15 de fevereiro de 2004 é levada a público a primeira grande denúncia de corrupção, envolvendo Waldomiro Diniz, subchefe de Assuntos Parlamentares da Casa Civil, que

\footnotetext{
30 A unificação dos programas de transferência de renda no Bolsa-Família permitiu aumento no valor pecuniário aos beneficiários, podendo chegar até R \$ 95 por família atendida (FREI BETTO, 2007:214). Em que pese a capilaridade e a popularidade do Bolsa-Família, Frei Betto tece série de considerações críticas, de que o superdimensionamento deste ocorreu em detrimento do Fome Zero. Dessa forma, o governo Lula abandonou um programa de inclusão e cidadania por outro, de caráter meramente compensatório e assistencial (FREI BETTO, 2007)
} 
apareceu em vídeo pedindo propina para si próprio e dinheiro para a campanha eleitoral, ao bicheiro Carlinhos Cachoeira. Por mais que se tentasse desvincular Waldomiro Diniz do PT, estava ligado à Casa Civil e ao ministro José Dirceu, uma das figuras centrais da coordenação do governo Lula.

Os efeitos dos programas sociais do governo federal, bem como o caso envolvendo Waldomiro Diniz, não chegaram a se refletir diretamente no resultado das eleições municipais de 2004, quando os partidos da oposição (PSDB e PFL) enfrentaram pela primeira vez o governo Lula nas urnas. Para Frei Betto, assessor especial da presidência, a derrota da então prefeita Marta Suplicy, em São Paulo, e de Raul Pont, em Porto Alegre (onde o PT governava havia 16 anos) "são sinais de que campanhas baseadas no pragmatismo do marketing e "desideologizadas" precisam ser revistas, retomando a militância ao primeiro plano. Para ele, Lula "terá que operar, nos próximos dois anos [2005-2006], as mudanças prometidas, pois a eleição municipal deixou claro que a reeleição dele não é fava contada. O PSDB poderá surpreender com um concorrente forte". (FREI BETTO, 2007:482)

Mas a partir de 2005 o governo Lula viveu seus piores momentos, no campo político, com a chamada "crise do mensalão".

Ela começou de modo quase imperceptível, a partir da denúncia de que um dos diretores da Empresa de Correios e Telégrafos (ECT), Maurício Marinho, havia recebido propina de R\$ 3 mil de um empresário, aparentemente em um caso isolado de corrupção no serviço público.

Para José Genoíno, então presidente nacional do PT, "essa CPI [CPI dos Correios] nasceu com o DNA tucano-pefelê de fazer um palanque para desgastar o governo", avaliou. "O que eles menos querem é combater irregularidades", acusou, lembrando que os adversários conseguiram evitar diversas CPIs no governo Fernando Henrique Cardoso, inclusive as que investigariam compra de votos no Congresso para aprovação da reeleição e a privatização de estatais. (PC do B, 2005)

No entanto, a crise começou a ganhar maior proporção quando vieram à tona as primeiras acusações de que o deputado federal Roberto Jefferson (PTB-RJ), partido da base aliada do governo no Congresso, estaria por trás, utilizando cargos no governo, ocupado por pessoas indicadas pelo PTB, para financiar atividades de seu partido. Segundo denúncias da época, diretores de empresas estatais seriam constrangidos a participar do esquema. 
No dia 6 de junho de 2005, o jornal Folha de S.Paulo trouxe entrevista de Roberto Jefferson que mudaria completamente o cenário da crise, mergulhando o país em um dos maiores turbilhões de sua história ${ }^{31}$.

"O deputado Roberto Jefferson decidiu denunciar uma série de irregularidades que estariam sendo cometidas pelo tesoureiro do PT, Delúbio Soares, juntamente com o publicitário mineiro Marcos Valério. Jefferson acusou Delúbio de repassar recursos por meio de caixa dois para partidos da base aliada saldarem suas dívidas de campanha e, assim, garantir seus votos no Congresso. Foi o estopim para a instalação de três CPIs - a do Mensalão, a dos Correios e, ainda, a dos Bingos, após uma decisão do Supremo Tribunal Federal (STF), um ano depois de protocolada, no auge da crise que envolveu o ex-funcionário da Casa Civil, Waldomiro Diniz. Ao mirar contra Delúbio Soares e Marcos Valério, Roberto Jefferson almejava, na verdade, atingir o ministro-chefe da Casa Civil, José Dirceu, por ele acusado de comandar o suposto esquema. Delúbio Soares, que inicialmente negara todas as acusações, explicou mais tarde que o PT havia financiado parte da campanha para as prefeituras em 2004 com recursos de um caixa paralelo. A partir daí, desabou uma avalanche de denúncias, além da exposição constrangedora de lideranças políticas do governo e do parlamento". (PALOCCI, 2007:187)

A crise se arrastou por todo o ano de 2005, com desdobramentos imprevisíveis, que poderiam ter chegado até mesmo ao pedido de impeachment, pela oposição, de Lula, no Congresso Nacional.

Os parlamentares da oposição (PSDB e PFL) vociferavam cada dia mais contra o governo, procurando enfraquecê-lo para derrotá-lo nas eleições presidenciais de 2006. Partidos da situação defendiam o governo a todo custo, constrangidos ou não, classificando muitas críticas oposicionistas como "golpistas".

Entretanto, o jornal O Estado de S. Paulo noticiou, em 31/8/2008, que no auge da crise, o ex-presidente Fernando Henrique Cardoso foi procurado pelos ministros Márcio Thomaz Bastos (Justiça) e Antonio Palocci (Fazenda) para refrear o ímpeto da oposição ${ }^{32}$. Argumentavam - disse o jornal - que ninguém podia apostar no pior, porque o país ficaria

\footnotetext{
${ }^{31}$ Para acompanhar uma cronologia detalhada da crise ética e de corrupção no governo Lula, com notícias entre 16/5/2005 e 1/4/2006, ver o site http://www.vermelho.org.br/especial/correios/default.asp

${ }^{32}$ Entre 2005 e 2006, o próprio Palocci também foi alvo de denúncias pela oposição no Congresso. No dia 27 de março de 2006 encaminhou carta de demissão ao presidente Lula. Em função de supostamente estar envolvido com a quebra de sigilo bancário do caseiro Francenildo Santos Costa. Seria uma testemunha do envolvimento do ministro em casos de corrupção que remontavam aos tempos em que havia sido prefeito de Ribeirão Preto (SP), e estariam relacionados a Delúbio Soares, tesoureiro do PT.
} 
ingovernável. "O ex-presidente concordou, deu um conselho e fez uma promessa. O conselho foi que Lula cuidasse de segurar os números da economia e impedisse que se evidenciassem sinais externos de desgoverno; a promessa foi que não jogaria lenha na fogueira e tentaria acalmar seus pares. (...) Três anos depois, olhando para trás e avaliando a situação, o ex-presidente minimizou o fato de ter atendido aos apelos. 'Eu não fiquei contra o impeachment porque eles me pediram, mas porque sou muito cauteloso nessas questões. Na época, não havia condições políticas para sustentar um pedido de impeachment de Lula. Criaria uma cisão no Brasil', alinhou”. (MARCHI, 2008)

Independentemente de conselhos do ex-presidente, o governo Lula manteve inalterada a política econômica, mesmo nos momentos mais graves da crise. Em 2005, o governo conseguiu o maior superávit primário em todo o primeiro mandato: $4,84 \%$ do PIB. No mesmo ano, favorecido por um cenário internacional positivo e sentindo os efeitos dos programas sociais, o Brasil experimentou crescimento com recorde nas exportações, queda no nível de desemprego e recuperação da renda dos trabalhadores. (CARREIRA e STEFANEL, 2006).

Os primeiros sinais de recuperação da economia viriam se consolidar, de modo que alguns autores afirmam que "os dados dos últimos anos têm revelado uma reversão de vários índices negativos do mercado de trabalho brasileiro, a ponto de se poder dizer nos dias atuais que houve uma melhora generalizada, ainda que pequena, nesses índices. As questões que surgem a partir desta constatação permitem especular sobre as razões que levaram a essa nova situação depois de uma década de problemas. No nosso ponto de vista, esse processo tem relação direta com experiências de negociação implementadas sindicatos e centrais sindicais a partir da posse de Lula". (CONCEIÇÃO; RAMALHO; RODRIGUES, 2008:109)

Porém, no contexto de 2005, a crise política rendeu holofotes a oposicionistas e varreu ministros e lideranças políticas e históricas do poder, mas não contaminou a economia do país, e os agentes do mercado permaneceram tranquilos.

Apesar dos ataques cotidianos irascíveis de parlamentares e políticos na grande imprensa, a popularidade do presidente permanecia surpreendentemente alta. Qualquer outro governante teria sucumbido ao mar de acusações.

O fenômeno foi analisado por intelectuais ligados ao PT. Para Marilena Chauí, o efeito da manutenção da popularidade alta de Lula se deveu ao fato de que ele não desmantelou programas sociais, nem privatizou direitos sociais e culturais, em uma menção sutil ao 
governo anterior, de FHC. "Ao contrário, ampliou as políticas sociais, inovou em várias delas, criou outras novas. Não distribuiu, mas transferiu renda. Contrariando o neoliberalismo, investiu prioritariamente os fundos públicos no polo da força de trabalho". (CARREIRA e STEFANEL, 2006)

“O aumento de $16,67 \%$ do salário mínimo em abril, para $\mathrm{R} \$ 350$, junto com a correção da tabela do imposto de renda, que diminui a retenção na fonte, deve gerar um volume extra de recursos na economia, este ano. A estimativa é do Dieese. Esse volume vira alimentos, vestuário, remédios, quitação de dívidas e novas prestações. Mais crescimento, mais empregos e mais arrecadação. Ainda segundo o Dieese, em 72\% das negociações coletivas no país em 2005, os trabalhadores conseguiram reajustes acima da inflação apurada no período. Com inflação sob controle, isso é sinônimo de aumento de renda. É nesse cenário que os institutos de pesquisa tentam descobrir o segredo da resistência de Lula às pancadas que tem levado.

"O que conta para as pessoas é o dia a dia. E o Brasil nunca esteve tão bem. Quem não comia, tem uma refeição agora. Quem tinha uma, passou a ter duas. Quem tinha duas, agora come três vezes por dia', analisa Carlos Augusto Montenegro, diretor do Ibope. Na mesma linha, Marcos Coimbra, do Instituto Vox Populi, apontou, em reportagem publicada no site Terra, que Lula é 'a cara' do povo brasileiro". (CARREIRA e STEFANEL, 2006)

Por causa desses fatores, Lula conseguiu concluir seu primeiro mandato com alto índice de popularidade, conferindo-lhe a reeleição em 2006 ao derrotar o ex-governador de São Paulo, Geraldo Alckmin, do PSDB, com 58.295.042 votos (60,83\%), no segundo turno. Mesmo longe de ser uma unanimidade entre a militância de esquerda.

Para Frei Betto, "no primeiro mandato, o medo venceu a esperança. O projeto petista de nação cedeu lugar ao de eleição (...) O governo Lula optou por privilegiar alianças partidárias que, por vezes, incluíram políticos notoriamente corruptos, de práticas antagônicas aos fundamentos do PT. No calor do processo eleitoral, essas alianças não se pautaram por metas estratégicas capazes de delinear o perfil de um novo país. O balaio de votos mais que a utopia de construir 'um outro Brasil possível'. Nem parece ter servido de lição a crise ética de 2005, tumor fétido de alianças nefastas que reduziram o contrato programático a um balcão de negócios com moeda suspeita." (FREI BETTO, 2007:521)

Em um breve balanço do primeiro mandato, Frei Betto indica os principais avanços e os grandes desafios que ficaram para o segundo mandato: 
"Apesar dos desacertos, o primeiro mandato do presidente Lula logrou emancipar o Brasil do controle do FMI, repudiar a proposta neocolonialista da Alca, defender a soberania de Cuba e da Venezuela, reduzir a inflação e o preço dos gêneros de primeira necessidade. Promoveu distribuição de renda mínima através do Bolsa-Família; estendeu a energia elétrica à população mais pobre e a regiões distantes dos grandes centros urbanos, graças ao programa Luz para Todos; iniciou significativa reforma na Educação; transformou o direito à alimentação e nutrição em política de Estado; reprimiu crimes do colarinho branco; estancou o processo irresponsável de privatização do patrimônio público; e ampliou o volume de exportação dos produtos brasileiros, diversificando os mercados.

Malgrado todos esses avanços, ainda são expressivas, para com a nação, as dívidas eleitorais e, sobretudo, sociais. A reforma agrária restringiu-se a tímidos passos, a violência urbana e a questão prisional estão à espera de políticas efetivas, o índice de desemprego permanece alto, o sistema de saúde permanece sucateado, a infraestrutura de transportes reduz-se à malha esburacada, a Educação requer maior parcela do PIB, as parcerias público-privadas são suspeitas de embutir um novo modelo de privatizações, a carga tributária cresceu, onerando sobretudo os mais pobres, e os pensionistas e aposentados correm o risco de arcar com os desmandos das contas públicas". (FREI BETTO, 2007:521)

Com a reeleição folgada em 2006, após dois anos de intenso bombardeio da oposição, em um cenário macroeconômico mais estável, e sem novas denúncias de corrupção envolvendo membros do governo, o segundo mandato de Lula tem avaliação positiva, que lhe assegura índices de popularidade cada vez maiores.

Segundo pesquisa CNI/Ibope, divulgada em 15/12/2008 ${ }^{33}$, o governo do presidente Luiz Inácio Lula da Silva obteve novo recorde de popularidade: $73 \%$ avaliaram o governo como ótimo ou bom em dezembro, contra $20 \%$ como regular. Outros $6 \%$ como ruim ou péssimo.

Ainda de acordo com o CNI/Ibope, essa é a melhor avaliação do governo desde que a pesquisa começou a ser feita.

Pela mesma pesquisa de opinião, a avaliação pessoal do presidente Lula também obteve novo recorde, e chegou a $84 \%$ em dezembro, contra $14 \%$ de desaprovação. Outros $2 \%$ não responderam ou não opinaram. $\mathrm{O}$ aumento da popularidade de Lula foi registrado em

\footnotetext{
${ }^{33}$ A pesquisa CNI/Ibope foi realizada entre os dias 5 e 8 de dezembro de 2008, em 141 municípios. Foram ouvidas 2001 pessoas, e a margem de erro é de dois pontos percentuais, para mais ou menos. (http://www1.folha.uol.com.br/folha/brasil/ult96u479636.shtml)
} 
quase todos os segmentos da sociedade, com destaque para a faixa de brasileiros que ganha entre cinco e dez salários mínimos, diz a pesquisa CNI/Ibope. No Nordeste, o saldo de aprovação positiva de Lula chega a 94\%.

Em entrevista, o próprio Lula afirmou que "estamos colhendo tudo aquilo que foi semeado (...) Isso tem permitido que o governo todo atue com muito mais desenvoltura e dinamismo, e penso que há uma tendência de melhorar a cada dia que passa". (PIMENTEL e SOUZA, 2008)

Publicação da Secretaria de Comunicação do governo (Secom) divulga mensalmente os destaques das ações e programas do governo federal. De acordo com o exemplar de novembro de 2008, a desigualdade de renda cai sucessivamente de 2001 a 2007, a queda mais duradoura em 30 anos. O coeficiente de Gini da renda familiar per capita passou de 0,593 para 0,552 (-7\%) e, embora ainda elevado, vem caindo há anos. A razão de renda entre brancos e negros caiu de 2,38 em 1999 para 2,06 em 2007. O número de pobres caiu de 64,6 milhões em 2002 para 50,6 milhões em 2007, queda de 38,2\% para $28 \%$ da população. (SECOM, 2008)

Ainda segundo os dados do governo, de 2002 a 2007 foram geradas 11,8 milhões de novas ocupações; cresceu a proporção de contribuintes da previdência social, passando de $45 \%$ (2002) para 51\% (2007). O rendimento médio real dos trabalhadores (2007) foi de $\mathrm{R} \$ 960$, aumento real de 7\% em relação a 2002 e o maior nível desde 1999. O salário mínimo teve reajuste real de 50,9\% entre janeiro/2003 e outubro/2008, sendo o aumento de rendimento maior nas regiões Norte e Nordeste; 13,8 milhões de pessoas experimentaram mobilidade social ascendente e, em função disso, a classe média tornou-se a maioria da população em seis regiões metropolitanas: passou de 44,2\% em 2002 para 51,9\% em 2008, segundo a Fundação Getúlio Vargas. (SECOM, 2008)

Do ponto de vista econômico, os dados anunciados em novembro de 2008 sinalizam que "fundamentos sólidos da economia brasileira contribuem para resistir à crise financeira internacional": a inflação ficou em 0,45\% em outubro de 2008, e 6,41\% no acumulado dos últimos 12 meses; o superávit primário alcançou 5,59\% do PIB entre janeiro e setembro de 2008. As reservas internacionais alcançaram US\$203,2 bilhões e, pela primeira vez, o Brasil é credor externo. O consumo cresceu 6,7\% entre o segundo trimestre de 2007 e o segundo trimestre de 2008, aumentando 19 meses consecutivos. O PIB também registrou 
aumento de 6,1\% entre o segundo trimestre de 2007 e o segundo trimestre de 2008, crescendo 26 trimestres consecutivamente. (SECOM, 2008)

A crise financeira global desatada pela crise norte-americana em setembro de 2008 pode ter forte impacto sobre a economia brasileira (tal como a crise da Coreia sobre o Plano Real) e transformar todas as realizações do governo Lula em cinzas, ou, ao contrário, cacifá-lo como grande estadista, com repercussão internacional. De todo modo, os desdobramentos da crise internacional estarão na pauta da sucessão do presidente Lula em 2010, opondo visões distintas de Nação e de projeto político para o país. Só o tempo dirá o que está por vir. O texto-base da Direção Nacional da CUT ao $10^{\circ}$ Congresso Nacional da CUT $\left(10^{\circ}\right.$ CONCUT), a realizar-se em agosto de 2009, afirma que "a crise constitui uma extraordinária oportunidade, tanto para impor limites ao capitalismo quanto para iniciar um novo ciclo de tentativas de construção do socialismo. A CUT, então, posiciona-se no sentido de enfrentar a crise ampliando a luta de classes e organizando a transição para um novo modelo de desenvolvimento". (CUT, 2009: 11)

Do ponto de vista político, o relatório da Secom afirma que entre 2003 e 2008 mais de 3,4 milhões de brasileiros participaram de 49 conferências para debater e aperfeiçoar políticas públicas. Da já tradicional conferência de saúde, em sua $13^{\mathrm{a}}$ edição, a conferências dos direitos da criança e do adolescente (realizada ordinariamente a cada dois anos, teve a sétima edição em dezembro de 2007). Como outras criadas no período do mandato, como, por exemplo, a Conferência Nacional de Segurança Alimentar e Nutricional (em 2004 e em 2007), a Conferência Nacional das Políticas Públicas para as Mulheres (2004 e 2007), Conferência Nacional de Promoção da Igualdade Racial (2005) e a Conferência Nacional de Saúde do Trabalhador (2005), entre outras. ${ }^{34}$

\footnotetext{
34 Algumas dessas conferências têm aprovado medidas importantes de iniciativa da sociedade, convertendose depois em políticas de Estado, como é o caso do Nexo Técnico Epidemiológico e Previdenciário (NTEP), aprovado na Conferência Nacional de Saúde do Trabalhador sob impulso dos delegados representantes da CUT em plenário. O NTEP prevê nova forma de reconhecimento de doenças adquiridas em função do trabalho, ampliando os direitos dos trabalhadores. Em outras conferências, a sociedade civil (inclusive a CUT) se colocou em lado oposto ao do governo, como na $13^{\text {a }}$ Conferência Nacional de Saúde, em 2007, em que os representantes da sociedade, a contragosto do ministro da Saúde, aprovaram "fortalecer a gestão e a rede pública de saúde e rejeitar a adoção do modelo de gerenciamento por fundação estatal de direito privado, organizações sociais e Organizações da Sociedade Civil de Interesse Público (Oscip), bem como regimes de concessão pública, ampliando os serviços públicos como condição para efetivar a universalidade e a integralidade da atenção". (Relatório final da $13^{\mathrm{a}}$ Conferência Nacional de Saúde in http://conselho.saude.gov.br/biblioteca/Relatorios/13cns_M.pdf)
} 
No mandato do presidente Lula foram criados mais dez conselhos/comissões com a participação da sociedade civil: o Conselho de Desenvolvimento Econômico e Social CDES (2003), o Conselho Nacional dos Direitos do Idoso - CNDI (2003), a Comissão Nacional de Erradicação do Trabalho Escravo - Conatrae (2003), o Conselho Nacional das Cidades (2003), o Conselho Nacional de Segurança Alimentar e Nutricional - Consea (2003), Conselho Nacional de Aquicultura e Pesca - Conape (2003), Conselho Nacional de Promoção da Igualdade Racial - CNPIR (2003), Conselho Nacional de Desenvolvimento Rural Sustentável - Condraf (2003), Conselho Nacional de Juventude (2005) e Conselho Nacional de Política Cultural (2007) ${ }^{35}$.

O governo Lula encontra-se em andamento, e qualquer análise corre o risco de ancorar-se em posições favoráveis ou desfavoráveis. Procura-se aqui resgatar alguns aspectos relevantes para identificar ambiguidades e contradições, percalços e êxitos.

$\mathrm{Na}$ seção seguinte, se contextualiza a trajetória do governo Lula sob o ponto de vista do debate para as forças de esquerda e para o sindicalismo-CUT.

\section{Impasses da CUT diante do governo Lula}

A CUT apoiou a candidatura de Lula à presidência desde a primeira disputa, em 1989, pelo fato de a Central e o PT encarnarem um projeto comum de sociedade, fruto de trajetória histórica que confunde central sindical e partido (apesar do papel diferente de cada um).

Nem sempre, ao longo da história, esse apoio pôde ser explícito ${ }^{36}$, mas na $10^{\text {a }}$ Plenária Nacional, realizada em 2002, a CUT deliberou pelo apoio aberto a Lula.

Como já detalhadamente tratado nesse capítulo, o mandato do presidente Lula tem se caracterizado pela ambiguidade: política econômica restritiva de ajuste fiscal e política social pautada pela inserção social dos mais pobres, mesmo quando sujeito à crítica de que o faz por efeito populista ou de forma meramente compensatória, apartado da noção de direitos e de cidadania.

\footnotetext{
35 Além desses Conselhos, diversos outros fóruns tripartites foram criados, como o Fórum Nacional do Trabalho, que discutiu a reforma sindical. Já foi aprovada, mas ainda não sancionada pelo presidente, a criação do Conselho Nacional de Relações de Trabalho (CNRT), como fruto dos debates do FNT entre as representações do governo, patronal e trabalhadores.

${ }^{36}$ Em várias ocasiões, a CUT externou seu apoio, eufemisticamente, ao "candidato dos trabalhadores". Não explicitava seu apoio formal por causa da legislação eleitoral e/ou porque na CUT havia correntes que apoiavam outros candidatos, como Leonel Brizola.
} 
Na relação com o movimento sindical, o governo Lula procurou manter canal de diálogo permanentemente aberto, buscando sustentação política, especialmente da CUT, ainda que reconhecesse a importância e a necessidade de a Central manter autonomia e independência frente ao governo.

Ainda antes da posse, em novembro de 2002, José Dirceu, membro da equipe de transição e futuro ministro-chefe da Casa Civil, compareceu a um encontro de sindicalistas em São Paulo. Estavam presentes todas as centrais sindicais e confederações oficiais. Discorreu sobre as dificuldades que seriam enfrentadas no primeiro ano de mandato, pediu apoio às medidas (mesmo sem dizer exatamente quais eram) e "convocou" as centrais sindicais a se manterem vigilantes, pressionando o governo a tomar medidas em favor dos trabalhadores.

Em janeiro de 2003, dirigentes sindicais ligados à CUT assumiram cargos de destaque na administração pública. Além do próprio presidente, um dos fundadores da CUT, sete exdirigentes sindicais assumiram cargos de ministro. Vários sindicalistas ocuparam cargos de alto escalão em ministérios e órgãos federais ${ }^{37}$. Além desses, ex-dirigentes sindicais assumiram postos de comando em conselhos de estatais e fundos de pensão, como na Previ, Petros, Sebrae, Sesi e Itaipu. (BRANDT e TOSTA, 2008)

Segundo a pesquisa de Maria Celina D`Araújo, $45 \%$ dos cargos de alto comando dentro do governo estão hoje nas mãos de sindicalizados (sic), enquanto a média nacional é de apenas 14\%". (TOSTA, 2008) $)^{38}$

Para Boito Jr., "a presença de ex-sindicalistas no governo trouxe inúmeras vitórias para a máquina sindical, mas poucas conquistas que beneficiaram diretamente os trabalhadores assalariados”. Segundo ele, “...a presença de sindicalistas não tem resultado numa política

\footnotetext{
${ }^{37}$ Entre os ministros que assumiram a titularidade em ministérios junto com Lula em 2003, Antonio Palocci (Fazenda), Jaques Wagner (Trabalho), Luis Gushiken (Secretaria de Comunicação), Luiz Dulci (Secretaria Geral), Ricardo Berzoini (Previdência Social), Miguel Rossetto (Desenvolvimento Agrário) e Olívio Dutra (Cidades) haviam sido dirigentes sindicais cutistas. Em sucessivas mudanças de governo esse quadro se alterou. Além desses, “...dos 21 membros titulares da bancada do governo no Fórum, pelo menos sete são exdirigentes ou ex-assessores da CUT, dois dos quais ex-presidentes. Os postos que ocupam estão entre os de maior peso estratégico, entre esses: o atual ministro do Trabalho e Emprego (assim como o anterior), o Secretário de Relações de Trabalho, o Secretário Adjunto de Relações de Trabalho, o Coordenador Técnico do Fórum, o coordenador da Comissão de Reforma Trabalhista da Câmara dos Deputados." (VERAS, 2004:17)

${ }^{38} \mathrm{Na}$ mesma matéria com a pesquisa de Maria Celina D'Araujo - "Era Lula consagra república sindical" (6/4/2008) -, o jornal $O$ Estado de $S$. Paulo afirma que o movimento sindical, e a CUT em particular, tem recebido benesses do governo como jamais havia ocorrido, tal como "a política de reajuste para o salário mínimo até 2023, a correção da tabela de IR, ou mesmo a garantia de que os trabalhadores terão assento nos conselhos das estatais". (BRANDT e TOSTA, 2008)
} 
favorável aos trabalhadores assalariados. Tem trazido, sim, vantagens para as diretorias sindicais, para a burocracia sindical", salienta. (BRANDT e TOSTA, 2008)

A vitória eleitoral de Lula confundiu dirigentes do sindicalismo-CUT. Passou a ser frequente ouvir de sindicalistas que "agora nós somos governo".

Segundo Artur Henrique, presidente da CUT, "muitas pessoas que passaram pela CUT durante sua história assumiram tarefas no governo. No início, achavam que íamos "entender" que elas não poderiam atender todas as nossas reivindicações. E também teve gente do lado de cá que achava que eleger o Lula resolvia todos os problemas. Que ele daria uma canetada, "artigo $1^{\circ}$, instale-se o socialismo; artigo $2^{\circ}$, revogam-se as disposições em contrário", e não precisaria mais luta, greve, mobilização. Duas visões erradas. Trata-se de um governo em disputa. Ganhamos a eleição, não o poder. A gente deixou claro a independência e a autonomia. Mas não vamos permitir um processo de golpe, como foi tentado por grande parte da mídia e da direita, para derrubar o Lula. Para eles, o Lula presidente é um pesadelo". (SOUZA, 2008)

Desse modo, havia nos primeiros anos do governo Lula setores da CUT que propunham postura mais radical em torno de antigas reivindicações do movimento, que queriam ver prontamente atendidas. Para esses setores, o governo deveria apoiar-se na legitimidade política do resultado eleitoral e na mobilização dos trabalhadores em grandes manifestações, cabendo importante papel à CUT. Qualquer postura diferente seria interpretada como "traição" de Lula aos trabalhadores e a conversão da CUT em "central chapa branca".

Enfim, foi detonado um tensionamento entre as diferentes correntes políticas da CUT. Fruto de diferentes perspectivas e expectativas, acompanhou o ritmo dos fatos e acontecimentos que marcaram o mandato, mencionado nas seções anteriores. A política contraditória do governo Lula teve forte impacto sobre a CUT, colocando a Central em uma situação por vezes embaraçosa perante a base.

Exatamente como aconteceu com parlamentares da oposição e situação, as primeiras medidas do governo Lula causaram perplexidade na sociedade e entre dirigentes e militantes da CUT.

No decorrer de 2003, primeiro ano de mandato, o cenário se agravou à medida que se mantinha elevada a taxa de juros e o superávit primário das contas públicas, até então sem demonstrar qualquer resultado positivo sobre a queda da inflação, melhoria do nível de emprego e de renda, condições que haviam justificado o apoio da CUT em 2002. 
Em junho de 2003, o presidente Lula compareceu ao plenário do $8^{\circ}$ Congresso Nacional da CUT ( $8^{\circ}$ CONCUT), no qual discursou aos delegados eleitos à instância máxima de deliberação da CUT. Falou das primeiras medidas do governo, justificou a necessidade da política econômica e saiu aplaudido pela maioria, embora se ouvissem vaias de delegados ligados à corrente Movimento dos Trabalhadores ao Socialismo (MTS), em geral vinculados ao Partido Socialista dos Trabalhadores Unificados (PSTU).

O $8^{\circ}$ CONCUT deliberou pelo apoio ao governo, mantendo princípios que sempre nortearam a CUT: defender a autonomia e independência frente ao governo, e participar do Fórum Nacional do Trabalho (FNT), espaço tripartite criado para debater a reforma sindical e a reforma trabalhista, entre outros temas.

Mas o ponto de maior conflito no $8^{\circ}$ CONCUT girou em torno da posição que a CUT adotaria diante da discussão sobre a reforma da previdência para os servidores públicos, em pauta no Congresso Nacional. Foi o grande teste na relação do governo com a base de apoio da CUT. (MELLEIRO e RADERMACHER, 2007)

O que estava em jogo, no fundo, era a postura da CUT diante do governo Lula, não apenas frente à reforma. A escolha de Luiz Marinho, dirigente do Sindicato dos Metalúrgicos do ABC como presidente nacional da CUT foi sinal de que a CUT teria postura mais negociadora e menos conflitiva com o governo. ${ }^{39}$

O desconforto interno com o governo Lula se acirraria até o final do ano, quando foi aprovada reforma da previdência no Congresso Nacional e diante da expulsão dos parlamentares petistas que votaram contra a emenda constitucional.

Em função do descontentamento em relação aos rumos do governo e da postura da CUT, em março de 2004 ocorre, pela primeira vez na história da entidade, a deserção de uma tendência. Cerca de 1.800 dirigentes e militantes sindicais e de outros movimentos sociais participaram do Encontro Sindical Nacional, em Luiziânia (GO), e fundaram a Coordenação Nacional de Lutas (CONLUTAS). ${ }^{40}$ A maior parte dos dirigentes e militantes

\footnotetext{
${ }^{39}$ É recorrente a versão de que a escolha de Luiz Marinho como presidente nacional da CUT teria atendido a um desejo do presidente Lula, que o preferia em função não só de amizade pessoal, mas de afinidade política.

${ }^{40}$ A CONLUTAS não se caracteriza como central sindical, mas uma coordenação "composta por entidades sindicais, organizações populares, movimentos sociais etc, que tem como objetivo organizar a luta contra as reformas neoliberais do governo Lula (sindical/trabalhista, universitária, tributária e judiciária) e também contra o modelo econômico que este governo aplica no país, seguindo as diretrizes do FMI" (CONLUTAS, 2007). Só mais recentemente a CONLUTAS tem buscado ser reconhecida, como central sindical, no Ministério do Trabalho e Emprego.
} 
que migraram da CUT para a CONLUTAS era vinculada ao Movimento dos Trabalhadores ao Socialismo (MTS), majoritariamente ao PSTU.

José Maria de Almeida, presidente do PSTU e antigo membro da Executiva Nacional da CUT, publicou artigo no jornal $O$ Globo, de 26/08/2004, intitulado "A CUT morreu". Afirmou: "A Central Única dos Trabalhadores morreu para as lutas dos trabalhadores. É preciso construir uma nova ferramenta (...) As razões, devemos buscar numa análise do que tem sido o governo Lula para os trabalhadores, e no papel da CUT frente a esse governo. Lula não está realizando as mudanças, em nosso país, para propiciar vida digna para todos. (...) E [a classe trabalhadora] encontra a CUT, que deveria ser o seu instrumento para essa luta, na trincheira oposta, apoiando a reforma da previdência, a reforma sindical, calando-se frente ao mísero salário mínimo de R \$ 260 e um longo etecétera. (...) Não podemos mais contar com a CUT para nossas lutas, nem tampouco recorrer às outras centrais, pois são piores ainda que ela...” (ALMEIDA, 2004).

A CUT, que permanecera unificada mesmo com a saída daqueles setores do $\mathrm{PT}^{41}$, passou a ter correntes oposicionistas que se situam em posição mais radical.

No documento em que se afirmam a concepção, os princípios e o programa da CONLUTAS, observa-se a postura adotada diante da CUT: “...é importante para evitar a dispersão das forças que se afastam da CUT e demais centrais pelegas neste momento (...) trata-se de uma necessidade dos trabalhadores, de uma alternativa para organizar e impulsionar suas lutas frente à traição e ao abandono da CUT. (...) E deve, por último, intensificar o trabalho de construção de oposições sindicais para disputar os sindicatos com a pelegada, seja da CUT, seja das outras centrais pelegas". (http://www.conlutas.org.br/downloads/concepcao_programa.pdf) ${ }^{42}$

\footnotetext{
${ }^{41}$ O Partido Socialista dos Trabalhadores Unificados (PSTU) foi fundado em março de 1994, em uma ruptura com o PT. A retirada daquele segmento do PT não alterou o cenário sindical, e os militantes do novo partido permaneceram organizados na CUT, em uma corrente chamada Movimento dos Trabalhadores ao Socialismo (MTS). (PSTU, )

${ }^{42}$ Em artigo mais recente, Waldir Rodrigues Junior, editor do jornal Massas, faz uma crítica "à esquerda" do PSTU: "O PSTU afirma a necessidade da "unidade nas lutas concretas contra o governo", mas vincula essa tarefa ao objetivo de "ruptura com a CUT e a construção da Conlutas". Como se vê, não se trata de uma frente de "unidade nas lutas concretas", mas de usar essa "unidade" para transformar a Conlutas em outra central. O partido definiu o objetivo de desfiliar seus sindicatos da CUT e passou a constituir a Conlutas, apresentando-a como frente de unidade na luta. Por essa via, a tarefa de organizar a frente única fracassará, porque se coloca um objetivo errado e que pode conduzir a uma aventura ultraesquerdista. Equivoca-se o PSTU por considerar que existe uma ruptura de massa com a CUT. Não se pode confundir descontentamento de uma camada com a burocracia petista/pecedobista com o fenômeno de ruptura. Os exemplos dados não são suficientes para caracterizar a ruptura de massa. O fato de a campanha por desfiliação da CUT se circunscrever aos sindicatos dirigidos pelo PSTU e por aqueles que nunca foram filiados à CUT, e o fato de o PSTU não defender abertamente a desfiliação em sindicatos dirigidos pela burocracia cutista demonstram que a tal ruptura não corresponde à objetividade da situação. O PSTU pisa em ovos nos sindicatos dirigidos pela burocracia porque o descontentamento não é generalizado e não expressa uma tendência de ruptura. Justamente pelo PSTU não atuar sobre tendências objetivas de ruptura é que está obrigado a usar apenas retórica sobre a tática de
} 
A CUT, comandada pela corrente Articulação Sindical, seguiu apoiando criticamente o governo Lula, participando das negociações no FNT. A difícil arte de manter-se em equilíbrio entre criticar e pressionar o governo de um lado e, de outro, apoiá-lo no enfrentamento com os setores mais conservadores da sociedade - tanto da oposição no Congresso ou como da própria base do governo.

A tensão interna crescia também à medida que resultados positivos do governo na área social tardavam a chegar.

O debate interno refletia essa dificuldade. Dois textos de balanço acerca do primeiro ano do governo Lula foram apresentados à reunião da Direção Nacional da CUT, nos dias 18 e 19 de agosto de 2004.

Em um deles, assinado por membros das correntes Articulação Sindical, Correntes Sindical Classista (CSC) e CUT Socialista e Democrática (CSD), lê-se:

“...diante desse quadro e de um governo presidido pela maior liderança sindical da história do nosso País, o desafio da independência e autonomia da Central adquiria um caráter estratégico. Durante anos a propaganda anticutista da direita brasileira sustentou que a Central não passava de correia de transmissão do PT. Com a vitória de Lula, outras vozes identificadas com o radicalismo inconsequente, vieram somar-se a este coro reacionário. Enfrentar essa campanha era também fazer a necessária disputa política com as centrais sindicais fortalecidas pelo tucanato que, de pronto, abraçaram as bandeiras do emprego e as bandeiras cidadãs que a CUT sustentou ao longo de sua história. (...) Não faltaram oportunidades para que a postura de independência da Central se tornasse pública. Ainda nos primeiros meses da gestão, toma forma mais definitiva a discussão da reforma da previdência. Em diferentes oportunidades, a Central denunciou com firmeza vários aspectos do projeto que contrariavam os interesses dos trabalhadores, em particular no que diz respeito ao funcionalismo público, buscando sempre a negociação e deixando clara a insatisfação da Central com os rumos impostos à reforma. A posição fundamentada e equilibrada de apontar erros do governo sem ferir compromissos estratégicos assumidos ao longo de sua história prosseguiu durante todo o período."

convencimento das bases. A posição de ruptura com a CUT acabará por inviabilizar a Conlutas como frente única "nas lutas concretas contra o governo". Tornar-se-á um aparato minoritário, sem capacidade de enfrentar a burocracia dominante (...) O PSTU defende que a Conlutas atue nas eleições sindicais com chapas frentistas, mas com o objetivo de construir uma nova Central. Essa posição dificultará ainda mais o combate à burocracia, uma vez que a Conlutas comparecerá como divisionista da CUT. O descontentamento no seio dos trabalhadores com a direção burocrática favorece a formação de uma fração revolucionária, que nesse momento pode se colocar por meio de uma oposição antiburocrática e de luta pela independência e democracia sindicais". (JUNIOR, 2005) 
O texto apresentado na mesma ocasião por membros das correntes Alternativa Sindical Socialista (ASS) e O Trabalho afirma o contrário:

"A atual gestão da CUT não passou no teste, nesse primeiro ano de governo. Desde o início estava claro que esse governo (que foi apoiado pela central), daria continuidade à política econômica ditada pelo FMI, do qual estávamos combatendo desde 1994, em alguns casos até aprofundando sua aplicação como no caso do superávit primário que passou de 3,75\% para 4,25\%, tudo isso para conquistar a confiança do mercado e como prova de que o cumprimento de todos os contratos está em curso e que não haverá 'surpresa' com mudanças de rumos, nem no modelo em curso, ou seja, de submissão ao FMI. (...) Mesmo assim, nossa central não teve uma política de enfrentar e combater as consequências desse processo que se revelaram ao longo desse período com exemplos categóricos como a reforma da previdência, conforme resolução aprovada no CONCUT, com a ilusão de que haveria espaço para negociação com o governo Lula, pois havia a expectativa que o tratamento do debate sobre essa proposta de reforma teria um caráter mais democrático do que foi FHC."

Em janeiro de 2005, durante a realização da $5^{\text {a }}$ edição do Fórum Social Mundial (FSM), em Porto Alegre, mais de cem filiados ao PT - intelectuais, sindicalistas e parlamentares anunciam a desfiliação coletiva do partido. Jorge Luis Martins, então membro da Executiva Nacional da CUT pela tendência Alternativa Sindical Socialista (ASS) é um dos que deixa o PT e, em entrevista ao jornal Correio da Cidadania, elucida sua posição no debate.

“...Analisando o plano econômico percebemos que o presidente não só mantém o núcleo central do modelo Fernando Henrique Cardoso como, em alguns casos, o aprofunda. São exemplos disso o superávit primário, que teve seu índice elevado para além do pedido pelo FMI; a reforma da Previdência, que impõe mais sacrifício ao funcionalismo público; a Lei de Falências, que acaba com o risco do capital; o não cumprimento das metas de reforma agrária e da promessa de dobrar o salário mínimo; e, também, a reforma sindical, a gota d'água que, na minha opinião, abre a porta para a flexibilização das relações de trabalho. (...)É um momento dramático, pois ela [a esquerda] está vivendo uma grande derrota. Uma esquerda que, durante mais de 25 anos, lutou para chegar ao governo central e disputar o seu projeto, chegou lá com alianças e programas deformados. E assumindo as teses e concepções neoliberais de desregulamentação do Estado e fortalecimento do capital. Então, é uma sensação de derrota e, também, de dispersão.

CC: O senhor tem planos de também deixar a CUT? 
JM: Uma coisa é o movimento partidário. A outra é a central. Mas queremos fazer uma reflexão também na CUT. Nesse $5^{\circ}$ Fórum Social Mundial, a CUT, na pessoa do seu presidente Luiz Marinho, foi mais vaiada do que o próprio governo. Creio, então, que isso deve levar a uma reflexão da maioria da CUT de que ou ela assume uma postura de independência e autonomia com relação ao governo ou a central tende a perder a credibilidade conquistada no decorrer dos seus 21 anos. Mas não há debate no sentido de sair da CUT, o que temos é a disposição de discutir com os três mil sindicatos para rejeitar a proposta de reforma sindical do Fórum Nacional do Trabalho (...) A central é uma frente que envolve vários partidos. Tem gente do PSOL, do PCdoB, independentes, PSB, PT... O sindicato, para nós, é uma frente plural e vamos lutar para que a CUT continue se construindo enquanto frente. Já o PT não. Quem lá está, concorda em gênero, número e grau com o que está sendo aplicado”.(BRASILINO, s.d.)

Em 2005 a CUT realizou a $11^{\text {a }}$ Plenária Nacional entre os dias 10 e 13 de maio. A crise ética que abalou o governo e o PT ainda não havia eclodido. Os principais desafios colocados então era garantir no último ano de gestão do presidente Lula a aprovação da reforma sindical que vinha sendo debatida no FNT e atuar na formulação de propostas voltadas para o desenvolvimento econômico com justiça e inclusão social.

O texto base assinado por membros da Articulação Sindical, CSD e CSC fazia uma avaliação geral positiva do governo, "ainda que persistam nossas críticas à política de juros altos, carga tributária crescente, superávits primários volumosos, desindexação salarial e timidez nas políticas de distribuição de renda". (CUT, 2005)

Algumas semanas depois da $11^{\text {a }}$ Plenária as denúncias de corrupção irromperia no cenário nacional dificultando a viabilização da estratégia da CUT de pressionar o governo. Para dirigentes e militantes, o momento era o de "defender o governo contra o golpismo da direita neoliberal". Diante das dificuldades conjunturais no Congresso Nacional e de forte resistência de setores do sindicalismo, o governo desistiu da reforma sindical nos moldes propostos. Faria mudanças pontuais mais à frente. (MELLEIRO e RADERMACHER, 2007)

Em meio a crise política que o país mergulhara, Luiz Marinho, então presidente nacional da CUT, é nomeado ministro do Trabalho no dia 12 de julho de $2005^{43}$. Simbolicamente, esse

\footnotetext{
${ }^{43}$ Em 29 de março de 2007, Luiz Marinho deixa o Ministério do Trabalho para o sucessor Carlos Lupi (PDTRJ) e assume o Ministério da Previdência Social. Em seu lugar, assume a presidência nacional da CUT, João
} 
ato confirma o imaginário de que CUT e governo Lula são iguais e compartilham da mesma política, sem nenhum distanciamento crítico da central frente ao governo.

Em maio de 2006, às vésperas do $9^{\circ}$ CONCUT que se realizaria em junho, mais uma corrente política deixa a CUT e vai constituir uma via própria de ação no movimento sindical. Dirigentes e militantes sindicais da Alternativa Sindical Socialista (ASS), muitos que haviam acompanhado a opção partidária do Partido Socialismo e Liberdade (PSOL), fundam a Intersindical.

Para estes dirigentes a CUT surgiu como uma central sindical combativa e de unificação das lutas dos trabalhadores na construção de uma sociedade socialista, mas no decorrer de sua história, converteu-se no seu contrário. Para eles, "essa guinada inicia-se na década de 90 de maneira mais visível, esta crise se origina de dois processos combinados. Um deles diz respeito à situação da classe em tempos de globalização neoliberal como uma nova forma de manifestação do capital, que provocou alterações profundas no mundo do trabalho e na estrutura do Estado. Gerando um duro ataque aos(as) trabalhadores (as), com a precarização das condições de trabalho. Outro é o processo de burocratização das direções sindicais e principalmente da direção majoritária da CUT chegando ao seu atrelamento ao governo Lula, tendo como exemplo a cooptação de dirigentes para a direção de empresas através dos fundos de pensão e apadrinhados políticos nas diversas esferas do governo". (INTERSINDICAL, s.d.)

Continua o documento:

“A experiência vivida durante a década de 90 é coroada com a chegada de Lula à Presidência da República, a partir de então vamos viver as consequências drásticas para nossa classe por conta da submissão e defesa cega da CUT em relação ao governo. Não apoiou a luta do funcionalismo público contra a Reforma da Previdência e, mais do que isso até o último momento tentou "florear" o projeto do governo, além de colocar trabalhadores do setor privado contra os do setor público. Participou ativamente do Fórum Nacional do Trabalho, elaborando uma Reforma Sindical que vai ao encontro dos interesses dos patrões e dos pelegos e na contramão das reivindicações históricas da classe trabalhadora". (INTERSINDICAL, s.d.)

Por fim, a Intersindical declara o seguinte entendimento:

Felício, dirigente do Sindicato de Professores do Ensino Oficial do Estado de São Paulo (APEOESP); e para o lugar deste, que ocupava a Secretaria Geral, Artur Henrique da Silva Santos, do Sindicato dos Trabalhadores na Indústria de Energia Elétrica do Estado de São Paulo (SINERGIA). 
"...é preciso mostrar com vigor que o sindicalismo brasileiro vai além dos "sindicatos de carimbo", não se limita ao sindicalismo de resultados da Força Sindical e tampouco à forma proposta pela Articulação Sindical de "Sindicato Cidadão", ou do sindicalismo do pacto social.

A forma mais eficaz para disputarmos os rumos do movimento sindical neste momento é reconstruirmos a unidade dos trabalhadores contra o neoliberalismo, buscando uma ação coordenada do movimento sindical combativo, através do instrumento da Intersindical. O que, em nosso ponto de vista, pode dar-se independentemente de qualquer divergência organizativa que tenhamos no momento. Pois a crise atual do movimento sindical - que é de concepção, mas também reflete a situação objetiva de defensiva de nossa classe - não será resolvida por ações na superestrutura, pela criação deste ou daquele "novo" aparelho ou estrutura sindical.

A resolução desta crise depende, isto sim, de nossa capacidade em colocar realmente em prática uma ação sindical democrática, plural, autônoma, socialista e baseada na independência de classe. O que exigirá, em primeiro lugar, uma postura autocrítica e generosa de nossa parte, oposta a qualquer tipo de sectarismo ou autoproclamação". (INTERSINDICAL, s.d.)

Embora tenha sido determinante, a saída da Intersindical e da CONLUTAS da CUT não foi motivada exclusivamente pela crítica que tinham em relação ao governo Lula e ao apoio que a CUT emprestava ao governo. Outro fator presente, que veremos mais detidamente no terceiro capítulo, foi também o debate em torno da reforma sindical e da profunda discordância que tinham em relação à orientação da corrente majoritária da CUT, a Articulação Sindical, em questões de organização interna da Central.

Se, de um lado, a reforma da previdência e a reforma sindical foram fatores de tensionamento dentro da CUT, a ponto de ter motivado a saída de duas correntes políticas; por outro lado, a CUT, em especial a Articulação Sindical, apoiava-se nos resultados sociais da política do governo para manter seu apoio, mesmo com possível desgaste em sua imagem de central sindical independente e autônoma em relação ao governo, justificando assim que o caráter popular do governo Lula ia ao encontro do projeto defendido pela CUT. A boa margem de aprovação do presidente nas pesquisas de opinião, mesmo depois da exaustão provocada na crise política de 2005-2006, principalmente entre as camadas mais pobres da população e nas regiões mais carentes do país, era, na interpretação desse grupamento político, sinal do acerto do governo, e da CUT em apóia-lo. A reeleição de 
Lula reforçou a convicção da Articulação Sindical no acerto de sua política, em oposição aos setores mais radicalizados que saíram da CUT.

O $9^{\circ}$ CONCUT, realizado em 2006, foi desaguadouro das principais questões colocadas ao longo da gestão iniciada em 2003: a relação com o governo Lula; e o projeto organizativo da Central. Soma-se a estes o debate sucessório na CUT, que envolve uma discussão de balanço da gestão e tem-se um quadro do que foi o Congresso, suas principais polêmicas e tensões.

A relação da CUT com o governo Lula foi balizada por um debate de balanço sobre este e, consequentemente, na estratégia de apoiar ou não sua reeleição.

A resolução do $9^{\circ}$ CONCUT não deixa dúvidas quanto a isso:

"A chegada à presidência das novas forças representou um marco histórico e abriu novo ciclo político no país, marcado pela disputa de rumos do país em torno à superação do neoliberalismo. Mas a eleição não significou imediatamente uma total alteração da correlação de forças políticas. Assim, tanto no governo como na sociedade há forte disputa política.

Os avanços que obtivemos nesse primeiro mandato de Lula são inequívocos: o aumento do emprego formal, com a criação de aproximadamente 4 milhões de empregos com carteira assinada; o investimento de mais de $\mathrm{R} \$ 15$ bilhões entre 2004 e 2005 na agricultura familiar; a promulgação do Estatuto do Idoso; o combate ao trabalho escravo; a luta contra a discriminação por sexo e raça nas relações de trabalho; a contratação de funcionários públicos por concurso; o aumento real de quase $20 \%$ do salário mínimo, que hoje compra duas vezes mais produtos da cesta básica do que no início do governo; a ampliação do ensino público universitário; a não assinatura do tratado da Alca; o fortalecimento dos laços com outros países do Sul do mundo e, em especial, com os da América Latina e a reorientação de empresas públicas (como Petrobrás e BNDES), são alguns exemplos dentre outros importantes.

Além disso, a democracia estabelecida através da abertura de inúmeros canais de diálogo, se não atingiu a qualidade e institucionalidade que reivindicamos, propiciou uma melhora substancial nas relações do Estado com o movimento sindical, que precisa ser aperfeiçoada, a exemplo dos Conselhos Nacionais, Mesas de Negociação e Fóruns Públicos.

Contudo, aspectos da política macroeconômica representam uma limitação importante às mudanças, como o esforço para alcançar os superávits primários e as altas taxas de juros. Mas, a economia vem se recuperando graças à ampliação do crédito popular, ao incremento real do salário mínimo, ao aumento do gasto público com políticas sociais, à reorientação do BNDES para facilitar o financiamento de investimentos produtivos, entre outras medidas. 
A CUT intervém nessa disputa como entidade destacada do movimento social, mantendo sua autonomia e independência frente ao governo. Em aliança com outros movimentos sociais, tem construído campanhas que pressionam pela efetivação de mudanças que superem a herança neoliberal e consolidem a implantação de um projeto democrático e popular”. (CUT, 2006b: 7-8)

Diante desse diagnóstico, a CUT traçou a seguinte estratégia neste Congresso:

"O centro de nossa tática combina duas tarefas imbricadas entre si: impedir o retrocesso (o que aconteceria com a vitória da candidatura PSDB-PFL) e apoiar a reeleição do presidente Lula, na perspectiva do avanço no projeto democrático-popular, pressionando pela aplicação da plataforma democrática definida no CONCUT, que orientará as posições da CUT frente às ações do próximo governo". (CUT, 2006b: 8)

Em que pese diferentes posicionamentos sobre o balanço, a resolução aprovada foi de apoio a sua reeleição por representar "a única alternativa da classe trabalhadora".

Para José Lopez Feijóo, então presidente do Sindicato dos Metalúrgicos do ABC, "nos governos anteriores, era a tropa de choque que nos recebia em Brasília. Agora, a gente faz uma manifestação e o presidente nos recebe, coloca ministro para receber, dialoga, estabelece processo de negociação (...) Foram essas negociações que resultaram na política do salário mínimo, no envio para o Congresso da Convenção 151 e 158 da OIT sobre negociação coletiva no setor público e contra demissões sem justa causa na iniciativa privada. Então, veja, há uma postura diferenciada em relação aos movimentos sociais", conclui. (BRANDT e TOSTA, 2008) Na mesma linha, Artur Henrique da Silva Santos, então presidente da CUT, afirma que "o movimento sindical tem conquistas históricas no governo Lula e tem ampliado seu espaço, pois agora pode ser ouvido pelo presidente". (BRANDT e TOSTA, 2008)

As correntes mais "à esquerda" que já se colocavam criticamente no $8^{\circ}$ CONCUT (2003), reafirmaram essa posição no $9^{\circ}$ CONCUT, organizados na Frente de Esquerda Socialista (FES). A maior diferença é que, na época, este grupo, então denominado Alternativa Sindical Socialista (ASS), situava-se dentro do PT; e no $9^{\circ}$ CONCUT, sob a nova denominação, encontrava-se organizado majoritariamente dentro do PSOL, que apoiava a senadora Heloísa Helena como candidata à presidência da República.

A participação da FES no $9^{\circ}$ CONCUT refletiu um debate no interior daquela tendência, uma vez que a Intersindical já tinha sido criada em maio daquele ano, mas parte dela ainda se encontrava participando da CUT. 
A corrente $O$ Trabalho, que no $8^{\circ}$ CONCUT (2003) fazia severas restrições políticas no início do governo Lula (configurando um "bloco" com a ASS), manteve sua posição bastante crítica, porém se distanciou da linha mais opositora - da FES -, e apoiou a resolução de apoio à reeleição de Lula.

As demais correntes da CUT posicionaram-se amplamente favoráveis à reeleição de Lula: a Articulação Sindical, a CUT Socialista e Democrática (CSD) e a Corrente Sindical Classista (CSC).

No entanto, mesmo entre estas correntes que apóiam decididamente o governo Lula e sua reeleição, o voto aberto em plenário a favor de Lula não significou necessariamente uma ausência de conflitos / tensão nessa tomada de decisão.

Enfim, a relação da CUT com o governo Lula define campos, aliados e adversários, e estratégias, permeando também outras discussões no Congresso tais como o debate organizativo da Central e a sucessão presidencial.

Foi em torno do debate sobre a relação da CUT com o governo Lula e sobre o balanço da gestão 2003-2006 que se configuraram as três chapas que concorreram à sucessão presidencial da CUT.

A chapa 1 foi composta unicamente com membros da FES, contrário à reeleição de Lula e às formas de gestão da Direção Nacional, para eles de feição governista e pouco atuante na defesa dos trabalhadores.

A chapa 2 contou com membros da CSC e do Trabalho. Estas duas correntes apresentaram em comum o apoio à reeleição de Lula e críticas à forma de gestão da Direção Nacional, na opinião destes, pouco respeitosa em relação às correntes minoritárias. Vale ressaltar uma vez mais que a postura da CSC e do Trabalho são bastante díspares no tocante ao governo Lula: a primeira de apoio mais intensivo; e a segunda, com uma postura mais radicalizada nas críticas ao governo.

A chapa 3 agregou membros da Articulação Sindical e da CSD, ambas prestando apoio irrestrito à reeleição de Lula.

Vale ressaltar, entretanto que os momentos mais acalorados no processo sucessórios da CUT ficaram por conta da discussão interna da Articulação Sindical, a corrente majoritária 
da Central, que se prolongou por meses entre duas candidaturas que rivalizaram a disputa pela presidência no mandato 2006-2009: João Felício, dirigente do Sindicato de Professores do Ensino Oficial do Estado de São Paulo (APEOESP), eleito Secretário Geral no $8^{\circ}$ CONCUT, depois assumindo a presidência da CUT quando Luis Marinho foi chamado a assumir o Ministério do Trabalho; e Artur Henrique da Silva Santos, do Sindicato dos Trabalhadores na Indústria de Energia Elétrica do Estado de São Paulo (SINERGIA), eleito no $8^{\circ}$ CONCUT Secretário Nacional de Organização e depois assumindo a Secretaria Geral da CUT na gestão que então se encerrava. A escolha do candidato só foi resolvida nos dias do Congresso, após várias plenárias específicas da Articulação Sindical diariamente após os trabalhos do Congresso.

O principal motivo alegado para sustentar dois postulantes da Articulação Sindical à presidência da CUT foi o debate em torno da autonomia da Central frente ao governo Lula. Enfim, mesmo a posição consensual da Articulação Sindical em apoiar o governo Lula e sua reeleição comporta tensionamentos na forma como faze-lo. Acrescenta-se a isso, um debate de gestão no interior da Direção Nacional, em que houve entre ambos os lados, críticas de má condução e desrespeito às diferentes opiniões / posições.

Na plenária específica com os delegados da Articulação Sindical que definiu quem seria o candidato da corrente, o plenário estava dividido praticamente ao meio, prenunciando um resultado apertado para qualquer um dos candidatos.

Ao final, Artur Henrique somou 789 votos (55\%) do total de 1446 delegados da Articulação Sindical. João Felício teve 652 votos (45\%); sendo os demais 1 voto nulo e 4 votos em branco.

Resolvido este impasse interno da Articulação Sindical, o processo sucessório na CUT, envolvendo as três chapas já mencionadas, teve o seguinte resultado:

A chapa 1 (FES) obteve 152 votos, representando 6,40\% dos votos dos delegados. Com isso, a chapa 1 não teve nenhum representante na Direção Nacional da CUT 2006-2009, tendo em vista que não obteve o mínimo de $20 \%$ dos votos dos delegados. Isso precipitou a decisão desta corrente de retirar-se da CUT em direção à Intersindical.

A chapa 2 (CSC e O Trabalho) obteve 583 votos $(24,56 \%)$ e teve seis cargos efetivos e uma suplência indicada na Direção Nacional. 
Em 12 de dezembro de 2007 a CUT sofreu o terceiro movimento de deserção de correntes políticas: militantes ligados ao Partido Comunista do Brasil (PCdoB), que na CUT se organizavam na Corrente Sindical Classista (CSC), decidem pela criação de outra central sindical, a Central dos Trabalhadores e das Trabalhadoras do Brasil (CTB).

O motivo alegado pela CSC para promover a saída da CUT foi a falta de democracia interna da CUT, como foi divulgado na página do PC do B.

“...A saída da CUT destes dois setores [CONLUTAS e Intersindical] reduziu o espaço das correntes cutistas mais à esquerda, fortalecendo as visões hegemonistas na entidade e fragilizando ainda mais o seu pluralismo e a democracia interna. (...) Em primeiro lugar, os classistas criticam a ausência de democracia interna e as práticas exacerbadas de hegemonismo da força majoritária. Acusam a CUT de se tornar uma entidade partidarizada, que não dá espaço para outras correntes de pensamento. Afirmam que não há no seu interior respeito ao pluralismo e nem transparência na gestão inclusive nas finanças. A segunda crítica diz respeito à burocratização e à institucionalização desta entidade, que teria refluído no seu ímpeto combativo e se afastado das bases dos trabalhadores. Por último, afirmam que esta central perdeu autonomia durante o governo Lula, adotando uma postura de passividade acrítica que reforçaria as marcas de uma entidade chapa-branca”. (BORGES, 2008) Em entrevista ao mesmo site, Wagner Gomes, dirigente do Sindicato dos Metroviários de São Paulo e até então vice-presidente da CUT declarou que "passamos os últimos cinco anos insistindo com a CUT que era necessário termos uma posição mais incisiva com relação ao governo. Também apontamos nossas discordâncias com a proposta da Articulação Sindical (Artisind) de defender uma reforma sindical sem a unicidade. Apesar dos esforços, nada mudou a postura hegemonista da Artisind que é majoritária na direção da CUT”. (SANTOS, 2008)

E continuou: "no último congresso cutista a CSC teve $25 \%$ dos delegados e fizemos um alerta e um pedido a Artisind para que nos cedesse a secretaria geral da entidade. Porém, nenhum desses apelos foram levados em conta. Então pensamos: porque continuar na CUT se ela simplesmente era surda às nossas opiniões e não nos oferecia nenhum espaço para que pudéssemos confrontar essa diversidade de idéias?", explica o dirigente classista. (SANTOS, 2008)

Em relação ao governo Lula, Altamiro Borges, do PC do B afirma que "a CTB defende uma tática diante do presidente Lula que evite tanto a passividade acrítica da CUT como o voluntarismo esquerdista da Conlutas e da Intersindical. Nem chapa-branca, nem oposição sectária! Sem fazer o jogo da direita para evitar qualquer risco de retrocesso, ela propõe 
apoiar as medidas progressistas do governo Lula, mas também pressioná-lo para que avance nas mudanças". (BORGES, 2008)

Por fim, Wagner Gomes explicita o motivo da saída da CSC da CUT: "Somos a terceira maior central sindical do país. À frente está apenas a CUT e depois a Força Sindical. Isso prova o quanto estávamos escondidos dentro da CUT, o quanto aquele ambiente não revelava nossa verdadeira capacidade de mobilização e intervenção nos rumos do país". (SANTOS, 2007) ${ }^{44}$ Por fim, o $9^{\circ}$ CONCUT elegeu a chapa 3 (Articulação Sindical e CSD) para dirigir a CUT entre 2006-2009, com 1639 votos (69,04\%), lhe conferindo 18 cargos efetivos e 5 suplentes na composição da Direção Nacional da CUT.

O segundo mandato de Lula encontra-se em andamento. Nesse período a CUT completou 25 anos de sua fundação (1983-2008) marcando um momento de inflexão de sua história, não só pelo reconhecimento legal das centrais sindicais ${ }^{45}$ como fruto de uma reforma sindical parcial, mas talvez, principalmente, pela redefinição do campo das forças políticas no movimento sindical.

Não podemos compreender tais mudanças sem aprofundar o tema da relação da CUT com a estrutura sindical corporativista e o que se passou na experiência da reforma sindical debatida no Fórum Nacional do Trabalho.

\footnotetext{
${ }^{44}$ Outra versão sobre a saída da CSC da CUT foi dada por um dirigente nacional da CUT em entrevista realizada no trabalho de campo dessa pesquisa. Para o dirigente a decisão foi tomada no Comitê Central do PCdoB, motivada em fortalecer uma base social que permitisse sustentar o crescimento do partido diante do desgaste do PT no processo de crise do mensalão. Enfim, a criação da CTB, na visão desse dirigente, teria sido tomada em função de uma estratégia de disputa partidária dentro da base aliada do governo Lula no segundo mandato, que viria a ser confirmado nas urnas em outubro de 2006.

${ }^{45}$ No dia 11 de março de 2008 a CUT é reconhecida legalmente como entidade de caráter sindical e conta com $42,5 \%$ das entidades sindicais recadastradas no Ministério do Trabalho que tem alguma filiação a central sindical.
} 


\section{Capítulo 2 - A trajetória da CUT frente ao corporativismo}

\section{Pluralismo, corporativismo estatal e neocorporativismo: arranjos para o modelo sindical brasileiro na atualidade.}

Nessa primeira seção do capítulo 2, abordaremos a bibliografia que trata da relação Estado - sociedade através dos conceitos de pluralismo e corporativismo, em suas formas estatal e social (também chamada de neocorporativa).

O conceito de corporativismo surgiu como uma alternativa de interpretação à concepção pluralista predominante na bibliografia até os anos 1970.

Schmitter definiu assim o corporativismo:

"Habiendo rechazado toda una serie de usos alternativos del concepto corporativismo y expresado nuestra preferencia por una especificación más empíricamente delimitada, que se centre en un conjunto de rasgos relativamente observables de manera directa e institucionalmente distintivos sobre la práctica real de la representación de intereses, ahora me toca a mí producir esa especificación conceptual:

El corporativismo puede definirse como un sistema de representación de intereses en que las unidades constitutivas están organizadas en un número limitado de categorías singulares, obligatorias, no competitivas, jerárquicamente ordenadas y funcionalmente diferenciadas, reconocidas o autorizadas (si no creadas) por el Estado, y las que se ha concedido un deliberado monopolio representativo dentro de sus respectivas categorías a cambio de observar ciertos controles sobre la selección de sus dirigentes y la articulación de sus demandas y apoyos". (SCHMITTER, 1979:24) $^{46}$

Quanto ao pluralismo, assim o definiu Schmitter:

"El pluralismo puede definirse como un sistema de representación de intereses en el que las unidades constitutivas están organizadas en un número no especificado de categorías múltiples, voluntarias, competitivas, no-jerárquicamente ordenadas y auto-determinadas (en cuanto a su tipo o gama de intereses), que no están especialmente autorizadas, reconocidas, subsidiadas, creadas o de algún modo controladas por el Estado en la selección de sus dirigentes o la articulación de sus

\footnotetext{
${ }^{46}$ Para Panitch: “...aunque son muchas las variedades de la teoría corporativista, su premisa común es que la armonía de clases y la unidad orgánica eran esenciales para la sociedad, y podían lograrse si los diferentes grupos funcionales, y especialmente las organizaciones del capital y del trabajo, estaban imbuidas de una concepción de mutuos derechos y obligaciones, un tanto similar a la que supuestamente unió a los estamentos medievales en una sociedad estable”. (PANITCH, 1979: 141)
} 
intereses, y que no ejercen un monopolio de la actividad representativa dentro de sus respectivas categorías". (SCHMITTER, 1979:27)

Em síntese, o modelo pluralista vê o sistema político como sendo ativado por numerosos grupos agregados em torno de uma variedade de interesses sociais, cada qual portador de recursos que lhe permite influenciar as decisões; qualquer grupo tem acesso a qualquer lugar onde decisões são tomadas; os recursos de poder são distribuídos desigualmente, mas não são cumulativos, podendo haver múltiplas combinações de recursos; qualquer grupo pode exercer o seu poder de veto sobre outro; existem vários centros de poder e este é disperso nas mãos de muitos atores". (ARAÚJO e TÁPIAS, 1991:4-5)

$\mathrm{Na}$ lógica do pluralismo, os diferentes grupos da sociedade manifestam seus interesses particulares aliando-se a uns e opondo-se a outros para ampliar sua capacidade de pressão, num sistema que lembra a livre concorrência de mercado. A dinâmica da interação entre os grupos é capaz de explicar tudo. Nesse esquema, caberia ao Estado garantir a legitimidade da competição e o respeito às regras do jogo. (ARAÚJO e TÁPIAS, 1991:4)

Comparando pluralismo e corporativismo, Schmitter assinala:

"En suma, tanto los pluralistas como los corporativistas reconocen, aceptan y tratan de superar la creciente diferenciación estructural y diversidad de intereses de la sociedad moderna, pero ofrecen remedios políticos opuestos e imágenes divergentes de la forma institucional que asumirá semejante sistema moderno de representación de intereses. Los primeros sugieren una formación espontánea, una proliferación numérica, una extensión horizontal y una interacción competitiva; los segundos defienden el surgimiento controlado, la limitación cuantitativa, la estratificación vertical y la interdependencia complementaria. Los pluralistas depositan su fe en el equilibrio cambiante de fuerzas que mecánicamente se intersectan; los corporativistas apelan al ajuste funcional de un todo orgánicamente interdependiente (...) intuyo que estos dos síndromes contrastantes pero no diametralmente opuestos no agotan, ni mucho menos, los posibles sistemas alternativos de la representación moderna de intereses". (SCHMITTER, 1979:27)

Boschi e Diniz também questionam a polarização "entre uma ordem social pluralista fundada na pressão dos interesses organizados de grupos ou classes sociais e uma ordem estatal corporativa controlada pelo alto. [Para eles] ... Trata-se, nesse sentido, de qualificar cada uma dessas perspectivas, propondo um enfoque alternativo capaz de dar conta da complementaridade entre os dois formatos citados, explorando, portanto, a possibilidade de que aspectos da lógica de um dos modelos estejam contidos no outro". (BOSCHI e DINIZ, 1991:12) 
De fato, discutiremos mais adiante como o movimento sindical brasileiro vem estabelecendo desde os anos 1990 um cenário que combina o pluralismo a partir da competição entre as diversas centrais sindicais existentes, coexistindo ao mesmo tempo com formas de corporativismo estatal e mesmo de neocorporativismo.

Voltando à contribuição de Araújo e Tápias, para os autores, nenhuma das duas alternativas colocadas é incompatível com a construção da democracia e, nos diversos casos empíricos, observa-se múltiplas formas de combinação na relação Estado - sociedade nos vários "modelos" corporativistas.

Vê-se, portanto, que embora o conceito de corporativismo parta de uma crítica consensual à noção do pluralismo, ele foi adquirindo múltiplos significados a partir de estudos empíricos sobre diversos sistemas políticos, derivando daí correntes distintas de análise ${ }^{47}$.

Dentre as possibilidades de análise partindo da categoria de corporativismo, uma que se destaca pela relevância e fecundidade analítica é a vertente estruturalista.

“A abordagem estruturalista define corporativismo como estruturas de representação de interesses e/ou de vinculação entre Estado e sociedade civil. Rompendo radicalmente com as principais premissas das outras duas vertentes [político-culturalista e societalista], os estruturalistas enfatizam o papel do Estado, os fatores estruturais e extrapolíticos e os elementos de descontinuidade na explicação da emergência de dispositivos corporativistas (...) estabeleceu-se um certo consenso entre um grupo expressivo de autores em torno da utilização do termo "corporativismo" como uma categoria ideal-típica para descrever sistemas de representação de interesses que se distinguem do pluralismo na medida em que são constituídos por unidades não-competitivas, oficialmente sancionadas e supervisionadas pelo Estado.” (ARAÚJO e TÁPIAS, 1991:9)

A partir do trabalho de Schmitter, como um dos principais expoentes dessa corrente, constituiu-se uma primeira diferenciação através de subcategorias como "corporativismo

\footnotetext{
${ }^{47}$ Já referimos na introdução deste trabalho, citando Schmitter, que a noção de corprativismo remete a uma grande diversidade de significados. Segundo Araújo e Tápias (1991), “...três tipos de interpretação sobre o fenômeno corporativista podem ser identificados na literatura política sobre a América Latina: a) a vertente político-culturalista; b) a vertente societalista; e c) a vertente estruturalista." (ARAÚJO e TÁPIAS, 1991:6). Nessa tese minha abordagem concentra-se mais especificamente na vertente estruturalista devido ao fato de que foi esta que adquiriu maior relevância no debate presente na bibliografia voltada ao sindicalismo brasileiro, sem com isso ocultar ou negar a importância do conceito de neocorporativismo, que se mostra particularmente rico para compreendermops o sindicalismo brasileiro nos anos 1990. A riqueza da vertente estruturalista se dá também em função de outras subdivisões que vão se estabelecendo tendo em vista a necessidade de compreender a variedade de casos que os estudos empíricos vão identificando.
} 
estatal" e "corporativismo social", também chamado de "neocorporativismo". Vejamos sua análise:

"Mihaïl Manoïlesco, el más original y estimulante de los teóricos del corporativismo, aportó la distinción clave entre dos subtipos diferentes. Aquel al que llamó corporativisme pur, en que la legitimidad y funcionamiento del Estado dependían básica o exclusivamente de la actividad de las "corporaciones" representativas singulares, no competitivas y jerárquicamente ordenadas. Al segundo, en contraste, lo llamó corporativisme subordonné, en que 'corporaciones" similarmente estructuradas fueron creadas y mantenidas por órganos auxiliares independientes del Estado., cuya legitimidad y funcionamiento efectivo descansaba en otras bases [1936:92] ... Para nuestros fines, podremos llamar al primero corporativismo social, autónomo y penetrante, y al segundo, corporativismo estatal, dependiente y penetrado". (SCHMITTER, 1979:34)

Ao que completa Araújo e Tápias:

"O corporativismo estatal é definido como aquele no qual as representações dos grandes interesses sociais estão subordinadas à autoridade estatal, quando não são criadas por ela. O corporativismo estatal é monista, buscando a unidade dos múltiplos interesses presentes. Um dos seus traços definidores é a identificação entre Estado e sociedade, ou seja, a supressão da demarcação entre o público e o privado. (...) O corporativismo societal ou liberal, ao contrário do estatal, nasce quase que espontaneamente da dinâmica da sociedade civil, ficando preservada a autonomia fundamental dos atores coletivos envolvidos... Nesse sistema a coerção joga um papel bastante marginal: a ênfase é colocada na troca, na negociação e na adaptação recíproca". (ARAÚJO e TÁPIAS, 1991:10)

Nessa linha de interpretação, o corporativismo estatal estaria associado aos sistemas políticos latino-americanos; ao passo que o corporativismo social, ou neocorporativismo, foi a base do sistema do Welfare State na Europa ocidental.

Neste trabalho, contudo, defendo a tese que de que a ação do sindicalismo-CUT e outros movimentos sociais nos últimos trinta anos, aproximadamente, vêm construindo experiências de um neocorporativismo sem, contudo, romper definitivamente a herança do corporativismo estatal erigido durante os anos 1930 e 1940.

Focando especificamente as experiências latino-americanas, o corporativismo estatal mostrou-se fecundo, porém insuficiente para explicar as diferenças existentes entre os casos encontrados. Desse modo, Stepan aportou um avanço teórico às análises corporativistas ao 
constatar a necessidade de acrescentar a elas a relação entre os tipos de políticas do Estado corporativo e os diferentes tipos de sociedade civil (STEPAN, 1980:72).

Nesse quadro, "esse autor vai distinguir dois subtipos de corporativismo estatal: o inclusivo e o excludente. No primeiro, a elite estatal procura forjar um novo padrão de relações Estado/sociedade através da incorporação política e econômica de setores significativos da classe trabalhadora, utilizando principalmente políticas de bem-estar, distributivas e simbólicas. No segundo, a tentativa de estabelecer um novo equilíbrio entre Estado e sociedade se baseia fortemente numa política repressiva e na utilização das estruturas corporativistas para desmobilizar e submeter uma classe trabalhadora previamente organizada e ativa”. (ARAÚJO e TÁPIAS, 1991:12)

De acordo com a bibliografia, essas tipologias propostas quanto às políticas públicas de Estados corporativos vão referir-se a diferentes regimes de Estado, um de caráter "populista", associado às políticas inclusivas; e outro de caráter "burocrático-autoritário", identificado às políticas excludentes.

"Stepan chama a atenção para o fato dele se referir a políticas inclusivas ou excludentes, e não a regimes, por duas razões. Primeiro, porque a reordenação das relações Estado/sociedade através de mecanismos corporativistas, geralmente combina políticas inclusivas e excludentes como nos casos de Vargas e Perón. Segundo, porque um mesmo regime pode mudar de um padrão predominantemente inclusivo para um claramente excludente (o regime mexicano de Cárdenas, por exemplo)". (ARAÚJO e TÁPIAS, 1991:12 - grifo dos autores) ${ }^{48}$

Utilizando-se desse referencial, Leôncio Martins Rodrigues assinala em sua análise que o Brasil viveu um período de corporativismo inclusivo entre 1930 e 1945; e um de corporativismo excludente entre 1964 e 1978 (RODRIGUES, 1990:59)

Outra subdivisão presente no debate sobre corporativismo estatal foi proposta por Ruth e David Collier. Esses autores acrescentaram a noção de incentivos e de constrangimentos.

"Constituem incentivos as provisões utilizadas para estruturar a representação de interesses que conferem vantagens aos organismos sindicais que os recebem, tais como reconhecimento oficial, monopólio de representação, filiação compulsória e subsídios. Através desses incentivos, a elite em controle do Estado busca o suporte das organizações operárias, sua cooperação com o Estado, e sua aceitação dos constrangimentos impostos por ele. Constrangimentos são os dispositivos voltados diretamente para o controle das organizações dos trabalhadores e de suas lideranças. O

\footnotetext{
${ }^{48}$ Os subtipos do corporativismo estatal que Stepan classifica de "excludente" e "inclusivo" é análogo ao que Boito Jr. denomina "modelo ditatorial de gestão e controle de gestão e controle sobre os sindicatos" e "modelo democrático de gestão e controle de gestão e controle sobre os sindicatos", respectivamente (BOITO Jr., 1991).
} 
corporativismo é entendido, por esses autores, como uma combinação entre esses dois tipos de provisões". (ARAÚJO e TÁPIAS, 1991:13)

Collier e Collier combinam essa noção de incentivos e constrangimentos às formas políticas inclusivas e excludentes. Desse modo, as políticas inclusivas teriam proporcionalmente maior teor de incentivo do que de constrangimentos, em busca de apoio dos sindicatos; ao passo que, ao contrário, um corporativismo estatal de tipo excludente teria uma carga maior de constrangimentos do que de incentivos, em busca de repressão e de controle mais estrito sobre os sindicatos.

As correntes interpretativas calcadas na noção de corporativismo estatal serviram de referência, direta ou indiretamente, aos estudos presentes sobre o sindicalismo no Brasil. ${ }^{49}$ Durante muitos anos prevaleceu uma interpretação entre historiadores e cientistas sociais de que o modelo sindical corporativista havia sido imposto unicamente pela força sobre o movimento sindical.

Entretanto, se isso não é de todo equivocado, pois não podemos obliterar a repressão que se abateu sobre o sindicalismo após 1935 e durante o Estado Novo, por certo esta também não é uma interpretação única. Estudos têm apontado que a montagem da estrutura sindical brasileira, ao mesmo tempo em que suplantou o sindicalismo livre do período anterior, muitas vezes com base na violência, prisão e extradição de dirigentes e militantes sindicais, também propiciou, paradoxalmente, maior estabilidade na organização sindical de categorias que enfrentavam a intransigência patronal.

Esse foi o caso, por exemplo, dos bancários do Rio de Janeiro, cujo estudo de caso empreendido por Oliveira (1990) sobre suas origens identifica a importância da lei de sindicalização no 19.770/31. Segundo a autora:

"Os mais mobilizados e com tradição de luta - trabalhadores em energia elétrica, hotéis e similares, ferroviários, têxteis, e metalúrgicos -, com experiência na organização de sindicatos livres, sob a influência de diferentes correntes ideológicas do movimento operário (anarco-sindicalistas, comunistas, trotskistas, socialistas e cristãos), reagiram contrariamente à política sindical (...)

Distinto será o comportamento de outros setores, como o dos bancários, ligados aos setores 'médios', sem tradição de luta e organizados apenas em instituições assistencialistas e recreativas.

\footnotetext{
${ }^{49}$ Autores como Cardoso (2003) divergem da conceituação de corporativismo nas relações de trabalho no Brasil. Para ele, o modelo brasileiro é legislado e não, corporativo. Voltarei a essa discussão mais adiante.
} 
Nessas categorias, a Lei de Sindicalização apresentou-se como uma possibilidade de facilitar a conquista de suas reivindicações, rompendo com o temor da repressão patronal. Nos documentos de então, fica perfeitamente claro que as lideranças viram na iniciativa do Estado a abertura de um espaço a ser utilizado na organização sindical, a qual, por lei, o patronato seria obrigado a reconhecer". (OLIVEIRA, 1990:21)

Desse modo, não há um consenso na bibliografia sobre o tema acerca do efeito do corporativismo sobre a organização dos trabalhadores (BOSCHI e DINIZ, 1991:21). Preferimos seguir a esteira de Oliveira e adotar a posição de que seu efeito foi diferenciado segundo o grau de organização sindical previamente existente, dada as condições de enfrentamento com o setor patronal.

Esse paradoxo acerca do efeito mobilizador / desmobilizador na montagem da estrutura sindical corporativista no Brasil foi tema do estudo de Ângela Araújo (1998). Para essa autora a organização corporativista no Brasil viveu uma contradição entre seu propósito controlador e a prática sob a qual efetivamente ela ocorreu, a ponto de ser possível afirmar que o sistema corporativo promoveu a inclusão dos trabalhadores no sistema político, ainda que limitando sua ação classista evidentemente, mas não a sua exclusão.

Ao invés de serem tratados exclusivamente como "caso de polícia", tal como ocorrera no período da Primeira República, os sindicatos passaram a ser reconhecidos como legítimos interlocutores perante o Estado e os empregadores, enquanto entidades de representação dos trabalhadores.

Desse modo, a constituição do modelo sindical corporativista representou ganhos políticos importantes como a legitimidade de atuação dos sindicatos em espaços públicos e a conquista de direitos há tanto tempo reclamados pelos anarco-sindicalistas, regulamentando o mercado de trabalho para parcela importante da classe trabalhadora ${ }^{50}$.

Rodrigues compartilha dessa análise e ressalta que a estabilidade trazida pelo sistema corporativista ao sindicalismo do início do século XX foi um dos fatores que lhe garantiu

\footnotetext{
${ }^{50}$ Apesar do avanço social proporcionado com as medidas de Vargas, é digno de nota salientar que inúmeros trabalhadores permaneceram à margem do sistema, como os trabalhadores rurais, as empregadas domésticas e o funcionalismo público. Essa característica fez com que o sindicalismo no Brasil tenha se concentrado durante décadas em grandes centros urbanos.
} 
permanência na sociedade brasileira ${ }^{51}$. Para esse autor, trata-se de um equívoco analítico tomar o corporativismo como sinônimo do fascismo, ainda que a Consolidação das Leis do Trabalho (CLT) tenha sido inspirada na Carta del Lavoro de Mussolini. Para ele, "na época, o corporativismo estava 'no ar' e inspirava várias correntes políticas" (Rodrigues, 1990:52). Em que pese as diferenças políticas e ideológicas significativas quanto ao rumo da construção da Nação, socialistas, sindicalistas, getulistas, intelectuais progressistas, tenentistas, e integralistas, entre outros, inspiravam-se nos ideais corporativistas como instrumento de modernização do país para vencer o "atraso" representado pelas elites oligárquicas que comandavam as fazendas de café e os governos da Primeira República ao seu feitio.

Assim sendo, segundo Rodrigues, “...o Estado Novo, nesse aspecto, só fez reforçar tendências ideológicas já existentes, em maior ou menor grau, nas forças políticas que se opuseram às 'elites oligárquicas"” (RODRIGUES, 1990:52)

Para Luiz Werneck Vianna a nova ordem corporativa suplantou as bases do liberalismo vigente no pré-1930 (VIANNA, 1976). Para o autor, "não se trata de obscurecer a radical diferença entre as duas ordens estatais - antes e depois de 30 - mas exatamente de isolar especificidade concreta de uma contraposta à outra (...) Quando se suscita o tema do corporativismo sindical, a rigor, tem-se que pensar previamente no estatuto do corporativismo como ordem legal geral. Vale dizer, é porque a concepção do estado se radica no corporativismo que o sindicato assume feição corporativista”. (VIANNA, 1976)

O ideal corporativista no Brasil, segundo esses diversos estudiosos, representou um processo de modernização na construção da Nação, ainda que com um viés autoritário, pois propiciou a inserção de grupos sociais - os trabalhadores - no campo político com legitimidade e direitos reconhecidos, embora tutelados, sem autonomia perante o Estado.

\footnotetext{
${ }^{51}$ Para o autor, outros fatores também estão presentes na persistência do sindicalismo corporativo ao longo da história do Brasil, entre eles, a mudança na composição da classe trabalhadora, com a redução relativa de imigrantes italianos acostumados com a agitação dos anarquistas e o aumento de migrantes rurais que vieram à cidade empregar-se nas indústrias que surgiram a partir do modelo de substituição de importações, sem terem uma experiência organizativa anterior, sujeitos que estavam ao mando das oligarquias dos coronéis. Outros fatores seriam a composição étnica da "nascente classe empresarial" ocupada por imigrantes italianos, judeus, turcos e de outras nacionalidades, deixando às tradicionais famílias da oligarquia os principais postos do Estado no serviço público. Enfim, o autor assinala que todos os grupos sociais tiveram ganho com a implementação do sistema corporativista - as oligarquias tradicionais, os imigrantes bem-sucedidos na indústria e no comércio, os setores médios, os sindicalistas, etc - de modo que nenhum daqueles teve o empenho em desmontar o sistema, pelas vantagens dele advindas. (RODRIGUES, 1990)
} 
A vertente autoritária se acentua, segundo Gomes (1991), no período do final do Estado Novo, após 1942, quando o regime ditatorial de Vargas passa a viver seu ocaso e se dedica a construir as bases do "trabalhismo" enquanto um instrumento ideológico que lhe permitiria sobrevida no período democrático. Foi quando, para a autora, a definição da cidadania passa para o comando do Estado. Assim, continua ela, "o discurso trabalhista apaga a memória da 'palavra' dos trabalhadores; apaga a experiência arduamente vivida durante a primeira república. Tudo, literalmente tudo, o que se fala nesse discurso ignora o passado da classe trabalhadora. Ele sequer é rotomado para receber críticas. Ele não é mencionado e, portanto, não existe. No entanto, ao mesmo tempo em que essa operação é realizada, o discurso emitido pelo Estado constrói-se lidando com os mesmos elementos básicos presentes no discurso operário desde o século XIX, que são relidos e integrados em outro contexto. O valor fundamental do trabalho como meio de ascensão social e não de saneamento moral - e a dignidade do trabalhador são o eixo em torno do qual se monta a comunicação do Estado com a sociedade". (GOMES, 1991:77)

O projeto corporativista no Brasil, mesmo tomado por esse viés "inclusivo" para usar a expressão de Stepan, tinha um cunho autoritário, não deixou de sofrer a oposição do segmento industrial paulista, que jogou seu peso político contra as medidas mais reformistas do Estado. Para Costa, "é absolutamente verdadeira a percepção da classe empresarial paulista de que o Ministério do Trabalho estava criando a luta de classes. Se entendemos, obviamente, que essa luta só é possível através do equilíbrio de forças antagônicas. O corporativismo proposto pelo MTIC visava essa simetria. A recusa da elite patronal em reconhecer a legitimidade de um programa que buscava organizar os trabalhadores dando-lhes voz e voto, é a origem da perversão da utopia de Oliveira Vianna”. (COSTA, 1991:117)

Uma interpretação bastante distinta acerca da estrutura sindical corporativista nos é oferecida por Boito Jr.

Dessa forma, para o autor a afirmação que os sindicatos estão subordinados ou tutelados pelo Estado é absolutamente redundante, uma vez que é exatamente essa a natureza da estrutura corporativista.

Nesse trabalho, Boito Jr. polemiza com diversos outros estudiosos do sindicalismo brasileiro: Werneck Vianna, José Álvaro Moisés, Maria Hermínia Tavares, John Humphrey, entre outros. Afirma ele:

"Esses autores e essas correntes sindicais não deixam de indicar alguns obstáculos que a estrutura opõe à organização e à luta dos trabalhadores. Ocorre que possuem uma concepção errônea desses 
obstáculos. O erro principal consiste em não compreender que tais obstáculos são irremovíveis. É certo que o sindicato de Estado não funciona de maneira idêntica em toda e qualquer conjuntura e qualquer que seja o setor considerado das classes trabalhadoras. Mas, ao contrário do que sustentam esses autores, as variações possíveis da prática sindical são, no sindicato de Estado, limitadas. $\underline{\mathrm{O}}$ que, precisamente, a estrutura não comporta é a conversão do sindicato oficial, de instrumento de controle dos trabalhadores, em seu contrário. O sindicato de Estado é, sempre, e ao contrário do que se passa com outros tipos de sindicalismo, uma instituição que amortece os conflitos de classe" (BOITO Jr, 1991: 15 e 16 - grifos meus)

E continua o autor em outro trecho:

“Os estudos sobre sindicalismo no Brasil, embora usem e abusem do termo estrutura, não concebem o aparelho sindical oficial como uma estrutura, no sentido forte do termo. Concebem-no, em vez disso, como um aparelho dotado de uma maleabilidade sem limites que, dependendo da conjuntura e circunstâncias, pode desempenhar funções antagônicas, ora correspondendo aos interesses da burguesia, ora, ao contrário, constituindo-se em instrumento eficaz para a organização do operariado e das demais classes trabalhadoras.” (BOITO Jr., 1991:13)

Em síntese, a bibliografia atinente ao corporativismo não tem um sentido unívoco, pois que procura conceituar as relações Estado - sociedade e a incorporação dos grupos de interesse pelo Estado de acordo com os casos empíricos analisados. Resgatamos aqui, novamente, Schmitter, para quem o conceito de corporativismo é um tipo ideal, no sentido weberiano. No caso brasileiro, o conjunto dos estudos de diversos autores, cada um com seu foco de interesses específico, indica que a formação corporativista entre nós se constituiu em meio a paradoxos e contradições. Obstaculizou o processo de organização sindical mais autônomo, mas conferiu capacidade e estabilidade organizativa para outros sindicatos que não conseguiriam se firmar, não fosse a legislação corporativa. Procurou "sufocar" as vozes das correntes políticas sindicais que se mobilizavam desde o início do século XX tomando para si a "palavra" e a legitimidade para falar diretamente à classe trabalhadora; entretanto angariou também a oposição do empresariado paulista ao projeto corporativo, pois que esse previa uma simetria e 'igualdade' entre as organizações sindicais patronais e de trabalhadores. Constituiu-se, no campo econômico, em um dos vetores impulsionador da industrialização e de modernização do país, mas também não descuidou dos interesses das oligarquias latifundiárias mais atrasadas. De acordo com Vanda Ribeiro Costa, "a CLT, mais do que consagrar os direitos dos trabalhadores, expressa o acordo entre burguesia e 
Estado sobre os limites do exercício desses direitos do ponto de vista político". (COSTA, 1991:115-116)

Enfim, o corporativismo entre nós combinou um caráter simultaneamente inclusivo e excludente (Stepan), ao mesmo tempo apoiado em incentivos, sem deixar de ter à mão mecanismos de constrangimento (Collier e Collier) para conter alguma ação sindical mais autônoma.

A contradição entre garantir benefícios às organizações sindicais, embora mantendo um controle estrito sobre sua ação é um dos fatores que, a nosso ver, propicia a permanência da estrutura sindical corporativista ao longo dos últimos setenta anos de nossa história, sobrevivendo com vigor a todo tipo de mudança de regime político, bem como de mudanças substanciais na sociedade brasileira, como o intenso processo de industrialização e de urbanização vivido no período.

Não compartilho da opinião de Rodrigues de que a configuração das classes sociais - mão de obra rural, pouca experiência política de organização, mais afeita a um paternalismo, etc. - seria um dos fatores favorável à continuidade do corporativismo. Minha objeção a essa tese é de que ela até poderia ser observada nos anos 1940 / 50 /60. Mas não poderia ser fator explicativo da persistência do corporativismo nos anos 1980 / 90, pois a configuração das classes no Brasil é completamente diferente nestas décadas mais recentes. Se essa tese fosse factível, a experiência da classe nos anos 1980, plenamente urbanizada e com maior experiência de organização sindical, seria um "elemento de pressão" para a mudança da estrutura corporativista. E nada aponta que o é...

Outra explicação dada pelo mesmo autor ao vigor do corporativismo entre nós é de "que o sistema corporativo e a legislação paternalista revelaram-se mais capazes de garantir à massa de trabalhadores, especialmente aos menos qualificados ( $i$ ic), mais vantagens e proteção do que um sindicalismo independente voltado para a pressão e negociação com o patronato". (RODRIGUES, 1990:63)

Também apresento minha objeção a essa explicação, pois, se assim fosse, porque então os trabalhadores rurais e as empregadas domésticas - algumas das categorias mais "desqualificadas" -, juntamente com os servidores públicos, ficaram sem sindicato e sem os 
direitos da CLT durante tantos anos $?^{52}$ Minha posição é de que os direitos assegurados pela CLT não tinham como perspectiva garantir direitos aos trabalhadores dos segmentos mais "desqualificados", mas para cooptar os segmentos com maior potencialidade de organização, independente de serem mais ou menos "qualificados": metalúrgicos, químicos, bancários, etc.

Devido então à contradição inerente ao corporativismo no Brasil, os atores sindicais que ao longo da história se colocaram em oposição ao sistema corporativista de relação de trabalho e de organização sindical, quando se pronunciaram, nunca conseguiram propor de fato um projeto de mudança sistêmica, mas antes mudanças parciais que tornasse possível manter benefícios existentes e retirar apenas os aspectos indesejados.

Esse é o sentido da crítica de Boito Jr. à CUT. Para ele, "a CUT encontra-se, em muitos aspectos fundamentais, integrada à estrutura sindical. Suas ações efetivas, em certos casos, e sua omissão em outros contradizem as declarações de princípio em defesa da liberdade sindical. A relação da CUT com a estrutura sindical não está, contudo, isenta de contradições. Talvez se pudesse falar em uma 'integração conflituosa' das lideranças cutistas ao sindicalismo de Estado". (BOITO Jr., 1991:76)

Essa avaliação crítica sobre a relação da CUT com a estrutura sindical corporativista é assumida pela própria CUT e algumas resoluções congressuais: "Por força de nossa herança histórica, a CUT teve que optar pela transformação da estrutura oficial e não pela construção de uma estrutura paralela, desde o sindicato de base [...] Persistiram, portanto, os pilares básicos do modelo e não conseguimos superar todos os limites impostos à prática sindical, mantendo-se a tendência à corporativização e burocratização dos sindicatos. Hoje, na maioria dos casos não há mecanismos que garantam o controle da base sobre os sindicatos, as direções não mantém canais diretos de contato com os trabalhadores desde os locais de trabalho e ocorre um distanciamento dos dirigentes da realidade dos trabalhadores, limitando-se o poder de pressão, mobilização e negociação dos sindicatos.” (Resolução da $5^{\text {a }}$ Plenária Nacional, julho de 1992)

Do lado patronal, também faltou um projeto que tivesse como finalidade o fim do corporativismo e o estabelecimento de uma ordem plenamente de mercado, sem intervenção do Estado.

Será que o empresariado brasileiro, qualquer que seja sua origem social / étnica, em algum momento de nossa história, teve realmente interesse em contrapor-se aos grupos dirigentes

\footnotetext{
${ }^{52}$ Só após a Constituição de 1988, estes conquistaram formalmente os direitos da CLT
} 
do aparelho estatal? Creio que, entre nós, a tradição ibérica que nos fala Sergio Buarque de Holanda em Raízes do Brasil, ou seja, a característica usufrutuária dessa elite, nunca a tornou de fato uma elite liberal adepta do princípio da economia de mercado. Nesse sentido, o corporativismo de Estado não se antepôs aos interesses da burguesia, mas, ao contrário, foi fiador dela nesse processo de industrialização. Daí porque mantenho a posição de que a burguesia industrial e a oligarquia rural nunca tiveram muito interesse em livrar-se do corporativismo estatal como um todo, mas, da mesma forma que os sindicatos de trabalhadores, retirar apenas os aspectos indesejados e manter um Estado só para si, para seus interesses. Isso foi conseguido, por exemplo, com a ditadura militar pós-1964, quando se alterou a correlação de forças e mudou o regime político, de um "corporativismo inclusivo" para um "corporativismo excludente".

Cabe aqui um comentário acerca da restrição de Cardoso (2003) ao uso do termo "corporativismo" para definir as relações de trabalho no Brasil. Para ele, nosso modelo é legislado, e não um modelo corporativo. Seu argumento para sustentar essa posição é pelo fato de que no Brasil foi o Estado que se converteu no lugar de onde são emanados os direitos sociais e trabalhistas, acima dos interesses das entidades sindicais, e, portanto, é este o lugar onde recorrem os trabalhadores para verem seus direitos assegurados.

Dessa forma, tratar o modelo como "corporativista", na visão do autor, perde o sentido à medida que os sindicatos não teriam o papel de intermediação de interesses, nem mesmo de forma subordinada e tutelada. Para ele, o modelo corporativo, enquanto vigeu entre nós, teve o efeito apenas de excluir os sindicatos, jamais exercendo qualquer capacidade de elaboração de políticas ou de direitos, e não de dotá-los de capacidade de intermediação de interesse, mesmo que subsumido na estrutura estatal.

A despeito da argumentação do autor, preferimos manter o uso do conceito de corporativismo nessa tese, pois a nosso ver, ela permite uma compreensão de escopo mais amplo sobre a relação Estado - sociedade em nosso país bem como acerca do desenvolvimento histórico da organização sindical e suas vicissitudes, lançando luzes sobre aspectos relevantes do tema que de outro modo não seriam percebidos.

Para Francisco de Oliveira, "o importante não é tanto denunciar a tutela do Estado sobre os sindicatos, mas descobrir como, através da mesma tutela e negando-a, os sindicatos funcionaram como os elaboradores das identidades das várias categorias de trabalhadores no Brasil e de uma 
identidade do trabalhador enquanto tal. Em suma, daquilo que antes chamávamos, sem pejo, de consciência de classe. Todos os estudos mais sérios sobre o sindicalismo, antigo e moderno, são unânimes em reconhecer o papel formador do sindicato, atenuando e, no limite, negando a famosa tutela". E continua o autor:

"Na realidade, a tutela era mais um problema estrutural que ideológico. Sendo indiscutível, vale a pena perguntar por que ela pode se exercer. E a resposta é encontrada mais na estrutura industrial que na força da ideologia. Em outras palavras, de um lado, a desigualdade do tecido industrial, entre grandes, médias e pequenas empresas, e, de outro, as desigualdades regionais explicam melhor a chamada "tutela" que uma pretensa submissão e colaboração de classe. Sob outro aspecto, a "tutela" foi, desde o princípio, um instrumento de regulação econômica sob as condições de um capitalismo periférico. Coube aos trabalhadores a façanha de elaborar sua identidade e sua consciência de classe - a consciência de seus direitos - aproveitando-se da regulação que a entrada do Brasil numa divisão internacional do trabalho, comandada pelo capital oligopolista, tornava imperativa. Assim, a "aceitação" da "tutela" não foi ingênua nem submissa, mas um ardil que fazia da fraqueza, força". (OLIVEIRA, 1998:10)

Até aqui abordamos a bibliografia sob o enfoque do corporativismo estatal. Vejamos a vertente do corporativismo social, ou neocorporativa. Essa vertente está intrinsecamente relacionada às experiências desenvolvidas nos países da Europa ocidental, em especial no período do pós-guerra, nos governos de orientação social-democrata. Aqui no Brasil, como de resto em toda a América Latina, como vimos, não faz sentido falar em neocorporativismo, dada a relação construída entre Estado e sociedade, em particular com o movimento sindical.

Já foi mencionada no capítulo uma definição prévia acerca do corporativismo social na resenha bibliográfica de Araújo e Tápias, bem como para Schmitter.

Podemos argumentar que o processo de democratização da sociedade brasileira ao longo dos anos 1980 e a pressão e conquistas dos movimentos sociais na Constituição de 1988 favoreceram o avanço da sociedade sobre o Estado, conferindo entre nós, senão exatamente um modelo neocorporativo, tal como na Europa, mas espaços de negociação bipartite e tripartite para onde os movimentos sociais, e a CUT em particular, canalizaram não apenas suas demandas, mas também o exercício do controle social sobre o Estado através dos diversos conselhos de políticas públicas. 
É essa característica da democratização política no Brasil e o papel destacado dos movimentos sociais e da CUT na conquista / construção da nova ordem política que nos permite fazer aproximações com a experiência neocorporativa europeia, ainda que com as devidas adequações necessárias.

Para Araújo e Tápias, "de um modo geral, o debate travado em torno do conceito de [neo]corporativismo obedeceu às seguintes linhas de clivagens: de um lado, encontramos autores que enfatizaram na análise o corte classista, como Offe (1981) e Panitch (1980); de outro, autores que, mesmo reconhecendo a importância da problemática classista, colocaram ênfase nos aspectos político-organizacionais (Schmitter, 1974, 1979, 1981, 1989b; Lehmbruch, 1982; Cawson, 1978, 1981, 1985 e 1986)”. (ARAÚJO e TÁPIAS, 1991:16)

Analisando o neocorporativismo sob o prisma marxista, os autores destacam a relevância de alguns temas e conceitos nos estudos dessa vertente, como a dominação de classe e a ideia de impactos diferenciados dos arranjos corporativos sobre as organizações representativas do capital e do trabalho. Dessa forma, Araújo e Tápias apóiam-se em Offe para afirmar que "o neocorporativismo é um "método de redução de conflitos de classe", que expressa uma reordenação da representação de interesses fundado no pressuposto lógico de "impor uma certa dose de autocontrole, disciplina e responsabilidade aos grupos de interesse", visando tornar mais cooperativa e previsível a relação entre Estado e interesses organizados". (ARAÚJO e TÁPIAS, 1991:16)

$\mathrm{Na}$ outra vertente acerca do neocorporativismo, Lehmbruch assim o define: "o corporativismo é algo mais que um modelo particular de articulação de interesses. Ele é, antes de tudo, um modelo institucionalizado de formação das políticas no qual as grandes organizações de interesse colaboram entre si e com a autoridade pública não só na articulação (ou também na intermediação) dos interesses, mas, nas suas formas desenvolvidas, também nas alocações imperativas dos valores e na implementação dessas políticas". (ARAÚJO e TÁPIAS, 1991:17)

A linha de interpretação estruturalista, defendida por Schmitter, Lehmbruch e Cawson, entre outros, acabou prevalecendo nos estudos sobre neocorporativismo em relação à linha marxista.

No entanto, para além das diferentes correntes analíticas, Araújo e Tápias analisaram o corporativismo como mecanismo institucional de regulação de conflitos de classe nas sociedades de capitalismo avançado. Para eles: 
“A partir do final da década de 1970, frente ao assédio das teses conservadoras acerca da crise das democracias ocidentais e do papel que nela desempenha o Welfare State, os autores filiados ao paradigma neocorporativista passaram a sustentar que neocorporativismo era um instrumento poderoso para compreender o sistema político nas sociedades capitalistas liberais, sendo o pontochave para o entendimento de como se assegura a governabilidade.

Rebatendo as teses conservadoras que insistiam a respeito do peso das demandas dos setores organizados na crise das democracias avançadas, os teóricos do neocorporativismo defendiam uma tese oposta: o funcionamento e a estabilidade do sistema político nos países capitalistas avançados nos chamados "trinta anos gloriosos" foi possível graças ao surgimento e à consolidação de práticas e estruturas que permitiram mediar os conflitos de classe, através do envolvimento das classes trabalhadoras na formação de políticas e sua cooptação pelas instituições públicas.

Esse processo expressaria um traço típico das sociedades capitalistas avançadas: a formação das principais medidas de política econômica e social tornou-se progressivamente dependente do processo de produção de consenso no interior do sistema político. O reforço do papel regulador do Estado sobre a economia e a perda de eficácia do mercado como mecanismo de regulação por excelência, teriam deslocado as decisões do mercado para o sistema político, ou seja, de um espaço neutro [onde os autores assinalaram "neutro", diria tratar-se de um espaço hegemônico capitalista] para um outro para um outro onde as decisões são objeto de negociação e mediação política.

Nesse contexto político-econômico a classe política passaria a ter a necessidade crescente de produzir consenso em torno das decisões de política econômica e social, encontrar um acordo entre as necessidades de gestão da economia e o Welfare State de modo a fazer frente às demandas provenientes dos vários interesses organizados.

Em suma, nas origens do neocorporativismo há a exigência de dar uma resposta à força conquistada pelo movimento operário, dentro de limites aceitáveis para o funcionamento de uma economia de mercado. Esse seria o "acordo social-democrata", segundo o qual os representantes da classe operária são integrados ao processo de formação de decisões econômicas em troca do respeito à compatibilidade entre a economia capitalista e o controle da própria base sindical". (ARAÚJO e TÁPIAS, 1991: 18-19)

O neocorporativismo esteve associado historicamente a acordos em nível macro envolvendo o compromisso entre capital e trabalho. Para assegurar o desenvolvimento de tais acordos, os autores destacam duas condições institucionais que, em existindo, fortalecem um arranjo neocorporativo: 1) o nível de centralização e concentração das 
organizações de interesse, ou seja, "quanto mais concentrada e centralizada a representação de interesse mais facilmente se poderá desenvolver arranjos e estruturas neocorporativas"; e 2) a presença no governo dos partidos ligados à classe operária, ou em coalizões com a presença desses partidos. ${ }^{53}$

Progressivamente os estudos tendo por base a interpretação neocorporativa foram sofrendo deslocamentos no plano de análise, de um nível macro para níveis intermediários, setoriais, chamados de meso-corporativismo e micro-corporativismo.

A razão do deslocamento da análise nos estudos está associado às transformações operadas no mundo do trabalho e a partir da dinâmica da globalização que, de um lado, desterritorializa o capital exacerbando instâncias supra-nacionais de circulação de mercadorias; ao mesmo tempo, paradoxalmente, fortalecendo identidades locais/regionais e setoriais. Nesse sentido, a nova dinâmica do capitalismo avançado vai solapando o "acordo social-democrata" em detrimento de uma orientação neoliberal, desregulamentadora por excelência dos acordos políticos que expressavam o compromisso entre as diferentes representações de interesse em torno de um projeto nacional inclusivo.

Por esse motivo, o neocorporativismo, na visão de Araújo e Tápias, e de acordo com os autores que abordam sobre o tema, tem uma perspectiva futura reconhecidamente problemática: "Os impactos de alguns processos como a 'explosão dos movimentos sociais', a extrema individualização das demandas, o questionamento das estruturas hierarquizadas, potencializados pelas mudanças impulsionadas nas formas de organização das empresas, dos mercados e das modalidades de concorrência no mercado internacional, na esteira da 'revolução tecnológica', parecem colocar em xeque as forma corporativistas (...) as mudanças (no processo de produção, nas relações entre os indivíduos, entre países etc) em curso desde os anos 70 indicam um cenário cético para a evolução dos arranjos corporativistas”. (ARAÚJO e TÁPIAS, 1991:23).

\footnotetext{
${ }^{53}$ Veremos adiante nesse trabalho que uma das iniciativas que a CUT empreendeu entre 1995 e 2000 foi no sentido de construir estruturas de representação centralizadas como condição importante para efetivar a estratégia do contrato coletivo nacional articulado. Nesse sentido, foi lançada a criação dos sindicatos orgânicos e, depois dos sindicatos nacionais, como meio de dar maior organicidade e centralização/concentração da representação nas estruturas da CUT. Esse tema volta à polêmica entre as correntes internas da CUT já quando no debate do FNT, entre 2003 e 2006, durante o governo Lula, o FNT debate a legislação que estimula a negociação coletiva sob o parâmetro de contratos nacionais. A segunda précondição assinalada pelos autores - presença de partidos de base operária no governo - tornou-se realidade com a eleição de Lula à presidência da República.
} 
Para os autores, a crise social-democrata, correlato à crise do arranjo neocorporativo, traria potencialmente o risco do predomínio de um cenário de fortes conflitos sociais, numa situação de extrema fragmentação dos interesses sociais e de suas demandas.

Em outro artigo, Schmitter faz uma discussão acerca do conceito de corporativismo e modelos de mudança social. Para ele:

“...la corporativización de la intermediación de intereses está relacionada con ciertos imperativos básicos o necesidades del capitalismo para reproducir las condiciones de su existencia y acumular continuamente nuevos recursos. Las diferencias en la naturaleza específica de estos imperativos o necesidades en diversas etapas del desarrollo institucional y del contexto internacional del capitalismo, especialmente cuando afectan la pauta de los intereses de clases en conflicto, explican las diferencias de origen entre las formas social y estatal del corporativismo.

Resumiendo, la decadencia del pluralismo y su gradual desplazamiento por el corporativismo social pueden atribuirse principalmente a la imperativa necesidad de un régimen estable y dominado por la burguesía, debido a procesos de concentración de la propiedad, competencia entre economías nacionales, expansión del papel de las políticas públicas y racionalización de la toma de decisiones dentro del Estado, para asociar o incorporar más estrechamente en el proceso político a las clases subordinadas y grupos con estatus (...)

Dado que esta hipótesis fue claramente 'hiperpredictiva', es decir, implicaba que todas las sociedades de Europa Occidental (y, para el caso, también extra-europeas) que caen en los dos contextos (nacional-institucional e internacional) del desarrollo capitalista debían exhibir por igual las propiedades de los respectivamente apropiados modos de intermediación corporativistas - y esto, descriptivamente, no era el caso -, mi respuesta fue añadir algunos elementos 'hiperdeteminantes' que podían combinarse con afinidades estructurales más generales para explicar diferencias nacionales específicas". (SCHMITTER, 1979b: 91)

Assim, Schmitter oferece três modelos distintos, mas que podem ser complementares para explicar os processos de mudança social nos diferentes arranjos corporativos de sociedade: um primeiro baseado em Durkheim e Parsons, seria o modelo de diferenciação estrutural. O segundo é o materialismo histórico tomado a partir dos escritos históricos de Marx, continuado com a contribuição de Max Weber e determinadas correntes marxistas; e o terceiro seria originado na economia política de Marx, considerado a partir de textos como os Grundrisse. (SCHMITTER, 1979b:92-93) 
Que elementos dessa análise focalizada na experiência europeia fazem sentido ao pensarmos no Brasil? Quais seriam as adequações necessárias para o conceito de corporativismo social fazer algum sentido entre nós?

Tais questões merecem um aprofundamento que não cabe no escopo desse trabalho, mas arrisco dizer que o modelo neocorporativo de sociedade está em disputa na sociedade brasileira desde a transição democrática, concorrendo com o ideário neoliberal do livre mercado e, nessa disputa, logrou alguns êxitos. Não observo no Brasil um arranjo neocorporativo "clássico" de tipo europeu, tal como o "acordo social-democrata"; mas há alguns de seus elementos entre nós, como, por exemplo, são os espaços de participação da sociedade nos mais diversos conselhos de políticas públicas consubstanciados no artigo $1^{\circ}$ da Constituição Federal de 1988; e que a CUT percebe como espaço estratégico na disputa de hegemonia na sociedade.

A CUT delineou sua estratégia política dentro de um escopo neocorporativo através da noção de sindicato-cidadão ou CUT-cidadã, a partir do $4^{\circ}$ e do $5^{\circ}$ CONCUT, respectivamente em 1991 e 1994. (VÉRAS, 2002; FERRAZ, 2003)

Para esses autores a noção de CUT-Cidadã está relacionada a três esferas: as lutas em defesa dos direitos; a participação institucional, aliada ao esforço de influir sobre políticas públicas; e a execução de políticas públicas, com desenvolvimento de projetos cooperativos e oferta de serviços. (VÉRAS, 2002: 419)

Tal estratégia tem sofrido fortes críticas pelas correntes políticas internas situadas em um campo "mais à esquerda" na CUT, bem como em estudos de caráter acadêmicos (ALVES, 2000; BOITO Jr, 1994 e 1999; e GALVÃO, 2007)

O traço em comum entre os opositores da concepção de CUT-cidadã, considerando as diferentes abordagens, pode ser resumido pela crítica à postura propositiva adotada pela Central expressando uma perspectiva de conciliação de classes entre capital e trabalho, como no caso da participação nas câmaras setoriais; uma diluição da classe trabalhadora na noção mais asséptica de cidadão ao participar dos espaços tripartites com o governo e outros atores sociais, ou ainda a adesão consciente da corrente majoritária da CUT ao ideário neoliberal. ${ }^{54}$

\footnotetext{
54 Boito Jr. (1999) faz um ataque à Articulação Sindical, classificando-a no marco da adesão ao neoliberalismo, mas na conclusão do livro, ameniza o tom e analisa os motivos que a levaram à estratégia propositiva e de participação: a ofensiva neoliberal; o contexto adverso de reestruturação internacional do
} 
A perspectiva que essa tese comparte diverge daquele veio de análise, pois compreende que a participação em espaços de negociação não elimina a natureza intrinsecamente conflituosa das relações de classe e, além do mais, segundo noção primordial básica e prática consagrada pelo senso comum, política é espaço que se ocupa. Desse ponto de vista, todos os espaços de representação onde os interesses de classe sejam tema de debate, enquanto trabalhador e também na condição de cidadão, a entidade sindical deve fazer-se presente e manifestar-se em defesa daqueles interesses. Isso não significa, a nosso ver, abrir mão de interesses, nem promover conciliação com o capital, nem render-se à cooptação ou aderir ao neoliberalismo, mas, ao contrário, significa ampliar atuação sindical a mais um espaço de luta sob a perspectiva classista. Negar-se a participar de tais espaços é que significa abrir mão de seu papel classista e deixar o destino da classe exclusivamente aos ditames do capital, sem estar lá sequer para protestar.

Observamos também, para reforçar mais uma vez essa tese, que tais espaços tripartites foram conquistas da sociedade fruto de intensa luta nos anos oitenta, resultando, de um lado, no avanço do controle social sobre o Estado ao constituir espaços públicos de elaboração de políticas públicas; de outro, obrigando Estado e patrões a sentarem-se e discutir temas como investimentos, emprego, projeto de desenvolvimento econômico (regional ou nacional) etc, com a representação de trabalhadores. Temas estes que sempre foram costumeiramente tratados em âmbito privado ou como prerrogativa "exclusiva" do Estado capturado pela lógica privatista e que, trazidos a público nos fóruns tripartites e nas conferências, foram mais um fator de resistência ao neoliberalismo, pois que no contexto dos ataques aos direitos trabalhistas e outras leis de proteção social, os movimentos sociais, a CUT aí incluída, pautaram-se em defesa dos direitos sociais e da universalização das políticas públicas conquistados na Constituição de 1988 na contramão do pensamento

capital; o alto índice de desemprego no período que atemorizava os trabalhadores; a fragmentação da classe através da precarização que resulta em diferentes tipos de contratação; criação de uma corrente opositora competitiva, como a Força Sindical; entre outros (BOITO Jr., 1999: 202-208). A divergência em relação à análise do autor reside apenas na sua afirmação de que as bases sociais da Articulação Sindical são os maiores sindicatos da CUT e, por isso, foram mais impactados pelo neoliberalismo, daí sujeitos a responder defensivamente à ofensiva neoliberal; ao passo que as correntes mais à esquerda da CUT seriam de sindicatos menores, portanto menos atingidos pela onda neoliberal e, em consequência, menos defensivos, ou seja, mais atuantes diante do neoliberalismo. Essa classificação do autor verifica-se apenas parcialmente na realidade pois a Articulação Sindical também é majoritária em correntes que o autor julga "menor", como o setor rural e o funcionalismo público em geral e, além disso, não se observa uma relação tão direta entre caracterização do setor sócio-econômico e grau de reatividade ao neoliberalismo. 
único, tachados pela imprensa conservadora e pelo governo de plantão de "marajás", "vagabundos", "jurássicos", "neobobos", ultrapassados, e antiquados.

Ainda neste ponto, a conquista de tais espaços de participação e proposição não foi criada a partir de um movimento de cooptação do Estado ou do capital sobre o trabalho no contexto neoliberal, mas, ao contrário, fruto da organização da classe, daqueles personagens que entraram em cena a partir dos anos oitenta e se colocou em marcha no período constituinte reivindicando aqueles espaços.

Os elementos de um arranjo neocorporativismo verificados no Brasil a partir dos anos noventa foram, portanto, uma conquista das lutas sociais e mais um elemento de resistência à hegemonia neoliberal.

Isto posto, não se deve negligenciar os limites e os problemas da estratégia da CUT-cidadã, pois, como bem assinala Véras (2002), esta comporta oportunidades, mas também riscos.

O limite dessa concepção que tem sido formulada na CUT é o próprio limite da institucionalidade dos conselhos de políticas públicas. Por tratar-se de uma experiência muito recente na sociedade brasileira, o avanço firmado a partir da Constituição de 1988 ainda é muito contrastante com a prática do Estado (seja no nível da União, estados e municípios), muito marcada ainda pelo clientelismo, pelo patrimonialismo e outras características de uma sociedade historicamente autoritária em que a esfera pública sempre esteve a serviço de interesses privados e fez dos políticos em geral - vereadores, deputados, prefeitos, etc. - credores da população pelo "favor" de serviços prestados: asfaltamento de rua, abertura de creche, arranjar vaga em escolas públicas, posto de saúde, ambulância, etc. Desse modo, a atribuição deliberativa conferida a muitos conselhos não tem se efetivado na prática, pela resistência da forma tradicional de "fazer política" ser ainda muito forte na sociedade.

Por outro lado, alguns problemas dessa concepção também puderam ser identificados em seminários e cursos de formação voltados para o tema de políticas públicas, em que o relato de dirigentes retratou muitas vezes uma falta de compreensão sobre a importância da participação sindical nos conselhos, ao destacar membros para ocuparem tais espaços sem debater na direção qual a linha de atuação para orientar a intervenção do indicado, nem 
tampouco reservando espaço na pauta de reunião da entidade para debruçar-se sobre os temas tratados no conselho ${ }^{55}$.

Do mesmo modo, a CUT no estado de São Paulo tem promovido nos últimos anos, em nome do sindicato - cidadão, um conjunto de iniciativas de prestação de serviço à população que, a nosso ver, não tem nada a ver com o debate sobre políticas públicas nem trata da noção de direitos, se assemelhando mais a iniciativas filantrópicas que proporcionam alguma visibilidade midiática. Percebe-se, nesse caso, uma falta de clareza para alguns dirigentes de destaque na Central sobre o que vem a ser cidadania realmente ${ }^{56}$. As críticas a serem feitas, do ponto de vista aqui apresentado, devem centrar-se na distorção revelada em práticas equivocadas sobre o que vem a ser realmente cidadania e, daí, uma proposta de sindicato-cidadão; e não uma crítica conceitual que, a pretexto de sustentar uma posição classista, renega a participação sindical em espaços onde se discute temas de interesse dos trabalhadores.

A noção de sindicato-cidadão, ou de CUT-cidadã, é coerente com o projeto histórico desde a fundação da Central de fortalecer a democracia no país, associado aos direitos e à cidadania. Percebe-se que muito há ainda a ser percorrido pela CUT nessa trajetória.

\section{Corporativismo estatal, populismo e desenvolvimento econômico brasileiro: algumas questões}

O conceito de populismo está associado a um período histórico de nosso país ${ }^{57}$, entre o final do primeiro governo de Vargas (meado dos anos 40) e o golpe militar de 1964, e seu uso denota uma explicação sobre as formas de relação política entre o "povo" e seus

\footnotetext{
55 Retornaremos a esse tema mais adiante, nesse capítulo, quando abordarmos mais especificamente a participação de dirigentes sindicais cutistas nas Comissões Municipais de Trabalho e Emprego.

${ }^{56}$ Nos referimos aqui às celebrações de $1^{\circ}$ de Maio (depois levadas a outras datas significativas ao movimento sindical cutista, como o 8 de Março, por exemplo), promovida pela CUT-SP a partir de 2004, que "inovaram" com atividades em locais da periferia da capital com "tendas da cidadania" onde se ofereceu serviço de corte de cabelo, medição de pressão, podólogos entre outros. Essa "festa de cidadania" no Dia dos Trabalhadores era associada a shows de artistas renomados da música que levaram multidão de pessoas às atividades da Central, numa clara disputa numérica e de marketing com a atividade da Força Sindical. O financiamento da "festa" ficava a cargo do patrocínio de grandes empresas públicas e privadas. Esse tipo de celebração com patrocínio de empresas foi fortemente criticado pelos delegados(as) à Plenária Estatutária da CUT-SP, em junho de 2008, quando foi aprovado o fim desse tipo de comemoração. No $1^{\circ}$ de Maio de 2009 já não se viu mais a estrutura de tamanha envergadura de show e patrocínio de empresas, mas manteve-se ainda a ideia das "tendas de cidadania".

${ }^{57} \mathrm{O}$ conceito de populismo não é exclusivo do Brasil. Não nos convém enveredar por esse caminho, mas fazse necessário lembrar que em vários países da América Latina se usa esse conceito para explicar fenômenos da relação Governo - Povo (ou Estado - Sociedade), grosso modo, da mesma forma que aqui.
} 
governantes no Brasil. Assim, como assinalado na seção anterior, "populismo" foi a forma como se viabilizou o modelo corporativista estatal no Brasil, denotando um certo tipo de relação Estado - sociedade.

As definições possíveis para esse conceito são controversas, comportando abordagens diferenciadas sobre ele. De todo modo, resumidamente, a noção de populismo remete a um processo de industrialização baseado na substituição de importações e em um processo de urbanização acelerada no país. (FERREIRA, 2001)

Enormes levas de migrantes rurais chegavam às grandes cidades destituídas de uma tradição de mobilização por seus direitos porque se encontravam sob o jugo patriarcal dos coronéis. Exacerbando a definição deste conceito, pode-se dizer que aqueles trabalhadores migrantes comportavam-se na política como massa, sendo supostamente "passivos" a todo tipo de "manipulação" por políticos carismáticos que se dirigiam diretamente a eles, por cima dos partidos ou de qualquer mediação institucional, portadores de benesses ao qual o "povo" deveria ser grato e retribuir-lhes com voto.

Essa noção de populismo é a versão predominante entre os estudos das ciências sociais (na sociologia, na ciência política e na história), e "fez escola" no mundo real da política.

São inúmeros os autores que trilharam esse caminho para explicar as relações políticas constituídas no Brasil dos anos 1945 - 1964, com ênfase para os trabalhos de Weffort (1973, 1975, 1978) e Ianni (1968), entre outros.

É importante assinalar que essa definição hegemônica de populismo mereceu críticas em estudos mais recentes sobre o período 1945-1964 (GOMES: 1988; COSTA: 1995; FONTES, 1997; FORTES, 1999; SANTANA, 2002). Tais autores divergem da noção de populismo em que o povo se encontraria totalmente destituído de vontade própria, à mercê das ações da classe dominante.

Para eles não se trataria de uma via de mão única, do Estado controlando a sociedade, mas antes uma via de mão dupla, em que o "povo" também exerceria pressão sobre o Estado (governo) para terem atendido suas demandas. 
Para o tema que nos interessa na pesquisa - a estrutura sindical - essa polêmica é extremamente relevante para refletirmos sobre a natureza do movimento sindical no período referido.

Para Weffort o movimento sindical do período pré-64 teria contribuído para a perpetuação da política populista com sua estratégia organizativa e sua prática sindical "a reboque" dos governantes de então devido à crença na "democracia burguesa" na "aliança com a burguesia nacional". Por tudo isso, eles não teriam enfrentado os limites da estrutura sindical corporativa. Essa crítica é feita, sobretudo à atuação do Comando Geral dos Trabalhadores (CGT) no período efervescente que antecedeu o golpe militar.

Obscurecia-se dessa forma, uma leitura mais amiúde do movimento sindical da época, evocando apenas a análise da atuação das lideranças sindicais.

Essa é a linha do trabalho dos demais autores mencionados. Costa (1995), por exemplo, aponta o foco para a militância comunista nas células e nos mostra o quanto havia de tensão entre este e a direção do PCB, pois que eles viviam diuturnamente os anseios dos trabalhadores que pressionavam e imprimia uma ação nem sempre alinhada ao comando do Partido. Por vezes, mostra o autor, a base subvertia as orientações do Partido.

Assim, indica-se que os trabalhadores não eram marionetes, nem das lideranças sindicais, nem do governo. Sua adesão à política do governo reflete, antes, uma postura política para obter conquistas.

O mesmo pôde ser observado em outros estudos sobre a atuação dos comunistas entre os metalúrgicos do Rio de Janeiro, entre 1945 e 1964, na tensão vivida pela militância entre a orientação do Partido e as demandas dos trabalhadores de base. (SANTANA, 1992 e 2002; SANTANA e RAMALHO, 2001)

O corporativismo no Brasil revestiu-se de aspecto político - a relação entre Estado e sociedade, e a incorporação de grupos de interesses -, mas também de aspecto econômico, de modernização e ampliação do parque industrial de modo que configurou um modelo de desenvolvimento nacional que fez do país um dos que teve crescimento mais acelerado ao longo do século XX e também de maior concentração de renda, gerador de desigualdades sociais brutais. Com isso não queremos dizer que o Estado "autônomo" em relação às classes, fosse neutro ou isento. A nosso ver o corporativismo no Brasil, mesmo 
assegurando direitos e conquistas aos trabalhadores, se revestiu também de interesse de classe, expresso no modo diferenciado como foi implementado frente às organizações dos trabalhadores e às patronais ${ }^{58}$.

Desse ponto de vista, na história do Brasil, o corporativismo articula dimensão política, econômica e social. Assim sendo, em nosso modelo corporativista o Estado acabou por ganhar "autonomia relativa" em relação às classes sociais e assumiu um papel indutor na economia, intervindo na formação de uma indústria de base e de infraestrutura através do serviço público direto ou de empresas estatais, como a Petrobrás, a Companhia Siderúrgica Nacional (CSN), a Companhia Vale do Rio Doce (CVRD), a construção e manutenção de portos e estradas de rodagem, e todo um sistema de telefonia estatal (Sistema Telebrás e a Embratel), e de sistema elétrico (Furnas, etc) entre outras.

Esse empenho do Estado na economia se consubstanciou no modelo "desenvolvimentista", de que a plataforma do presidente Juscelino Kubitschek de promover um crescimento de "50 anos em 5" carrega a imagem mais simbólica. A partir da ação do Estado, configurouse o que ficou conhecido como o tripé de sustentação desse crescimento: as empresas multinacionais, estimuladas a instalarem-se em território nacional; as empresas estatais que formariam a indústria de base e toda infraestrutura; e as empresas de capital privado nacional, como a ponta mais frágil e dependente do tripé.

Ao cumprir esse papel indutor no desenvolvimento econômico, o Estado brasileiro punhase também à disposição da burguesia nacional, capturado pelos interesses privados daquela classe, ainda que impondo a esta uma cesta de direitos trabalhistas que, ao menos em tese, deveria ser obedecida.

Desse modo, no Brasil o período mais intenso de industrialização do país após a década de 1930 veio acompanhada de uma legislação trabalhista protetora, embora nem sempre observada pelo patronato; e uma legislação sindical restritiva às ações sindicais, sob a égide de uma concepção corporativista de sociedade e de Estado, em que caberia aos sindicatos, tal como prescrito no artigo 514 da CLT, promover a conciliação e harmonia entre as

\footnotetext{
${ }^{58}$ Ver a esse respeito, o artigo de Vanda Ribeiro Costa (1991)
} 
classes $^{59}$. (MORAES FILHO, 1978; FÜCHTNER, 1980; SEGATTO, 1987; GIANNOTTI, 1988; GOMES, 1988; SOUZA MARTINS, 1989; BOITO Jr., 1991)

Tudo isso em um regime político "populista", de inclusão de trabalhadores diretamente no mundo da política, enquanto "povo" e não enquanto "classe", cujas organizações sindicais encontravam-se legislados pela CLT.

Conforme já assinalado nesse trabalho, a instauração desse "jogo contraditório" do Estado em relação à classe trabalhadora e aos sindicatos não tinha um sentido único, do Estado controlando o sindicato; mas acabou por constituir-se em uma via de mão dupla, em que os sindicatos também exerciam pressão sobre o Estado cobrando que este cumprisse seu papel junto à classe trabalhadora, em contraposição / complementação ao movimento de controle do Estado sobre os sindicatos.

Evidentemente que, embora exitosa em boa medida, a estrutura sindical oficial não fez tábula rasa das lutas do movimento sindical no Brasil. Grosso modo, as lutas sindicais permaneceram no Brasil desde a segunda metade dos anos 1940 até o golpe militar de 1964, quando vivemos um período democrático e o corporativismo revestiu-se de caráter inclusivo, sendo retomada quando do recrudescimento da democracia a partir do final dos anos 1970, com o "novo sindicalismo". Tais lutas no pré-64 foram efetivadas por organizações sindicais que também procuravam pautar sua atuação para além do corporativismo $^{60}$, mas que, a despeito disso, as fizeram sob o enquadramento tutelar da estrutura sindical.

O resultado dessa tensão de classe no interior do regime populista, com a intensa ação dos sindicatos oficiais organizados pelos comunistas e trabalhistas questionando os limites da estrutura sindical oficial, foi a instauração do regime militar, que muda o viés do corporativismo, acentuando a faceta excludente e os mecanismos de constrangimento.

\footnotetext{
${ }^{59}$ Diz textualmente o artigo 514 da CLT: "São deveres dos Sindicatos: a) colaborar com os poderes públicos no desenvolvimento da solidariedade social; b) manter serviços de assistência judiciária para os associados; c) promover a conciliação nos dissídios de trabalho; d) sempre que possível, e de acordo com as suas possibilidades, manter no seu Quadro de Pessoal, em convênio com entidades assistenciais ou por conta própria, um assistente social com as atribuições específicas de promover a cooperação operacional na empresa e a integração profissional na Classe. (Alínea incluída pela Lei no 6.200, de 16-04-75, DOU 17-04-75)".

${ }^{60}$ Nossa pesquisa não versará exatamente sobre tais iniciativas das organizações sindicais do pré-64, exceto quando se fizerem necessárias. Contudo, para efeito de registro, podemos mencionar como organizações em legítima defesa pelos direitos dos trabalhadores e não-oficiais na estrutura oficial, entre outras, o Movimento Unificado dos Trabalhadores (MUT), entre 1945 e 47; o Pacto de Unidade e Ação (PUA) e o Pacto de Unidade Intersindical (PUI), no início dos anos 1960 e o Comando Geral dos Trabalhadores (CGT), entre 1962 e 1964; e o Movimento Intersindical Anti-arrocho (MIA), em 1967/68.
} 


\section{Mecanismos de incentivo e de constrangimento da estrutura sindical corporativista}

Deve-se ressaltar, entretanto, que foi necessário efetivar a concepção sindical corporativista de colaboração de classes a partir de todo um arcabouço jurídico a moldar as ações dos sindicatos, conhecido por estrutura sindical, materializando aquela concepção em práticas sociais efetivas.

Essa "teia jurídica" que enredou as organizações sindicais a partir da década de 1930, como já foi dito nessa tese, contém elementos de incentivo e de constrangimento sobre a ação sindical. Mais do que uma questão jurídica, a legislação sindical forjou uma cultura no meio sindical, tão responsável pela conservação de um padrão de ação sindical quanto às leis. É sobre tais aspectos que essa sessão abordará.

Resumidamente esse sistema (ou a estrutura sindical) é composto pelos seguintes pilares: o enquadramento das entidades sindicais por categoria profissional, a unicidade sindical, a ausência da representação sindical nos locais de trabalho, a negação do conflito através do sistema de negociação por datas-base e pelo poder normativo da Justiça do Trabalho, e a sustentação financeira compulsória através da contribuição sindical, conhecido como imposto sindical. (MORAES FILHO, 1978; FÜCHTNER, 1980; SEGATTO, 1987; GIANNOTTI, 1988; GOMES, 1988; SOUZA MARTINS, 1989; RODRIGUES, 1990; BOITO Jr., 1991)

Tomada em seu conjunto, a combinação destes pilares tornou os sindicatos no Brasil controlados pelo Estado (Ministério do Trabalho), com a tentativa de torna-los acomodados em seu papel legal, que seria de conciliação de interesses e harmonia entre as classes, dominados por um tipo de sindicalista conhecido pela denominação de pelego ${ }^{61}$.

Enfim, a estrutura sindical persiste no Brasil seja para manter o poder discricionário de dirigentes sindicais pouco afeitos à mobilização de suas respectivas categorias; seja, paradoxalmente, para sustentar melhores condições de mobilização social dos trabalhadores fornecendo recursos (políticos e financeiros) que de outro modo seria difícil manter.

\footnotetext{
${ }^{61}$ Pelego é a pele de carneiro utilizada pelos cavaleiros entre a cela e o animal de modo a amortecer o impacto. Passou a ser também a denominação popular para designar o sindicalista que amacia o conflito entre patrão e empregados, em geral burocratas e corruptos que se locupletam das benesses do Estado e dos patrões para vender os interesses dos trabalhadores nas negociações trabalhistas.
} 
Passemos de forma breve sobre cada um dos pilares da estrutura sindical corporativista, debatendo qual o sentido de cada um dos seus elementos sobre a organização sindical, observando o que há nela de constrangimento e de incentivo à ação sindical.

Boito Jr. vê como elemento central do edifício corporativista o reconhecimento oficial-legal dos sindicatos pelo Estado. A outorga da representação sindical é o primeiro e fundamental passo para o sindicalismo de Estado "porque dele dependem todos os demais elementos que compõem essa estrutura”. (BOITO Jr., 1991:51)

Partindo dessa premissa de Boito Jr., uma das primeiras medidas de controle sobre os sindicatos foi fragmentar e pulverizar a organização dos trabalhadores. Isso foi conseguido através da divisão dos sindicatos por categorias profissionais. Dessa forma, entidades que no pré-1930 poderiam aglutinar trabalhadores de diversos segmentos profissionais (por exemplo: trabalhadores da indústria têxtil com a indústria de bebidas e massas, com motorneiros de bonde) foram proibidos por lei. Os sindicatos de metalúrgicos só poderiam aceitar como sócios metalúrgicos, e assim por diante, com cada categoria.

Depois de divididos em categorias profissionais, foi estabelecida por lei a unicidade sindical em bases territoriais nunca inferiores a um município, ou seja, além de divididos por categoria, os sindicatos passaram a ter o monopólio da representação naquela base territorial.

A fim de evitar sua atuação coesa em articulações intersindicais horizontais, a legislação preconizou o verticalismo como mais um pilar da estrutura corporativista, provocando que qualquer atuação conjunta fosse deslocada do nível do sindicato para órgãos superiores como as federações estaduais ou interestaduais, e estas, em nível nacional, através das confederações.

Essas três medidas da legislação sindical - enquadramento sindical por categorias profissionais, unicidade sindical e verticalismo -, compreendidas de forma articulada e complementar, promoveram enorme fragmentação e pulverização das organizações sindicais, e, por conseguinte, à fragmentação das lutas e dificuldade de mobilização conjunta, enquanto classe. Esse foi o sentido desejado com tais medidas.

Entretanto, esses fatores que consideramos inibidores de uma ação sindical voltada à defesa dos interesses dos trabalhadores, e que, portanto, seriam elementos de constrangimento à 
ação sindical, contraditoriamente pode ser interpretado como fatores positivos de garantias e estabilidade por inúmeros dirigentes sindicais.

Dessa forma, cultivou-se uma "cultura" no meio sindical brasileiro de que cada categoria tem suas especificidades e, desse modo, cada qual deve constituir seu próprio sindicato. Qualquer tentativa de reorganização buscando ampliar o escopo de representação para além da categoria sofre resistência, que é anterior à restrição legal da CLT. Nesse sentido, cria-se uma noção em que "ser combativo e atuante é formar seu próprio sindicato"... Esse é um dos fatores que dificulta a proposta da CUT de constituir os sindicatos por ramo de atividade, unificando sindicatos de áreas de trabalho semelhantes, como veremos adiante. A unicidade é um mecanismo de controle dos mais sutis. Muitos dirigentes de sindicatos filiados à CUT consideram positiva a unicidade, entendendo que dessa forma asseguram uma unidade de ação ao menos na base territorial. Não se dão conta de que o regime de unicidade sindical, ao contrário do que as aparências indicam, não assegura unidade alguma, muito pelo contrário, contribuem para a fragmentação sindical ainda mais. Segundo dados do censo sindical do IBGE, em 2001 havia 11.354 sindicatos, mesmo com a unicidade sindical em vigor. Seu efeito mais perverso, entretanto, nem é esse, mas a acomodação de dirigentes sindicais ao aparelho uma vez que não tem concorrência de outras entidades sindicais a disputar a filiação dos trabalhadores de base. Então temos mais uma vez um fator que ao mesmo tempo serve de incentivo para dirigentes pouco afeitos à organização de trabalhadores e de constrangimento a uma ação sindical combativa mais efetiva.

O verticalismo contribui com o afastamento cada vez maior da base, propiciando um tipo de sindicalismo em que as decisões são tomadas pela cúpula.

Enfim, cada um dos pilares mencionados da estrutura sindical corporativista têm como sentido último a fragmentação, a pulverização, o acomodamento e o afastamento da base, convertendo-se em constrangimento à ação sindical mais autônoma, segundo Stepan. Contudo, os mesmos pilares podem ser tomados como elementos de incentivo. A combinação entre esses dois tipos de provisões (incentivo e constrangimento) em cada um dos pilares acaba sendo um obstáculo a supressão destes, pois que abrir mão dos aspectos de constrangimento necessariamente leva a perda dos incentivos assegurados por lei. 
A sagacidade do regime de Vargas consistiu em que os elementos da estrutura sindical mencionado até aqui converteriam os sindicatos em instituições absolutamente inúteis, sem representatividade política e social sequer para promover a conciliação de classe. Aliados àqueles três pilares ditos anteriormente, o Estado estabeleceu formas de financiamento compulsórias para manutenção do sistema sindical, como a contribuição sindical, também conhecida como imposto sindical, arrecadada de cada trabalhador com registro na CTPS. Desse modo, almejava o Estado, os dirigentes não precisariam se preocupar em buscar a filiação de trabalhadores para obter fundos e sustentação financeira autônoma. O desconto de um dia de trabalho por ano estaria assegurado em lei.

Mas isso também não resolveria o problema de falta de credibilidade e representatividade sindical frente aos trabalhadores... O sindicato precisaria converter-se em um prestador de serviços que estimulasse uma parcela mínima que fosse de trabalhadores a frequentar o sindicato e conferir-lhe um mínimo de legitimidade como representação perante o patronato e o Estado. Como não poderia se constituir em entidade de organização das lutas, os sindicatos foram convertidos em instrumento de assistencialismo para os sócios, outro pilar da estrutura corporativista. ${ }^{62}$

Por fim, a última pedra de toque da estrutura corporativista é a disciplinarização das relações de trabalho através do estabelecimento de datas-base e a instituição do poder normativo da Justiça do Trabalho de modo a que, ao invés de ter no conflito algo "natural" das relações de trabalho, o Estado se converte em árbitro e interfere nas relações capital trabalho, negando o espaço de livre negociação entre as partes.

Assim, o imposto sindical, o assistencialismo, a organização das 'negociações' em períodos específicos de datas-base e o poder normativo da Justiça do Trabalho se articulam àqueles outros três pilares - enquadramento por categoria profissional, unicidade e verticalismo para amarrar e tutelar as organizações sindicais ao Estado.

Em comum, cada um deles pode ser tomado simultaneamente como elemento de incentivo e constrangimento à ação sindical.

\footnotetext{
${ }^{62}$ Alguns desses "pilares" apoiaram-se em uma cultura política anterior à estrutura corporativa, como é o caso do assistencialismo. Já havia no pré-30 a experiência das associações de auxílio mútuo e mesmo sindicatos anarquistas mantinham prática que combinavam a luta, o lazer e as festas. Esse "assistencialismo" no pré-30 era parte de uma ação de solidariedade de classe e de manifestação da cultura operária que foi incorporada à estrutura sindical oficial e distorcida pelo Estado passando a ter uma lógica de cooptação para afastar-se da luta.
} 
Almeida (1992) ressaltou como um fator comum ao sindicalismo o baixo índice de sindicalização, evidenciando que os elos entre representantes e representados são frágeis. No entanto, a autora não retira daí a mesma conclusão de Rodrigues (1999) de observar no fenômeno a fragilidade da instituição sindical como um todo.

No Brasil, a manutenção da sindicalização em patamares continuamente baixos não tem tal significado porque a capacidade de mobilização sindical é bem maior que a sua representação formal, adverte a autora.

Assim, a questão é que há um descolamento entre os sindicatos e os trabalhadores, de modo que esperam muito pouco de suas lideranças sindicais. Em outras palavras: é o sindicato para um lado; os trabalhadores para outro.

Além disso, pesquisa da autora em quatro grandes sindicatos de metalúrgicos no estado de São Paulo, em 1978, constatou que menos de $20 \%$ dos trabalhadores tinham mais de cinco anos de sócio, em função provavelmente da alta rotatividade e do contexto em que foi realizada a pesquisa (ditadura militar). Almeida cita ainda os dados da Pesquisa sobre Participação político-social nos sindicatos acerca do motivo pelo qual os trabalhadores filiavam-se aos sindicatos, realizada pelo IBGE, em 1988: "62,2\% dos sindicalizados da amostra indicavam os benefícios assistenciais (assistência médica ou jurídica) oferecidos; $10,6 \%$ as atividades esportivas ou culturais; $11,6 \%$ a atividades políticas; e 12,0\% outras atividades" (ALMEIDA, 1992: 103-104)

Desse modo, a partir dos dados de ambas as pesquisas, a autora nos permite afirmar os sindicatos têm sua sobrevivência assegurada pelo imposto sindical e pelo monopólio de representação. É pela combinação desses dois fatores que os sindicatos continuam a existir apesar do descolamento de sua real base de representação.

Esse descolamento de representação dos sindicatos em relação aos seus representados é que permite, por sua vez, a persistência de uma das principais características da estrutura sindical brasileira, segundo a autora, a desconcentração, ou seja, a fragmentação sindical em milhares de entidades de pequeno porte.

Para Almeida, "a desconcentração tem pelo menos duas consequências importantes para a conformação do poder sindical. Ela o fragmenta e dispersa por uma miríade de sindicatos municipais, em sua maioria pouco expressivos e com exíguo capacidade de barganha. Com efeito, aquela imagem do sindicato rico, instalado em grande edifício, materialmente bem equipado, com um corpo de funcionários numeroso, escola, colônia de férias, serviço médico, departamento 
jurídico e um sistema ágil de comunicação com os associados corresponde a uma parcela ínfima das entidades de primeiro grau espalhadas pelo país. Em 1988, $20 \%$ dos sindicatos não possuíam um único funcionário - não passavam de sindicatos de carimbo -, 55\% possuíam até cinco funcionários e apenas 1,3\% tinham mais de 50 funcionários. A mesma pesquisa do IBGE revela que 77, 8\% dos sindicatos não possuía médicos; 75,2\% não tinha advogados; $82,5 \%$ não dispunha de contadores e cerca de 97,0\% não contava com qualquer tipo de assessor especializado". (ALMEIDA, 1992:109-110)

Essa desconcentração, segundo a autora, fortalece a tendência ao conservadorismo no mundo sindical.

A desconcentração é complementada através de outra característica da estrutura sindical: a descentralização.

Com efeito, é o sindicato que concentra o poder de representação formal dos trabalhadores, evidenciado pelo seu papel de ser o único ente legítimo para assinar acordos e convenções coletivas. As federações representam sindicatos; não os trabalhadores, portanto, em geral não assinam acordos nem convenções coletivas, exceto quando não há sindicato no município. Isso confere às federações, e mais ainda às confederações, um papel praticamente inexpressivo e irrelevante, mais afeito à acomodação de dirigentes do que ao fortalecimento das lutas.

Quando funcionam efetivamente, as federações e confederações cumprem um papel de articular os sindicatos, mas não lhes faculta maior representatividade, pois a "palavra final" é sempre do sindicato de base.

As centrais sindicais criadas a partir dos anos1980 padecem desse "mal" originado na estrutura sindical corporativa: estimulam ações unificadas de várias categorias num esforço de coordenação, mas acabam, vias de regra, dependentes dos grandes sindicatos oficiais que lhes garante a sustentação financeira e política.

Martins (1989) analisa, no quadro da legislação corporativa, a transformação dos sindicatos em um aparato dentro da ordem estatal. Diz a autora: "foram as constantes determinações do Estado brasileiro, regulamentando a vida sindical trabalhista, que tornaram impossível ao dirigente sindical realizar as tarefas impostas ou exigidas pela legislação, sem uma burocratização administrativa". (MARTINS, 1989: 163) 
Essas são as bases sobre a qual o sindicalismo brasileiro tem se desenvolvido, como vimos, tentando organizar e efetivar suas lutas em defesa dos interesses de classe apesar das amarras da legislação e da cultura sindical forjada pelo espírito corporativo.

\section{O "novo sindicalismo" e a fundação da CUT}

Já foi colocado sucintamente, no início do capítulo 1 dessa tese, o contexto de ascensão dos movimentos sociais, em geral, ao longo dos anos 1980, em particular do "novo sindicalismo" e da CUT. Cabe-nos, agora, voltar mais em detalhe a esse período da história a fim de compreender como a CUT foi enfrentando os desafios colocados pela estrutura sindical corporativista, em um movimento de adequação / superação que vem marcando a constante transformação de ambos. Nem a estrutura sindical é a mesma depois da fundação da CUT; nem a CUT é a mesma depois de inúmeros dirigentes e militantes sindicais terem vivido experiências à frente dos sindicatos oficiais.

Vimos então que a origem da CUT remonta o período de ascensão das lutas sindicais entre o final dos anos 1970 e início dos anos 1980 impulsionados pelas greves de diversas categorias que sacudiram todo o país. Toda aquela mobilização foi ensejando diversas articulações intersindicais, então proibidas pela CLT e vista como um perigo pelo governo militar da época.

Foi nesse processo que combina lutas sociais, notadamente as greves, e os vários encontros de trabalhadores e lideranças sindicais que aos poucos foi se tecendo a aliança entre os setores que fundariam a CUT em 1983.

Retomando o trabalho seminal de Sader (1988), a CUT é fruto de três grandes pilares em sua formação.

De um lado encontravam-se dirigentes sindicais chamados "autênticos", que emergiam de dentro dos sindicatos oficiais, mas que se colocavam em oposição ao regime da ditadura militar. A oposição que travavam frente ao regime não era motivada tanto por questões estritamente ideológicas ou políticas, mas, sobretudo por reposição de perdas inflacionárias que o governo havia manipulado entre 1973 e 1974, na gestão do ministro da fazenda Delfim Neto. O questionamento econômico, naquele contexto, se desdobrava como uma crítica à política do governo como um todo e se somava a outras vozes que também bradavam por mais liberdade, pela anistia aos presos políticos e pela abertura política no país. 
Tais dirigentes "autênticos" - entre eles Lula como a liderança de maior envergadura, que comandava as greves dos metalúrgicos do $\mathrm{ABC}$ paulista como presidente do Sindicato dos Metalúrgicos de São Bernardo do Campo e Diadema -, representavam um fato novo na cena política brasileira, permitindo uma expressão pública àqueles que sempre tiveram reservado um lugar subalterno em nossa História. ${ }^{63}$

Outro grupo social e político, diferente dos "autênticos", que também estiveram ao longo de todo o processo que levou à fundação da CUT foram os militantes das oposições sindicais. É comum encontra-los na bibliografia sob a denominação de "combativos". (RODRIGUES, 1991; RODRIGUES, 1997; SANTANA 1999)

A trajetória desse grupo é de acúmulo de forças ao longo dos anos 1970 fora dos sindicatos oficiais, ao qual teciam fortes críticas por identificarem como um espaço com mecanismos de cooptação do Estado sobre as lideranças dos trabalhadores através da ideologia de colaboração de classes, que resultava na figura dos "pelegos", legado do corporativismo getulista.

De fato, muitos sindicatos no período de 1964 em diante sofreram intervenção pelo Ministério do Trabalho, destituindo lideranças legítimas e, em seu lugar, alçando dirigentes da confiança do regime à frente dos órgãos de classe. Tudo dentro da lei, conforme disposto na Consolidação das Leis do Trabalho (CLT) desde a década de 1930.

A figura pública que mais catalizou o descontentamento e a contestação dos grupos de oposição no período foi Joaquim dos Santos Andrade, o Joaquinzão, que assumiu a presidência do Sindicato dos Metalúrgicos de São Paulo após o golpe militar, permanecendo no comando por oito mandatos até 1987, quando fez Luis Antônio de Medeiros seu sucessor, superando duas chapas de oposição cutista.

\footnotetext{
63 É muito interessante notar como Lula, por exemplo, desenvolveu seu processo de politização naqueles anos. Em uma nota de rodapé, Rodrigues assinala: "Lula, a grande liderança do novo sindicalismo, em 1980 declarava que, até 1979, era a pessoa 'mais apolítica' que existia no país (...) em abril de 1978, já tendo se projetado como o grande dirigente sindical brasileiro, Lula afirmava "não ter vocação política" e nunca ter pensado em se "candidatar a nada". (...) "...não se trata de uma declaração isolada. Lula reiteraria várias vezes essa afirmação. 'Não tenho pretensões políticas, não sou filiado a partido político e tenho certeza de que jamais participaria da vida política porque eu não sirvo pra político'. Mesmo depois da criação do Partido dos Trabalhadores, Lula ainda diria que o fato de participar de um partido político não significava que tivesse 'pretensões políticas'..". (Rodrigues, 1991:29) Segundo I.J. Rodrigues, a visão daquele segmento de dirigentes era pragmática, que depois se politiza (Rodrigues, I.J.1993:78)
} 
Entre as oposições sindicais encontravam-se inúmeros militantes organizados em correntes políticas da esquerda clandestina, leninista ou trotskista ${ }^{64}$. Algumas organizações eram egressas de uma autocrítica pela opção da luta armada contra a ditadura. Outras não chegaram à via armada para derrubar os militares do poder, optando pelo trabalho silencioso de organização dos trabalhadores. Em que pese diferentes trajetórias, o que havia em comum era que todos procuravam voltar-se para o trabalho de base nos bairros e nas fábricas, sempre em oposição à ditadura e aos "pelegos", tidos indistintamente como dirigentes sindicais representantes da ditadura militar.

A opção preferencial que a Igreja Católica fez pelos pobres a partir da $2^{\mathrm{a}}$ Conferência Geral do Episcopado Latino-americano, a Conferência de Medellín (1968) e a $3^{\text {a }}$ Conferência Geral do Episcopado Latino-americano, a Conferência de Puebla (1979), como consequência da Encíclica Rerum Novarum, do Papa Leão XIII e do Concílio Vaticano II, iniciado sob o papado de João XXIII e concluído com Paulo VI, que aproximou-a dos grupos de oposição à ditadura militar. A Igreja Católica, sob hegemonia da teologia da libertação na América Latina, voltava-se para os mais pobres e para a justiça social.

A formação das Comunidades Eclesiais de Base (CEBs), dada sua capilaridade e o apoio de que dispunham da Igreja, deu maior vigor ao trabalho de politização nas comunidades mais pobres, entre os trabalhadores rurais e urbanos. Assim, era comum encontrar nas oposições sindicais os militantes das pastorais junto aos militantes marxistas.

Vale ressaltar que alguns setores da esquerda, organizados no Partido Comunista Brasileiro (PCB), no Partido Comunista do Brasil (PCdoB) e no Movimento Revolucionário 8 de Outubro (MR-8), fizeram uma leitura diferente do período, apostando não nas lutas sociais como elemento que derrubaria os militares. Ao contrário, estes temiam que o acirramento das lutas levasse ao recrudescimento do regime diante da frágil transição lenta, gradual e segura para a redemocratização. Apostavam no fortalecimento de uma grande frente com diversos setores da sociedade civil, incluindo entre estes empresários, políticos do MDB - o único partido de oposição permitido pelo regime - e os sindicatos, sem restrição a quem estava na direção. Estes grupos também se organizaram no meio sindical, através de um

\footnotetext{
${ }^{64}$ Leôncio Martins Rodrigues diferencia os grupos de oposição sindical daqueles grupos de extrema esquerda (Rodrigues, 1991: 30)
} 
bloco chamado "Unidade Sindical", mais umas das muitas articulações intersindicais do período.

A formação da CUT então se deu pela conjugação de forças de três grandes correntes políticas da época: as lideranças "autênticas" egressas dos sindicatos oficiais e que, de dentro dos sindicatos, impulsionavam as maiores manifestações de massa do período; as correntes de esquerda de origem marxista (leninista ou trotskista); e a militância da "esquerda católica" oriunda das CEBs e sob inspiração da Teologia da Libertação. (SADER, 1988)

A aliança entre estes três setores não se deu de imediato. Ao contrário, ela foi sendo tecida aos poucos.

Em minha dissertação de mestrado propus uma análise baseada em documentos e entrevistas de que a Unidade Sindical teve em determinados momentos uma aproximação mais ideológica do que política com os dirigentes do "novo sindicalismo", sobretudo com o Sindicato dos Metalúrgicos de São Bernardo do Campo e Diadema. Essa aproximação ficou mais estreita na greve dos metalúrgicos em 1979, cujo movimento foi patrocinado diretamente pelo Sindicato ${ }^{65}$. De forma resumida, o resultado daquela greve foi a ameaça de intervenção sobre a entidade e o pedido de Lula de um voto de confiança da categoria em uma daquelas assembléias de massa, pondo fim ao ímpeto grevista para preservar a entidade.

Naquele contexto radicalizado, a atitude de Lula e da diretoria do Sindicato teve um significado interpretado pelas oposições sindicais de que, no fundo, Lula era igual aos demais dirigentes e "freava" a vontade dos trabalhadores. Para os dirigentes da Unidade Sindical, ao contrário, aquela atitude de Lula demonstrou equilíbrio e bom senso sem radicalismo inconsequente. Na visão da Unidade Sindical ele assumia um papel importantíssimo de enfrentamento à ditadura pela via mais moderada que então propunham, com forte base sindical organizada.

\footnotetext{
${ }^{65}$ As primeiras greves em 1978, como a da Scania, também contaram com o apoio da direção do sindicato, mas para todo efeito era uma greve dentro do local de trabalho, conduzida pelos trabalhadores ao largo da orientação do sindicato, motivo pelo qual ficou conhecida como "braços cruzados". A partir de 1979, as greves ganharam maior visibilidade pública, tomando as ruas da cidade em manifestações operárias.
} 
Lembremos que no mesmo ano de 1979, o operário Santo Dias, da Oposição Metalúrgica de São Paulo, foi assassinado em frente a uma empresa na greve de novembro. Mais um ingrediente para radicalizar a luta contra a ditadura.

A grande greve dos metalúrgicos de São Bernardo e Diadema em 1980, com duração de 41 dias e um grau acirrado de radicalidade frente ao governo sepultaram definitivamente que os dirigentes do "novo sindicalismo" caminhassem na mesma organização da Unidade Sindical. Não só pela radicalidade assumida pelo movimento grevista, mas também a fundação do PT havia colocado um fim no "namoro" da Unidade Sindical sobre os dirigentes do "novo sindicalismo".

Apesar de divergências pontuais, as lutas sociais alimentavam uma identidade entre o "novo sindicalismo" e as oposições sindicais; e contrário aos "pelegos" e à "ditadura militar" $" 66$.

Também foram importantes nesse processo os diversos encontros intersindicais, onde se reconheciam com posições políticas em comum e a partir de onde foram tecendo a construção da CUT, apoiados ambos na ideia de que as lutas sociais e a organização autônoma dos trabalhadores é que poriam fim à ditadura militar ${ }^{67}$.

Entre os primeiros encontros promovidos por entidades sindicais, consta o $5^{\circ}$ Congresso da Confederação Nacional dos Trabalhadores da Indústria (CNTI), realizado no Rio de Janeiro em julho de $1978^{68}$. Este foi o primeiro embate do Sindicato dos Metalúrgicos de São Bernardo contra as direções pelegas no cenário sindical da época. Nesse encontro estavam alinhados na mesma posição dirigentes como Lula, Arnaldo Gonçalves (Sindicato dos

\footnotetext{
${ }^{66}$ Outro fator importante que ajudou a forjar uma identidade entre as oposições sindicais e o "novo sindicalismo" foi a importância atribuída à base e ao que se passava no interior das fábricas por ser esse o local do conflito Capital - Trabalho. Um fator inovador da práxis do novo sindicalismo foi resgatar a luta por direitos a partir dos locais de trabalho. (Rodrigues, I.J. 1993: 63 - 66) Para esse autor, "existia certa convergência de concepção e práticas sindicais, no momento em que eclodiram as greves..." (Rodrigues, I.J.1993:77)

${ }^{67}$ Iram Jácome Rodrigues, mencionando Heloísa Souza Martins ressalta a importância da militância católica na convergência de idéias e práticas dos grupos de oposição e do "novo sindicalismo". (RODRIGUES, 1997:81)

${ }^{68}$ O Sindicato dos Metalúrgicos de São Bernardo do campo e Diadema já vinha realizando congressos específicos da categoria desde 1974 e a cada encontro formulavam propostas que iam de encontro à concepção sindical corporativista por propor a criação de comissões de fábrica, forjando aos poucos uma nova corrente no movimento sindical (Rodrigues, 1997:76-79)
} 
Metalúrgicos de Santos) e Hugo Peres, da Federação dos Metalúrgicos de São Paulo, os dois últimos quadros ligados ao PCB. (RODRIGUES, 1991:14; LADOSKY, 1995:104) Depois, seguiu-se a realização do Encontro Nacional de Dirigentes Sindicais, em Niterói, em agosto de 1979, de onde foi elaborada a Carta de Gragoatá. Realizado logo após o episódio da greve dos metalúrgicos de São Bernardo, em que Lula e a diretoria sofreram pequeno desgaste e, sob hegemonia do PCB, este encontro reforçou uma aproximação daqueles com os "sindicalistas autênticos" e realizou a fundação da Unidade Sindical. (LADOSKY, 1995:107)

A partir dos encontros realizados de 1980 em diante, com os acontecimentos da greve dos metalúrgicos de São Bernardo e sua repercussão política na sociedade, aliado à fundação do PT, houve uma grande mudança no cenário e começou-se a convergir a linha de ação dos chamados "combativos" e "autênticos".

O primeiro desses encontros, que funcionou meio que como uma "transição" no afastamento dos dirigentes ditos "autênticos" (Lula, Olívio Dutra, Jacó Bittar, entre outros) da Unidade Sindical e sua aproximação progressiva aos setores da teologia da libertação da Igreja Católica que atuavam nas CEBs, entre eles, Frei Betto, foi o Encontro de João Monlevade (MG), realizado em fevereiro de 1980. Dele ainda participou Arnaldo Gonçalves. (RODRIGUES, 1991:18)

Ainda em maio de 1980 tivemos a realização do Encontro Nacional das Oposições Sindicais (ENOS). Convocado pela Oposição Metalúrgica de São Paulo ${ }^{69}$, esse encontro polemizou em torno da presença ou não dos "sindicalistas autênticos". Em uma reunião voltada para sua preparação, em janeiro de 1980 (ou seja, quatro meses antes do ENOS) duas posições se fixaram no debate:

“A Oposição Metalúrgica de São Paulo (OSM/SP) propunha organizar um encontro restrito às oposições sindicais abrindo uma exceção só para dirigentes que, via oposição, tivessem chegado à direção de seu sindicato, excluindo, porém a participação dos sindicalistas do ABC e de outras regiões do país.

Parte das oposições sindicais, identificada com a posição defendida por José Ibrahim (Osasco) e José Cardoso, o 'Ferreirinha' (RJ), sindicalistas / exilados recém chegados ao

\footnotetext{
${ }^{69}$ A iniciativa desse encontro partiu do $1^{\circ}$ Congresso da Oposição Metalúrgica de São Paulo, realizado em abril de 1979. (LADOSKY, 1995:116)
} 
país, propunham um encontro amplo, reunindo oposições e sindicalistas "autênticos" como única forma de garantir as condições mínimas para as oposições sindicais influenciarem o conjunto do movimento e ter voz na disputa política mais ampla. Depois de várias horas de discussão ganhou a proposta de um novo tipo de encontro aberto para oposições e autênticos: o Encontro Nacional dos Trabalhadores em Oposição à Estrutura Sindical, o ENTOES”. (ZANETTI, 1993:56)

Assim realizou-se o ENOS em maio; e o ENTOES, em setembro de 1980. Entre ambos, teve ainda o Encontro de São Bernardo $^{70}$, em junho de 1980. Desse encontro não participaram dirigentes ligados à Unidade Sindical (PCB); apenas os "autênticos" e o pessoal ligado à Igreja. Segundo Rodrigues, "com relação à reunião de Minas Gerais, o Encontro de São Bernardo assinala um conjunto mais amplo e radical de reivindicações". (RODRIGUES, 1991:19)

No documento final do Encontro de São Bernardo constou que "o sindicalismo deve ser praticado em todos os locais possíveis: começando nos locais de trabalho, passando pelas mobilizações de bairro e terminando no sindicato, para se dar (sic) uma maior força e unidade na luta". (RODRIGUES, 1991:19-20)

O ENTOES foi precedido por reuniões estaduais, porém teve vida bastante curta. Na verdade, sequer chegou a nascer em virtude do ocorrido quando de sua realização em setembro de 1980, em Nova Iguaçu (RJ): uma grande polêmica sobre a delegação de São Paulo e a discussão acerca se o ENTOES deveria se tornar uma entidade ou não, praticamente inviabilizou a realização do evento. (LADOSKY, 1995)

"Enquanto articulação, o ENTOES não produziu resultados significativos mas houve alguns avanços reais. A prova disso é o fato que a ideia de um encontro só de oposições não voltará mais e, a partir do ENTOES, começa a ganhar força a ideia de se criar [uma] 'Articulação', ou seja, um movimento que juntará 'autênticos' e 'oposições' numa intervenção combinada durante a $1^{\text {a }}$ CONCLAT, em 1981, e no processo que levará à criação da CUT, em 1983”. (ZANETTI, 1993:57)

\footnotetext{
${ }^{70} \mathrm{Na}$ verdade esse Encontro realizou-se no município de Taboão da Serra em virtude de que o Sindicato dos Metalúrgicos de São Bernardo do Campo e Diadema encontrava-se sob intervenção do Ministério do Trabalho e sua diretoria cassada. Manteve-se o nome "Encontro de São Bernardo" em homenagem à cidadeberço das greves operárias naquele contexto.
} 
Essa 'Articulação' só se efetivou a partir do Encontro de Vitória (ES) - oficialmente o $3^{\circ}$ Encontro Nacional, depois de Monlevade e São Bernardo ${ }^{71}$-, realizado em junho de 1981. O Encontro já foi realizado no calor da preparação para a $1^{a}$ Conferência Nacional da Classe Trabalhadora ( $1^{\text {a }}$ CONCLAT), que se realizaria em agosto do mesmo ano, 1981. Foi nesse Encontro que se criou a ANAMPOS - Articulação Nacional dos Movimentos Popular e Sindical - que se constituiu enquanto um 'bloco' com ação unitária não só na $1^{\text {a }}$ Conferência Nacional da Classe Trabalhadora ( $1^{\mathrm{a}}$ CONCLAT), mas também no interior da Comissão Nacional Pró-CUT, entre 1981 e 1983, quando então, fundaram a CUT ${ }^{72}$.

A Conferência Nacional da Classe Trabalhadora (CONCLAT) foi, de fato, o único encontro que reuniu todas as correntes políticas e ideológicas existentes no movimento sindical do período, desde os dirigentes mais tradicionais na máquina sindical como Joaquinzão, até grupos de oposição sindical mais radicais, passando pela Unidade Sindical e pelos sindicalistas 'autênticos'. A CONCLAT foi precedida por Encontros nos estados, denominados de ENCLAT, Encontro da Classe Trabalhadora.

“A realização dos encontros regionais foi uma boa prévia do que seria a Conferência (...) Os ENCLATs acabaram tendo, portanto, um caráter reiterativo de propostas já hegemônicas em cada região.

A acirrada disputa de caráter partidário que distinguiu especialmente as ENCLATs do Rio e de São Paulo preocupou as principais lideranças sindicais, que se propuseram chegar a um acordo e tirar um documento que servisse de base para os três dias de debate e que reunisse os principais pontos de consenso (...)

Os tópicos que causaram as maiores divergências entre os sindicalistas acabaram tendo uma solução no documento. Sobre a CUT, todos concordaram que ela não tinha condições de se constituir nessa CONCLAT, mas deveria ser criada no prazo máximo de dois anos. Então ela seria submetida a um Congresso Nacional (...) Na CONCLAT seria eleita uma coordenação intersindical e nacional com a função dirigente até o Congresso. A discussão opondo unicidade e pluralidade sindical (...) foi esvaziada, pois ninguém propôs abertamente a tese pluralista. Quanto ao imposto sindical, acabou

\footnotetext{
71 “A reunião de Vitória veio a ser chamada de $3^{\circ}$ Encontro Nacional de Articulação de Movimentos Populares (ENAMP). Os Encontros de João Monlevade e de São Bernardo foram denominados simplesmente 'encontros"”. (RODRIGUES, 1991:22)

72 A ANAMPOS não era um órgão estritamente sindical, pois dele participavam também entidades do movimento popular, associações de moradores, pastorais etc. Houve ainda um $4^{\circ}$ Encontro (ENAMP), realizado em Goiânia, em julho de 1982, cujo centro da discussão foi evitar o adiamento do Congresso Nacional da Classe Trabalhadora (CONCLAT) em que seria fundada a CUT. Segundo Leôncio Martins Rodrigues, a criação da ANAMPOS ocorreu nesse Encontro de Goiânia. (RODRIGUES, 1991: 22)
} 
aparecendo um documento sob a forma defendida pela CONTAG: redução gradativa do imposto sindical com o movimento sindical elaborando formas alternativas para sua manutenção que aos poucos elimine sua dependência do Estado". (MENEZES e SARTI, 1981:42-44) ${ }^{73}$

Apesar das disputas existentes ter marcado a sua realização, uma averiguação mais apurada demonstra que as correntes políticas mais radicalizadas não tinham uma clareza exata quanto ao enfrentamento dos pilares da estrutura sindical corporativista. Essa é uma conclusão possível acerca da pesquisa empreendida por Braz José de Araújo, A imprensa alternativa e a CONCLAT. (LADOSKY, 1995:120). ${ }^{74}$ Assim:

“Acerca da questão unicidade X pluralidade, os jornais Convergência Socialista e O Companheiro defendiam em suas publicações a mesma posição dos jornais Hora do Povo, Tribuna Operária e Voz da Unidade, qual seja, a unicidade sindical. O jornal Em Tempo não se manifestou sobre essa questão e $O$ Trabalho, segundo Araújo, 'tende a fugir de uma opção clara contra o pluralismo sindical'. Por fim, o jornal Movimento 'deixa entender que a grande questão a ser resolvida pelos trabalhadores é se é possível conciliar unicidade sindical com autonomia frente ao aparelho de Estado'.

Quanto ao imposto sindical, os jornais Convergência Socialista, O Companheiro, e O Trabalho foram claramente contrários a sua manutenção, ao passo que Em Tempo não se refere a isso, e o Movimento não se coloca explicitamente.

No que se refere a opinião sobre os delegados sindicais, diz Araújo: 'Embora se saiba que não seria lógico nenhum desses jornais ser contra a presença de delegados sindicais nas empresas, o fato é que nos números analisados poucos deram atenção ao problema'." (LADOSKY, 1995:120-121) Ao que tudo indica, o principal confronto no plenário da CONCLAT, como em todo aquele contexto, foi estritamente político, no sentido de disputar diferentes encaminhamentos nas lutas para fazer o enfrentamento com a ditadura; e não propriamente uma diferença de concepção no debate sindical, estrito senso. Embora as diferenças de concepção sindical fossem afirmadas nos discursos.

\footnotetext{
${ }^{73}$ A Conferência Nacional da Classe Trabalhadora (CONCLAT) realizou-se entre os dias 21 e 23 de agosto de 1981, em Praia Grande (SP) com a presença de 5.247 delegados(as), sendo 969 do campo e 3.108 da cidade. Em termos sindicais, a CONCLAT reuniu 1126 entidades sindicais, dos quais 384 eram de rurais e 480 era urbanas.

${ }^{74} \mathrm{O}$ autor levantou os pontos mais polêmicos do debate através dos jornais Em Tempo (tendência Democracia Socialista), O Companheiro (do Movimento de Emancipação do Proletariado - MEP), Movimento (uma cisão do PCdoB), além dos jornais $O$ Trabalho e Convergência Socialista, cujos nomes são os mesmos das correntes que os produzia. Além destes jornais, fora do campo da ANAMPOS, a pesquisa relacionou também os jornais Hora do Povo, Tribuna Operária e Voz da Unidade, respectivamente jornais do MR-8, PCdoB e $\mathrm{PCB}$, que não estariam na fundação da CUT.
} 
Os acordos firmados previamente foram respeitados e, em virtude disso, o ponto alto da CONCLAT foi a eleição da Comissão Nacional Pró-CUT, que teria a tarefa principal de criar a CUT no ano seguinte, 1982.

O resultado, com a maioria da Comissão Pró-CUT em mãos dos dirigentes da Unidade Sindical, deixou entrever as dificuldades que viriam para a criação da CUT em 1982.

Em minha dissertação de mestrado, o depoimento de Abdias José dos Santos, então dirigente do Sindicato dos Metalúrgicos de Niterói (RJ), foi bastante elucidativo a esse respeito:

“...apesar de naquele plenário a gente estar com uma correlação de forças equilibrada, mas era uma correlação de forças de massa, não era uma correlação de forças de quadros e de entidades. E eles estavam em vantagem com um número de entidades superior, nós tínhamos mais delegados de base e eles mais delegados de entidades. Então, na hora da composição da Comissão, como se tirou um critério de representação por estado (...) quem são as pessoas mais representativas do estado? Não eram os delegados de base, era a nível de entidade. Então a Comissão Nacional Pró-CUT, tanto a primeira como a segunda, o "bloco combativo" ficou em desvantagem (...) mesmo quando era um a um, quem tinha a máquina, a estrutura, e que podia convocar etc, eram eles. O nosso representante do estado, sem a máquina sindical na mão, pouco podia fazer. Então eles levaram. E por conta disso, eles conseguiram enrolar esse primeiro ano, transferir o Congresso de 82 para 83 (...) Quando nós saímos de Praia Grande, nós sabíamos que o Congresso não ía ser realizado em 1982, mas a gente o que fez? Criamos a ANAMPOS. Que fazia a articulação e trazia recursos, porque se o Congresso não fosse realizado em 82, ele seria em 83 nem que chovesse canivete! E isso realmente aconteceu!" (LADOSKY, 1995:122)

\section{Continua Abdias:}

"Em 82 foi um ano de eleição, houve as justificativas, a Comissão Nacional Pró-CUT não realizou o Congresso, se dissolveu e se autoconstituiu à revelia da decisão da Conferência e jogou para 83. Então, como nós já tínhamos um saldo de trabalho de 81 e com a decisão de jogar para 83, em 82, nós aceleramos o processo porque já tínhamos a certeza absoluta - tinha companheiros que diziam 'se nós não realizarmos esse congresso, ele não vai se realizar nunca!' Articulamos a ANAMPOS, articulamos tudo, quando chegou a hora, em 83, faltando uns 14 dias para a realização do Congresso, a 'reforma' pisou na bola, voltou atrás, transferiu o Congresso, a ANAMPOS assumiu, realizou o Congresso e fundou a CUT!" (LADOSKY, 1995:125) ${ }^{75}$

\footnotetext{
75 Em novembro do mesmo ano, 1983, seria criada a Coordenação Nacional da Classe Trabalhadora
} (CONCLAT), uma intersindical que preferiu não tomar o caráter de uma central sindical com vista a uma 
O motivo que levou ao impasse e a cisão no movimento sindical foi o artigo oitavo do regimento interno do CONCLAT (Congresso Nacional da Classe Trabalhadora), que tratava do critério para participação de delegados ao Congresso.

Por esse artigo, as oposições sindicais poderiam convocar uma assembleia de base e eleger delegados da mesma forma que os sindicatos. Isso era inaceitável para a Unidade Sindical e seus aliados, pois que a aprovação desse artigo mudaria o perfil dos delegados, passando a ter uma representação maior de base do que de diretorias sindicais, o que garantiria a vitória ao grupo da ANAMPOS.

Por trás desse artigo havia também divergências acerca de que tipo de central sindical deveria ser formada: uma central que privilegiaria o movimento e a participação da base; ou uma central representante de entidades sindicais, com maior peso institucional no conjunto da sociedade.

Naquele contexto a CUT se constituiu enquanto uma central ativada principalmente pelo movimento e pela participação da base. Como veremos nas próximas seções desse capítulo, após sua consolidação como a maior central sindical brasileira, a CUT fará uma inflexão em sua trajetória, buscando afirmar sua força política na sociedade a partir de seu peso institucional e de representação de entidades sindicais. Iram Jácome Rodrigues analisa essa trajetória ressaltando que a CUT passou de um padrão de ação sindical mais conflitivo, em que estava em jogo a afirmação de sua identidade no meio sindical; para outro em que os conflitos de interesses de classe são enfrentados por uma via mais negocial. (RODRIGUES, 1993)

Desse modo, contando com a possibilidade de um olhar retroativo sobre a trajetória da CUT nos 25 anos de sua fundação, podemos dividi-los em três períodos, dos quais dois deles já estão publicamente reconhecidos por estudiosos e documentos da Central. O chamado terceiro período, na verdade, é ainda uma hipótese, pois acreditamos que desde a instauração do governo Lula a CUT passa a uma nova etapa de sua trajetória.

De todo modo, para compreendermos a trajetória da CUT partimos da análise de que a fundação da CUT em 1983 veio "ocultar" as diferentes concepções internas presentes na

reunificação do movimento sindical em futuro breve, mantendo a sigla que já era uma referência do movimento de então. Com o rápido crescimento da CUT nos seus primeiros anos, foi se dissipando cada vez mais o projeto de "reincorporação" da ANAMPOS em uma única central. Em março de 1986, a CONCLAT transformou-se em uma nova central: nascia a Central Geral dos Trabalhadores (CGT). 
composição dos grupos que formaram a central, ressaltando mais os pontos em comum que permitiram a sua criação, deixando as divergências existentes subsumidas frente ao desafio mais premente da disputa com a Unidade Sindical e com os "pelegos" alojados na Direção da maioria dos sindicatos. Tais diferenças vieram ganhando relevo à medida que a CUT foi se consolidando como a maior central sindical do país e mudando seu padrão de ação menos conflitivo e mais negocial (RODRIGUES, 1993) -, especialmente a partir dos anos 1990, a partir de quando, de uma certa forma, as disputas internas sobrepuseram-se às disputas com outras centrais sindicais.

\section{A CUT movimento: 1980 - 1989}

O primeiro período a ser identificado na trajetória da CUT foi a década de oitenta, desde as grandes greves que marcaram o surgimento do "novo sindicalismo" e que antecederam a fundação da CUT em 1983, até 1988/89, quando há uma primeira inflexão em sua trajetória.

Este período foi de criação e consolidação da CUT como a maior e mais representativa central sindical brasileira.

O contexto político da época favoreceu esse movimento de consolidação da CUT, uma vez que vivia no país o período de ocaso da ditadura e redemocratização, com a sociedade civil sedenta de espaços de participação livre ${ }^{76}$.

Em 1984, o movimento das "Diretas Já” deu um tom mais amplo às mobilizações populares que até então era muito intenso, mas restringia-se a demandas trabalhistas e contra a carestia.

Na transição do general Figueiredo para o regime civil, a eleição indireta pelo Congresso Nacional do presidente Tancredo Neves, e a posse de Sarney, o vice que havia sido da Arena, partido da base da ditadura militar, foi um dos motivos que legitimou a postura oposicionista da CUT à nova república. Nas passeatas do período, uma das palavras-deordem mais comuns era o "Fora Sarney!".

O período de democratização culminou com a eleição da Assembleia Nacional Constituinte, em 1986, em que se almejava "passar o país à limpo" depois do regime militar.

\footnotetext{
${ }^{76}$ Em contraste com a pujança do sindicalismo brasileiro, em particular da CUT, o movimento sindical nos países da Europa e Estados Unidos viviam no mesmo período uma enorme crise, verificando-se um decréscimo constante da taxa de sindicalização e de conflitos com paralisação. (NORONHA, 1994)
} 
A bancada dos partidos de esquerda ${ }^{77}$ era numericamente bastante diminuta na Câmara e no Senado, mas a mobilização de todos os movimentos sociais em torno das emendas populares, com milhares de assinatura da população, e a presença aguerrida nas galerias, garantiu conquistas importantes.

A riqueza no campo político contrastava com as dificuldades econômicas, pois que persistiu ao longo do período uma inflação em patamar elevado. Planos de estabilização e controle inflacionário se sucederam ao longo da década, de malogro em malogro, aumentando a percepção na população de que a democracia era incompatível com o bem estar social e os avanços na área econômica ${ }^{78}$.

O desemprego não era significativo, mas a estagnação no processo de crescimento impactava o nível de contratação de trabalhadores.

A CUT se colocou sistematicamente opositora a todos aqueles planos, em função de que todos eles tinham embutida uma lógica de que os aumentos salariais alimentavam a espiral de elevação de preços dos produtos e, portanto, apresentavam como um dos "remédios" o expurgo da inflação do cálculo de reajuste salarial dos trabalhadores, ou seja, promoviam uma desindexação salarial, acarretando em perda no poder de compra dos trabalhadores. Essa era a quota de sacrifício pedida aos trabalhadores que a CUT nunca aceitou ${ }^{79}$.

A resposta da CUT aos planos econômicos e à política de "arrocho salarial" foram as greves gerais ${ }^{80}$.

Para além da CUT, os sindicatos filiados e as oposições sindicais impulsionavam as diversas categorias a aderirem ao movimento de paralisação do trabalho.

\footnotetext{
${ }^{77}$ Eram tidos como "partidos de esquerda", o PT, o PSB, o PcdoB , o PCB, o PDT, do então governador do Rio de Janeiro, Leonel Brizola. O PMDB tinha parlamentares progressistas que apoiavam as demandas populares, mas enquanto partido político, o PMDB situava-se fora desse campo. (Ribeiro, Ary. 1988)

78 Os planos econômicos de combate à inflação no período foram o Plano Cruzado (1986), Plano Cruzado II (novembro de 1986), o Plano Bresser (1987), o Plano Verão (1989), o Plano Collor (1990) e o Plano Collor II ( $2^{\circ}$ semestre de 1990) até a chegada do Plano Real (1994) que efetivamente controlou a inflação e foi bastante discutido nessa tese. A respeito dos planos econômicos e análise de Moran, CAA e Witte, G. in http://www.upf.br/cepeac/download/rev_n01_1993_art6.pdf

${ }^{79}$ Somente a partir do Plano Real, em 1994, conseguiu-se promover uma desindexação salarial no país.

${ }^{80}$ Ao longo de sua trajetória, a CUT convocou os trabalhadores a participarem de cinco greves gerais, em 21 de julho de 1983, 12 de dezembro de 1986, 20 de agosto de 1987, 14 e 15 de março de 1989 e a última em 22 e 23 de maio de 1991. (ANTUNES, 1991:21-22). Há que se ressaltar que as bandeiras levantadas a cada greve geral não eram de cunho estritamente trabalhista/salarial, mas via de regra, apresentava também uma "reforma agrária radical sob controle dos trabalhadores" e o "não pagamento da dívida externa" como reivindicações da classe. A partir dos anos 1990, com o novo contexto sócio-político e econômico do país, o refluxo do movimento grevista e a mudança de orientação no padrão de ação sindical da CUT, a central sindical abandonou a estratégia de convocação de greves gerais. As maiores mobilizações "de massa" convocadas pela CUT em diversas ocasiões passaram a ser Dia Nacional de Luta, e as Marchas a Brasília.
} 
De acordo com Eduardo Noronha "no final dos anos oitenta, o volume de greves no Brasil estava entre os mais altos do mundo, sendo que há pouco mais de uma década elas praticamente inexistiam". (NORONHA, 1994:323)

Dados do autor apontam uma verdadeira explosão dos movimentos grevistas no período, inédito na história do país. (NORONHA, 1994:326) ${ }^{81}$

A necessidade de firmar-se no movimento sindical e na sociedade pautou um padrão de ação sindical conflitivo (RODRIGUES, 1997), que ficou conhecido também como CUTmovimento. Ou seja, a CUT era então um grande movimento de mobilização e ação da classe. Sua força maior residia na sua capacidade de agitar; de colocar a classe em movimento, reivindicando direitos, protestando com o que não concordavam.

Essa postura mais radicalizada de ação foi forjando uma identidade coletiva na militância e constituindo-se enquanto referência na sociedade

Já chamamos atenção que o conjunto dos sindicatos tinha à sua frente dirigentes colocados como interventores pelo regime militar e outros tantos que, mesmo eleitos, tinham sua atuação restrita aos limites da CLT. Os sindicatos, ao longo dos anos da ditadura, foram perdendo sua legitimidade como representante dos trabalhadores, se convertendo em simples instituição assistencial e de dissídio coletivo.

Junto às mobilizações e greves do período e ao enfrentamento aos governos da época, sobretudo a Sarney, somou-se também o ímpeto de conquistar a direção dos sindicatos para a CUT.

Essa foi, aliás, a estratégia que a CUT tomou quando de sua constituição. Na discussão interna acerca de sua estratégia, definiram-se duas posições quanto ao enfrentamento à estrutura sindical oficial: uma primeira foi de que a CUT deveria se constituir a partir das organizações de base, em entidades "paralelas", à margem da legislação sindical corporativista.

A segunda posição, que acabou por prevalecer, tinha como proposta que a CUT deveria consolidar-se no meio sindical incentivando a organização dos trabalhadores nas bases e constituindo oposições sindicais que conquistassem a direção dos sindicatos e

\footnotetext{
${ }^{81}$ Eduardo Noronha faz um estudo acerca das demandas grevistas frente ao processo de redemocratização do país nos anos oitenta. Desse modo, o autor divide o movimento das greves em dois períodos fundamentais, de 1978 a 1984, e de 1985 a 1989, derivando daí subdivisões que estreitam fluxos e refluxos das greves diante da conjuntura do país (NORONHA, 1991 e 1994)
} 
impulsionassem, de dentro do aparelho sindical, uma efetiva mudança na estrutura sindical, rompendo com o corporativismo.

Nos anos que se seguiram à fundação da CUT, essa estratégia teve bastante êxito. Em um período relativamente curto a CUT foi conquistando a direção de inúmeros sindicatos em eleições sindicais.

A partir de um levantamento de dados registrados nos congressos da CUT, observamos a evolução do quadro: no Congresso de sua fundação (1983), compareceram delegados representantes de 937 entidades sindicais, mas não necessariamente representantes de sindicatos (podia ser oposições e associações pré-sindicais de funcionários públicos); no $2^{\circ}$ CONCUT (1986) já havia representação de 1.014 entidades; no $3^{\circ}$ CONCUT (1988), 1.150 entidades; e no $4^{\circ}$ CONCUT (1991), compareceram 1.700 sindicatos filiados. (LADOSKY, 1995) Atualmente, 2009, a CUT registra em sua página na internet 3.438 entidades filiadas. (www.cut.org.br)

Todo esse movimento de ascensão da CUT entre os sindicatos, nas mobilizações e greves, e nas manifestações contra o governo e pela participação no processo constituinte eram refletidos nos Congressos da CUT, onde se expressavam as diferentes visões das correntes internas.

Esse período mais conflitivo, de estruturação da CUT ao longo dos anos oitenta, que denominamos "CUT - movimento", teve como momentos significativos de afirmação da identidade política, o Congresso de fundação (CONCLAT), em 1983; o $1^{\circ}$ CONCUT, em 1984; e seu apogeu no $2^{\circ}$ CONCUT, em 1986. O $3^{\circ}$ CONCUT, em 1988, representou um momento de inflexão na trajetória da Central, a partir do qual passou a se constituir uma nova orientação da CUT. Em comum, todos esses congressos tiveram mais de cinco mil delegados, com mais de $30 \%$ de trabalhadores rurais; representado por mais de $50 \%$ de delegados de base; e todos com cerca de $40 \%$ de delegados vindos dos estados do norte e nordeste. (GIANNOTTI e NETO, 1991:39)

A CONCLAT, junto com o $1^{\circ}$ CONCUT, teve a importância de declarar os princípios que orientam a política da CUT: classista, democrática, organizada pela base, de massa, e em defesa da liberdade e autonomia sindical.

Afirma ainda que a CUT defende os "interesses históricos e imediatos da classe trabalhadora", numa alusão ao socialismo. 
Este momento de consolidação da CUT no cenário sindical foi marcado também por um primeiro movimento de romper com a legislação sindical corporativista através de esforço de estruturar sua organização a nível nacional, pelos estados e regiões. Assim, foram se criando junto com a CUT Nacional, as CUTs estaduais e CUTs regionais.

O $2^{\circ}$ CONCUT começa a expor mais contundentemente as diferenças existentes entre as correntes no interior da CUT.

Assim, embora as correntes mais radicalizadas tenham conseguido prevalecer e aprovar nas resoluções a menção explícita ao socialismo como objetivo da Central, e uma nova estrutura organizativa, já estava semeada a proposta de mudança estatutária que se completaria no $3^{\circ}$ CONCUT.

Para Giannotti e Neto, “...começava a pairar no ar, uma proposta acabada, capaz de mudar o perfil da Central. A partir desse Congresso a tendência majoritária começa a imprimir à Central um estilo autoritário, hegemônico, que irá provocar vários tensionamentos e polêmicas na CUT. Junto com isso, passou a ser imprimido na Central um ritimo acelerado, na adoção de uma estrutura orgânica de forte influência europeia. O resultado disso aparecerá no Congresso seguinte”. (GIANNOTTI e NETO, 1991:43)

Para Iram Jácome Rodrigues, “o $2^{\circ}$ CONCUT serviu para demarcar posições muito nítidas entre as várias facções políticas no interior do sindicalismo-CUT (...) Se o $2^{\circ}$ CONCUT representou um forte impulso para a esquerda do sindicalismo-CUT, significou também um acirramento da luta política e ideológica entre as principais correntes políticas. Foi o último momento onde a esquerda socialista conseguiu imprimir sua marca mais fortemente. A partir daí, independentemente das questões políticas e organizativas, aqueles setores que poderíamos chamar de esquerda sindical ou contratualista (a Articulação Sindical e seus aliados), passam a definir mais concretamente o jogo político-sindical da CUT. Foi assim no $3^{\circ}$ CONCUT e, - apesar das dificuldades - também no $4^{\circ}$ CONCUT”. (RODRIGUES, 1997:109)

Em termos de sua atuação frente à estrutura sindical corporativista, a CUT apresenta pela primeira vez uma proposta alternativa mais definida seguindo a concepção de liberdade e autonomia sindical preconizado na Convenção 87 da OIT. (RODRIGUES, 1990:13) A proposta da CUT, aprovada no $2^{\circ}$ CONCUT previa duas formas de organização na base, uma dela as Comissões Sindicais de Base (CSB) em cada local de trabalho para representar o sindicato no "chão de fábrica". Diferente dessa, deveria se constituir também as Organizações nos Locais de Trabalho (OLT), para representar todos os trabalhadores do 
local de trabalho, fossem eles associados ou não ao sindicato. A OLT teria, pela proposta, autonomia política em relação ao sindicato, cabendo então aos militantes sindicais disputar aquele espaço de representação e aproxima-lo à linha de atuação do sindicato sem descaracterizar sua autonomia.

Partindo dos locais de trabalho, o $2^{\circ}$ CONCUT aprovou ainda a organização dos departamentos profissionais da CUT, que foram sendo criados aos poucos, como o Departamento Nacional dos Metalúrgicos (DNM), o Departamento Nacional dos Químicos (DNQ); o Departamento Nacional dos Bancários (DNB), entre outros.

Os departamentos, da mesma forma que os sindicatos, teriam que ser, pela resolução do $2^{\circ}$ CONCUT, organizados "por ramo de atividade" e não mais por categorias, conforme previa a legislação corporativista.

Em uma análise sobre a proposta de uma nova estrutura aprovada no $2^{\circ}$ CONCUT, Leôncio Martins Rodrigues afirma que "a proposta de reorganização sindical era bastante detalhada e ambiciosa. (...) de um voluntarismo a toda prova, fazia tábula rasa da estrutura sindical existente, ignorando as tradições e interesses organizados em torno do sindicalismo oficial e da resistência das empresas e do governo. Desse modo, a nova estrutura, tão minuciosamente elaborada, não saiu do papel (...) Na verdade, a Executiva da CUT, que apresentou a proposta da nova estrutura, e os delegados que a aprovaram no $2^{\circ}$ CONCUT subestimaram a força do sindicalismo corporativo no país e o apoio, explícito ou implícito, que ponderáveis parcelas das classes trabalhadoras e dirigentes sindicais (inclusive os da CUT) lhe outorgam. Por outro lado, o irrealismo da resolução (que reestruturou, no papel, toda a estrutura sindical brasileira segundo a vontade da CUT) não deixa de ser indicativo da imaturidade de uma organização em processo de formação". (RODRIGUES, 1990. 13-14)

Ainda que essa proposta não tenha sido de fato implementada, ela teve a importância de sistematizar pela primeira vez uma concepção cutista acerca da alternativa à estrutura corporativista balizando a orientação da Central em outras oportunidades, como no início dos anos 1990, com a proposta do Sistema Democrático das Relações de Trabalho (SDRT), e nas discussões do FNT, após 2003, sempre com a devida atualização ao contexto histórico da trajetória da CUT e da correlação de forças na sociedade do momento.

Com isso, embora não discordemos totalmente do professor Leôncio, temos uma percepção ligeiramente diferenciada, já contando com o benefício do tempo e um afastamento do fato. Nossa compreensão é, pois, de que a resolução do $2^{\circ}$ CONCUT não foi inócua e, por esse 
motivo, desnecessária; foi um primeiro momento de um processo de construção de alternativas à estrutura sindical que a CUT vem atualizando a cada contexto e tornou-se uma referência para a Central nas discussões de alteração da legislação sindical.

Contudo, embora a CUT tenha elaborado uma proposta de estrutura sindical bem minuciosa no $2^{\circ}$ CONCUT (1986), no debate da Constituinte esse posicionamento da Central não teve influência alguma nas mudanças ali processadas sobre a legislação sindical corporativista. Atuando além das questões trabalhistas, a CUT articulou sua atuação com outras entidades dos movimentos sociais no processo Constituinte em torno da ampliação de direitos sociais e, junto com outros setores populares, alcançou importantes conquistas. No plano trabalhista propriamente dito a atuação da CUT também firmou ganhos, consolidados no artigo $7^{\circ}$ da Constituição ${ }^{82}$. Mas em termos da estrutura sindical, o artigo $8^{\circ}$ da nova Carta manteve os pilares fundamentais do corporativismo, como o imposto sindical (então reforçado no inciso IV pela taxa confederativa, de caráter compulsório), a unicidade sindical (inciso II) e o poder normativo da Justiça do Trabalho.

Desde o ressurgimento das lutas sindicais no cenário político nacional no final dos anos 1970 questionando o sistema corporativo, e com a fundação da CUT em 1983 em oposição à estrutura vigente, o tema da reforma sindical tem sido reiteradamente encaminhado ao Congresso Nacional seja por iniciativa do Executivo ou do próprio Legislativo.

Almeida (1992) faz um bom apanhado desse processo de discussão para pôr fim ao sistema corporativo.

"Nos meses finais do governo Figueiredo, a Câmara Federal aprovou a ratificação da Convenção 87 da OIT. Assinada pelo governo brasileiro em 1949, deveria ser ratificada pelo Congresso Nacional para transformar-se em lei. Quando isso ocorresse, criava-se a possibilidade de instauração do pluralismo sindical e impunha-se a extinção da contribuição sindical compulsória. Sua lentíssima tramitação legislativa diz muito sobre a força dos interesses opostos à ratificação, eficazes por mais de trinta anos. Por fim, aprovada na Câmara Federal, a Convenção seguiu para discussão no Senado. A iminência de sua entrada em pauta criou a oportunidade do debate público sobre o destino das instituições corporativistas, por volta de maio de 1985. Provocou, também, a reação

\footnotetext{
${ }^{82} \mathrm{O}$ artigo $7^{\circ}$ torna constitucional inúmeros direitos dos trabalhadores, entre eles a indenização compensatória por despedida arbitrária ou sem justa causa; seguro-desemprego; fundo de garantia por tempo de serviço (FGTS); e cria outros como a licença-paternidade (Constituição Federal, 1988)
} 
convergente de associações empresariais e dos sindicalistas da CONCLAT [Coordenação Nacional da Classe Trabalhadora, futura CGT] contra a aprovação da medida". (ALMEIDA, 1992:142) (33 $^{83}$

Diante da veemência da reação, o então ministro Murilo Macedo prometeu que "nenhuma reforma sindical seria feita sem consulta e participação ampla dos interessados". (ALMEIDA, 1992:142)

Com o governo civil recém-empossado e o compromisso de levar a bom termo a redemocratização do país, o novo Ministro do Trabalho, Almir Pazzianotto, ex-advogado do Sindicato dos Metalúrgicos de São Bernardo do Campo e Diadema, desenterrou o tema em novembro de 1985 quando declarou à imprensa a defesa da ratificação da Convenção 87 e a intenção de produzir uma nova lei sindical.

Para Maria Hermínia Tavares de Almeida, “a manifestação do Ministro já não refletia tanto seu empenho em promover uma reforma profunda e negociada da organização sindical. Ela manifestava a tensão interna de um governo pressionado pela inflação montante e pela escalada do conflito grevista. A Convenção 87 era trazida à baila em tom de velada ameaça do governo aos sindicatos. Era um instrumento de pressão sobre um sindicalismo pouco disposto à automoderação e arredio à colaborar com o governo para barrar a alta descontrolada dos preços". (ALMEIDA, 1992:144)

De todo modo, a entrevista de Pazzianotto repercutiu mal entre sindicalistas e empresários. Naquela ocasião, a voz destoante foi do presidente da CUT, Jair Meneguelli, que declarou à imprensa: "os trabalhadores não precisam da tutela de ninguém... A liberdade de organização é uma reivindicação sagrada dos trabalhadores”. (ALMEIDA, 1992:144)

Reações à parte, o Ministro "tomou três medidas liberalizantes, com as quais o governo da Nova República tratava de sinalizar sua disposição de inaugurar uma nova fase nas relações entre a administração e o mundo sindical. As lideranças sindicais afastadas de seus cargos, por força de intervenção baseada no artigo 530 da CLT, tiveram anistia; aboliu-se o controle ministerial sobre as eleições sindicais; as centrais sindicais foram reconhecidas [isto é, politicamente legitimadas, mas não reconhecidas legalmente]. Pazzianotto anunciou, também, a formação de comissão ministerial para propor o debate de uma ampla reforma da Consolidação das Leis do Trabalho ${ }^{84}$. Além de

\footnotetext{
${ }^{83}$ A autora menciona que a reação maior veio do lado patronal naquela ocasião, em especial a Confederação Nacional das Indústrias (CNI), seguindo-se a ela a Federação dos Bancos (FEBRABAN), e FIESP, entre outras. A autora afirma que não há registro de manifestação empresarial favorável a ratificação da Convenção 87. Por outro lado, entre a representação dos trabalhadores, algumas Confederações e a CONCLAT pronunciaram-se contrários à Convenção 87 , em especial ao fim da unicidade sindical. Segundo ela, "a CUT não alimentou o debate, nem manifestou com clareza suas preferências". (Almeida, 1992:143)

${ }^{84}$ Onze dias depois de empossado, Pazzianotto deu a público o aviso-circular no 2072 solicitando às entidades sindicais, patronais e de empregados, sugestões e propostas de reforma sindical. (nota da autora)
} 
reconhecer a obsolescência do velho estatuto varguista, que ele próprio tantas vezes sublinhara, o Ministro atendia a uma demanda formulada pelos sindicalistas renovadores desde os anos 70". (ALMEIDA, 139-140)

Segue a autora: "Todavia o impulso reformista do governo logo arrefeceu. A continuidade das reformas revelar-se-ia bem mais difícil do que esses primeiros passos fariam supor. Apesar do discurso das lideranças sindicais renovadoras ter se tornado dominante, era reduzida a base de apoio com que o governo poderia contar para empreender a mudança da organização sindical. A representação sindical patronal, parcela significativa das entidades de trabalhadores sem participação ativa no movimento sindical, o stablishment do judiciário trabalhista e a burocracia ministerial formavam uma vasta coalizão a favor do status quo. Por outro lado, as mudanças já realizadas haviam satisfeito as principais demandas dos sindicalistas do CONCLAT, reduzindo, em consequência, seu entusiasmo pelo prosseguimento das reformas. Finalmente, a CUT, que tinha um projeto alternativo de organização sindical, preferia o confronto à colaboração (sic) com o Ministro do Trabalho. A estratégia confrontacionista além de fortalecer a central sindical dava maior nitidez e coerência ao perfil oposicionista do Partido dos Trabalhadores. Além do mais, como observa Rodrigues (1990: 7-33) a estrutura sindical corporativista era muito importante para a expansão rápida da organização do PT em escala nacional”. (ALMEIDA, 1992:140-141)

Desse modo, a questão foi ficando de lado por todo o ano de 1986 em meio às matérias mais prementes do Congresso Nacional, embora reiteradamente o Ministro fizesse promessa de apresentar o projeto da reforma sindical, sempre acompanhado de protesto do empresariado e de manifestações ambíguas de sindicalistas.

Em janeiro de 1987, após o fracasso do plano Cruzado e com a escalada das greves em rítimo intenso, Pazzianotto conseguiu reintroduzir o tema da Convenção 87 na pauta do Senado, tornando iminente sua votação. "Entre pressões e contrapressões, a liderança do Senado negociou o adiamento da votação em troca do compromisso formal do Ministério de apresentar um projeto de reforma sindical para apreciação e negociação entre os principais interessados (...) A proposta governamental foi divulgada em junho, dias depois da decretação do Plano Bresser. Elaborado no Ministério do Trabalho, o projeto de lei 164 constituiu a iniciativa reformista mais avançada de quantas haviam surgido até então. Rompia as amarras do corporativismo de Estado, tornando possível - mas não inevitável - o pluralismo sindical e previa uma fórmula de extinção progressiva da contribuição sindical”. (ALMEIDA, 1992:146) ${ }^{85}$

\footnotetext{
${ }^{85}$ Os principais pontos do projeto eram: 1) liberdade de organização de sindicatos de acordo com a opção de trabalhadores e empregadores, garantida a escolha do sistema a adotar, de unidade voluntária ou não. $\mathrm{O}$
} 
Como já era previsível, o projeto caiu no vazio e foi substituída pela agenda Assembleia Nacional Constituinte.

Para a autora, o tratamento dado ao tema no período pré-constituinte pelos atores sociais diretamente envolvidos (representantes do empresariado e dos trabalhadores) e a consequente irrelevância dada pelo legislativo não permitiam expectativas positivas sobre o resultado que sairia no texto constitucional: "ela [a reforma sindical] já não era tema prioritário de quaisquer das correntes sindicais. Deixara de ser prioridade para os cegetistas que defendiam abertamente a permanência do modelo corporativista. Não o era, tampouco, para os sindicalistas da CUT, que se movimentavam cada vez mais à vontade no interior da estrutura corporativista desafogada da tutela estatal efetiva”. (ALMEIDA, 1992:147)

O trabalho da Assembleia Nacional Constituinte compreendeu as seguintes etapas:

01/02/1987 a 18/03/1987 - elaboração do regimento interno da primeira fase: redação do anteprojeto;

20/03/1987 a 02/04/1987 - eleição da mesa e das comissões

03/04/1987 a 10/04/1987 - escolha dos membros das subcomissões;

15/04/1987 a 20/05/1987 - trabalho das subcomissões;

25/05/1987 a 16/06/1987 - trabalho das comissões temáticas;

17/06/1987 a 18/11/1987 - trabalho da comissão de sistematização;

17/06/1987 a 26/06/1987 - compatibilização dos relatórios das comissões

10/07/1987 - finalização do $1^{\circ}$ anteprojeto

26/08/1987 - alteração do $1^{\circ}$ anteprojeto, redação do "Cabral I"

18/09/1987 - $2^{\text {a }}$ alteração do $1^{\circ}$ anteprojeto, redação do "Cabral II"

18/11/1987 - finalização do anteprojeto de Constituição

projeto estabelecia um número mínimo de associados no caso da fundação de um segundo sindicato na mesma base; 2) possibilidade de criação de sindicatos por categoria, por profissão, por empresa ou por estabelecimento. 3) permissão de centrais sindicais; 4) proibição da intervenção ministerial nos sindicatos e de cassação de dirigentes eleitos; 5) possibilidade de dissolução judicial de sindicatos por decisão do Ministério Público em casos previstos em lei; 6) extinção gradativa da contribuição sindical em cinco anos. A partir de então, os sindicatos estipulariam a parte de sua receita destinada às federações e confederações; 7) receitas sindicais provenientes de mensalidades dos associados, cotas fixadas em acordos coletivos, rendas provenientes de suas atividades e de aplicação do patrimônio; 8) Sindicato como pessoa jurídica de direito privado; 9) funções do sindicato decididas por assembléia geral da categoria; 10) criação de sindicato mediante depósito de estatuto e registro no Ministério do Trabalho; 11) Direito de voto restrito aos associados e regulado pelos estatutos. A íntegra do projeto está em Gazeta Mercantil, de 23/06/1987. (ALMEIDA, 1992 - nota da autora). 
24/11/1987 a 22/01/1988 - elaboração do regimento interno da segunda fase: votação do anteprojeto constitucional;

28/01/1988 a 04/07/1988 - $1^{\circ}$ turno das votações: votação do texto do anteprojeto, inclusive alterações;

29/07/1988 a 02/09/1988 - $2^{\circ}$ turno das votações: votação do texto aprovado no $1^{\circ}$ turno, incorporando apenas emendas supressivas;

05/10/1988 - promulgação da nova Carta constitucional.

A Comissão Afonso Arinos, encarregada de elaborar o Anteprojeto, firmou uma concepção nitidamente anti-corporativista ao tema da reforma sindical, estabelecendo a autonomia e a liberdade sindical; o fim da unicidade sindical; do imposto sindical e do sistema confederativo hierarquizado. Segundo Almeida, o texto refletia de alguma forma o discurso do novo sindicalismo (ALMEIDA, 1992:148)

No entanto, os setores parlamentares situados mais "à esquerda" decidiram contestar o formato dos parlamentares eleitos diretamente pelo sufrágio popular terem como referência o trabalho de uma comissão de notáveis juristas e constitucionalistas. Contando com a simpatia geral, prevaleceu, assim, a idéia da participação geral, criando-se oito comissões temáticas e três subcomissões em cada uma daquelas comissões, além de uma comissão de sistematização, de modo que todos os constituintes pudessem ter uma participação mais direta em alguma comissão ou subcomissão. (RIBEIRO, 1988:11)

Assim, segundo Ribeiro, "vinte e quatro subcomissões deram início a um tumultuado e apressado trabalho - devido a exiguidade dos prazos - de ouvir os setores interessados, coletar subsídios e elaborar as suas propostas”. (RIBEIRO, 1988:12-13)

Segundo o autor, na subcomissão dos direitos dos trabalhadores e do serviço público, prevaleceu o ponto de vista dos parlamentares do campo progressista apesar do equilíbrio numérico em sua composição com os congressistas do campo conservador. Assim, "o anteprojeto da subcomissão tomou por base o roteiro dos sindicalistas. E esse roteiro foi quase integralmente endossado, na etapa seguinte dos trabalhos, pela Comissão da Ordem Social. Essa comissão tinha também uma composição aparentemente equilibrada: trinta e três integrantes situados do centro para a direita e trinta, do centro-esquerda para a esquerda. Mas, como ocorrera na subcomissão, vários parlamentares de centro votaram a favor dos avanços sociais". (RIBEIRO, 1988:13) 
Daí porque a Constituição inscreveu inúmeros direitos sociais aos trabalhadores, diferentemente da matéria sindical, devido ao fato de que o movimento sindical "não colocou entre suas demandas prioritárias", segundo Almeida. Para ela, "o texto produzido pela subcomissão expressou um compromisso entre o conservadorismo e a mudança". (ALMEIDA, 1992:150)

Entre a subcomissão e a redação da $1^{\mathrm{a}}$ e da $2^{\mathrm{a}}$ versão do anteprojeto - Cabral I e II - o texto foi tomando a feição que permaneceu na Carta Magna, a despeito de iniciativas da CUT e parlamentares do PT na votação de emendas em defesa da liberdade e autonomia sindical ${ }^{86}$. Desse modo, o texto constitucional aprovado referente à matéria sindical ficou com a seguinte redação:

“Art. $8^{\circ}$ - É livre a associação profissional ou sindical, observado o seguinte:

I - a lei não poderá exigir autorização do Estado para a fundação de sindicato, ressalvado o registro no órgão competente, vedadas ao poder público a interferência e a intervenção na organização sindical;

II - é vedada a criação de mais de uma organização sindical, em qualquer grau, representativa de categoria profissional ou econômica, na mesma base territorial, que será definida pelos trabalhadores ou empregadores interessados, não podendo ser inferior à área de um Município;

III - ao sindicato cabe a defesa dos direitos e interesses coletivos ou individuais da categoria, inclusive em questões judiciais ou administrativas;

IV - a assembléia geral fixará a contribuição que, em se tratando de categoria profissional, será descontada em folha, para custeio do sistema confederativo da representação sindical respectiva, independentemente da contribuição prevista em lei;

V - ninguém será obrigado a filiar-se ou a manter-se filiado a sindicato;

VI - é obrigatória a participação dos sindicatos nas negociações coletivas de trabalho;

VII - o aposentado filiado tem direito a votar e ser votado nas organizações sindicais;

\footnotetext{
${ }^{86}$ Diz Almeida que, "quando o anteprojeto foi para o primeiro turno de votação, em plenário, três emendas disputaram o apoio dos constituintes. A CUT apresentou uma proposta de emenda popular que tratava de restabelecer o princípio do pluralismo e a plena liberdade de organização. Ela foi derrotada por 305 votos contra 148 e 19 abstenções. A seguir defrontaram-se a emenda do deputado José Fogaça (PMDB), que garantia a unicidade sindical e uma proposta do Centrão que estabelecia o pluralismo. A emenda Fogaça venceu por 343 votos contra 100 dados à iniciativa do Centrão e 42 abstenções. Os partidários decididos do pluralismo formavam uma coalizão política heterogênea, composta por larga maioria dos deputados do PFL, maioria apertada dos constituintes do PDS, ínfima minoria de pemedebistas e de outros partidos. Os deputados do PT, à exceção de um, preferiram marcar distância dessa amálgama de indiscutível inclinação conservadora". (ALMEIDA, 1992: 152-153)
} 
VIII - é vedada a dispensa do empregado sindicalizado a partir do registro da candidatura a cargo de direção ou representação sindical e, se eleito, ainda que suplente, até um ano após o final do mandato, salvo se cometer falta grave nos termos da lei.

Parágrafo único. As disposições deste artigo aplicam-se à organização de sindicatos rurais e de colônias de pescadores, atendidas as condições que a lei estabelecer.” (BRASIL, 2001)

Para Leôncio Martins Rodrigues, em uma análise pouco tempo depois da promulgação da Carta Magna, "os sindicatos obtiveram a sua autonomia ante o Ministério do Trabalho" que perdeu a prerrogativa até então vigente de intervir nos sindicatos. Mas isso não garantiu o fim do corporativismo uma vez que o inciso II ordena a manutenção da unicidade sindical, em franca contradição com o conteúdo do caput. (RODRIGUES, 1988:48)

Para Boito Jr., no campo da legislação sindical, a Constituição de 1988 "elevou os principais elementos da estrutura sindical, que anteriormente eram normas contidas na CLT, à condição de normas constitucionais". Para ele, o artigo da Constituição também encontra-se em flagrante contradição, mas, adverte, "no seu espírito, o texto não é contraditório: os legisladores e sindicalistas entendem por intervenção apenas e tãosomente as intervenções próprias do modelo ditatorial de gestão do sindicalismo de Estado - deposições de diretorias, eleições rigidamente controladas, etc. -, mas não as intervenções necessárias para o funcionamento e reprodução da estrutura sindical. (BOITO Jr. 1991:74) Em verdade, mantendo o Estado como tutor das entidades sindicais, a Constituição de 1988 promoveu o que Boito Jr. afirma ser uma liberalização dos aspectos mais restritivos da estrutura corporativista sobre os sindicatos. Dessa forma, os sindicatos ficaram livres para fazerem seus estatutos da forma como bem entendessem, mantendo aqueles aspectos já mencionados: unicidade sindical, imposto sindical e o poder normativo da Justiça do Trabalho.

A consequência disso foi a "explosão" na criação de sindicatos, muitos deles como fruto do aumento da organização dos trabalhadores, como o de servidores públicos; mas muitos outros apenas como reflexo dessa "meia liberalização" das exigências legais combinados com as "facilidades" mantidas na Lei.

Assim, a CUT, fundada em 1983, chega ao final da década com um saldo bastante positivo em sua organização, mas com um passivo em relação ao desafio de implodir a estrutura sindical corporativista "por dentro", conforme a estratégia adotada inicialmente. 
Contudo, a estrutura sindical corporativista, por sua parte, também sofreu abalo significativo no período, perdendo sua faceta mais diretamente autoritária sobre a organização sindical, ainda que tenha mantido controle sobre os sindicatos justamente através daqueles quesitos "aceitos" tácita ou explicitamente pelos sindicalistas como garantia de manutenção da máquina sindical sem maiores riscos políticos.

As mudanças operadas durante esse período na legislação referente à estrutura sindical podem ser compreendidas como uma estratégia perspicaz de manutenção da ordem corporativista no contexto de redemocratização e de ascensão das lutas sindicais - do tipo "dar os anéis para não perder o dedo" -, mas certamente elas não seriam efetivadas na direção e intensidade em que o foram não fosse a atuação do sindicalismo-CUT. Portanto, as mudanças na estrutura sindical foram também conquistas do movimento sindical naquilo que era primordial para ele, qual seja, na retirada dos elementos de "constrangimento" e de manutenção dos mecanismos de "incentivo", ainda que esses instrumentos de incentivo representem também um controle do Estado sobre a ação sindical.

\section{CUT instituição: 1990 - 2002}

O segundo período da trajetória da CUT, identificado em diversos estudos sobre o tema, teve como ponto de mutação, a rigor, o $3^{\circ}$ CONCUT, realizado em 1988, em Belo Horizonte (MG), que representou um marco na transição de uma "CUT - movimento" para uma "CUT - Instituição".

Mudanças que já vinham sendo sinalizadas desde 1986, no $2^{\circ}$ CONCUT, conforme Giannotti e Neto:

“A partir de 86 começaram a aparecer propostas de mudanças que iam todas no mesmo sentido: maior estruturação interna, maior poder das direções, e menor peso das bases. Na verdade a CUT, à medida que não rompeu totalmente com a velha estrutura, foi criando uma prática sindical híbrida, ambivalente. Pouco a pouco a força dos aparelhos sindicais começou a aparecer e a provocar um processo gradativo de burocratização e a diminuição do esforço democrático inicial.

O $3^{\circ}$ Congresso - Belo Horizonte, 1988 -, foi quase todo absorvido pela discussão sobre a reestruturação da CUT, enquanto máquina sindical (...) O objetivo da maioria da Direção era claro: aprovar uma mudança no estatuto que permitisse implementar uma nova visão de Central. Uma Central de representação, de negociação, mais do que uma Central de mobilização e organização para a luta de amplas massas. (...) A CUT optou por se aproximar do modelo das centrais sindicais europeias". (GIANNOTTI e NETO, 1993:42) 
É importante salientar que tal estratégia não paira no ar, mas se assenta e se relaciona com a dinâmica da política real desenrolada pelos fatos que vão se sucedendo na história.

Assim, o número cada vez maior de sindicatos filiados conquistados ao longo da década de oitenta e o peso político cada vez maior que estes passaram a ter sobre as oposições sindicais fez com que assumisse maior ênfase o fortalecimento institucional da CUT, legitimando-se a partir de então não apenas pela sua capacidade de mobilização, mas principalmente pela sua representatividade formal e conquistas em negociações coletivas.

A opção da CUT por essa perspectiva de ação exigiu algumas mudanças estatutárias que apontasse essa nova direção.

Desse modo, a CUT aprovou no $3^{\circ}$ CONCUT a ampliação dos mandatos da Direção com um espaçamento maior entre os Congressos Nacionais, de dois para três anos. Mudou o critério para eleição de delegados aos Congressos e Plenárias da CUT, que passou a ser com base no número de sócios e não mais pelo número de trabalhadores na base. A eleição dos delegados aos Congressos regionais e estaduais seria feita nas assembleias dos sindicatos, sem distinção entre diretoria e base, mas a eleição ao Congresso Nacional passaria a ser feito no plenário dos Congressos estaduais ${ }^{87}$.

Tais propostas foram calorosamente debatidas nos trabalhos em grupo e nas plenárias do Congresso e explicitaram diferentes posições entre as correntes políticas no interior da CUT.

Na defesa de uma CUT pautada pelo seu peso institucional encontrava-se a Articulação Sindical com sua Tese 10. De outro lado estavam as tendências CUT Pela Base, Convergência Socialista e Força Socialista pela manutenção de uma CUT-movimento.

A proposta da Articulação Sindical vinha ao encontro da ideia de um Contrato Coletivo Nacional Articulado que começava a ser divulgado no Brasil. Claramente inspirado na experiência sindical europeia, principalmente na italiana, o Contrato Coletivo previa uma estratégia de negociação nacional centralizado estabelecendo patamares mínimos de direitos e conquistas de modo que acordos de âmbito estadual, regional ou local, nessa ordem, só poderiam ser firmados ampliando aqueles direitos já garantidos em instância de abrangência territorial mais ampla. Para implementar o Contrato Coletivo a CUT deveria fazer as mudanças no sentido do fortalecimento de sua representação sindical.

\footnotetext{
${ }^{87}$ Anos depois, voltou-se a eleger delegados ao CONCUT em assembleias de base dos sindicatos.
} 
Para Iram Jácome Rodrigues "o $3^{\circ}$ CONCUT representou, com as mudanças estatutárias, o começo da transformação de uma concepção movimentista para uma visão mais organizativa da Central Única dos Trabalhadores. Em outras palavras, o que estava em jogo neste congresso eram duas alternativas para o sindicalismo-CUT: a primeira, da CUT-movimento; a segunda, da CUTorganização . Esta venceu... Iniciava-se realmente a implantação da CUT como estrutura verticalizada, administrativa, enfim, como uma organização complexa e, nesse sentido, burocrática (...) Simbolicamente, esse encontro significou o fim da fase heróica de construção da CUT e tudo o que ela representava para uma parte da militância cutista. Abria-se, agora, um novo patamar, onde a construção de um aparelho administrativo, institucional, se colocava na ordem do dia. E, em consonância com o processo de democratização do país, setores ponderáveis do sindicalismo-CUT começavam a vislumbrar a possibilidade das classes trabalhadoras influírem mais decididamente na esfera política e, para isso, era necessário deixarem de dizer apenas não e também indicarem soluções para os problemas sociais, políticos e econômicos do país”. (RODRIGUES, 1997:117) Com a aprovação das propostas da Articulação Sindical em 1988, a CUT começa a sofrer uma inflexão em sua trajetória e a explicitação de divergências internas em torno de um projeto político-organizativo da Central passou a ser cada vez mais constante e polarizado, a partir de então.

A CUT reafirmou no $3^{\circ}$ CONCUT que a estratégia de implantação de sua estrutura fora dos parâmetros do corporativismo deveria passar fundamentalmente pela luta, pela construção na prática, não através de aprovação no parlamento. Para isso, como reflexo e encaminhamentos do $3^{\circ}$ CONCUT, a $4^{\text {a }}$ Plenária Nacional da CUT, realizada em agosto de 1990, adota medidas de ajustes financeiros e administrativos visando fortalece-la como entidade de representação dos trabalhadores, a saber: criação dos departamentos por ramo de atividade econômica (desenhados no $2^{\circ}$ CONCUT, mas com detalhamento de suas funções e critérios de organização no $3^{\circ}$ CONCUT); registro da CUT em cartório e na Receita Federal; adoção de um regimento administrativo adequado aos estatutos; campanha nacional visando a auto-sustentação financeira da CUT e dos sindicatos; ação junto aos sindicatos para que aprovem a mensalidade de $1 \%$ do salário dos associados; adoção de um sistema de cobrança bancária e débito automático; garantia do pagamento da contribuição dos sindicatos à CUT em 5\% de seus orçamentos; entre outras. (VÉRAS, 2001:63-64) 
A partir daquele momento os Congressos Nacionais da CUT nunca mais teriam em torno de cinco mil delegados como fora até então, e a representação nos congressos, que antes tinha um peso de trabalhadores de base, passou a ser basicamente uma representação de dirigentes sindicais. $\mathrm{O}$ peso dos trabalhadores rurais diminuiu significativamente e a delegação das regiões norte e nordeste também reduziram proporcionalmente em relação às delegações dos estados do sudeste. ${ }^{88}$

Mas as mudanças verificadas foram bem além da composição dos congressos. A CUT passou a ter outra postura política diante dos graves problemas existentes na sociedade.

Tal inflexão ganha corpo a partir de 1990, quando Fernando Collor de Melo toma posse como presidente da República.

As medidas tomadas pelo novo governo trouxeram à CUT um novo cenário de atuação conforme já dissemos anteriormente: abertura do mercado brasileiro aos produtos importados, acarretando recessão, elevação no nível de desemprego e o arrefecimento do ímpeto de mobilização sindical. Do mesmo modo, a busca de maior competitividade pelas empresas pela introdução de inovações tecnológicas e organizacionais - Programas de Qualidade Total para obter o compromisso dos trabalhadores com os interesses da empresa, kanbam, Just-in-time, automação flexível, reengenharia, reestruturação produtiva, terceirização, etc. - implantaram, em poucas palavras, um modelo de globalização subordinada e as regras do Consenso de Washington (neoliberalismo) no Brasil.

Tudo isso em meio a um governo legitimamente eleito pelo voto direto, trouxe à CUT até então um dos piores momentos políticos em sua trajetória.

Completa esse quadro de dificuldades para a CUT a criação da Força Sindical, que se firmou em pouco tempo como uma oponente de expressão à CUT, diferentemente da CGT ao longo dos anos 1980. A Força Sindical apareceu no cenário como uma corrente de

\footnotetext{
${ }^{88} \mathrm{O} 4^{\mathrm{o}}$ CONCUT, realizado em 1991 teve a participação de 1.546 delegados credenciados. Em um quadro comparativo entre o $3^{\circ}$ e o $4^{\circ}$ CONCUT, observamos que a proporção de delegados membros de diretoria elevou-se de $49,2 \%$ para $83,0 \%$ e as delegações de base reduziram de 50,8\% para $17,0 \%$. (RODRIGUES, 1997:185) De acordo com o mesmo autor, o setor rural, que representava $36,8 \%$ dos delegados ao $3^{\circ}$ CONCUT, expressaram apenas 12,3\% do total de delegados ao $3^{\circ}$ CONCUT. (RODRIGUES, 1997:213) Dados sobre a composição dos delegados pelas regiões do país podem ser observados no mesmo autor. (RODRIGUES, 1997:205)
} 
dentro da CGT sob a denominação de um "sindicalismo de resultado" em contraposição à posição mais radical e oposicionista da $\mathrm{CUT}^{89}$.

Diante desse contexto adverso e inédito, e com a nova orientação de fortalecimento institucional, a postura mais negocial da CUT foi "testada" quando a Central foi chamada pelo governo ao "entendimento nacional", reedição de propostas anteriores do governo Sarney em torno de um Pacto Social, na ocasião prontamente rechaçada pela CUT.

Dessa vez a CUT aceitou sentar-se à mesa com o governo. Mais uma vez a polêmica entre as correntes internas da CUT se acirram. Para a Articulação Sindical tratava-se de defender os interesses da classe trabalhadora onde quer que fosse, em qualquer espaço, e que a recusa ao chamado deixaria um espaço ainda maior a ser ocupado pela Força Sindical. Para a Articulação Sindical, ainda, a CUT deveria deixar de ser uma "CUT do não", ou seja, deixar de ser uma Central que apenas diz "não" a tudo e a todos para começar a ser uma CUT mais propositiva, ou seja, a dizer quais propostas defende para a classe trabalhadora, e em torno dessas propostas, negociar com quem quer que fosse.

Para as demais correntes, ir ao encontro do presidente, que massacrava os trabalhadores com sua política neoliberal para negociar em torno de um "entendimento nacional" não fazia qualquer sentido, pois entendiam que a CUT não tinha nada a conquistar naquele espaço senão sinalizar para a classe uma "rendição" frente ao governo. Para eles, a CUT deveria tomar as ruas e gritar alto e bom som "Fora Collor".

A resposta da Articulação Sindical ao "Fora Collor" foi o "Não a Collor", ou seja, não à sua política recessiva, não ao desemprego, não ao arrocho salarial. Discordavam do slogan "Fora Collor" também porque, ao contrário de Sarney, este havia sido eleito democraticamente pelo sufrágio universal e, empunhar aquela palavra de ordem, significaria ir contra as regras democráticas estabelecidas no país. Nessa visão, o presidente, por pior que fosse, tinha o direito de cumprir seu mandato. Caberia à CUT fazer oposição ao governo, mas não propor sua saída ${ }^{90}$.

\footnotetext{
${ }^{89}$ A origem da Força Sindical é uma cisão da CGT, que perde na ocasião também a militância sindical ligada ao PCB e ao PCdoB, que haviam optado pela CGT no momento de fundação da CUT, mas que naquele contexto de enfrentamento ao neoliberalismo decidem juntar-se à CUT.

${ }^{90}$ Dois anos depois, em 1992, na $5^{\text {a }}$ Plenária Nacional, a CUT mudaria sua posição diante das denúncias de corrupção feitas pelo próprio irmão do presidente, que levaria a manifestações de massa até seu afastamento do cargo de presidente da república, como já mencionamos anteriormente. O "fora Collor" ganhou as ruas do país, liquidando o debate político com o slogan "Não a Collor". Entretanto, a CUT saiu ainda com a palavra-
} 
Controvérsias à parte, a Central comparece ao chamado do governo para uma reunião em junho e foi à negociação do "entendimento nacional" com o governo em setembro de 1990, exigindo a readmissão dos trabalhadores do serviço público, entre outras reivindicações, e o governo recua. (VÉRAS, 2001:66)

Evidentemente a CUT saiu da mesa sem firmar qualquer acordo, fazendo a denúncia de que o governo não tinha, de fato, uma boa vontade em atender as reivindicações dos trabalhadores. Convoca uma greve geral para os dias 22 e 23 de maio de 1991, mas o movimento, diante da recessão provocada pela política econômica do governo Collor, teve repercussão bem menor que as greves gerais do período anterior.

O $4^{\circ}$ CONCUT $^{91}$, realizado entre 4 e 8 de setembro de 1991, em São Paulo, expressa esse conjunto de questões aqui assinaladas que acirra o tensionamento interno e aprofunda a linha que já vinha sendo implementada na CUT, de reforçar seu caráter institucional. Assinala importantes mudanças nesse sentido, como a indicação de transformação dos Departamentos profissionais em Confederações e Federações e a polêmica filiação da CUT à Confederação Internacional das Organizações Sindicais Livres (CIOSL), inaceitável para as correntes da esquerda socialista na CUT.

A transformação dos Departamentos em Federações e Confederações, para a Articulação Sindical, tinha o sentido de conferir maior legitimidade institucional para negociação de Contratos Coletivos, mesmo não sendo reconhecida pela estrutura sindical oficial. Para as correntes da CUT no campo "mais à esquerda" tal mudança significava, ao contrário, ceder à estrutura corporativista e não buscar sua superação como era a proposta inicial da CUT.

A filiação à CIOSL se justificava, para a Articulação Sindical, para fortalecer maior integração com centrais sindicais de outros países.

"O determinante na defesa da filiação da CUT a uma central mundial foi sua avaliação do que se passava no sindicalismo internacional. Tratava-se de um processo de reorganização, de alteração de correlação de forças e que deveriam promover um realinhamento das centrais sindicais que estavam em processo de discussão de suas filiações às centrais mundiais, promovendo assim o equilíbrio das

de-ordem "Impeachment já", "Basta de corrupção!", e "CPI pra valer!" durante a Jornada Nacional de Luta. que foram aprovadas pela maioria dos delegados da $5^{\text {a }}$ Plenária Nacional (VÉRAS, 2001:73-74)

${ }^{91}$ Uma análise pormenorizada sobre o $4^{\circ}$ CONCUT pode ser encontrada na tese de doutoramento de Iram Jácome Rodrigues (1993) e em Vito Giannotti e Sebastião Lopes Neto, ambos militantes e dirigentes sindicais, no livro CUT Ontem e Hoje. (1991) 
relações entre o movimento sindical dos países desenvolvidos e subdesenvolvidos". (SRI, 2002: 48)

Os tempos de guerra fria em que a disputa ideológica entre o bloco pró-capitalismo o bloco pró-socialismo se dava, no meio sindical, através da disputa entre a CIOSL e a Federação Sindical Mundial (FSM) já era coisa do passado. A queda do Muro de Berlim e a derrocada da União Soviética e dos regimes em todos os países do leste europeu haviam combalido a FSM. A CMT (Confederação Mundial de Trabalhadores), de orientação democrata-cristã também não atendia às plataformas da CUT. A CIOSL passou a ser praticamente a única central mundial de expressão, que aglutinava praticamente todas as centrais sindicais nacionais no sindicalismo internacional. Para a ArtSind, a CUT não poderia ficar alheia ao que se passava no sindicalismo internacional, nem tampouco permanecer fora das discussões que se dava nesse campo. A participação de delegações da CUT nos Congressos internacionais ocorria apenas mediante convite, e só lhe era conferida a voz para uma saudação aos delegados congressistas. A filiação permitiria à CUT poder de voz e de voto, possibilitando ser um ator efetivamente atuante no cenário internacional. Daí porque deveria filiar-se à CIOSL e participar de suas instâncias de deliberação. (SRI, 2003)

As demais correntes da CUT se opunham à filiação à CIOSL porque ainda tinham muito presente na memória a ação dessa central sindical mundial na América Latina, apoiando regimes ditatoriais em diversos países ou fechando os olhos para a repressão que se passava neles.

$\mathrm{O} 4^{\circ}$ CONCUT transcorreu em clima de forte tensão entre as correntes pelo equilíbrio que se observava entre o número de delegados no plenário. Em oposição à Articulação Sindical, formou-se a Antártica (anti-Articulação) com todas as demais correntes internas da CUT. O ponto de maior acirramento se deu na votação sobre a forma de organização da Direção Nacional da CUT, se respeitando uma proporcionalidade simples ou uma proporcionalidade qualificada na sua composição. Na proposta da proporcionalidade simples a corrente com maior votação escolheria proporcionalmente os cargos que ficaria na Direção, deixando os demais cargos à escolha da segunda corrente mais votada, depois da terceira e assim sucessivamente. Na proporcionalidade qualificada, a divisão na composição da Direção Nacional se daria proporcionalmente, mas a ordem de escolha seria alternada: a corrente com maior número de votos escolheria um cargo a ser ocupado, mas a segunda corrente 
mais votada teria o direito de escolher o segundo cargo para, só então a corrente mais votada ter a escolha do terceiro cargo. Essa proposta da proporcionalidade qualificada ficou conhecida como "puladinha" por causa da alternância na escolha dos cargos pelas correntes.

O resultado da votação deu vitória à Articulação Sindical, de proporcionalidade simples, por uma margem muito apertada, e a contagem de três votos em separado reverteria o quadro em favor da proposta da proporcionalidade qualificada, defendida pelas demais correntes da CUT. O Congresso ficou paralisado diante desse fato, se apuraria ou não aqueles votos em separado. Após um dia inteiro de discussões tensas, a Articulação Sindical fez valer sua apertada maioria e deliberou-se pela não contagem dos votos em separado, alegando que um dos votos em separado seria repetido, e assim sendo, um mesmo delegado teria seu voto contado duas vezes. O resultado dessa votação acirrou a disputa não só na continuidade do Congresso, mas na própria gestão da Direção eleita. As correntes minoritárias acusavam a Articulação Sindical de não respeitar a democracia interna, rejeitando o resultado de uma votação em que, pela primeira vez, ela colheria uma derrota.

Na plenária final do $4^{\circ}$ CONCUT, a tensão do ambiente de disputa e as acusações entre os delegados resultou em pancadaria geral.

Passado o Congresso, mas ainda sob forte tensão, a Direção Executiva Nacional da CUT firma em documento as bases para um compromisso conjunto com todas as tendências ${ }^{92}$, que possibilitaria um arrefecimento dos ânimos e a manutenção da unidade da Central, quando muitos acreditavam que ela cindiria após o confronto levado às vias de fato na plenária de encerramento do $4^{\circ}$ CONCUT.

Segundo Véras, "após a assinatura do documento "Bases para um compromisso" se estabeleceu uma outra dinâmica interna na relação entre as correntes. Criou-se um clima de maior tolerância e as divergências passaram a ter um tratamento mais respeitoso da parte de cada uma delas". (VÉRAS, 2001:73)

\footnotetext{
${ }^{92}$ Apenas João Salame Neto e Francisco Zoccoli, do Partido da Libertação Proletária (PLP) recusaram-se a assinar o termo de compromisso. (GIANNOTTI e NETO, 1991)
} 
No ano seguinte, 1992, durante a $5^{\text {a }}$ Plenária Nacional da CUT, os delegados aprovaram tudo o que o $4^{\circ}$ CONCUT havia indicado, ou seja, a transformação dos departamentos em federações e confederações e a filiação da CUT à CIOSL.

Já mencionamos nessa tese a resolução da $5^{\text {a }}$ Plenária, em que pela primeira vez se reconhecia a dificuldade da CUT superar o atrelamento colocado pela estrutura sindical corporativista.

O documento reconhece que não havia explorado ao máximo sua atuação "por dentro" dos sindicatos oficiais (poucos tinham sido os sindicatos que, após a promulgação da Constituição de 88, "reformularam seus estatutos ou alteraram sua base de representação, rompendo com o enquadramento sindical"); e avalia que a estrutura horizontal construída pela CUT não estava conseguindo "cumprir satisfatoriamente a tarefa de representação política e organizativa do conjunto dos trabalhadores" e que a estrutura vertical não tinha favorecido efetivamente a organização por ramos e a unificação das lutas no plano nacional e que a CUT não tinha avançado na organização por local de trabalho nem conseguira mudar o sistema de negociação coletiva (a CUT não superara a dinâmica fragmentária das negociações coletivas por data-base). Conclusão: "a transição para o novo sindicalismo está dificultada e o modelo sindical cutista incompleto". (CUT, 1992)

A "resposta" da CUT para enfrentar tais dificuldades foi a elaboração da proposta de um Sistema Democrático de Relações de Trabalho (SDRT), em que ela articula de modo mais acabado uma alternativa global que vá além de mudanças na estrutura sindical corporativista e contemple as relações de trabalho como um todo ${ }^{93}$.

Segundo Véras, "para ser viabilizado, [o SDRT] deverá contar com uma transição negociada em bases tripartites, envolvendo temas como: organização sindical, negociação coletiva, direito de greve, legislação esparsa, poder judiciário do trabalho, Ministério do Trabalho". (VÉRAS, 2001: 85)

\footnotetext{
93 O Informacut $n^{\circ} 250$ apresenta uma atualização do texto com a proposta do Sistema Democrático de Relações de Trabalho (SDRT) que, originalmente, teria sido publicado no Informacut no205, de 1992. No entanto, há outras versões que a proposta do SDRT foi elaborada na $7^{\mathrm{a}}$ Plenária Nacional, em 1995. Independente da data de origem, o que importa reter aqui é que o SDRT não foi um "raio em céu azul", mas fruto de um processo de acúmulo de discussões no interior da CUT, balizado por uma estratégia de fortalecimento institucional de representação sindical e negociação de um contrato coletivo nacional articulado.
} 
A principal justificativa da CUT ao propor o SDRT é a necessidade de modernização das relações de trabalho, ainda mais em um contexto de intensas transformações do mundo do trabalho com inovações tecnológicas, de organização do trabalho e da produção que evidenciam a inadequação da velha legislação sindical para enfrentar tais mudanças. A modernização das relações de trabalho passaria, na proposta da CUT, pelo reconhecimento da natureza conflitiva entre Capital e Trabalho em uma sociedade capitalista, e a necessidade de se promover o diálogo e a negociação entre as partes interessadas. A democracia e a justiça social são o fundamento da proposta da CUT.

Por vezes, ao longo dos anos oitenta, a defesa enfática de dirigentes sindicais cutistas em torno da negociação direta e sem constrangimento da legislação se aproximou de uma visão "liberal" de não intervenção do Estado. O SDRT representa então um amadurecimento da CUT em torno do tema para que tais mudanças sejam processadas dentro de uma legislação transitória que preveja garantias à ação sindical.

A proposta de SDRT da CUT defende um ordenamento jurídico baseado nas convenções da OIT, como a Convenção 87 (sobre a liberdade sindical e a proteção do direito sindical); a 98 (sobre a aplicação dos princípios do direito de sindicalização e de negociação coletiva); 135 (sobre proteção e facilidade a serem dispensadas a representantes de trabalhadores na empresa); 151 (sobre o direito de sindicalização dos trabalhadores do serviço público); 154 (sobre a promoção da negociação coletiva); 158 (sobre a proteção dos trabalhadores contra o término da relação de trabalho sem causa justificada); e as Convenções 11, 110 e 141, voltadas aos trabalhadores rurais.

De acordo com o documento da CUT "esse novo arcabouço jurídico deve garantir a liberdade sindical, especialmente a necessária autonomia frente ao Estado, a liberdade de exercício frente às empresas, e o direito de greve; a organização dos trabalhadores desde o local de trabalho até o plano nacional, e a contratação coletiva, entendida como possibilidade de negociar, sem a intervenção compulsória do Estado, e de contratar, fiscalizar e fazer cumprir normas sobre salários e condições de trabalho”. (CUT, 1992b:35) Desse modo, a Justiça do Trabalho perderia seu poder normativo e teria uma nova função de assegurar condições equivalentes entre as partes negociadoras, reequilibrando as relações de poder. 
Em relação à legislação transitória para o novo modelo proposto pela CUT, a Central acentua as seguintes finalidades:

“a) remover todas as restrições e obstáculos ao exercício das liberdades sindicais, inscritos na Constituição federal e na legislação ordinária (CLT), atacando, especialmente o poder normativo da Justiça do Trabalho; o monopólio de representação sindical (o sindicato único definido em lei); a contribuição sindical compulsória; a imposição do sistema confederativo; e a proibição da negociação coletiva no setor público.

b) proporcionar a ratificação e/ou adequação legislativa das Convenções da OIT: 11, 87, 98, $110,135,141,151,154$ e 158.

c) Consignar, na Constituição Federal, os princípios e direitos básicos que caracterizam o sistema proposto, com base nas Convenções da OIT.

d) Formular legislação ordinária que garanta regras e procedimentos que dêem funcionalidade ao sistema proposto e que evitem prejuízos aos trabalhadores, na transição de um sistema para outro, ou seja, manter assegurados em lei, preceitos fundamentais protetivos do trabalho.

e) Assegurar em legislação específica de transição a vigência e o atual sistema de acordos e Convenções coletivas; as datas-base atuais das categorias; registros das entidades sindicais existentes, com a configuração da representação atual das categorias profissionais e o patrimônio das entidades sindicais. Essas condições devem estar garantidas até que, com base nas novas regras a serem introduzidas, os trabalhadores interessados promovam as alterações desejadas.

f) celebrar um Contrato de Negociação Coletiva para estabelecer, mesmo antes da conclusão das alterações legislativas, os princípios, regras e procedimentos definidos”. (CUT, 1992b:37)

Como encaminhamentos práticos, o documento do SDRT aponta:

“a) A constituição de uma Comissão Tripartite de Revisão do Sistema de Relações de Trabalho, a ser integrado por representantes do Estado, os empregadores e dos trabalhadores, para promover e propor iniciativas de transição, tomando por base o Documento Final do Fórum Nacional de Debates sobre Contrato Coletivo e Relações de Trabalho (dezembro - 1993) 
b) Será tarefa dessa Comissão a formulação de uma Agenda Nacional para o estabelecimento de metas, ampliação e aprofundamento da discussão.

c) Entre as tarefas da Comissão deverá estar o impulsionamento de um Sistema Permanente e Articulado de Negociação Coletiva de Trabalho, visando alterar, desde logo, o atual processo de negociação, estabelecer novas regras e, com base nos princípios mencionados, criar condições para a celebração de um Contrato Coletivo Nacional de Trabalho.

d) No âmbito da Comissão deve ser formulada em detalhe também a proposta do Conselho Nacional de Administração Pública". (CUT, 1992b:38)

A proposta do SDRT não teve condição de ser efetivada, mas permaneceu como orientação da ação da CUT nos espaços oficiais de discussão sobre as mudanças na legislação sindical, mesmo antes do FNT, em 2003. Contudo, todas as iniciativas de mudança das leis sindicais no país antes de Lula foram rechaçadas pela CUT pelo fato de que foram iniciativas unilaterais do governante da ocasião. Exceção seja feita no processo constituinte em que a CUT teve oportunidade de influenciar o rumo das mudanças através de parlamentares, mas não o fez com o afinco necessário e logo, como já observamos nesse trabalho, mantiveramse os pilares da estrutura sindical corporativista e foram até reforçados.

Para Armando Boito Jr., as iniciativas de alteração da legislação sindical "reflete o declínio histórico da estrutura sindical e a crise do modelo ditatorial de gestão dessa estrutura. Ora, trata-se de projetos que visam ajustar o sindicalismo de Estado às necessidades novas do governo, outras vezes são formas de sondar as posições de empresários e sindicalistas, e, não poucas vezes, tudo é mero jogo de cena para impressionar sindicalistas ou, inclusive, chantageá-los com a perspectiva eliminação do que eles consideram ser os "aspectos positivos" da estrutura sindical - o dinheiro seguro das contribuições compulsórias, a segurança legal e monopolística da representação sindical, etc. A ideologia legalista vigente no meio sindical permite que governos conservadores como Sarney e Collor [e FHC, acrescento] possam chantagear o movimento sindical, "ameaçando-o" com a liberdade e autonomia sindical - embora nenhum desses governos tenha ousado até aqui dar o salto e suprimir, de fato, a estrutura sindical brasileira”. (BOITO Jr.,1991:74-75)

Veremos no capítulo seguinte que somente no contexto do governo Lula, durante os debates no FNT, essa proposta vai aparecer nas discussões em mesa de negociação. Até lá cabe a constatação de que a CUT permaneceu na defensiva, qualquer que seja o motivo e a análise a ser feita. 
Em paralelo às discussões internas dos Congressos e Plenárias, a CUT seguia enfrentando as lutas sociais contra o governo Collor.

A greve geral empreendida em maio de 1991 malogrou, mas a CUT reviveu com vigor as lutas que marcaram sua trajetória nos anos 1980 quando as denúncias de corrupção do presidente Collor começaram a adquirir maior vulto. A CUT, como a principal central sindical do país, assume papel destacado nas mobilizações pelo impeachment do presidente junto a outras entidades da sociedade civil.

Durante o curto período de vigência do governo Itamar Franco, de 1992 a 1994, a CUT se lançou à experiência das câmaras setoriais $^{94}$, que tinham um formato tripartite para alavancar o investimento nos diversos setores, gerando crescimento econômico que o país não vivenciava há anos com a contrapartida social da geração de empregos.

Mais uma vez, a participação da CUT nas rodadas das câmaras setoriais provocou polêmica na Central entre a Articulação Sindical e as demais correntes e deu o tom do debate durante a $6^{\text {a }}$ Plenária Nacional, realizada em agosto de 1993. A primeira, favorável à participação da CUT e seus sindicatos nos espaços das câmaras setoriais. As demais correntes, criticando a Direção da CUT / ArtSind, colocaram-se contrários à participação nas câmaras setoriais por entenderem tratar-se de um espaço de cooptação e colaboração de classes. ${ }^{95}$

\footnotetext{
${ }^{94}$ As câmaras setoriais foram inicialmente projetadas no governo Sarney, em 1988, para estabelecer uma discussão governo-empresários sobre política industrial a partir de diversas cadeias produtivas. Mas logo adquiriram outra função: diante das dificuldades para o controle da inflação, as câmaras foram usadas visando o controle de preços em negociações restritas a governos e empresários. Nesse contexto, tiveram vida praticamente virtual. Pela natureza política liberalizante do governo Collor, as câmaras setoriais foram aproveitadas mais para administrar a saída do congelamento de preços. Através de uma emenda do então deputado federal Aloísio Mercadante (PT-SP) à Lei $n^{\circ} 8.178$ que havia criado as câmaras, seu caráter passou a ser tripartite, ao invés de bipartite, como no momento anterior. Somente a partir de maio de 1991 as câmaras foram orientadas a deixarem de discutir preços e passarem a elaborar políticas industriais, para além das questões imediatas. (VÉRAS, 2001:78)

${ }^{95}$ No campo acadêmico, a participação da CUT nas câmaras setoriais também foi alvo de muitas críticas. Para Galvão a experiência da câmara setorial automotiva fortaleceu a ação sindical fragmentada, uma vez que as negociações coletivas abrangeram apenas um setor, ao contrário da prática anterior de se fazer negociações que unificavam toda a categoria metalúrgica (GALVÃO, 2002:94). Boito Jr. levanta dados que indicam ganhos para empresas - aumento no faturamento em mais de $50 \%$; redução na participação do setor na arrecadação de Imposto sobre Produto Industrializado (IPI) de 2,0\% para 1,1\%; além de facilidades creditícias para alavancar suas vendas - e perdas para os trabalhadores: redução constante no número de funcionários no período e demissão de três mil operários após a desativação da câmara, acompanhado de aumento na produção de veículos. Boito Jr, citando Galvão, afirma que "os objetivos declarados do acordo da câmara setorial do setor automotivo que mais interessavam aos trabalhadores não foram cumpridos. (...) Os objetivos que interessavam diretamente ao patronato, por seu turno, foram largamente ultrapassados". (BOITO Jr, 1999:166)
} 
A experiência mais exitosa das câmaras setoriais foi a do setor automotivo. Em março de 1992 foi celebrado o primeiro acordo envolvendo os seguintes pontos principais: a) redução de $22 \%$ nos preços dos automóveis e veículos comerciais a partir da redução de impostos e margens de lucro da indústria e concessionárias); b) manutenção do nível de emprego e correção mensal dos salários; c) prorrogação da data-base por dois meses; discussão do contrato coletivo de trabalho etc. (VÉRAS, 2001)

Em fevereiro de 1993 a câmara setorial do setor automotivo chegou a um segundo acordo envolvendo metas relacionadas com investimentos, produção, ampliação dos prazos dos consórcios, convenção coletiva com vigência de dois anos, além dos itens anteriores (impostos, preços, nível de emprego). (VÉRAS, 2001)

O impacto dos dois acordos da câmara setorial do setor automotivo evidenciou-se no crescimento vertiginoso das vendas, aumento significativo de 43,3\% na produção e na suspensão temporária de planos de demissão pelas empresas, que, apesar dos resultados positivos, teve um desempenho considerado tímido, segundo Arbix. (VÉRAS, 2001)

Para Oliveira, a câmara setorial é o exemplo mais evidente que o movimento sindical "se revelou capaz de entender as razões do adversário, sair de um jogo de soma-zero, intervir diretamente na alocação de capital e, por tabela, na política macroeconômica do Estado. É o mais notável exemplo de uma nova cidadania". (OLIVEIRA, 1998:11)

Mas não foi só a câmara setorial do setor automotivo que se revelou um espaço importante de participação da CUT.

A partir dos anos 1990, começaram a ser regulamentados em legislação específica as diversas formas de participação da sociedade civil nas políticas públicas, conforme o quadro abaixo:

\begin{tabular}{|l|l|l|}
\hline \multicolumn{1}{|c|}{ Conselho } & \multicolumn{1}{|c|}{ Segmentos } & \multicolumn{1}{c|}{ Fundamentação } \\
\hline \multirow{3}{*}{ Saúde } & $\begin{array}{l}\text { - Governo e prestadores de serviço (1/4) } \\
\end{array}$ & - Profissionais de saúde (1/4) \\
& $\bullet$ Usuários (1/2) & $\begin{array}{l}\text { Lei n }{ }^{\circ} 8142, \text { de } 28 \text { de dezembro } \\
\text { de 1990, Art. } 1^{\circ}, \S 2^{\circ}\end{array}$ \\
\end{tabular}




\begin{tabular}{|c|c|c|}
\hline Conselho & Segmentos & Fundamentação \\
\hline $\begin{array}{l}\text { Direitos da Criança e } \\
\text { do Adolescente }\end{array}$ & $\begin{array}{l}\text { - Órgãos governamentais (1/2) } \\
\text { • Órgãos não-governamentais (1/2) }\end{array}$ & $\begin{array}{l}\text { Lei n }{ }^{\circ} 8169 \text {, de } 13 \text { de julho de } \\
\text { 1990, Art. } 86 \text { e } 88 \text { II. }\end{array}$ \\
\hline Assistência Social & $\begin{array}{l}\text { - Órgãos governamentais (1/2) } \\
\text { - Órgãos não-governamentais (1/2), } \\
\text { subdivididos por igual entre: } \\
\text { ○ Trabalhadores } \\
\text { Usuários } \\
\text { O Prestadores de serviço }\end{array}$ & $\begin{array}{l}\text { Lei } n^{\circ} 8742 \text {, de } 7 \text { de dezembro de } \\
\text { 1993, Art. } 17, \S 1^{\circ} \text { II }\end{array}$ \\
\hline Trabalho e Emprego & $\begin{array}{l}\text { - Governo }(1 / 3) \\
\text { - Trabalhadores }(1 / 3) \\
\text { - Empregadores }(1 / 3)\end{array}$ & $\begin{array}{l}\text { Lei } \text { n }^{\circ} 7998 \text {, de } 11 \text { de janeiro de } \\
\text { 1990, Art } 18 \text { e Resolução do } \\
\text { CODEFAT nº } 80 \text {, de } 19 \text { de abril } \\
\text { de 1995, alterada pela Resolução } \\
\text { CODEFAT no 114, de } 1^{\circ} \text { de } \\
\text { agosto de } 1996 .\end{array}$ \\
\hline
\end{tabular}

Desde então, inúmeros dirigentes sindicais de sindicatos filiados à CUT vem participando dos mais diversos conselhos, seja em instância municipal, estadual ou federal.

Segundo Elenaldo Teixeira, "trata-se efetivamente de órgãos públicos de natureza sui generis: são criados por lei, regidos por um regulamento que é aprovado por seu plenário mas referendado pelo Executivo, têm caráter obrigatório para todo o país, como condição para repasse de recursos (...) Abstraindo a questão legal, cremos importante conceber os conselhos como estruturas de uma nova institucionalidade no país. São resultantes em grande parte de um processo de discussão pública que ocorre a partir dos anos 80 e que se consolida no final desta década, sobretudo em relação às grandes áreas das políticas públicas: saúde, educação, assistência social, criança e adolescente. (...) Todo esse processo se insere num movimento maior de constituição de uma esfera pública que poderia ser melhor caracterizada como esfera pública ampliada, uma vez que é uma 
extensão do Estado até a sociedade através da representação desta regida por critérios diferenciados da representação parlamentar ou mesmo sindical. Estamos entendendo esfera pública como espaço de interação entre Estado e sociedade inserido nas instituições estatais. (...) Trata-se de um aparato misto, pelo qual a sociedade penetra no Estado e busca introduzir uma lógica de persuasão sobre as questões mais sentidas pela sociedade, criando assim novas agendas e novos parâmetros para as ações governamentais". (TEIXEIRA, 2000:103-104)

Para Celso Daniel, então prefeito do PT em Santo André (SP), "os conselhos gestores de políticas públicas fazem parte de uma dimensão mais ampla das ações do governo e envolvem, na verdade, uma transformação na própria forma de fazer gestão pública. Eles têm a ver com uma concepção de co-gestão, uma concepção de partilha de poder. São novos espaços, novas esferas públicas no interior das quais a agenda fundamental é justamente a agenda voltada ao fortalecimento dos direitos de cidadania".(CARVALHO, M.C. e TEIXEIRA, A.C., 2000:123)

Mas o peso de nossa herança autoritária faz desses espaços, um grande desafio na construção da democracia e da cidadania ativa, em que se misturam inúmeras possibilidades e também limites de realização. (NASCIMENTO, 1999; TEIXEIRA, 2000)

Embora se encontre dirigentes sindicais ligados à CUT em todos os tipos de conselho, a Central deu prioridade à atuação nos espaços relacionados às políticas públicas de trabalho e renda, com a estratégia de fazer frente ao modelo neoliberal que vinha sendo implementado pelo governo FHC, com efeitos danosos para o crescimento do país e para o emprego. A proposta cutista era promover um novo modelo de desenvolvimento com geração de emprego e renda a partir da ação das Comissões de Trabalho e Emprego conferindo maior efetividade ao Sistema Público de Emprego (SPE) ${ }^{96}$ para combater o desemprego e a precarização no trabalho.

O quadro seguinte deixa ver a dimensão dessa estratégia da CUT.

\footnotetext{
${ }^{96}$ O Sistema Público de Emprego (SPE) foi efetivado através de conquistas logradas na Constituição Federal de 1988 e se constitui em cinco frentes de ação articuladas em um sistema, a saber: seguro-desemprego, produção de informações, intermediação de mão de obra, formação profissional, apoio à geração de renda através de microcrédito para pequenos empreendimentos de economia solidária (cooperativas). As Comissões de Trabalho e Renda nos Estados e nos municípios é o espaço de articulação dessas frentes, que delibera a política.
} 


\begin{tabular}{|c|c|c|c|c|}
\hline \multicolumn{5}{|c|}{ QUADRO QUANTITATIVO DAS COMISSÕES MUNICIPAIS DE TRABALHO E EMPREGO (23/11/1999) } \\
\hline UF & Municípios (A) & Criadas (B) & $\%(\mathbf{B} / \mathbf{A})$ & Homologadas (C) \\
\hline $\mathrm{AC}$ & 22 & 1 & 4,5 & 1 \\
\hline $\mathrm{AM}$ & 62 & 5 & 8,1 & 3 \\
\hline AP & 16 & 10 & 62,5 & 6 \\
\hline PA & 143 & 9 & 6,3 & 9 \\
\hline RO & 52 & 25 & 48,1 & 9 \\
\hline RR & 15 & 8 & 53,3 & 0 \\
\hline TO & 139 & 14 & 10,1 & 14 \\
\hline Norte & 449 & 72 & 16,0 & 42 \\
\hline $\mathrm{AL}$ & 101 & 6 & 5,9 & 6 \\
\hline BA & 416 & 299 & 71,9 & 280 \\
\hline $\mathrm{CE}$ & 184 & 99 & 53,8 & 35 \\
\hline MA & 217 & 21 & 9,7 & 13 \\
\hline PB & 223 & 48 & 21,5 & 47 \\
\hline $\mathrm{PE}$ & 185 & 72 & 38,9 & 51 \\
\hline PI & 222 & 3 & 1,4 & 3 \\
\hline RN & 166 & 11 & 6,6 & 8 \\
\hline $\mathrm{SE}$ & 75 & 24 & 32,0 & 19 \\
\hline Nordeste & 1789 & 583 & 32,6 & 462 \\
\hline DF & 0 & 0 & 0,0 & 0 \\
\hline GO & 242 & 61 & 25,2 & 61 \\
\hline MS & 77 & 19 & 24,7 & 14 \\
\hline MT & 126 & 57 & 45,2 & 5 \\
\hline Centro Oeste & 445 & 137 & 30,8 & 80 \\
\hline $\mathrm{ES}$ & 77 & 49 & 63,6 & 47 \\
\hline MG & 854 & 242 & 28,3 & 159 \\
\hline RJ & 91 & 85 & 93,4 & 54 \\
\hline SP & 645 & 57 & 45,2 & 5 \\
\hline Sudeste & 1667 & 694 & 41,6 & 509 \\
\hline PR & 404 & 368 & 91,1 & 350 \\
\hline $\mathrm{RS}$ & 467 & 350 & 74,9 & 349 \\
\hline $\mathrm{SC}$ & 293 & 228 & 77,8 & 210 \\
\hline Sul & 1164 & 946 & 81,3 & 909 \\
\hline TOTAL & 5514 & 2432 & 44,1 & 2002 \\
\hline
\end{tabular}

Fonte: SPES/Dised. Obs.: essas informações são fornecidas mensalmente pelas Secretarias Executivas das Comissões Estaduais de Trabalho e Emprego

Elaboração: João Marcelo 
A atuação de dirigentes sindicais ligados à CUT com a estratégia de alavancar alternativas de desenvolvimento com geração de emprego e renda poderia alcançar, potencialmente, 2.432 municípios em todos os Estados da União, representando 44,1\% dos 5.514 municípios existentes no país.

No entanto, pela novidade da demanda aos sindicatos e à própria CUT, de discutir políticas públicas de emprego e renda nos espaços locais, e por uma falta de cultura política, a estratégia da CUT efetivada ficou bem aquém do potencial aberto, como demonstra o depoimento de alguns conselheiros cutistas abaixo ${ }^{97}$ :

"Quando fui indicado para representar o sindicato na Comissão Municipal de Trabalho e Emprego, não tinha claro o que fazer e qual o papel a desempenhar. Nas primeiras reuniões, achei algo bastante limitado, pouca coisa era discutida, o maior interesse de todos era aprovar rapidinho qualquer projeto que chegasse".

"No início, a nossa Comissão tinha um bom trabalho, todos estavam motivados. Fizemos seminários sobre o desemprego no município, reuniões com o Banco do Brasil e a Caixa Econômica Federal, contatos com a universidade etc. Mas, aos poucos, a coisa foi esfriando e hoje a Comissão está abandonada. A sensação é que ela perdeu sua função".

"Logo no início, a Comissão de Trabalho e Emprego era controlada pelo prefeito, mas fomos questionando esse controle. Hoje, não está mais tão dependente do prefeito".

"A bancada dos trabalhadores está sempre em desvantagem. A paridade só existe no papel pois, na prática, estamos em desvantagem. É bom termos claro que esses espaços não anulam as relações de classe e de poder mais gerais da sociedade".

"Na Comissão de Trabalho e Emprego as informações custam a chegar. Não se sabe praticamente nada sobre as decisões tomadas no estado e, muito menos, em nível nacional”.

"É muito difícil conseguir que a Comissão tenha uma pauta regular de discussões e atividades. As reuniões são eventuais e acontecem muito em função da necessidade de discutir algum projeto que chega de última hora".

"O sindicato apenas me designou para acompanhar a Comissão. Depois, nada mais foi feito. Pouca coisa é discutida na direção e os sindicatos da cidade não demonstram maior interesse. Atuo de forma isolada e, muitas vezes, defendo somente as minhas próprias opiniões".

${ }^{97}$ Os depoimentos constam da publicação Capacitação de Conselheiros das Comissões de Trabalho e Emprego. A experiência da CUT, do Convênio MTE/SEFOR/CODEFAT 024/99 - CUT. 
"Um dos caminhos encontrados para animar a Comissão foi o contato com os movimentos, instituições e entidades do município. Fizemos reuniões com Universidade, ONGs, Câmara de Vereadores etc. A partir dessas reuniões, criamos um fórum para discutir o desemprego no município. Esse fórum se reúne sistematicamente e está avançando para elaborar um plano local de desenvolvimento".

Observa-se nos depoimentos todo tipo de dificuldade no funcionamento das Comissões, desde a falta de preparação política do dirigente em atuar como conselheiro, passando pelo desinteresse da entidade sindical em alguns casos, até dificuldades burocráticas de funcionamento do conselho e o autoritarismo do governante local. Da mesma forma que vêse também alguns êxitos.

Outro espaço importante de atuação da CUT para implementar o Sistema Público de Emprego com efetividade é o Conselho Deliberativo do Fundo de Amparo ao Trabalhador (CODEFAT), criado a partir da Lei 7998 com o objetivo de gerir os recursos do FAT, que tinha em sua composição as três centrais sindicais da época (CUT, Força Sindical e CGT), as três confederações patronais (CNI, CNF, e CNC) e três órgãos do governo federal (Ministério do Trabalho e Emprego, Ministério da Previdência e BNDES).

O FAT foi criado em janeiro de 1990, na mesma lei que instituiu o CODEFAT, para financiar o programa do seguro-desemprego recém instituído na ocasião. O patrimônio financeiro do FAT passou a ser composto principalmente por contribuições do Programa de Integração Social (PIS) e do Patrimônio do Servidor Público (PASEP), recolhidos pelos empregadores à alíquota de $0,65 \%$ sobre o faturamento bruto das empresas.

O patrimônio total do FAT alcançava, até fevereiro do 1999, R \$ 41,3 bilhões, dos quais R \$ 26,1 bilhões $(63,3 \%)$ encontravam-se à disposição do BNDES, sob a forma de empréstimo sem data de retorno, e R $\$ 4,8$ bilhões representavam o caixa do Fundo, aplicados em títulos públicos no Banco do Brasil. O restante, R \$ 10,4 bilhões, estava depositado em instituições financeiras federais para aplicação em programas diversos. Alguns desses programas haviam sido instituídos pelo governo federal, através de medida provisória, à revelia do CODEFAT, como os recursos disponibilizados para os atingidos pela seca de 1998 (cerca de R 780 milhões; os recursos emprestados compulsoriamente para a saúde e para o Inamps haviam sido quitados pelo governo no início de 1999). 
Ou seja, de um patrimônio de mais de $\mathrm{R} \$ 40$ bilhões, pouco mais de $\mathrm{R} \$ 10$ bilhões estavam aplicados em programas criados e geridos por iniciativa do CODEFAT, dando a entender o limite desse instrumento de participação, elaboração e acompanhamento de políticas públicas de emprego e renda no país. (CUT, 1999:32-33)

A CUT chega nos anos 1990 com uma estrutura organizativa que combina a chamada "estrutura horizontal" com a "estrutura vertical", também conhecida como os ramos da CUT.

A “estrutura horizontal” já vinha sendo constituída desde a fundação da CUT, em 1983, para ser um órgão ou instância de organização do conjunto da classe trabalhadora em determinado nível de abrangência. Assim sendo, a "estrutura horizontal" é toda ela fora da estrutura sindical oficial, criada a partir do movimento e composta pelas instâncias da CUT em todos os níveis (CUTs Regionais, CUTs Estaduais e CUT Nacional). Recebe esta denominação porque aglutina o conjunto da classe trabalhadora nos respectivos níveis de ação caracterizando um recorte transversal / horizontal na sociedade, devido a abrangência de sua representação. Assim, por exemplo, uma luta acerca de preço das passagens de ônibus em determinada região, que afeta a toda população é tema a ser colocado em pauta pela Central propriamente dita. Da mesma forma, o tema da dívida externa, ou da redução da jornada de trabalho, e assim por diante. A CUT então convoca os sindicatos filiados à ação sob sua coordenação.

A estrutura vertical / ramos, como vimos, foi aprovada a partir do $2^{\circ}$ CONCUT (1986) com a denominação de Departamentos, e após a $5^{\text {a }}$ Plenária Nacional (1992) são transformadas nas Federações e Confederações da CUT. Dentro da estratégia da CUT, caberia aos ramos organizar os setores de acordo com a especificidade das questões que afligem os trabalhadores, tendo por objetivo principal estabelecer o Contrato Coletivo de Trabalho. Foi dada a denominação "vertical" pelo seu caráter de aprofundamento de temas específicos de um determinado conjunto de categorias, de um mesmo ramo de atividade. Assim, temas como, por exemplo, as condições de trabalho, terceirizações, inovações tecnológicas e organizacionais do trabalho, enfim, temas pertinentes aos trabalhadores de determinado setor são o foco de atuação dos ramos. Desse modo, a estrutura vertical é composta pelas 
Confederações, que atuam em âmbito nacional, pelas Federações, em geral de âmbito estadual, pelos sindicatos, e teria que se enraizar nos locais de trabalho através de instrumentos de organização dos trabalhadores que tenham caráter sindical ou não (comissão de fábrica, CIPA, Sistema Único de Representação, delegados sindicais, representantes sindicais etc.)

Ao contrário da estrutura horizontal, que foi toda criada fora do sindicalismo oficial, a estrutura vertical da CUT apresenta um quadro bem mais complexo devido à estratégia adotada para seu crescimento e consolidação.

A estrutura vertical da CUT teve sua origem na criação dos departamentos que depois foram transformados em federações e confederações. Mas onde foi possível, a partir dos sindicatos oficiais, disputar e ganhar as eleições em federações / confederações oficiais, filiando-as à CUT isso foi feito ${ }^{98}$. Assim, ao contrário dos sindicatos, que são todos filiados à CUT, há federações / confederações oficiais, reconhecidas pela CLT, que são filiadas à CUT (que, portanto mantém sua autonomia e pode se retirar da CUT); e outras que são orgânicas à CUT, ou seja, que foram criadas pela CUT à margem da estrutura oficial e que até então, via de regra, não tinha representação oficial para desenvolver suas negociações nem a autonomia de decisão de sair da CUT, pois é parte integrante da CUT $^{99}$.

\footnotetext{
${ }^{98}$ Há inúmeros exemplos, mas o caso mais evidente dessa situação é o da CONTAG. No momento de fundação da CUT, a direção da CONTAG na ocasião optou por ficar fora da CUT. Em virtude disso a CUT organizou o ramo dos rurais a partir do DNTR. No $4^{\circ}$ CONCUT (1991) aprovou-se pela participação dos sindicatos de trabalhadores rurais filiados à CUT no Congresso da CONTAG, para defender o plano de lutas aprovado no $10^{\circ}$ Congresso do DNTR, articular uma chapa cutista para as eleições de sua direção e defender a filiação da CONTAG à CUT. Essa ação vai persistir até a $7^{\mathrm{a}}$ Plenária Nacional da CUT, realizada em 1995, formaliza a filiação da CONTAG à CUT. Em março de 2009, entretanto, a CONTAG aprovou em seu Congresso por mais de 300 votos a desfiliação da CUT. A CUT, desde sua $1^{\text {a }}$ Plenária Nacional (1985), apontou quais seriam suas instâncias, entre elas os ramos de atividade econômica, que deveriam ser "criados ou resultante das conquistas de federações ou confederações" (VÉRAS, 2001:47). O $2^{\circ}$ CONCUT apenas ratificou a deliberação da $1^{\mathrm{a}}$ Plenária.

${ }_{99}$ A estratégia traçada de fortalecer as oposições sindicais e conquistar a direção de sindicatos trouxe para dentro da CUT elementos do sindicalismo oficial, regido pela CLT. Desse modo, todos os sindicatos são entidades juridicamente, administrativamente e politicamente autônomas que se filiam à CUT através de decisão tomada em assembleia ou em congresso, passível de reversão, pois, sendo uma entidade autônoma, pode se retirar / se desfiliar da CUT. As entidades orgânicas, por serem próprias da CUT, não se desligam da Central. Outra diferença grande entre a estrutura filiada e orgânica à CUT é em relação ao financiamento: as entidades filiadas, por serem reconhecidas oficialmente pelo Ministério do Trabalho, recebem o imposto sindical e pagam mensalidade à CUT. De modo diametralmente oposto, a estrutura orgânica da CUT, por não ser reconhecida, não recebe diretamente imposto sindical e outros recursos compulsório previstos em lei, mas como fazem parte da estratégia de consolidação da CUT no ramo, recebem recursos da CUT proporcionalmente ao número de sindicatos do ramo filiados à CUT. Veremos adiante que isso tem sofrido pressões por mudança no quadro mais recente da CUT.
} 
Desse modo, as Federações e Confederações filiadas podem contemplar entre seu quadro de entidades associadas, sindicatos e/ou federações não cutistas. Por exemplo, a Federação dos Químicos do Rio de Janeiro, filiada à CUT, tem 14 sindicatos associados e, destes, sete não são filiados à CUT, sendo que dois são ligados à Força Sindical. Do mesmo modo, a CONTAG, enquanto esteve filiada à CUT, manteve em seu quadro Federações de Trabalhadores Rurais não filiados à CUT, entre eles, por exemplo, a de São Paulo (FETAESP), que é filiada à Força Sindical. A construção da CUT entre os rurais em São Paulo se faz através da Federação dos Empregados Rurais Assalariados do Estado de São Paulo (FERAESP) e da Federação da Agricultura Familiar (FAF), que são entidades orgânicas à CUT.

Por outro lado, há também inúmeros sindicatos de base filiados à CUT (que, automaticamente, participam de federações e confederações orgânicas à CUT), mas que mantiveram a decisão política de permanecer como membro associado de federações oficiais que não tem filiação a qualquer central sindical ou que sejam filiadas a outras centrais.

Esse cenário se reproduz em quase todos os $\operatorname{ramos}^{100}$, de modo que, assim, ao longo de sua trajetória a CUT foi constituindo um hibridismo entre sua estrutura orgânica (própria) e a estrutura oficial.

Acrescenta-se a esse cenário de "hibridismo" da CUT com a estrutura sindical oficial a existência que há de muitos conflitos internos de representação entre os ramos da CUT, como por exemplo, entre os rurais, em que CONTAG (enquanto esteve filiada) e FETRAF disputaram a mesma base sindical de pequenos produtores.

\footnotetext{
${ }^{100} \mathrm{Na}$ CUT foram se estruturando diversos ramos e na $5^{\text {a }}$ Plenária Nacional se chegou a definição de 18 ramos dentro da CUT, cada um deles com uma ou mais confederações, a saber: metalúrgicos (CNM), químicos (CNQ), bancários e o setor financeiro (CONTRAF), trabalhadores do comércio e serviços (CONTRACS), vestuário (CNTV), construção civil e madeira (CONTICOM), seguridade social (CNTSS), educação (CNTE e CONTEE), servidores públicos municipais (CONFETAM), servidores públicos federais (CONDSEF), telecomunicações (FITTEL), serviços urbanos de energia elétrica, água e esgoto (FNU); trabalhadores da comunicação (FENAJ, FITTERT e FENECT), trabalhadores da informação (FENADADOS), do transporte (CNTT); rurais (CONTAG, filiada durante um período, e FETRAF, orgânica), alimentação (CONTAC) e aposentados (SINTAP).
} 
Do mesmo modo, os sindicatos do setor público municipal que fazem parte da CONFETAM organizam trabalhadores da saúde e da educação, reivindicados respectivamente pela CNTSS e pela CNTE.

Setores como o de petróleo pertence à base da CNQ, mas há uma discussão se não deveria ser de um ramo de energia, que desmembraria parte da FNU (eletricitários) para compor um novo ramo, específico.

Os telefônicos organizados na FITTEL deveriam ser de um ramo de telecomunicações, de comunicação ou de serviços urbanos?

A duplicidade de interpretação quanto à base de representação dos ramos se deve não apenas a mera disputa política, mas reflete a complexidade e imbricação da organização das cadeias produtivas na realidade.

A CUT tenta enfrentar tais questões no $5^{\circ}$ CONCUT (1994), aprofundando sua autocrítica sobre a relação com a estrutura sindical oficial ao avaliar o processo de "acomodação" à estrutura corporativista e o surgimento de sinais de deterioração da prática sindical como o burocratismo o sectarismo e a violência entre chapas cutistas em diversas nas eleições sindicais. Frente a isso, capitaneada pela ArtSind e com a oposição das demais correntes, o plenário do $5^{\circ}$ CONCUT delibera pela transformação dos sindicatos filiados em entidades orgânicas à Central, a ser tratado na Plenária Nacional seguinte.

O "clima" do $5^{\circ}$ CONCUT, realizado em maio de 1994, transcorreu de forma bem mais amena que o Congresso antecessor, e foi marcado pela iminente de vitória de Lula à presidência nas eleições que ocorreriam em outubro daquele ano. Sua vantagem nas pesquisas de intenção de voto era bastante ampla e a CUT já se preparava para o novo momento político no país.

Há poucos dias do $5^{\circ}$ CONCUT, Vicentinho, então candidato à sucessão de Jair Meneguelli à presidência da CUT, afirmou em entrevista que "o governo Lula será um governo que do ponto de vista da pessoa, dos compromissos e de propostas tem muitas coincidências com o que pensa a CUT. Mas é o governo Lula. Vamos contribuir para que ele seja um governo que funcione sob a ótica dos trabalhadores. Aí é que está o papel da Central Única dos Trabalhadores, que vai apresentar propostas e se manter coerente. A CUT não pode ser uma central puxa-saco do governo, como também não pode ser uma central de oposição 
sistemática a um governo democrático-popular que tem compromissos com a classe trabalhadora. Será preciso da parte do governo como também da parte do movimento sindical muita habilidade, muita transparência e a conquista de confiança de ambos os lados". (SRI, 1994:2) Chamamos a atenção que a certeza expressa na entrevista de Vicentinho em relação à vitória de Lula estava na cabeça de todos os dirigentes e militantes sindicais cutistas.

Com a implantação do Plano Real em julho, a candidatura de Fernando Henrique Cardoso, ex-ministro da Fazenda do governo Itamar franco, toma vulto e atropela a corrida eleitoral vencendo ainda no primeiro turno com $54,3 \%$ dos votos.

O impacto econômico imediato do Plano Real possibilitou não só a vitória de FHC e um índice de popularidade elevado, como também colocou a CUT em novo período defensivo, reforçado ainda mais após a batalha da greve dos petroleiros, em junho de 1995, já mencionada nesse trabalho.

Entretanto, afora as disputas entre as correntes, realizou-se durante o $5^{\circ}$ Congresso a aplicação de uma pesquisa de perfil e de opinião dos delegados(as) acerca de diversos temas da agenda sindical e política do país.

De acordo com Roberto Véras de Oliveira, "sobre a pergunta "você é a favor da possibilidade legal de criação de mais de um sindicato de uma mesma categoria profissional na mesma base territorial?", nada menos do que 56,9\% responderam "não". Ou seja, a maioria dos delegados manifestou opinião contrária à extinção da unicidade sindical". (VÉRAS, 2002:33)

Em relação às fontes de sustentação financeira das entidades sindicais, as respostas dos delegados expressaram posição contrária ao imposto sindical, de modo coerente com a posição histórica da CUT. Apenas 10,0\% dos delegados manifestaram-se favoravelmente à manutenção do imposto sindical. (VÉRAS, 2002:34)

Quanto ao poder normativo da Justiça do Trabalho, os delegados ao $5^{\circ}$ CONCUT dividiram-se em opiniões extremas; 2,9\% colocaram-se a favor da manutenção do poder normativo da Justiça do Trabalho e 11,4\% defenderam posição pela completa extinção da Justiça do Trabalho. Prevaleceu, nesse quesito, as opiniões medianas: “37,6\% manifestaram concordância em manter tal poder normativo, mas tão somente como recurso exclusivo dos 
trabalhadores; enquanto que 36,4\% optou por sua extinção, mas com manutenção da Justiça do Trabalho para julgamento dos pleitos individuais dos trabalhadores (posição mais próxima da que a CUT defende oficialmente)". (VÉRAS, 2002:34)

Assim, conclui Véras, "ficou evidente o quanto as posições históricas da CUT não encontrava uma base de sustentação sólida mesmo entre seus principais militantes (que são aqueles que frequentam seus congressos nacionais)". (VÉRAS, 2002:34)

A julgar pelo posicionamento refratário dos(as) delegados(as) do $5^{\circ}$ CONCUT a questões consensuais da CUT em torno do sindicalismo corporativo, a aprovação da proposta de transformar os sindicatos filiados em orgânicos sofreria grande resistência em ser levada à prática.

Não obstante a resistência, a $8^{\mathrm{a}}$ Plenária Nacional (1996) reafirmou a construção dos sindicatos orgânicos como meio de superação do corporativismo, no sentido da liberdade e autonomia sindical. A oposição explícita das correntes mais à esquerda da CUT permaneceu, apesar da explicitação pela ArtSind de que "a autonomia do sindicato, mesmo orgânico (tido como uma instância da Central) deveria ser preservada, tanto do ponto de vista político , como administrativo”. (VÉRAS, 2001:89)

O $6^{\circ}$ CONCUT (1997) foi a última vez que o tema do sindicato orgânico se fez presente nos debates da CUT como alternativa aos sindicatos oficiais, mesmo sem apresentar unanimidade entre as correntes internas. A principal marca do $6^{\circ}$ CONCUT foi a disputa à presidência da CUT, quando, pela primeira vez, a Articulação Sindical chegou dividida. Vicentinho, então presidente da CUT, pleiteava um novo mandato e teve que enfrentar a insatisfação de parte da base da ArtSind que ameaçaram não apóia-lo a poucas semanas do Congresso em favor de João Vaccari Neto, então secretário geral da CUT. O impasse se arrastou por todo o Congresso e só foi solucionado através de acordo momentos antes da eleição da nova Direção. (VÉRAS, 2001:92)

O segundo mandato de Vicentinho na presidência da CUT coincidiu com um momento de acirramento da crise do mercado financeiro nos países emergentes, que teve início do segundo semestre de 1997 entre os "tigres asiáticos", sobretudo a Coreia do Sul. A crise teve um efeito dominó, atingindo a Rússia em 1998 e o Brasil, em pleno período sucessório de FHC. Mesmo com os primeiros sinais de desgaste do Plano Real, o candidato FHC 
conseguiu contornar as dificuldades conjunturais pela ação do presidente FHC que segurou a adoção de medidas impopulares, lançando o pacote de ajuste após devidamente reempossado.

Apesar das dificuldades provocadas pelo pacote de FHC, ao gosto do receituário do FMI, a CUT passa a viver no período um momento mais intenso de mobilizações em todo o país, como a Jornada Nacional de Luta por Emprego e Direitos Sociais, em maio de 1998; a luta dos trabalhadores da Ford em São Bernardo do Campo contra a demissão em pleno período de Natal, entre 1998 e início de 1999; o Dia Nacional de Luta contra a Política Econômica do Governo FHC e em defesa do Brasil, em março de 1999; e a Marcha dos 100 mil, em agosto de 1999, o maior protesto organizado contra o governo FHC.

A 9 $9^{a}$ Plenária Nacional (1999) lançaria uma polêmica inédita entre as correntes internas da CUT com o debate em torno de uma nova alternativa aos sindicatos oficiais através da criação do Sindicato Nacional dos Metalúrgicos, em substituição à Confederação Nacional dos Metalúrgicos (CNM).

Sergio Nobre, então secretário da Comissão de Fábrica da Mercedes-Benz e dirigente da CNM-CUT, justificou a criação do Sindicato Nacional dos Metalúrgicos pela necessidade de se romper a fragmentação da organização sindical unificando os sindicatos em uma só estrutura, conferindo-lhes maior representatividade e maior poder de negociação em uma base territorial mais ampla que o tradicionalmente permitido na CLT. (NOBRE, 2002) Para ele, a maior dificuldade para implantação do Sindicato Nacional, além das correntes que se opunham abertamente, era que muitos dirigentes "não perceberam ainda que o atual modelo sindical está falido, ou então perceberam e sabem que se esse modelo mudar, ele estará fora do sindicato. Esse modelo fragmentado não serve mais para os trabalhadores. Mas para alguns dirigentes esse modelo serve, porque ele está ali garantido dentro do sindicato, não importa se o sindicato não funciona, se não tem capacidade de representação. Essa é a principal dificuldade". (NOBRE, 2002:46)

E completa ele: "acho que esse pessoal [refere-se às correntes mais à esquerda da CUT, opositores do Sindicato Nacional] está correndo um sério risco. Essa estrutura sindical só está sendo mantida porque a Força Sindical não se preparou ainda para um novo modelo, mas a estratégia dela é criar 
sindicatos em todas as bases importantes dos metalúrgicos (...) $\mathrm{Na}$ hora que eles estiverem preparados, esse modelo cai e aí quem estiver preparado, como nós estamos nos preparando... vai sobreviver. Agora, quem ficar dormindo e achando que esse modelo vai sobreviver para o resto da vida, vai perder espaço, ou para nós, do Sindicato Nacional, ou para a Força Sindical, o que é pior. É um caminho desastroso que esse pessoal está trilhando". (NOBRE, 2002:46).

Esse depoimento de Sergio Nobre foi voltado aos dirigentes organizados na CUT através do Movimento dos Trabalhadores ao Socialismo (MTS, ligados ao PSTU) e da Alternativa Sindical Socialista (ASS), mas bem caberia a inúmeros dirigentes da ArtSind, pois a resistência ao Sindicato Nacional, o tempo mostrou, também partia de sindicalistas ligados à ArtSind, que eram a ampla maioria e poderiam ter levado à experiência adiante se dependesse exclusivamente da vontade política deles.

Mas chama atenção na entrevista a ideia distorcida sobre o poder da Força Sindical diante da estrutura sindical corporativa, como se esta fosse ruir a partir do momento que a Força Sindical decidisse qual o melhor momento para faze-lo. Evidentemente que os mesmos problemas enfrentados pela CUT diante da estrutura corporativa também o são para as demais centrais sindicais e correntes internas à CUT. Talvez essa imagem acerca da Força Sindical exista em razão da mesma crítica que Leôncio Martins Rodrigues fez, quando referindo-se às deliberações do $2^{\circ}$ CONCUT ao propor o fim da estrutura sindical como sendo "de um voluntarismo a toda prova, fazia tábula rasa da estrutura sindical existente, ignorando as tradições e interesses organizados em torno do sindicalismo oficial e da resistência das empresas e do governo”. (RODRIGUES, 1990:13).

Por outro lado, a exacerbação acerca da Força Sindical pode também ser utilizada para justificar uma acomodação cutista ao modelo atual de estrutura sindical. Ao longo de inúmeros cursos de formação sindical tratando da superação do modelo corporativo ao longo dos últimos quinze anos, é muito frequente ouvir de participantes das atividades que, sem a unicidade sindical, por exemplo, a Força Sindical viria com o apoio de patrões e governos fundar sindicatos na mesma base e enfraquecer o sindicato cutista. A consequência é manter o estado da arte atual como está... ${ }^{101}$

\footnotetext{
${ }^{101}$ Em um levantamento para a CUT-SP aplicando questionário nas subsedes por todo o Estado de São Paulo, Ladosky e Véras encontraram de forma generalizada uma menção à Força Sindical como o maior problema enfrentado pela CUT nas regiões, no entanto, esse receio sobre o poder de fogo da Força Sindical não se
} 
Voltando ao debate sobre o Sindicato Nacional, para as correntes mais à esquerda, tratavase de uma nova tentativa de fazer vingar o sindicato orgânico, uma vez que os sindicatos do ramo filiados à CUT (todos da estrutura sindical oficial) seriam transformados em seções sindicais do sindicato nacional.

Emanuel Melato, então presidente da Federação Nacional Democrática dos Metalúrgicos e membro da corrente ASS, contrargumenta a partir do seguinte referencial:

"Não há ninguém no ramo metalúrgico que seja contra a sua criação! [referindo-se ao Sindicato Nacional]. O problema foi a forma como foi colocado. Então, iniciou-se um debate dentro do $4^{\circ}$ Congresso da Confederação [CNM], em 1998, sobre a necessidade da criação de um Sindicato Nacional, no qual já se previa que seria centralizado pela cúpula desse sindicato, no qual até a discussão da autonomia das assembleias de base estava questionada. Nesse Congresso, cerca de $40 \%$ dos delegados se recusaram a participar dessa votação e se retiraram no momento da votação, voltando posteriormente, dizendo: "podem votar que não vamos implementar". Diziam isso porque já trabalhavam com a ideia de que a direção do Sindicato Nacional não poderia fazer um acordo sem consulta ao sindicato de base. A experiência dos sindicatos cutistas, de respeitar as decisões dos trabalhadores em assembleia, não pode ser jogada na lata do lixo! Se esses sindicatos vieram de uma estrutura corporativa e fascista que conhecemos, também, a partir do momento em que foram ganhos pela CUT passaram a ter uma experiência de democratização dos sindicatos que não pode ser simplesmente desprezada”. (MELATO, 2002:50)

E emenda, Melato: "Achamos que isso não funciona aqui. Funciona na Europa, nos EUA, onde muitos acordos são feitos sem que os trabalhadores sejam consultados, são feitos pelas direções. Esse é um modelo sindical que vem da social-democracia europeia para controlar o movimento sindical. Na Europa, no pós-segunda guerra (1945), e mesmo nos EUA, criou-se uma mentalidade de que era preciso conceder algumas coisas aos trabalhadores por conta da guerra fria que existia no mundo, o que se chamou de "bem estar social". Mas isso não tem a menor possibilidade de ser aplicado em país algum de terceiro mundo, que sofre toda a pressão dos planos econômicos do FMI, do capital financeiro internacional. (...) Trabalhamos com o objetivo de existir uma única estrutura

verificava quando questionávamos sobre quantas oposições sindicais ligadas à Força estavam fazendo o enfrentamento contra a CUT, nem mesmo sobre o número de desligamentos de sindicatos da CUT para aderirem à Força. Desse modo, concluímos na ocasião que se tratava de uma imagem da Força Sindical que vinha sendo construída com muita intensidade através do destaque atribuído a ela pelos grandes meios de comunicação (suas ações de lobby no parlamento, a criação do Centro de Solidariedade para promover a intermediação de mão-de-obra, entre outros) e a uma estratégia de marketing mais "agressivo" que produzia tais resultados. Denominamos essa "presença" da Força como um espectro que rondava causando o "receio" nas bases cutista, parafraseando Marx no Manifesto Comunista. (LADOSKY e VÉRAS, 2001:84) 
nacional dos metalúrgicos. Porque na Europa existem inúmeras centrais sindicais? Porque a lógica deles é de centralização, é a lógica da divisão, da divisão, da divisão. Qualquer divergência política que exista sobre alguma decisão, você só pode não aplicar aquela decisão se você sair. A centralização tem esse problema. Por exemplo, a FEM/SP [Federação Estadual dos Metalúrgicos da CUT no Estado de São Paulo] fez acordo que reduz alguns direitos da convenção coletiva dos metalúrgicos, e nós não precisamos sair da CUT por causa disso. Criamos uma outra mesa de negociação e continuamos na CUT, só que negociando em mesa separada..." (MELATO, 2002:50-53)

Andréia Galvão (2007) menciona três iniciativas de reforma sindical ao longo do governo FHC.

A primeira delas foi o Projeto de Lei n 390/95 (PL 390), de autoria do deputado João Mellão Neto (PL-SP), na verdade uma reapresentação do PL 3747/93, do deputado Carlos Alberto Campista (PDT-RJ). Como se tratava de lei infraconstitucional, o PL 390 mantinha a unicidade sindical, mas, segundo a autora, abria uma brecha para mudanças mais profundas, uma vez que não estabelecia procedimentos para a resolução de conflitos de representação sindical (GALVÃO, 2007: 269).

A segunda tentativa de reformar a legislação sindical durante a gestão do presidente Fernando Henrique Cardoso foi encaminhada pelo Ministro do Trabalho da ocasião, Edward Amadeo, em que revogava praticamente todos os artigos dos capítulos I e II do título V da CLT, que tratam da instituição sindical e do enquadramento sindical, respectivamente.

O PL 4691/98 procurava retirar toda interferência do Estado, adequando o texto da CLT à Constituição Federal. Galvão cita artigo do Ministro publicado em jornais da época, ressaltando o entusiasmo de Amadeo, que superestimou o acolhimento a sua proposta:

"O primeiro passo rumo a uma vasta reforma trabalhista no Brasil já foi dado. Em reunião com as centrais sindicais, associações patronais e juristas no Rio, em 10 de agosto, houve ampla convergência sobre as bases para uma mudança histórica das relações de trabalho. Chegou-se praticamente a um consenso sobre a necessidade de extinguir o imposto e a unicidade sindicais e sobre a eliminação do chamado 'poder normativo' da Justiça do Trabalho. São avanços que aumentarão a representatividade dos sindicatos de trabalhadores e patronais. Ademais, valorizarão a negociação coletiva como for privilegiado de formação de compromissos entre capital e trabalho, 
aproximarão empregados e empregadores em torno da mesa de negociações (elemento básico para a preservação de empregos) e erradicarão, de uma vez por todas, os traços mais corporativistas da legislação trabalhista brasileira”. (GALVÃO, 2007:270)

A iniciativa do Ministro parou na própria Constituição, pois um projeto de lei não tem prerrogativa para alterar dispositivos constitucionais, apenas uma proposta de emenda constitucional (PEC).

Essa foi a terceira e última iniciativa de alteração da lei sindical do país no período 19952002: a PEC 623/98.

Apesar das divergências internas, a $9^{\text {a }}$ Plenária da CUT foi contra a Proposta de Emenda Constitucional $n^{\circ}$ 623/98 (PEC 623), lançada pelo presidente Fernando Henrique Cardoso para promover uma reforma da legislação sindical.

De acordo com Queiroz (2002), "no governo do presidente Fernando Henrique houve duas tentativas nessa área, uma na esfera infraconstitucional, e outra em nível constitucional. No primeiro caso, foi o projeto de flexibilização da CLT, atualmente em tramitação no Senado. No segundo, foi a Proposta de Emenda Constitucional 623, que foi arquivada na Câmara. (...) No caso da PEC 623, o objetivo era instituir a pluralidade sindical, dando aos trabalhadores e empregadores total e irrestrita liberdade para fundação ou criação de sindicato, sem qualquer outra exigência além da vontade política dos interessados. A proposta, como se verá a seguir, ultrapassava os limites da Convenção 87 da OIT, que trata de liberdade e autonomia sindical.

Resumidamente, a Proposta de Emenda pretendia o desmonte sindical, com: a) o fim da unicidade sindical, b) a instituição de um sistema de liberdade plena, de pluralidade sindical, c) a extinção da contribuição sindical, d) a eliminação da substituição processual, e) a possibilidade de criação de sindicato por empresa, f) a limitação da representação sindical apenas aos associados, g) a restrição do acesso individual do trabalhador à Justiça do Trabalho, através de conciliação prévia no âmbito da empresa, h) a extinção do poder normativo da Justiça do Trabalho, e i) a definição do critério de razoabilidade na definição da mensalidade social e contribuições em favor das entidades sindicais". (QUEIROZ, 2002)

A impressão de que a PEC 623 tinha o objetivo único de atacar as organizações sindicais com o desmantelamento imediato de toda estrutura corporativa foi compartilhada também por estudiosos com posicionamento exatamente oposto ao da CUT, como José Pastore. 
Para ele, "a referida Proposta de Emenda Constitucional (PEC 623/98) acaba com a unicidade sindical, elimina a contribuição sindical, termina com a noção de categoria, muda inteiramente a negociação e reduz o poder normativo da Justiça do Trabalho. Trata-se, sem dúvida, de uma transformação de profundidade. Resta indagar se, ao deixar intocável a prevalência do legislado sobre o negociado, essa transformação conseguirá superar os entraves que hoje prejudicam o emprego formal dos trabalhadores e a competitividade das empresas.

As transformações propostas, portanto, não prescindem de uma reforma na jurisdição da lei e da negociação em nosso País. Isto é prioritário. Só depois de estabelecido esse alcance é que se pode pensar na em mudar a organização sindical e a Justiça do Trabalho.

Se for para manter a prevalência do legislado sobre o negociado, não há muita razão para mudar. Mas se admitirmos que o negociado possa prevalecer sobre o legislado, aí sim, necessitaremos de uma criativa engenharia social para apoiar a difícil transição. Sem essa mudança de concepção, temo que a PEC 623/98 venha a provocar apenas a ira dos grupos atingidos e o reforço do sistema que se pretende mudar”. (PASTORE, 1999)

Desse modo, a $9^{\text {a }}$ Plenária Nacional da CUT aprovou apresentar o Sistema Democrático de Relações de Trabalho (SDRT) como alternativa à PEC 623/98. Também aprovou delegar à Direção Executiva Nacional articular projetos pontuais que favoreçam a viabilização do SDRT, bem como articular um fórum quadripartite envolvendo centrais sindicais, governo, empresários e a Comissão de Trabalho da Câmara (legislativo) para acertar as regras da negociação coletiva em um regime de liberdade sindical.

Enquanto não lograva tais conquistas, a $9^{\text {a }}$ Plenária aprovou também a definição de normas básicas para o estatuto dos sindicatos filiados à CUT que incluía mandato de três anos, simultaneidade nas eleições para representantes de base e direções sindicais; adoção unicamente de taxas voluntárias, com um percentual de no mínimo $1 \%$ da renda do trabalhador; garantia de eleições democráticas; adoção de organização de base e sua participação nas instâncias de direção, entre outros itens. Tais mudanças deveriam ser efetivadas até o $7^{\circ}$ CONCUT, ou seja, em um prazo de um ano. (VÉRAS, 2001:96)

A ideia do Sindicato Nacional do ramo metalúrgico foi um dos pontos altos da polêmica entre as correntes no $7^{\circ}$ CONCUT $(2000)^{102}$. A resolução aponta uma vitória dos segmentos

\footnotetext{
${ }^{102}$ Mais uma vez a corrida à presidência da CUT seria um momento de indefinição e disputa interna entre candidaturas da ArtSind. João Felício (APEOESP), João Vaccari Neto (Sind. Bancários de São Paulo) e
} 
da esquerda socialista da CUT, pois se decide que "durante o processo de discussão da implantação do Sindicato Nacional dos Metalúrgicos, os sindicatos de metalúrgicos que não tiverem aderido ao Sindicato Nacional terão mantida sua filiação à CNM"; "enquanto não houver uma definição estatutária no ramo da CUT alterando a representação metalúrgica nacional, o SNM em questão deverá ser filiado à CNM, sem prejuízo de outras experiências de unificação dos sindicatos"; "não poderá haver construção de representação na base de outro sindicato filiado". (VÉRAS, 2001:100-101)

No que se refere ao enfrentamento à estrutura sindical corporativa, o $7^{\circ}$ CONCUT aprovou ainda redefinir os ramos constitutivos da CUT; priorizar a organização por local de trabalho (comissões sindicais de empresa, delegados sindicais, organizações unitárias); revigorar a estrutura horizontal da CUT; estabelecer o $8^{\circ}$ CONCUT como prazo para que os sindicatos filiados incorporem em seus estatutos as normas básicas aprovadas na $9^{\text {a }}$ Plenária, como condição para participar do próximo congresso". (VÉRAS, 2001:100).

\section{O enfrentamento com a estrutura sindical corporativa}

O $7^{\circ}$ CONCUT (2000) foi o último Congresso realizado nesse período caracterizado pelo processo de institucionalização da CUT, pois o $8^{\circ}$ CONCUT (2003) já transcorreu com Lula recém empossado presidente da República. Ao longo dos anos 1990, em que pese a dificuldade de uma conjuntura adversa com os governos de orientação neoliberal que solaparam os direitos trabalhistas e alimentaram o desemprego colocando o movimento sindical na defensiva, a CUT experimentou um crescimento intenso no número de sindicatos filiados, conforme ilustra o quadro seguinte:

Mônica Valente (Sindsaúde), todos membros da Direção Executiva Nacional que concluía seu mandato, apresentaram-se para a sucessão de Kjeld Jacobsen, que ocupava interinamente a presidência após o licenciamento de Vicentinho para concorrer às eleições municipais de São Bernardo do Campo. Em plenária da Art.Sind. os 1266 delegados definiram-se pela candidatura de João Felício com $66 \%$ dos votos, cabendo a João Vaccari, 26\%; e à Mônica Valente $8 \%$ dos votos. 
Número de sindicatos filiados à CUT (1983 - 1997)

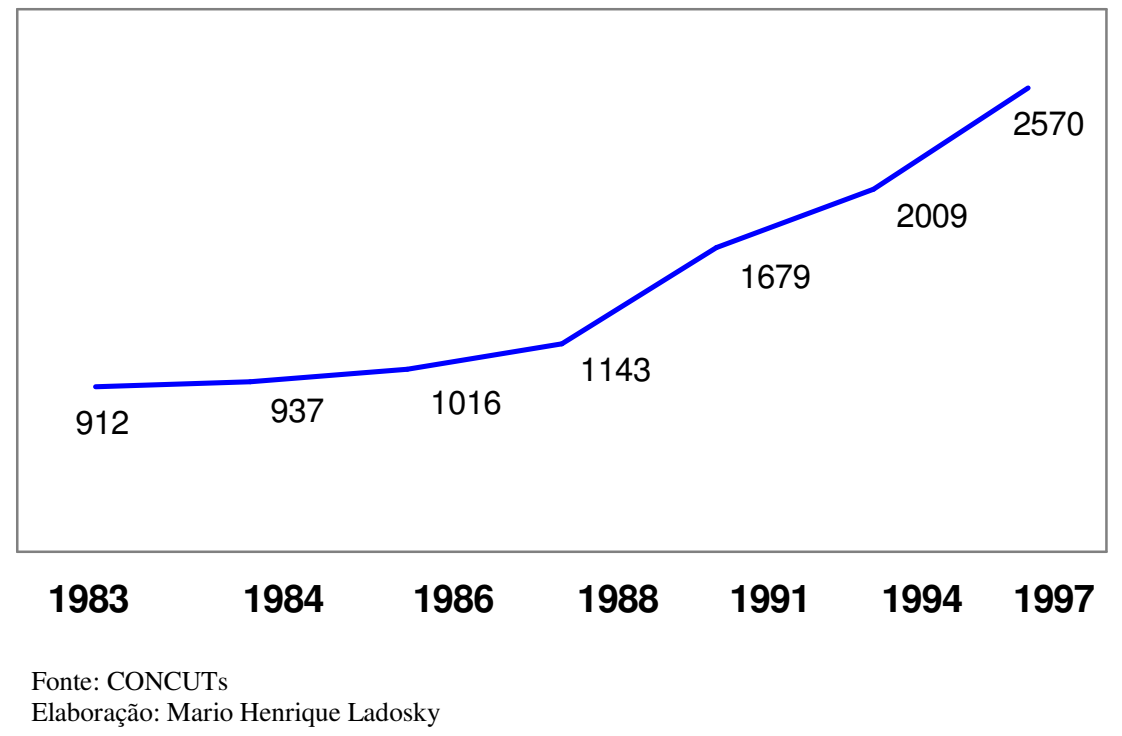

Deixamos evidenciado que a CUT permaneceu aprovando congresso após congresso; plenária após plenária, medidas para enfrentar e superar a estrutura sindical corporativa, porém as resoluções aprovadas nunca foram de fato implementadas na íntegra, apenas parcialmente, como a criação dos ramos, por exemplo. De modo que a superação da estrutura sindical corporativa continua sendo um dos principais desafios para a CUT 25 anos após sua fundação.

Porém, mesmo reconhecendo a situação de manutenção da ordem corporativa, mesmo com algumas mudanças assinaladas na Constituição Federal de 1988, não se pode dizer de modo algum que a experiência do sindicalismo-CUT resultou em fracasso total... Muitas iniciativas, pontuais é verdade, foram implementadas e devem ser contabilizadas em um processo de lentas mudanças na estrutura sindical.

Uma das mais interessantes é a experiência do Sinergia-CUT, o Sindicato que representa trabalhadores da indústria de energia e do gás no Estado de São Paulo, fruto da unificação e criação de uma nova estrutura sobre dois sindicatos oficiais já existente: o Sindicato dos Eletricitários de Campinas e o Sindicato dos Gasistas de São Paulo. Os Sindicatos oficiais continuam a existir, pois "não podemos simplesmente acabar com as entidades existentes, por conta dos problemas que temos na legislação trabalhista. Não vamos colocar em risco acordos coletivos, a base territorial, a existência legal de cada sindicato, sem antes termos as condições jurídicas e políticas. A proposta é de que essa entidade maior, principal e 
nova, chamada Sinergia, seja a única daqui a alguns anos, porque vamos acabar fechando e aprovando o fim do Sindicato dos Eletricitários de Campinas e o Sindicato dos Gasistas de São Paulo. Enquanto não houver liberdade e autonomia sindical, é um risco fazer isso". (SANTOS, 2002:71)

Desde sua fundação, em 1997, o Sinergia tem representado politicamente todos os trabalhadores do setor elétrico e de gás em todo o Estado, inclusive em bases cujo sindicato oficial não é filiado à CUT, como, por exemplo, o Sindicato dos Eletricitários de São Paulo, de Antônio Rogério Magri, Ministro do Trabalho durante o governo Collor, filiado à época na CGT. Rompe-se assim, na prática com a unicidade sindical: "estamos mudando radicalmente uma forma de fazer sindicato que anteriormente era muito clara: resumia-se a uma assembleia para aprovar a pauta de reivindicações da categoria na sede do sindicato - a mesma assembleia já aprovava um desconto de taxa confederativa ou desconto para taxa assistencial - e, depois, apenas uma assembleia ao final da campanha salarial para propor a assinatura do acordo que havia sido negociado com a empresa. Ao longo da negociação, nenhuma informação ou discussão no local de trabalho. Essa era a realidade que tínhamos na base da CGT em São Paulo, ou seja, um boletim "aguardem, companheiros, estamos em meio a um processo de negociação, mantenham-se mobilizados e unidos em torno de seu sindicato". Só palavras de ordem soltas, sem o menor sentido político do ponto de vista da mobilização. Enquanto nossos sindicatos no interior do Estado já faziam paralisações de meia hora, uma hora, duas horas, sofrendo as pressões da empresa, que afirmava que só o interior fazia isso, São Paulo ficava com essa lengalenga. Essa nova forma de fazer sindicato, indo para as bases, discutindo com os trabalhadores, paralisando as atividades, café da manhã no local de trabalho, tarja preta, enfim, uma série de manifestações, acabou criando também na base da CGT um olhar que era possível fazer um sindicato de forma diferente. Um sindicato que enxerga o trabalhador como o principal responsável pela existência da entidade, tendo liberdade de escolher seu sindicato. Essa figura da liberdade individual não poderia deixar de ser levada em conta quando trabalhamos a proposta do Sinergia (...) Os limites são os da legislação trabalhista. Representamos politicamente esses trabalhadores e temos uma quantidade bastante grande de sócios na base de outras centrais sindicais, mas ainda não os representamos do ponto de vista jurídico: não assinamos acordos coletivos fora das bases dos Eletricitários e Gasistas. Enfrentamos o obstáculo da legislação trabalhista, que ainda impõe a assinatura de acordos coletivos em várias empresas, apesar de já termos alguns em empresas. No caso específico das bases de outras entidades ainda temos o entrave da legislação, mas temos avançado em vários acordos coletivos, e assinado como Sinergia CUT. É interessante porque na verdade, politicamente, 
nossos dirigentes acabam fazendo um trabalho no sentido de representar, na mesa de negociação, não o trabalho do Sindicato dos Eletricitários, mas sim, a proposta de representar os trabalhadores energéticos (...) Por isso o Sinergia tem uma quantidade enorme de impugnações no Ministério do Trabalho, porque os demais sindicatos das outras bases onde estamos entrando com ação sabem que não podem menosprezar, porque temos nossos dirigentes dos Eletricitários de Campinas e dos Gasistas. E as empresas também acabam, na prática, querendo utilizar essas impugnações no Ministério como forma de pressionar pela não-assinatura de acordos. Mas a negociação, na prática, acaba sendo feita pelo próprio Sinergia”. (SANTOS, 2002:71-74)

No ramo dos rurais no estado de São Paulo, sindicalistas ligados à CUT também promoveram uma intensa organização, que rompeu parcialmente com as limitações da legislação corporativa, mas em um sentido diverso ao do Sinergia. Ao invés de buscar a unificação, procurou-se reconhecer as especificidades e as diferenças forjadas no processo de produção de trabalhadores ligados à pequena propriedade rural baseada na agricultura familiar; e a de trabalhadores assalariados rurais, em situação de emprego, portanto. Os sindicatos oficiais - STRs (Sindicatos de Trabalhadores Rurais) - organizavam indistintamente a todos e, "hoje, estamos transformando os STRs em duas organizações: os sindicatos de agricultores familiares (SINTRAF) e sindicatos de empregados rurais (SER). Ambos funcionando dentro da mesma estrutura, com a proposta da CUT de estrutura solidária”. (PEREIRA, 2002:99)

Para Hélio Neves, então presidente da Federação dos Empregados Rurais Assalariados do Estado de São Paulo (FERAESP), aponta na organização sindical rural um forte enfrentamento à estrutura corporativa:

"Se nós tínhamos o diagnóstico das mudanças nas relações de trabalho, por outro lado a organização dos trabalhadores estava presa a um sistema de organização no qual o recorte ruralista predominava. Tínhamos os Sindicatos de Trabalhadores Rurais e ainda temos a Federação de Trabalhadores da Agricultura e a própria CONTAG (Confederação Nacional dos Trabalhadores na Agricultura), que vêem o trabalhador rural, especificamente, como um homem do campo. Não que ele não seja. Efetivamente o é. Ocorre, porém, que os complexos econômicos predominam no campo e no setor rural propriamente dito. Um seminário realizado em 1987, antes da fundação da FERAESP, promoveu uma discussão importante. O pessoal debatia a necessidade de criar o Sindicato dos trabalhadores do Conjunto Agroindustrial, porque havia um sindicato isolado de trabalhador rural, um sindicato isolado de trabalhadores da indústria, um sindicato isolado na área 
de transportes, outro isolado na área química, enfim, todas essas categorias trabalhando isoladas, enquanto se encontram integradas no mesmo complexo agroindustrial, com vínculo com o comércio (no caso das grandes redes de supermercado), e até com o setor financeiro (os banqueiros são os grandes acionistas da agroindústria); estas categorias separadas estão fadadas ao fracasso, porque o patrão negocia com todas elas isoladamente, fecha acordo do jeito que bem entende, e nós estamos fracionados pela estrutura sindical corporativista. Como rural, historicamente, somos uma categoria fraca e difícil de organizar. Imaginamos, na fundação da FERAESP, criar uma forte organização sindical de assalariados rurais, consolida-la e iniciar um processo de unidade com os demais trabalhadores da cadeia produtiva de alimentos. Exatamente por isso, a FERAESP está se integrando à CONTAC, Confederação Nacional da Alimentação da CUT”. (NEVES, 2002:106)

Os ramos químico e metalúrgico da CUT também promoveram inovações interessantes na organização por local de trabalho.

Os químicos deram início em 1997 a uma experiência então inédita de fundir em uma só organização de base a Comissão Interna de Prevenção de Acidentes (CIPA), prevista pela Norma Regulamentadora $n^{\circ} 5$ (NR-5) do Ministério do Trabalho, com a comissão de fábrica, não prevista em qualquer lei ou norma. A nova organização, denominada Sistema Único de Representação (SUR), foi formada em uma grande empresa de São Bernardo do Campo (a maior existente na base do sindicato) e alterou profundamente a relação desta com os trabalhadores.

Segundo Wanderley Salatiel, diretor do Sindicato dos Químicos do ABC, "a empresa tinha uma política muito excludente sobre o processo de participação dos trabalhadores; agora é diferente: com o SUR na fábrica, toda discussão é feita pelos trabalhadores e todos os problemas que acontecem na fábrica são debatidos com os trabalhadores... Antigamente você não tinha esse canal aberto. Pela dificuldade da organização no local de trabalho, muitas vezes a diretoria do sindicato ficava sem esse elo de ligação com as fábricas. E aí, muitas ações eram definidas de cima pra baixo e os trabalhadores eram apenas agentes passivos nesse processo, sem estímulo para participar do processo decisório. Hoje, não; a lógica se inverteu. Os problemas, as ações, emergem de baixo para cima. Todo debate se inicia na fábrica, depois levamos para os fóruns maiores do sindicato". (SALATIEL, 2002:56) O SUR é totalmente autônomo em relação ao sindicato, embora preserve uma relação política e ações organizativas em consonância com o sindicato. 
Em relação a avanços na experiência organizativa que vá além da cultura corporativa, a contribuição dos metalúrgicos do $\mathrm{ABC}$, que dispensa maiores comentários pelo que simbolicamente representaram no processo de fundação da CUT, foi a implementação de mudanças significativas em seu processo eleitoral e na forma de composição da diretoria, tendo em vista enraizar o sindicato no chão de fábrica. A partir de 1999, o processo eleitoral no Sindicato passou a ser realizado em dois turnos: no primeiro, são eleitos, em cada empresa, os membros do Comitê Sindical de Empresa (CSE). A condição sine qua non para concorrer ao CSE é o(a) candidato(a) pertencer ao quadro de funcionários da empresa. Todos os membros eleitos para o CSE compõem a direção do Sindicato dos Metalúrgicos, ou seja, para ser eleito diretor(a) do sindicato, a pessoa tem que pertencer a uma base. Colocado dessa forma, parece não ser tão extraordinário, mas com essa medida o sindicato impede que pessoas sem a representatividade de seu local de trabalho, sem a legitimidade perante os demais trabalhadores associados ao sindicato na empresa em que trabalha, possa falar em nome dos trabalhadores por ser diretor(a) do sindicato.

Outro fator positivo dos CSEs é a ampliação da representação sindical que deixou de ter um número específico de diretores e passou a ter um número "flutuante", de acordo com o grau de organização do sindicato pelas empresas. Quanto maior a organização na base, maior o número de CSEs / direção do sindicato, contrariando súmula do Tribunal Superior do Trabalho (TST), que prevê o reconhecimento da estabilidade legal apenas de sete membros da direção executiva. Entre os metalúrgicos do $\mathrm{ABC}$, a direção do sindicato alcançou na ocasião da entrevista concedida por Francisco Duarte de Lima (Alemão), diretor do Sindicato, a formação de 68 Comitês com 110 membros ao todo. Por estarem fora do parâmetro do TST, os CSEs não tem reconhecimento legal, o que significa que seus membros não gozam necessariamente de estabilidade no emprego, como prevê a CLT. (LIMA, 2002:65)

O setor público, em geral, é o que mais tem contribuído para encontrar alternativas à estrutura corporativa. A organização dos servidores públicos remonta às associações présindicais originada ainda na década de 1930 com caráter assistencial, pois a CLT não previa a existência de sindicatos para aqueles trabalhadores. No contexto de emergência do novo sindicalismo, no início dos anos 1980, em que as greves se alastraram por todo o país e pelas mais diversas categorias, os trabalhadores do serviço público começam a adentrar 
pelas associações e impulsionar a ação daquelas no sentido das reivindicações de cunho trabalhista. Assim, antes mesmo de terem sua organização sindical reconhecida oficialmente, os servidores já constituíam seus sindicatos na prática, que só veio a partir da Constituição de 1988. (NOGUEIRA, 1999)

No entanto, segundo o autor, "do ponto de vista organizatório, o sindicalismo no Estado desenvolve-se com mais independência, autonomia e democracia, relativamente ao sindicalismo do setor privado. Após a Constituição de 1988, o direito à livre associação sindical não alterou as características básicas desse movimento. Apenas multiplicou a diversidade e a pluralidade organizatórias entre as associações assistenciais que foram mantidas e os novos sindicatos legalizados. Também não foram instituídas a contribuição sindical obrigatória ${ }^{103}$, a unicidade sindical por lei, a base territorial e nem o poder normativo da Justiça do Trabalho". (NOGUEIRA, 1999:56)

Para Boito Jr. a transformação das associações de servidores públicos em sindicatos reconhecidos oficialmente apenas implicou no seu atrelamento ao Estado, subjugando um movimento livre e legítimo dos trabalhadores à estrutura corporativa, fruto da ideologia legalista de dirigentes e militantes sindicais, que é uma das fontes de sustentação do sindicalismo de Estado. Para o autor, esse movimento realizado pelo sindicalismo do setor público representa a aceitação da tutela do Estado sobre a organização dos trabalhadores, de onde derivaria uma ação sindical acomodada e de colaboração de classes. (BOITO Jr, 1991:54)

A organização do setor público apresenta questões que, a meu ver, extrapola os limites da análise do autor, apontando maior complexidade que o presumido.

No município de São Paulo, por exemplo, existem trinta e um sindicatos e associações que funcionam tal como um sindicato. $\mathrm{O}$ único que busca representar o conjunto dos trabalhadores da Prefeitura é o Sindicato dos Servidores Públicos e das Autarquias no Município de São Paulo - SINDSEP (filiado à CUT), sendo que os demais sindicatos se

\footnotetext{
${ }^{103}$ Atualmente, o Ministério do Trabalho e Emprego (MTE) procura estender a contribuição sindical ao setor público através da Instrução Normativa $n^{\circ} 1$, lançada em 30/09/2008 pelo MTE, e da Nota Técnica $n^{\circ} 36$, da Secretaria de Relações do Trabalho do MTE, de 12/03/2009, que prevê o recolhimento do imposto sindical dos servidores públicos em favor dos respectivos sindicatos, tal como na legislação do setor privado. Essa iniciativa foi interposta por Decreto Legislativo da Câmara dos Deputados (PDC 862/08), de autoria do deputado Raul Jungmann (PPS-PE), que susta a Instrução Normativa $n^{\circ} 1$ por violação ao princípio da legalidade tributária. (http://www.diap.org.br/images/stories/files/2699.pdf)
} 
organizam por categoria profissional, quando não por função ${ }^{104}$. No entanto, na prática, rompeu-se a unicidade sindical, pois os servidores públicos da capital paulista têm amplo leque de escolha a qual sindicato pertencer, sendo bastante comum a prática de sindicalização de trabalhadores em entidades diferentes de sua categoria profissional; por exemplo, um funcionário em cargo de agente de apoio da administração estar filiado em sindicato de professores.

A concorrência entre os sindicatos pela filiação de trabalhadores da prefeitura de São Paulo não impediu a unidade em torno de algumas ações, como na ocasião das negociações coletivas na mesa central do Sistema de Negociação Permanente - SINP - durante a gestão da prefeita Marta Suplicy (2001-2004) ${ }^{105}$. Na época, sentavam-se à mesa de negociação com a Administração apenas nove sindicatos - SINDSEP, APROFEM, SINPEEM, SAVIN, Sindsaúde, Sindicatos dos Farmacêuticos, Sindicatos dos Psicólogos, Sindicatos dos Enfermeiros, e a Associação das Atendentes de Enfermagem - que, por iniciativa própria, organizaram o Fórum de Entidades, composto pelas 31 entidades sindicais, a fim de discutir o processo de negociação em curso.

Os sindicatos do setor público em São Paulo, ligados à CUT, como o Sindicato dos Professores do Ensino Oficial do Estado de São Paulo (APEOESP) e o Sindicato dos Funcionários e Servidores da Educação do Estado de São Paulo (AFUSE), o Sindicato dos Servidores Públicos e das Autarquias no Município de São Paulo (SINDSEP) e o Sindicato dos Trabalhadores Públicos da Saúde no Estado de São Paulo (Sindsaúde) alimentaram experiências interessantes de organização sindical nos locais de trabalho, muito pouco

\footnotetext{
${ }^{104}$ Além do SINDSEP, o único que é geral, existe um conjunto de sindicatos da área da educação como o Sindicato dos Profissionais em Educação no Ensino Municipal de São Paulo (SINPEEM); Sindicato dos Professores e Funcionários Municipais de São Paulo (APROFEM); Sindicato dos Especialistas de Educação do Ensino Público do Município de São Paulo (SINESP); e o Sindicato dos Trabalhadores em Estabelecimentos de Educação Infantil do Município de São Paulo (SEDIN). Da mesma forma, há inúmeros sindicatos da área da saúde, vários deles de abrangência territorial estadual que também atuam no serviço público municipal de São Paulo, como o Sindicato dos Médicos (SIMESP), Sindicato de Enfermeiros, Sindicato dos Psicológicos, Sindicato dos Farmacêuticos, Sindicato dos Técnicos de Raio-x, Associação das Atendentes de Enfermagem. Tem ainda um conjunto grande de sindicatos de categoria ou por função dentro da prefeitura, como o Sindicato dos Agentes Vistores e Agentes de Apoio Fiscal de São Paulo (SAVIN), o da guarda civil metropolitana, o de motoristas, o de servidores de nível operacional, o de técnicos de contabilidade etc. De todos estes, são filiados à CUT o SINDSEP, o SINPEEM, o SIMESP, o Sindicato dos Enfermeiros e o de Psicólogos. O Sindsaúde (CUT), que representa os servidores estaduais da saúde, passou a ter um nicho de sua base entre os municipais após a municipalização de Unidades Básicas de Saúde (UBS) estaduais e a manutenção de funcionários estaduais nas UBSs transferidas à prefeitura.

${ }^{105}$ Após a gestão da prefeita Marta Suplicy o SINP foi perdendo importância na gestão de José Serra e, atualmente, na gestão de Gilberto Kassab, está praticamente desativado.
} 
conhecidas pelos estudos de caráter acadêmico, que valorizam mais as experiências do ramo industrial.

Carlos Ramiro de Castro (Carlão) explica a organização da APEOESP. Começa na escola com os Representantes de Escolas (REs), eleitos pelos professores no início de cada ano para atuar em cada período (manhã, tarde e noite): “...os REs são a ligação da escola com o sindicato. Por intermédio deles, as propostas tiradas são levadas para a reunião de Representantes de Escola (REs) da região, da abrangência de cada uma das nossas 93 subsedes no Estado. Dentro das subsedes, todas as propostas são discutidas por esse Conselho de Representantes, votadas, e as propostas aprovadas pela maioria são levadas ao Conselhos Estadual de Representantes. Quem participa do conselho representante são os Conselheiros Estaduais da entidade, contanto que tenham participado da reunião de representantes nas subsedes. Esses conselheiros são responsáveis por levar as indicações e propostas discutidas nas subsedes ao Conselho Estadual. Ali se discutem todas as propostas e se aprovam aquelas que a maioria do conselho decide e, conseqüentemente, serão encaminhadas pela direção. Essas propostas são, depois, homologadas e votadas novamente na assembléia geral”. (CASTRO, 2002:86)

Essa organização permite uma tremenda capilaridade, como se pode concluir dos dados apresentados por Carlão: "Temos 93 subsedes no Estado de São Paulo; nosso conselho estadual é formado por 568 conselheiros estaduais, eleitos nas subsedes, proporcionalmente ao número de associados. Temos 1284 conselheiros regionais que participam da executiva de nossas subsedes e, conseqüentemente, fazem um trabalho visitando escolas, ajudando no trabalho de representantes das escolas... temos cerca de sete mil representantes de escolas - todos cadastrados, e algumas escolas que não tem cadastro; então, informalmente, deve haver uns 10 mil representantes - praticamente temos representantes em todas as escolas, que chegam a 6.800 escolas no estado de São Paulo". (CASTRO, 2002:88)

Essa organização da APEOESP é bastante semelhante a do Sindsaúde, AFUSE e Sindicato dos Municipais de São Paulo: começa a estruturar-se nos locais de trabalho através das comissões sindicais de base (Sindsaúde), dos Representantes Sindicais de Unidade (RSUs) no Sindicato dos Municipais de São Paulo (SINDSEP); e os Representantes de Unidade de Trabalho (RUTs), no caso da AFUSE. A organização de base vai ampliando-se para representação em níveis mais amplos até constituir uma instância colegiada com capacidade deliberativa acima da Direção, orientando as ações mais gerais das respectivas 
entidades. Em todas elas observa-se uma capilaridade ampliada do sindicato a partir da organização nos locais de trabalho.

Mas um fenômeno pouco conhecido é que alguns dos sindicatos mais importantes do ramo de serviço público em São Paulo - o Sindicato dos Servidores Públicos e das Autarquias no Município de São Paulo (SINDSEP) e o Sindicato dos Trabalhadores Públicos da Saúde no Estado de São Paulo, o Sindsaúde -, ambos criados logo após a promulgação da Constituição de 88 como fruto de intensa organização e mobilização das associações présindicais, somente conseguiram o registro formal de reconhecimento pelo Ministério do Trabalho apenas muitos anos depois, entre 2005 e 2007 já durante o governo Lula. Ou seja, exerceram intensamente todo tipo de atividade sindical durante mais de quinze anos sem a carta sindical!

Uma outra experiência do sindicalismo-CUT ao longo dos anos noventa é a organização do ramo bancário que, dada a característica de organização empresarial do setor, conquistou o Contrato Coletivo de Trabalho Nacional. Segundo João Vaccari Neto, ex-presidente do Sindicato dos Bancários de São Paulo e ex-tesoureiro da CUT Nacional, "foi uma experiência que começou a ser discutida na categoria em 1983, mas que veio a se efetivar em um único instrumento assinado em 1992. Ou seja, de 83 a 92 nós fizemos um processo de unificação. O processo de unificação da mesa de negociação era o primeiro passo para que todos os sindicatos negociassem juntos e deixassem de negociar separados. Depois, passamos à solução de as reivindicações serem iguais. Em um primeiro momento, passamos a negociar todos juntos, baseados nas reivindicações regionais, respeitando a regionalidade. Em um outro passo, negociamos todos juntos com a pauta nacional, ou seja, a importância das especificidades regionais diminuiu. No passo seguinte, negociamos todos juntos e já com uma formulação de benefícios nacionais, da igualdade nacional em todos os benefícios de Norte a Sul, Leste a Oeste do país, o que veio a se consolidar em 88, do ponto de vista da negociação e dos benefícios e devidamente refletido em um único instrumento em 1992 (...) Ou seja, temos direitos iguais entre os bancos públicos e privados, e também temos assinado um único instrumento". (VACCARI, 2002:77)

A construção desse processo de unificação das pautas de reivindicação, negociação e a assinatura de um único instrumento foram sendo acompanhados de novas formas de organização sindical, gerando uma cultura de organização nacional, indo além dos limites 
do corporativismo que sempre se constituiu sobre a fragmentação e pulverização dos sindicatos, baseados em uma abrangência territorial municipal.

Ao longo do percurso foram aparecendo desafios que colocavam em tela a questão da representatividade e a democratização na relação direção-base. A esse respeito, Vaccari afirma: "Esse tem sido um exercício pleno de democracia. É a assembleia que vai decidir se devemos ou não devemos aceitar um acordo e a somatória das assembleias, das representações dos sindicatos do país todo, é que vai referendar uma posição ou desclassifica-la. Sempre que nós vamos fazer um acordo com os bancários, a representação nacional emite uma posição a respeito do acordo, pela aceitação do acordo ou pela rejeição do acordo. E as assembleias discutem se acatam ou não. Já houve casos da a representação nacional dizer "somos pela aceitação", e os sindicatos dizerem "não, mas nós não queremos aceitar, vocês tratem de falar com os representantes patronais que nós queremos mais". E já houve também casos - a grande maioria dos casos -, em que se aceitam. Tivemos uma ou duas vezes casos de rejeição. Tivemos também decisões sobre temas nacionais: nós nos propusemos a fazer debates e votação dentro dos locais de trabalho sobre se deveríamos ou não aceitar a proposta. Como era extremamente polêmico, decidimos ampliar ao máximo o debate. Aí o que nós fizemos? Um plebiscito, em 2000. Decidimos fazer um plebiscito em todos os locais de trabalho, para decidir se aceitaríamos ou não. E, nesse plebiscito, os bancários decidiram pela aceitação. Foi uma decisão contra a direção. Por unanimidade, a direção se apresentou defendendo contra a proposta, e a base aceitou a proposta". (VACCARI, 2002:81)

Vimos ao longo deste capítulo que a CUT desde suas origens tentou romper com a herança do sindicalismo corporativo, mas não teve êxito nessa tarefa, como atestam inúmeras resoluções de congressos e plenárias nacionais: permaneceu a lógica da acomodação, do burocratismo e do afastamento da base.

Em busca de soluções para o impasse entre promover um sindicalismo classista e combativo, e persistir uma cultura corporativa, a CUT foi forjando alternativas ao longo de sua trajetória, dialogando com as demandas dos trabalhadores, com as diversas lutas sindicais e com as diferentes conjunturas econômicas e políticas vividas no país dentro de um contexto mais amplo de transformação do padrão de acumulação do sistema capitalista, como a crise do taylorismo-fordismo e a ascensão do modelo da acumulação flexível, bem como a crise internacional do paradigma do Estado de Bem-Estar Social (que no Brasil 
nunca chegou a se efetivar de fato, mas que assumiu uma perspectiva promissora após a Constituição de 1988, quando se conquistou novos espaços de participação da sociedade), e a emergência de um Estado dominado pelos ajustes estruturais na lógica do primado do mercado.

Em meio a todos esses fatores, a CUT se consolidou como a mais importante central sindical brasileira e uma das maiores do mundo através de um vigoroso crescimento nos anos 1980 / 1990, impulsionado pela vitória eleitoral de inúmeras oposições sindicais e a criação de novos sindicatos sob inspiração cutista.

Considerando todos esses fatores da dinâmica externa a CUT foi travando em sua dinâmica interna uma mudança em sua orientação ao longo do percurso, passando de um padrão mais conflitivo (CUT-movimento) nos anos 1980 para um padrão mais negociado e propositivo nos anos 1990, que requeria maior peso institucional. Essas mudanças ocorreram em um ambiente tenso de disputa político-ideológica entre os campos de uma esquerda socialista e uma esquerda contratualista.

Ao mesmo tempo em que se debatiam tais questões nos fóruns e instâncias da CUT, o sindicalismo-CUT (sindicatos, federações e confederações) ia experimentando diversas inovações aqui e acolá, enfrentando temas colocados pela estrutura corporativa de modo bem concreto.

Os "casos" aqui identificados procuraram expressar que tais "experimentos" são generalizados, ocorrem no setor público, no setor industrial, setor de serviços e entre os rurais. Da mesma forma, os "casos" em tela realçam diferentes aspectos de superação da estrutura corporativa que constituem os principais desafios para a CUT: a organização no local de trabalho, o enraizamento do sindicato na base e ampliação de sua representatividade, o enfrentamento à unicidade sindical e a fragmentação da organização. Nos concentramos nas experiências de São Paulo unicamente devido à minha trajetória, que nos últimos anos concentrou-se nesse Estado. Mas certamente existem muitas outras regiões em que o sindicalismo-CUT tem sido criativo e inovador para enfrentar as dificuldades concretas de organização ...

De modo que não podemos afirmar pura e simplesmente que o sindicalismo-CUT aderiu ao sindicalismo de Estado deixando de lado a organização e a luta dos trabalhadores. Como 
explicitado na introdução dessa tese, continuidades e rupturas caminham lado a lado no enfrentamento pela superação da estrutura corporativa.

Por outro lado, também é forçoso reconhecer que, embora bastante disseminado em vários sindicatos e ramos pelo país afora, as experiências inovadoras do sindicalismo-CUT ainda estão localizados em relativamente poucos sindicatos, especialmente naqueles, digamos assim, "de ponta". Metaforicamente, se fosse possível traçar uma média matemática da ação cutista, talvez se concluísse que as experiências aqui sucintamente narradas estariam em sindicatos "acima da média" política da CUT, sendo que a imensa maioria estão mergulhados no que Leôncio Martins Rodrigues chamou de rame-rame do cotidiano sindical (RODRIGUES, 1990).

E mesmo uma investigação acerca do cotidiano dos sindicatos aqui referidos talvez permitisse observar algum grau de contradição com a cultura corporativa, com uma certa acomodação aos limites do corporativismo, a despeito das iniciativas positivas aqui relatadas.

Assim chegou o sindicalismo-CUT em 2002, ano em que se jogou na eleição de Lula à presidência da República. A partir de 2003 o sindicalismo-CUT se veria desafiado, mais uma vez, a sair da retórica e acelerar efetivamente o passo no caminho da liberdade e autonomia sindical. Mas a CUT levaria ao FNT não apenas o ímpeto das mudanças, mas também o receio e a vacilação diante do "novo". 


\section{Capítulo 3 - A reforma sindical inconclusa}

\section{Uma terceira etapa na trajetória da CUT?}

Na nossa periodização acerca da trajetória da CUT, assumimos a divisão consagrada em estudos sobre o tema. Existiu a fase denominada "CUT-movimento", nos anos 1980, à qual se seguiu a chamada "CUT-Instituição", ou "CUT-organização", nos anos 1990.

Tratadas em pormenores no capítulo anterior, cada uma coincidiu com determinado momento histórico em que a Central respondia aos desafios conjunturais a partir de um padrão de ação sindical: conflitivo no primeiro momento, negocial no decênio seguinte. Mas sempre acompanhado de proposta organizativa distinta para cada período, coerente com a concepção predominante em cada situação.

O governo Lula encontra-se em andamento há sete anos, tempo insuficiente para afirmação conclusiva acerca de novos caminhos da organização sindical. O tempo talvez se encarregue de contradizer, mas proponho neste trabalho que o governo Lula representa divisor na história da CUT, configurando-se a terceira etapa na trajetória da Central.

Neste capítulo há argumentos sobre o tema, mas ao menos três fatores têm alterado o sindicalismo-CUT, fruto desse novo contexto, com efeitos no padrão da ação sindical da Central: reconhecimento legal das centrais sindicais e estruturas verticais da CUT (ramos); fragmentação da CUT e divisão em três outras centrais (CTB, Conlutas e Intersindical, embora as duas últimas não sejam propriamente central sindical); e o acirramento da disputa com as demais centrais sindicais pela filiação de sindicatos, federações e confederações.

Em termos conceituais, na terceira etapa da trajetória da CUT, estão incorporadas definitivamente ${ }^{106}$ características peculiares de um pluralismo que viria agregar-se aos

\footnotetext{
${ }^{106}$ A relação da CUT com as demais centrais sindicais, em especial a Força Sindical, foi bastante conflituosa em seu início, dada a história distinta que acentuava diferenças político-ideológicas, a ponto de inviabilizar, de parte a parte, qualquer tipo de relação amistosa e colaborativa. Desde meados dos anos 1990, apesar da continuidade das diferenças entre CUT e Força Sindical, passou-se a ter uma convivência mais "civilizada", mesclando disputas de projeto com ações conjuntas, como, por exemplo, o festival de greves nas montadoras, em 1999, em defesa de um contrato coletivo no setor e pela redução da jornada de trabalho para 40 horas, sem redução de salários; como têm sido as Marchas pela Valorização do Salário Mínimo e a coleta de assinaturas na Campanha pela Redução da Jornada de Trabalho sem redução de salário (incluindo outras centrais, além da Força). Mesmo em campanhas salariais de diversas categorias as duas centrais têm ações articuladas. Isso não
} 
elementos ainda vigentes do corporativismo estatal e do neocorporativismo, tornando mais complexo o cenário sindical atual.

\section{Diagnóstico comum entre o MTE e a CUT acerca da atual estrutura sindical corporativa.}

Conforme colocado na introdução desta tese, a CUT surgiu com a bandeira histórica do fim da estrutura sindical corporativa, defendendo a implementação da liberdade e autonomia sindical a partir da ratificação da Convenção 87 da OIT.

A vitória de Lula e a perspectiva de realizar seu projeto histórico entusiasmaram a CUT a participar do FNT convocado pelo presidente.

A resolução do $8^{\circ}$ Congresso Nacional da CUT mostrou a orientação pela qual a Central deveria guiar-se nas discussões:

“... garantir direitos, fortalecer a organização sindical e democratizar as relações de trabalho. A concepção da CUT, desde sua fundação, é de que a superação da estrutura sindical oficial será fruto de um movimento articulado entre as iniciativas para a transformação dos sindicatos, a construção da estrutura da CUT e as alterações no marco institucional legal”. (CUT, 2003a)

A proposta de Sistema Democrático de Relações de Trabalho (SDRT), formulada em 1992, consolidou sistemicamente o acúmulo da CUT sobre organização sindical. Desde a $9^{\mathrm{a}}$ Plenária Nacional, em 1999, a CUT tem proposta global de reforma sindical e trabalhista, que se expressa, inclusive, em formato de projeto de lei e de emenda constitucional, com ênfase na Organização por Local de Trabalho (OLT), negociação coletiva e contrato coletivo de trabalho, e o fim da unicidade e do imposto sindical.

A base fundamental do SDRT é a instituição de um regime de plena liberdade de organização sindical, em sintonia com vários princípios consagrados pelas convenções da Organização Internacional do Trabalho (OIT): Convenção 87 - liberdade sindical e proteção ao direito de sindicalização; Convenção 98 - aplicação dos princípios do direito de sindicalização e da negociação coletiva; Convenção 135 - proteção aos representantes dos trabalhadores nas empresas; Convenção 151 - proteção ao direito de sindicalização e procedimentos para definir as condições de emprego na administração pública; Convenção

significa, ressaltamos, que as diferenças entre CUT e Força Sindical se diluíram totalmente, e que não há mais conflito. Mas a convivência conflitiva e civilizada expressa um novo contexto no cenário sindical após a instauração do governo Lula e do FNT, no qual se debateu a reforma sindical. 
158 - sobre o término da relação de trabalho por iniciativa do empregador. Há ainda as relacionadas à eliminação de diferentes formas de discriminação, como a Convenção 100 igualdade de remuneração entre homens e mulheres; 111 - sobre discriminação em matéria de emprego e profissão; 156 - igualdade de oportunidades e de tratamento para homens e mulheres.

"A CUT buscará garantir na reforma sindical a instituição do SDRT, e na reforma trabalhista, alterações da Consolidação das Leis Trabalhistas (CLT), baseadas na ampliação do atual patamar de conquistas e de direitos já assegurados para os trabalhadores". (CUT, 2003a: 87-88)

O contexto de instalação do FNT para discussão da reforma sindical, no entender da CUT, era amplamente favorável não apenas pela eleição de Lula (recém-empossado e sem o desgaste do escândalo do mensalão), mas também pela composição do Ministério de Trabalho e Emprego, condutor do processo de reforma sindical ${ }^{107}$.

No entanto, mais do que viabilizar um projeto histórico, a participação da CUT na reforma sindical guiou-se por um diagnóstico preciso sobre a situação do movimento sindical brasileiro após a promulgação da Constituição de 1988. O diagnóstico da CUT parte da mesma premissa elaborada pelo ministro Berzoini na exposição de motivos do anteprojeto de lei de Relações Sindicais:

“...o texto constitucional refletiu o estágio das lutas sindicais e a dinâmica das relações de trabalho característicos do período de redemocratização nacional. Contudo, a tentativa de conciliação da liberdade sindical com a unicidade sindical revelou-se contraditória e abriu brechas para a pulverização de entidades sindicais e para o surgimento de "sindicatos de carimbo".

O aumento significativo do número de entidades sindicais nos últimos anos, que já ultrapassam 18 mil, resultou menos do avanço na organização sindical e bem mais da fragmentação de entidades preexistentes, em um processo que está enfraquecendo tanto a representação de trabalhadores como a de empregadores, tendência que a vigência da unicidade não tem sido capaz de impedir. É certo que não são poucas as entidades sindicais que possuem ampla representatividade e capacidade de atuação, mas isso contrasta com a proliferação de sindicatos cada vez menores e menos

\footnotetext{
${ }^{107}$ A Coordenação do FNT teve os seguintes membros, quando de sua instalação: presidente do FNT: Ricardo Berzoini (ministro, deputado federal licenciado pelo PT-SP e ex-dirigente sindical do Sindicato dos Bancários de São Paulo e da CNB-CUT); coordenador geral: Osvaldo Martines Bargas (secretário de Relações do Trabalho do MTE e ex-dirigente sindical do Sindicato dos Metalúrgicos do ABC e da CUT Nacional); coordenador geral adjunto: Marco Antonio de Oliveira (secretário adjunto de Relações do Trabalho do MTE e ex-assessor da CUT Nacional); coordenador técnico: José Francisco Siqueira Neto (advogado e consultor da OIT, ex-assessor da CUT), além de três coordenadores adjuntos do FNT.
} 
representativos, o que só reitera a necessidade de superação do atual sistema, há anos criticado por sua baixa representatividade e reduzida sujeição ao controle social. (...) A prioridade conferida a ela [à reforma sindical] não decorre de motivações estritamente políticas, mas do entendimento de que a redefinição do sistema de relações coletivas de trabalho deve ser o centro dinâmico de qualquer esforço de democratização das relações de trabalho, precedendo, assim, a revisão dos demais institutos que regulam o trabalho no Brasil.

Ao contrário de se inspirar em um modelo doutrinário preconcebido, o presente anteprojeto de lei considerou a realidade atual do sindicalismo brasileiro, a dinâmica das relações coletivas de trabalho e o desejo de mudança dos próprios atores sociais, sem perder de vista a necessidade de incorporar princípios consagrados pelo direito internacional e supranacional”. (FNT, 2005: 13-14)

O motivo da reforma sindical, portanto, não foi apenas questão histórica, resgate de dívida herdada dos tempos do presidente Getúlio Vargas. Mas a necessidade de disciplinar a matéria após a Constituição de 1988, que criou situação tal de hibridismo entre o fim da intervenção governamental e as garantias do "velho" corporativismo que conduziram à pulverização/fragmentação da organização sindical e o consequente enfraquecimento da representatividade sindical no país.

Nos vários debates que se seguiram com dirigentes sindicais cutistas, com o intuito de sensibilizar e mobilizar a base a se engajar ativamente no movimento da reforma sindical, a Secretaria Nacional de Organização da CUT (SNO) preparou uma apresentação. Nela, mencionava casos de pedidos de registro de entidades sindicais no MTE, exemplificando "absurdos" permitidos pela lei. Daí, ser essencial sua alteração: Sindicato dos Proprietários de Veículos Escolares do Estado do Rio Grande do Sul, Sindicato dos Proprietários de Veículos Escolares do Município de Porto Alegre; Sindicato Porto-Alegrense de Proprietários de Veículos de Transporte de Escolares; Sindicato das Empresas de Desmanche de Veículos, Comércio de Peças Recuperadas e Sucatas de Metais Ferrosos e Não Ferrosos em Geral do Estado de São Paulo; Sindicato dos Empregados em Empresas de Desmanche de Veículos, Comércio de Peças Recuperadas e Sucatas de Metais Ferrosos e Não Ferrosos em Geral do Estado de São Paulo; Sindicato dos Empregados em Empresas Coletoras de Lixo, Agências de Viagens, Instituições Beneficentes Religiosas e Filantrópicas, Condomínios, Recursos Humanos e Prestadoras de Serviços Ltda de Manaus 
e do Estado do Amazonas; Sindicato Nacional dos Revendedores de Discos Novos e Usados; e Sindicato Nacional da Cerveja.

O pedido de registro dessas e outras entidades não tinha, segundo o argumento da SNOCUT, o intuito de fortalecer a organização e luta dos trabalhadores representados, mas somente visava aos benefícios da arrecadação compulsória das taxas e contribuições sindicais em favor da entidade, dirigida em geral como uma máfia.

No sentido contrário, entidades sindicais representativas e atuantes como instrumento de organização sindical não gozavam dos direitos legais conferidos pela lei, sendo as centrais sindicais exemplo mais evidente dessa distorção.

Para o MTE e CUT, a reforma sindical desfaria a situação criada pela Constituição de 1988, a fim de garantir dois pontos fundamentais na legislação sindical: maior representatividade das entidades sindicais e fortalecimento do diálogo social pelo mecanismo de incentivo à negociação coletiva. Dos dois pontos derivariam outras questões: organização nos locais de trabalho, regulamentação da lei de greve, coibição de práticas antissindicais, autocomposição de conflitos (fim do poder normativo da Justiça do Trabalho), ratificação das Convenções 151 e 158 da OIT, etc.

\section{A instauração do FNT e o debate sobre a reforma sindical nas conferências estaduais}

A reforma sindical é parte de projeto mais amplo de reforma da regulação do mercado de trabalho no Brasil, que inclui reforma na legislação trabalhista, uma das promessas de campanha do candidato Lula em 2002.

No entanto, afirma Carlos Henrique Horn, "para levar adiante a reforma trabalhista, o governo federal decidiu por um procedimento específico e diferente daquele observado nas duas polêmicas reformas submetidas ao Congresso Nacional em 2003. Em lugar de propor ativa e explicitamente um projeto de novas normas para o exame do legislativo, como fizera com as reformas previdenciária e tributária, o governo optou por envolver os agentes sociais diretamente vinculados ao tema num processo de consulta em que esperava atingir um consenso com vista à formulação do projeto da reforma. Nascia, em consequência dessa opção, o Fórum Nacional do Trabalho (FNT), com natureza tripartite e sob a coordenação do Ministério do Trabalho e Emprego (MTE)". (HORN, 2005:2)

Segundo Horn, “...a primeira foi a decisão por segmentar (em linguagem governamental, "fatiar") o debate sobre a mudança no marco regulatório do mercado de trabalho em duas reformas - a 
reforma sindical e a reforma trabalhista -, assegurando-se precedência à reforma sindical no envio de projeto ao Congresso. A segunda consequência foi o adiamento da pretensão anteriormente anunciada de dar início à fase legislativa da reforma ainda em 2003”. ${ }^{108}$ (HORN, 2005: 3)

O FNT foi lançado pelo governo federal em 29/7/2003, ao amparo do Decreto $n^{\circ} 4.764$, de 24/6/2003. O regimento interno do FNT foi aprovado na Portaria MTE $n^{\circ} 1.029$, de 12/8/2003. (HORN, 2005: 4-5)

\footnotetext{
${ }^{108}$ A decisão por segmentar as reformas, dando precedência à reforma sindical, parece ter partido do próprio governo e é contemporânea à instalação do FNT (Bittar, Delgado, 2003, p. A6; Brandão, 2003, p. A6). O adiamento do envio dos projetos ao Congresso Nacional impôs-se apesar do declarado otimismo governamental em concluir a reforma em prazo curto. Conforme o secretário de Relações de Trabalho do MTE, Osvaldo Martines Bargas, "a previsão [era] que o projeto da reforma trabalhista [estivesse] aprovado pelo Congresso Nacional até julho de 2004” (Pacheco, 2003, p. 28). Ver, também, Alves (2003), Brandão (2004), Correia (2003) e Gazeta Mercantil (2003, 2004). As razões do adiamento prendem-se às dificuldades de se chegar ao esperado consenso. Não é por menos que o então presidente do Tribunal Superior do Trabalho, Francisco Fausto, declarou que "a reforma trabalhista e sindical será 'uma guerra'... considera 'difícil' a votação da proposta, em fase de elaboração pelo governo, ainda este ano e em 2004, um ano eleitoral” (TRINDADE, 2003, p. A8). NOTA DO AUTOR
} 
Fórum Nacional do Trabalho

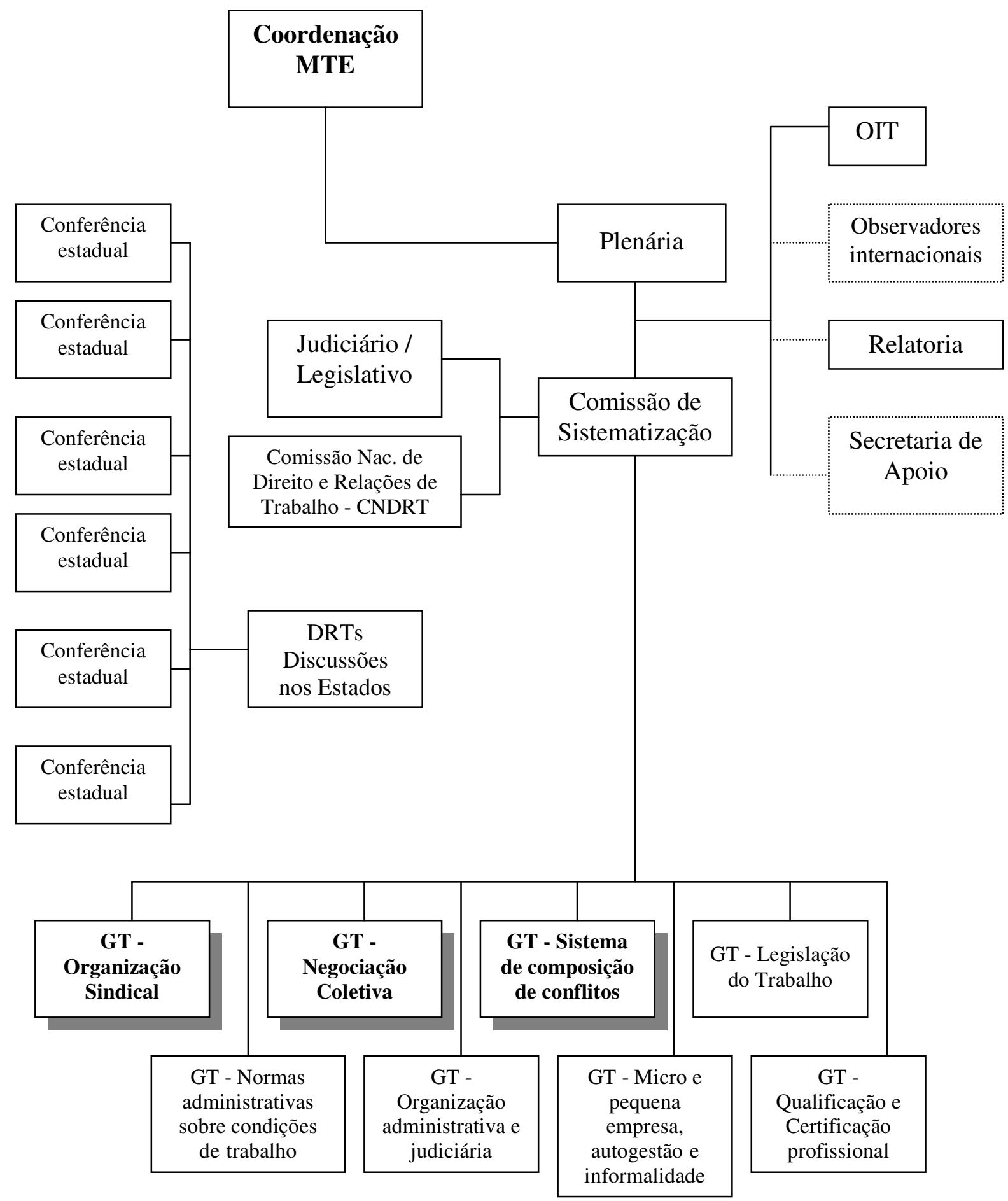

Extraído de FNT, 2003: 12-13. 
A estrutura do FNT previu alguns órgãos, como a coordenação composta exclusivamente por sete representantes do governo; plenária de representantes; comissão de sistematização e oito grupos temáticos (GTs) para abordar: a) Organização Sindical; b) Negociação Coletiva; c) Sistema de Composição de Conflitos; d) Legislação do Trabalho; e) Organização Administrativa e Judiciária do Trabalho; f) Normas Administrativas sobre Condições de Trabalho; g) Qualificação e Certificação Profissional; e h) Micro e Pequenas Empresas, Autogestão e Informalidade.

A reforma sindical, propriamente dita, foi debatida nos Grupos Temáticos de Organização Sindical, Negociação Coletiva e Sistema de Composição de Conflitos.

A plenária de representantes foi composta por 72 pessoas indicadas por entidades de âmbito nacional de trabalhadores e de empregadores com notória representatividade, além do governo. As 72 cadeiras foram distribuídas de modo paritário, 21 membros em cada bancada, além de nove membros indicados pelo Grupo de Trabalho sobre Micro e Pequenas Empresas, Autogestão e Informalidade, criado no âmbito do Conselho de Desenvolvimento Econômico e Social (CDES), representando diferentes formas de empreendedorismo responsáveis por novas modalidades de relações de trabalho. (FNT, 2003)

A Comissão de Sistematização foi composta por 21 membros, distribuídos por seis representantes dos trabalhadores, seis representantes dos empregadores, seis membros indicados pelo MTE e três membros indicados pelo Grupo de Trabalho sobre Micro e Pequenas Empresas, Autogestão e Informalidade, criado no âmbito do CDES, representando diferentes formas de empreendedorismo responsáveis por novas modalidades de relações de trabalho.

Por fim, cada Grupo Temático foi composto por 18 membros: seis vagas para representantes dos trabalhadores, seis para representantes dos empregadores e seis para membros indicados pelo MTE.

O regimento interno do FNT previa a solução por consenso ou a explícita e incontornável divergência declarada pela(s) parte(s) interessada(s). Na hipótese de impasse entre os integrantes do FNT sobre qualquer um dos temas em questão, prevaleceriam nos projetos as posições do governo federal.

O início dos trabalhos ocorreu em agosto de 2003, indo até março de 2004, produzindo um relatório que serviu de base à elaboração da Proposta de Emenda Constitucional no 369, de 
2 de março de 2005 (PEC 369/05), e do Anteprojeto de Lei de Relações Sindicais (ALRS), com 238 artigos, encaminhada na mesma data da PEC.

Ao longo do processo, mobilizou-se enorme contingente de dirigentes de entidades sindicais de trabalhadores e de empregadores, juristas, operadores do Direito, membros de associações da área trabalhista, reunidos na Comissão Nacional de Direito e Relações do Trabalho. Bem como autoridades de outras esferas do poder público, como Tribunal Superior do Trabalho - TST, Ministério Público do Trabalho - MPT, Câmara dos Deputados e Senado Federal. (FNT, 2005: 11)

"Mais de 500 pessoas participaram de 44 reuniões oficiais em Brasília e de diversos encontros preparatórios. Durante esse período, foram realizadas Conferências Estaduais do Trabalho em todas as unidades da Federação. Elas contaram com a participação de mais de 20 mil pessoas ligadas à área sindical e trabalhista, em ciclos de debates, oficinas, seminários e plenárias. Coordenadas pelas Delegacias Regionais do Trabalho, as Conferências colheram subsídios para a Comissão de Sistematização do Fórum. (...) Além disso, a coordenação do Fórum recebeu e examinou diversas contribuições, de caráter individual e institucional, e o governo empenhou-se em dialogar com os setores que reivindicavam maior participação no debate, como as confederações de trabalhadores, com as quais chegou a realizar cinco encontros oficiais". (FNT, 2005: 10-11)

Carlos Henrique Horn analisa detalhadamente os resultados das Conferências Estaduais do Trabalho realizadas em todas as unidades da Federação no segundo semestre de 2003 período inicial do debate no FNT -, antecipando as dificuldades de consenso que ocorreriam nas instâncias do Fórum em torno da alteração do sistema sindical corporativo. As CETs, cabe salientar, obedeceram à mesma lógica tripartite de representação, e se debruçaram em debater as questões discutidas nas mesas do FNT, em Brasília: 
Quadro 1: Roteiro de questões para as Conferências Estaduais do Trabalho (CET)

\section{ORGANIZAÇÃO SINDICAL}

1. As Convenções $\mathrm{n}^{\circ} 87$ e 151 da OIT devem ser ratificadas pelo Brasil?

2. As referências à Liberdade Sindical que figuram nas Convenções n 98, 135 e 154 devem ser incorporadas ao ordenamento jurídico nacional?

3. O artigo $8^{\circ}$ da Constituição Federal deve ser mantido na íntegra ou ser alterado?

4. Na hipótese de alteração do artigo $8^{\circ}$ da Constituição Federal, quais seriam os novos dispositivos?

5. Em caso de reforma constitucional, seria necessária uma legislação sobre Organização Sindical?

6. Na hipótese de uma legislação sobre Organização Sindical, quais seriam os capítulos desejáveis? Qual o tratamento normativo mais adequado para os critérios de representação e representatividade sindical?

7. Qual o tratamento normativo mais adequado para a representação coletiva nos locais de trabalho?

8. Qual o tratamento normativo mais adequado para a sustentação financeira das organizações sindicais?

9. Qual o tratamento normativo mais adequado para as regras de transição para o novo modelo de organização sindical?

\section{NEGOCIAÇÃO COLETIVA}

10. A negociação coletiva deve sofrer restrições ou ser estimulada em diferentes níveis (empresa, profissão, setor econômico e intersetores) e âmbitos (local, regional, interestadual e nacional)?

11. Na hipótese de estímulo à negociação coletiva em diferentes níveis, qual deve ser o grau de articulação entre diferentes níveis e âmbitos de negociação coletiva?

12. A estrutura da negociação coletiva deve receber que tratamento quanto aos períodos e tipos de negociação?

13. A estrutura da negociação coletiva deve receber que tratamento quanto ao objeto das negociações?

14. A estrutura da negociação coletiva deve receber que tratamento quanto aos tipos de 
instrumentos normativos?

15. A estrutura da negociação coletiva deve receber que tratamento quanto à vigência dos instrumentos normativos?

16. As negociações coletivas devem ser acompanhadas pelo Ministério do Trabalho e Emprego?

17. Deve haver a possibilidade de extensão administrativa dos efeitos da negociação coletiva?

18. Alguns princípios da negociação coletiva devem constar em legislação específica? Quais?

19. Quais devem ser os limites da negociação coletiva?

20. Qual a relação que a negociação coletiva deve manter com o ordenamento jurídico nacional?

\section{COMPOSIÇÃO DE CONFLITOS}

21. O poder normativo da Justiça do Trabalho deve ser mantido, extinto ou revisto?

22. Em caso de revisão do poder normativo da Justiça do Trabalho, quais os aspectos que deveriam ser revistos?

23. Quais devem ser os meios voluntários e compulsórios de composição dos conflitos coletivos?

24. Em que situação cada um dos meios de composição dos conflitos coletivos deve ser aplicado?

25. Os meios de solução de conflitos coletivos devem ser públicos e/ou privados?

26. Quais situações e condicionantes deveriam se aplicar aos meios privados?

27. Quais devem ser os meios de solução de conflitos individuais de trabalho?

Fonte: Fórum Nacional do Trabalho (2003c). Horn, 2005: 9.

Segundo Horn, a metodologia das CETs definiu que "as questões desse roteiro e outras que surgiram nos debates foram submetidas ao escrutínio das bancadas participantes das CETs na forma de proposições para uma reforma (ou para uma não reforma). Em conformidade com o resultado dos debates, cada proposição específica foi registrada no relatório final em uma de três possíveis 
condições: consenso, recomendação ou sugestão. Se uma determinada proposição específica recebesse a aprovação das três bancadas principais - empregadores, trabalhadores e governo -, seria considerada consenso. Se duas das três bancadas favorecessem a proposição, seria denominada recomendação. Por fim, se apenas uma das bancadas concordasse com a proposição, seria chamada de sugestão". (HORN, 2005: 10)

O autor procedeu à análise das 283 proposições identificadas nos relatórios de $24 \mathrm{CETs}^{109}$, segundo três critérios de classificação: por Estados, grupos temáticos (Grupo 1 - da Organização Sindical; Grupo 2 - da Negociação Coletiva; e Grupo 3 - da Composição de Conflitos), e por pontos polêmicos da reforma sindical (unicidade e pluralidade, liberdade sindical, estrutura do sistema sindical, centrais sindicais, financiamento do sistema sindical, organização dos empregados no local de trabalho, garantia de estabilidade aos dirigentes sindicais, "legislado" versus "negociado", poder normativo da Justiça do Trabalho, vigência dos instrumentos normativos e a questão da ultratividade, e substituição processual). Em cada um desses critérios, Horn observou quantas proposições haviam sido indicadas como consenso, recomendação ou sugestão.

Como síntese da análise dos resultados das Conferências nos Estados, Horn ressalta que "dois são os principais resultados evidenciados nos relatórios das CET: (a) sob qualquer ângulo em que se aborde a questão da formação de um consenso para a mudança, a conclusão é de que esse objetivo da Coordenação do FNT não foi atingido através dos debates descentralizados nas Conferências Estaduais. A taxa geral de consenso foi de apenas 27,3\% das proposições específicas. Assim, o modelo proposto no relatório final do FNT é, em verdade, a consequência de um trabalho persistente na esfera dos Grupos Temáticos, da Comissão de Sistematização e da Plenária de Representantes, mas não a expressão de uma convergência de opiniões nas CETs; (b) o conteúdo normativo de parte ponderável das proposições singulares registradas nas CETs aponta para uma divisão dos atores em dois consensos opostos. De um lado, um consenso reformista formou-se em torno às linhas gerais das críticas esboçadas pela Coordenação do FNT ao sistema vigente. De outro, os partidários da continuidade agruparam-se em favor das teses caras aos que defendem a manutenção de aspectos essenciais do sistema, como, por exemplo, a unicidade e o financiamento sindical compulsório e não vinculado a critérios de representatividade ou de realização de negociação coletiva”. (HORN, 2005: 27)

109 "Excluíram-se apenas as Conferências Estaduais do Trabalho de Minas Gerais e do Amazonas, cujos relatórios não foram disponibilizados no sítio do FNT na Internet. O relatório do Estado do Rio Grande do Sul, que também não aparece no sítio do FNT, foi obtido diretamente durante a realização da Conferência desse Estado" (HORN, 2005, 11 - NOTA DO AUTOR). 
Portanto, ao caracterizar os projetos em confronto nas Conferências, a principal conclusão de Horn é que as Conferências Estaduais serviram de palco para a disputa entre partidários da reforma e partidários da continuidade do sistema sindical em vigor. Para ele, "assistiremos [na etapa congressual da reforma sindical] a um renovado confronto entre os partidários da mudança expressa no projeto de reforma sindical e os da continuidade do velho corporativismo estatal alterado. O risco, para o qual todos os defensores da democratização do sistema devem estar atentos, é o surgimento, na deliberação congressual, de um novo Frankenstein tupiniquim". (HORN, 2005: 30)

\section{Opinião dos delegados ao $8^{\circ}$ CONCUT sobre temas da reforma sindical}

O $8^{\circ}$ Congresso Nacional da CUT realizou-se quando haviam se passado apenas seis meses da posse do presidente Lula para o primeiro mandato, em junho de 2003.

Era enorme a expectativa em torno de seu governo, sobretudo em relação às possibilidades de uma reforma sindical que ratificasse a Convenção 87 da OIT e inaugurasse a liberdade e a autonomia sindical no Brasil.

Parecia se estar diante de momento de redefinição da estrutura sindical no Brasil, e de grande impacto sobre o movimento sindical. Muitos acreditavam viver período de inflexão tão importante para o sindicalismo brasileiro, e para a CUT em particular, como haviam sido os anos 1930/40, quando se estruturou a atual legislação sindical corporativa.

Por esse motivo, uma pesquisa de opinião entre os delegados ao $8^{\circ}$ CONCUT tinha como um dos objetivos captar a percepção dos dirigentes sobre aquele momento e observar em qual direção as transformações deveriam seguir.

De início, o gráfico abaixo mostra que a maior parte dos delegados ao $8^{\circ}$ CONCUT almejava (ou admitia) mudanças parciais na CLT. 


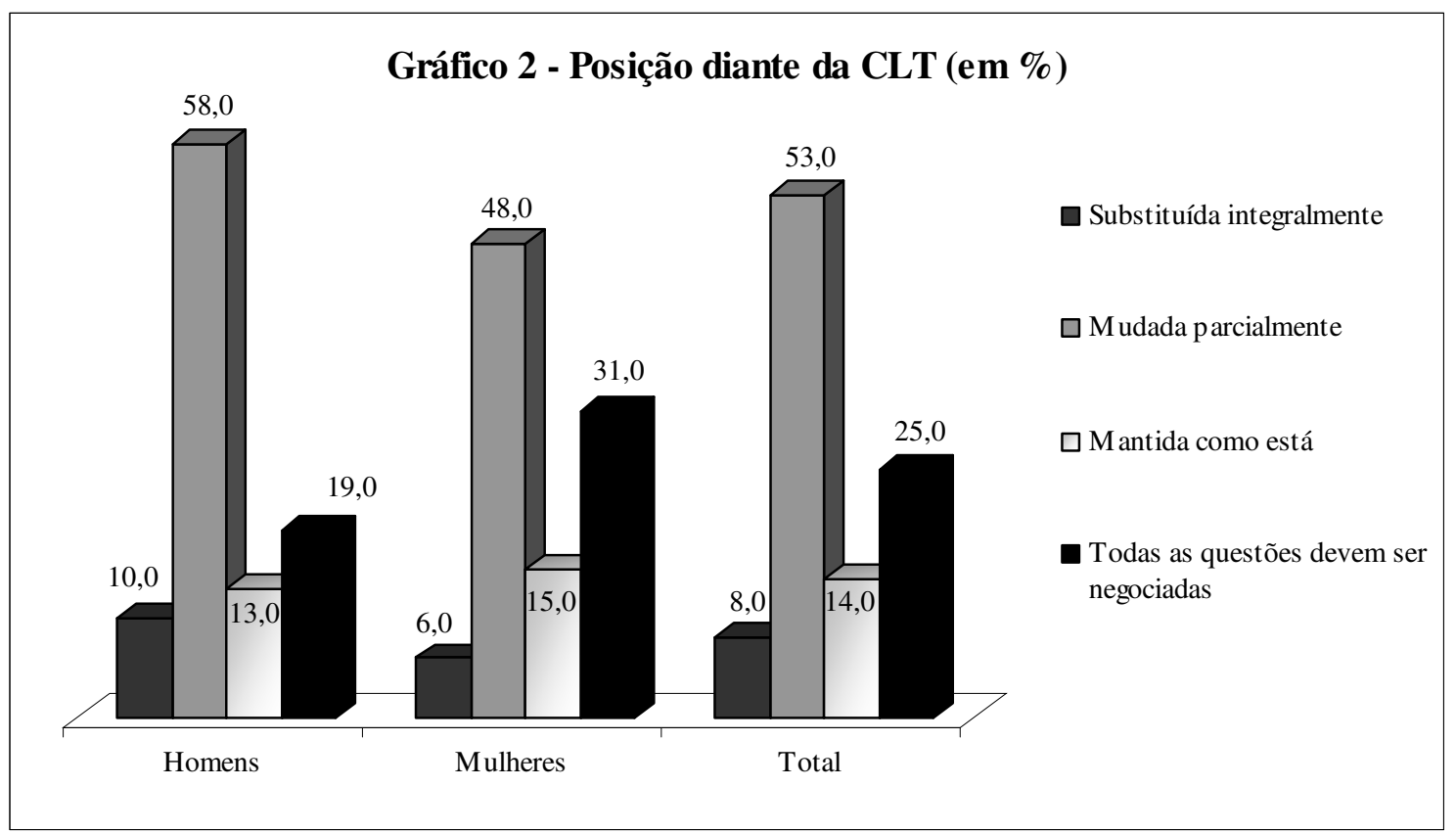

Fonte: Pesquisa 8o. CONCUT 2003, Escola Sindical SP/CUT e Cesit/Ie/Unicamp.

As tabelas 1 e 2 refletem a opinião dos delegados sobre duas questões: prioridades a serem asseguradas na reforma sindical e sobre a unicidade sindical.

\begin{tabular}{|c|c|c|c|}
\hline & Total & Homens & Mulheres \\
\hline Convenção 87 da OIT & 54,3 & 56,5 & 49,2 \\
\hline $\begin{array}{l}\text { Legislação de sustento para a atividade sindical e a } \\
\text { negociação coletiva }\end{array}$ & 53,3 & 51,6 & 57,1 \\
\hline Garantia legal da organização por local de trabalho & 31,2 & 31,6 & 30,1 \\
\hline Fim do imposto sindical & 26,6 & 27,6 & 24,5 \\
\hline
\end{tabular}

Fonte: Pesquisa $8^{\circ}$ CONCUT, Escola Sindical SP/CUT e Cesit/IE/Unicamp.

Tabela 2 - Deve existir mais de um Sindicato por categoria?

\begin{tabular}{lrrr}
\hline & A Favor & Contra & $\begin{array}{c}\text { Não tem } \\
\text { opinião } \\
\text { formada }\end{array}$ \\
\hline homens & 31,2 & 61,5 & 7,2 \\
mulheres & 22,4 & 68,8 & 8,8 \\
Total & 28,5 & 63,8 & 7,7 \\
\hline Fonte: Pesquisa 8o. Concut 2003, Escola Sindical SP/CUT e Cesit/le/Unicamp.
\end{tabular}


Na primeira tabela, se assinalava que a reforma sindical deveria ter mais garantias organizativas: liberdade sindical, negociação coletiva e organização nos locais de trabalho. O fim do imposto sindical ocupava apenas a quarta prioridade, bem abaixo das primeiras $(26,6 \%)$, indicando que não era quesito central da reforma sindical, opinião reiterada pelos delegados ao $9^{\circ}$ CONCUT, como se verá a seguir.

A Convenção 87 da OIT, assinalada pelos delegados ao $8^{\circ}$ CONCUT como item essencial da reforma sindical, não era compreendida, contraditoriamente, como direito à plena liberdade sindical. A opinião da maioria dos delegados (63,8\%) contrários à existência de mais de um sindicato na categoria, pode denotar, na prática, posição favorável à unicidade sindical.

Como mostra a tabela 3, a maior parte dos delegados indicou critérios para aferir representatividade caso aprovada a plena liberdade de organização sindical: plebiscito entre os trabalhadores e índice de sindicalização.

\begin{tabular}{|l|l|c|c|}
\hline \multicolumn{4}{|c|}{$\begin{array}{c}\text { Tabela } 3 \text { - Quem deve negociar pelos trabalhadores, caso seja aprovado mais de um } \\
\text { sindicato por categoria? (\%) }\end{array}$} \\
\hline & homens & mulheres & Total \\
\hline Sindicato indicado por meio de plebiscito de base & 26,4 & 20,0 & 24,5 \\
\hline Sindicato com maior número de associados & 24,2 & 24,2 & 24,2 \\
\hline Não tem opinião formada & 17,5 & 21,0 & 18,5 \\
\hline Comissão única proporcional aos vários sindicatos & 17,0 & 21,0 & 18,2 \\
\hline Cada entidade negocia apenas pelos associados & 13,0 & 12,2 & 12,8 \\
\hline Sindicato que ganha representação pela justiça & 2,0 & 1,5 & 1,8 \\
\hline
\end{tabular}

Fonte: Pesquisa $8^{\circ}$ CONCUT 2003, Escola Sindical SP/CUT e Cesit/Ie/Unicamp

Tabela 4 - Com a liberdade sindical, os contratos coletivos devem valer:

\begin{tabular}{lrrr}
\hline & homens & mulheres & Total \\
\hline Somente para os associados do Sindicato & & & \\
que assinou o contrato coletivo & 35,8 & 24,1 & 32,2 \\
Para todos os trabalhadores da categoria & 51,9 & 58,1 & 53,8 \\
Não tem opinião formada & 12,4 & 17,9 & 14,1 \\
\hline
\end{tabular}

Fonte: Pesquisa 8o. Concut 2003, Escola Sindical SP/CUT e Cesit/Ie/Unicamp.

$\mathrm{Na}$ tabela 4, tendo ou não a liberdade sindical assegurada, a opinião de 53,8\% dos delegados é de que os contratos coletivos devem valer para todos os trabalhadores da 
categoria, independentemente de serem sócios do sindicato. Conjugado à tabela 2 , talvez esse dado corrobore a leitura de que os delegados prefiram um só sindicato na base.

\begin{tabular}{|l|c|c|c|}
\hline \multicolumn{4}{|c|}{$\begin{array}{c}\text { Tabela 5 - Quais devem ser as principais fontes de financiamento das entidades } \\
\text { sindicais? (\%) }\end{array}$} \\
\hline & Homens & Mulheres & Total \\
\hline Mensalidade dos associados & 94,2 & 94,6 & 94,3 \\
\hline Constituição do fundo público & 10,7 & 10,6 & 10,6 \\
\hline Taxa de financiamento das campanhas salariais & 32,0 & 22,8 & 29,2 \\
\hline Manutenção da contribuição federativa & 18,0 & 17,2 & 17,8 \\
\hline Manutenção do imposto sindical & 13,5 & 17,5 & 14,7 \\
\hline $\begin{array}{l}\text { Recursos públicos para projetos especiais (qualificação } \\
\text { profissional, economia solidária etc) }\end{array}$ & 22,5 & 28,2 & 24,3 \\
\hline Contribuição assistencial & 21,1 & 11,4 & 18,1 \\
\hline Investimentos em atividades produtivas ou comerciais & 10,9 & 14,2 & 11,9 \\
\hline Organismos internacionais para apoio político/organizativo & 8,6 & 14,2 & 10,3 \\
\hline
\end{tabular}

Fonte: Pesquisa $8^{\circ}$ CONCUT 2003, Escola Sindical SP/CUT e Cesit/Ie/Unicamp.

Em relação ao financiamento das entidades sindicais, a tabela 5 indica que a esmagadora opinião dos delegados é pela sustentação por meio da mensalidade dos associados $(94,3 \%)$. Outras formas indicadas com relevância foram taxas advindas das campanhas salariais (aprovadas em assembleias e não compulsórias), 29,2\%; utilização de recursos públicos em projetos especiais, $24,3 \%$. 


\begin{tabular}{|l|c|c|c|}
\hline \multicolumn{4}{|c|}{ Tabela 6 - Opiniões sobre a Justiça do Trabalho (\%) } \\
\hline & Concorda & Discorda & Não tem opinião formada \\
\hline $\begin{array}{l}\text { Tem papel importante nas negociações e deve } \\
\text { ser mantida como está. }\end{array}$ & 28,4 & 57,0 & 14,5 \\
\hline $\begin{array}{l}\text { Deve continuar existindo, mas intervindo nas } \\
\text { negociações quando solicitado pelos } \\
\text { representantes dos(as) trabalhadores(as) }\end{array}$ & 77,3 & 14,4 & 8,4 \\
\hline $\begin{array}{l}\text { Deve ser extinta, sendo os conflitos entre } \\
\text { trabalhadores e patrões resolvidos por meio da } \\
\text { livre negociação }\end{array}$ & 24,4 & 62,4 & 13,2 \\
\hline $\begin{array}{l}\text { Deve existir apenas para julgar processos } \\
\text { individuais dos(as) trabalhadores }\end{array}$ & 26,3 & 54,4 & 19,3 \\
\hline
\end{tabular}

\begin{tabular}{|l|c|c|c|}
\hline \multicolumn{4}{|c|}{ Tabela 7 - Opinião sobre a forma da solução dos conflitos (\%) } \\
\hline & homens & mulheres & Total \\
\hline Intermediada pelo Estado & 22,7 & 14,9 & 20,3 \\
\hline Sempre negociada entre as partes & 73,0 & 79,4 & 74,9 \\
\hline Não têm opinião formada & 4,3 & 5,8 & 4,8 \\
\hline Total & 100,0 & 100,0 & 100,0 \\
\hline
\end{tabular}

Fonte: Pesquisa $8^{\circ}$ CONCUT, Escola Sindical SP/CUT e Cesit/IE/Unicamp.

As tabelas 6 e 7 indicam as opiniões sobre a Justiça do Trabalho, outro pilar da estrutura sindical que deveria ser enfrentada na reforma sindical.

Os delegados disseram explicitamente que aceitam a existência da Justiça do Trabalho, desde que cumpra outro papel, intervindo nas negociações apenas quando isso for solicitado pelos representantes dos trabalhadores, mesmo em caso de conflito.

Analisando as tabelas com as respostas, constata-se que as mudanças almejadas na reforma sindical deveriam acontecer como Boito Jr. assinalou, "modelo democrático da gestão sindical". Significa dizer que os delegados desejavam eliminar o que consideravam interferência autoritária, conservando o que, a despeito de ser intervenção estatal nos sindicatos, é tolerado pelos mesmos dirigentes, sobretudo a unicidade sindical (BOITO Jr., 1991 e 1991b) 
Considerando que os delegados ao $8^{\circ}$ CONCUT, ao menos em tese, representam grupo diferenciado de dirigentes sindicais, "a nata do sindicalismo-CUT", e que esse grupo expressou opiniões contraditórias ao projeto histórico da CUT, nada indica que a maioria dos dirigentes sindicais cutistas tenha participado das Conferências Estaduais, reforçando o que Horn denominou de "consenso reformista". A pesquisa de opinião deixou patente que a CUT teria problemas em sua própria base para convencer a mobilização pela reforma sindical.

Mas quem eram os delegados que hesitaram diante da estrutura sindical corporativa?

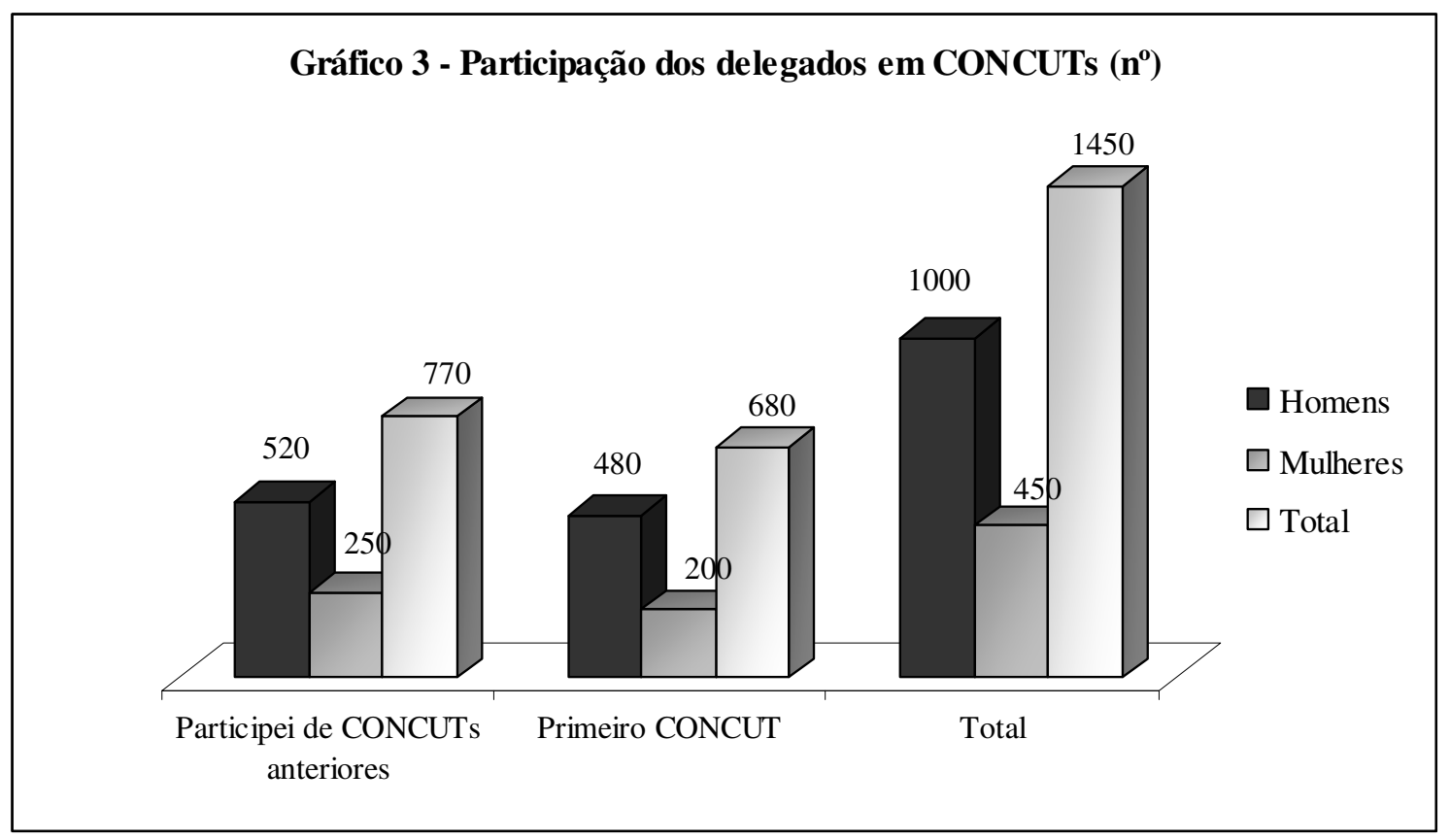

Fonte: Pesquisa 8o. CONCUT 2003, Escola Sindical SP/CUT e Cesit/Ie/Unicamp.

De acordo com o gráfico anterior, aproximadamente metade dos delegados participava de um Congresso Nacional da CUT pela primeira vez. 


\begin{tabular}{|c|c|c|c|}
\hline \multicolumn{2}{|c|}{ Tabela 8 - Composição dos delegados segundo a inserc̃ão na estrutura sindical (\%) } \\
\hline & Homens & Mulheres & Total \\
\hline Delegados com cargos sindicais & 90,8 & 88,6 & 90,1 \\
\hline Diretor da Executiva & 66,1 & 50,0 & 61,2 \\
\hline Diretor & 17,2 & 27,2 & 20,2 \\
\hline Membro de Organização no Local de Trabalho & 1,4 & 1,7 & 1,5 \\
\hline Representante sindical no local de trabalho & 3,4 & 5,0 & 3,9 \\
\hline Membro da CIPA & 0,6 & 0,4 & 0,5 \\
\hline Outro & 2,1 & 4,4 & 2,8 \\
\hline Delegados sem cargo sindical & 9,2 & 11,4 & 9,9 \\
\hline Associado & 4,6 & 6,0 & 5,0 \\
\hline Associado de oposição & 2,2 & 2,1 & 2,2 \\
\hline Associado e membro de algum grupo de trabalho & 0,6 & 1,2 & 0,8 \\
\hline Outro & 1,8 & 2,1 & 1,9 \\
\hline Total & 100,0 & 100,0 & 100,0 \\
\hline
\end{tabular}

Fonte: Pesquisa 8o. CONCUT 2003, Escola Sindical SP/CUT e Cesit/Ie/Unicamp

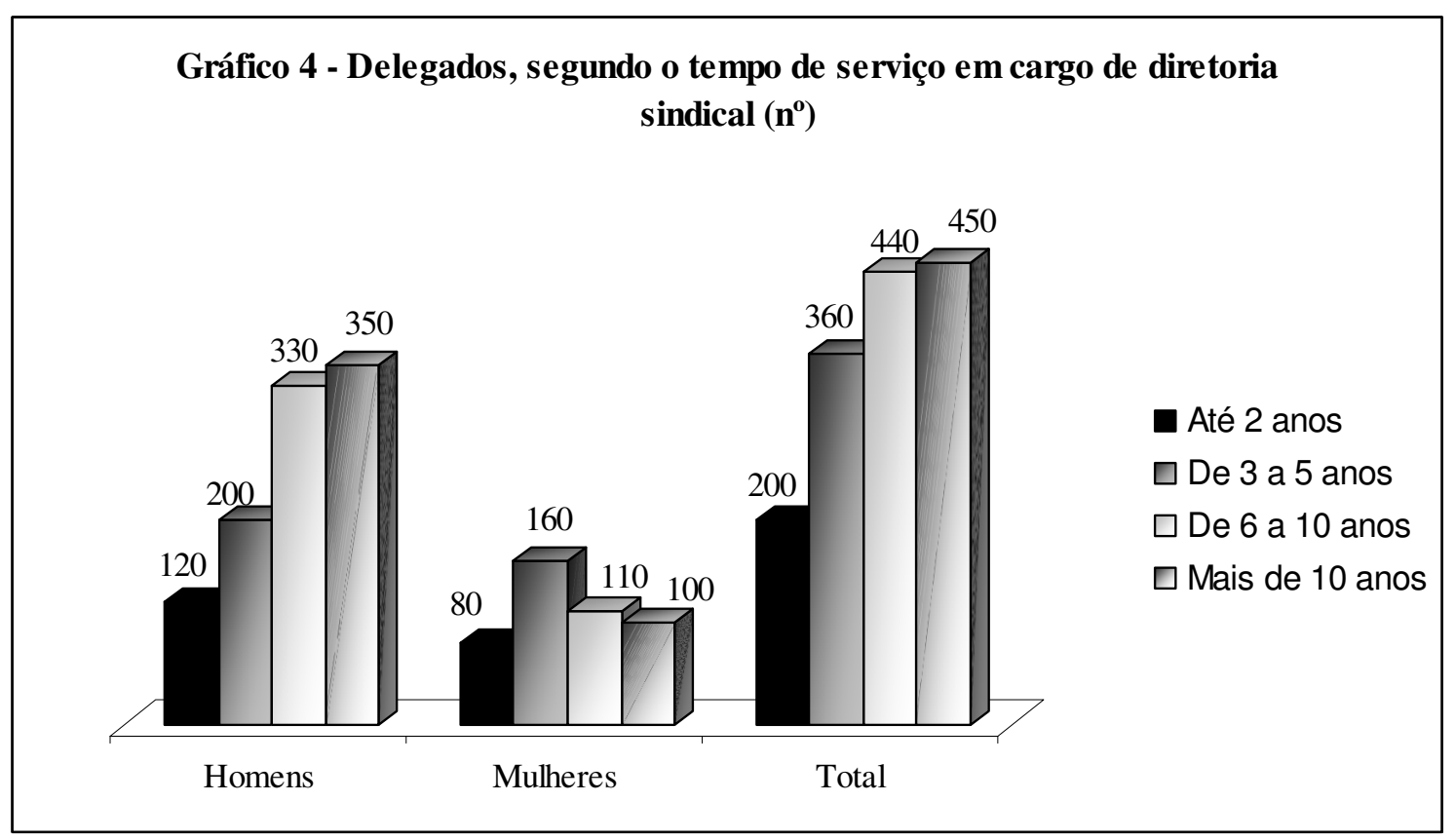

Fonte: Pesquisa 8o. CONCUT 2003, Escola Sindical SP/CUT e Cesit/Ie/Unicamp. 
Apesar de relativamente pouco experientes em participação em CONCUTs, tinham cargo de representação sindical $(90,1 \%)$. Em sua maioria, membros de direção executiva $(61,2 \%)$ ou direção plena $(20,2 \%)$ de sua entidade. Eram delegados com certa vivência de movimento sindical, a maioria com dois ou mais mandatos na entidade que representa.

\section{Projeto Estratégia e Organização da CUT: construindo o Futuro}

Paralelamente aos debates do FNT, a CUT, por meio da Secretaria Nacional de Organização (SNO) e Secretaria Nacional de Formação (SNF), desenvolveu, de 2004 a 2006, projeto intitulado Estratégia e Organização da CUT: construindo o Futuro.

Para a CUT, “....as principais motivações para a realização do Projeto Estratégia e Organização da CUT: Construindo o Futuro foram a necessidade e a perspectiva de retomar, atualizar e consolidar o projeto político-organizativo da CUT, balizado especialmente pelo Sistema Democrático de Relações de Trabalho (formulado pela Central em 1992); a possibilidade de negociar, no âmbito do Fórum Nacional do Trabalho (instituído pelo governo federal), uma reforma sindical que atendesse às nossas propostas e reivindicações; e a necessidade de aprimorar nossas organizações sindicais para disputar com outros projetos sindicais a representação de trabalhadores e a negociação coletiva".(CUT, 2006a: 9)

Durante o projeto houve dois seminários nacionais, oito oficinas macrossetoriais ${ }^{110}$ e sete oficinas regionais, envolvendo praticamente todas as CUTs estaduais. Nas atividades foi se aprofundando o diagnóstico do sindicalismo-CUT, resultando proposições na forma de texto-base ou emendas para apreciação dos delegados ao $9^{\circ}$ CONCUT, em junho de 2006.

Neste trabalho há apenas a síntese das atividades, mostrando os resultados alcançados.

A primeira parte do diagnóstico versou sobre o mercado de trabalho formal a partir do Relatório Anual de Informações Sindicais (RAIS) do MTE, e também dados do Censo Sindical do IBGE na Pesquisa Nacional por Amostra de Domicílios (PNAD), indicando as mudanças desenvolvidas de forma mais contundente a partir da década de 90, implicando consequências para a ação sindical.

Ressalta o relatório: "Em 2004, a população ocupada era 84.596.294. Desse total, apenas 31.407.577 trabalhavam com carteira assinada ou eram estatutários, ou seja, apenas $37 \%$.

\footnotetext{
${ }^{110}$ Foram definidos quatro macrossetores na CUT, aglutinando os 18 ramos de atividade: rural; industrial; comércio e serviços; e serviço público.
} 
Os demais 63\% são trabalhadores ocupados, mas sem registro, autônomos, por conta própria ou com outras formas de ocupação. Dos ocupados formais, temos $24 \%$ concentrados na indústria e $36 \%$ em comércio e serviços, enquanto a administração pública é responsável por $23 \%$ desses empregos formais (...) Os dados por faixas de rendimento indicam que $43 \%$ dos trabalhadores formais no Brasil recebem até dois salários mínimos, sendo que, no setor rural, são mais de $72 \%$, enquanto no setor de comércio, 59\%; e no setor de serviços, 54\%. Quando ampliamos para a faixa de até três salários mínimos, o percentual para o setor de Rurais passa para quase 89,5\%, o setor de Comércio chega a $82,2 \%$, e o setor de Serviços a $75,8 \%$. (...) Os dados por tempo de serviço indicam grande concentração em até um ano, 30,6\% para o total, sendo que o setor rural, seguido pelo comércio, apresentam os maiores percentuais: $43,8 \%$ e $41,9 \%$, respectivamente. Se considerarmos o período de até três anos, temos que 55,7\% dos trabalhadores e trabalhadoras formais têm até três anos de serviço". (CUT, 2006a: 71-75)

\begin{tabular}{|c|c|c|}
\hline \multicolumn{3}{|c|}{ Tabela 9 - Taxa de Sindicalização por Setor de Atividade - 2004} \\
\hline Setor de Atividade & $\%$ total de trab. ocupados* & $\%$ trabalhadores formais $* * *$ \\
\hline Comércio e serviços & $10,20 \%$ & $22,80 \%$ \\
\hline Extração mineral & $17,80 \%$ & $26,60 \%$ \\
\hline Seguridade social & $29,90 \%$ & $33,40 \%$ \\
\hline Autônomos urbanos & $6,60 \%$ & - \\
\hline Educação & $30,50 \%$ & $37,60 \%$ \\
\hline Construção e madeira & $9,00 \%$ & $24,10 \%$ \\
\hline Urbanitários & $46,30 \%$ & $50,00 \%$ \\
\hline Alimentação & $17,50 \%$ & $27,30 \%$ \\
\hline Metalúrgica & $30,70 \%$ & $37,90 \%$ \\
\hline Químicos & $31,80 \%$ & $37,50 \%$ \\
\hline Aposentados $(* *)$ & $34,40 \%$ & - \\
\hline Rurais & $23,00 \%$ & $23,60 \%$ \\
\hline Sistema financeiro & $41,10 \%$ & $48,00 \%$ \\
\hline Comunicação e informação & $27,30 \%$ & $33,20 \%$ \\
\hline Transporte & $24,60 \%$ & $39,40 \%$ \\
\hline Administração pública & $26,00 \%$ & $30,50 \%$ \\
\hline Vestuário & $16,60 \%$ & $30,70 \%$ \\
\hline Total & $17,90 \%$ & $30,00 \%$ \\
\hline
\end{tabular}


Do ponto de vista da representação sindical, a tabela 9 que consta no relatório assinala que "somente 30\% dos trabalhadores formais brasileiros são sindicalizados. Dados da Pesquisa Nacional por Amostra de Domicílios, realizada pelo IBGE em 2004, revelaram que, do total de ocupados, somente $17,9 \%$ responderam ser associados a algum sindicato". (CUT, 2006a: 77)

\begin{tabular}{|l|c|c|c|c|c|}
\hline \multicolumn{5}{|c|}{ Tabela 10 - Associados segundo regiões e filiação à Central } \\
\hline \multirow{2}{*}{ CUT } & FS & Outras & Nenhuma & Total \\
\hline Brasil & $\mathbf{7 . 2 5 1 . 5 8 3}$ & $\mathbf{1 . 7 3 4 . 7 3 3}$ & $\mathbf{1 . 2 2 4 . 8 6 9}$ & $\mathbf{9 . 3 1 7 . 1 2 6}$ & $\mathbf{1 9 . 5 2 8 . 3 1 1}$ \\
Norte & 754.199 & 56.625 & 91.493 & 408.169 & 1.310 .486 \\
Nordeste & 3.007 .745 & 169.475 & 309.853 & 3.192 .077 & 6.679 .150 \\
Sudeste & 2.139 .048 & 1.256 .990 & 540.890 & 3.003 .535 & 6.940 .463 \\
Sul & 761.511 & 208.986 & 178.591 & 2.008 .571 & 3.157 .659 \\
Centro-Oeste & 589.080 & 42.657 & 104.042 & 704.774 & 1.440 .553 \\
\hline \multirow{2}{*}{ Brasil } & $\mathbf{3 7 \%}$ & $\mathbf{9 \%}$ & $\mathbf{6 \%}$ & $\mathbf{4 8 \%}$ & $\mathbf{1 0 0 \%}$ \\
Norte & $58 \%$ & $4 \%$ & $7 \%$ & $31 \%$ & $100 \%$ \\
Nordeste & $45 \%$ & $3 \%$ & $5 \%$ & $48 \%$ & $100 \%$ \\
Sudeste & $31 \%$ & $18 \%$ & $8 \%$ & $43 \%$ & $100 \%$ \\
Sul & $24 \%$ & $17 \%$ & $6 \%$ & $64 \%$ & $100 \%$ \\
Centro-Oeste & $41 \%$ & $3 \%$ & $7 \%$ & $49 \%$ & $100 \%$ \\
& & \multicolumn{5}{|c|}{ Em } & & \\
\hline
\end{tabular}

Fonte: IBGE, Pesquisa Sindical 2001. (CUT, 2006a)

Elaboração: Subseção Dieese CUT Nacional

O relatório analisa a distribuição do índice de sindicalização de acordo com as centrais sindicais (tabela 10): "Outro indicador a ser observado é o de representação de central sindical. A Tabela 10 mostra que, de um total de 19 milhões de trabalhadores associados, $48 \%$ não são vinculados a nenhuma central sindical, dado indicativo de um enorme potencial de crescimento. Dentre as centrais sindicais, a CUT tem o maior percentual de filiação, 37\%, seguida da Força Sindical, com 9\%. Por região do país, a CUT é a central sindical com maior representação no Norte (58\%); Nordeste $(45 \%)$ e Sudeste $(31 \%)$. A Força Sindical tem 18\% de representação no Sudeste e 7\% no Sul”. (CUT, 2006:79) 


\section{Gráfico 5 - Trabalhadores na base por central sindical (\%)}

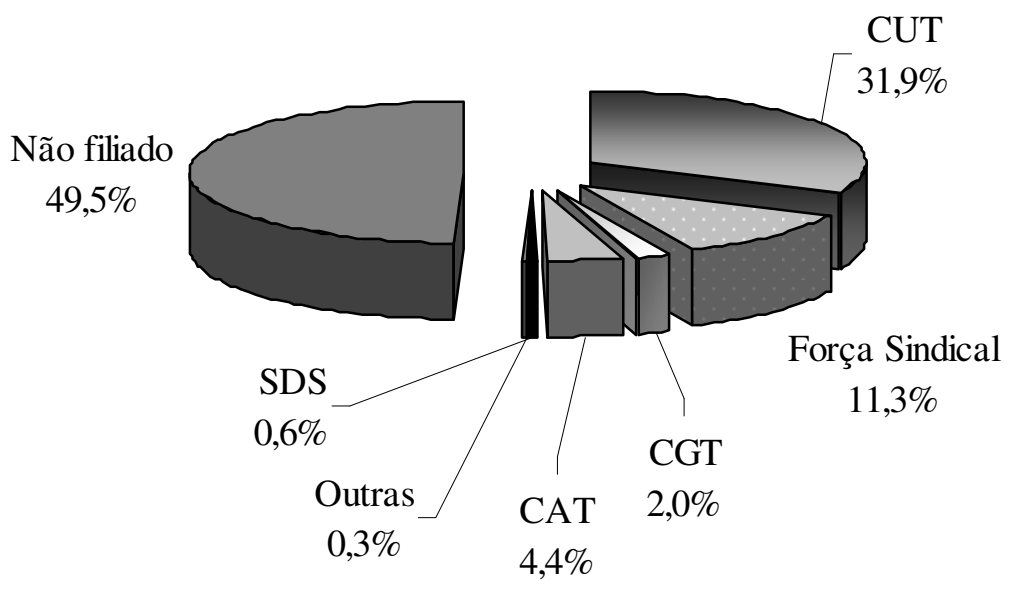

Fonte: CUT, 2006a: 79

O gráfico 5 mostra ligeira alteração quando compara as centrais sindicais de acordo com o número de trabalhadores na base. Nesse caso, a representação da CUT cai (de 37\% para $32 \%$ ), e o número de trabalhadores na base de sindicatos sem filiação a centrais sindicais aumenta de $48 \%$ para $50 \%$.

O relatório do projeto adverte que "somam-se a esses 26,7 milhões de trabalhadores formais sem representação sindical, os 20 milhões de trabalhadores sem carteira de trabalho. Essa é a medida do potencial de crescimento e do desafio da organização sindical dos trabalhadores". (CUT, 2006a: 80)

\begin{tabular}{|l|c|c|c|c|}
\hline \multicolumn{5}{|c|}{ Tabela 11 - Crescimento dos sindicatos filiados às centrais } \\
\hline \multicolumn{1}{|c|}{ Centrais Sindicais } & $\mathbf{1 9 9 1}$ & $\mathbf{2 0 0 1}$ & Abs & Variação \\
\hline CUT & 1.668 & 2.834 & 1.166 & $70 \%$ \\
FS & 284 & 839 & 555 & $195 \%$ \\
CGT & 102 & 238 & 136 & $133 \%$ \\
SDS & - & 287 & - & - \\
CAT & - & 86 & - & - \\
CGT Central Geral & 183 & - & - & - \\
USI & 35 & - & - & - \\
\hline
\end{tabular}

Fonte: IBGE, Pesquisa Sindical 2001. (CUT, 2006)

Elaboração: Subseção Dieese CUT Nacional 
O capítulo anterior mostrou o crescimento vertiginoso da CUT nos anos 1990. Embora, em números absolutos aquém da CUT, a Força Sindical e a CGT lograram taxas de crescimento superiores, em parte por causa de o número base de referência ser mais baixo. Mesmo com crescimento menor do que a CUT em termos absolutos, percentualmente ele se sobressai.

Segundo a análise da CUT, "o aumento no número de sindicatos não veio acompanhado de uma maior sindicalização [como se verá a seguir], o que pode significar a existência de maior número de sindicatos pouco representativos". (CUT, 2006a: 80)

\begin{tabular}{|l|c|c|c|}
\hline \multicolumn{2}{|c|}{ Tabela 12 - Taxa de sindicalização por setor de atividade - 1992, 2002 e 2004 } \\
\hline \multicolumn{2}{|c|}{ Setor de Atividade } & \multicolumn{3}{|c|}{ \% total de Ocupados* } \\
\cline { 2 - 4 } & $\mathbf{1 9 9 2}$ & $\mathbf{2 0 0 2}$ & $\mathbf{2 0 0 4}$ \\
\hline Comércio e serviços & $9,40 \%$ & $9,60 \%$ & $10,20 \%$ \\
\hline Extração mineral & $24,50 \%$ & $20,30 \%$ & $17,80 \%$ \\
\hline Seguridade social & $29,90 \%$ & $27,70 \%$ & $29,90 \%$ \\
\hline Autônomos urbanos & $7,40 \%$ & $6,60 \%$ & $6,60 \%$ \\
\hline Educação & $26,60 \%$ & $29,70 \%$ & $30,50 \%$ \\
\hline Construção e madeira & $10,20 \%$ & $7,30 \%$ & $9,00 \%$ \\
\hline Urbanitários & $64,80 \%$ & $42,90 \%$ & $46,30 \%$ \\
\hline Alimentação & $21,10 \%$ & $17,50 \%$ & $17,50 \%$ \\
\hline Metalúrgica & $33,60 \%$ & $28,10 \%$ & $30,70 \%$ \\
\hline Químicos & $32,90 \%$ & $27,40 \%$ & $31,80 \%$ \\
\hline Aposentados (**) & $24,30 \%$ & $33,70 \%$ & $34,40 \%$ \\
\hline Rurais & $15,00 \%$ & $21,20 \%$ & $23,00 \%$ \\
\hline Sistema financeiro & $58,80 \%$ & $40,50 \%$ & $41,10 \%$ \\
\hline Comunicação e informação & $41,60 \%$ & $26,60 \%$ & $27,30 \%$ \\
\hline Transporte & $34,40 \%$ & $24,80 \%$ & $24,60 \%$ \\
\hline Administração pública & $20,00 \%$ & $25,60 \%$ & $26,00 \%$ \\
\hline Vestuário & $26,20 \%$ & $15,00 \%$ & $16,60 \%$ \\
\hline Fonte: PNAD, 1992,2002 e 2004 (microdados). CUT,2006a & & \\
\hline *laboraça: Gomes, 2006 Cesit/Unicamp & & & \\
\hline & & & \\
\hline
\end{tabular}


Observa-se a partir dos dados da tabela 12 que, em geral, os setores tiveram redução nas taxas de sindicalização nos anos 90, exceto os ramos de comércio e serviços, educação, rurais, aposentados e administração pública, que tiveram crescimento maior ou menor. A explicação da CUT é de que a queda expressa o efeito da política governamental de privatização do setor produtivo estatal (energia elétrica, telecomunicações etc.), a flexibilização das relações de trabalho e o patamar elevado de desemprego na década.

Contudo, para os sindicatos brasileiros os dados não confirmam a tese de Leôncio Martins Rodrigues acerca da crise terminal do sindicalismo por causa da inexorável dessindicalização. (RODRIGUES, 1999)

\begin{tabular}{|c|c|c|c|c|c|c|c|}
\hline \multicolumn{8}{|c|}{ Tabela 13 - Total de Filiados por Ramos } \\
\hline Ramos & $\begin{array}{l}\text { Entidades } \\
\text { filiadas }\end{array}$ & $\begin{array}{c}\text { Trab. } \\
\text { Base (A) }\end{array}$ & $\begin{array}{c}\text { Trab. } \\
\text { Assoc. } \\
\text { (B) }\end{array}$ & $\begin{array}{c}\% \\
(\mathbf{B} / \mathbf{A})\end{array}$ & $\begin{array}{l}\text { Trab. } \\
\text { Sócio } \\
\text { quite (C) }\end{array}$ & $\begin{array}{c}\% \\
(\mathrm{C} / \\
\text { B) }\end{array}$ & $\begin{array}{c}\text { Trab. } \\
\text { Aposentado }\end{array}$ \\
\hline Alimentação & 96 & 426.097 & 102.016 & $23,9 \%$ & 62.896 & $61,7 \%$ & 5.134 \\
\hline Vestuário & 76 & 241.702 & 74.677 & $30,9 \%$ & 55.805 & $74,7 \%$ & 7.084 \\
\hline Construção & 92 & 443.327 & 164.498 & $37,1 \%$ & 109.981 & $66,9 \%$ & 8.561 \\
\hline Químico & 67 & 310.336 & 135.673 & $43,7 \%$ & 102.043 & $75,2 \%$ & 26.663 \\
\hline Metalúrgico & 101 & 793.014 & 356.647 & $45,0 \%$ & 245.395 & $68,8 \%$ & 88.559 \\
\hline Urbanitários & 49 & 262.839 & 182.100 & $69,3 \%$ & 132.377 & $72,7 \%$ & 44.411 \\
\hline Extração & 34 & 88.909 & 31.330 & $35,2 \%$ & 18.097 & $57,8 \%$ & 3.459 \\
\hline Comércio & 244 & 1.984 .548 & 287.506 & $14,5 \%$ & 189.083 & $65,8 \%$ & 7.421 \\
\hline $\begin{array}{l}\text { Comércio } \\
\text { Autônomo }\end{array}$ & 42 & 100.562 & 59.054 & $58,7 \%$ & 39.206 & $66,4 \%$ & 892 \\
\hline Saúde & 166 & 1.358 .375 & 405.018 & $29,8 \%$ & 331.386 & $81,8 \%$ & 25.179 \\
\hline Transporte & 99 & 490.026 & 204.574 & $41,7 \%$ & 124.186 & $60,7 \%$ & 37.599 \\
\hline $\begin{array}{l}\text { Comunicação, } \\
\text { Publicidade e } \\
\text { Jornalismo }\end{array}$ & 103 & 399.717 & 177.841 & $44,5 \%$ & 118.216 & $66,5 \%$ & 9.559 \\
\hline Financeiro & 112 & 384.844 & 258.014 & $67,0 \%$ & 202.620 & $78,5 \%$ & 54.206 \\
\hline Educação & 207 & 2.854 .189 & 1.303 .500 & $45,7 \%$ & 1.026 .007 & $78,7 \%$ & 196.630 \\
\hline $\begin{array}{l}\text { Estabelecimentos } \\
\text { Hípicos }\end{array}$ & 1 & 800 & 105 & $13,1 \%$ & 105 & $100,0 \%$ & 0 \\
\hline $\begin{array}{l}\text { Profissionais } \\
\text { Liberais }\end{array}$ & 25 & 318.467 & 69.394 & $21,8 \%$ & 13.665 & $19,7 \%$ & 1.611 \\
\hline $\begin{array}{l}\text { Administração } \\
\text { Pública }\end{array}$ & 689 & 2.079 .923 & 681.438 & $32,8 \%$ & 557.811 & $81,9 \%$ & 85.871 \\
\hline Aposentados & 2 & 120.000 & 1.266 & $1,1 \%$ & 1.266 & $100,0 \%$ & 0 \\
\hline Informática & 18 & 105.038 & 19.092 & $18,2 \%$ & 16.652 & $87,2 \%$ & 1.252 \\
\hline Rural & 1.266 & 9.773 .472 & 3.188 .804 & $32,6 \%$ & 650.321 & $20,4 \%$ & 374.494 \\
\hline Total & 3.489 & 22.536.185 & 7.702 .547 & $34,2 \%$ & 3.997.118 & $51,9 \%$ & 978.585 \\
\hline
\end{tabular}

Fonte: Cadastro da CUT, 2006. (CUT, 2006a) Elaboração: Subseção Dieese- CUT Nacional 
A tabela 13 apresenta dados da síntese sobre a sindicalização nos ramos da CUT e o grau de adimplência a partir da relação entre os sócios quites e o total de associados.

O conjunto das entidades filiadas à CUT tem média de $34,2 \%$ da base associada. Estão acima dessa média os sindicatos do ramo químico (43,7\%), metalúrgico (45,0\%), urbanitário $(69,3 \%)$, financeiro $(67,0 \%)$ e educação $(45,7 \%)$, entre outros. Se se comparar esse quadro com os dados de sindicalização pelos setores, segundo a PNAD (tabela 12), o sindicalismo-CUT tem taxa de sindicalização bem acima da média em praticamente todos os ramos de atividade. Ou seja, a CUT não apenas tem maior número de sindicatos, comparativamente às demais centrais sindicais (tabela 11), mas tem índice de sindicalização mais alto que a média nacional de 30,0\% (tabela 9). Embora fique ainda em torno de patamar mediano, de aproximadamente $1 / 3$ de filiados, tendo, portanto, bom espaço para crescimento.

Debate interessante, mas que foge ao escopo desta tese, seria tentar elucidar os fatores que levam os trabalhadores a associarem-se aos sindicatos cutistas. Pode-se especular várias razões, inclusive a perspectiva de conquistas através de ações reivindicatórias entre eles. Mas é preciso reconhecer o "peso" que a oferta de determinados benefícios têm no momento do trabalhador decidir pela filiação ao seu sindicato, como o convênio com faculdades particulares, farmácias, academias de ginástica, desconto em entradas em cinemas, teatros e parque de diversões, agência de turismo, consultórios médico e dentista, e acesso a crédito em financeiras. Ao lado de serviços mais "tradicionais" dos sindicatos, como o acesso a colônias de férias, clube de campo etc. Não é muito comum a oferta direta de atendimento médico-odontológico (ou barbeiro/cabeleireiro) nas dependências do sindicato, como ocorria no passado. De certa forma, o sindicalismo-CUT não acabou com o assistencialismo, mas o terceirizou, desafogando em boa medida a finança do sindicato com o custo fixo que havia, transformando-o em fonte maior de receita do que de despesa.

O número de sócios pagantes em dia é bem alto (tabela 13), observando-se maior dificuldade de arrecadação entre os setores não assalariados, como profissionais liberais e rurais $(19,7 \%$ e $20,4 \%$, respectivamente). Todos os demais setores, que têm como sócios trabalhadores formais, registram índices de adimplência acima de 50\%.

O conjunto dos dados tratados no projeto Estratégia e Organização da CUT: construindo o Futuro expressa de forma contundente o que vinha sendo mostrado em outras partes deste 
trabalho, ou seja, o reflexo negativo da dinâmica externa sobre o sindicalismo-CUT nos anos 1990. A política econômica neoliberal de Collor e FHC e as profundas transformações no mundo do trabalho, além da defensiva do movimento sindical, resultaram em mercado de trabalho premido pelo desemprego, informalidade, baixos salários e alta rotatividade. Além da pressão pela flexibilização nas formas de contratação e perda de direitos.

Diante de um cenário desastroso, a CUT conseguiu resistir bem, passando pelo período não só com um número maior de sindicatos (por si só não significa ser algo positivo, haja vista o diagnóstico do MTE e da própria CUT sobre a pulverização de sindicatos com o consequente enfraquecimento da capacidade de representação), mas principalmente mantendo um patamar de sindicalização razoável, que permite espaço grande de crescimento, e que nem de longe indica crise terminal de falta de identidade e de legitimidade perante os trabalhadores.

As dificuldades vividas no plano externo se aprofundam quando se penetra na análise da dinâmica interna do sindicalismo-CUT. A relação entre as tendências da CUT foram se agravando à medida que a corrente majoritária imprimia seu ritmo de mudança no padrão de ação sindical, pautando sua estratégia, nos anos 1990, na força institucional mais por do que na capacidade de mobilização dos trabalhadores. O diagnóstico elaborado a partir do projeto Estratégia e Organização da CUT: construindo o Futuro indica situação mais grave, muito além das crises entre as correntes políticas internas:

"Nas primeiras atividades do Projeto, embora a avaliação que os participantes fizeram do projeto organizativo da CUT seja, no geral, bastante positiva (...), as dificuldades, fragilidades e conflitos de organização apontados foram eloquentes, mostrando aspectos que reiteraram a necessidade de unificação das entidades sindicais:

- Pulverização/fragmentação;

- Alta rotatividade nos postos de trabalho;

- Dificuldade de manter o número de associados/sindicalizados;

- Dificuldade de sustentação financeira das categorias baseadas em pequenas empresas e dependendo das contribuições compulsórias;

- Coeficiente de $20 \%$ de sindicalizados na base, para representatividade das centrais sindicais, apontados nos debates do Fórum Nacional do Trabalho.

Quanto às dificuldades para a organização dos trabalhadores e trabalhadoras, emergiu o seguinte quadro: 
- Heterogeneidade nas relações de trabalho: contratos de trabalho distintos (setor público e privado), terceirizações etc;

- Baixíssima concretização das Organizações por Local de Trabalho - OLTs;

- Pouca tradição de trabalho conjunto e articulado;

- A persistência do corporativismo, processo de acomodação à estrutura oficial e de apego ao patrimônio e ao status de dirigente;

- Especificamente no setor público: a organização dos sindicatos de base é heterogênea, e há a necessidade de regulamentar a negociação coletiva;

- Existem experiências de negociação nacional (várias categorias), inclusive no setor público. No entanto, os processos de negociação, nos últimos anos, apontam tendência à perda e à flexibilização de direitos, que parecem estar sendo invertidas atualmente". (CUT, 2006a: 87-88)

Em meio a esse quadro, a CUT, sentindo dificuldade na aprovação de uma reforma que atendesse plenamente às suas reivindicações, se preparava para seguir construindo seu projeto político-organizativo em direção à liberdade e à autonomia sindical, independentemente do êxito da reforma sindical.

No que diz respeito à estrutura horizontal da CUT - as CUTs Estaduais e Regionais ${ }^{111}$-, formulou-se para debate em grupos a seguinte pergunta no tema Construção do Projeto Organizativo da CUT: qual o papel das Estaduais?

Seguem os quadros com a síntese da discussão:

\footnotetext{
${ }^{111}$ Logo após a fundação da CUT em 1983 iniciou-se um processo de estruturação da CUT nos Estados com a criação das CUTs Estaduais e, em cada Estado, a criação de CUTs Regionais, de modo a conferir maior capilaridade à CUT em todo o país. A partir de 1994, no Estado de São Paulo, começou a tecer-se crítica à organização das CUTs regionais sob a alegação de que "configurava a criação de pequenas ilhas, como se fossem CUTs à parte", porque eram dotadas de alguma autonomia política, em razão de serem instâncias com direção própria. (FEIJÓO, 2002: 113) Desse modo, a CUT-SP lançou a discussão ao $6^{\circ}$ CONCUT (1997) para ser alterado o estatuto nacional a fim de comportar a mudança. A proposta foi rejeitada, mas aprovou-se a partir de então que cada CUT Estadual estabelecesse que tipo de regionalização era mais adequada à sua realidade. Desse modo, em São Paulo, a CUT alterou sua estrutura organizativa e transformou as CUTs Regionais em subsedes da CUT Estadual. Em outros lugares, como CUT-MG e CUT-PR, por exemplo, ainda persistem as CUTs Regionais.
} 


\begin{tabular}{|c|c|}
\hline Questões & Resultados \\
\hline $\begin{array}{l}\text { Com relação à ampliação da } \\
\text { representatividade... }\end{array}$ & $\begin{array}{l}\text { Reafirmou-se o papel classista das estruturas } \\
\text { horizontais da CUT, para além do específico dos } \\
\text { sindicatos e ramos. } \\
\text { Pautam sua intervenção em temas mais gerais de } \\
\text { interesse dos trabalhadores na sociedade, } \\
\text { buscando articular suas ações com os interesses } \\
\text { específicos das categorias. }\end{array}$ \\
\hline $\begin{array}{l}\text { A Estadual da CUT é referência para a } \\
\text { organização e mobilização dos sindicatos de } \\
\text { base? }\end{array}$ & $\begin{array}{l}\text { O peso das Estaduais na organização e } \\
\text { mobilização dos sindicatos de base é heterogêneo, } \\
\text { dependendo dos seguintes aspectos: } \\
\text { - Organização, estrutura e grau de } \\
\text { descentralização das CUTs nos Estados; } \\
\text { - Relações políticas nas direções estaduais; } \\
\text { - Setor/ramo considerado em cada Estado; } \\
\text { - Relações políticas entre verticais e estaduais. }\end{array}$ \\
\hline $\begin{array}{l}\text { Sobre planejamento, organização, estrutura e o } \\
\text { grau de descentralização das CUTs nos Estados }\end{array}$ & $\begin{array}{l}\text { Planejamento estratégico: } \\
\text { - O processo de planejamento é diferenciado entre } \\
\text { as CUTs, algumas não planejam; } \\
\text { - A maioria tem dificuldades para implementação } \\
\text { e monitoramento do planejado; } \\
\text { • No geral, as verticais (como instituições) } \\
\text { participam muito pouco do planejamento e de sua } \\
\text { execução organizada. } \\
\text { A grande maioria tem dificuldades em dar } \\
\text { visibilidade às suas ações. } \\
\text { As estaduais com regionais, mesorregionais ou } \\
\text { microrregionais, demonstram maior capacidade e } \\
\text { densidade organizativa. }\end{array}$ \\
\hline Sobre a organização e estrutura & $\begin{array}{l}\text { Dificuldades quanto à estrutura: } \\
\text { Financeiras - alto índice de inadimplência dos } \\
\text { sindicatos, acarretando: }\end{array}$ \\
\hline
\end{tabular}




\begin{tabular}{|c|c|}
\hline & $\begin{array}{l}\text { - Instabilidade na manutenção de prédios e } \\
\text { insumos (telefone, internet, luz etc); } \\
\text { - Dificuldades no cumprimento de agendas } \\
\text { (especialmente as mais distantes). } \\
\text { Recursos humanos: } \\
\text { • Pessoal administrativo insuficiente e } \\
\text { necessitando qualificação; } \\
\text { • Faltam assessorias técnico-políticas; } \\
\text { - Instabilidade na manutenção de políticas } \\
\text { estruturantes (formação, organização, sindical } \\
\text { etc). } \\
\text { Direções: } \\
\text { • Muitos dirigentes não têm liberação sindical. }\end{array}$ \\
\hline $\begin{array}{l}\text { Sobre as relações políticas nas direções } \\
\text { estaduais }\end{array}$ & $\begin{array}{l}\text { - Com poucas exceções, a tônica geral é de ver a } \\
\text { disputa interna como sério obstáculo ao } \\
\text { desenvolvimento do projeto CUT; } \\
\text { • Dirigentes assumem os cargos, mas não } \\
\text { cumprem o mandato, e alguns simplesmente } \\
\text { abandonam a CUT, independentemente de } \\
\text { liberação; } \\
\text { • Vários dirigentes priorizam a gestão em seus } \\
\text { sindicatos de origem, ou disputas/projetos } \\
\text { partidários, em detrimento das ações da CUT; } \\
\text { - A formação sindical é uma necessidade geral. } \\
\text { Duas a três CUTs apresentavam problemas } \\
\text { políticos mais graves, levando à quase } \\
\text { inoperância. }\end{array}$ \\
\hline $\begin{array}{l}\text { Sobre os setores/ramos considerados em cada } \\
\text { Estado }\end{array}$ & $\begin{array}{l}\text { Em geral, os setores que estão representados nas } \\
\text { direções das CUTs: } \\
\text { - Têm maior apoio e acompanhamento em suas } \\
\text { mobilizações; } \\
\text { - Têm maior adesão nas mobilizações gerais das } \\
\text { CUTs, possibilitando inclusive a utilização } \\
\text { solidária de estruturas (auditórios, gráficas, carros }\end{array}$ \\
\hline
\end{tabular}




\begin{tabular}{|c|c|}
\hline & $\begin{array}{l}\text { de som); } \\
\text { Têm índice de inadimplência relativamente } \\
\text { menor, dependendo da correlação de forças } \\
\text { interna (a exceção é a região Norte). }\end{array}$ \\
\hline $\begin{array}{l}\text { Sobre as relações políticas entre verticais } \\
\text { e estaduais nas regiões - I }\end{array}$ & $\begin{array}{l}\text { • Há distanciamento generalizado entre CUTs e } \\
\text { sindicatos; } \\
\text { - A interação entre eles ocorre, via de regra, em } \\
\text { momentos críticos: greves, negociações } \\
\text { frustradas, conflitos de base e eleitorais; } \\
\text { - A relação da CUT com os sindicatos por vezes é } \\
\text { substituída pela relação entre correntes/tendências } \\
\text { e os sindicatos; } \\
\text { • Por vezes, são projetos político-partidários que } \\
\text { orientam a criação de sindicatos, muitas vezes à } \\
\text { margem da atuação/projeto da CUT no Estado. }\end{array}$ \\
\hline $\begin{array}{l}\text { Sobre as relações políticas entre verticais } \\
\text { e estaduais nas regiões - II }\end{array}$ & $\begin{array}{l}\text { As CUTs mais bem organizadas, com menores } \\
\text { índices de inadimplência dos sindicatos e com } \\
\text { menos disputas internas, conseguem desenvolver } \\
\text { várias ações: } \\
\text { • Campanhas salariais unificadas - algumas } \\
\text { CUTs; } \\
\text { - Acompanhamento da elaboração de pautas e } \\
\text { negociação } \\
\text { dos setores - com alguns setores; } \\
\text { - Mobilização para lutas gerais envolvendo } \\
\text { sindicatos/ setores. }\end{array}$ \\
\hline $\begin{array}{l}\text { As CUTs atuam na Organização por } \\
\text { Local de Trabalho - OLT? }\end{array}$ & $\begin{array}{l}\text { A concepção geral é de que as CUTs têm de ser o } \\
\text { referencial político/formativo na constituição e } \\
\text { implementação da OLT. O acompanhamento mais } \\
\text { direto é função dos sindicatos. }\end{array}$ \\
\hline
\end{tabular}

Sistematização: Secretaria Nacional de Formação/Marta Regina Domingues (CUT, 2006a)

Em relação aos ramos, o resultado do Projeto Estratégia e Organização da CUT: construindo o Futuro elencou as seguintes questões: 
"Em relação ao papel das entidades na coordenação de lutas as respostas foram bastante distintas. Por um lado, havia diversas entidades que faziam avaliação positiva do seu papel de coordenar e dinamizar as lutas, pois se constituíram em referência ao conjunto das entidades sindicais de base e, também, aos trabalhadores. Algumas apresentaram avaliação destacando as dificuldades da entidade nacional no sentido de desempenhar o papel de coordenação, afirmando que o seu papel está aquém das necessidades, no máximo conseguindo acompanhar e orientar as lutas.

Havia poucos projetos envolvendo diversos ramos. Os exemplos destacados foram atuação conjunta na Companhia do Vale do Rio Doce, certificação profissional, política nacional de transporte, defesa da saúde e educação. Também aparece a atuação transversal das entidades de profissionais liberais em diversos ramos. As atividades conjuntas são mais comuns a partir de lutas gerais e concretas coordenadas pela Central.

A questão da organização sindical (consolidação do ramo, unificação, reforma sindical, OLT, reestruturação da estrutura sindical do ramo) apareceu, de diferentes maneiras, como uma das prioridades dos diversos ramos entrevistados. Também apareceram, em relação à negociação coletiva, preocupações comuns, tais como contrato coletivo nacional e viabilização da negociação. Ao mesmo tempo, são indicadas questões específicas, a partir da realidade de cada entidade nacional.

Os problemas indicados para viabilizar as prioridades não apresentavam grandes convergências. Os citados foram complexidade do ramo, cultura corporativa e atomizada dos sindicatos; problemas organizativos e financeiros do ramo; estruturação do setor e resistências patronais; resistências de outras organizações sindicais (sindicatos majoritários).

Em relação às principais diretrizes de cada ramo, o enfoque principal esteve em consolidar ou reestruturar o projeto organizativo da entidade sindical. As demais diretrizes prioritárias refletem as preocupações específicas de cada ramo”. (CUT, 2006a:93) 


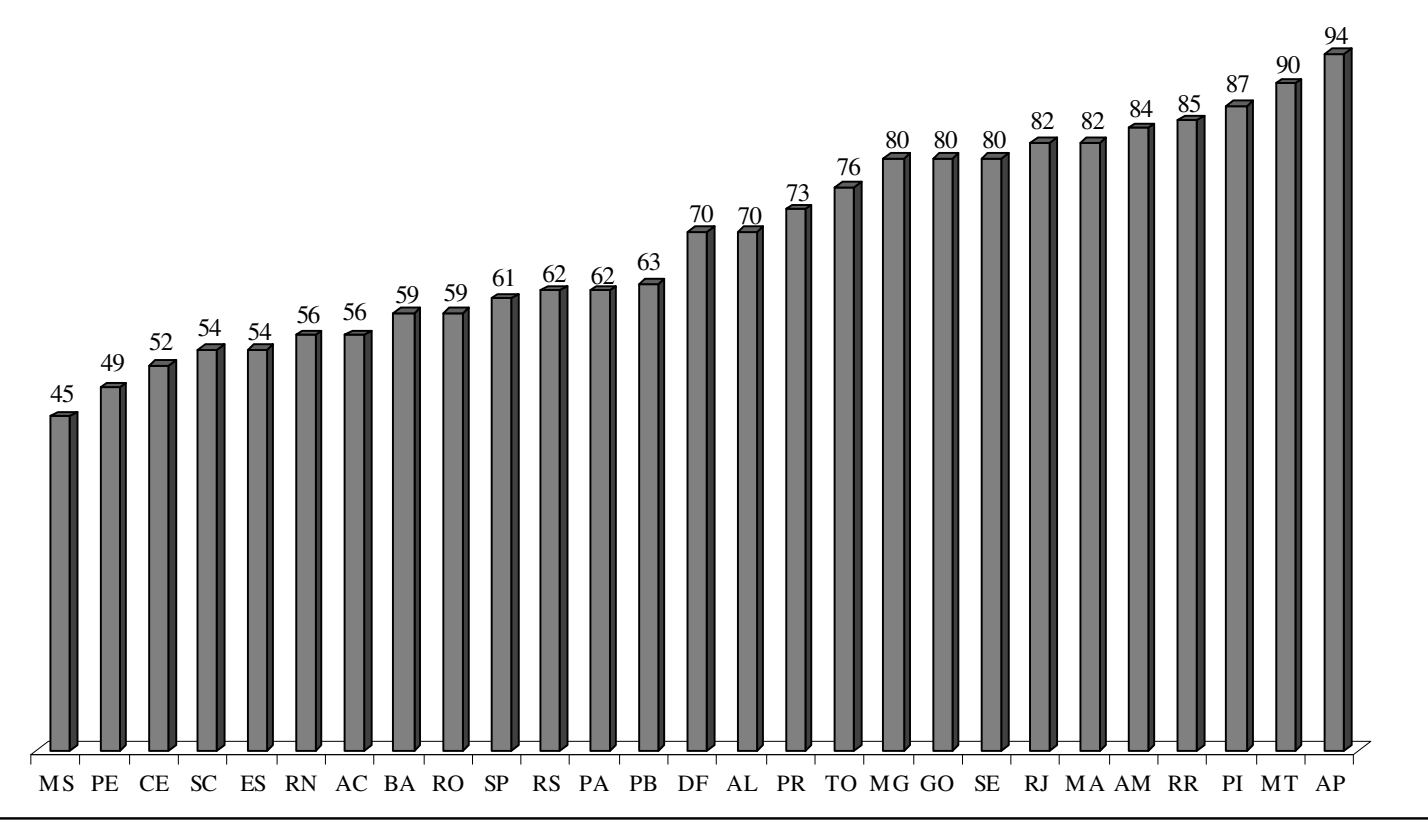

Fonte: Tesouraria CUT Nacional / Projeto CUT Estratégia e Organização da CUT: Construindo o Futuro

A sustentação financeira é grave problema na estrutura vertical e na estrutura horizontal. Como mostra o gráfico 6, o índice de inadimplência dos sindicatos com a CUT é altíssimo, variando de $45 \%$ de sindicatos devedores no Mato Grosso do Sul, até 94\% de sindicatos em débito no Amapá. De acordo com o artigo 71 do estatuto da CUT, a mensalidade paga à CUT corresponde a $10 \%$ da receita bruta anual da entidade filiada - sindicato, federação ou confederação $^{112}$. Pelo artigo 72 do estatuto, o dinheiro é recolhido pela CUT Nacional que então distribui o montante arrecadado do seguinte modo: 3,6\% para as CUTs Estaduais; 3,8\% para as Confederações Orgânicas e entidades nacionais filiadas; $2,2 \%$ para a CUT Nacional; 0,2\% para o Fundo de Fortalecimento das Estaduais e 0,2\% para Fundo de Solidariedade. (CUT, 1999)

\footnotetext{
${ }^{112} \mathrm{O} 3^{\circ}$ CONCUT (1988) definiu que a contribuição das entidades filiadas à CUT deveria ser 5\% das receitas brutas anuais. Até aquele momento, as entidades pagavam 5\% das mensalidades a título de "taxa de luta ou de solidariedade". Na 4 a Plenária Nacional (1990) adotou-se um sistema de cobrança bancária e débito automático, mantendo o pagamento dos sindicatos à CUT em 5\% de seus orçamentos. A $7^{\text {a }}$ Plenária (1995) aprovou o aumento do percentual da mensalidade cobrada pela CUT às entidades filiadas, de 5\% para 9\% (com indicativo de aumento para $10 \%$ na plenária seguinte), incluindo contribuições pagas à estrutura vertical orgânica e/ou filiada, distribuindo-a da seguinte maneira: $2 \%$ para a CUT Nacional; 3,5\% para as CUTs Estaduais; e 3,5\% para entidades da estrutura vertical. A 8 a Plenária (1996) confirmou o aumento da contribuição para $10 \%$ e uma forma de distribuição que permanece até o presente momento. (VÉRAS, 2001)
} 
As entidades em débito perdem o direito de participar dos fóruns de deliberação da CUT, como o Congresso e a Plenária Nacional. Da mesma forma, as entidades nessa situação ficam impedidas de participar de qualquer atividade da CUT, mesmo sem ser deliberativa, como curso de formação sindical, por exemplo.

As sanções obrigam muitos sindicatos devedores a procurar a tesouraria da CUT Nacional perto dos períodos congressuais, a fim de propor acordo de parcelamento de dívida, habilitando-se a participar com delegação das instâncias máximas da CUT e das atividades do ramo. Em caso de não cumprimento do acordo, o sindicato volta à situação de impedimento na participação da vida política da CUT.

Além dessa fonte de receita, a CUT Nacional também busca financiamento em projetos de cooperação internacional com centrais sindicais internacionais. Desde meados dos anos 90, com o Planfor, tem conseguido estabelecer convênios com o Ministério do Trabalho para a execução de cursos de formação profissional com recursos do Fundo de Amparo ao Trabalhador (FAT), entre outras fontes, como prevê o artigo 69 do estatuto.

Em função desse quadro, a restrição orçamentária da CUT (nacional e estaduais) e dos ramos (federações e confederações orgânicos) é fator de fragilidade nas ações da Central. O que a torna, muitas vezes, dependente de grandes sindicatos filiados, que por sua vez assumem espaço central de poder na CUT. A "consulta" aos principais dirigentes dos grandes sindicatos sobre questões políticas relevantes, sobretudo em períodos congressuais, para definição da chapa que concorrerá aos cargos de direção, é prática comum nas instâncias horizontais e nos ramos da CUT. Isso confere aos principais dirigentes dos grandes sindicatos papel, no mínimo, de "influência" no sindicalismo-CUT.

Em relação à questão financeira, as conclusões do Projeto Estratégia foram:

“...nossa expectativa é de que, a partir dos debates realizados nos CECUTs, a Direção Nacional Executiva apresente propostas objetivas para os seguintes pontos:

- a relação financeira da CUT Nacional, suas instâncias e estruturas, com critérios que contemplem as reais necessidades das CUTs e ramos em dificuldades;

- o fortalecimento do Fundo de Solidariedade;

- a implementação de uma política de financiamento para concretizar a estratégia de formação da Central, conforme deliberações do $5^{\circ}$ CONCUT.

Considerando também o alto índice de inadimplência financeira de sindicatos com a CUT, o que, inclusive, tem comprometido o funcionamento das Estaduais, os participantes do Projeto 
Construindo o Futuro propõem que a atual Executiva da CUT apresente ao $9^{\circ} \mathrm{CONCUT}$ propostas e critérios para a questão da inadimplência das entidades. Apresentamos a seguir algumas possibilidades construídas nos debates, a título de subsídio, nos quais se propõe que a Central:

- Crie mecanismos concretos de monitoramento e sensibilização para coibir as inadimplências e a sonegação dos sindicatos, mas identificando situações especiais, como sindicatos que não recebem os repasses da fonte pagadora;

- Implemente o desconto automático da contribuição estatutária à CUT; e reveja e distinga o percentual de contribuição de acordo com a realidade das entidades;

- Defina parâmetros claros para tomada de decisão no sentido de desfiliar sindicatos ou negociar as dívidas, estabelecendo, ao mesmo tempo, uma política de desfiliação de entidades que venha a abranger as questões relativas à inadimplência e à criação de oposições cutistas, no que se refere àqueles sindicatos que não assumem as políticas da Central”. (CUT, 2006a, 100-101)

O relatório final do Projeto apresentou propostas aos CECUTs e ao $9^{\circ}$ CONCUT, resultado do diagnóstico e dos debates em dois anos de execução, contemplando temas como organização sindical e ampliação de representatividade (inclui subtemas como estratégias de organização por local de trabalho - OLT; fortalecimento da atuação das estaduais da CUT; formação sindical; terceirização; desempregados e trabalhadores do setor informal); organização sindical e negociação coletiva; estrutura organizativa e relação entre entidades cutistas (inclui como subtemas a relação financeira entre as entidades cutistas e a solução de conflitos na base da CUT, observando princípios éticos); relação da CUT com o Estado e a sociedade, tendo como subtema a intervenção nos orçamentos públicos. Contribuições dos quatro macrossetores (indústria, comércio e serviços, serviço público e rurais) foram agregadas como sugestões a serem observadas após o período congressual do $9^{\circ}$ CONCUT.

\section{O FNT e seus resultados}

Apenas ratificando, a reforma sindical propriamente dita foi debatida em três grupos temáticos: organização sindical; negociação coletiva; e sistema de composição de conflito. Foi mencionado que o resultado gerou a Proposta de Emenda Constitucional no 369 (PEC 369/05) e o Anteprojeto de Lei de Relações Sindicais (ALRS).

Nesta seção está o detalhamento das propostas aprovadas para apreciação e as polêmicas geradas. A fim de organizar melhor, neste trabalho, a exposição do debate, isso se concretizará a partir do resultado de cada GT, da forma como apresentada no Relatório 
Final do FNT. Antes de o debate ser transformado em texto jurídico, com artigos, capítulos, parágrafos e incisos. Ressaltaremos as mudanças observadas entre o relatório final e as propostas (PEC e ALRS).

\section{A PEC 369/05 e o Anteprojeto de Lei de Relações Sindicais (ALRS)}

A PEC 369/05 dá nova redação aos artigos $8^{\circ}, 11^{\circ}, 37^{\circ}$ e $114^{\circ}$ da Constituição Federal.

$\mathrm{O}$ artigo $8^{\circ}$, que na atual CF regulamenta a associação profissional ou sindical, passaria a vigorar com a seguinte redação, encaminhada pela PEC:

"Art. $8^{\circ}$. É assegurada a liberdade sindical, observado o seguinte:

I - O Estado não poderá exigir autorização para fundação de entidade sindical, ressalvado o registro no órgão competente, vedadas ao Poder Público a interferência e a intervenção nas entidades sindicais;

II - O Estado atribuirá personalidade sindical às entidades que, na forma da lei, atenderem a requisitos de representatividade, de participação democrática dos representados e de agregação que assegurem a compatibilidade de representação em todos os níveis e âmbitos da negociação coletiva; III - Às entidades sindicais cabe a defesa dos direitos e interesses coletivos ou individuais do âmbito da representação, inclusive em questões judiciais e administrativas;

IV - A lei estabelecerá o limite da contribuição em favor das entidades sindicais que será custeada por todos os abrangidos pela negociação coletiva, cabendo à assembleia geral fixar seu percentual, cujo desconto, em se tratando de entidade sindical de trabalhadores, será efetivado em folha de pagamento;

V - A contribuição associativa dos filiados à entidade sindical será descontada em folha de pagamento;

VI - Ninguém será obrigado a filiar-se ou a manter-se filiado a sindicato;

VII - É obrigatória a participação das entidades sindicais na negociação coletiva;

VIII - O aposentado filiado tem direito a votar e ser votado nas organizações sindicais; e

IX - É vedada a dispensa do empregado sindicalizado a partir do registro da candidatura a cargo de direção ou representação sindical; se eleito, ainda que suplente, até um ano após o final do mandato, salvo se cometer falta grave nos termos da lei.

Parágrafo único: as disposições deste artigo aplicam-se à organização de entidades sindicais rurais e de colônias de pescadores, atendidas as condições que a lei estabelecer". (FNT, 2005) 
A mudança mais evidente é a que altera o inciso II, que atualmente dá amparo legal à unicidade sindical e propõe a questão da personalidade sindical, submetida aos "requisitos de representatividade, participação democrática dos representados e agregação, que assegurem a compatibilidade de representação em todos os níveis e âmbitos da negociação coletiva".

Outra inovação importante na PEC foi observada por Silva: "A PEC esvazia a expressão sindicato, que deixaria de ser o centro do sistema sindical. Em seu lugar, a locução entidades sindicais alarga o campo das prerrogativas e incidência da norma constitucional sobre a totalidade das entidades sindicais, sejam elas centrais, confederações, federações, sindicatos ou representações nos locais de trabalho. (...) A constitucionalização da expressão entidades sindicais pretende possibilitar que o conjunto das entidades, de todas as instâncias, possam negociar, firmar acordos (inciso VI, Art. $8^{\circ}, \mathrm{CF}$ ), receber contribuições (incisos IV e IVA Art. $8^{\circ}, \mathrm{CF}$ ) e representar em juízo em defesa dos direitos e interesses coletivos no âmbito de representação (inciso III, Art. $8^{\circ} \mathrm{CF}$ )". (SILVA, 2005)

A nova redação do artigo $11^{\circ}$, proposta pela PEC, assegura a representação dos trabalhadores nos locais de trabalho, na forma da lei. A mudança da PEC em relação à Constituição é que o atual texto constitucional assegura a eleição de um representante dos trabalhadores nas empresas com mais de 200 empregados, ao passo que o ALRS estipula um quadro em que a representação dos trabalhadores nos locais de trabalho varia de um membro nas empresas de 30 a 80 empregados, até seis membros nas empresas de 801 a 1000 empregados, acrescendo mais representantes nas empresas acima de 1000 empregados, conforme fração superior a 500 empregados.

A PEC altera o artigo $37 \mathrm{da} \mathrm{CF}$, que trata do direito de greve no setor público. A redação proposta - "a negociação coletiva e o direito de greve serão exercidos nos termos e nos limites definidos em lei específica" - acrescenta a negociação coletiva ao texto constitucional, assegurando que também ele será direito para os sindicatos do setor público e não apenas o direito de greve, que permanece.

Por fim, o artigo $114^{\circ}$ da CF tem alterado o texto do inciso III para ferir o poder normativo da Justiça do Trabalho:

“...Recusando-se qualquer das partes à arbitragem voluntária, é facultado às mesmas, de comum acordo, na forma da lei, ajuizar ação normativa, podendo a Justiça do Trabalho decidir o conflito, 
respeitadas as disposições mínimas legais de proteção ao trabalho, bem como as convencionadas anteriormente". (FNT, 2005)

Inicialmente, o texto da PEC afirma a possibilidade de arbitragem voluntária, isto é, escolhida entre as partes. Em seguida reserva à Justiça do Trabalho poder decidir o conflito não a partir de sua exclusiva vontade, mas respeitando as "disposições mínimas legais de proteção ao trabalho, bem como as convencionadas anteriormente".

A PEC introduz no artigo $114^{\circ}$ o texto: "Em caso de greve em atividade essencial, o Ministério Público do Trabalho tem legitimidade para ajuizamento de ação coletiva quando não forem assegurados os serviços mínimos à comunidade ou assim exigir o interesse público ou a defesa da ordem jurídica".

Em resumo, "a redação proposta [pela PEC] determina a extinção da unicidade sindical, da contribuição sindical obrigatória, da contribuição confederativa e dos conceitos de categoria profissional e econômica como critérios de aglutinação legal para a formação de sindicatos". (SILVA, 2005)

\section{O Conselho Nacional de Relações de Trabalho (CNRT)}

A primeira inovação proposta pelo FNT no sistema sindical em vigor foi a criação do Conselho Nacional de Relações de Trabalho.

De acordo com o ALRS, o CNRT seria órgão tripartite que teria as seguintes atribuições definidas no artigo 133:

“Art. 133. Compete à Câmara Tripartite:

I - aprovar o regimento interno do CNRT;

I - examinar e encaminhar para deliberação do ministro do Trabalho e Emprego a lista de agregação por setores econômicos e ramos de atividades das entidades sindicais de trabalhadores e de empregadores, conforme propostas apresentadas pelas respectivas Câmaras Bipartites;

III - aprovar o procedimento de recolhimento e da prestação de contas dos valores da contribuição de negociação coletiva;

IV - propor, para aprovação do ministro do Trabalho e Emprego, as disposições estatutárias mínimas a serem observadas pelos sindicatos que postularem a exclusividade de representação, visando assegurar princípios de liberdade organizativa, democracia interna e de respeito aos direitos de minoria;

$\mathrm{V}$ - definir os procedimentos e prazos relativos à contestação e à confirmação da personalidade sindical; 
VI - propor os setores econômicos e os ramos de atividade suscetíveis de representação específica, consideradas suas peculiaridades;

VII - propor a revisão de critérios e dirimir dúvidas relativas aos setores econômicos e ramos de atividade;

VIII - examinar, a cada 8 (oito) anos, a necessidade de revisão dos critérios de representatividade das entidades sindicais, propondo as alterações que julgar cabíveis;

IX - propor diretrizes de políticas públicas e opinar sobre programas e ações governamentais no âmbito das relações de trabalho;

X - opinar sobre as matérias previstas no art. $5^{\circ}$ da Convenção 144 da Organização Internacional do Trabalho;

XI - opinar sobre pareceres referentes aos projetos legislativos em tramitação no Congresso Nacional, no âmbito das relações de trabalho;

XII - propor disposições normativas sobre assuntos afetos às relações de trabalho;

XIII - definir critérios para a utilização dos recursos do FSPS, considerando as propostas elaboradas pelas Câmaras Bipartites;

XIV - elaborar a proposta orçamentária do FSPS;

XV - deliberar sobre a prestação de contas e os relatórios de execução orçamentária e financeira do FSPS;

XVI - acompanhar a fiscalização e a administração do FSPS, podendo solicitar informações sobre contratos celebrados, ou em vias de celebração, e quaisquer outros atos, sem prejuízo das competências dos órgãos de controle interno e externo;

XVII - dar publicidade, com periodicidade anual, aos critérios de alocação e de uso dos recursos do FSPS;

XVIII - propor a alteração do rol de serviços ou atividades essenciais previsto nesta Lei;

XIX - propor diretrizes sobre as estatísticas e as informações referentes às relações de trabalho, representatividade, índice de filiação sindical, práticas antissindicais, greves, celebração de contratos coletivos e sentenças judiciais e arbitrais proferidas na solução de conflitos coletivos de interesses". (FNT, 2005)

O rol de atribuições ao CNRT detalhou a proposta contida no Relatório final do FNT, ampliando seu poder. No Relatório, consta como uma das atribuições do CNRT "propor ao Poder Executivo... o procedimento de cobrança e comprovação do repasse dos valores da contribuição de negociação coletiva"; e no ALRS o texto encaminhado afirma como 
atribuição "aprovar o procedimento de recolhimento e da prestação de contas dos valores da contribuição de negociação coletiva".

Da mesma forma, o ALRS ampliou a responsabilidade do CNRT em relação ao Fundo Solidário de Promoção Sindical (FSPS), que no Relatório tinha apenas a afirmação genérica de "estabelecer critérios para a utilização dos recursos do Fundo Solidário de Promoção Sindical” (FNT, 2004: 18) No texto final, além do que constava no Relatório, incluiu-se "elaborar a proposta orçamentária do FSPS; deliberar sobre a prestação de contas e os relatórios de execução orçamentária e financeira do FSPS; acompanhar a fiscalização e a administração do FSPS, podendo solicitar informações sobre contratos celebrados, ou em vias de celebração, e quaisquer outros atos, sem prejuízo das competências dos órgãos de controle interno e externo; e dar publicidade, com periodicidade anual, aos critérios de alocação e de uso dos recursos do FSPS". (FNT, 2005:62)

Enfim, entre o relatório final do FNT e o encaminhamento do ALRS ao Congresso Nacional, o CNRT teve as atribuições ampliadas, justificando com isso algumas críticas recebidas quanto ao exagero da intervenção do Estado na reforma do sistema sindical.

Para Carlos Alberto Grana, então presidente da Confederação Nacional dos Metalúrgicos da CUT e um dos representantes da Central no FNT, o CNRT deveria ter ainda mais atribuições do que o encaminhado, para esvaziar o poder discricionário do ministro do Trabalho, transferindo-o para um espaço tripartite de negociação entre os representantes sindicais de trabalhadores, empregadores e governo:

“... se observarmos a primeira versão do anteprojeto de lei, veremos que o poder do ministro era inclusive superior ao que acabou sendo enviado agora no projeto de lei. Tentamos amenizar o máximo possível a presença do ministro do Trabalho, mas é um problema que não conseguimos superar na negociação com o governo. Vamos continuar insistindo junto ao Congresso - deixamos claro isso - que o Conselho não seja meramente homologador das decisões do ministro. Essa crítica cabe sim ao projeto de lei. Temos feito e vamos continuar fazendo. Há um excesso de poder do ministro. Da parte do governo, eles sempre afirmam que 'como não passou a ideia da Convenção 87, o Estado ainda prevalece com atribuições em função da exclusividade de representação'. E aí na lei não existem os poderes plenos do Conselho, então o ministro permanece no período de transitoriedade. Não sei como vamos conseguir avançar, mas de fato ainda mantém muito no projeto a presença do Estado. Inclusive na própria PEC, estávamos trabalhando uma ideia ontem de diminuir esse papel que reserva ao Estado. É uma disputa. Nossa posição é muito clara. Achamos que tem um excesso de poder do ministro (...) Temos que continuar trabalhando para alterar o poder 
do ministro. E olha que foi amenizado da primeira versão. Mas na primeira versão o CNRT era só praticamente para assinar. Em boa parte era 'sugerir', 'sugerir', 'sugerir'... Aí o governo nos responde: 'mas você acha que o ministro é louco de tomar uma decisão sem levar em conta a posição do Conselho?' E nós falamos: 'É. Lógico que é.' Como já teve várias vezes. E vai comprar briga. Então a gente tem que diminuir ao máximo o poder do ministro e dar mais poderes ao Conselho, que seja mais deliberativo..." (GRANA, 2004)

\section{Organização Sindical}

Entre os temas debatidos no GT Organização Sindical, destacamos, resumidamente, como principais pontos de discussão, a representatividade das entidades sindicais e os critérios estabelecidos para auferi-la (representatividade comprovada e representatividade derivada); a possibilidade de manutenção da exclusividade na representação, desde que aprovada na assembleia da categoria e que o sindicato assuma em seu estatuto algumas "regras democráticas"; o reconhecimento das centrais sindicais dentro do sistema sindical; o enquadramento sindical pelo ramo de atividade econômica e não mais pela categoria profissional, exclusivamente; a sustentação financeira das entidades, e a representação sindical nos locais de trabalho.

Para a advogada Sayonara Grillo Coutinho Leonardo da Silva, "três seriam os critérios introduzidos na Constituição que norteariam o novo sistema sindical a ser fixado pelo legislador ordinário: requisitos de representatividade, de agregação e participação democrática dos representados. (...) Em síntese, estas seriam as principais alterações nos princípios e regras constitucionais aplicáveis ao sistema sindical brasileiro se aprovada a PEC 369, provocando uma reforma importante na organização sindical”. (SILVA, 2005: 5-6)

Diante da necessidade de fortalecer a representatividade das entidades sindicais tendo em vista o estímulo à negociação capital/trabalho, o FNT manteve a lógica da liberdade para criação de sindicatos, permanecendo a ideia do artigo $8^{\circ}$ da CF, inciso I. Entretanto, para limitar a pulverização e o consequente enfraquecimento pela criação de inúmeros sindicatos cartoriais, a proposta definiu critérios para o reconhecimento da representatividade das entidades e a habilitação das mesmas para o efetivo exercício da atividade sindical.

A representatividade das entidades sindicais adviria de duas fontes. Uma delas - a representatividade comprovada -, a comprovação do índice de sindicalização requerido 
pela lei para a entidade em seu grau (sindicato, federação, confederação ou central sindical).

Por exemplo, o sindicato teria a representatividade comprovada alcançando o índice de $20 \%$ de sócios entre os trabalhadores de base ${ }^{113}$. Para as entidades de grau superior (federações, confederações e centrais sindicais), além do índice de sindicalização de trabalhadores na base dos sindicatos-membro, deveria constar também a abrangência territorial e por setores econômicos ${ }^{114}$.

Outra possibilidade prevista é a da representatividade derivada, ou seja, quando advém de entidades de grau superior (federação, confederação ou central sindical) que já tenha representação comprovada e decidem transferir parte de sua representatividade para apoiar sindicatos/federações/confederações. No linguajar dos dirigentes sindicais, significa "ter gordura" (representatividade acima da requerida por lei) para assumir a criação/existência de sindicato com índice de sindicalização abaixo do requerido por lei.

Diz o Relatório final do FNT, em relação às centrais sindicais: “... as centrais sindicais, obedecidos os critérios de enquadramento por setores econômicos e por ramos de atividade econômica, poderão constituir, por meio de representação derivada ou comprovada, estruturas

\footnotetext{
${ }^{113}$ Segundo Nelson José dos Santos, do MTE, em seminário para sindicalistas da CUT, em Bauru (SP), “... hoje o sistema é extremamente autoritário, dependendo da "canetada" de funcionários do ministério, que tomam decisão com base em uma portaria. E muitas vezes vemos situações ridículas, a gente reconhece, mas a gente não tem o poder de indeferir a criação de um sindicato que a gente sabe que é uma fraude, porque a papelada está toda de acordo com a lei. Em assembleias que nem existiram. Esse processo vai mudar. O MTE vai aferir a representatividade. Como vai se dar esse processo? Os trabalhadores da Petrobras aqui de São Paulo, por exemplo, querem ter a prerrogativa da representação sindical. Eles então irão apresentar ao MTE uma relação comprovando que tem $20 \%$ de sócios na categoria, em tais e tais locais de trabalho. O MTE vai averiguar essa documentação tendo como referência as informações que todas as empresas têm de enviar para o RAIS/CAGED. Pelo RAIS/CAGED, o MTE tem condição de saber o tamanho de todas as categorias do Brasil. O segundo processo de auditagem será saber se esses trabalhadores estão filiados ao sindicato. Os sindicatos terão que apresentar documentação comprovando que aqueles trabalhadores se filiaram ao sindicato. Se houver algum questionamento, podemos chegar até o trabalhador, porque na RAIS/CAGED tem o nome do trabalhador com o número do CPF. Nós estamos mudando todo o sistema de registro sindical. Vai ter um censo, um recadastramento sindical agora em dezembro para pegar os sindicatos e amarrar o nosso cadastro com a CNPJ". (ESCOLA SINDICAL SÃO PAULO, 2004)

${ }^{114}$ Critérios para representatividade comprovada das centrais sindicais: contar com sindicatos reconhecidos em pelo menos 18 unidades da Federação, contemplando as cinco regiões do país; ter o índice de sindicalização igual ou superior a $15 \%$ em pelo menos nove dos 18 Estados; a soma dos trabalhadores sindicalizados nos sindicatos pertencentes à Central deve ser igual ou superior a 22\%; e deve ter o índice de sindicalização igual ou superior a $15 \%$ em nível nacional em pelo menos sete setores econômicos. O critério para reconhecimento da representatividade comprovada exigida das confederações e federações é muito semelhante ao das centrais, com a diferença que as federações teriam âmbito estadual de atuação e não nacional. Além disso, confederações poderiam ter representatividade derivada de alguma das centrais sindicais; e as federações, representatividade derivada de alguma das centrais sindicais ou confederações. (FNT, 2004: 30 - 32)
} 
organizativas próprias, tais como confederações por setor econômico e federações estaduais e interestaduais por ramo de atividade econômica; (...) desde que não comprometam o percentual mínimo exigido para o seu reconhecimento, as centrais sindicais poderão criar, como parte de sua estrutura organizativa, sindicatos municipais, intermunicipais, estaduais, interestaduais e nacionais por ramo de atividade econômica, pelo critério de representatividade derivada...” (FNT, 2004: 28) As confederações não filiadas à central sindical, obedecido o mesmo critério de manutenção de sua representatividade comprovada, poderia criar federações e sindicatos por meio de representatividade derivada; e as federações não filiadas à central sindical criar sindicatos. (FNT, 2004: 28-29)

À primeira vista, as entidades de grau superior, especialmente as centrais sindicais, conquistaram enorme poder com a prerrogativa de conceder ou não representatividade derivada para reconhecimento de sindicatos, federações e confederações. No entanto, diz o texto, que "as centrais sindicais serão constituídas a partir dos sindicatos com a representatividade comprovada...". O mesmo ocorre para as confederações e federações não filiadas à central sindical. Ou seja, antes de exercer a prerrogativa de conceder representatividade derivada, a entidade deve contar com sindicatos que tenham a representatividade comprovada com pelo menos $20 \%$ de sócios.

A esse respeito, Osvaldo Bargas, ex-dirigente da CUT e na ocasião secretário das Relações de Trabalho do MTE e membro da coordenação do FNT, explicou a proposta a dirigentes da CUT:

"O que é a história do derivado? Para reconhecer o direito do sindicato negociar ele tem que ter $20 \%$, porque se estabelece na medida em que ele quer. Se quiser, junta dez trabalhadores, vai a um cartório e está criado o sindicato. Mas esse sindicato que foi criado lá no cartório com dez pessoas vai existir, mas não tem direito de negociar enquanto não chegar aos $20 \%$ de sócios. O patrão não é obrigado a negociar com ele, ele não tem estabilidade, não pode arrecadar a contribuição negocial, não pode obrigar as empresas a descontar a mensalidade em folha de pagamento... Praticamente vai ser muito difícil criar sindicatos novos... O pessoal defensor da unicidade fica com medo disso (...) o medo deles na verdade é não atingir os $20 \%$, porque não querem trabalhar. (...) Para chegar a $20 \%$ é muito complicado, e todo sindicato hoje existente vai ter cinco anos para chegar aos 20\%. Vamos supor que nesse período o sindicato chegue a $18 \%$. Vai fazer o quê? Vai virar ONG, sem poder descontar em folha, sem estabilidade, tudo isso?... O derivado é para salvar primeiro esse (...) Para ele não morrer como sindicato ele vai se filiar a uma federação/confederação/central sindical. E se essa federação/confederação/central sindical tiver uma "gordura", vai poder emprestar para ele os 
2\%. Se a federação/confederação/central sindical tiver um excedente de representatividade. E a federação/confederação/central sindical vai poder dizer que o sindicato vai ter que alcançar os $20 \%$ em dois anos porque ela precisa ajudar outros. Derivado é para dar um fôlego a essas categorias". (BARGAS, 2004)

Bargas explicou também que a representação derivada é meio de a federação/confederação/central sindical fazer sua política a partir de estratégia nacional: "Por exemplo, numa região que está tendo um grande crescimento econômico, até se constituir um sindicato e este obter $20 \%$ vai demorar muitos anos. Por isso, a federação/confederação/central sindical vai poder criar a partir de uma estratégia sua. A derivada é para permitir às centrais ter uma estratégia nacional. Mas para não permitir a pluralidade, a pulverização de sindicatos, tem aquela "trava", que é a gordura. Porque senão vira pluralismo mesmo; sai uma central sindical qualquer criando sindicato em tudo que é lugar...”. (BARGAS, 2004)

Contrapondo-se às análises da época, que afirmavam que a proposta do FNT beneficiaria as centrais sindicais, Bargas levanta a seguinte objeção: "É o sindicato que cria, que dá sustentação de representatividade para a federação/confederação/central. Todo o centro do poder do processo de construção de representação está sempre no sindicato. Ao contrário do que dizem aqueles que a central sindical faz tudo. O poder está sempre no sindicato". (BARGAS, 2004)

Ainda em relação à representatividade derivada conferida pela central a algum sindicato, os dirigentes sindicais cutistas expressaram, em diversos seminários sobre a reforma sindical, se a derivação da representatividade tornaria o sindicato orgânico à Central.

Bargas não deixou dúvidas:

"A relação de um sindicato de base para com a federação, para com a confederação, para com a central sindical, vai depender do estatuto dela. (...) Em nenhum momento diz no projeto que tem que ser ou não tem que ser orgânico. Diz que as entidades, cada uma, podem ser autônomas umas das outras. Por exemplo, se uma federação criar um sindicato derivado, esta federação é que vai dizer se aquele sindicato vai ser orgânico ou não. Esse é um problema dela". (BARGAS, 2004) Bargas ainda explicou, a partir de exemplo hipotético, que se a federação quiser criar um sindicato, ele começará com pouca sindicalização. Por isso, até alcançar os $20 \%$ de sócios levará "uns bons anos". Quando isso acontecer, o sindicato será autônomo porque não há na lei nada que o obrigue a permanecer ligado à federação/confederação/central sindical que o criou. Por esse motivo, acredita que as federações/confederações/centrais sindicais, ao criar um sindicato, provavelmente procurarão se resguardar para quando atingir 20\% de sócios. 
Mas isso não se resolve "pela lei ou estatuto". Segundo Bargas, "é na relação política que vai se firmar um compromisso de estar junto ou não. Com $20 \%$ de sócio eu faço uma assembleia, mudo de nome, todos os filiados vão continuar, e pronto. Volto a ser autônomo novamente. Essa relação tem que ser política". (BARGAS, 2005)

A proposta contida no Relatório final do FNT admite, portanto, segundo Bargas, a coexistência de entidades sindicais com e sem personalidade sindical. Ou seja, sindicato registrado em cartório, mas sem a prerrogativa de representação, negociação e sustentação financeira pelo recolhimento de contribuições e desconto da mensalidade em folha de pagamento. A personalidade sindical da entidade - direito de exercer efetivamente a atividade sindical - seria concedida apenas em caso de a entidade atender aos critérios de representatividade comprovada ou pela representatividade derivada de entidades de graus superior $^{115}$.

Além de um período de transição para a adoção do critério de representatividade comprovada, o Relatório final do FNT prevê a possibilidade de manutenção da exclusividade de representação para sindicatos existentes até a data da promulgação da nova lei. Com isso, ficaria uma "janela aberta" para permanecer a unicidade sindical.

A diferença é que a unicidade, ou a exclusividade de representação, ao invés de garantida por lei, deveria ser aprovada em assembleia da categoria, com ampla divulgação para participação dos trabalhadores. A eventual aprovação da exclusividade na assembleia não eximiria a entidade de cumprir o critério de representatividade comprovada no prazo de 36 meses, sendo prorrogado por 24 meses, a depender da análise da Câmara Bipartite do Conselho Nacional de Relações de Trabalho (CNRT).

Vencido esse prazo, que pode chegar a cinco anos, se a entidade sindical não tiver conseguido o índice requerido para reconhecimento da representatividade comprovada, perderá o direito à exclusividade de representação, instituindo-se a liberdade sindical naquela base. A representatividade derivada do sindicato, em nenhuma hipótese previa a possibilidade de manutenção da exclusividade de representação.

\footnotetext{
115 No ALRS, o artigo $\mathrm{n}^{\circ} 13$ define as atribuições e prerrogativas da entidade dotada de personalidade sindical: I - representar os interesses do respectivo âmbito de representação perante as autoridades administrativas e judiciárias; II - propor e participar de negociação coletiva; III - celebrar contratos coletivos de trabalho; IV - atuar em juízo como legitimado ordinário ou extraordinário; V - estabelecer contribuições de negociação coletiva.
} 
Mesmo em caso de aprovação da exclusividade pela assembleia de base e o alcance da representatividade comprovada, ainda assim o sindicato deveria adotar "regras estatutárias previstas na lei”. Tais normas estatutárias deveriam ser propostas pela Câmara Bipartite do CNRT no prazo de 120 dias após a promulgação da lei, tratando dos seguintes aspectos: "Direitos e deveres dos associados e dos membros da diretoria; estrutura organizativa e suas finalidades; composição da diretoria e suas atribuições; período dos mandatos dos membros da diretoria; penalidades e perda do mandato; requisitos para votar e ser votado; conselho fiscal e prestação de contas; remuneração dos membros da diretoria; processo eleitoral; e dissolução da entidade". (FNT, 2004:26-27). As normas estatutárias estabelecidas pelo CNRT seriam aprovadas por ato do Poder Executivo, sendo uma das condições para reconhecimento da exclusividade de representação.

Outro item polêmico do GT Organização Sindical diz respeito ao financiamento da estrutura sindical.

Atualmente, o financiamento do sistema sindical decorre de cinco principais fontes. Uma delas a contribuição associativa (mensalidade) dos trabalhadores que aderem, de livre e espontânea vontade, ao quadro de sócios do sindicato, autorizando, no ato da filiação, o desconto do valor percentual estabelecido pelo sindicato da folha de pagamento do empregador ${ }^{116}$.

Outra fonte é a contribuição sindical, disciplinada no art. 578 e seguintes da CLT, mais conhecida como imposto sindical, cuja receita provém de um dia de trabalho descontado do trabalhador em favor da estrutura sindical, assim distribuída: 60\% do arrecadado permanecem no sindicato; $15 \%$ se destinam às federações; $5 \%$ às confederações e $20 \%$ iam para o Ministério do Trabalho ${ }^{117}$.

A Constituição Federal de 1988, no artigo $8^{\circ}$, inciso IV, estabeleceu nova fonte, conhecida como contribuição confederativa, fixada por assembleia, "para custeio do sistema

\footnotetext{
${ }^{116}$ Segundo Flávia Moreira Pessoa, juíza do Trabalho (TRT - 20ª Região/Sergipe), professora de Direito do Trabalho, especialista em Direito Processual pela UFSC e mestranda em Direito, Estado e Cidadania pela UGF/RJ, a contribuição associativa está “...prevista no art. 548, alínea b, da CLT, mas que se funda no estatuto ou ata de assembleia geral de cada entidade sindical, fontes formais de sua exigibilidade. É, ainda, voluntária, sendo, portanto, paga apenas pelos associados ao sindicato". (PESSOA, 2003)

117 Veremos adiante que com a manutenção do imposto sindical e o reconhecimento legal das centrais sindicais, $10 \%$ do bolo arrecadado pelo imposto sindical ficam com as centrais, proporcionalmente ao número de trabalhadores representados pelos sindicatos filiados; e outros 10\% permanecem com o MTE.
} 
confederativo da contribuição sindical respectiva, independente da contribuição prevista em lei”.

Além destas, há também a contribuição assistencial. Também denominada taxa assistencial, taxa de reversão, contribuição ou cota de solidariedade ou desconto assistencial, a contribuição sob análise é uma prestação pecuniária voluntária feita pelo membro da categoria profissional ou econômica ao sindicato, com o objetivo de custear a participação da entidade nas negociações coletivas ou propiciar a prestação de assistência jurídica, médica, dentária, entre outras. A contribuição assistencial é estabelecida com fundamento no art. 513, alínea "e", da CLT. Sua fonte, porém, é sempre norma coletiva, seja acordo ou convenção coletiva, ou ainda sentença normativa. (PESSOA, 2003)

O FNT propôs a extinção gradual do imposto sindical ao longo de três anos ${ }^{118}$ e das contribuições confederativa e assistencial imediatamente a partir da vigência da nova legislação, substituindo-as pela contribuição de negociação coletiva. O relatório indica o seguinte:

“a) A contribuição de negociação coletiva, de periodicidade anual, vinculada à negociação coletiva, será recolhida por todos os trabalhadores beneficiados por instrumento normativo, independentemente de filiação sindical (...) c) os valores pagos pelos trabalhadores a título de contribuição de negociação coletiva não poderão ultrapassar $1 \%$ (um por cento) do valor da remuneração líquida recebida no ano anterior, que será paga em, no mínimo, 3 (três) parcelas mensais, a partir do mês de abril (...) f) os recursos provenientes da contribuição de negociação coletiva serão destinados ao custeio dos sindicatos, federações, confederações, centrais sindicais e do Fundo Solidário de Promoção Sindical, devendo ser fixado em lei os percentuais devido a cada nível de representação e ao Fundo..." (FNT, 2004:38-39)

Os percentuais para distribuição da contribuição de negociação coletiva aludida foram estabelecidos do seguinte modo: centrais sindicais (10\%); confederações (5\%); federações (10\%); sindicatos (70\%); e fundo solidário $(5 \%)$.

A substituição das contribuições sindical, confederativa e assistencial pela contribuição de negociação coletiva pode parecer inócua do ponto de vista político, ou algo meramente administrativo. Mas a premissa para a entidade sindical ter direito à contribuição de negociação coletiva é celebrar qualquer espécie de acordo coletivo ou convenção coletiva.

\footnotetext{
${ }^{118}$ A transição obedeceria às seguintes etapas: redução para 75\% de um dia de trabalho no primeiro ano; para 55\% de um dia de trabalho no segundo ano; e para 35\% de um dia de trabalho no terceiro ano. (FNT, 2004: 40)
} 
Dessa forma, se vincula a discussão sobre o financiamento da estrutura sindical com a da personalidade sindical a ser conferida para as entidades com representatividade comprovada ou derivada. Atualmente, para a entidade sindical receber a contribuição sindical, a confederativa ou a assistencial, basta ser reconhecida pelo ministério, independentemente de ser exercida qualquer ação em defesa dos interesses dos trabalhadores. Ao passo que o acesso à contribuição de negociação coletiva como receita para a entidade sindical pressupõe ação de representação e negociação em nome dos trabalhadores. Nessa lógica, poderia haver sindicatos que não pactuam instrumento de acordo ou convenção coletiva não tendo o direito de receber a contribuição de negociação coletiva, mesmo com representatividade comprovada ou derivada. Receberia apenas a mensalidade dos associados.

O último ponto a ser abordado nesta seção acerca do GT Organização Sindical trata da representação nos locais de trabalho, tema caro à CUT.

O Relatório final do FNT, bastante sucinto nesse ponto, indicou que o consenso foi frágil, dada a resistência patronal em aceitar a organização nos locais de trabalho.

O Relatório apenas menciona a representação sindical no local de trabalho e remete o tema para regulamentação por parte da Comissão de Sistematização, após a Plenária do FNT, devendo constar no projeto legislativo a ser remetido ao Congresso Nacional.

No ALRS o tema mereceu um título inteiro - do artigo 59 ao 89 - detalhando objetivos, instalação, eleição e posse, mandato, proteção aos representantes e à representação, direito de informação e de reunião, negociação coletiva no âmbito da empresa e mecanismos de conciliação de conflito individual.

No entanto, é digno de nota ressaltar que entre o Relatório do FNT e o envio do ALRS ao Congresso Nacional, o caráter da organização mudou de representação sindical para representação dos trabalhadores no local de trabalho.

Artigo n61 do ALRS:

“A representação dos trabalhadores nos locais de trabalho integra o sistema sindical e, sem prejuízo de sua autonomia, atua em colaboração com as entidades sindicais.

$\S 1^{\circ}$ Somente poderá existir uma única representação por local de trabalho.

$\S 2^{\circ}$ A representação dos trabalhadores será exercida conforme o regimento aprovado em assembleia". (FNT, 2005: 47) 
O ALRS enviado ao Congresso Nacional é concessão da CUT, que sempre defendeu dupla representação nos locais de trabalho: uma de caráter sindical, e outra geral, representando todos os trabalhadores da empresa, sócios ou não do sindicato, conforme também preconiza a Convenção 135 da OIT $^{119}$.

\section{Negociação Coletiva}

A seção referente à negociação coletiva no Relatório final do FNT e o Título IV do ALRS Do diálogo social, da negociação coletiva e do Contrato Coletivo de Trabalho -, têm o mesmo sentido: afirmar o primado da negociação coletiva para levar a bom termo as relações de trabalho, pressupondo boa fé entre as partes.

A recusa à negociação coletiva é vista como ato antissindical. A continuidade reiterada dessa postura implica perda da titularidade da entidade sindical no processo de negociação, seja ela representante dos trabalhadores ou dos empregadores. A nova legislação tem por pressuposto a promoção do diálogo.

O ponto mais polêmico, contido no Relatório do FNT e no ALRS, trata do relacionamento entre os níveis da negociação coletiva. Diz o texto do ALRS, artigo $100^{\circ}$, parágrafos $3^{\circ}$ e $4^{\mathrm{O}}$ :

"§ $3^{\circ} \mathrm{O}$ contrato coletivo de nível superior poderá indicar as cláusulas que não serão objeto de modificação em níveis inferiores.

$\S 4^{\circ} \mathrm{O}$ sindicato ficará vinculado ao contrato coletivo de nível superior se não requerer sua exclusão até o momento da celebração." (FNT, 2005: 55).

Esse foi um dos pontos considerados inaceitáveis pelas correntes da chamada "esquerda socialista" da CUT, sob a alegação que feriria a democracia ao prescindir das assembleias de base para celebrar acordos e convenções coletivas, caracterizando um grau de concentração e centralização "inaceitável”.

Osvaldo Bargas contra-argumentou:

"Se falou muito que esse projeto é para fortalecer as centrais sindicais, que dá superpoder às centrais sindicais, que as centrais sindicais é que vão negociar e não os trabalhadores; que os sindicatos vão perder força... Se me apontarem um artigo que se refere a isso, que dá margem a esse

119 A Convenção 135 da OIT afirma em seu artigo $3^{\circ}$ que a expressão "representante dos trabalhadores" significa pessoas reconhecidas como tais por lei ou práticas nacionais, quer sejam "representantes sindicais" ou "representantes eleitos"... cujas funções não incluem atividades reconhecidas como prerrogativas exclusivas de sindicatos no país interessado. (OIT, 2000: 21) 
entendimento, por favor, me digam onde está isso. Nenhum artigo diz que central sindical vai substituir sindicatos em processo de negociação, ou que confederação vai substituir sindicato... (...) Central sindical, no mundo inteiro, negocia o quê? Acordos nacionais. Com quem? Com o governo, com os partidos, com as instituições nacionais dos empregadores, temas como, por exemplo, política industrial, política de crédito, alíquota de imposto de renda, salário mínimo. Essas são tarefas das centrais sindicais. Isso é diferente do que acontece hoje? Esse é o papel da central sindical. Papel das confederações: as confederações têm que ser por setor de atividade. Hoje, por exemplo, a Volks não está só em São Bernardo; está em diversos Estados. A mesma coisa acontece com o Carrefour, com a Sadia... Então você acha que o acordo do sindicato da Sadia lá no interior do Rio Grande do Sul vai resolver os problemas dos trabalhadores negociando só ali? Não seria muito mais inteligente por parte dos trabalhadores se tentar buscar um acordo nacional com a Sadia, onde se estabelece um piso nacional, onde você define as diferenças regionais etc? Hoje isso não é possível... Quem já faz isso são os bancários. A CNB tira o poder dos sindicatos quando negocia? Ao contrário, dá poder ao sindicato! ‘Ah, mas eles vão negociar e decidir tudo por nós...' Não. Todo processo de negociação inicia-se com assembleia no sindicato. Quem define a pauta de reivindicação é o sindicato. Quem decide são os trabalhadores. É quem inicia o processo de negociação e quem termina o processo de negociação. A assembleia tem que autorizar unificar a pauta. Unificou a pauta, a confederação negocia. Se o acordo não for bom para algum sindicato, a assembleia pode rejeitar o acordo e fazer um acordo sozinho, porque ela acha que tem poder de fazer um acordo melhor sozinho. A assembleia é soberana. Quando tiver negociando nacionalmente, o patrão pode dizer: 'Tudo bem, eu aceito fazer um acordo nacional com você, mas o que adianta isso se depois detona lá na base? Nós perdemos tempo...'. Aí já deixa que cada sindicato faça sua negociação. Vamos ver o que é aceito em nível nacional e o que pode ser modificado embaixo. Por isso tem a regra: quando você faz acordo nacional, já se estabelece o que embaixo pode atender em função da sua realidade. Ser contra isso é não entender que os trabalhadores da Fiat ganham um terço do que ganham os trabalhadores em São Bernardo do Campo... O que nós conseguimos aqui foi uma conquista. Os patrões não queriam isso de jeito nenhum. Quando ameaçamos não reconhecer entidade patronal como sindicato foi que eles recuaram. Mas para conquistar um acordo desse como estou falando vai ser muito difícil. Não é porque está aqui que vamos conseguir amanhã. Porque eles podem negociar, mas não são obrigados a fechar acordo... Conseguimos obrigá-los a sentar à mesa de negociação, mas não a fazer acordo. $\mathrm{O}$ poder está sempre no sindicato, porque é ele que decide”. (BARGAS, 2004) 
Além dessa polêmica, à qual voltaremos, o GT Negociação Coletiva abordou outras questões igualmente importantes, como a ultratividade dos acordos, fixado em 90 dias após expirar sua vigência, podendo ser prorrogado pelas partes.

O Relatório Final e o ALRS ocuparam-se em detalhar como deverá ser a negociação coletiva em um regime de liberdade sindical, quando poderão existir dois ou mais sindicatos de trabalhadores (ou de empregadores) representantes na mesa de negociação. Quem participa da negociação? Quem assina o acordo nessa circunstância? Pode um sindicato assinar o acordo que valha para o(s) outro(s) sindicato(s)? Foram algumas questões debatidas, e que os sindicalistas da CUT apresentaram nos seminários de debate acerca da reforma sindical.

A esse respeito, Bargas mais uma vez esclareceu:

"Se você tem mais de um sindicato, somente aquele que é mais representativo negocia. Não fizemos essa opção, porque achamos que isso criaria uma espécie de unicidade. Se tiver dois sindicatos, os dois têm que negociar, e são obrigados a se compor na mesa de negociação. Quando há mais de um sindicato, as condições para se instalar a mesa de negociação é que os trabalhadores apresentem pauta única (...) Mesa de negociação única e pauta única. E mais: você tem que oferecer, antes de começar o processo de negociação, quais serão os mecanismos de consulta aos trabalhadores. Toda negociação termina com a aprovação dos trabalhadores. Se é o acordo que vai abranger todos aqueles trabalhadores, então as condições para se iniciar o processo de negociação é mesa única, pauta única, e sistema de consulta de acordo com eles. Se quiserem fazer separado, problema deles. Só que aquela que ganhar, que conseguir mais votos, ganha. Se quiser fazer um plebiscito faça; se quiser fazer uma assembleia só, faça; tudo bem. Se você tem um sistema de consulta único, os sindicatos que aceitaram aquele sistema de consulta e perderam, têm que acatar o que o outro decidiu. 'Tudo bem, eu vou acatar, mas não assino porque isso aqui vai contra meus princípios'. E não assina. O outro sindicato está autorizado a assinar porque acatou a decisão da assembleia".

(BARGAS, 2004)

Por fim, inúmeros dirigentes cutistas questionaram como garantir que os atos antissindicais dos empregadores sejam efetivamente punidos. Nelson José dos Santos ressaltou que "a legislação de conduta antissindical é muito clara na redação, afirmando que "é nulo todo ato". Então, se é nulo, você tem o retorno imediatamente à situação anterior. A caracterização da conduta antissindical está prevista na legislação sob todos os aspectos que porventura a gente pudesse prever. Caso do chefe obrigar o cara a se desfiliar do sindicato, tem uma redação bem detalhada quanto a isso, e passa a ter prazos para serem julgadas". (SANTOS, 2004) 
No que diz respeito ao tema da negociação coletiva já adentrando no tema da composição de conflitos, Bargas analisou as implicações da reforma sindical sobre a dinâmica das relações de trabalho. Uma delas é a questão da data-base, que não será mais estabelecida em lei, mas fruto de acordo. Por esse motivo, disse ele: "poderá ter datas diferentes para cada grupo de cláusulas, o que vai permitir que as relações de trabalho sejam muito mais dinâmicas, porque estará permanentemente discutindo com as empresas na medida em que você pode estabelecer o prazo de validade dessas cláusulas. Mas todo processo de negociação, de assembleias, mudará muito a nossa cultura. E mudará muito o perfil dos dirigentes sindicais, porque o perfil dos dirigentes sindicais terá que ser muito mais preparado. Nós temos que investir muito na capacitação do dirigente sindical para esse modelo (...) O que vai ser diferente? [Daqui pra frente] cada cláusula que a gente colocar na pauta tem que estar fundamentada: o que nós estamos reivindicando aqui? Quais são as necessidades dos trabalhadores para isso? Porque isso é importante? Quando o patrão for negociar, ele não vai poder mais baixar o pacote do que aceita e do que não aceita. Ele vai ter que também fundamentar porque não está atendendo aquelas reivindicações. Ele vai ter que explicar no papel, porque está atendendo parcialmente ou porque não está atendendo. Ele vai ter que fazer isso porque não vai ter mais aquele grupo de juízes que não conhecem a realidade dos trabalhadores, nem das empresas, e decidem assim mesmo. Na proposta do novo sistema não vai ter isso. Quando não tiver acordo, a validade do acordo vigente será prorrogado, valendo mais 90 dias para as partes continuarem negociando. Se, em 90 dias, você não conseguir fazer greve, você não tem bala na agulha... Principalmente com os direitos de greve ampliados. Vamos encontrar um árbitro para resolver nosso problema. Se elege um árbitro imparcial (árbitro privado ou árbitro público), mas ele não vai mais ficar 'isso aqui eu dou; isso eu não dou'... Ele não vai julgar. Não tem poder de julgar; apenas de arbitrar. Se os trabalhadores estão pedindo $20 \%$ e os patrões oferecendo $6 \%$, ele vai ter que decidir entre $20 \%$ e $6 \%$ (não vai oferecer algo intermediário). Ele vai poder falar para as partes: 'vocês não querem sentar e chegar a uma proposta final que procure chegar mais próximo?' Você estimula o processo de negociação e o árbitro, na hora que optar, vai observar as razões das reivindicações e as razões de negar. Ele vai se fundamentar. Isso vai mudar a nossa cultura dos trabalhadores e dos empregadores no processo de negociação, porque se você não fundamentar...” (BARGAS, 2004)

\section{Composição de Conflitos de Trabalho}

Esse GT debateu, sobretudo, mecanismos de composição entre as partes, que envolve conciliação, mediação e arbitragem; o papel do poder judiciário trabalhista; a 
regulamentação do direito de greve e a prestação de serviço em áreas essenciais quando há paralisação dos trabalhadores; e a substituição processual.

$\mathrm{O}$ ponto de maior divergência entre a bancada dos trabalhadores e a bancada patronal esteve associada a esse GT, tanto no item do direito de greve, como também no de substituição processual.

Este foi um panorama geral dos resultados alcançados no FNT, que gerou a PEC 369/05 e o ALRS. Evidentemente que há mais detalhes e minúcias que uma análise mais profunda teria que se deter, mas, como já foi colocado na introdução dessa tese, não é esse nosso objetivo aqui $^{120}$.

Já chamamos atenção, no capítulo 1, que o governo do presidente Lula surpreendeu a todo o espectro político partidário, mantendo muitas das linhas mestras da política econômica de FHC, mas ao mesmo tempo desenvolvendo ações que vêm promovendo a melhora de alguns indicadores sociais no país. Isso tencionou fortemente a relação entre as correntes internas da CUT, conforme já demonstramos.

As pressões de um processo de transformação no mercado de trabalho permanecem, a despeito do novo presidente: terceirizações, informalidade, precarização nas formas de contratação. Entretanto, a legalização dessa prática é obstruída quando Lula retira do

\footnotetext{
120 Em outubro de 2004, em pleno andamento das discussões da reforma sindical, Força Sindical, Confederação Geral dos Trabalhadores (CGT) e Social Democracia Sindical (SDS) anunciaram a suspensão de suas participações no Fórum Nacional do Trabalho (FNT), motivado pela Portaria 160 do Ministério do Trabalho, que dificulta a cobrança pelos sindicatos de contribuições confederativa e assistencial de trabalhadores não-sindicalizados. "O governo quer quebrar os sindicatos no meio de uma negociação de reforma e isso não podemos aceitar", afirmou o presidente da Força Sindical, João Carlos Gonçalves (Juruna). A Portaria 160 foi publicada em abril e chegou a ser suspensa após negociação com as centrais sindicais. Ela estabelece que, para cobrarem contribuições confederativas e assistencial dos trabalhadores nãosindicalizados, os sindicatos precisam ter autorização dos trabalhadores, por escrito. No final de setembro, entretanto, o Ministério Público Federal obteve ação liminar restabelecendo a aplicação da Portaria 160. "Queremos que o governo dê um jeito de retirar a Portaria 160 em caráter definitivo", alegou Juruna. "Enquanto esse desrespeito permanecer, não negociaremos nenhuma reforma, sindical ou trabalhista", acrescentou, ao dizer que a portaria coloca os sindicatos em risco de entrar em colapso financeiro. Luiz Marinho, então presidente da CUT criticou a decisão da Força, CGT e SDS. Para ele, os demais sindicalistas mostram-se imaturos ao tomar a iniciativa: "a Portaria 160 foi um erro do governo, que só pode ser resolvido com as discussões dentro do próprio FNT. A ruptura não ajuda e, por parte do movimento social, houve imaturidade porque sair do Fórum serve apenas para manter tudo como está e, ao que sabemos, só a reforma sindical pode de fato mudar essa situação e até acabar com distorções como a Portaria 160", argumentou. "Se deixam o Fórum, parece que a reforma sindical não é para valer e, pior, ficamos sem solução." (Jornal Tribuna da Imprensa, 28/10/2004)
} 
Congresso Nacional as propostas enviadas por seu antecessor, que o movimento sindical cutista chama de "entulho autoritário de FHC".

Paralelamente a isso, a CUT já vinha mudando sua orientação político-organizativa, de um padrão de ação sindical conflitivo pautado fundamentalmente em sua capacidade de mobilização; para outro padrão, mais negociado e propositivo, baseado em seu peso institucional.

O resultado do debate no FNT é mais um elemento nesse cenário e não só acirrou o enfrentamento entre as correntes da CUT, mas foi mais um fator a contribuir para a saída de várias delas da CUT.

Em uma breve avaliação sobre os resultados alcançados pelo FNT, Bargas disse que "há duas formas de se avaliar os resultados a que o processo de negociação do FNT chegou: uma a partir dos nossos princípios, dos nossos ideais. Outra, a partir do que se tem hoje na estrutura sindical, o que melhora e o que piora o que temos na atualidade". (BARGAS, 2004)

Assim, pelo fato do governo ter adotado o caminho da negociação tripartite para promover a reforma sindical, "o resultado a que se chegou no anteprojeto de lei, se colocado para avaliação sob parâmetro de nossos princípios, nossos ideais, é insuficiente!", disse Bargas. Ele mesmo disse discordar de muitas coisas do anteprojeto porque não corresponde ao projeto que sempre defendeu quando dirigente sindical cutista. Portanto, para ele, avaliar o projeto a partir de posições de princípio, "serve muito para a academia. Quando é o resultado de um processo de negociação, e é isso que está colocado sobre a mesa (...) eu tenho que avaliar de um ponto de vista mais pragmático: vai ou não fortalecer o movimento sindical? Vai ou vai fortalecer as relações de trabalho? Os trabalhadores vão ou não ganhar com isso? A análise tem que ser em cima disso". (BARGAS, 2004)

Portanto, para ele, o debate correto é aquele que analisa se a proposta colocada representa ou não avanços em relação ao que existe atualmente. Nesse sentido, para Bargas, o resultado é positivo; representa avanços, ainda que não represente exatamente o ideal, que seria a ratificação da Convenção 87 da OIT.

$\mathrm{Na}$ avaliação dele "o resultado não cria as condições para o Brasil fazer a ratificação da Convenção 87 da OIT, porque a ratificação da Convenção 87 exige um sistema de liberdade sindical em que nada do Estado intervenha na organização sindical. E na proposta tem algumas coisas, como estabelecimento no número de dirigentes sindicais, a figura da exclusividade da representação, entre outras, que ferem o princípio da liberdade sindical. (...) Quando nós fizemos o 
processo de discussão, nós não nos preocupamos se o resultado alcançado nos daria ou não as condições para ratificar a Convenção 87 da OIT. Não foi por aí que nós pautamos (...) nós nos pautamos pela nossa cultura. Nós não fomos lá na Europa, copiar modelos e implantar aqui. Nós falamos: 'vamos trabalhar a partir da nossa cultura. E vamos tentar arrumar a nossa casa'. O que significa arrumar a nossa casa? Hoje nós temos centrais sindicais que são reconhecidas mas não são legalizadas. Temos federações que são reconhecidas, que negociam, mas que não são legalizadas. Temos Confederações que são reconhecidas, que representam mais de 90\% da categoria, mas que não são legalizadas. E temos entidades que não são reconhecidas, não tem representatividade e que são sindicatos (legalmente reconhecidos). Temos sindicatos de criadores de cavalo de raça inglesa; mas não temos condições de criar (legalmente) uma Confederação Nacional de Bancários, que faz uma greve que pára o país e representa mais de 90\%".

"O que precisamos fazer é mudar essa realidade; dar representatividade para aqueles que tem representatividade. (...) Nós fugimos daquele debate (ideologizado), que muitas vezes se coloca: unicidade X liberdade. O que nós precisamos é deixar esse debate ideológico de lado (...) e resolver a nossa casa. Foi isso que orientou o nosso debate". (BARGAS, 2004)

A PEC e o ALRS foram encaminhados ao Congresso Nacional no dia 2 de março de 2005, fruto de um consenso frágil entre os atores sociais envolvidos, como já vinha se revelando nas discussões públicas desde o lançamento do Relatório final do FNT e que se acentuaria ainda mais no debate da PEC e do ALRS no Congresso Nacional.

\section{A plataforma democrática da CUT e as posições político-ideológicas contrárias à PEC e ao ALRS}

Diante da fragilidade do consenso obtido no FNT, a Direção da CUT sabia que teria uma árdua tarefa pela frente, mas mantinha uma expectativa positiva em torno de sua aprovação e debateu na $11^{\text {a }}$ Plenária Nacional, realizada entre os dias 10 e 13 de maio de 2005, uma estratégia de ação em defesa da reforma sindical no Congresso Nacional.

Nesse sentido, a CUT reafirmou na $11^{\mathrm{a}}$ Plenária a necessidade de democratizar a estrutura sindical, de forma a contar com entidades sindicais realmente representativas e, para isso, seria fundamental "criar as melhores condições políticas para que os objetivos (...) possam ser conquistados, condições essas que ainda não estão dadas, mas que podem ser criadas pela nossa ação política e que as medidas aqui listadas visam criar". (CUT, 2005)

Dentro do debate de estratégia para atuar no período, a $11^{\text {a }}$ Plenária aprovou também uma Plataforma Democrática, elencando doze pontos consensuais no interior da Central de 
modo a coesionar os esforços da CUT na sociedade e nortear a intervenção da CUT sobre os rumos da tramitação da reforma sindical no Congresso Nacional. A estratégia da CUT envolvia um conjunto de ações no Congresso Nacional e na sociedade de modo geral, como "Abrir na sociedade o debate sobre a necessidade da reforma e da justeza dessa Plataforma, como forma de pressão política de contraposição às forças conservadoras na sociedade que também atuam sobre o Congresso". (CUT, 2005)

Propôs-se na época organizar um Comitê Pró-Reforma Sindical supra-partidário em conjunto com as demais centrais sindicais. Esse Comitê deveria realizar gestões junto aos partidos progressistas com representação parlamentar para que assumissem o empenho na aprovação da reforma com o movimento sindical. Para a CUT "isso significa que [os parlamentares] assumirão o compromisso de trabalhar para que os pontos dessa Plataforma [Democrática] sejam aprovados no Congresso ou, no caso de ficar identificado que os pontos da Plataforma estão prejudicados, obstruir sua tramitação". (CUT, 2005)

Em relação à sociedade, a CUT propunha uma atuação ainda mais persistente de convencimento pela aprovação explicando o tema junto a setores formadores de opinião, como os grandes meios de comunicação, o poder judiciário e as universidades / academia, buscando ampliar a compreensão e apoio no movimento sindical cutista e não cutista à Plataforma. Da mesma forma, foi aprovado também abrir o diálogo com outros movimentos sociais e organizações populares para explicar o conteúdo do que a CUT defendia na reforma sindical e obter o apoio daqueles a sua estratégia.

Por fim, foi aprovada também na $11^{\text {a }}$ Plenária Nacional uma agenda de mobilização dos trabalhadores através de uma jornada de lutas pela aprovação da Reforma Sindical e pela redução da jornada de trabalho entre julho/agosto de 2005.

Os pontos de consenso aprovado na $11^{\text {a }}$ Plenária - a Plataforma Democrática - foram os seguintes:

“a) Reconhecimento das Centrais Sindicais com liberdade na estrutura vertical;

b) Manutenção da estrutura atual nos sindicatos de base, condicionando a critérios de representatividade e democratização dos estatutos;

c) Organização Sindical por Setores e Ramos de atividade;

d) Fim do Imposto Sindical (contribuição compulsória) e das taxas confederativa e assistencial e instituição da Contribuição Negocial;

e) Direito de Organização por Local de Trabalho - OLT; 
f) Direito de Organização e Greve no Setor Público nas três esferas e poderes;

g) Contrato Coletivo Nacional por Ramo;

h) Ultratividade dos Contratos;

i) Substituição Processual

j) Contra práticas antissindicais;

1) Ratificação da Convenção 158 da OIT;

m) Não intervenção do Estado". (CUT, 2005)

Para Artur Henrique, então secretário nacional de organização da CUT, a Plataforma Democrática foi necessária, levando em consideração a contrariedade de outras centrais, notadamente no que se refere ao fim da unicidade sindical. Esse foi o motivo pelo qual, segundo ele, a CUT "concordou em introduzir na PEC artigo que prevê a possibilidade de entidades sindicais requererem exclusividade de representação na base, se assim tiverem interesse. Essa possibilidade já era prevista no texto do projeto de lei, elaborado a partir do FNT, e sua migração para a PEC foi aceita pela CUT como forma de dissipar outro foco de resistência das centrais (...) Essa mudança diminui a possibilidade de extinguir a unicidade sindical em todos os rincões do país, mas é uma maneira de preservar a plataforma mínima antes citada, mantendo a tramitação da reforma. Inadmissível seria trava-la inteira, definitivamente”. (SANTOS, 2005: 23) Wagner Gomes, então vice-presidente da CUT, membro da Corrente Sindical Classista, que agrupava a militância do PCdoB, advertiu em seu artigo publicado na mesma edição da revista Teoria e Debate: "Se no FNT buscava-se o consenso, no Congresso Nacional as forças políticas que lá atuam exporão suas convicções (...) O anteprojeto, além de conter retrocessos, é confuso e contraditório". (GOMES, 2005: 28)

E segue tecendo suas críticas: "O Estado é expulso do mundo do trabalho, prevalecendo a autonomia de vontade entre o patrão e o empregado, que terão liberdade para negociar à exaustão, como se tivesse desaparecido a luta de classes. Nesse particular, não há ganho de força para a ação sindical, uma vez que o direito do trabalho passará a ser assunto privado, resolvido entre sindicato e empresas e novas conquistas somente virão do poder negocial de cada entidade". (GOMES, 2005: 29)

Em relação à unicidade sindical, tema bastante caro à CSC e ao PCdoB, Wagner Gomes entende que "não é aconselhável permitir a criação de mais de uma entidade sindical em uma única base, o que resulta, sem sombra de dúvida, na fragmentação e, em consequência, no enfraquecimento do movimento sindical e das lutas por ele travadas. Por isso e para isso, defendemos o aperfeiçoamento da unicidade sindical e a organização dos sindicatos em regras 
claras, gerais, e com a publicidade necessária, a fim de que sejam aplicáveis e acessíveis ao conjunto da categoria". (GOMES, 2005: 29)

Por fim, em relação à Plataforma Democrática aprovada na $11^{\text {a }}$ Plenária, ele afirmou: "A CSC entende que, em primeiro lugar, a plataforma em questão, em debate no interior das outras centrais e entidades do movimento sindical, significou uma vitória das forças mais consequentes e representativas do movimento. Em segundo, constitui uma negação dos princípios e interesses que orientam a PEC 369, na medida em que mantém e aprimora a unicidade como condição de representação dos sindicatos, fechando a porta ao pluralismo nas bases, preconizando também critérios de democracia e representatividade sugeridos pelos sindicalistas classistas". E conclui: "A plataforma situa a luta em torno da reforma sindical em outro patamar. Deve ser um instrumento para a recomposição da unidade dos trabalhadores e seus representantes e o ponto de partida para um novo projeto de organização sindical definido em comum acordo pelas centrais, confederações, federações e outras entidades sindicais, de forma autônoma e independente em relação a patrões e ao governo". (GOMES, 2005: 30)

Acertada a unidade interna entre a Articulação Sindical, a CUT Socialista e Democrática (CSD) e a Corrente Sindical Classista (CSC), ao menos em tese..., a estratégia da Plataforma Democrática esbarraria em pelo menos dois fatores que inviabilizaram seu êxito, o primeiro deles o dissenso no interior da própria CUT com as demais correntes internas em torno da Reforma ${ }^{121}$, como de resto as divergências com os outros atores que não assumiram a defesa dos pontos acordados no FNT. A outra questão foi a alteração da conjuntura política no país depois da crise do mensalão, a partir de 6 de junho com a publicação da entrevista do deputado Roberto Jefferson, que como já vimos, abalou o governo Lula e mudou totalmente a pauta e os interesses no Congresso Nacional e entre as grandes empresas de comunicação.

Vamos nos concentrar mais nas diversas reações negativas à PEC e ao ALRS quando levados ao Congresso Nacional. Veremos que tais reações surgiram por todo espectro ideológico, "à direita” e "à esquerda”; tanto no meio acadêmico, como no meio jurídico,

\footnotetext{
121 Veremos mais adiante o posicionamento de outras tendências internas da CUT que não aderiram à Plataforma Democrática aprovada na $11^{\mathrm{a}}$ Plenária Nacional, como a corrente $O$ Trabalho e Articulação de Esquerda $(A E)$. Essas correntes permanecem no interior da CUT ainda hoje, ao contrário da CSC que, conforme já mencionado nessa tese, retirou-se da CUT para formar outra central sindical, a CTB.
} 
entre sindicalistas, políticos, empresários, e mesmo em editoriais da chamada grande imprensa.

A data do envio da PEC e do ALRS ao Congresso foi 2 de março de 2005. Antes mesmo do então ministro Ricardo Berzoini ir à Câmara explicar aos congressistas sobre os pontos da reforma, Almir Pazzianotto, ex-ministro do Trabalho no governo do presidente Sarney e expresidente do Tribunal Superior do Trabalho (TST), publicou artigo no Jornal $O$ Estado de S. Paulo (OESP) em 14 de março, intitulado "A contra-reforma sindical", tecendo várias críticas às propostas do FNT.

Para ele, “...os projetos [PEC e ALRS] são de tal forma autoritários, contraditórios, confusos e atrasados que, de pronto, surgiram adversários entre empregadores e empregados, para impedir que uma contra-reforma cause mais dificuldades às relações individuais e coletivas de trabalho e se converta em fator de desestímulo a investimentos geradores de emprego". (PAZZIANOTTO, 2005)

Depois dessa introdução ao texto, ele vai pontuando as questões às quais faz suas objeções. Em primeiro lugar, ele critica o paradoxo do projeto assegurar a liberdade sindical e, em seguida, reservar ao Executivo a prerrogativa de conceder personalidade sindical às entidades que atenderem a requisitos de representatividade, participação democrática dos representados e agregação (sindicato por ramo). Segundo ele, "em resumo, a situação persiste inalterada pois, como há 60 anos, caberá ao ministro do Trabalho decidir a quem outorgar ou deixar de outorgar a personalidade sindical (...) Associação sindical é livre ou não. Aqui não há meiotermo. Os autores da CLT, vinculados ao Estado Novo, tiveram a coragem de assumir, sem rodeios, o controle da vida sindical (...) A leitura dos projetos evidencia, entretanto, o risco de retrocesso ao modelo de Vargas, bastante piorado". (PAZZIANOTTO, 2005)

Outro ponto abordado no artigo de Pazzianotto refere-se ao sistema de custeio da estrutura sindical proposto no ALRS. A crítica aqui se centra no fato do projeto estender a proposta de contribuição de negociação coletiva a todos os trabalhadores, associados ou não aos sindicatos, com direito de oposição apenas na assembleia. Diz ele: "Em outras palavras, o cidadão trabalhador ficaria privado do direito de resistir à decisão de assembleia de que não participou, da qual discorda e que o prejudica. Registre-se que o projeto remete as regras sobre quorum de assembleia geral às disposições estatutárias. Pode-se antecipar, com segurança, que em segunda convocação, como habitualmente acontece, a assembleia delibera com qualquer número de associados, e mesmo que não se façam presentes”. (PAZZIANOTTO, 2005) 
Mesmo em relação ao valor da nova contribuição de negociação coletiva, afirma Pazzianotto, "ultrapassará a importância hoje devida a título de contribuição sindical, equivalente a um dia de salário por ano. Aprovado o projeto, todo empregado sofrerá a retenção em folha, em três ou mais parcelas mensais, de $1 \%$ da remuneração total do ano anterior ao do desconto. Simples cálculo aritmético demonstrará o brutal aumento da carga tributária sindical, em benefício das centrais, confederações, federações, dos sindicatos e do governo". (PAZZIANOTTO, 2005)

As duas últimas objeções de Pazzianotto referem-se à unicidade sindical - segundo ele, "é óbvio que as entidades existentes convocarão assembleia para decidir pela exclusividade de representação" -, e à estabilidade dos dirigentes sindicais, ao qual ele não se opôs, mas observou: "nenhuma referência às reeleições, hoje permitidas tantas vezes quantas desejar a diretoria". (PAZZIANOTTO, 2005)

Na conclusão do artigo ele afirma: "a contra-reforma está em marcha. Aguardam-se as manifestações da Câmara dos Deputados e do Senado Federal”. (PAZZIANOTTO, 2005) A primeira iniciativa de explicar os projetos da reforma sindical à sociedade partiu do ministro Berzoini que, em artigo publicado no dia 16/03/2005, expôs as linhas gerais da PEC e do ALRS, já abordada nessa tese. No entanto, vale a pena mencionar a conclusão do artigo do ministro que, em uma espécie de premonição, aliado a uma análise precisa do contexto, afirmou: "não temos ilusões. Fazer essa mudança afeta interesses, que serão mobilizados para evita-la”. (BERZOINI, 2005)

No dia seguinte ao desse artigo do ministro, em 17/3/2005, matéria publicada no mesmo jornal - "Berzoini é hostilizado ao explicar a reforma sindical" - relatou as dificuldades na Comissão do Trabalho da Câmara, onde esteve para explicar a proposta da PEC 369 e do ALRS em audiência pública.

"Sua tentativa de expor os principais pontos da proposta de emenda constitucional mal foi ouvida pelos parlamentares que acompanhavam a audiência pública na Comissão do Trabalho. Entre vaias, palavras de ordem e gritos de "pelego!", “mentira!” e “vendido!”, a plateia de sindicalistas contrários às mudanças tumultuou a sessão, que só não foi suspensa por interferência de alguns deputados (...) Quando Berzoini chegou ao plenário das comissões, a plateia de militantes sindicais da CGT, do PSTU e do PCdoB ocupava boa parte da sala e, em pé, gritava refrões como 'Berzoini, seu pelegão, essa reforma é coisa de patrão' (...) O diretor da Federação Nacional dos Frentistas, Luiz Tenório de Lima, de 81 anos, avançou descontrolado pela lateral gritando que ele era 
mentiroso, mas foi contido pela segurança e passou mal. 'Não aceitamos essa reforma, que foi encomendada pelo FMI', disse Lima”. (MARIN e CRISTINO, 2005)

Vale reprisar uma vez mais que os militantes do PCdoB a que a matéria se refere opondo-se à reforma eram na ocasião membros do sindicalismo-CUT e os do PSTU haviam sido da CUT até organizarem-se na CONLUTAS a partir de março de $2004^{122}$.

A matéria afirma ainda que "Berzoini acabou abandonado até mesmo pelas centrais que apóiam a reforma - a Força Sindical e a parcela majoritária da Central Única dos Trabalhadores (CUT)... Paulo Pereira da Silva, presidente da Força, se manteve quieto. (...) e saiu mais cedo. 'A manifestação foi inexpressiva. Só tinha gente do PSTU e da CGT. Assim que a discussão esquentar, na CCJ, vamos estar juntos do ministro. (...) Luiz Marinho, presidente da CUT, nem foi [à audiência]”. (MARIN e CRISTINO, 2005)

Na mesma edição, em outra matéria - "Pontos da reforma podem parar no Supremo" -, foi noticiado que mais de mil juízes trabalhistas reunidos em um seminário alertaram que "a reforma sindical poderá ter sua constitucionalidade questionada no Supremo Tribunal Federal". Para o ministro Lélio Bentes, do TST, "a Constituição é muito clara ao consagrar o princípio da não intervenção do estado na atividade sindical (...) Não se pode exigir do sindicato autorização do governo para funcionar, não se pode permitir sequer ao Estado interferir no desempenho da atividade sindical legítima de trabalhadores e empregadores". (MACEDO, 2005)

Por esse motivo, disse o ministro do TST, caso fosse aprovado o ALRS com a prerrogativa do Estado em conferir personalidade sindical, "esse dispositivo poderá [poderia] ter sua constitucionalidade questionada". (MACEDO, 2005)

"É um ponto extremamente negativo da reforma, acentua Grijaldo Coutinho, presidente da Associação dos Magistrados do Trabalho. 'A possibilidade de o Estado voltar a conferir personalidade sindical é muito preocupante. A Constituição avançou bastante porque acabou com a possibilidade de intervenção e fiscalização. Isso agora pode voltar com outra roupagem. O Estado, através do Ministério do Trabalho, vai aferir a representatividade sindical, vai conferir o preenchimento ou não dos critérios para que uma entidade seja reconhecida' Para Coutinho 'existe sempre o caráter subjetivo na hora da avaliação, que pode funcionar ainda mais quando se entrega essa avaliação a um órgão do estado (...) qualquer governo, havendo diferenças com determinadas

\footnotetext{
${ }^{122}$ É digno de nota lembrar que esse fato, ocorrido em março de 2005, antecedeu a realização da $11^{\text {a }}$ Plenária Nacional da CUT e o acordo entre a Art.Sind., a CSD e a CSC (PCdoB) em torno da Plataforma Democrática básica para ação diante da tramitação da reforma sindical no Congresso Nacional.
} 
correntes do movimento sindical, pode perfeitamente utilizar subterfúgios para recusar o reconhecimento dessa personalidade sindical. É um retrocesso"'. (MACEDO, 2005)

O próprio jornal, em editorial do dia 21/03/2005 - "Reforma polêmica" -, posiciona-se diante do debate posto na sociedade. Fugindo à boa regra da isenção jornalística de informar aos leitores, o jornal assume a defesa do lado contrário à reforma sindical, mais especificamente do setor empresarial. Afirma o editorial: "apesar de ter participado ativamente das discussões... o patronato alega que suas ponderações pouco foram ouvidas e que o projeto de reforma privilegia uma das partes em detrimento da outra". (OESP, 2005) De forma explícita, o editorial afirma que "se quiser realmente ver seu projeto aprovado pelo Congresso, o governo terá de transigir nesses dois pontos”, a saber, a substituição processual e a criação de comitês de empregados nos locais de trabalho.

Além da opinião francamente favorável aos interesses do empresariado nos dois pontos mencionados, o editorial ainda critica a proposta da contribuição de negociação coletiva, seja pela restrição do direito de oposição exclusivamente em assembleia, seja pelo valor cobrado. Ainda assim, conclui o editorial que “... muitos dos dispositivos do projeto representam um avanço. Mas é preciso que, durante sua tramitação no Legislativo, deputados e senadores saibam depura-lo de tudo o que ele tem de ideológico, de corporativo e de segundas intenções". (OESP, 2005)

Outra demonstração da imprensa irascível contra o governo, o PT, a CUT, o MST e todas as demais organizações populares foi dada na edição de maio da revista Primeira Leitura, onde se lê: "do relatório final com as propostas de reforma sindical 'consensuadas', como gosta de dizer o Ministério do Trabalho, tiram-se quatro conclusões para lá de claras: 1) nada será aprovado em 2004; 2) campeiam as generalidades, menos quando se trata de definir o fortalecimento da CUT; 3) as mudanças são menores do que se apregoa, a não ser na tarefa de retirar poder dos sindicatos de base em nome do fortalecimento das centrais sindicais; 4) está em curso uma manobra histórica: trocar o getulismo sindical pelo cutismo petista". (NOGUEIRA, 2004)

Diante de tamanha controvérsia em torno da reforma, as forças contrárias a ela vão fortalecendo sua posição no Congresso. Matéria publicada em OESP, em 23/4/2005 "Severino prepara ataque à reforma sindical de Lula" -, afirma: "Dois dias depois de o presidente Luiz Inácio Lula da Silva fazer uma defesa contundente da reforma sindical, apresentada ao Congresso na Proposta de Emenda Constitucional 369, o presidente da Câmara, Severino Cavalcanti (PP-PE), convocou a sociedade a se mobilizar contra ela. 'Como presidente da Câmara 
dos Deputados, não tive alternativa a não ser receber o projeto do governo, mas nunca vi tanta divergência como tenho encontrado nesta reforma, que não me parece representar o anseio dos trabalhadores brasileiros', disse ele ontem, no Recife". (LACERDA, 2005)

Segundo a reportagem do jornal, "o comentário foi feito em discurso durante almoço de homenagem de federações e sindicatos de trabalhadores de várias categorias, e de diferentes estados. No encontro, a reforma sindical proposta pelo governo foi considerada 'maléfica', 'um embuste' e promotora do enfraquecimento do sindicalismo. 'Precisamos nos irmanar, tomar uma posição. No silêncio ninguém consegue nada', disse Severino. 'Vamos entrar nessa luta"'. (LACERDA, 2005)

A esse respeito, Vicentinho, ex-presidente da CUT e deputado federal, relator da Comissão de Trabalho da Câmara, já havia alertado em um seminário realizado para dirigentes sindicais da CUT ainda em outubro de 2004, quando o FNT já tinha concluído seu Relatório final e o texto estava sofrendo mudanças para transformar-se na PEC e no ALRS: "Nós percebemos que há uma falta de conhecimento por parte dos deputados sobre o que é uma reforma sindical e também a reforma trabalhista. Essa falta de conhecimento traz temores. Não foram poucas as vezes que companheiros nossos, por desinformação, ou por divergência, saíram dizendo que essa proposta é para retirar direitos, o $13^{\circ}$, etc. É o mesmo discurso que valia para aquela outra proposta que foi aprovada na Câmara contra nossa vontade, que já estava no senado [está se referindo à PEC 618, do governo FHC, que preconizava a prevalência do negociado sobre o legislado], quando na verdade foi o presidente Lula que pediu que ela fosse arquivada no senado. Estão baseados naquele outro parâmetro. Cria-se confusão com isso...” (VICENTINHO, 2004)

E continua ele: "E o que eu tenho sentido é que a maior pressão é dos que estão contra a reforma e isso "sensibiliza" parlamentares. A gente vê companheiros que deviam estar junto com a gente, estão contra a reforma, como o companheiro Paulo Paim (PT-RS). É preciso que a nossa central se mobilize logo em defesa da reforma. E naqueles pontos que somos contra, podemos ir lá na Comissão da Câmara influir nesse debate. Eu estava até pensando em criar uma frente parlamentar em defesa da liberdade sindical, senão eles é que vão criar uma frente para manter isso que aí está. E o governo é sensível a isso, às pressões". (VICENTINHO, 2004)

Em artigo publicado no dia 24/03/2005 - "A um passo do novo sindicalismo" -, Eleno José Bezerra, então presidente do Sindicato dos Metalúrgicos de São Paulo e diretor da Força Sindical, responde às críticas de Pazzianotto no artigo de 14/03. Ele reafirmou o caráter democrático da construção da PEC e do ALRS em ambiente negociado em fórum tripartite 
com a representação de bancadas representando trabalhadores, empregadores e governo. Da mesma forma, atestou a intenção da proposta, já mencionada nessa tese, que era a de conferir maior representatividade às entidades sindicais tendo em vista fortalecer os processos negociados. Argumenta, enfim, que o conjunto da proposta tinha um caráter modernizador das relações de trabalho no país, representando um avanço, e não um retrocesso, como afirmara o ex-ministro Pazzianotto. (BEZERRA, 2005)

A continuação do debate pelo jornal se deu no artigo "A polêmica reforma sindical", em 07/05/2005, de Dagoberto Lima Godoy, empresário e membro do Conselho de Administração da OIT à época.

Em alusão direta aos dois artigos anteriores ele afirmou: "Primeiro, devemos conferir o que o governo alega e Bezerra confirma: que a PEC resulta dos consensos construídos no Fórum Nacional do Trabalho (FNT), órgão tripartite para o qual o governo convidou representações de trabalhadores e de empresas. Era, de fato, para ser assim, mas, na verdade, o texto da PEC apresenta dois desvios importantes: a) Pontos de consenso não foram refletidos com fidelidade (exemplos: a exigência de 'compatibilidade de representação em todos os níveis e âmbitos da negociação coletiva' - como requisito de representatividade sindical - e a substituição processual do empregado pelo sindicato); b) pontos sem consenso foram incluídos ao arbítrio do governo (exemplos: a alteração da disposição constitucional sobre a representação dos trabalhadores no local de trabalho e a obrigatoriedade do desconto em folha das contribuições ao sindicato)". (GODOY, 2005)

Em relação ao artigo de Pazzianotto, Godoy afirma que o ex-ministro tem razão em suas críticas, mas esclarece que a PEC não institui de fato a Convenção 87 da OIT por decisão tomada no próprio FNT, por consenso entre as três bancadas.

Mais à frente em seu texto, Godoy expõe a posição do empresariado, segundo ele a mesma desde o início dos debates no FNT, "firme em dois pontos: 1) os consensos obtidos no fórum deveriam ser respeitados pelo governo, ao formular sua proposta de reforma ao Legislativo; 2) seria adotado o princípio do single entertainment, consagrado pela diplomacia nas negociações internacionais, segundo o qual 'nada estaria acordado antes que tudo estivesse acordado'. Em outras palavras, representantes dos empregadores - em especial os da CNI -, conscientes da complexidade do tema, sempre se opuseram ao 'fatiamento' da reforma. Pois é esse princípio essencial que é posto em xeque quando o governo precipita a discussão da reforma sindical pelo Congresso. Como se ela não fosse simplesmente um meio para ser alcançado o que realmente interessa ao Brasil: uma legislação que garanta liberdade e segurança jurídica para os acordos negociados entre as empresas 
e seus empregados, a fim de permitir à gestão empresarial a flexibilidade exigida pela dura competição da economia globalizada". (GODOY, 2005)

Em resumo, o interesse do empresariado, a julgar pelo artigo de Godoy, concentrava-se exclusivamente na reforma trabalhista.

Foram inúmeros os seminários para esclarecimento e debate sobre o resultado do FNT. Já foram mencionados dois que a CUT realizou em São Paulo para seus dirigentes sindicais, além de outras atividades nos demais estados ${ }^{123}$. Além desses, houve iniciativas de fazer a discussão conjuntamente entre as centrais sindicais. Esse foi o sentido do seminário "Reforma Sindical em Debate", realizado pelo DIEESE junto com o MTE, em São Paulo, no dia 15/06/2005, que reuniu intelectuais envolvidos em estudos e pesquisas sobre o tema, além de sindicalistas e assessores das diversas centrais sindicais; técnicos do DIEESE e do MTE.

Na mesa "O Projeto da reforma sindical na visão do governo", Marco Antonio de Oliveira, então secretário-adjunto de relações de trabalho do MTE, fez uma exposição sobre os principais pontos da proposta do FNT defendendo-a das críticas que tomavam vulto na sociedade. Acerca, por exemplo, da contradição apontada entre a manutenção da liberdade sindical no texto constitucional e a prerrogativa de concessão da personalidade sindical pelo Executivo, ele disse que todos os conselhos existentes (CODEFAT, Conselho do FGTS etc.) tem incidência sobre a ação do Executivo e, dessa forma, toda e qualquer decisão do ministro tem que estar motivado, circunstanciado, nas sugestões do Conselho. $\mathrm{O}$ mesmo aconteceria com o CNRT, apesar de realmente haver na proposta da nova lei um poder discricionário do ministro. Na prática, argumentou ele, o Ministro se submete ao conselho embora legalmente a decisão seja do ministro.

Disse ainda que a concessão da personalidade sindical, com prerrogativa de negociação e recolhimento de contribuição dos trabalhadores para fim de sustentação financeira das entidades sindicais não confronta a Convenção 87 da OIT.

\footnotetext{
${ }^{123}$ A rede de formação da CUT, composto por sete escolas sindicais - Escola Sul (RS-SC-PR), Escola São Paulo, Escola 7 de Outubro (MG-RJ-ES), Escola Marise Paiva de Morais (Nordeste), Escola Amazônia (PAAM-AP-RR), Escola Chico Mendes (RO e AC) Escola Centro-Oeste - entre outras instâncias, dedicou toda sua energia no período para difundir e debater ao máximo as resoluções do FNT e refletir as ações necessárias para ver sua aprovação pelo Congresso Nacional, seguindo a resolução dos Congressos e Plenárias da CUT. Além do envolvimento delas na contribuição para a viabilização de alternativas através da participação delas no Projeto "Estratégia e Organização da CUT: Construindo o Futuro", já abordado nessa tese.
} 
Artur Henrique, representante da CUT no seminário, afirmou que as quatro centrais sindicais tem acordo em $90 \%$ do que está proposto na PEC e no ALRS e mesmo nos pontos que devem ser alterados. Para ele, o próximo passo para aprovação da reforma sindical seria "esperar a poeira baixar e voltar a reunir com as centrais sindicais em uma manifestação conjunta em Brasília". Um "plano B", para ele, seria trazer todas as centrais de volta, os empresários e rediscutir os pontos pendentes. O "plano C" é a CUT apresentar sua plataforma democrática. Segundo Artur, havia um acordo entre as quatro centrais sindicais de "não caminhar um milímetro a reforma trabalhista enquanto não fosse aprovada a reforma sindical”.

Para Danilo Pereira da Silva, representante da Força Sindical no evento, mencionou que "havia desconfiança dentro da Força Sindical em participar do FNT, devido à proximidade da CUT com o governo, em especial com o MTE”. Segundo ele, esse ambiente foi desfeito ao longo das reuniões do FNT e a Força Sindical "trabalha dentro do espírito de consenso com as demais centrais sindicais", disse. "Mesmo a plataforma democrática aprovada na $11^{\text {a }}$ Plenária Nacional da CUT é aceita pela Força Sindical, com pequenas alterações”. Enfim, para ele, mantém-se uma divergência entre Força Sindical e CUT, mas criou-se uma confiabilidade entre ambas.

Os problemas com a tramitação da reforma, como vemos, não se restringiu às chamadas "forças conservadoras". Como já foi dito no primeiro capítulo, o governo Lula e suas ações em diversos campos desnortearam o que costumeiramente chamamos de "direita" e "esquerda", gerando alianças as mais inusitadas e cizânias naquilo que parecia tão sólido. Na luta contra a reforma sindical lançou-se mão de todo tipo de expediente, desde o debate sincero para dirimir dúvidas e propor alterações no sentido de aperfeiçoar a proposta até, principalmente, disseminar a desinformação; lançar dúvidas com má-fé para tumultuar o ambiente de debate e fazer a disputa sindical ideológica descolado do entendimento da proposta; e, aliado a isso, o apelo ao "medo" da mudança expressa na PEC e no ALRS. Por motivos diversos, "direita" e "esquerda" irmanaram-se contra a reforma sindical. As críticas em geral situam-se nos mesmos itens, variando pouco entre as diferentes correntes de pensamento, seja no meio acadêmico, seja entre as correntes políticas. 
Em entrevista ao jornal Correio da Cidadania, o prof. Ricardo Antunes analisou a proposta de reforma sindical "consensuada" no FNT e entregue pelo governo ao Congresso Nacional. Eis alguns trechos de sua entrevista:

"O projeto é um grande retrocesso na medida em que deixa de mudar questões centrais na estrutura sindical brasileira. Na maioria das vezes, não altera os pontos essenciais e faz uma mescla entre a estrutura vigente e uma nova proposta, sem romper efetivamente com o passado, ainda que tentando introduzir novos elementos. Dessa forma, assemelha-se a um monstrengo". (BRASILINO, s/d)

Questionado como os trabalhadores perdem com a reforma sindical, Ricardo Antunes aponta o cupulismo que priorizará as centrais sindicais, confederações e federações que centralizarão as negociações coletivas, deixando pouco espaço aos sindicatos e trabalhadores de base: “...apesar das brechas, o que marca é a concepção cupulista. As centrais sindicais serão o núcleo das negociações..." (BRASILINO, s/d)

Ricardo Antunes critica ainda o encaminhamento da reforma sindical acerca da unicidade "temos uma unicidade limitada e uma pluralidade restringida. O projeto não tem coragem nem de manter a unicidade plena, nem efetivar a liberdade e autonomia" -; da mesma forma que critica o encaminhamento do enquadramento sindical por ramo e não mais por categoria profissional - “...tem que ser um ou outro. O que faz esse projeto é contemplar os dois. Permite que o modelo represente a categoria profissional e também o ramo de atividade econômica ou coordenando um com o outro" -; e o financiamento dos sindicatos: "se esse projeto fosse comprometido com os empregados, ele deveria prever o fim do imposto sindical e das contribuições assistenciais de modo a forçar o sindicato a se sustentar baseado nas contribuições voluntárias dos seus associados. Claro que muitos sindicatos iriam quebrar, mas seriam os pelegos e os de carimbo. Estes desapareceriam porque não teriam mais a mamata de receber dinheiro mesmo sem ter associados. Mas esse projeto é um remendo O que a reforma faz... é substituir o imposto sindical e as contribuições assistenciais criando a contribuição de negociação coletiva... Então, o que se fez foi trocar gato por lebre". (BRASILINO, s/d)

Por fim, ele critica ainda o item que trata da greve - "no artigo 109, ele cria a obrigação dos trabalhadores informarem com antecedência mínima de 72 horas e por escrito o início de cada paralisação. Parece a versão inglesa, da Margareth Thatcher para o nosso sindicato" -; lança suas dúvidas: "o que for negociado terá prevalência sobre o legislado? Isto não está claro e, por isso, cria-se um problema. Se for depender da interpretação judicial, podemos ter casos e casos. Isso ainda vai gerar muita polêmica"; critica a forma como ficou colocada a organização dos 
servidores públicos e a legislação sobre as OLTs: “... o artigo 62 do projeto coloca que a instalação da representação dos trabalhadores nos locais de trabalho visa 'aprimorar o relacionamento entre a empresa e os trabalhadores, com base no princípio da boa-fé e do respeito mútuo'. Fica evidente que o objetivo dessa organização no local de trabalho é a colaboração de classe..." (BRASILINO, s/d)

Assim, conclui ele: "Esse projeto não tem nenhuma coragem política e ideológica como deveria ser se fosse feita por um governo de esquerda. Ele é medroso, é uma mescla de muitas coisas, é um mix de bandeiras recauchutadas do novo sindicalismo acrescido do velho peleguismo rejuvenescido, com uma pitada moderna do sindicalismo social democrático europeu, na era neoliberal. Não temos interesse em defender isso (...) É o resultado da descaracterização completa do PT enquanto partido vinculado às lutas sociais e da perda do sentido de classe da CUT. Por isso, não somos obrigados a aceita-lo e nem ver dados positivos naquilo que é negativo. A reforma é a síntese de como o governo do PT quer regular as relações de trabalho no Brasil. E como as centrais sindicais se tornaram cupulistas ao longo dos últimos anos, estão lutando pesadamente por isso, apesar de dizerem que o projeto não é cupulista". (BRASILINO, s/d)

Outra publicação bastante crítica à reforma sindical foi a Revista PUC Viva, que dedicou o $\mathrm{n}^{\mathrm{o}} 23$ (janeiro a março de 2005) ao tema. Em seu editorial afirma "O projeto de reforma sindical do governo PT/Lula passou a ser o centro das polêmicas, divergências e campanhas para a sua não aprovação. Dada a sua importância para os assalariados, a revista PUCVIVA abre suas páginas para que as mais diversas correntes políticas e de opiniões analisem o projeto". (http://www.apropucsp.org.br/revista/r23_r01.htm - grifos meus)

Observa-se nos trechos destacados a intenção da publicação em ser contrária à reforma sindical a priori. Primeiro porque só menciona a campanha pela sua não-aprovação, omitindo qualquer movimentação favorável. Da mesma forma, os analistas chamados para emitir suas opiniões acerca da reforma sindical eram quase todos do "campo à esquerda da CUT" e da CONLUTAS.

Continua o editorial: "o secretário de Relações do Trabalho e coordenador geral adjunto do Fórum Nacional do Trabalho, Osvaldo Martines Bargas, procura dar a ideia de que a reforma resultou de um processo democrático, envolvendo trabalhadores, patrões e governo. Como se expressasse a vontade consciente de milhões de assalariados, que têm os sindicatos como organização de defesa contra a exploração do trabalho e opressão patronal. Na realidade, reuniu burocratas sindicais, chefes patronais e um governo interessado em limitar a capacidade de ação coletiva dos sindicatos, 
portanto pró-patronal”. (APROPUCSP, 2005) E assim segue o editorial com pesadas críticas à reforma sindical, ao governo e à CUT.

Entre os artigos lá publicados, Galvão descreve o resultado do FNT no texto da PEC e do ALRS e, quando trata da representação derivada, afirma que "a representatividade é transferida da entidade de nível superior para a entidade de nível inferior, e esta torna-se vinculada à estrutura organizativa daquela, devendo se submeter ao seu estatuto. As entidades de grau superior também podem criar entidades de nível inferior como parte de sua estrutura organizativa. É o reconhecimento do modelo de sindicato orgânico, defendido pela CUT”. (GALVÃO, 2005)

Embora houvesse esse receio entre muitos sindicalistas ligados à CUT, inclusive à própria Articulação Sindical, o fato é que não há artigo no ALRS que mencione que a representatividade derivada configura uma vinculação orgânica à entidade de grau superior. Osvaldo Bargas e Marco Antonio Oliveira, em diferentes seminários, afirmaram que a organicidade depende da relação política interna de cada central sindical / confederação / federação com a entidade solicitante da representatividade derivada, e não da lei.

No mais, segue as críticas da autora referentes à composição do CNRT, à negociação coletiva de caráter centralizado nas entidades de grau superior; ao reconhecimento das centrais sindicais.

Em relação à composição do CNRT, diz a autora: "a nomeação de seus membros compete ao MTE, a partir das indicações feitas pelas entidades de trabalhadores e empregadores. Tal qual no FNT, a indicação de representantes é restrita às entidades de cúpula: apenas as centrais sindicais e as confederações patronais que adquirirem personalidade sindical têm poder de decisão. Por fim, a presença do Estado é preponderante: enquanto os cinco representantes a que tanto os trabalhadores quanto os empregadores têm direito serão indicados pelas diferentes centrais e confederações existentes, os cinco representantes do governo serão indicados pelo MTE. Ademais, o governo será sobre-representado, pois participará das duas câmaras bipartites que serão criadas para deliberar questões específicas referentes às entidades de trabalhadores e empregadores”. (GALVÃO, 2005) Continua Andréia Galvão, agora sobre a negociação coletiva: "um dos artigos mais polêmicos sobre essa matéria é o artigo 100, cujo parágrafo $3^{\circ}$ estabelece que "o contrato coletivo de nível superior poderá indicar as cláusulas que não serão objeto de modificação em níveis inferiores”. Este artigo tem sido apresentado por seus defensores como uma forma de evitar que acordos em nível inferior possam piorar cláusulas negociadas em âmbito superior. Porém, tudo isso poderia ser evitado com o reconhecimento do princípio da norma mais benéfica ao trabalhador, não importando o âmbito em que foi negociada. Todavia, justamente o artigo - presente em versões anteriores do 
projeto - que estabelecia a prevalência da norma mais favorável ao trabalhador em caso de conflito entre cláusulas contratuais, bem como entre estas e as disposições legais, foi eliminado. O impacto desta mudança pode ser o oposto daquilo que tem sido anunciado pelo governo, já que pode evitar que as bases resistam a acordos nefastos negociados pela cúpula do movimento sindical". (GALVÃO, 2005)

Por fim, as centrais sindicais: "Um outro aspecto é que as medidas fortalecem as centrais sindicais, não apenas por reconhecê-las, mas também por lhes dar poder de criar confederações, federações e sindicatos. Paradoxalmente, o fortalecimento das centrais sindicais hoje pode engendrar o enfraquecimento da capacidade de resistência das bases, uma vez que as centrais inclusive a CUT - estão cada vez mais propensas a negociar direitos. Este representa, sem dúvida, o maior perigo para os trabalhadores. Mesmo que o texto não inclua as centrais entre as entidades dotadas de poder para celebrar contatos coletivos de trabalho (cf. artigo 97, parágrafo único), não nos parece que essa possibilidade esteja de todo descartada: de um lado, porque as centrais podem realizar acordos e negociações tripartites; de outro, porque podem coordenar os acordos formalmente assinados pelas entidades que integram sua estrutura. A esse respeito, convém destacar que o princípio segundo o qual o contrato celebrado em nível superior poderá indicar matéria não passível de negociação nos níveis inferiores pode implicar a flexibilização de direitos". (GALVÃO, 2005 - grifo meu)

Julio Turra, membro da Direção Executiva da CUT e da corrente $O$ Trabalho, critica a manutenção do Estado interferindo na organização sindical, contrário ao princípio da liberdade e autonomia sindical. A diferença dele para Ricardo Antunes e Andréia Galvão situa-se no fato de que para ele, “o 'reconhecimento das centrais', alardeado pelos defensores dessa reforma como 'ponto positivo', resume-se à sua participação no 'diálogo social' institucional com patrões e governos. Afirma ele: "Um neocorporativismo - em que o Estado aparece como árbitro de interesses "complementares" de patrões e trabalhadores - confesso! A CUT, assim, não poderá negociar e assinar acordos coletivos nacionais com a representação patronal sobre questões de interesse do conjunto dos trabalhadores (como redução da jornada, piso salarial e garantias mínimas), mas apenas opinar nos "foros tripartites" sobre projetos de lei que o governo enviará ao Congresso". (TURRA, 2005 - grifo meu)

Subentende-se que Julio Turra reivindica para a CUT um papel negocial com o setor patronal que é justamente o ponto da crítica de Antunes e Galvão.

No tema da negociação coletiva, aí sim, ele volta à mesma lógica daqueles: "Eliminou-se um parágrafo, presente em versão preliminar do PL, que estabelecia a prevalência da "norma mais 
favorável ao trabalhador" em caso de conflito entre a lei e o acordo coletivo. Ora, se não prevalece a lei (quando mais favorável ao trabalhador), abre-se a porta para "o negociado prevalecer sobre o legislado", objetivo perseguido pelos patrões desde o projeto Dornelles (da era FHC), que a CUT combateu e derrotou na época". (TURRA, 2005)

Em relação à representatividade derivada, ele menciona que "trata-se de uma aberração, que consiste em dar à cúpula das centrais, confederações e federações a prerrogativa de criar, de cima para baixo, sindicatos "orgânicos". Isso ataca a soberania dos sindicatos de base, livremente constituídos pelos trabalhadores, de decidir sobre sua filiação a uma federação, confederação ou central sindical (tal como a própria CUT veio sendo construída, baseada na livre adesão de sindicatos)". (TURRA, 2005)

Observa-se aqui, novamente a crítica à representatividade derivada por compreende-la consentânea ao sindicato orgânico.

Ele segue as mesmas críticas já assinaladas aqui em relação ao financiamento da estrutura sindical, direito de greve, organização nos locais de trabalho - segundo ele, a "cereja em cima do bolo" - e a questão dos servidores públicos. A conclusão dele é que "essa proposta de reforma sindical ataca as bases históricas sobre as quais a CUT se construiu e abre as portas para a flexibilização dos direitos trabalhistas". Mas completa: "Ao mesmo tempo, combato a via proposta por setores como a Conlutas, que pregam a desfiliação dos sindicatos da CUT, que é o outro lado da moeda da destruição de uma conquista da classe, que não se resume à maioria eventual de sua cúpula dirigente (neste caso, uma precária maioria formada por membros de sua Executiva nacional ligados à Articulação Sindical e à CSD/DS)". (TURRA, 2005)

Para concluir, Julio Turra aponta suas propostas:

"Em conclusão, essa reforma sindical deve ser rejeitada em bloco. Não se pode entrar na cantilena de que "há aspectos positivos e negativos", e fazer lobby no Congresso para emendar os "negativos"!

Ser contra essa reforma seria defender a atual estrutura sindical, herdada do varguismo? De nenhum modo.

Defendemos que a CUT retire seu apoio à PEC e ao PL dessa reforma sindical, exigindo do governo que os retire do Congresso Nacional, debate que é feito na base da própria CUT - que em maio terá sua plenária nacional.

No lugar dessa proposta de reforma sindical, a CUT deve exigir o que o $8^{\circ}$ Congresso Nacional de 2003, sua instância máxima, estabeleceu como pré-requisitos para qualquer reforma sindical ou trabalhista: 
- revogação imediata de todas as medidas de flexibilização herdadas do governo FHC ("banco de horas", contrato precário, "lay off" etc.);

- fim das perseguições aos dirigentes sindicais; ratificação da convenção 158 contra demissões imotivadas;

- ultratividade das convenções coletivas (se não há acordo com os patrões, prevalece a convenção anterior);

- fim do poder normativo da Justiça do Trabalho.

O que a CUT deve exigir do governo são medidas que garantam e ampliem direitos sindicais e trabalhistas, o que passa por:

- Liberdade e autonomia sindical, ratificação da convenção 87 da OIT;

- Soberania das assembleias de base; livre filiação dos sindicatos à central;

- Garantia plena dos direitos trabalhistas e do direito de greve;

- Garantia dos direitos sindicais dos servidores públicos (Convenção 151 da OIT)”. (TURRA, 2005)

Posicionamento ligeiramente diferente teve a corrente Articulação de Esquerda (AE). Segundo documento da AE, "A reforma sindical (PEC 369/05 + Anteprojeto de Lei) corre, portanto, o risco de ser desfigurada no Congresso, tendo seus poucos aspectos positivos "varridos" pela direita e pelos lobbies patronais, e seus variados aspectos negativos mantidos e até "aperfeiçoados" pelos agentes do poder econômico. Nesse momento, as melhores possibilidades de ajuda do Governo Lula à classe trabalhadora e ao movimento sindical combativo não estão em uma reforma sindical duvidosa e ambígua como esta. Estão na geração massiva de empregos; na realização efetiva da reforma agrária; no combate sem tréguas às precarização e terceirização do trabalho e na fiscalização das condições de trabalho; na transferência de renda para os assalariados". (ARTICULAÇÃO DE ESQUERDA, 2005:2)

O principal ponto de crítica expresso pela AE é que o governo, ao longo do FNT, enfatizou a valorização do diálogo e da negociação abdicando de "uma proposta preliminar do Poder Executivo, que servisse de guia para o debate, em nome do consenso possível entre os principais interessados na reforma sindical - os próprios atores do mundo do trabalho". Em virtude disso, segundo a $\mathrm{AE}$, o governo equiparou os patrões aos trabalhadores, dando a todos o mesmo tratamento de "atores no mundo do trabalho". A ênfase excessiva no diálogo e na negociação entre as partes permite a seguinte conclusão da AE: "Portanto, a reforma sindical do governo Lula tem como pressuposto a colaboração de classes". (ARTICULAÇÃO DE ESQUERDA, 2005:3) 
Desse modo, "a IV Conferência Sindical Nacional da Articulação de Esquerda, realizada em Olinda em março de 2004, considerou que a atual reforma sindical é globalmente negativa, em que pesem os aspectos positivos, os quais tendem a ser rejeitados pela maioria conservadora do Congresso Nacional. Por isso, dedicaremos nossos esforços para convencer os companheiros que compõem o setor majoritário da CUT a defender a retirada, do Congresso Nacional, da PEC 369/05. E nos colocamos ao lado dos demais setores da esquerda da CUT engajados na mobilização social e parlamentar contra esta reforma sindical". (ARTICULAÇÃO DE ESQUERDA, 2005:3)

\section{Outras propostas de reforma da estrutura sindical corporativa}

A reforma sindical proposta pelo governo Lula a partir do debate no FNT ganhou evidência e tornou-se a principal referência na discussão pública para a mudança na legislação sindical corporativa herdada de Vargas.

Mas devemos pontuar nessa tese outras iniciativas que a antecederam e, de uma certa forma, algumas delas conquistaram visibilidade maior justamente quando a PEC 369 e o ALRS começaram a tramitar no Congresso, a partir de 2005. Já mencionamos de forma breve no segundo capítulo a discussão travada no processo constituinte de 1986 - 1988 e algumas iniciativas durante o governo FHC.

Vamos retoma-lo nesse momento e ver também quais foram as demais propostas que surgiram.

Foram analisadas brevemente no segundo capítulo dessa tese as iniciativas de alteração da legislação sindical corporativa desde o ressurgimento do movimento sindical nas grandes greves do final dos anos setenta ${ }^{124}$. As primeiras iniciativas partiram exclusivamente do Poder Executivo, tanto no final do governo Figueiredo, como na Nova República. A primeira oportunidade que a representação sindical dos trabalhadores foi chamada a participar de discussões acerca da mudança da ordem jurídica no campo da organização sindical foi no processo constituinte.

124 Pelo recorte temporal dessa pesquisa, que tem o sindicalismo-CUT como objeto, negligenciei propositalmente as inúmeras iniciativas de alteração da legislação sindical no período pré-64, bem como as lutas empreendidas pelo movimento sindical que tinham como perspectiva romper a estrutura oficial. Tais iniciativas foram importantes e servem como lição para os sindicalistas contemporâneos, mas escapam ao escopo dessa pesquisa. 
Conforme já analisado no corpo dessa tese, o movimento sindical em geral, e a CUT em particular, não deu a devida prioridade ao tema e, além disso, atuou de forma dividida na votação de diversos itens importantes como, por exemplo, na manutenção da unicidade sindical ou na instituição da liberdade sindical.

Desse modo, o resultado obtido trouxe algumas garantias como a proibição da intervenção do Estado na criação de novas entidades sindicais e a possibilidade dos trabalhadores no serviço público constituírem seus sindicatos, ao mesmo tempo em que, paradoxalmente, manteve o princípio da unicidade sindical, do imposto sindical e do poder normativo da Justiça do Trabalho.

Nos anos 1990, a principal iniciativa de alteração da legislação sindical foi através da PEC 623/98, encaminhada pelo presidente FHC.

Um traço em comum em todas propostas de reforma sindical é que elas partiram exclusivamente de iniciativas do Poder Executivo, sem estabelecer o diálogo com as partes mais interessadas - as entidades de representação sindical patronal e de trabalhadores -, e tiveram muito mais um caráter de chantagem sobre tais entidades ameaçando acabar abruptamente com as garantias legais da atual regra, gerando enorme insegurança e, por conseguinte, uma oposição sistemática por parte daqueles atores.

Esse é seguramente o maior mérito da proposta de reforma sindical levado à cabo por iniciativa do governo Lula através do FNT, o que representa um feito inédito em nossa história.

Contudo, outras iniciativas, essas oriundas do Poder legislativo, também concorreram no intuito de promover uma reforma sindical.

A Proposta de Emenda Constitucional no 29 (PEC 29) foi apresentada pelos seus autores, os deputados Mauricio Rands (PT-PE) e Vicentinho (PT-SP), em 10/04/2003, quando então estavam em pleno andamento as negociações no FNT.

De acordo com a PEC 29, "os incisos do art. $8^{\circ}$ da Constituição Federal passam a vigorar com as seguintes redações:

"Art. $8^{\circ}$

II - organizações sindicais representativas de trabalhadores e empregadores podem se organizar a partir do local de trabalho e constituir federações, confederações e centrais sindicais e a elas se filiarem, e qualquer uma dessas organizações pode filiar-se a organizações internacionais de 
trabalhadores e empregadores;

III - ao sindicato, federação, confederação ou central sindical cabe a defesa dos direitos e interesses coletivos ou individuais dos trabalhadores, inclusive como substituto processual, em questões judiciais ou administrativas;

IV - o empregador fica obrigado a descontar em folha de pagamento e a recolher às organizações sindicais as contribuições associativas, as contribuições para o custeio do sistema confederativo e as contribuições de fortalecimento sindical ou similares que sejam aprovadas pela assembleia geral $\begin{array}{lllll}\text { representativa } & \text { de } & \text { acordo } & \text { os } & \text { respectivos }\end{array}$

VIII - é vedada a dispensa do empregado sindicalizado a partir do registro da candidatura a cargo de direção ou representação sindical, inclusive como representante no local de trabalho e, se eleito, ainda que suplente, até um ano após o final do mandato, salvo se cometer falta grave nos termos da lei." (RANDS e VICENTINHO, 2003)

Além disso, a PEC 29 acrescentava mais dois incisos ao artigo $8^{\circ}$ da Constituição Federal: "IX - nenhum empregado poderá sofrer retaliação, inclusive despedida, por motivo de participação em atividade sindical, sendo-lhe facultado recorrer ao Judiciário pleiteando tutela antecipada específica para anular o ato de retaliação."

"X - os litígios entre as entidades sindicais pela legitimidade para negociação coletiva serão submetidos à central sindical a que elas sejam filiadas ou a comissão mista composta pelas diversas centrais sindicais quando elas forem filiadas a centrais distintas; ou por mediação e arbitragem, quando não houver acordo na comissão mista ou quando as entidades não forem filiadas a qualquer central." (RANDS e VICENTINHO, 2003)

Por fim, a PEC 29 encaminhava também a extinção gradual do imposto sindical em cinco anos, mantendo a obrigatoriedade de desconto e repasse aos sindicatos das contribuições voluntárias dos empregados.

A proposta de Rands e Vicentinho, de todas apresentadas pelo legislativo sem discussão com as partes interessadas, é a que mais se coaduna com os princípios da CUT, mais até do que a PEC 369 e o ALRS resultantes do debate no FNT. De uma tacada só estabelecia a Convenção 87 como parâmetro para organização sindical retirando o princípio da unicidade sindical do inciso II, permitia a organização dos trabalhadores nos locais de trabalho, firmava a atribuição de substituto processual aos sindicatos (ambos, motivo de desacordo entre as bancadas de empregadores e de trabalhadores no FNT), assegurava a proteção a atos antissindicais pelo patronato; reconhecia as centrais sindicais e conferia a elas poder de 
dirimir "os litígios entre as entidades sindicais pela legitimidade para negociação coletiva..." ou, senão, a mediação e arbitragem escolhida entre as partes.

No texto de justificativa da PEC 29, seus autores afirmam que "uma reforma neste sentido seria capaz de compensar as imperfeições existentes no mercado de trabalho que redundam em relações de poder desiguais entre empregados e empregadores". E completam adiante: "O governo anterior tentou mudar a organização sindical através da PEC 623. Limitando-se a eliminar a unicidade sindical e a contribuição sindical obrigatória, a proposição era falha por conceber a liberdade sindical apenas no seu aspecto negativo. A reforma sindical necessária tem que ir mais além. Tem que eliminar interferências indevidas do estado na organização sindical (aspecto negativo), mas tem de criar mecanismos que fortaleçam a organização sindical autônoma e a negociação coletiva (aspecto positivo)... O país precisa é de que o Estado abandone o detalhe ou o controle da atividade sindical; mas, que intervenha com dispositivos para equilibrar relações estruturalmente desiguais como são as do tipo capital-trabalho". (RANDS e VICENTINHO, 2003)

Com esse teor e lançado sem um debate prévio com todos os atores interessados no tema, o destino da PEC 29 não era nada promissor. A última ação da tramitação da PEC foi o parecer do Relator, Dep. José Genoíno (PT-SP) à Comissão de Constituição e Justiça e de Cidadania (CCJC), pela admissibilidade desta e da PEC 121/2003, apensada ${ }^{125}$.

Outra iniciativa foi tomada pelo deputado Tarcísio Zimmermann (PT-RS), que, diante do impasse da reforma sindical, aproveitou Projeto de Lei no 1528 de 1989 (PL 1528/89) ao qual foram apensados outros catorze PLs, e fez uma redação única, encaminhando o texto à Comissão de Trabalho, de Administração e Serviço Público como um substitutivo ao Projeto original $^{126}$.

\footnotetext{
${ }^{125}$ A PEC 121/03 é de autoria de Almir Moura (PL-RJ), retira da PEC original qualquer menção às centrais sindicais, embora mantenha o fim do imposto sindical, preveja outra forma de contribuição compulsória baseada na negociação coletiva e assegure a liberdade sindical, dispensando a unicidade sindical. (MOURA,2003)

${ }^{126}$ O substitutivo iniciou sua tramitação na Comissão do Trabalho da Câmara em 15 de dezembro de 2004, estabelecendo uma "concorrência" com o ALRS encaminhado pelo FNT através do Executivo. Após receber dezesseis emendas até 21/09/2007 seguiu seu rito no Congresso e no dia 26/09/2007 teve um parecer do relator, o deputado Vicentinho (PT-SP), pela sua rejeição, e pela aprovação do Projeto de Lei no 1990/2007, que conferiu o reconhecimento legal às centrais sindicais. Apesar do parecer do relator, o substitutivo seguiu o trâmite legislativo no plenário da Câmara e foi arquivado no dia 25/03/2008. (http://www2.camara.gov.br/proposicoes)
} 
Assim sendo, o Projeto de Lei no 1528 de 1989 (PL 1528/89), de autoria do deputado Jones Santos Neves (PMDB-ES), é a mais antiga proposição da qual partiu Zimmermann na elaboração de seu substitutivo.

As garantias estabelecidas nesse Projeto são os já previstos constitucional ou ordinariamente na CLT. No entanto, o PL 1528 amplia a definição legal de "empregado" ao incluir os servidores públicos. O projeto inova também ao permitir que as entidades sindicais se agrupem em entidades internacionais e centrais sindicais, em um reconhecimento explícito da legitimidade delas. Porém, proíbe recebimento de doações, financiamento ou empréstimo de entidades estrangeiras, numa clara intenção de interromper os projetos de cooperação internacional que ajudavam a financiar algumas ações da CUT no Brasil.

Outra novidade deste PL é a aquisição de personalidade jurídica apenas após o registro da entidade sindical na Comissão de Assuntos Sindicais, instituída pela proposição, que teve prevista composição tripartite e mandato de três anos aos representantes.

Em virtude da época em que foi apresentado o projeto, ainda há menção à representação classista da Justiça do Trabalho, extinta pela Emenda Constitucional $\mathrm{n}^{\circ}$ 24, de 1999. Também dispõe ser competência da Justiça do Trabalho a conciliação e o julgamento de conflitos entre entidades sindicais, matéria que consta da Emenda Constitucional $n^{\circ} 45$, de 2004.

Mantém o imposto sindical, alterando tanto o valor como o percentual destinado aos demais entes do sistema confederativo; estipula que a contribuição associativa (mensalidade) seja descontada em folha e tenha parcela também distribuída às confederações e federações.

Os sindicatos permaneceram enquadrados por categoria econômica ou profissional, organizado em base territorial, no mínimo, municipal.

O PL prevê a unicidade sindical, mas abre a possibilidade para a liberdade sindical se, após dois anos ou mais de registro de um sindicato, alguma associação profissional (sem caráter sindical, portanto) reivindicar a condição de sindicato, podendo substituir o sindicato existente caso tenha maior representatividade que aquele, ou seja, um número maior de associados quites que o sindicato nos últimos doze meses completos.

A esse projeto de lei foram apensados outros treze projetos de lei ao longo dos anos. 
O primeiro Projeto de Lei apensado ao PL 1528/89 foi o PL 3408/89, cuja autoria é do então deputado Paulo Paim (PT-RS) e estabelece os cartórios de registro civil como os órgãos competentes para o registro das entidades sindicais; estabelece o sindicato único por categoria, mas define a categoria como trabalhadores de um mesmo ramo; e estipula que as contribuições sindicais serão quantificadas e definidas sua destinação em assembleia da categoria de base. Observa-se que o PL 3408/89 é uma tentativa, dentro dos limites do texto constitucional de 1988, de alterar a legislação "pelas beiradas" e com o sentido de algumas bandeiras da CUT, como o sindicato por ramo e a democratização do imposto sindical ao colocar para a assembleia de trabalhadores a decisão sobre valores e percentuais a serem distribuídos para o sistema confederativo.

O PL 4911/90, do deputado Augusto Carvalho (PCB-DF, atual PPS-DF) trata do direito de organização e sindicalização dos servidores civis (administração direta, fundações, autarquias e empresas públicas) nas esferas municipal, estadual e federal, reproduzindo vários dispositivos constitucionais relacionados aos sindicatos representativos das categorias profissional e econômica, como a unicidade sindical, a referência na base territorial municipal, a contribuição associativa (mensalidade) independente de contribuição prevista em lei; assegura o direito à negociação coletiva; e direito do aposentado votar e ser votado à direção da entidade sindical.

Rita Camata (PMDB-ES) é a autora do PL 4967/90, em que acrescenta novo parágrafo ao artigo 543 da CLT facultando às entidades sindicais o credenciamento de um empregado em cada empresa para atuar como delegado sindical, garantida a estabilidade provisória, nos mesmos termos concedidos ao dirigente sindical.

Antonio Carlos Mendes Thame, do PSDB-SP, cria o Conselho Nacional de Assuntos Sindicais (CONASI), de caráter bipartite com representação das confederações patronal e de trabalhadores, a fim de analisar os pedidos de registro das organizações sindicais, bem como as dúvidas sobre enquadramento sindical, base territorial, representação sindical, entre outras questões, a ser custeado pelas próprias confederações de modo proporcional à arrecadação das mesmas. Esse é o teor do PL 38/91.

O PL 60/91 e o 264/91 são da autoria do deputado Nilson Gibson (PMDB-PE). No primeiro (PL 60/91) ele simplesmente prevê o fim da contribuição sindical (imposto sindical); e no segundo (264/91), prevê a contribuição confederativa para custeio do 
sistema sindical definida em assembleia geral através de votação secreta e com participação mínima de dois terços dos associados para ser considerada válida.

O deputado Paulo Rocha (PT-PA) dispõe, no PL 646/91, que as entidades sindicais são pessoas jurídicas de direito privado, cuja constituição depende de assembleia geral dos interessados. Para tanto, o registro da entidade deve ser efetuado no serviço extrajudicial de registro público civil das pessoas jurídicas. Em outras palavras, o PL 646 retira os sindicatos da tutela do Estado.

Este PL prevê ainda o reconhecimento das centrais sindicais, cabendo a elas dirimir conflitos ou dúvidas e regulamentar a criação, desmembramento, fusão ou extinção de uma categoria profissional, após decisão da assembleia geral dos interessados.

Da mesma forma, o PL assegura a organização dos trabalhadores nos locais de trabalho e estipula que as contribuições e mensalidade serão decididas em assembleia geral dos representados.

O PL 830/91, de Amaury Muller (PDT/RJ) dispõe que a contribuição para o custeio da representação sindical será fixada em assembleia geral, estipulando a forma de desconto pelos empregadores às entidades sindicais e multa em caso de descumprimento dos prazos definidos no PL. Trata também do órgão competente para registro das entidades sindicais e determina a criação de um banco de dados das entidades sindicais no IBGE.

Aloísio Mercadante (PT-SP) e Paulo Rocha (PT-PA) são os autores do PL 2585/92, que dispõe sobre o enquadramento sindical decidido exclusivamente pelos trabalhadores em assembleia geral e estipula que, quando houver conflito, prevalecerá sempre a atividade econômica predominante da empresa.

O PL 3267/92, do deputado Carlos Alberto Campista (PDT-RJ) define o órgão competente para registro das entidades sindicais e cria a Comissão Paritária Sindical para resolver conflitos de representação, sem vínculo com o Estado.

Paes Landim, do PTB-PI, é o autor do PL 3107/04, apresentado simultaneamente aos trabalhos do FNT, e regulamenta os incisos II e IV do artigo $8^{\circ}$ da Constituição Federal, dispondo que é livre a criação, fusão, desmembramento ou alteração da base de entidade sindical, devendo ser respeitada a unicidade sindical e a abrangência territorial mínima de um município. Estipula também o teto de 3\% do salário mensal para a contribuição confederativa, sendo não obrigatória para o trabalhador não sindicalizado. O PL 3107/04 
reconhece as centrais e destina a arrecadação da contribuição sindical do seguinte modo: $60 \%$ ao sindicato, $15 \%$ às federações, $10 \%$ às confederações, $5 \%$ às centrais sindicais e $10 \%$ ao MTE. Pelo PL, as entidades são autorizadas a estabelecer taxa negocial em convenção coletiva.

Sergio Miranda, do PC do B - MG na ocasião, através do PL 4554/04, regulamenta o artigo $8^{\circ}$ da CF, assegurando a manutenção do regime de unidade sindical; reconhece comissões sindicais de base, federações, confederações e centrais sindicais; mantém o enquadramento das entidades sindicais por categoria profissional e econômica; estende as regras de organização sindical aos servidores públicos; cria os Conselhos Sindicais Nacionais de Trabalhadores e Empregadores com detalhamento bem minucioso de sua atribuição, composição e custeio; define número de dirigentes nas entidades sindicais e regras eleitorais; estipula a distribuição da contribuição sindical (70\% para os sindicatos, $15 \%$ para as federações, $6 \%$ para confederações, $5 \%$ às centrais sindicais e $2 \%$ para o Conselho proposto); institui a cobrança compulsória de contribuição para o financiamento das negociações coletivas e outras atividades; e assegura as OLTs através da comissão sindical de base.

O PL 5275/05, de Marcelo Barbieri (PMDB-SP), reconhece as centrais sindicais, mantém a unicidade sindical, estabelece o Conselho Sindical Nacional e também nos Estados, ambos compostos pelas Câmaras Sindicais de trabalhadores e de empregadores, onde as entidades sindicais ficam obrigadas a registrarem-se. Estipula ainda contribuições sindicais compulsórias, distribuídas da seguinte forma: (70\% para os sindicatos, 15\% para as federações, $5 \%$ para confederações, $5 \%$ às centrais sindicais e 5\% para o Conselho proposto).

Estabelece, ainda, o conceito para conduta antissindical:

"Configura conduta antissindical todo e qualquer ato do dirigente sindical que tenha por objetivo impedir ou limitar a liberdade ou a atividade sindical, tais como: I - sonegar informações relativas à aprovação de contas da entidade sindical a que pertence; II - lesar o patrimônio da entidade sindical; III - exercer atividades sindicais sem pertencer à respectiva categoria econômica ou profissional; IV - ter sido condenado por crime doloso enquanto persistirem os efeitos da pena; V - não estar em pleno gozo de seus direitos políticos; VI - abusar das prerrogativas sindicais, fraudando a sua organização, ou utilizando-se da entidade em benefício próprio, para fins ilícitos ou contrários às 
disposições desta lei; VII - contrariar as normas estatutárias da entidade a qual pertence". (BARBIERI, 2005)

O deputado Eduardo Valverde (PT-RO) apresentou o PL 1321/07 estabelecendo normas para a criação e o funcionamento dos sindicatos, mantendo a unicidade sindical, visando normatizar os procedimentos de registro sindical, hoje direcionados por portarias do MTE e sepultar definitivamente as dúvidas no tocante a quantidade de dirigentes sindicais.

Por fim, há também o PL 2085/07, de Augusto Carvalho (PPS-DF) e o PL 1990/07, do Executivo. O primeiro trata da autorização individual dos empregados para descontar em folha de pagamento o valor da contribuição sindical; e o segundo manifesta-se favorável ao reconhecimento das centrais sindicais.

Num esforço de sintetizar no substitutivo o conjunto desses PLs mais o resultado do FNT, o deputado Tarcísio Zimmermann encaminhou documento bem mais "enxuto" que o ALRS com setenta artigos, enquanto o ALRS contém 238 artigos. Na prática o projeto do deputado funciona como uma reforma sindical infra-constitucional, propondo profundas alterações legais no título VI da CLT, mantendo o respeito ao disposto na atual Carta: "Um projeto de lei que venha a alterar a organização sindical, portanto, deve observar os estritos limites traçados pela nossa Constituição, respeitando a não intervenção e não interferência do Poder Público e observando, outrossim, os aspectos de unicidade sindical...”, e, mais adiante: "qualquer alteração ao modelo vigente deve, além de respeitar os dispositivos constitucionais, observar os princípios democráticos, os valores da cidadania, da participação política e social, da representatividade, do direito ao trabalho digno, da valorização da negociação coletiva entre trabalhadores e empregadores e da promoção dos direitos fundamentais. Essas são as diretrizes do nosso substitutivo". (ZIMMERMANN, 2005)

Desse modo, explica o deputado, seu substitutivo foi elaborado a muitas mãos, aproveitando as contribuições de cada um dos projetos de lei anteriores e o resultado do FNT, foi adaptado em alguns itens para não ferir o preceito constitucional na forma atual, ou seja, em caso de rejeição ou não apreciação da PEC 369 pelo Congresso:

"Para evitar contestações futuras, excluímos do nosso substitutivo aspectos dos projetos [dos PLs] que podem vir a ser considerados inconstitucionais pela Comissão de 
Constituição e Justiça e de Cidadania. Optamos, assim, por não incluir a criação de um Conselho ou órgão ligado ao Poder Executivo, uma vez que a competência é privativa da Presidência da República”. (ZIMMERMANN, 2006)

Os princípios que subjazem o substitutivo, segundo seu autor, são os mesmos do FNT: a busca de maior representatividade às entidades sindicais, a valorização do diálogo e dos processos de negociação coletiva baseados na boa-fé, que tenham como resultado a valorização do trabalho digno, a melhoria das relações de trabalho e o fortalecimento da democracia".

Segue alguns dos pontos principais do substitutivo, comparado com o ALRS.

No capítulo I - "Das entidades sindicais" - a proposta de Zimmermann trás no artigo $3^{\circ}$ a extensão da representação sindical aos trabalhadores terceirizados: "integram a categoria profissional preponderante todos os trabalhadores que estiverem à disposição da mesma empresa, independentemente da forma de contrato a que estiverem vinculados".

No artigo $4^{\circ}$, inciso II, o projeto garante a substituição processual, um dos motivos de maior restrição da bancada empresarial contra a reforma sindical.

$\mathrm{O}$ artigo $4^{\circ}$, inciso IV, estabelece a contribuição sindical de todos os trabalhadores; e a contribuição assistencial e confederativa apenas do associados.

Mais adiante, no capítulo que aborda a questão de sustentação financeira das entidades sindicais, definiu-se no artigo 35 todas as fontes de custeio da atividade sindical, quais sejam: I. as contribuições associativa e confederativa; II. a contribuição sindical; III. os frutos dos rendimentos de seu patrimônio; IV as doações e legados, quando aceitos na forma de seus estatutos; e inciso V. as multas e outras rendas.

Nos artigos 39, 42, e 44 observa-se aqui clara influência da proposta do ALRS na redação do substitutivo:

“Art. 39. A contribuição sindical é o valor devido em favor das entidades sindicais, fundada na participação em negociação coletiva ou no efeito geral do seu resultado.

Art. 42. A cobrança de contribuição sindical é prerrogativa do sindicato, sendo o desconto ou pagamento realizado mediante a celebração da convenção ou do acordo coletivo de trabalho ou da comprovação da frustração da negociação coletiva, de acordo com os valores ou percentuais das contribuições determinadas pelas assembleias dos sindicatos envolvidos nas negociações.

Art. 44. A contribuição sindical é devida por todos os trabalhadores representados na negociação coletiva. 
$\S 1^{\circ}$ A contribuição sindical não pode ultrapassar $1 \%$ (um por cento) do valor da remuneração do trabalhador e é descontada mensalmente, enquanto vigorar a convenção ou o acordo coletivo de trabalho". (ZIMMERMANN, 2005)

No artigo $6^{\circ}$ e no $14^{\circ}$, no parágrafo único - mantém a unicidade sindical e, no artigo $8^{\circ}$ e $9^{\circ}$ mantém o sistema confederativo exatamente no mesmo molde da CLT.

No artigo $10^{\circ}$ o substitutivo reconhece as centrais sindicais.

A gestão sindical das entidades (número de diretores, quais as instâncias; atribuições da diretoria, etc) é tratada entre o artigo 15 e o 23 . E do 24 ao 28 estipula as regras eleitorais no sindicato, inclusive inegebilidades.

Do art. 46 ao 68 o substitutivo trata da representação dos trabalhadores nos locais de trabalho em minúcias, desde a instalação, eleição e posse; mandato, proteção aos representantes e à representação, direito de informação e de reunião.

De um modo geral, observando os artigos da proposta, o substitutivo teve a intenção de fazer encaminhar a reforma sindical que estava então travada e em meio às polêmicas discussões que ganhavam espaço na sociedade. Não logrou êxito, como as demais iniciativas.

Contudo, a CUT se opôs aos PLs e também ao substitutivo de mudança na estrutura sindical, mas não abriu mão de negociar partindo dessas propostas para chegar a algo que contemplasse seu projeto político: “...a bem da verdade, nenhum dos substitutivos contemplava integralmente a Plataforma Democrática aprovada na $11^{a}$ Plenária da CUT. O do deputado Tarcísio Zimmerman (PT-RS) continha oito dos 12 pontos de nossa Plataforma. Mas, ainda assim, seria necessário aperfeiçoá-lo. O do deputado Marcelo Barbieri (PMDB-SP) trazia retrocessos, como a criação do imposto sindical para o setor público. Por isso foi importante que os projetos, junto com os votos em separado apresentados pela deputada Dra. Clair (PT-PR) fossem retirados e, a partir disso, o compromisso de a Comissão de Trabalho criar uma nova discussão para redigirmos um novo substitutivo, em consenso com outras centrais". (DAU, 2006)

Mesmo após o envio da PEC 369 e do ALRS ao Congresso Nacional, o FNT continuou se reunindo ao longo de 2005 para negociar os pontos divergentes que se explicitavam no debate da Comissão de Trabalho, de Administração e Serviço Público (CTASP). O objetivo era buscar alternativas de consenso para viabilizar a reforma sindical, mesmo que a mudança se restringisse ao plano infraconstitucional. 
Veremos adiante, na última seção desse capítulo, alguns resultados concretos da negociação no FNT que promoveram mudanças efetivas.

\section{Avaliação dos delegados ao $9^{\circ}$ CONCUT sobre a reforma sindical}

Os três anos da gestão da Direção Nacional da CUT, entre o $8^{\circ}$ e o $9^{\circ}$ CONCUT (2003 e 2006, respectivamente) foram bastante intensos: enfrentou a situação inédita de ter Lula na presidência da República, colhendo bônus e ônus em virtude das contradições que se acirraram, como mostramos no capítulo 1 dessa tese. Da mesma forma, viu a possibilidade real de viabilizar sua bandeira histórica em defesa da liberdade e autonomia sindical através da participação no FNT. Esses dois fatores, dentre outros, ocasionou as primeiras cisões na trajetória da CUT, com a retirada dos segmentos ligados à "esquerda socialista" para formar a CONLUTAS e a Intersindical. Mais adiante, sairia também a CSC para formar a CTB.

O $9^{\circ}$ CONCUT foi realizado em junho de 2006, quando a conjuntura política nacional se voltava para a eleição presidencial marcada para outubro daquele ano. O $9^{\circ}$ Congresso ocorreu também em meio ao processo final do FNT, quando já se discutia a PEC e o ALRS. Da mesma forma, no capítulo 1 foi mencionado que dissensões precipitariam nova saída de correntes internas da CUT, como foi o caso da Frente de Esquerda Socialista (FES) que participou do CONCUT já dividida entre manter-se ou não na Central.

Diante desse contexto, a CUT realizou nova pesquisa de opinião e de perfil dos(as) delegados(as) ao Congresso, tendo em vista conhecer o perfil e a opinião como mais um subsídio à ação da Central.

O resultado foi publicado em uma revista - Quem são e o que pensam os delegados $e$ delegadas do $9^{\circ}$ CONCUT - que abordou também uma comparação com os dados levantados no Congresso anterior, o $8^{\circ}$ CONCUT.

Em relação ao perfil dos delegados, propriamente dito, chama atenção o fato de que 53,4\% dos delegados e 59,3\% das delegadas participavam pela primeira vez de um Congresso da CUT. Isso não significa, contudo, que fossem dirigentes sindicais inexperientes. $54,1 \%$ dos homens e 35,8\% tinham sete anos ou mais de tempo de direção, ou seja, participavam de alguma instância de direção há pelo menos dois mandatos. De modo inverso, 12,6\% dos homens e 21,4\% das mulheres delegadas ao CONCUT estavam, naquela ocasião, participando de sua primeira experiência em mandato de direção sindical. 


\begin{tabular}{|c|c|c|}
\hline \multicolumn{3}{|c|}{$\begin{array}{r}\text { Tabela } 14 \text { - Total de delegados(as) ao } 9^{\circ} \text { CONCUT } \\
\text { anteriores }(\%)\end{array}$} \\
\hline & Masculino & Feminino \\
\hline $1^{\mathrm{a}}$ CONCLAT (1981) & 4,7 & 2,2 \\
\hline Congresso Fundação da CUT & 3,9 & 1,9 \\
\hline $1^{\circ} \mathrm{CONCUT}$ & 4,9 & 2,5 \\
\hline $2^{\circ} \mathrm{CONCUT}$ & 9,4 & 4,0 \\
\hline $3^{\circ} \mathrm{CONCUT}$ & 14,6 & 7,8 \\
\hline $4^{\circ}$ CONCUT & 23,1 & 14,6 \\
\hline $5^{\circ}$ CONCUT & 21,0 & 11,5 \\
\hline $6^{\circ} \mathrm{CONCUT}$ & 37,9 & 22,1 \\
\hline $7^{\circ} \mathrm{CONCUT}$ & 44,3 & 28,7 \\
\hline $8^{\circ}$ CONCUT & 71,5 & 62,9 \\
\hline
\end{tabular}

Fonte: CUT 2006c

A tabela acima sobre a participação nos congressos anteriores da CUT completa o perfil $\operatorname{dos}($ as) delegados(as).

Tomados em conjunto, tais dados indicam que uma boa parte dos(as) delegados(as) não havia participado pessoalmente do sindicalismo-CUT nos anos oitenta (até o $3^{\circ}$ CONCUT), nem dos anos noventa (do $4^{\circ}$ ao $6^{\circ}$ CONCUT). Vimos que a maior parte dos delegados(as) tinha, então, sete anos ou mais em mandato sindical. Como o $9^{\circ}$ CONCUT realizou-se em 2006, significa que os delegados (ou, pelo menos, um percentual significativo deles) estavam chegando no movimento sindical próximo do ano 2000, mas não muito antes disso.

Com isso, aqueles delegados, homens e mulheres, não participaram do processo de discussão do Sistema Democrático de Relações de Trabalho (SDRT), elaborado em 1992, 
tampouco da experiência mais conflitiva da CUT-movimento. Só podem compartilhar dessa história através do processo de formação sindical da CUT.

Para nós, isso explica ao menos parcialmente, a opinião emitida na entrevista de um dirigente nacional da CUT acerca do balanço da participação da Central durante o FNT. Para ele, a CUT em geral, e a formação sindical em especial, fizeram um enorme esforço de fazer chegar até o conjunto das direções sindicais o debate travado no FNT explicando as razões da bancada da CUT nas negociações da reforma sindical, em defesa da Convenção 87 da OIT, que pressupõe o fim da unicidade e do imposto sindical. Tal empreendimento, na opinião deste dirigente, não conseguiu ter êxito pleno, enfraquecendo o potencial de pressão da CUT em defesa da PEC e do ALRS diante dos ataques que a proposta recebia de outros atores sociais.

Já havia uma indicação dessa falta de clareza do conjunto do sindicalismo-CUT acerca dos pontos a serem defendidos na reforma sindical quando da realização das Conferências Estaduais do Trabalho analisadas por Horn, bem como a própria pesquisa de opinião dos delegados ao $8^{\circ}$ CONCUT também já denotava a dificuldade interna que a CUT teria em mobilizar a base de seus sindicalistas para pressionar pelas mudanças na estrutura sindical oficial. Ou seja, se a proposta de reforma sindical enfrentava ataques em diversas frentes políticas, de outro lado, seus defensores dentro do sindicalismo-CUT eram bem vacilantes, a despeito do esforço empreendido.

No $9^{\circ}$ CONCUT, a pesquisa de opinião teve como uma de suas intenções identificar as opiniões dos delegados(as) referente a esse debate, que estava em andamento, e reforçou um retrato da dificuldade interna do sindicalismo-CUT em ter uma ação mais decidida em defesa da reforma sindical, em todas as correntes políticas.

Vejamos os dados.

Foram três as perguntas elaboradas a respeito do FNT e da reforma sindical:

- Qual a sua avaliação sobre a participação da CUT no Fórum Nacional do Trabalho $(\mathrm{FNT})$ ?

- Quais foram as dificuldades encontradas para a aprovação da proposta de Reforma Sindical enviada ao Congresso Nacional em 2005?

- Quais das alternativas você considera que devem ser priorizadas para compor a Reforma sindical? 
Segue abaixo as tabelas e uma análise com as respostas dos(as) delegados(as).

\section{Participação da CUT no FNT}

No $8^{\circ}$ CONCUT (2003) uma das principais deliberações do Congresso foi pela participação da Central no Fórum Nacional do Trabalho (FNT), construindo uma proposta de reforma sindical no país.

Três anos depois, os delegados ao $9^{\circ}$ CONCUT, em sua maior parte, fizeram uma avaliação positiva da participação da CUT no FNT. 
Tabela 15 - Participação da CUT no Fórum Nacional do Trabalho (FNT)

\begin{tabular}{|c|c|c|c|c|c|c|c|}
\hline & $\begin{array}{c}\text { A CUT acertou ao } \\
\text { participar do } \\
\text { processo, } \\
\text { procurando garantir } \\
\text { uma proposta que } \\
\text { considerasse as suas } \\
\text { principais posições } \\
\text { históricas }\end{array}$ & $\begin{array}{c}\text { A CUT não teve } \\
\text { condições de } \\
\text { viabilizar uma } \\
\text { proposta que } \\
\text { contemplasse as suas } \\
\text { posições históricas, } \\
\text { dada a composição do } \\
\text { FNT }\end{array}$ & $\begin{array}{c}\text { A CUT errou em } \\
\text { aceitar fazer parte } \\
\text { de uma negociação } \\
\text { com outros atores } \\
\text { sociais, ao invés de } \\
\text { apresentar a sua } \\
\text { proposta ao FNT }\end{array}$ & $\begin{array}{c}\text { A CUT fez } \\
\text { muitas } \\
\text { concessões para } \\
\text { o FNT ter uma } \\
\text { proposta de } \\
\text { reforma sindical }\end{array}$ & $\begin{array}{c}\text { A CUT foi transparente } \\
\text { ao fazer o boletim de } \\
\text { todas as reuniões } \\
\text { temáticas, possibilitando } \\
\text { aos interessados } \\
\text { acompanhar e intervir }\end{array}$ & $\begin{array}{l}\text { Não tenho } \\
\text { condições de } \\
\text { avaliar pelas } \\
\text { informações } \\
\text { que disponho }\end{array}$ & $\begin{array}{c}\text { Outra } \\
\text { avaliação }\end{array}$ \\
\hline Comércio e Serviços & 50,0 & 14,7 & 9,8 & 17,6 & 22,5 & 21,6 & 3,9 \\
\hline Extração Mineral & 33,3 & 25,0 & 8,3 & 16,7 & 16,7 & 16,7 & 0,0 \\
\hline Seguridade Social & 49,2 & 21,5 & 13,8 & 16,9 & 21,5 & 20,0 & 1,5 \\
\hline Profissionais Liberais & 36,4 & 36,4 & 0,0 & 9,1 & 18,2 & 36,4 & 9,1 \\
\hline Vestuário & 30,0 & 20,0 & 10,0 & 13,3 & 20,0 & 30,0 & 3,3 \\
\hline Educação & 45,2 & 14,5 & 9,6 & 11,2 & 21,3 & 29,9 & 3,1 \\
\hline Construção e Madeira & 60,8 & 21,6 & 11,8 & 27,5 & 23,5 & 15,7 & 3,9 \\
\hline Urbanitário & 56,9 & 33,8 & 4,6 & 12,3 & 35,4 & 13,8 & 4,6 \\
\hline Alimentação & 55,6 & 27,8 & 5,6 & 22,2 & 44,4 & 22,2 & 16,7 \\
\hline Financeiro & 55,6 & 24,8 & 7,7 & 16,2 & 27,4 & 26,5 & 5,1 \\
\hline Metalúrgico & 59,8 & 17,1 & 5,1 & 14,5 & 33,3 & 19,7 & 2,6 \\
\hline Aposentados & 45,2 & 3,2 & 3,2 & 25,8 & 35,5 & 41,9 & 0,0 \\
\hline Químico & 46,6 & 32,8 & 19,0 & 12,1 & 22,4 & 15,5 & 8,6 \\
\hline Rural & 50,8 & 8,0 & 7,7 & 9,6 & 20,9 & 28,3 & 2,6 \\
\hline Comunicação / Informação & 61,8 & 23,5 & 5,9 & 20,6 & 17,6 & 11,8 & 0,0 \\
\hline Administração Pública & 39,3 & 17,9 & 17,2 & 15,2 & 19,3 & 29,0 & 2,1 \\
\hline Transporte & 46,4 & 25,0 & 7,1 & 21,4 & 25,0 & 21,4 & 7,1 \\
\hline Total & 50,2 & 17,9 & 9,9 & 14,3 & 24,4 & 26,3 & 3,5 \\
\hline
\end{tabular}

Fonte: CUT 2006c 
Ao responder à pergunta "Qual a sua avaliação sobre a participação da CUT no Fórum Nacional do Trabalho (FNT)?", 50,2\% dos delegados assinalaram que "a CUT acertou ao participar do processo, procurando garantir uma proposta que considerasse as suas principais posições históricas". Entre os delegados que mais contribuíram para uma avaliação positiva da participação da CUT no FNT, estão os dos ramos da comunicação, rurais, metalúrgicos e da construção civil e da madeira, em torno de 58,3\%.

Considerado um ponto polêmico e de divisão no debate interno da CUT, os delegados que assinalaram uma avaliação francamente negativa da participação da CUT no FNT totalizaram 9,9\%, mais assinalada entre os delegados da Administração pública, químicos e da seguridade social, que atingiram uma média de aproximadamente 16,6\%.

Contudo, há que se ressaltar também que um contingente expressivo de delegados $(26,3 \%)$ declarou-se sem informações disponíveis para avaliar a participação da CUT no FNT. Estes representam o segundo maior número de delegados que responderam esta questão, só ficando atrás dos que tem uma avaliação positiva.

Apesar da maior parte dos delegados ter expressado sua opinião sobre a CUT no FNT, observamos que este dado da pesquisa revela a necessidade de dar maior capilaridade às informações e ao debate para alguns segmentos de dirigentes sindicais.

Os delegados que não emitiram opinião sobre o tema, por falta de informação, estão em sua maior parte entre as bancadas de delegados aposentados, profissionais liberais, e do vestuário. 
Tabela 16 - Dificuldades para a aprovação da proposta de Reforma Sindical enviada ao Congresso Nacional em 2005

\begin{tabular}{|c|c|c|c|c|c|c|c|c|}
\hline & \begin{tabular}{|c} 
Falta de \\
pressão no \\
Congresso \\
Nacional
\end{tabular} & $\begin{array}{l}\text { Composição do } \\
\text { Congresso } \\
\text { Nacional não é } \\
\text { favorável para } \\
\text { reformas desta } \\
\text { natureza }\end{array}$ & \begin{tabular}{|c|} 
A proposta \\
negociada no \\
Fórum \\
Nacional não \\
representa os \\
anseios da \\
base sindical
\end{tabular} & \begin{tabular}{|c} 
A forma de \\
encaminhamento \\
do Fórum de \\
estabelecer \\
consenso com \\
outros atores \\
sociais, contribuiu \\
para articular os \\
setores \\
\end{tabular} & \begin{tabular}{|c|} 
As garantias \\
proporcionadas \\
pela estrutura \\
levaram a uma \\
acomodação dos \\
dirigentes que \\
inviabilizam uma \\
reforma sindical
\end{tabular} & \begin{tabular}{|c} 
Os trabalhadores \\
estão mais \\
preocupados com \\
as suas demandas \\
imediatas do que \\
com a discussão \\
sobre \\
organização \\
sindical
\end{tabular} & $\begin{array}{c}\text { Houve confusão } \\
\text { no debate sobre a } \\
\text { reforma sindical } \\
\text { e a reforma } \\
\text { trabalhista, que } \\
\text { tende a } \\
\text { flexibilizar } \\
\text { direitos }\end{array}$ & \begin{tabular}{|} 
Os \\
sindicalistas, \\
em geral, \\
não estão \\
preparados \\
para a \\
reforma \\
sindical
\end{tabular} \\
\hline Comércio e Serviços & 35,3 & 21,6 & 43,1 & 14,7 & 17,6 & 21,6 & 42,2 & 23,5 \\
\hline Extração Mineral & 41,7 & 41,7 & 25,0 & 16,7 & 8,3 & 25,0 & 33,3 & 25,0 \\
\hline Seguridade Social & 30,8 & 35,4 & 33,8 & 26,2 & 29,2 & 35,4 & 30,8 & 24,6 \\
\hline Profissionais Liberais & 18,2 & 27,3 & 36,4 & 9,1 & 18,2 & 18,2 & 54,5 & 63,6 \\
\hline Vestuário & 40,0 & 26,7 & 33,3 & 23,3 & 26,7 & 20,0 & 26,7 & 23,3 \\
\hline Educação & 35,6 & 39,0 & 23,9 & 19,2 & 14,8 & 27,3 & 32,5 & 20,8 \\
\hline Construção e Madeira & 33,3 & 27,5 & 47,1 & 21,6 & 21,6 & 31,4 & 41,2 & 31,4 \\
\hline Urbanitário & 40,0 & 43,1 & 29,2 & 16,9 & 26,2 & 27,7 & 26,2 & 16,9 \\
\hline Alimentação & 38,9 & 50,0 & 16,7 & 33,3 & 33,3 & 38,9 & 44,4 & 55,6 \\
\hline Financeiro & 31,6 & 42,7 & 28,2 & 23,9 & 28,2 & 29,1 & 42,7 & 32,5 \\
\hline Metalúrgico & 46,2 & 41,9 & 29,1 & 17,9 & 23,1 & 30,8 & 31,6 & 23,9 \\
\hline Aposentados & 45,2 & 16,1 & 29,0 & 29,0 & 16,1 & 25,8 & 22,6 & 25,8 \\
\hline Químico & 34,5 & 46,6 & 25,9 & 24,1 & 32,8 & 32,8 & 27,6 & 29,3 \\
\hline Rural & 32,8 & 31,5 & 16,4 & 13,5 & 9,0 & 23,8 & 21,5 & 29,9 \\
\hline Comunicação / Informação & 20,6 & 29,4 & 41,2 & 32,4 & 23,5 & 20,6 & 29,4 & 17,6 \\
\hline Administração Pública & 33,1 & 25,5 & 37,9 & 17,2 & 11,7 & 22,8 & 34,5 & 24,1 \\
\hline Transporte & 32,1 & 32,1 & 42,9 & 21,4 & 25,0 & 28,6 & 21,4 & 35,7 \\
\hline Total & 36,0 & 35,1 & 29,1 & 19,7 & 18,2 & 27,4 & 32,7 & 26,7 \\
\hline
\end{tabular}

Fonte: CUT 2006c 
Dificuldades encontradas para aprovação da Reforma Sindical enviada ao Congresso

A opinião dos delegados ao $9^{\circ}$ CONCUT acerca das dificuldades encontradas para aprovação da Reforma Sindical está percentualmente bem equilibrada.

Em ordem decrescente, os principais quesitos assinalados pelos delegados foram: "Falta de pressão no Congresso" (36,0\%); "Composição do Congresso não é favorável para reformas desta natureza" $(35,1 \%)$; "Houve confusão no debate sobre a reforma sindical e a reforma trabalhista, que tende a flexibilizar direitos" (32,7\%); "A proposta negociada no FNT não representa os anseios da base sindical" $(29,1 \%)$; "Os trabalhadores estão mais preocupados com as suas demandas imediatas do que com a discussão sobre organização sindical" $(27,4 \%)$; e "Os sindicalistas, em geral, não estão preparados para a reforma sindical" $(26,7 \%)$.

Assim, se por um lado os delegados avaliaram positivamente a participação da CUT no FNT, por outro, eles identificam como a principal dificuldade para aprovação da reforma a falta de pressão no Congresso, o que não deixa de ser, implicitamente, uma auto-avaliação em que se aponta uma lacuna da atuação da CUT em todo esse processo.

Observa-se que um percentual relevante de delegados imputa a fatores externos, no caso, à composição do Congresso Nacional, a dificuldade para aprovação da reforma sindical.

Somente a partir do quarto quesito assinalado pelos delegados é que se expressa uma certa avaliação de leniência política dos sindicalistas, em geral, quanto à vontade de aprovação da reforma sindical: a proposta não representa os anseios da base sindical, os trabalhadores não estão preocupados com a organização sindical e os sindicalistas não estão preparados para a reforma sindical. 


\begin{tabular}{|c|c|c|c|c|c|c|c|}
\hline \multicolumn{8}{|c|}{ Tabela 17 - Prioridades para compor a reforma sindical } \\
\hline & $\begin{array}{l}\text { Fim do } \\
\text { imposto } \\
\text { sindical }\end{array}$ & $\begin{array}{l}\text { Obrigatorie- } \\
\text { dade da } \\
\text { negociação } \\
\text { coletiva (no } \\
\text { setor público } \\
\text { e privado) }\end{array}$ & $\begin{array}{l}\text { Organiza- } \\
\text { ção no } \\
\text { local de } \\
\text { trabalho }\end{array}$ & $\begin{array}{l}\text { Sindicato } \\
\text { Único com } \\
\text { critério de } \\
\text { representati- } \\
\text { vidade }\end{array}$ & $\begin{array}{l}\text { Fim da } \\
\text { intervenção } \\
\text { do Estado e } \\
\text { da Justiça na } \\
\text { organização } \\
\text { livre dos } \\
\text { trabalhadore } \\
\text { s }\end{array}$ & $\begin{array}{l}\text { Fim das } \\
\text { práticas } \\
\text { antissin } \\
\text { dicais }\end{array}$ & Outra \\
\hline $\begin{array}{l}\text { Comércio e } \\
\text { Serviços }\end{array}$ & 42,2 & 49,0 & 68,6 & 24,5 & 60,8 & 60,8 & 3,9 \\
\hline $\begin{array}{l}\text { Extração } \\
\text { Mineral }\end{array}$ & 25,0 & 50,0 & 75,0 & 33,3 & 58,3 & 58,3 & 0,0 \\
\hline $\begin{array}{l}\text { Seguridade } \\
\text { Social }\end{array}$ & 64,6 & 75,4 & 76,9 & 36,9 & 67,7 & 61,5 & 1,5 \\
\hline $\begin{array}{l}\text { Profissionais } \\
\text { Liberais }\end{array}$ & 36,4 & 63,6 & 54,5 & 18,2 & 72,7 & 54,5 & 0,0 \\
\hline Vestuário & 60,0 & 50,0 & 63,3 & 26,7 & 76,7 & 66,7 & 0,0 \\
\hline Educação & 48,4 & 58,4 & 64,9 & 24,2 & 54,8 & 61,6 & 2,1 \\
\hline $\begin{array}{l}\text { Construção e } \\
\text { Madeira }\end{array}$ & 49,0 & 56,9 & 66,7 & 35,3 & 51,0 & 56,9 & 0,0 \\
\hline Urbanitário & 75,4 & 64,6 & 76,9 & 33,8 & 66,2 & 61,5 & 6,2 \\
\hline Alimentação & 61,1 & 72,2 & 83,3 & 16,7 & 50,0 & 55,6 & 0,0 \\
\hline Financeiro & 68,4 & 53,8 & 81,2 & 21,4 & 67,5 & 74,4 & 3,4 \\
\hline Metalúrgico & 61,5 & 44,4 & 82,1 & 31,6 & 53,8 & 65,0 & 0,9 \\
\hline Aposentados & 54,8 & 45,2 & 58,1 & 32,3 & 51,6 & 54,8 & 6,5 \\
\hline Químico & 74,1 & 44,8 & 74,1 & 34,5 & 63,8 & 60,3 & 5,2 \\
\hline Rural & 25,4 & 27,0 & 33,8 & 36,0 & 37,0 & 39,9 & 0,3 \\
\hline $\begin{array}{l}\text { Comunicação / } \\
\text { Informação }\end{array}$ & 41,2 & 67,6 & 70,6 & 38,2 & 52,9 & 64,7 & 2,9 \\
\hline $\begin{array}{l}\text { Administração } \\
\text { Pública }\end{array}$ & 49,7 & 64,8 & 68,3 & 27,6 & 53,8 & 58,6 & 2,8 \\
\hline Transporte & 42,9 & 39,3 & 46,4 & 28,6 & 46,4 & 50,0 & 0,0 \\
\hline Total & 50,2 & 52,6 & 64,8 & 30,2 & 55,3 & 59,6 & 2,2 \\
\hline
\end{tabular}

Fonte: CUT 2006c

\section{Prioridades para compor a Reforma Sindical}

Quando questionados "quais das alternativas você considera que devem ser priorizadas para compor a reforma sindical", os delegados ao $9^{\circ}$ CONCUT deram um recado muito claro. 
A maior prioridade, assinalada por $64,8 \%$ dos delegados, é a organização no local de trabalho.

Ela vem seguida pelo "fim das práticas antissindicais" (59,6\%); pelo "fim da intervenção do Estado e da Justiça na organização livre dos trabalhadores" (55,3\%); e pela “obrigatoriedade da negociação coletiva no setor público e privado" $(52,6 \%)$.

As duas últimas alternativas apresentadas pelo questionário assinaladas pelos delegados foram "fim do imposto sindical" $(50,2 \%)$ e "sindicato único com critérios de representatividade" $(30,2 \%)$.

Percebe-se que a reforma sindical, para os delegados, deveria ter o caráter de garantir um fortalecimento organizativo e do poder de negociação sindical; deixando em segundo plano aspectos da atual estrutura que, a despeito de ser também uma intervenção do Estado, não são percebidas necessariamente como "malefícios". É por isso, cremos, que o fim do imposto sindical e os critérios de representatividade foram os itens que receberam menor menção pelos delegados.

As opiniões dos delegados ao $9^{\circ}$ CONCUT são coerentes com as dos delegados ao $8^{\circ}$ CONCUT (2003), já apontadas nesse capítulo 3, quando então se iniciava os primeiros passos na formação do FNT e na discussão da reforma sindical. Da mesma forma que condizem com a análise sociológica comumente empregada, que expressa a intenção de manter as garantias à ação sindical (incentivos) e retiram os mecanismos de constrangimento.

Assim, percebe-se, no conjunto das tabelas, que as opiniões dos delegados ao $8^{\circ}$ e ao $9^{\circ}$ CONCUT acerca do FNT e da reforma sindical demonstram uma posição cautelosa em relação a possíveis mudanças na estrutura sindical brasileira. E cabe acrescentar que essa opinião atravessa transversalmente todas as correntes políticas internas da CUT, inclusive a Articulação Sindical.

Esta cautela reforça um diagnóstico presente na CUT desde o $5^{\circ}$ CONCUT (1994), em que se apontava um acomodamento das entidades filiadas à estrutura sindical corporativista. 


\section{A reforma sindical fatiada e seus desdobramentos}

A resistência histórica às mudanças na estrutura sindical é a fonte de todo tipo de dificuldade aqui mencionada e impediu que a reforma sindical fosse aprovada, seja através da PEC 369 e do ALRS elaborados no FNT; da PEC 29 dos deputados Mauricio Rands e Vicentinho; ou ainda através do substitutivo do deputado Tarcísio Zimmermann.

Isso não significa, contudo, que continua tudo como dantes...

Desde que ficou claro a todos os envolvidos que a reforma sindical mais global (PEC 369 e ALRS) não progrediria no Congresso, começou-se a desenhar um "plano B", que vem sendo chamada de reforma sindical fatiada. Ou seja, ao invés de uma mudança no atacado, com a substituição de uma lógica corporativa por outra baseada na liberdade e autonomia sindical ou algo que se aproximasse disso, vêm se processando no varejo mudanças pontuais e bem significativas que estão alterando o cenário sindical.

Já mencionamos nesse trabalho que o FNT continuou se reunindo e negociando acerca dos pontos divergentes tendo em vista viabilizar alguma reforma sindical no Congresso Nacional. Diante das dificuldades de avançar no plano legislativo a partir do diálogo entre as partes, o Executivo tomou a iniciativa e propôs duas Medidas Provisórias (MP): uma delas, a MP $n^{\circ} 293$, de 08/05/2006, reconhecendo legalmente as centrais sindicais, garantindo a participação das mesmas nos espaços públicos de diálogo social, a partir de critérios claros e objetivos de representatividade.

Outra medida provisória lançada pelo Executivo foi para constituir o Conselho Nacional de Relações de Trabalho (CNRT), a MP n ${ }^{\text {o } 294, ~ t a m b e ́ m ~ d e ~ 08 / 05 / 2006 ~}{ }^{127}$.

Com essa medida o governo provocava o Congresso Nacional a sair de sua desídia a partir de um fato dado, forçando sua resposta.

A MP 293 teve sua tramitação no Congresso da data de sua publicação no Diário Oficial, 09/05/2006 até o dia 05/09/2006. Nesse período a MP acolheu quarenta e duas emendas e teve o parecer do relator pela rejeição, o deputado Luiz Antônio de Medeiros (PL-SP), exsindicalista ligado à Força Sindical, que fez o seguinte pronunciamento: “...conclui pelo atendimento dos pressupostos constitucionais de relevância e urgência; pela constitucionalidade,

\footnotetext{
127 Além dessas duas medidas provisórias, o Executivo enviou na mesma ocasião um Projeto de Lei das Cooperativas, que regulamentava o funcionamento de cooperativas de trabalho, resultado de consenso obtido no Conselho Nacional de Economia Solidária. O conteúdo do PL era o de reconhecer e definir as Cooperativas do ponto de vista normativo e jurídico para estimular sua criação formal, evitando que os patrões soneguem os direitos trabalhistas dos funcionários pela contratação de cooperativas.
} 
juridicidade e técnica legislativa; pela adequação financeira e orçamentária; e, no mérito, pela rejeição desta MPV e das Emendas de ns 1 a 42”. O relator alegou no Plenário da Câmara que “... é claro que elas [as centrais sindicais] precisam ser legalizadas no Brasil (...) Porém, durante a discussão, surgiu o debate sobre o financiamento das centrais sindicais. Não foi uma discussão fácil... Inclusive, havia uma proposta de que o sindicato de base indicaria a central para onde iria o recurso, bem como a federação e a confederação. Houve o consenso de que o sindicato de base poderia indicar a central, mas não houve consenso sobre o sindicato de base indicar a federação ou a confederação, porque isso seria ilegal, seria a pluralidade sindical no movimento. O movimento sindical precisa de tempo para a discussão. Não podemos parar a discussão agora nem nunca mais discutir a legalidade das centrais". (MEDEIROS, 2006)

Depois do parecer do relator a MP seguiu seu curso até ser rejeitada pelo presidente da Câmara. ${ }^{128}$

A nova tentativa foi através do PL 1990/07, também enviado pelo Executivo ao Congresso Nacional. O Projeto de Lei foi apresentado no dia 11/09/2007, tendo sido apensada ao PL $1528 / 89$.

Como já anotado anteriormente nessa tese, o substitutivo teve um parecer do relator, o deputado Vicentinho (PT-SP), pela sua rejeição, e pela aprovação do Projeto de Lei ${ }^{o}$ 1990/07.

O prosseguimento do PL 1990/07 foi condicionado a um acordo estabelecido entre as centrais sindicais de que o reconhecimento legal daquelas instituições ocorreria somente mediante o compromisso dos mesmos em extinguir o imposto sindical, substituindo-o pela contribuição de negociação coletiva, conforme havia sido encaminhado pelo FNT no $\operatorname{ALRS}^{129}$.

Em depoimento à página da CUT, Artur Henrique, presidente da CUT Nacional, declarou que o reconhecimento jurídico das centrais é o primeiro passo importante para uma mudança na estrutura sindical brasileira. "Nós temos hoje uma situação onde as centrais são

${ }^{128}$ A MP 294, cujo relator foi o deputado Vicentinho (PT-SP), teve o seguinte parecer “...eu, que tenho experiência de vida em negociação, aprendi que nada é mais importante do que a busca de uma proposta construída com base no entendimento entre todos os setores. Evidentemente o entendimento pressupõe todo mundo ceder um pouco para se chegar a uma conclusão. Diante desse fato e apostando que voltaremos a discutir o assunto por querermos criar um fórum nacional do trabalho, que propiciar- uma série de debates e soluções de conflitos, na condição de Relator desta medida provisória, seguirei a linha do que foi acordado. Nossa posição é pela constitucionalidade e admissibilidade, mas contrária ao mérito". (http://www.camara.gov.br/sileg/integras/416704.pdf)

${ }_{129}$ A página da CUT na internet, www.cut.org.br, trouxe minuciosamente, passo a passo, toda a tramitação do PL 1990, sendo a principal fonte que essa pesquisa utilizou nessa seção. 
reconhecidas do ponto de vista político, mas não do ponto de vista jurídico. Para o conjunto da classe trabalhadora isto tem uma importância fundamental, pois as centrais passam a ter um papel de representar os interesses gerais dos trabalhadores e não apenas de uma categoria isolada. Reafirmo que é um primeiro passo porque ainda temos muito a avançar, principalmente, em relação às medidas que consideramos fundamentais para a mudança da estrutura sindical em nosso país: fim do imposto sindical, organização por local de trabalho, legislação contra os atos antissindicais e fim da unicidade sindical”. (SANTOS, 2007)

$\mathrm{Na}$ mesma matéria da página da CUT, Denise Mota Dau, secretária nacional de organização, declarou que "nesse momento esperamos agilidade do Congresso Nacional e sensibilidade para aprovar o PL 1.990, que é parte, na verdade, uma pequena parte de uma reforma sindical democrática, pois a reforma sindical que queremos é bem mais ampla". (DAU, 2007)

Vale ressaltar que o projeto estabeleceu um critério de representatividade das centrais exigindo cem sindicatos filiados nas cinco regiões do País; vinte sindicatos filiados em cada uma de pelo menos três regiões do Brasil; filiação de sindicatos em, no mínimo, cinco setores de atividade econômica; e filiação de sindicatos que representem, no mínimo, 7\% do total de empregados sindicalizados em âmbito nacional. Os deputados retiraram, do texto, a possibilidade de as centrais sindicais somarem os índices de sindicalização dos sindicatos a elas filiados para cumprirem a exigência relativa a esses 7\%, mas flexibilizaram aprovando que "nos dois primeiros anos contados da data de publicação da futura lei, esse índice de 7\% ficará reduzido a 5\%". (CUT, 2007) Além disso o projeto permitia que as centrais representassem os trabalhadores na Justiça e recebesse parte do imposto sindical, metade do que cabia ao MTE na "Conta Salário e Emprego", ou seja, $10 \%$ do arrecadado pela contribuição sindical, distribuído proporcionalmente de acordo com o número de trabalhadores representados nos sindicatos filiados a cada central sindical, respectivamente ${ }^{130}$.

\footnotetext{
${ }^{130}$ Em uma entrevista, Denise Motta Dau ressaltou que "a CUT defende que $70 \%$ fique com os sindicatos, o que significaria uma redução do percentual de repasse para as federações. Nós queremos o fortalecimento do sindicato, que é quem negocia diretamente e representa os trabalhadores e trabalhadoras das diversas categorias profissionais e ramos de atividades. Então, o fortalecimento dos sindicatos é fundamental - com liberdade de indicação da federação, confederação e central sindical a qual este sindicato esteja filiado, o que a estrutura sindical brasileira hoje não permite, pois é bastante autoritária e inviabiliza a indicação, por exemplo, de confederações não oficiais. Este é um ponto polêmico". (DAU, 2008)
} 
No decorrer da tramitação legislativa, o PL foi recebendo diversas emendas e o texto aprovado na Câmara levou ao Senado a proposta do deputado Augusto Carvalho (PPS-DF) que recolocava o conteúdo do PL 2085/07, de sua autoria, exigindo autorização do trabalhador para o desconto em folha de pagamentos do imposto sindical. Apenas para os trabalhadores. $\mathrm{O}$ imposto sindical recolhido compulsoriamente pelas empresas às entidades sindicais patronais, de acordo com a emenda do deputado, não estava passível de autorização empresa por empresa, permanecendo o desconto automático. O PL 2085/07 havia sido rejeitado junto com o PL 1528/89, mas sua proposta de emenda foi encaminhada em votação nominal e aprovada pelo Plenário por 215 votos a favor; 161 contrários; e 7 abstenções.

Outra emenda agregada ao projeto, de autoria do líder do PSDB, deputado Antonio Carlos Pannunzio (SP), incluiu explicitamente na lei a prerrogativa do Tribunal de Contas da União (TCU) de fiscalizar os recursos do imposto sindical direcionados às centrais sindicais.

Para Denise Mota Dau, o que se viu na noite da aprovação do PL na Câmara, em 17/10/2007, foi "um filme que passou por drama, terror e até comédia, protagonizado pelos representantes dos interesses patronais na Câmara Federal". Inicialmente, ela explicou, os parlamentares ligados ao DEM e ao PSDB tentaram impedir ou prorrogar a apreciação da matéria no Plenário: "Durante toda a votação do PL 1990 os representantes dos patrões tentaram distorcer a centralidade do projeto, que é o reconhecimento das centrais e seu respectivo financiamento, agredindo verbalmente as entidades sindicais e seus/suas representantes. Fomos chamados de "vendidos, traidores, neopelegos, braços do governo, autarquias sindicais, proprietários de dinheiro sujo da contribuição sindical e patrocinadores da farra com a dinheirama que vem do trabalhador". Porém esses ataques não vieram só dos que se dizem de esquerda radical, mas principalmente da direita, em resumo os representantes dos patrões, concentrados em especial no DEM e no PSDB”. (DAU, 2007b)

Segundo a dirigente, "foram apresentadas dezenas de Emendas que diminuíam os critérios de representatividade das centrais (tornando-as menores e mais frágeis); outras emendas tentavam diminuir o já limitado poder de negociação garantido pelo projeto. Mas nenhuma delas foi aprovada, devido à atuação dos parlamentares ligados aos trabalhadores: Tarcísio Zimermam, Paulinho, Roberto Santiago e em especial o Deputado Vicentinho, relator do PL, que, durante todo o processo de votação defendeu o conteúdo que contemplava o acordo realizado entre as Centrais 
Sindicais e o poder Executivo, ressaltando 'a importância histórica das centrais sindicais na democratização do país, assim como nas negociações em prol de melhores salários e condições de vida para a classe trabalhadora'." (DAU, 2007b)

A ação mais imediata da CUT e das demais centrais sindicais foi procurar o presidente do Senado, na ocasião o Senador Tião Viana (PT-AC), no dia 23/10/2007, para cobrar dele celeridade no processo e o restabelecimento do acordo firmado entre as centrais com o governo. Além disso, as centrais decidiram fazer corpo-a-corpo no Senado, com o objetivo de convencer os senadores a manter o texto original do PL de reconhecimento das centrais, em respeito ao acordo firmado.

Em nova matéria na página da CUT, Artur Henrique, presidente da Central, frisou que o acordo precisa ser respeitado, resgatando os seus quatro pontos: "1. O reconhecimento das centrais; 2. que enquanto existir o Imposto Sindical, parte dele, os $10 \%$ da conta do Ministério do Trabalho, sejam destinados às centrais; 3. que os Sindicatos de base indicarão qual a Federação, Confederação e Central que receberá sua contribuição e 4. o compromisso das centrais de criarem novas formas de financiamento da estrutura sindical no prazo de 90 dias". Com o estabelecimento da contribuição negocial, sublinhou o líder cutista, "são os próprios trabalhadores, livremente, que debaterão em assembleia sobre as formas de sustentação da entidade". "Será como numa reunião de condomínio: se você não comparece, tem de acatar; se você apresenta uma proposta, ela pode ser votada. É esta ideia, é este o princípio que defendemos que seja estabelecido daqui pra frente. É claro que se todos são beneficiados pelo acordo coletivo, o direito de oposição ficará obviamente restrito à assembleia”, declarou”. (SANTOS, 2007b)

Paralelamente ao trâmite do PL no Senado, agora sob a denominação Projeto de Lei da Câmara - PLC 88/07 -, o Ministério do Trabalho criou o Grupo de Trabalho para debater a sustentação financeira das entidades sindicais, tendo em vista a extinção do imposto sindical e a sua substituição pela contribuição de negociação coletiva.

Foi divulgado na página da CUT:

"Atendendo reivindicação das centrais sindicais CUT, FS, CGTB, NCST e UGT, e honrando o Protocolo de Entendimentos firmado com suas lideranças no dia 10 de maio, o ministro do Trabalho e Emprego, Carlos Lupi, anunciou na tarde desta quarta-feira (07/11/2007), a constituição de um Grupo de Trabalho para debater a sustentação financeira das entidades sindicais. Com reunião marcada para a próxima terça-feira, o GT terá prazo 
de 90 dias para encontrar uma proposta de transição do Imposto Sindical para a contribuição negocial, acordada durante o Fórum Nacional do Trabalho (FNT) (...) Como "fiel depositário do acordo" firmado pelas centrais com o governo, Lupi defendeu sua manutenção: "enquanto debatemos outra forma de custeio, propomos manter o Imposto Sindical como está e sem qualquer controle do Tribunal de Contas da União, até porque isso representaria uma ingerência indevida do Estado. Nós não queremos nem mais nem menos, estamos apenas construindo uma alternativa e, para isso, o acordo original das centrais com o governo precisa ser respeitado". (...) Em sua cláusula primeira, o Protocolo de Entendimentos assinado pelas centrais com o MTE estabelece que o Grupo de Trabalho terá como objetivo "consolidar uma proposta definitiva de custeio da organização sindical brasileira, regulamentando a cobrança das contribuições devidas às entidades sindicais, na direção da constituição de uma contribuição negocial, vinculada ao exercício efetivo da negociação coletiva e à aprovação em assembleia geral". Além disso, o GT tem o objetivo de "firmar o compromisso público das centrais subscritas de apoio à instituição do Conselho Nacional de Relações do Trabalho (CNRT), que a exemplo do Fórum Nacional do Trabalho, se pretende um espaço de composição tripartite e paritária para a discussão de temas relacionados às relações de trabalho e organização sindical no Brasil”. (CUT, 2007)

O Grupo de Trabalho entregou a proposta de novo modelo de financiamento poucos dias depois, em 13/11/2007, resgatando o conteúdo do ALRS acordado no FNT.

No Senado o PLC 88/07 recebeu vinte e uma emendas, sendo que os principais temas abordados foram a manutenção do imposto sindical, derrubando a emenda do Augusto Carvalho e restabelecendo o acordo entre as centrais; a destinação do recurso do imposto sindical quando não houver a indicação das entidades de grau superior a receber; e algumas emendas afirmando que era desnecessário o sindicato indicar a qual federação / confederação está vinculado, em virtude de que permanecia o instituto da unicidade sindical.

As emendas dos senadores foram apreciadas e tiveram o parecer dos relatores da Comissão de Assuntos Sociais (CAS) e da Comissão de Assuntos Econômicos (CAE) do Senado, respectivamente os senadores Paulo Paim (PT-RS) e Francisco Dornelles (PP-RJ).

No parecer da CAS, Paulo Paim rejeitou cinco das 21 emendas apresentadas ao projeto.

As emendas aprovadas pelo relator são as que procuraram restabelecer os eixos do projeto apresentado pelo Governo em acordo com as centrais sindicais. No entanto, a emenda $\mathrm{n}^{\mathrm{o}} 1$ 
foi aprovada e altera o artigo $1^{\circ}$, inciso I, do PLC 88, substituindo a expressão "representa" por "coordena".

Desse modo, o texto do artigo passou a vigorar com a seguinte redação: “...coordenar a representação [antes falava em “exercer a representação"] dos trabalhadores, por meio das organizações sindicais a ela filiados; e..."

$\mathrm{Na}$ análise das emendas feita pelo relator, ele justifica a aprovação da substituição:

“A Emenda $n^{\circ} 1$ promove duas alterações: a primeira substitui a expressão "exercer" por "coordenar" (inciso I, do art. $1^{\circ}$ do projeto) para estabelecer que esta última [ou seja, a coordenação das entidades sindicais e não o exercício efetivo da representação de sindicatos] é que estará entre as prerrogativas e atribuições das centrais. A segunda pretende vedar às centrais sindicais a celebração de acordos e convenções coletivas de trabalho.

A primeira alteração é bem-vinda na medida em que se harmoniza melhor com a atuação das centrais, que tem alcance nacional. Assim, elas estão realmente em condições de promover essa coordenação e integração do movimento sindical brasileiro, razão pela qual estamos incorporando, nesse particular, a emenda apresentada.

Todavia, relativamente à segunda alteração que se propõe, apontamos que o reconhecimento formal que o projeto dá às Centrais Sindicais preserva a autonomia política e administrativa dos sindicatos.

A Consolidação das Leis do Trabalho e a própria Constituição já ressalvam o caráter indispensável da participação dos sindicatos nas negociações coletivas de trabalho e na defesa dos direitos e interesses coletivos ou individuais da categoria, inclusive em questões judiciais ou administrativas. Por essas razões, não acolhemos a emenda, nessa parte. Pela aprovação parcial”. (PAIM, 2007)

Nenhum dirigente da CUT ou de qualquer outra central sindical protestou contra essa alteração, que modifica substancialmente o propósito do projeto. A aprovação do artigo com essa emenda joga por terra parte da crítica à reforma sindical que ela foi feita para centralizar e fortalecer a cúpula do movimento sindical, as centrais sindicais.

As emendas 3 e 4 rejeitam a redação aprovada na Câmara (emenda Augusto Carvalho) para que a contribuição sindical só seja depositada na conta do sindicato caso o trabalhador aprove previamente o desconto no contracheque. Assim, no parecer, Paulo Paim resgata o desconto automático da contribuição sindical e seu repasse conforme estabelecido no projeto original.

Do mesmo modo, o parecer da CAE também rejeitou a emenda do deputado Augusto Carvalho. $\mathrm{O}$ argumento de ambos, afora questões de concepção sindical que não vem ao 
caso, foi de que a eventual não autorização pelo trabalhador do desconto da contribuição sindical em folha não o exime de realizar o pagamento, deixando em aberto uma pendência do tributo, que teria que ser pago diretamente pelo trabalhador na rede bancária. Ou seja, como o recolhimento do imposto sindical é obrigatório, uma vez não procedendo a operação de forma automática, o ônus do pagamento recairia sobre o trabalhador. Esse foi o motivo que balizou ambos os relatores a rejeitar a emenda de Augusto Carvalho.

No caso do parecer da CAE, o relator aceitou a emenda do deputado Pannunzio que determina que os recursos provenientes da contribuição sindical sejam fiscalizados pelo Tribunal de Contas da União (TCU).

Do mesmo modo, as emendas relativas ao sistema confederativo foram excluídas do texto.

O plenário do Senado aprovou o relatório dos senadores no dia 29/11/2007, mantendo a essência do acordo firmado pelas centrais sindicais com o governo.

Voltava-se agora para a batalha na segunda votação na Câmara, retomando o número original (1990/07) antes de submeter o projeto à sanção do presidente.

Mas, de acordo com a norma da Casa, a Câmara só pode aprovar ou rejeitar as emendas aprovadas no Senado, estando vedada tanto a inclusão de novas emendas como a rejeição de partes do texto - artigos, incisos ou parágrafos - aprovados no Senado. Desse modo, a Câmara apenas se pronunciaria sobre as novas emendas vindas do Senado.

O rito na Câmara foi demorado, à espera da votação de várias MPs que trancavam a pauta. Mas no dia 11/03/2008, por 234 votos a favor e 171 contrários, foi aprovado o PL 1990/07. A página da CUT na internet fez um relato de como transcorreu a aprovação do PL que confere o reconhecimento às centrais:

"A sessão da Câmara de ontem foi marcada, durante toda a tarde, por obstruções de parlamentares do ex-PFL e do PSDB. Muitos pronunciamentos foram dirigidos contra a crítica que o presidente Lula fizera na véspera, quando disse que os parlamentares deveriam trabalhar mais. Por detrás das falas, no entanto, o que se travava era uma disputa para evitar a aprovação do Orçamento e a liberação de verbas para o PAC. (...)

Por volta das 19h30, o presidente da Câmara, Arlindo Chinaglia, destacou a necessidade de votação do reconhecimento das centrais, cobrando cumprimento de acordo anterior entre base aliada e oposição. Os ex-pefelistas, na figura de Antonio Carlos Magalhães Neto, tentaram resistir, mas a votação foi aberta. (...) 
Para defender o texto sem emendas, revezaram-se na tribuna os deputados Maurício Rands (PTPE), Vicentinho (PT-SP), Tarcísio Zimmermann (PT-RS) e Roberto Santiago (PV-SP). Do lado de lá, um dos mais afoitos era Ronaldo Caiado (ex-PFL-GO), acompanhado de Augusto Carvalho". (CUT: 2007)

Para Denise Motta Dau, o reconhecimento das centrais é o primeiro passo na caminhada pela democratização da estrutura sindical. (DAU, 2008).

O PL 1990/07 - redefinido como Lei 11.648 - foi sancionado pelo presidente com o veto do artigo que obriga sindicatos, federações, confederações e centrais sindicais a prestarem contas ao TCU, conforme a emenda do deputado Pannunzio. Artur Henrique, presidente da CUT, defende o veto. "O TCU já fiscaliza as entidades sindicais, e deve mesmo fazê-lo, em parcerias ou convênios onde há participação de dinheiro público. Porém, o dinheiro de que trata o reconhecimento das centrais não é dinheiro público, é dinheiro privado, vem do trabalhador", afirma. "Assim, a fiscalização do TCU nestes casos seria inconstitucional e uma ingerência indevida do governo sobre as entidades". (CUT, 2008)

Outro item do sistema sindical corporativo que sofreu alteração no período em direção ao regime de liberdade e autonomia sindical foi a instauração, na prática, do fim da unicidade sindical. ${ }^{131}$

O principal motor que impulsionou essa mudança foi a Portaria 186, publicada pelo Ministro do Trabalho Carlos Lupi em 10/04/2008, que normatiza os procedimentos para o registro sindical, revogando, na íntegra, a portaria 343 que, por mais de oito anos, regulou o tema $^{132}$. As novidades ficam por conta do detalhamento dos procedimentos necessários ao registro, impugnação e negociação de eventuais conflitos de representação.

Segundo análise do Departamento Intersindical de Assessoria Parlamentar (DIAP), "a Portaria $n^{\circ} 186$ trouxe, desta forma, as adequações necessárias aos procedimentos administrativos

${ }^{131} \mathrm{O}$ artigo $2^{\circ}$ da Portaria menciona o procedimento para registro e alteração estatutária de entidades sindicais, ou seja, subentende-se sindicatos, federações e confederações. No entanto, o efeito mais imediato da Portaria ocorreu entre entidades de grau superior, federações e confederações. Só mais recentemente a Portaria têm tido sua eficácia também para sindicatos estimulando a criação de novos sindicatos. Em entrevista concedida à pesquisa, um assessor da CUT afirmou que o movimento de fragmentação de base de sindicatos que já vinha ocorrendo antes da Portaria se manteve. A novidade mesmo, confirmou ele, está nas instâncias de grau superior.

132 Outra mudança que pode estar em curso no sistema sindical atual teve seu primeiro passo no dia 30/04/2009, quando o MTE editou a Portaria $n^{\circ}$ 694, criando uma instância tripartite no âmbito do Ministério do Trabalho semelhante a proposta debatida do CNRT, chamada Comitê de Acompanhamento de Assuntos Trabalhistas - CAAT. 
para registro sindical e alterações estatutárias, estabelecendo as exigências claras para efetiva e concreta comprovação de representatividade e base territorial, adotando a possibilidade da autocomposição para a solução de conflitos intermináveis, objetivando amparar categorias que se encontram à margem da própria evolução em razão de infindáveis discussões sobre quem, efetivamente, é seu representante sindical". (GHERARDI, 2008)

Não é o caso de afirmar que a Portaria rompeu com a unicidade sindical, mas ela permite, pelos seus critérios, o reconhecimento de uma federação estadual de determinado ramo criada pela CUT (de químicos, por exemplo), mesmo já existindo uma federação no mesmo estado, filiado ou não a outra central sindical. A lógica é de que a federação da CUT representaria exclusivamente os trabalhadores da base sindical filiada à CUT; e a outra federação, seria representante exclusiva dos trabalhadores dos sindicatos não cutistas, nesse exemplo. Desse modo, se preserva a lógica da unicidade sindical, ao mesmo tempo em que permite e reconhece mais de uma entidade sindical.

Essa é, seguramente, a grande novidade da Portaria 186: o fim da unicidade na estrutura superior. Essa medida permite que as centrais sindicais recentemente legalizadas possam, a partir dos critérios definidos nesta portaria, construir e legalizar suas federações e confederações. Do mesmo modo, a portaria possibilita maior liberdade de organização sindical, principalmente em relação às entidades de segundo grau, possibilitando que a partir de cinco sindicatos, não necessariamente localizados no mesmo estado da federação, possa se constituir uma federação e a existência de três federações possibilite a criação de uma confederação.

Por tudo isso, “a CUT imediatamente manifestou sua posição favorável à Portaria 186, reforçando ainda sua posição intransigente em defesa da Convenção 87 da OIT. (...) Finalmente queremos reforçar que a Portaria 186 não tem o mesmo papel na organização sindical que a Convenção 87, pois mantém a unicidade sindical e ainda mantém um papel determinante do Estado na organização sindical, mas se aproxima do projeto defendido pela CUT”. (CUT, 2008)

Altamiro Borges, em artigo na página do Departamento Intersindical de Assessoria Parlamentar (Diap), afirmou que “onze confederações nacionais de trabalhadores já protocolaram no Supremo Tribunal Federal (STF) uma Ação Direta de Inconstitucionalidade (Adin) contra a Portaria. Elas garantem que o projeto incentiva a multiplicação das federações e 
confederações, ferindo de morte o atual sistema confederativo, e que é inconstitucional. Elas também denunciam que foram excluídas do grupo ministerial que redigiu a medida”. E continua ele: “com exceção da CUT, que sempre defendeu a implosão do sistema confederativo (...) Todas as outras [centrais sindicais], CTB, NCST, UGT e CGTB, já condenaram a medida e exigem a sua revisão". Para Wagner Gomes, presidente da CTB, "a Portaria 186 contribuiu para multiplicar o número de entidades sindicais, sobretudo as de segundo grau, e afronta a unicidade sindical consagrada na CLT e na Constituição". ${ }^{133}$

(“http://www.diap.org.br/index.php/artigos/5083-portaria_186_fere_unicidade_sindical)

Mas, a bem da verdade, a Portaria veio também reconhecer uma situação que já vinha ocorrendo no meio sindical ao arrepio da legislação.

Citando Edésio Passos, ex-deputado federal do PT-PR e assessor técnico do Departamento Intersindical de Assessoria Parlamentar (Diap), Borges escreve que "o Governo Lula, desde o primeiro mandato, vinha reconhecendo "a pluralidade no campo federativo e confederativo, embora esse campo sindical esteja definido há muitos anos no sistema da unicidade sindical”. A nova portaria apenas legalizaria esta prática ilegal - 'um fato saudado pela CUT'”.

Alguns ramos da CUT, como o dos metalúrgicos, já vinham se movimentando no sentido de terem seu reconhecimento legal mesmo antes da Portaria 186.

No Estado de São Paulo, por exemplo, o Departamento Estadual de Metalúrgicos da CUT foi criado em 1988, rompendo com a Federação Estadual dos Trabalhadores nas Indústrias Metalúrgicas de São Paulo, reconhecida oficialmente pelo Ministério.

Em 1992, fruto das deliberações da $5^{\text {a }}$ Plenária Nacional da CUT, o Departamento transformou-se em Federação dos Sindicatos Metalúrgicos da CUT-SP (FEM-CUT), mas sobreviveu à margem da legislação, impugnada pelo Ministério a partir da provocação da federação oficial. Essa situação persistiu até 2005, quando a FEM-CUT teve seu reconhecimento enquanto entidade sindical pelo MTE, portanto durante as negociações da reforma sindical e antes da Portaria 186.

\footnotetext{
${ }^{133}$ Ainda na crítica à CUT, Borges cita José Carlos Arouca, desembargador aposentado do TRT e membro da Academia Nacional de Direito do Trabalho, para quem a Portaria 186 é um dos piores golpes na unicidade na história do país. Sem papas na língua, ele arremata: "Salta a evidência que a portaria atende ao empenho da CUT e da Força Sindical em assumir a direção do sindicalismo. O propósito é seguir o modelo orgânico da CUT, a partir das centrais e não das bases, com ramificações para baixo e a criação de instâncias próprias desde sindicatos até federações. A portaria, obra isolada de um segmento do Poder Executivo, sobrepõe-se a lei, ferindo o artigo 516 da CLT, e ofende dolosamente a Constituição". (BORGES, 2008)
} 
Em outros casos, como no ramo químico, utilizou-se da Portaria para buscar sua oficialização.

A Confederação Nacional do Ramo Químico (CNQ), confederação orgânica à CUT, fez uma aliança com o Secretariado Nacional dos Químicos da Força Sindical e, juntas, constituíram a Confederação Nacional dos Trabalhadores Químicos (CNTQ), tendo por base uma soma de federações de cada central sindical. Pelo lado da CUT, participaram a Federação Única dos Petroleiros (FUP), orgânica à CUT; a Federação dos Trabalhadores na Indústria Química e Farmacêutica no Estado do Rio de Janeiro (federação oficial filiada à CUT que tem alguns sindicatos não cutistas na base); e a Federação dos Trabalhadores do Ramo Químico da CUT no Estado de São Paulo - FETQUIM, que foi fundada recentemente, em 2007, orgânica à CUT e à CNQ, a partir de um pacto para reconhecer sua representação entre os sindicatos do ramo filiados à CUT, feito com a Federação dos Trabalhadores nas Indústrias Químicas e Farmacêuticas do Estado de São Paulo (FEQUIMFAR), entidade oficial filiada à Força Sindical.

A CNTQ, juntando federações da CUT e da Força Sindical no ramo químico, foi fundada em 22/11/2007 $7^{134}$ (poucos meses após a edição da Portaria 186), a partir de uma estratégia das duas centrais sindicais para minar a representação da Confederação Nacional dos Trabalhadores da Indústria (CNTI), tendo em vista que seu presidente, José Calixto Ramos, foi a liderança que teve maior proeminência na oposição a qualquer iniciativa de reforma sindical, fiador da fundação da Nova Central Sindical dos Trabalhadores (NCST).

Em entrevista concedida a mim para essa pesquisa, um dirigente nacional da CUT afirmou que uma das estratégias da Central no atual período é buscar o reconhecimento legal de toda a estrutura vertical da CUT (federações e confederações orgânicas) junto ao MTE para ser o desaguadouro da contribuição sindical (imposto sindical) dos sindicatos da CUT, minando assim o poder financeiro de outras confederações que se utilizam desse recurso cobrado de trabalhadores da base cutista para desenvolver suas ações contra a CUT.

Porém, reforçou o dirigente, a CUT permanece sendo contrária à cobrança do imposto sindical e defende a sua substituição pela contribuição de negociação coletiva. Mas,

\footnotetext{
${ }^{134}$ A Confederação Nacional dos Trabalhadores Químicos - CNTQ, presidida por Antonio Silvan Oliveira, agora representa oficialmente os trabalhadores químicos de forma nacional. No dia 10 de dezembro de 2007, o Secretario do Trabalho do Ministério do Trabalho, Luiz Antonio Medeiros, entregou a carta de reconhecimento oficial da CNTQ, na sede da Superintendência Regional do Trabalho do Estado de São Paulo - SRTE/SP. (http://www.cntq.org.br/)
} 
enquanto não se concretiza o acordo entre as centrais sindicais firmado no Protocolo de Entendimentos, ele entende que as entidades da CUT devem "disputar" esses recursos. Para ele, nada mais justo, pois são trabalhadores de bases cutistas financiando a CUT e não a representação de outra proposta política. O risco, continuou, é a contribuição de negociação coletiva não ser aprovada e as federações e confederações da CUT acomodarem-se com o recurso do imposto sindical.

A própria CUT, em 2009, recebeu pela primeira vez o depósito de recursos do imposto sindical diretamente. ${ }^{135}$

Em reunião da Executiva Nacional em 17 e 18 de março de 2009, deliberou-se a prioridade a ser dada na utilização de recursos do imposto sindical, voltado prioritariamente para as ações de formação e de comunicação da Central, em especial àquelas destinadas à ampliação da base de sindicatos filiados.

Outro esforço que tem sido empreendido é o de incentivar os sindicatos filiados à CUT a preencherem o cadastro do MTE indicando a CUT como sua central sindical, tendo em vista reforçar a condição de Central mais representativa, conquistando assim não só a maior parte do imposto sindical destinado às centrais, como também a prerrogativa de ter maior número de representantes nos fóruns e conselhos que as centrais têm participação.

Neste sentido, em relação à Nota Técnica 36, de 16/03/2009 que trata do desconto do imposto sindical para o setor público, a CUT passou a seguinte orientação aos sindicatos:

“1) Somos contra o Imposto Sindical e pela aprovação do PL de implantação da Contribuição Negocial para os setores público e privado, e não abriremos mão desta luta.

2) Somos favoráveis à suspensão da Instrução Normativa 01 (IN-01) que decide que o Imposto Sindical deve ser cobrado dos servidores.

3) Diante da inevitabilidade da cobrança, queremos que a verba relacionada à base de representação das entidades de servidores públicos filiadas à CUT, seja respeitada e a elas destinada.

4) Que nossas entidades acompanhem a implantação da Nota Técnica 36 e do desconto - por meio da GRCSU - Guia de Recolhimento da Contribuição Sindical Urbana - assim como fiscalizem o recolhimento para as entidades receptoras, por parte dos gestores municipais, estaduais

\footnotetext{
135 É evidente que a mensalidade paga pelos sindicatos à CUT incluem recursos advindos da contribuição sindical dos trabalhadores de base. Mas a CUT em si não recebia imposto sindical. Era o repasse da mensalidade dos sindicatos filiados que lhe era devido. Agora a CUT terá acesso a esse recurso diretamente da Caixa Econômica em face dos $10 \%$ atribuídos proporcionalmente às centrais sindicais, como prevê a Lei $11.648 / 08$.
} 
e federal. Comunicando-nos imediatamente qualquer distorção ou repasse incorreto que possa ter ocorrido.

5) Que as entidades verifiquem os seus respectivos códigos sindicais e confirmem se o repasse para a estrutura superior (federações e confederações) está de acordo com a vontade da entidade.

6) Que as entidades cutistas chequem e atualizem todos os seus dados junto ao CNES - Cadastro Nacional de Entidades Sindicais do MTE, tais como renovação e prazo de mandato, número de filiados, alteração na base de representação e demais dados cadastrais.

7) Reiteramos ser importante que as entidades representativas do setor público busquem - e possam - legalizar-se, informando-nos sobre todas as demandas para tal.

8) Reivindicamos que entidades com pública e notória atuação sindical as quais possuem o reconhecimento político, mas ainda não jurídico, possam obter a concessão do registro sindical, se necessário for com uma nova legislação, visto que o modelo de organização do setor privado não se adequou às demandas do setor público, e vamos trabalhar neste sentido junto ao MTE”. (Circ. EE 05015088427/09/SG/SNO/CUT - grifo meu)

Em uma Oficina de Organização Sindical, realizada em maio de 2008, o secretário-geral da CUT, Quintino Severo, afirmou que "a disputa pelas bases já está acirrada e ficará ainda mais à medida que a Portaria 186 for mais bem compreendida". De fato, um ano depois da análise de Quintino, observa-se um grande número de entrada de pedido de reconhecimento sindical no MTE. Para o secretário-geral, "a luta insistente pelo fim do imposto e das taxas é que vai impedir a pulverização de entidades pelo Brasil". Mas paralelamente a isso, "é necessário iniciar um amplo e consistente movimento para filiar mais sindicatos à CUT e intensificar a disputa pelas vias eleitorais”. Essas foram duas das conclusões da Oficina sobre Organização Sindical, promovida pela CUT. (CUT, 2008)

Para o secretário nacional de Política Sindical da época, Vagner Freitas, "é uma batalha sindical que se inicia. E a disputa deve ser feita, e a CUT tem clareza de que precisamos iniciar um movimento compacto, amplo, para trazermos mais sindicatos para nossa Central. Mas isso se dará de acordo com nossa concepção de ação sindical, pela via do convencimento político e ideológico", afirmou. (CUT, 2008)

Em uma Oficina sobre Organização Sindical, realizado pela CUT em 19 e 20 de maio de 2008, Artur Henrique fez um retrospecto do que ele chamou de "momento de reorganização da estrutura sindical brasileira", para então afirmar que "se por um lado isso nos impõe problemas na disputa pelas bases, por outro nos traz oportunidades imensas de 
reafirmarmos nossas concepções e práticas sindicais e levá-las a um número maior de bases". (CUT, 2008)

Vagner Freitas, na ocasião secretário nacional de política sindical, no mesmo evento, lembrou que a velha estrutura sindical já está passando por mudanças positivas. "Menos ousadas que o que a CUT sempre defendeu, pois ainda lutamos pela Convenção 87 da OIT - sobre liberdade e proteção de direto sindical - e pelo fim do imposto sindical. Porém, estamos caminhando, algumas vezes contra a vontade das demais entidades, e para continuar nesse caminho, precisamos nos adaptar à Portaria 186, inclusive nos atentando para os riscos que possa trazer". (CUT, 2008)

Em reunião da Executiva Nacional da CUT, em maio de 2009, foram apresentados dados do MTE no tocante à representatividade das centrais. Através de dados parciais levantados a partir do Diário Oficial da União (DOU) no período de janeiro à dezembro de 2008, foram criados 480 novos sindicatos, dos quais 321 sem filiação a qualquer central sindical, e 159 já sob a égide de alguma central sindical. Dentre essas, a Força Sindical foi a que conquistou maior número de sindicatos (63), seguida da NCST (31), CUT (29), UGT (14) e CTB (11), entre outras.

Embora o crescimento da CUT esteja em rítimo mais lento que às demais, ela permanece sendo a maior central sindical e uma das poucas que cumpre os requisitos de representatividade da Lei 11.648, conforme o quadro abaixo:

\begin{tabular}{|c|c|c|}
\hline CENTRAL SINDICAL & $\mathbf{2 0 0 8}$ & $\mathbf{2 0 0 9}$ \\
\hline CUT & $35,84 \%$ & $36,79 \%$ \\
\hline FS & $12,33 \%$ & $13,10 \%$ \\
\hline UGT & $6,29 \%$ & $7,19 \%$ \\
\hline CGTB & $5,02 \%$ & $5,02 \%$ \\
\hline CTB & $6,27 \%$ & $6,12 \%$ \\
\hline NCST & $5,09 \%$ & $5,47 \%$ \\
\hline
\end{tabular}


No entanto, talvez o dado mais interessante apresentado pela assessoria na reunião Executiva da CUT é a alteração no quadro das entidades não filiadas a nenhuma central sindical, reflexo da investida das centrais sindicais sobre estas entidades em busca de sua adesão. Há cerca de um ano, em 2008, apenas 47\% dos sindicatos haviam indicado a filiação a alguma central sindical. Em 2009, os dados apresentados mostram que passou a $55,0 \%$, ou seja, 4613, o número de sindicatos que tem alguma filiação à centrais sindicais. Ainda há um enorme campo a ser disputado pelas centrais uma vez que 45,0\% (3781 sindicatos) não pertencem ao quadro de nenhuma delas.

Os dados reforçam a análise feita por dirigentes de que o contexto atual trás uma forte competição entre as centrais sindicais em função de atenderem os requisitos de reconhecimento colocados na Lei 11.648. Para alcança-lo, as centrais estão não só intensificando suas ações na base, mas também junto ao MTE, aproveitando da Portaria 186 para criar novos sindicatos a partir da fragmentação de outros existentes ${ }^{136}$.

Tais alterações - reconhecimento das centrais sindicais através da Lei 11. 648; e a flexibilidade da unicidade sindical através da Portaria 186 - são profundamente imbricadas e fazem parte de um movimento mais profundo que vem ocorrendo atualmente na estrutura sindical corporativa, fruto de uma ação muito decidida do sindicalismo-CUT, inclusive enfrentando resistências internas na própria Central.

Este movimento de mudanças vem recompondo o cenário das centrais sindicais no Brasil, de acordo com o rítimo e a direção que a "reforma sindical fatiada" vem imprimindo.

Segundo Vagner Freitas, "nessa conjuntura tem aparecido um grande número de centrais sindicais em busca da legalização, algumas antigas e conhecidas, como é o caso da CUT e da Força Sindical e outras mais recentes, como a União Geral dos Trabalhadores (UGT), que resultou de uma fusão da Social Democracia Sindical (SDS), Central Geral dos Trabalhadores (CGT), Central Autônoma dos Trabalhadores (CAT) e parte da Força Sindical, a Nova Central Sindical dos Trabalhadores (NCST), que reúne parte das

\footnotetext{
${ }^{136}$ Em entrevista, alguns dirigentes e assessores da CUT identificaram na postura não republicana do MTE sob o comando de Carlos Lupi (PDT-RJ) um dos motivos pelo qual a Força Sindical tem tido um crescimento maior que o de outras centrais. Para eles, o registro de entidades sindicais anda mais rápido ou pára em alguma gaveta a depender da central que está encaminhando o pedido. Na versão apresentada, isso não acontecia na gestão dos ministros anteriores, Jacques Wagner, Ricardo Berzoini e Luis Marinho, que, a despeito de serem todos egressos das fileiras da CUT e do PT, tinham uma postura republicana de não privilegiar qualquer um dos atores sindicais, segundo os entrevistados.
} 
federações e confederações oficiais, que defendem a atual estrutura sindical; a Central Geral dos Trabalhadores do Brasil (CGTB), ligada ao MR8; o Conlutas, ligado ao PSTU, (mas que não se apresenta enquanto central sindical) e mais recentemente, a Confederação dos Trabalhadores do Brasil (CTB), ligada ao PCdoB"137. (FREITAS, 2008)

Para ele e outros dirigentes sindicais da CUT entrevistados por mim, as centrais sindicais estão cada vez mais articuladas a um projeto partidário e mobilizam suas alianças e fracionamentos no movimento sindical levando em conta não apenas a disputa partidária nacional, mas também a possibilidade de sobreviver frente aos critérios de representatividade da Lei 11.648 - 7\% de representação de trabalhadores associados na base no prazo de dois anos, contado a partir da promulgação da lei, em 2008 - e à manutenção do imposto sindical compulsório como principal mecanismo de financiamento do sistema sindical.

A julgar pela avaliação desses dirigentes, poderemos ter mais mudanças no cenário sindical em um futuro próximo, principalmente se a contribuição sindical vier a ser substituída pela contribuição de negociação coletiva.

Outros caminhos que a "reforma sindical fatiada" pode tomar é a ratificação das Convenções 151 e 158 da OIT através do acolhimento delas na legislação nacional.

A Convenção 151 preconiza o direito de negociação coletiva no setor público e entrou em pauta no Congresso Nacional a partir da Mensagem $n^{\circ} 58$, do Poder Executivo, em 14/02/2008, sendo encaminhado à Comissão de Relações Exteriores e de Defesa Nacional (CREDN); à Comissão de Trabalho, de Administração e Serviço Público (CTASP) e à Comissão de Constituição e Justiça e de Cidadania (CCJC) para futura apreciação do Plenário como Projeto de Decreto Legislativo no 795, de 2008 (PDL 795/08).

Até o momento já teve o parecer pela aprovação do relator da CCJC, o deputado José Genoíno (PT-SP); e da CTASP, o deputado Daniel Almeida (PCdoB-BA); e aprovado com ressalvas pelo relator da Comissão de Relações Exteriores e de Defesa Nacional, o deputado Vieira da Cunha (PDT-RS). (http://www2.camara.gov.br/proposicoes)

\footnotetext{
${ }^{137}$ O secretário nacional de política sindical da CUT esqueceu-se de mencionar a Intersindical, egressa da CUT, que envolve a militância ligada ao PSOL, e que também não se configura enquanto central sindical.
} 
No mesmo dia, 14/02/2008, o presidente Lula também encaminhou para apreciação do Congresso Nacional a Mensagem no 59, submetendo a Convenção 158 da OIT, que tem como tema a garantia do emprego contra a dispensa imotivada.

Do mesmo modo que a 151, a 158 também foi encaminhada à CREDN, à CTASP e à CCJC. A Convenção 158 teve parecer do relator, deputado Julio Delgado (PSB-MG). Pela rejeição. O motivo alegado pelo relator em sua exposição de motivos foi o seguinte:

“...No documento, Sua Excelência [o Ministro das Relações Exteriores, Celso Amorim] menciona ainda que a referida Convenção ora em análise já havia sido ratificada pelo Governo Brasileiro em 5 de janeiro de 1995, passando a vigorar no país um ano depois, mas que foi denunciada à OIT em 20 de novembro de 1996, por alegado conflito com o art. $7^{\circ}$, inciso I, da Constituição Federal.

Após ser ratificada, a presente Convenção entrará em vigor doze meses após a data de seu registro na OIT, e só poderá ser denunciada a cada dez anos da data inicial de sua vigência, ocorrida em 1995, o que significa que a próxima denúncia só poderá ocorrer em 2015 (Artigo 17, item 1)”. (http://www.camara.gov.br/sileg/integras/571982.pdf) ${ }^{138}$

Como se observa, muitas das propostas defendidas pela CUT durante a reforma sindical tem vindo à baila e efetivado mudanças de forma pontual, porém profundas. No entanto, o Congresso Nacional é também um campo onde ocorre a luta de classes e os setores conservadores se manifestam com força, seja colocando dificuldades à aprovação da plataforma da CUT (contraditoriamente, com apoio de grupos considerados "de esquerda"), seja colocando os seus interesses em pauta, como a reforma trabalhista, que havia sido postergada em razão da preeminência da reforma sindical.

Da mesma maneira que a reforma sindical negociada de forma global no FNT não prosperou do modo como se esperava, com a aprovação da PEC 369 e do ALRS, a reforma trabalhista ganhou o espaço de discussão no Congresso Nacional, inicialmente através da chamada emenda $3^{139}$, que foi fortemente combatida pelas centrais sindicais, e mais

\footnotetext{
${ }^{138}$ Denúncia da Convenção da OIT significa que Estado que a havia ratificado declara já não desejar mais ser considerado a cumprir suas disposições. (OIT/ACTRAV, 2000)

${ }^{139}$ A chamada emenda 3, de autoria do senador Nei Suassuna (PMDB-PB), foi uma proposta de emenda ao Projeto de Lei 6272/05 que criou a Super-receita (Lei no 11.457/07). Dizia o texto da emenda: "no exercício das atribuições da autoridade fiscal de que trata esta Lei, a desconsideração da pessoa, ato ou negócio jurídico que implique reconhecimento de relação de trabalho, com ou sem vínculo empregatício, deverá sempre ser precedida de decisão judicial". A iniciativa da emenda, alegada nos principais meios de comunicação e por representantes do setor patronal na sociedade, era de se evitar o arbítrio de fiscais do trabalho e da receita em suas atribuições. No entanto, aprovada essa emenda, os auditores fiscais da receita, da previdência e do trabalho, ficariam impedidos de apontar irregularidades no vínculo empregatício entre patrões e empregados, como a contratação de empregados como Pessoas Jurídicas através das chamadas "empresas de uma pessoa
} 
recentemente pelo Projeto de Lei n ${ }^{\circ}$ 1987/07. Em ambos os casos a alteração da legislação trabalhista foi feita sem passar por qualquer tentativa de diálogo com as centrais sindicais em fóruns tripartites, como o FNT.

O propósito do PL 1987/07, de autoria do deputado federal Cândido Vaccarezza (PT-SP) é o de fazer uma consolidação da CLT, que em outras palavras significa analisar toda a legislação trabalhista tendo em vista facilitar aos cidadãos e às empresas o entendimento sobre seus direitos. O deputado justifica a proposição pelo fato de que "o imenso volume de leis existentes no Brasil coloca o cidadão em um grande labirinto, impedindo-o de exercer plenamente e de forma eficaz suas atividades". (VACCAREZZA, s.d.) Em outras palavras, “o projeto não objetiva criar direito novo, mas apenas sistematizar a CLT reunindo num mesmo instrumento legislativo toda a legislação esparsa, para facilitar seu exame, estudo e aplicação pelo operador do direito".

O problema identificado pela CUT e seus sindicatos é que, ao fazer essa "limpeza" na CLT procurando desburocratizá-la, o deputado jogou fora diversos direitos; e fatores prejudiciais que estavam enterrados pela jurisprudência ganharam sobrevida. Mas o pior, na interpretação da CUT sobre o PL 1987/07, é que este institui um novo paradigma com a prevalência do acordo individual ao invés da negociação coletiva, autorizando a flexibilização e a precarização do direito laboral.

Por esse motivo, em reunião realizada na CUT com o deputado, autor do PL, Artur Henrique exortou pela retirada do projeto advertindo que o projeto enfrentaria forte oposição da Central: "Num Congresso em que a correlação de forças não nos é favorável, abrir tal discussão seria um passo rumo ao cadafalso, aos ataques conservadores à CLT", disse ele. (CUT, 2008)

só”, com a consequente autuação da empresa contratante fraudulenta, sendo permitida apenas aos juízes fazelo quando acionados em processos judiciais. Guardadas as diferenças, seria como impedir um guarda de trânsito de multar um motorista infrator, apenas um juiz... A discussão da emenda 3 ganhou grande vulto na sociedade e colocou em campos diametralmente opostos as entidades sindicais de empregadores e de trabalhadores, que entendiam que a aprovação da emenda 3 implicaria em perda de inúmeros direitos trabalhistas como o registro em carteira, o pagamento de férias, de $13^{\circ}$ salário, de FGTS, de PLR, de seguroacidente de trabalho, entre outros. A emenda 3, na visão destes, seria uma verdadeira reforma trabalhista, legalizando, mais do que a precarização na relação de trabalho, o próprio fim da relação de trabalho, travestindo-a de relação entre empresas. Diante disso, as centrais tiveram uma atuação conjunta em protestos de rua e no campo institucional pressionando pela aprovação do veto do presidente Lula à emenda, que o fez no ato de promulgação da Lei, em 16/03/2007. 
Vimos nesse terceiro capítulo que a reforma sindical não ocorreu do modo como havia sido inicialmente planejado, seguindo-se de negociações tripartites entre governo, empregadores e trabalhadores que se revestiria por si só de tamanha legitimidade e facilitaria sua aprovação no Congresso Nacional.

Resistências e oposições de todo lado obstaculizaram seu trâmite legal. Muitas alternativas criadas, como a PEC 29 e o substitutivo do deputado Zimmermann também não foram adiante.

A reforma sindical, então, vem ocorrendo a partir da introdução de mudanças tópicas que tangenciam a Constituição Federal, sem feri-la, impulsionado, sobretudo pela CUT, que tem tido um papel importante de pressão junto ao Ministério do Trabalho, que tem sido sensível àquelas reivindicações.

O intuito da reforma sindical inconclusa, segundo a visão da CUT - fortalecimento da representatividade, da organização nos locais de trabalho, e da capacidade de negociação coletiva das entidades sindicais -, não é, por si só, um antídoto infalível às pressões pela precarização do trabalho, que tem acontecido ao arrepio da lei, na vida real, e, ao mesmo tempo, tem procurado se escudar na lei através da chamada emenda 3 e da consolidação da CLT de Vaccarezza.

Do ponto de vista conceitual, a reforma sindical inconclusa tem possibilitado emergir aspectos do pluralismo, interseccionando-se aos elementos do corporativismo estatal ainda vigente (e, para muitos, reforçado) e ao neocorporativismo, que se acrescentou ao longo do processo histórico pela ação dos movimentos sociais e da CUT.

Desse modo, acreditamos que o material analisado nos permite responder afirmativamente à pergunta colocada no início desse capítulo, se a CUT estaria passando para uma terceira etapa em sua trajetória. O futuro talvez venha nos trair, mas entendemos que a experiência do sindicalismo-CUT durante o governo Lula já significa um marco e, independente de quem venham a ser os próximos chefes de Estado, o movimento sindical não voltará ao patamar que estava, pois as mudanças pontuais da reforma sindical inconclusa, como o pluralismo, vieram para ficar, levando a um outro tipo de ação sindical no país. Assim, se tivemos, grosso modo, uma "CUT-movimento" nos anos 1980 e passamos à "CUTInstituição" ou "CUT-organização" nos anos 1990, podemos denominar o contexto atual por “CUT-representativa e negociadora” em função das novas exigências da Lei 11.648/08. 


\section{Considerações Finais}

Essa tese procurou situar a CUT e sua bandeira histórica em defesa da liberdade e autonomia sindical diante do governo Lula, que lançou a iniciativa inédita de promover uma reforma sindical a partir da negociação entre representantes de empregadores e de trabalhadores, sob a coordenação do Ministério do Trabalho e Emprego (MTE) no Fórum Nacional do Trabalho (FNT).

O tema, como observado na introdução do trabalho, não é inédito no ambiente acadêmico. Menos ainda entre dirigentes e militantes sindicais, que há décadas atuam para romper a herança corporativista deixada por Vargas na CLT.

Esta tese pretende contribuir com o debate em torno do tema no contexto atual, em que, para muitos, a CUT “chegou ao poder”..

Nossa posição é de que a CUT não chegou ao poder porque se trata, ao fim e ao cabo, de uma central sindical que busca representar os interesses específicos da classe trabalhadora apregoando desde sua origem e em seu estatuto, a independência de classe frente aos patrões, aos governos e partidos políticos e que, por isso, tem como concepção a preservação de sua autonomia.

Entretanto, analisamos a relação histórica e simbiótica entre CUT e PT. Com isso, ressaltamos a profunda identidade política e ideológica existente entre ambos. E, por conseguinte, com o governo Lula, que é do PT, mas se sustenta em base política de apoio bastante ampla e heterogênea. Base na qual estão - no arco das alianças - segmentos mais conservadores da sociedade.

O resultado do triângulo CUT-PT-governo Lula, cada um preservando interesses próprios (apesar dos diversos comuns), foi um grande tensionamento na definição da política econômica, reforma da previdência e reforma sindical, parte do tema desta tese.

Procuramos apresentar e elucidar a tensão entre os distintos interesses em jogo, que opuseram, em alguns momentos, trabalhadores e patrões; em outros, as diversas centrais sindicais; ainda a CUT contra o MTE e o governo Lula. E, finalmente, as divergências dentro da CUT, na disputa interna das correntes. 
Nesse cenário se reestruturaram as centrais sindicais, nas quais houve fusões e cisões. Como na CUT, que de março de 2004 a dezembro de 2007 assistiu a três seguidos movimentos de saída de correntes políticas.

Os campos de tensionamento não eram e não são estanques. Ao contrário, se interpenetram e influenciam-se mutuamente, conferindo enorme complexidade à situação.

Compreender o contexto atual forçou resgatar a trajetória da CUT desde as grandes greves no ABC - que se espraiaram pelo país no final da década de 1970 e início dos anos 1980 até os dias atuais. Ao longo do percurso, a CUT enfrentou os desafios conjunturais imprimindo padrão de ação sindical que respondesse mais efetivamente às demandas dos trabalhadores, combinando sua organização com condições reais que propiciavam maior ou menor capacidade de mobilização.

Em outras palavras, as diferentes combinações entre o que se denomina aqui dinâmica interna do sindicalismo-CUT (concepção, disputas entre correntes políticas, resoluções congressuais etc) com a dinâmica externa (desemprego, precarização e flexibilização do mercado de trabalho, ritmo de crescimento econômico, grau de democratização da vida política nacional etc) moldaram distintos padrões de ação sindical: "CUT-movimento", "CUT-instituição" ou "CUT-organização". Consideramos que a CUT vivencia uma terceira fase de sua trajetória, denominada aqui sob o 'rótulo' de "CUT-representativa e negociadora", em virtude das alterações na legislação sindical que ocorrem com a reforma sindical fatiada e inconclusa, e o papel que ela e as demais centrais sindicais desempenharão daqui em diante.

A nova etapa da CUT coincide com um contexto inédito do sindicalismo no país, caracterizado pela disputa mais intensa de representação entre as centrais sindicais.

No campo da teoria sobre corporativismo, a tese compartilha a posição de Boschi e Diniz (1991), e ressalta a imbricação de três perspectivas teóricas distintas - "corporativismo estatal"; "corporativismo societário" ou "neocorporativismo"; e o "pluralismo" -, consideradas tipos ideais weberianos para analisar e compreender a realidade social tomada como objeto de estudo.

Reafirmamos a perspectiva adotada nesta pesquisa, em contraposição a outras abordagens e autores, para quem a estrutura sindical corporativa é (quase) imanente, e a CUT não fez 
mais do que se adequar e sucumbir à lógica corporativa do sindicalismo atrelado e de colaboração de classes.

Entendemos que há farto material neste trabalho sustentando o argumento de que há um processo de mudança em curso da estrutura sindical vigente, evitando juízo de valor e paixão das posições políticas.

Contudo, reconhecemos que esse movimento de mudança é contraditório e, por isso, a interpretação trazida à luz por essa tese procura tornar mais complexa a "leitura" acerca da dicotomia "adequação - superação", evitando aferrar-se a qualquer uma das posições dadas, pois entendemos que ambos os polos aparecem indistintos na realidade social.

Com isso, concluímos esta tese, na expectativa de que o resultado contribua ao debate sociológico e aos caminhos do sindicalismo-CUT. 


\section{BIBLIOGRAFIA}

ALDÉ, Alessandra. "As eleições presidenciais de 2002 nos jornais" [on line] http://publique.rdc.puc-rio.br/revistaalceu/media/alceu_n6_Alde.pdf)

ALMEIDA, José Maria de. (2004) “A CUT morreu”, O Globo, Rio de Janeiro, 26/08/2004, pp. 6

ALMEIDA, Maria Hermínia Tavares de. Crise econômica e organização de interesses: estratégias do sindicalismo brasileiro nos anos 80. Tese de livre docência, Faculdade de Filosofia, Letras e Ciências Humanas, Universidade de São Paulo, São Paulo, 1992

ALVES, Giovanni. "Do "Novo Sindicalismo" à "Concertação Social”: ascensão (e crise) do Sindicalismo no Brasil (1978-1998)". Revista de Sociologia e Política, Curitiba, 15, p. 111-124, nov. 2000

ANTUNES, Ricardo. O Novo Sindicalismo. São Paulo: Editora Brasil Urgente1991

Uma esquerda fora do lugar. o Governo Lula e os descaminhos do PT; Armazém do Ipê:, 2006.

APROPUCSP. "Reforma Sindical”, 2005 [on line] In Revista PUC Viva, n 23, janeiro a março. http://www.apropucsp.org.br/revista/r23_r01.htm

ARAÚJO, Ângela e TÁPIAS, Jorge. "Corporativismo e Neocorporativismo: exame de duas trajetórias" Boletim Informativo e Bibliográfico de Ciências Sociais. Rio de Janeiro:

Relume Dumará, nº. 32, 1991.

ARAÚJO, Angela. A construção do consentimento: corporativismo e trabalhadores nos anos trinta. São Paulo: Scritta,1998

. (org.) Do corporativismo ao neoliberalismo. Estado e trabalhadores no Brasil e na Inglaterra São Paulo: Boitempo, 2002.

ARTICULAÇÃO DE ESQUERDA. "Nossa posição sobre a reforma sindical" Jornal Página 13 sindical. São Paulo, edição especial de maio de 2005.

BARBIERI, Marcelo. "Projeto de Lei $\mathrm{n}^{\mathrm{o}}$ 5275/2005" [on line] http://www.adunesp.org.br/reformas/sindical/PL\%205275-05\%20- 
\%20Regulamenta\%C3\%A7\%C3\%A3o\%20artigo\%208\%C2\%BA\%20CF\%20-

\%20Organiza\%C3\%A7\%C3\%A3o\%20Sindical.htm

BARGAS, Osvaldo Martinez. Escola Sindical São Paulo. Exposição transcrita no Relatório do Seminário sobre Reforma Sindical Sudeste I. São Paulo: Escola Sindical São PauloCUT, 12 e 13 de agosto de 2004.

BERZOINI, Ricardo "Democracia e transparência na estrutura sindical" O Estado de $S$. Paulo. São Paulo, 16/03/2005, pp. A2.

BEYNON, Huw. "O Sindicalismo tem futuro no século XXI" In: RAMALHO, José Ricardo; SANTANA, Marco Aurélio. (orgs). Além da fábrica: trabalhadores, sindicatos e a nova questão social. São Paulo, Boitempo, 2003.

BEZERRA, Eleno José. “A um passo do novo sindicalismo”, O Estado de S. Paulo. São Paulo, 24/03/2005, pp. A2.

BOITO Jr., Armando (org.). O Sindicalismo Brasileiro nos anos 80. São Paulo, Paz e Terra, 1991a.

. O Sindicalismo de Estado no Brasil. Uma análise crítica da estrutura sindical. São Paulo: Hucitec, 1991b.

. "De volta para o novo corporativismo: a trajetória política do sindicalismo brasileiro". São Paulo em Perspectiva, 8 (3), 1994, pp. 23-28.

. Política neoliberal e sindicalismo no Brasil. São Paulo: Xamã, 1999

. "Neoliberalismo e corporativismo de estado no Brasil" In: ARAÚJO, Angela. (org.) Do corporativismo ao neoliberalismo. Estado e trabalhadores no Brasil e na Inglaterra São Paulo: Boitempo, 2002.

BORGES, Altamiro. "CTB: a novidade no sindicalismo", 06/01/2008 [on line] In: www.vermelho.org.br

_. "186 fere unicidade sindical”, 10/09/2008 [on line] http://www.diap.org.br/index.php/artigos/5083-portaria_186_fere_unicidade_sindical 
BOSCHI, Renato; DINIZ, Eli. "O Corporativismo na construção do espaço público" In: BOSCHI, Renato. Corporativismo e Desigualdade. Rio de Janeiro: Rio Fundo Editora, 1991

BOURDIEU, Pierre. O poder simbólico, Rio de Janeiro, Bertrand Brasil, 1992.

BRANDT, Ricardo; TOSTA, Wilson. "Era Lula consagra república sindical”. O Estado de S. Paulo. São Paulo, 06/04/2008, pp. A4

BRASIL. Constituição da República Federativa do Brasil. São Paulo: Imprensa Oficial, revisada e atualizada até março de 2001

Emenda Constitucional $n^{o} 41 \quad(E C \quad 41), 2003$ [on line]. http://www.planalto.gov.br/Ccivil_03/Constituicao/Emendas/Emc/emc41.htm.

BRASILINO, Luís. "Reforma sindical é um desastre para os trabalhadores". Entrevista com Ricardo Antunes ao Correio da Cidadania, s.d.

. "Aprender com as derrotas". Entrevista com Jorge Luis Martins ao Correio da Cidadania, s.d.

BRESSER PEREIRA, Luiz Carlos. "O Estado no século 21". Folha de S. Paulo. São Paulo, Seção tendências / debates, 28/11/1996, pp. 3.

CAMATA, Rita. "Projeto de Lei $\mathrm{n}^{\text {o }}$ 4967/1990" [on line] http://www2.camara.gov.br/proposicoes

CAMPISTA, Carlos Alberto. "Projeto de Lei $\mathrm{n}^{\circ}$ 3267/1992" [on line] http://www2.camara.gov.br/proposicoes

CARDOSO, Adalberto Moreira. Sindicatos, Trabalhadores e a Coqueluche Neoliberal: A era Vargas acabou? Rio de Janeiro, Editora Fundação Getulio Vargas, 1999.

. A Década neoliberal e a crise dos sindicatos no Brasil. São Paulo: Boitempo, 2003.

CARNEIRO, Claudia. "Governo alcança pior índice de popularidade”, 1999. [on line] http://www.senado.gov.br/sf/noticia/senamidia/historico/1999/5/zn052810.htm

CARREIRA, Krishma; STEFANEL, Xandra. "Diga-me para quem governas..." Revista do Brasil. Ano 1, $\mathrm{n}^{\circ}$ 1, maio de 2006 
CARVALHO, Augusto. "Projeto de Lei n4911/1990 - PL-4911" [on line] http://www2.camara.gov.br/proposicoes

CARVAlHO, Maria do Carmo Albuquerque; TEIXEIRA, Ana Claudia (org.) Conselhos Gestores de Políticas Públicas. São Paulo: Polis, 2000.

CASTRO, Carlos Ramiro de. "Experiências de organização estadual de Servidores Públicos" In: VÉRAS, Roberto. (org) A CUT e a Reorganização Sindical. São Paulo: Escola Sindical São Paulo/CUT, Caderno de Formação n³, 2002b

COHN, Gabriel. (org.) Weber. São Paulo: Ática, Coleção Grandes Cientistas Sociais, 1986. CONCEIÇÃO, Jefferson José da; RAMALHO, José Ricardo; RODRIGUES, Iram Jácome. "Mercado de trabalho e ação sindical: novos dados, novas questões". Revista de Direito do trabalho. São Paulo: Editora Revista dos Tribunais, ano 34, nº 130, abr.-jun. de 2008

CONLUTAS. "Faça parte da luta. Conheça a Conlutas: história, estatuto e programa", 20/02/2007 [on line] In:http://www.conlutas.org.br/exibedocs.asp?tipodoc=noticia\&id=105

. “Concepção, princípios e programa” Caderno de resolução do CONAT [on line] http://www.conlutas.org.br/downloads/concepcao_programa.pdf

COSTA, Vanda Maria Ribeiro. "Origens do Corporativismo brasileiro". In: BOSCHI, Renato. Corporativismo e Desigualdade. Rio de Janeiro: Rio Fundo Editora, 1991

COSTA, Helio da. Em busca da memória. Comissão de fábrica, partido e sindicato no pósguerra. São Paulo: Scritta, 1995.

COSTA, Helio da; LADOSKY, Mario Henrique. "Entre a integração e a resistência: um breve retrospecto da trajetória do sindicalismo no Brasil” In: ESCOLA SINDICAL SÃO PAULO, Debates e Reflexões. São Paulo: Escola Sindical São Paulo - CUT, nº 12, 2003.

CRISTINO, Vânia; MARIN, Denise Chispin. "Berzoini é hostilizado ao explicar a reforma sindical”. O Estado de S. Paulo. São Paulo, 17/03/2005, pp. A10

CUT. Resoluções da $5^{a}$ Plenária Nacional. São Paulo: CUT, 1992

. Sistema Democrático de Relações de Trabalho: uma proposta para a adoção da ética, da transparência e da democracia nas relações de trabalho. Informacut, $\mathrm{n}^{\mathrm{o}} 250$ (2 $2^{\mathrm{a}}$ ed.). São Paulo: CUT, 1992b 
O que mudar na estrutura sindical e nas relações de trabalho? Propostas em discussão na CUT sobre Reforma da Constituição e Transição da Estrutura Sindical.São Paulo: CUT, 1995.

.Estatuto. São Paulo: CUT, 1999

. Capacitação de Conselheiros das Comissões de Trabalho e Emprego. A experiência da CUT de 1998 a 1999. São Paulo: CUT / Convênio MTE/SEFOR/CODEFAT 024/99, 1999

Resoluções do $8^{\circ}$ CONCUT. São Paulo: CUT, 2003a

A reforma sindical que o Brasil precisa. São Paulo: SNO, Jornal Especial, nov. de $2003 b$

Resoluções da $11^{a}$ Plenária Nacional. São Paulo: CUT, 2005

. Estratégia e Organização da CUT: Construindo o Futuro. São Paulo: SNO e SNF, $2006 \mathrm{a}$

Resolução do $9^{\circ}$ CONCUT. São Paulo: CUT, 2006b

. Quem são e o que pensam as delegadas e delegados do $9^{\circ}$ CONCUT. São Paulo: . Escola Sindical São Paulo-CUT; CESIT; Friedrich Ebert Stiftung, 2006c.

. “Aprovado PL que reconhece centrais: câmara aprova o Projeto com imposto sindical facultativo", 18/10/2007 [on line] www.cut.org.br

. "Lupi constitui Grupo de Trabalho com centrais para debater sustentação financeira dos sindicatos", 7/11/2007 [on line] www.cut.org.br

. “' 'Tucanos e demos' obstruem pauta da Câmara para prejudicar votação do PL 1.990”, 05/03/2008 [on line] www.cut.org.br . "234 votos a favor, 171 contra Reconhecimento das centrais é aprovado em sessão tensa. Próximo passo é o fim do imposto sindical”, 11/03/2008 [on line] www.cut.org.br . "Reconhecimento das centrais. Lei é sancionada com veto à fiscalização do TCU, considerada inconstitucional", 1\%04/2008 [on line] www.cut.org.br 
. "Normatização do registro sindical: Portaria abre espaço para legalização de várias entidades de nível superior", 15/04/2008 [on line] www.cut.org.br . "Oficina sobre organização sindical faz diagnóstico sobre disputa na base", 19/05/2008 [on line] www.cut.org.br.

- "Nenhum direito a menos" 09/04/2008 [on line] http://www.cut.org.br/content/view/9763/170/

- "Fim do imposto dará novo caráter à disputa sindical e CUT crescerá mais, concluem debatedores", 20/05/2008 [on line] www.cut.org.br

. Texto Base da Direção Nacional ao $10^{\circ}$ CONCUT. São Paulo: CUT, 2009

DANTAS, Fernando. "Um país melhor depois de oito anos". O Estado de S. Paulo. São Paulo, $1 \%$ 1/2003, pp.H2

DAU, Denise Motta. "Entrevista com Denise Motta Dau, secretária nacional de Organização da CUT” [on line] citado em 07/02/2006. www.cut.org.br.

"PL sobre o reconhecimento das centrais pode ser votado nesta quarta (17)" CUT [on line] citado em 17/10/2007. www.cut.org.br

- "Reconhecimento das centrais é o primeiro passo na caminhada pela democratização da estrutura sindical”, 12/03/2008. www.cut.org.

DIEESE. "Política Industrial no Brasil: o que é a nova Política Industrial". Nota Técnica, no 11, dezembro de 2005.2 [on line] http://www.dieese.org.br/notatecnica/notatecPoliticaindustrial.pdf

DOCA, Geralda. "Reforma trabalhista na gaveta". O Globo. Rio de Janeiro, 15/11/2004, pp. 17

DORNELLES, Francisco. "Parecer da Comissão de Assuntos Sociais do Senado sobre o Projeto de Lei 1990/07" [on line] www.cut.otg.br.

ERICKSON, Kenneth Paul. Sindicalismo no Processo Político no Brasil, São Paulo, Brasiliense, 1979. 
FEIJÓO. José Lopez. “A CUT São Paulo nas regiões: subsedes” In: VÉRAS, Roberto. (org) A CUT e a Reorganização Sindical. São Paulo: Escola Sindical São Paulo/CUT, Caderno de Formação n³, 2002b

FERRAZ, Marcos Alexandre dos Santos. "CUT-Cidadã: uma avaliação do sindicalismo recente". Trabalho apresentado no Seminário Intermediário do GT ANPOCS Trabalhadores, Sindicatos e a Nova Questão Social, 2003

FERREIRA, Jorge. (org.) O populismo e sua história: debate e crítica. Rio de Janeiro: Civilização Brasileira, 2001.

FILGUEIRAS, Luiz; PINTO, Eduardo Costa. "Governo Lula: Contradições e impasses da política econômica", 2003 [on line].

http://www.nec.ufba.br/artigos/Artigos/Congressos_e_Eventos/2004 -IX ENCONTRO DE ECONOMIA POLITICA - Governo Lula - Contradições e Impasses da Política Econômica.pdf

FÓRUM NACIONAL DO TRABALHO (FNT). Regimento Interno do FNT. Brasília: MTE, SRT, 2003 [on line] http://www.mte.gov.br/fnt/Regimento_Interno_do_Forum_Nacional_do_Trabalho.pdf . Reforma Sindical: relatório final. Brasília: MTE, SRT, 2004 . Reforma Sindical: Proposta de Emenda à Constituição - PEC 369/05 e Anteprojeto de Lei. Brasília: MTE, SRT, 2005

. Reforma Sindical: Proposta alternativa de regulamentação do art. $8^{\circ}$ da $\mathrm{CF}$, até aprovação da PEC 369/05. Brasília: MTE, SRT, 2006

FREI BETTO. Calendário do Poder. Rio de Janeiro: Rocco, 2007

FREITAS, Vagner. "Em defesa da portaria 186", 05/05/2008 [on line] www.cut.org.br . "As centrais sindicais brasileiras: história, concepções e formas de atuação", 8/04/2008 [on line] www.cut.org.br - "Federações e Confederações oficiais e orgânicas da CUT e sua relação com os sindicatos", 19/03/2008 [on line] www.cut.org.br 
FUCHTNER, Hans. Os Sindicatos Brasileiros: organização e função política, Rio de Janeiro, Edições Graal, 1980.

GALVÃO, Andréia. "Reforma sindical: as polêmicas por detrás de um falso consenso". Revista PUC Viva. $\mathrm{n}^{\mathrm{o}}$ 23, janeiro a março de 2005. [on line] http://www.apropucsp.org.br/revista/r23_r03.htm

. Neoliberalismo e reforma trabalhista no Brasil. Rio de Janeiro: Coedição, Revan, FAPESP, 2007

GHERARDI, Hélio Stefani. "Parecer à Portaria 186, do MTE Registro Sindical" [on line] Brasília: DIAP, 2008. http://diap.ps5.com.br/file/1774.doc

GIANNOTI, Vito; NETO, Sebastião Lopes. CUT: por dentro e por fora. Petrópolis: Vozes, 1990.

. CUT Ontem e Hoje. O que mudou das origens ao IV CONCUT. Petrópolis: Vozes, 1991.

. Para onde vai a CUT? São Paulo: Scritta Editora, 1993.

GIANNOTI, Vito. Força Sindical: a central neoliberal: de Medeiros a Paulinho. Rio de Janeiro: Mauad, 2002

GIBSON, Nilson. "Projeto de Lei no 60/1991 - PL 60/1991" [on line] http://www2.camara.gov.br/proposicoes

—. "Projeto de Lei no 264/1991 - PL 264/1991" [on line] http://www2.camara.gov.br/proposicoes

GODOY, Dagoberto Lima. "A polêmica reforma sindical”, O Estado de S. Paulo. São Paulo, 07/05/2005, pp. B2

GOMES, Ângela de Castro. A invenção do trabalhismo. São Paulo, Vértice, 1988.

. "República, Trabalho e Cidadania". In: BOSCHI, Renato. Corporativismo e Desigualdade. Rio de Janeiro: Rio Fundo Editora, 1991

GOMES, Wagner. "Impasses e contradições". Teoria e Debate, n 63, jul/ago 2005, pág.28-30. 
GRANA, Carlos Alberto. Exposição transcrita no Relatório do Seminário sobre Reforma Sindical Sudeste I. São Paulo: Escola Sindical São Paulo-CUT, 12 e 13 de agosto de 2004.

HAMU, Mariângela. "De certa forma, não temo o julgamento da História". Entrevista concedida. O Estado de S. Paulo. São Paulo, 1\%01/2003., pp. H1.

HARNECKER, Marta (org.). O Sonho era Possível - a História do Partido dos Trabalhadores narrada por seus protagonistas, São Paulo, MEPLA/Casa das Américas, 1994.

HORN, Carlos Henrique. "Reflexões sobre consenso e dissenso na reforma sindical" GT26

- Trabalho e sindicato na sociedade contemporânea, XXIX Encontro Anual da ANPOCS, 2005

HYMAN, Richard. "Trade Unions and the Disaggregation of the Working Class". In: REGINI, Marino. The Future of Labour Movements. London: Sage, 1994

INTERSINDICAL. "INTERSINDICAL: Instrumento de Luta e Organização da Classe Trabalhadora", s.d. [on line] In http://intersindical.org.br/apresentacao.php.htm

JUNIOR, Waldir Rodrigues (2005). "A reforma sindical e a formação da Conlutas". Revista PUC Viva, $\mathrm{n}^{\mathrm{o}}$ 23, janeiro a março. http://www.apropucsp.org.br/revista/r23_r07.htm

KREIN, José Dari; TEIXEIRA, Marilane. "A reforma sindical e trabalhista em tempos de crise do emprego e a proposta da CUT para um sistema democrático de relações de trabalho" In: ESCOLA SINDICAL SÃO PAULO, Debates e Reflexões. São Paulo: Escola Sindical São Paulo - CUT, nº 12, 2003.

LACERDA, Ângela. "Severino prepara ataque à reforma sindical de Lula" O Estado de $S$. Paulo. São Paulo, 23/04/2005, pp. A4

LADOSKY, Mario Henrique. Movimento Sindical e Estratégia Corporativista: a trajetória e os impasses da CUT no Rio de Janeiro Dissertação de mestrado, Instituto de Filosofia e Ciências Sociais, Universidade Federal do Rio de Janeiro, 1995. 
LADOSKY, Mario Henrique; MELLI, Ana Paula. "O que está em jogo na reforma sindical” In: ESCOLA SINDICAL SÃO PAULO, Debates e Reflexões. São Paulo: Escola Sindical São Paulo - CUT, nº 12, 2003.

LULA, 2003. Discurso de posse do presidente. O Estado de S. Paulo. São Paulo, $1 \% 01 / 2003$.

—. "Medida Provisória no 293, de 8/05/2003" [on line] http://www.camara.gov.br/sileg/integras/397635.pdf

"Medida Provisória no 294, de 8/05/2003" [on line] http://www.camara.gov.br/sileg/integras/397776.pdf

—. "Projeto de Lei $\mathrm{n}^{\text {o }}$ 1990/2007 - PL 1990" [on line] http://www.camara.gov.br/sileg/integras/501900.pdf

MACEDO, Fausto. OESP, "Pontos da reforma podem parar no Supremo" O Estado de $S$. Paulo. São Paulo, 17/03/2005, pp. A10.

MARCHI, Carlos. "Linha direta entre Lula e FHC evitou pedido de impeachment". $O$ Estado de S. Paulo, São Paulo, 31/08/2008, pp. A15.

MATTOSO, Jorge. O Brasil Desempregado. São Paulo: Fundação Perseu Abramo, 1999

MEDEIROS, Luis Antônio. Pronunciamento no Plenário da Câmara de Deputados [on line] http://www.camara.gov.br/sileg/integras/416680.pdf

MELATO. Emmanuel. "Federação Nacional, Democrática e Combativa dos Metalúrgicos" In: VÉRAS, Roberto. (org) A CUT e a Reorganização Sindical. São Paulo: Escola Sindical São Paulo/CUT, Caderno de Formação n³, 2002b

MELLEIRO, Waldeli; RADERMACHER, Reiner. "El sindicalismo bajo el gobierno de Lula”. Nueva Sociedad. Buenos Aires: Friedrich Ebert Stiftung, nº 211, 2007

MERCADANTE, Aluisio; ROCHA, Paulo. "Prometo de Lei n 2585/1992" [on line] http://www2.camara.gov.br/proposicoes

MIRANDA, Sergio. "Projeto de Lei $n^{\circ}$ 4554/2004" [on line] http://www2.camara.gov.br/proposicoes 
MOURA, Almir. "Proposta de Emenda à Constituição no 121/2003 - PEC 121" [on line] http://www.camara.gov.br/sileg/integras/150159.pdf

MULLER, Amaury. "Projeto de Lei no 830/1991" [on line] http://www2.camara.gov.br/proposicoes

MUNCK, Ronaldo. "Labour Dilemmas and Labour Futures" In: MUNCK, Ronaldo; WATERMAN, Peter. Labour Worldwide in the Era of Globalisation: alternative union models in the new world order. London: Macmillan Press, 1999.

.Globalisation and Labour: the new "great transformation". London: Zed Books, 2002

NEVES, Helio; PEREIRA, Geraldo José. "Novos caminhos da organização sindical dos trabalhadores rurais: FERAESP e FAF" In: VÉRAS, Roberto. (org) A CUT e a Reorganização Sindical. São Paulo: Escola Sindical São Paulo/CUT, Caderno de Formação $\mathrm{n}^{\circ} 3,2002 \mathrm{~b}$

NEVES, Jones Santos. "Projeto de Lei $\mathrm{n}^{\circ}$ 1528/1989 - PL 1528" [on line] http://www2.camara.gov.br/proposicoes

NOBRE, Sergio. "A organização nacional dos metalúrgicos da CUT em debate" In: VÉRAS, Roberto. (org) A CUT e a Reorganização Sindical. São Paulo: Escola Sindical São Paulo/CUT, Caderno de Formação n³, 2002b

NOGUEIRA, Rui. (2004). “A canga da CUT” Revista Primeira Leitura. São Paulo: edição n 27 , maio de 2004, pp. 44-47.

NORONHA, Eduardo. “A expansão das greves na década de 80”, in BOITO Jr., Armando, O sindicalismo Brasileiro nos Anos 80, São Paulo: Paz e Terra, 1991.

O ESTADO DE S. PAULO (OESP). "Sustos e vitórias na economia". O Estado de S. Paulo. São Paulo, 1\%01/2003, pp. H14 . "Reforma Polêmica" O Estado de S. Paulo. São Paulo, 21/03/2005, editorial, pp. A3.

OIT/ACTRTAV. Princípios e Direitos Fundamentais do Trabalho. Declaração e Normas da OIT. Brasília: OIT/ACTRAV, 2000 
OLIVEIRA, Ana Lúcia Valença de Santa Cruz. Sindicalismo bancário: origens. São Paulo: Oboré Editorial, 1990.

OLIVEIRA, Francisco de. "Corporativismo: conceito ou emplastro" Democracia Viva, no 3, julho de 1998.

PAES LANDIM. “Projeto de Lei n 3107/2004” [on line] http://www2.camara.gov.br/proposicoes

PAIM, Paulo. "Projeto de Lei no 3408/1989 - PL 3408/1989” [on line] http://www2.camara.gov.br/proposicoes . "Parecer da Comissão de Assuntos Sociais do Senado sobre o Projeto de Lei 1990/07" [on line] www.cut.otg.br.

PANITCH, Leo. "El desarrollo del corporativismo en las democracias liberales" In: SCHMITTER, Phillipe; LEHMBRUCH, Gerhard. Neocorporativismo I. Más allá Del Estado y el mercado. Cidade do México: Alianza Editorial, 1992a

PALOCCI, Antonio. Sobre formigas e cigarras. Rio de Janeiro: Objetiva, 2007

PASTORE, José. 1999. A Reforma Constitucional Trabalhista in http://www.josepastore.com.br/artigos/rt/rt_100.htm

PAZZIANOTTO, Almir. "A contra-reforma sindical”. O Estado de S. Paulo. São Paulo, 14/03/2005, pp. A2.

. “Liberdade Sindical”. O Estado de S. Paulo. São Paulo, 24/02/2007, pp. A2.

PARTIDO COMUNISTA DO BRASIL (PC DO B). "Genoíno: parlamentares que pediram CPI serão isolados”, 25/05/2005 [on ln: http://www.vermelho.org.br/diario/2005/0527/0527_pt-cpi.asp

PESSOA, Flavia Moreira. (2003). "Contribuições sindical, confederativa, associativa e assistencial: natureza e regime jurídicos", in http://jus2.uol.com.br/doutrina/texto.asp?id=5634

PIMENTEL, Spensy; SOUZA, Paulo Donizetti. "O piloto da sucessão". Revista do Brasil, $\mathrm{n}^{\mathrm{o}} 25$, julho de 2008 . 
PARTIDO DOS TRABALHADORES (PT). XII Encontro Nacional do PT. Um outro Brasil é $\quad$ possível, $\quad 2001 \mathrm{a} \quad$ [on $\quad$ line] http://www.pt.org.br/pt25anos/anos00/documentos/01_umoutrobrasil.pdf, pág. 18-19 Diretrizes do Programa de Governo do PT para Brasil - A Ruptura necessária, $2001 b$ [on line] http://www.pt.org.br/pt25anos/anos00/documentos/02_diretrizes_prog_governo.pdf

_. Carta ao Povo Brasileiro, $2002 . \quad$ [on line] http://www.pt.org.br/pt25anos/anos00/documentos/02_carta_povo_brasileiro.pdf

QUEIROZ, Antônio Augusto de. 2001. A reforma trabalhista e sindical no próximo governo in http://www.diap.org.br/index.php/artigos/5925a_reforma_trabalhista_e_sindical_no_proximo_governo. (13/8/2002)

RAMALHO, José Ricardo; SANTANA, Marco Aurélio. Trabalho e tradição sindical no Rio de Janeiro: a trajetória dos metalúrgicos. Rio de Janeiro: DP\&A, 2001.

. "Trabalhadores, Sindicatos e a Nova Questão Social". In: RAMALHO, José Ricardo; SANTANA, Marco Aurélio. (orgs). Além da fábrica: trabalhadores, sindicatos e a nova questão social. São Paulo, Boitempo, 2003.

RANDS, Maurício; VICENTINHO. "Proposta de Emenda Constitucional n ${ }^{\circ}$ 29/2003 PEC-29". [on line] http://www.camara.gov.br/sileg/integras/131762.pdf

RIBEIRO, Ary. "A história dos avanços sociais” In: ASSOCIAÇÃO BRASILEIRA DE RECURSOS HUMANOS. Os direitos sociais e trabalhistas na Constituição de 1988. São Paulo: ABRH, 1988.

RIZEK, Cibele. "A greve dos petroleiros”. Programa Integrar de Formação de Dirigentes, São Paulo: CNM-CUT, 1998

ROCHA, Paulo. "Projeto de Lei $n^{\circ}$ 646/1991 - PL 646/1991" [on line] http://www2.camara.gov.br/proposicoes

RODRIGUES, Iram Jácome. Sindicalismo e Política. A trajetória da CUT. São Paulo: Scritta, 1997. 
(org.) O novo sindicalismo vinte anos depois. Petrópolis: Vozes / São Paulo: EDUC e UNITRABALHO, 1999

RODRIGUES, Leôncio Martins. "O poder sindical na nova Constituição". In: ASSOCIAÇÃO BRASILEIRA DE RECURSOS HUMANOS. Os direitos sociais e trabalhistas na Constituição de 1988. São Paulo: ABRH, 1988.

. CUT: Os Militantes e a Ideologia, São Paulo: Paz e Terra, 1990. . "As tendências políticas na formação das Centrais Sindicais" in BOITO Jr. (org.), $O$ Sindicalismo Brasileiro nos Anos 80, São Paulo: Paz e Terra, 1991. O Destino do Sindicalismo. São Paulo: EDUSP, 1999.

SADER, Eder. Quando Novos Personagens Entraram em Cena, Rio de Janeiro, Paz e Terra, 1988.

SALATIEL. Wanderley. "Novas formas de organização de base no ABC: SUR e CSE”. In: VÉRAS, Roberto. (org) A CUT e a Reorganização Sindical. São Paulo: Escola Sindical São Paulo/CUT, Caderno de Formação n³, 2002b

SANDRI, Adriano. Sindicalismo em tempos de Qualidade Total. Belo Horizonte: Sindicato dos Trabalhadores na Indústria Energética de Minas Gerais, 1994.

SANTANA, Marco Aurélio. Homens partidos. Comunistas e sindicatos no Brasil. Rio de Janeiro: Universidade do Rio de Janeiro e São Paulo: Boitempo, 2001

SANTOS, Artur Henrique da Silva. "SINERGIA: Sindicato Estadual” In: VÉRAS, Roberto. (org) A CUT e a Reorganização Sindical. São Paulo: Escola Sindical São Paulo/CUT, Caderno de Formação n³, 2002b

. "O desafio de mudar a estrutura sindical brasileira". Teoria e Debate, $\mathrm{n}^{\circ}$ 63, jul/ago 2005, pp.22-24.

. "PL sobre o reconhecimento das centrais pode ser votado nesta quarta (17)" CUT [on line] citado em 17/10/2007. www.cut.org.br

SANTOS, Carla. "CUT acusa golpe e divisão; CTB responde conclamando unidade", 20/12/2007. In www.vermelho.org.br 
SANTOS, Nelson José dos. Exposição transcrita no Relatório do Seminário sobre Reforma Sindical Sudeste I. Bauru: Escola Sindical São Paulo-CUT, 14 e 15 de outubro de 2004.

SCHMITTER, Phillipe. “¿Continúa el siglo Del corporativismo?” In: SCHMITTER, Phillipe; LEHMBRUCH, Gerhard. Neocorporativismo I. Más allá del Estado y el mercado. Cidade do México: Alianza Editorial, 1992a

- "Modos de Intermediación de intereses y modelos de cambio social en Europa occidental" In: SCHMITTER, Phillipe; LEHMBRUCH, Gerhard. Neocorporativismo I. Más allá del Estado y el mercado. Cidade do México: Alianza Editorial, 1992a

. "A dónde ha ido la teoría del neocorporativismo y hacia dónde puede ir su práctica. Reflexiones" In: SCHMITTER, Phillipe; STREECK, Wolfgang; LEHMBRUCH, Gerhard. Neocorporativismo II. Más allá del Estado y el mercado. Cidade do México: Alianza Editorial, 1985

SECOM. Destaques: Ações e Programas do governo federal.Brasília: SECOM, novembro de 2008.

SECRETARIA DE RELAÇÕES INTERNACIONAIS (SRI-CUT). "CIOSL, CMT, FSM. As centrais mundiais respondem à CUT”. Informe Internacional. São Paulo: SRI-CUT, no 1, maio de 1992 . "Os sindicatos e os governos democráticos: Brasil, França, Espanha, Itália, Chile, Estados Unidos, Suécia”. Informe Internacional. São Paulo: SRI-CUT, nº 3, maio de 1994 . A política internacional da CUT. História e perspectivas São Paulo: CUT, 2003

SILVA, Sayonara Grillo Coutinho Leonardo da. "A reforma sindical negociada no âmbito do Fórum Nacional do Trabalho: deslocamentos normativos e impactos sobre os atores coletivos do trabalho" GT - Trabalho e Sindicato na Sociedade Contemporânea XXIX Encontro Anual da ANPOCS, 2005

SOUZA, Paulo Donizetti de. "Governo em disputa". Revista do Brasil. São Paulo, n²7, agosto de 2008

SOUZA MARTINS, Heloisa Helena de. O Estado e a burocratização do sindicato no Brasil. São Paulo: Hucitec, 1989. 
STEPAN, Alfred. Estado, Corporativismo e Autoritarismo. Rio de Janeiro: Paz e Terra, 1980

THAMES, Antonio Carlos Mendes. "Projeto de Lei no 38/1991 - PL 38/1991" [on line] http://www2.camara.gov.br/proposicoes

TEIXEIRA, Elenaldo. "Conselhos de Políticas Públicas: Efetivamente uma nova institucionalidade participativa?”. In: CARVALHO, Maria do Carmo Albuquerque; TEIXEIRA, Ana Claudia (org.) Conselhos Gestores de Políticas Públicas. São Paulo: Polis, 2000.

TELLES, Vera da Silva. “Operação desmanche: o espaço público em risco”. In VÉRAS, Roberto (org.). Ação Sindical no Espaço Local, Caderno de Formação no 2, São Paulo: Escola Sindical São Paulo-CUT/Sindicato dos Bancários de São Paulo, 2001.

TOSTA, Wilson. "Elite sindical tem $45 \%$ dos altos cargos". O Estado de S. Paulo. São Paulo, 06/04/2008, pp. A8.

TURRA, Julio. "Uma reforma sindical que ataca as bases históricas da CUT" in Revista PUC Viva, n ${ }^{\circ} 23$, janeiro a março. In http://www.apropucsp.org.br/revista/r23_r06.htm

VACCAREZZA, Cândido. "Consolidação das Leis", s.d [on line] http://www.vaccarezza.com.br/consolidacao_leis.php

VACCARI, João. "A experiência Nacional de Organização e Contratação dos Bancários”. In: VÉRAS, Roberto. (org) A CUT e a Reorganização Sindical. São Paulo: Escola Sindical São Paulo/CUT, Caderno de Formação n³, 2002b

VALVERDE, Eduardo. "Projeto de Lei no 1321/2007 - PL 1321/2007" [on line] http://www2.camara.gov.br/proposicoes

VÉRAS, Roberto. CUT 20 Anos, São Paulo: Escola Sindical São Paulo-CUT/SMABC. Caderno de Formação n ${ }^{\circ} 1,2001$. . Sindicalismo e democracia no Brasil: atualizações de novo sindicalismo ao sindicato cidadão. São Paulo: Tese de Doutorado, Faculdade de Filosofia, Letras e Ciências Humanas, USP, 2002. 
"A CUT e a estrutura sindical corporativista: entre a resistência, a sobreposição e a adesão”. In: VÉRAS, Roberto. (org) A CUT e a Reorganização Sindical. São Paulo: Escola Sindical São Paulo/CUT, Caderno de Formação n³, 2002b

VICENTINHO. Exposição transcrita no Relatório do Seminário sobre Reforma Sindical Sudeste I. Bauru: Escola Sindical São Paulo-CUT, 14 e 15 de outubro de 2004.

WATERMAN, Peter. "The New Social Unionism: A new union model for a new world order" In: MUNCK, Ronaldo; WATERMAN, Peter. Labour Worldwide in the Era of Globalisation: alternative union models in the new world order. London: Macmillan Press, 1999.

WEFFORT, Francisco. "Participação e Conflito Industrial: Contagem e Osasco 1968”, Cadernos CEBRAP, nº 5, São Paulo:CEBRAP, 1972.

WERNECK VIANNA, Luiz. Liberalismo e Sindicato no Brasil. Rio de Janeiro: Paz e Terra, 1976.

ZANETTI, Lorenzo. O "Novo" no Sindicalismo Brasileiro: característica, impasses e desafios, dissertação de mestrado apresentado ao Instituto de Estudos Avançados em Educação da Fundação Getúlio Vargas, mimeo., 1993.

ZIMMERMANN, Tarcisio. Substitutivo do PL 1528/89, publicado em 10/11/2005 in http://www2.camara.gov.br/proposicoes 